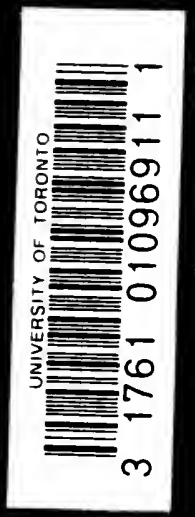



Digitized by the Internet Archive in 2008 with funding from Microsoft Corporation 

'T'HE' PUBLISHER.

\section{FAMINES OF THE WORLD:}

\section{PAST AND PRESENT.}

[Being Tro Papers Read before the Statistical Society of London in 1878 and 1879 respectively, and Reprinted from its Journal.]

CORNELIUS WALFORD, F.I.A., F.S.S., F.R.H.S., ETC., ETC.,

\section{BARRISTER-AT-LAW,}

ACTHOR OF "INSTRANCE CrCinparna," ETC., ETe.

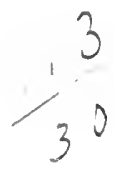

TONDON :

EUWARD STANEORD, 55, CHARING CROSS, S.W. 
HARRISON AND SONE,

PRINTERS IN ORDINARY TO HER MAJYSTY, ST. MARTIN'S LANE, LONDOX. 


\section{PREFACE.}

Srrce these papers were read, the demand for copies has been considerable-far beyond the regulation allowance of author's copies: there was no way of meeting this except by the reprint of a limited issue.

As stated in Part II, the author is by no means confident that he has adopted the very best mode of treating the wide subject of Famines. He adopted that mode which seemed best suited to the Journal wherein the papers originally appeared; and the same arrangement is here retained.

Belsize Park Gardens, London, N.W.

Mray, 1879. 



\section{FAMINESS OF TIIE WORLD: PAST AND. PRESENT.}

\section{CONTENTS :}

Chrouology of Famines ............... 4. Table of Plagnes of Inseets, Ver-

Analysis of Canses of Famines .... 20

'Table of Floods ........................... 21

Tible of Frosts ........................... 38

Table of Dry and Hot Seasons .... 47

Table of Comets, Cyelones, Earthquakes, Hailstorms, Hurricanes, and Violent Storms generally... 52

$$
\text { min, se. }
$$

Table of the literature of Meteorology as affecting Famines .... 71

Olject of Tables 86

Indian Famines ........................... 89

Sun-Spot Theory 91

$\mathrm{Mr}$ present subject has at onee the advantage and the disadvantage of being novel. I do not find that any previous writer has deemed the subject of famines worthy of careful investigation. I conld not find, when I required to write upon the subject some two years ago, that even a list of the famines which had oceurred in the history of the world, so far as we know of that history, had been compiled. I then made the chronologieal table, which I shall presently give, as a first effort in this direction. I felt that it must necessarily be incomplete. I have since added to it, and begin to hope that it is now sufficiently matured to be presented to this Society.

It is not so much a mere table of famines, instructive as I venture to think such records are, when compiled with any view to completeness, that I desire to bring before you this erening. There are many direct and indirect considerations arising out of the subject, which naturally commend themselves for elaboration. Anything affecting the food supply of the people has always been regarded as of importance here. Famines too often affect the very cxistence of the peoples among whom they occur. A tahle of the total deaths resulting from famines, even in one generation of wen, would present a terrible picturc. This can never be presented: the materials for its compilation nowhere exist. I know of no more terrible contemplation than that of the starvation of large numbers of our fellow creatures. Some writers liave appeared to look upon famines as furnishing onc of the necessary checks, upon what they 
would term the inordinate growth of population; and in that sense as being one of the means devised for the regulation of the universe. Such a view appears to me to be altogether incompatible with any jdeas of Divine wisdom: it can only be such a clumsy and cruel expedient, as might be resorted to in the working out of a design wherein wisdom had taken no part. The occurrence of famines wonld appear to me to be likely to result rather from the failure of human means and foresight in many instances than otherwise. In my table I have been careful to note the assigned cause wherever the records furnish any. I think it will be convenient at this point to present the table. It takes us at once from the domain of speculation into that of history. The authorities from which the materials of the table were drawn, are so numerous that it is impossible, except occasionally, to make any reference to them.

\section{Table I.-Chronalogy of Fumines.}

B.c. The Seriptures speak of several famines which had been in Palestine and in the neighbouring eountries, as that in the time of Abraham (Gen. sii, 10), and again in the time of Isaac (Gen. xxvi, 1).

1708 Egypt. The seven years' famine (Gen. xli, 27) began this year. It was not eonfined to Egspt, but extended to Palestine at least, if.not further. Vide r. 56.

503-143 India. During the reign of the Emperor Jei-ehund, extending over this period, there was a great pestilenee and famine.

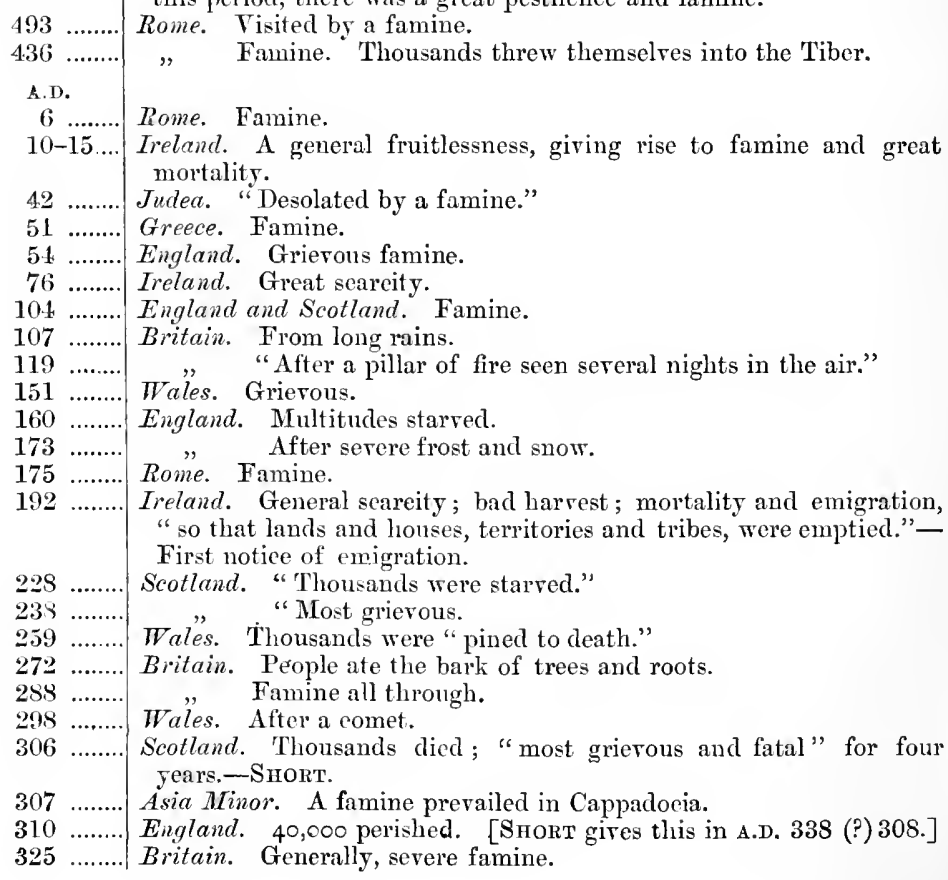




\section{TABLe I.-Chronology of Fumines-Contel.}

A. D.

331

370 .

381

410

434

439

416.

450 .

466 .

475 .

$4 \mathrm{SO}$.

$48 \mathrm{t}$

515 .

520 .

523.

527.

531 .

535

537.

538.

547 .

576.

590 .

592.

$600-604$

605 .

625

661 .

667.

669 .

669.

680

683.

695

700

703

712

718 .

730

$7+6$

748

759 .

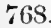

772

771

791

792

793

803

Antioch. This eity was aflicted by so terrible a famine that a bushel of wheat was sold for 400 pieces of silver. During this grievous distress Coustantine sent to the Bishop 30,000 bushels of corn, besides an immense quantity of all kinds of provisions, to be distributed among the ecclesiasties, widows, orphans, \&c.-Ency. Brit.

Syria. Also plague.

Plirygia. Awful famine.

Antioch. Reign of Thendosius the Great, again visited by a famine, "accompanied with a grievous plague;" also "terrib!c". famino amongst the Goths.

Rome. Followed by a plague.

Italy. Famine.

Britain. After a comet.

Constantinople. Severe famine.

Italy. When parents ate their children.-Dofresnor.

Britain. "And bad fatal air."-SnokT.

Northern Nations. A famine, partly from locusts.

Scotland. After a comet.

Africa. From drought.

Britain. "Most afllictive."

Tenice. A famine. The city reliered by Theodoric the Great.

Scotland. "Terrible."

North Wales. Famine.

South Wales. And a small plague.

Ireland. Destruction of food and scarcity, lasted four years.

Scotland. Dearth; also in Wales.

Italy. Great famine.

" Famine.

Scotland. "Fatal."

England. From a tempest that raised a great flood.

" Drought from 10th January to September ; and locusts.

France. Famine.

England. From heat and drought.

Britain. Grierous.

Ireland. Great famine preceding second appcarance of Buidhe Chonnaill.

Scotland. Grievous.

France. Great famine.

Ireland. Great scarcity ; and in following year.

Britain. From three years' drought.

Syria and Libya. Famine.

England $\{$ Famine and pestilence during three year's, "so that men Ireland $\}$ ate each other."

Italy. Three years' famine.

Wales. Famine.

Syria. Fumine.

England, Wales, and Scotland. Great famine.

Wales. Deartl.

Scotland. Famine.

Ireland. Great famine throughont the kingdom; and more or less for several years.

Ireland. Famine and an earthquake.

, Famine from drought.

Scotland. "With plague."

Wales. Grievous.

Scotland. Dearth.

England. "After many meteors;" and in other parts of the world.

Scotland. "Terrible." 


\section{Table I.-Chronology of Famines-Contd.}

\begin{tabular}{|c|c|}
\hline $822-23$ & $\begin{array}{l}\text { England. "Thousands starve;" also in Scotland, aceording to } \\
\text { SHORT. }\end{array}$ \\
\hline $821-25$. & Ireland. Great dearth. \\
\hline 836 & $\begin{array}{l}\text { Wales. "The ground eovered with dead bodies of men and beasts." } \\
\text {-SHorT. }\end{array}$ \\
\hline 845 & Bulgaria. Great famine. \\
\hline 850 & Paris. Famine prevailed. \\
\hline 851 & Italy and Germany. Famine. \\
\hline 856 & Scotland. A four years' famine began. \\
\hline 863 & With a plague. \\
\hline 868 & Paris. Suffered again from famine. \\
\hline 872 & England. "From ugly locusts." \\
\hline $873 \ldots .$. & Paris. Suffered again from famine. \\
\hline 879 & Universal famine prevailed. \\
\hline 883 & Itaiy. "Terrible." \\
\hline 887 & England. "Grierous two years." \\
\hline 890 & Scotland. Great dearth. \\
\hline$\$ 95-97$. & Ireland. Famine from invasion of locusts. \\
\hline $896-99$. & Paris. This city again suffers from famine. \\
\hline 898 & France. "Sore famine." \\
\hline 900 & England. Famine. \\
\hline 931 & Wales. Famine. \\
\hline 932 & France. Famine. \\
\hline 936 & $\begin{array}{l}\text { Scotland. After a comet; four years, "till people began to derour } \\
\text { one another."-- ВноRт. }\end{array}$ \\
\hline 945 & France. Famine. \\
\hline 16 & Italy. "Shocking." \\
\hline $95 \mathrm{t}$ & England, Wales, and Scotland. Great famine, which lasts four rears. \\
\hline 962 & England. Famine caused by frost. \\
\hline 968 & $\begin{array}{l}\text { Ireland. An intolerable famine, "so that parents sold their children } \\
\text { for food." }\end{array}$ \\
\hline 968 & Europe. Chiefly Germany and Scotland. \\
\hline 969 & England. "All grain burnt by the winds."-SHorT. \\
\hline 975 & Paris. A great number of inlabitants carried off by famine. \\
\hline 976 & $\begin{array}{l}\text { England. This was the "great famine," micla hungor.-Jons of } \\
\text { Bromptox. }\end{array}$ \\
\hline 987 & Albania. Dearth. \\
\hline 988 & England. From rains and barren land. \\
\hline 989 & $\begin{array}{l}\text { " "Grievous, from a rainy winter; bad spring; neither } \\
\text { plonghing nor sowing; snowy harvest." }\end{array}$ \\
\hline 100 & England. "Such a famine prevailed as no man could remember." \\
\hline 305 & $\begin{array}{l}\text { "This year was the great famine in England." Sweyn } \\
\text { the Dane quits in eonsequence. }\end{array}$ \\
\hline '08 & Wales. Attended with plague. \\
\hline 12 & England-Germany. Endless multitudes died of famine. \\
\hline ' 16 & $\begin{array}{l}\text { Europe. Awful famine throughout Europe. "Hails, thunder, and } \\
\text { lightning." } \rightarrow \text { SHORT. }\end{array}$ \\
\hline 22 & $\begin{array}{l}\text { Hindustan (reign of Musaood I). Great drought followed by } \\
\text { famine: whole countries entirely depopulated. } \\
\text { This year was remarkable for drought and famines in many parts of } \\
\text { the world.-Dow's Hindustan. }\end{array}$ \\
\hline 25 & England. From rains, and plague. \\
\hline '31 & From great rains and locusts.-SHORT. \\
\hline '35 & Byzantine Empire. Visited by famine. \\
\hline 4 & $\begin{array}{l}\text { England. About this time sueh a famine eame on that a sextarius } \\
\text { of wheat, which is usually a load for one horse, sold for } 5 \text { solidi } \\
\text { and more.-Henny of HuntingDon. Lasted seven years. }\end{array}$ \\
\hline 17 & $\begin{array}{l}\text { Ireland. Great famine and snow ; also in England, from snow and } \\
\text { frost. }\end{array}$ \\
\hline
\end{tabular}




\section{Table I.-Chronology of Famines-Contd.}

A.D.

Scotland. Famine extending orer two years.

England. Great famine and mortality ; from barremess of the land. Mexico. Famine which eaused the Tolters to migrate.

Hindustan. 'There was seven rears' drought in Ghor [? Ghore, supposed to be one of the earliest seats of the Afghan race], so that the earth was burned np, and thonsands of men and animals perished with heat and famine.-Dow's Hindustan.

England. Famine after a comet; lasted two years.

Poland. Grievous famine.

Egypt. For seven suceessive years the orerflow of the Nile failed, and with it almost the entire subsistence of the country; while the rebels interrupted supplies of grain from the north. 'Two provinees were entirely depopulated; in another lalf the inhabitants perished; while in Cairo eity (El-Káhrich), the people were redueed to the direst straits. Bread was sold for 14 dirhems to the louf; and all prorisions being exhausted, the worst horrors of famine followed. The wretched resorted to cannibalism, and organised bands kidnapped the unwary passenger in the desolate streets, prineipally by means of ropes furnished with hooks and let down from the latticed windows.

In the year 1072 the famine reached its height. It was followed by a pestilence, and this again was sneeceded by an invading army.Encyclopedia Britaniea, Art. Egypt.

England. Famine and plague after a serere winter.

" Normans desolated England, and in the following year famine spread orer the northern eounties of England, "so that man, driven by hunger, ate human, dog, and horse flesh ;" some to sustain a miserable life sold themselves for slares. All land lying "between Durham and Yorke lay waste, without inhabitants or people to till the ground, for the space of nine years, except only the territory of St. John of Bewlake" [Bererley].

"Divers other parts of his realm were so wasted with his wars that for want both of husbandry and habitation, a great dearth did ensue, whereby many were foreed to eat horses, dogs, eats, rats, and other loathsome and vile vermin; yea, some abstained not from the flesh of men. This famine and desolation did speeially rage in the north parts of the realm."-Harleian Miscellany, III, p. 151.

England. Famine, followed by mortality so fierce that the living could take no care of the siek, nor bury the dead.-HENRY of HoxtIxGDON.

Constantinople. "From the multitudes of strangers."-Sirort.

Denmark. Famine.

England. A great murrain of animals, and sneh intemperate weather that many died of ferer and famine.-HeNRY DE KNrgiton. Exeessive rains.-SHокт.

England. Pestilence followed by famine; great suffering.

Denmark. King Olaf II, surnamed the "Hungry," in consequenee of famine in his reign.

England. Great famine and mortality.-STow.

", "Heary-timed hunger that severely oppressed the earth."-

Saxon Chronicle. Snmmer rain, tempests, and bad air.-SHorT.

England. Famine from rains and floods.

Antioch. Famine.

England. From barren land; then plague.

"Winter long and very severe; great searcity followed.

Ireland. Great famine, "during which the people eren ate each other."

England. From tempest, hail, and a year's incessant rains.

Jerusalem. "Plague of mice and loensts."-Siront.

England. "Great famine from loug and cruel frosts." 


\section{TABLE I.-Chronology of Famines-Contd.}

A.D.

1123-24

'24 death."-PeNketmuar. famine did arise, and afflict the multitude of the people, even to

England. Great flood on St.
of destruction of erops, \&e.

'26 ....... England. Ineessant rains during the summer, "when followed in all England a most unheard of searcity. A sextarius of wheat sold for $20 s$."

'30-31 Rome. Great famine.

'35-37 Enyland. Great drought and famine.

41

'46

'51-52

'ธ3

54

, 57

'62

'75

76

's3

's 8

$93-96$

\section{Fiance. Famine.}

Europe and Palestine. Famine.

Ireland. Great fanine raged in Mumster, and spread all over Treland.

England. From rains, frost, tempest, thunder, and lightning.

Italy. After great snow and frost.

Said to have been a great famine all over the world.

England. Pestilenee, followed by great dearth.

Wrales. A great famine and mortality.

England and Wales. A great famine severely aflicted both England and Wales.

Ireland. Great scarcity of food in north of Ireland.

England, France. Famine occasioned by incessant rains. "The common people (vulgus pauperum) perished everywhere for lack of food; and on the footsteps of famine the fiercest pestilenee followed, in the form of an acute fever."-IVALTER HeMINGFord.

1200 ...... Ireland. "A cold, foodless year."

1200

03

'03

09

21

27

' 30

35

'39

43

'48

$' 52$

$' 57$

258

Egypt. Famine of great severity from defieient rise of the Nile.

England. A great mortality and famine, from long rains.

Ireland. A great fanine- "so that the priests ate flesh meat in Lent."

England. Famine from a rainy summer and severe winter. great famine.

A rery dry winter and bad seed-time, whence followed a

Ireland. A great famine throughout the country.

Rome. After a deluge of the Tiber.

England. Fannine and plague ; 20,000 persons die iu London; people eat horsellesh, bark of tres, grass, \&e.-SнonT.

England. Great famine, "people eat their children."-Sногт.

Hungary. Great famine from 'Tartar invasion.

Germany. Famine.

England. "By reason of embasing the eoin a great penury followed."

52 ....... No ram from Whitsuntide to autumn; no grass; heneo arose a serere famine; great mortality of man and cattle; dearness of grain and searcity of frrit.

57 ....... England. The inundations of autumn destroyed the grain and fruit, and pestilence followed.

England. North winds in spring destroyed vegetation; food failed, the preceding harrest haviug been small, and inmumerable multitudes of poor people died. Fifty shiploads of wheat, barley, and biead were procured from Germany; but citizens of London were forbidden by proclamation against dealing in same. "A great dearih followed this wet year pest, for a quarter of wheat was sold for $15 s$. and 20s., but the worst was in the end; there could be none found for money when-though many poor people were constrained to eat barks of trees and horsetlesh ; but many starved for want of food-20,000 (as it was said) in London."-PenkethunaN. 


\section{TABLE I.-Chronology of Fumines-Conted.}

A.D.

1262

'is

'71

'71

'sl

's6

' 89

'91

' 91

'95

'95

'97

'98

'99

1302

'14

'14

'I. 1

'16

'16

'17

'21

'32

'35

'36

'37

'39

'41

'42

'44-45

'47

Ireland. Creat destruction of people from plague and hunger.'

Sicily. Terrible fumine; also in Jiemna.

England. A violent tempest and inundation, followed by a severo famine in the entire dist riet of Canterbury.

Ireland. Pestilence and famine in the whole of Ireland.

Poland. Famine.

England. Short speaks of a twenty-three years' famine commencing this rear.

England. A tempest destroyed the seed, and eorn rose to a great price.

India. No rain fell in the prorinces about Delhi, and there was in consequence a most terrible famine.-Tide Birsi's Hist. of Feroze.

England. Severe famine; many thousands of the poor died.

", So grain or fruits, "so that the poor died of lunger." CAMDEx. Iriil, great concussion of elements.-SHorT.

Ireland. Great dearth during this and the prerious and following rears.

Scotland. "Calamitons" fimine and pestilence.

England. 26 Edward I. "A great famine in England, chiefly want of wine; so that the same could seareely be had to minister the communion in the eluurches."-Pexkethiras.

Persia raraged by famine and pestilence.

England, Scotland, Lreland.-Famine.

" Grains spoiled by the rains. Famine "so dreadful that the people devoured the flesh of horses, logs, eats, and rermin." Parliament passed a measure limiting the price of prorisions.

Ireland. Famine and rarious distempers.

Thuringia, Poland, Silesia. Lasted years in Lithuania.

England. Universal dearth, and such a mortality, particularly of the poor, followed, that the living eould seareely bury the dead. Royal proclamation : no more beer to be made. Ireland. Great dearth. Eight captured Scots eaten at siege of
Carrickfergus.

Ireland. A great famine throughout the country in consequence of Bruce's invasion.

England. Famine again; this is regarded by some writers as the last serious famine in this country.

Ireland. A peck of wheat sold for $22 s$.

England. Famine oceasioned by long rains.

Scotland. Desolated by a famine.

China. A famine oecasions a pestilential epidemic.

Ireland. A general famine.

England, Scotland. Great dearth in this and following year. People ate horses, dogs, eats, \&e., to sustain life.-Hounsined.

India. Famine in Delhi, very severe; few of the inhabitants could obtain the necessaries of life.

India. A famine, supposed to have extended more or less over the whole of Hindustan. Very severe in the Desean. The Emperor Mahommed, it is said, was unable to procure the necessaries for his household.-Dow's Hindnstan.

Italy. A dreadful famine which swept awas by absolute starration rast numbers of the inhabitants; and in the following rear a pestilenee of a deadly niture swept the peninsula. "Such was the sufferings produced by these visitations that it was caleulited that two-thirds of the whole population were destrojed." War followed. Encyclopadia Britanica, Art. Italy.

'50 ....... Barbary. Grain exported from England, causing dearth here.

'53 ........ England, France. Great famine-Rapis. much relief.

Great scarcity; grain brought from Iieland afforded 


\section{TABle I.-Chronology of Famines-Contd.}

A.D.

1358

'69

$74-75$

'90.

92

England. "A great dearth and pestilence happened in England, which was called the second pestilence."-Penkethuan.

Poland. Famine.

England. Great pestilence among men and larger animals ; followed by inundations and extensive destruction of grain. Grain very dear. Italy. Famine.

England. Great famine arising from scarcity of money to bny food. , Great scarcity for two years; people ate umripe fruit, and suffered greatly from "Flux." The Corporation of London adranced money and corn to the poor at easp rates.-STow. Short attributes the famine of these three years to the "hoarding of corn." Penkethman gires further details regarding the assistance rendered by the Corporation of London, as follows: "The Mayor and Citizens of London took out of the Orphan's chest in their Guildhall, 2,000 marks to buy Corn and other Victualls from beyond the sea; and the Aldermen each of them layd out 20 pound to the like purpose of buying Corn; which was bestowed in divers places, where the poore might buy at an appointed price, and snch as lacked money to pay doume, did put in surity to pay in the yeare following: in which yeare, when Harrest came, the fields yielded plentifull increase, and so the price of Corne began to decrease," p. 68.

1410 ....... Fireland. "A great famine."

'12-13 India. Great drought, followed by famine, occurred in the GangesJumma delta.

'27 ........ England. Famine from great rains.

29

'33

$37-38$

Scotland. Denrth.

Ireland. Famine of great sererity.

England. Wheat rose from its ordinary price of 4 s. to 4 s. $6 \mathrm{~d}$. per quarter to 26s. $8 d$. Bread was macle from fern-roots.-STow. Rains and tempests.-Short.

'3S.....

England. "In the 17th seere of Henry the Sixt, by meanes of great tempests, immeasurable windes and raines, there arose such a scarcitie that wheat was sold in some places for 2 shillings 6 pence the bushell."-PENKETHMAN.

'39 ....... England (1S Hen. VI). "Wheat was sold at London for 3 . the bushell, manlt at ${ }_{1} 3 s$. the quarter, and oates at $8 d$. the bushell, which cansed men to eat beanes, peas, and barley, more than in an hundred rears before : wherefore Stephen Browne, then maior, sent into Pruse (Prussia), and cansed to be brought to London many ships laden with rye, which did much good; for bread-corne was so scarce in England that poor people made their breade of ferne rootes." - Penkethuan.

'40 ....... England. A scarcity. Scotland. A famine.

'12 ........ Sweden. A famine.

+7 ...........

71

Ireland. Great famine in the spring.

's6

India. A famine in Orissa.

........ England. "Famine sore."

'91 ........ Treland. Such a famine that it was called "The Dismal Year." .

England. Considerable scarcity.

'94 ....... ", Great scarcity and high prices.

'95 ........ India. A great dearth occurred abont this date in Findustan.

97

1521

21

'.2.

Ijeland. "Intolerable famine throughoutallIreland - many perished."

England. Famine and mortality. "Wheat sold in London for zos. a quarter."

India. A rery general famine in Sind,

Ireland. A great famine.

England. Serere famine.

" (19 Hen. V11I). "Such scarcitie of bread was at London and throughout England that many dyed for want thereof. The 


\section{TABLE I.-Chronology of Fumines-Contd.}

A.ก. England-Contd.

King sent to the Citie, of his owne provision, 600 quarters: the bread earts then eoming from Stratford [where nearly all the bakings were, probably on account of proximity to Epping Forest] towards London, were met at the Mile End by a great number of eitizens, so that the maior and sherilles were forced to goe and resene the same, and see them brought to the markets appointed, wheat being then at $15 s$. the quarter. But shortly after the merchants of the Stiliard [Steelrard] bronght from Daniske [Danzic] such store of wheat and rre, that it was better cheape at London thim in any other part of the Realme."-PENintinas.

'28 ........ Venice. Famine.

'40 ......... Sardinia. The island desolated by a famine.

'40-13 India. A general famine in Sind during these years.

'45. England. A wonderful dearth and extreme prices.

'49 ........ :, Famine from negleet of agriculture.

'56-58 ", Famine from great rains, bad and ineonstant seasons; heat and long south winds.--ShorT.

'63 ........ London. Famine and pestilence, said to hare taken off 20,000 people.

'65 ......... Britisl Isles. Extended famine. 2,000,000l. said to have been expended in importation of grain.

'81 ........ Persia. Desolated by famine and plague.

'86

England. "In the 29th yeare of Queen Elizabeth, about January, IIer Majesty observing the general Dearthe of Corne, and otlier Victual, growne partly throngh the unseasonablenesse of the year then passed, and partly through the uncharitable greediness of the Corne-masters, but especially through the unlauful and over much transporting of graine in forreine parts; by the adrice of Her most Hon. Priry Council, published a Proclamation, and a Booke of Orders, to be taken by the Justices for reliefe of the Poore [eommencement of the poor law] notwithstanding all which the excessive prices of graine still encreased: so that Wheat in meale, was sold at London for $8 s$. the Bushel, and in some other parts of the Realme above that price."-PenkethMAN.

'86 ........ Hungary. Famine.

'86........

Ireland. Extreme famine consequent on the wars of Desmond. Human flesh said to have been eaten. Also in England.

'88-89 Ireland. Great famine period, "when one did eate another for hunger."

'91 ........ Italy. Famine.

'94........ England and Hungary. Famine. During the siege of Paris by Henry IV this year, owing to famine, bread whiel had been sold, while any remained, for a cromn a-pound, was at last made from the bones of the charnel-house of the Holy Innocents.-Hiradut.

'95 ........ England. (36 Elizabeth.) "By the lite 'Transportations of graino into forreine parts, the same was liere grown of an excessive price, as in some parts of this Realme, from $14 s$. to 4 markes the quarter, and more, as the Poore did feele; and all other things whatsoever were made to sustain man, were likewise raysed, without all eonseience and reason. For remedie whereof our Merchants brought back from Danshe [Danzie] much Rye and Wheat, but passing deere; thongh not of the best, yet serring the turn in such extremities. Some 'Prentices and other young people abont the Citie of London, being pinched of their Vietuals, more than they had beeno accustomed, tooke Butter from the market folkes in Southwarke, paying but $3 d$. where the owners would not afford it under $5 c$. by the pound. For whieh disorder the said young men were punished on the 27 th Jume, by whipping, setting on the Pilloric, and long imprisonment."-PENketrunan.

'95-96 Italy, Germany, foc. Faminc. 


\section{Table I.-Chronology of Fumines-Contd.}

A.D.

1600

'01-03

'10.

'30

'31 ........

49

'49.

$50-51$

, 56

61.

the Punjab.

'90 ....... Italy. From rains.

'93 ........ France. Awful famine.-VoltaIRE.

'94-99 scotland. Famine; England, great dearth, "from rains, colds, frosts, snows; all bad wcathers."-SHOR'T.

1700 ....... England. From min and cold of previous year.

03 .........

'09.......

'09

'11 ........

27-29

33

'39

'39

39-40

$40-41$

'41

'45-52

48 .

'65

'66

' $69-70$

Russia. Famine and plague, of which 500,000 die, and 30,000 in Livonia ; also in England, "cold, dry summer."- - Снокт.

Ireland. Great scarcity and want. Cannibalism again reported.

Dresden. Tisited by famine.

England. Dearth; bread made of turnips, \&c.

India. A general famine caused by dronght and war; and throughout Asia. following sear.

Lancashire. Oecasioned by the rarages of the armies; and the plague follows it.-SiLuov's Chronological Historian.

Ireland. A famine throughont the country. Sieges of Limerick and Galway.

Rome. Famine for two ycars.

India. Famine caused by drought, and supposed to be confined to

India. Famme in Thar and Parkar districts of Sind.

France. A severe famine throughont the kingdom.

Scottand. From rain and cold; also in England.

Carniola. Famine from rain and mildew ; continued several years.

Ireland. Corn rery dear. "Many hundreds perished." Emigration.

India. Famine; appears to have been confined to North Western Provinces.

France. A serere famine.

India. Famime in Delhi and its neighbourhood.

Ireland. Potatoes destroyed by frost; wheat $42 s$. per kilderkin.

England. "From frost, cold, exporting and hoarding up corn." SHORT.

Scotland. From "terrible shake-winds when corn was ready for reaping." -SHORT.

India. Famine in Nara districts of Sind, and Thar and Parkar.

England. Extended famine.

Ireland. Great scarcity; distilling and exportation of corn prohibited by Act of Parliament.

Scotland. "The magistrates of Edinburgh and Glasgow have put a stop to the exportation of grain, tallow, and butter, in their respective jurisdictions; a power which the magistrates of London do not seem to possess."-Gentleman's Magazine, February.

India (Hindustan). First great Indian famine of which we have record. It was estimated that 3,000,000 of people perished. The air was so infected by the noxious efluria of dead bodies, that it was scarcely possible to stir abroad withont perceiving it; and without hearing also the frantic cries of the victims of famine who were seen at every stage of suffering and death. Wbole families expired, and villages were desolated. When the new crop came forward in August it had in many cases no owners. Encyclopadia Britannica, Art. Hindustan. Other estimates have been that one-third of the population perished.

"Alarming want of rain was also reported throughout all the upper parts of Bengal. Madras was also suffering from drought, and from the rarages of the enemy, and the demands for grain caused a scarcity also in Caleutta. During September, October, and November, the drought continued nearly all over Bengal, the calamity being most severely felt in Behar and the Bengal districts 


\section{TaBLE I.-Chronology of Famines-Contd.}

A.D. India-Contd.

1769-70 north of the Ganges. A plentiful rain fell in June, 1770; but tlie hopes of relief from the next crop which were thereby raised, were disappointed by the overlowing of the rivers in the eastern prorinces; but the new crops in all the districts not greatly injured by floods were good." The famine ceased by the end of the year.Dixvers, 1877.

'70 ........ Bohemia. Famine and pestilence said to carry off 168,000 persons.

'70 ........ Russia and Poland. Famine and pestilence curry off some 20,000 people.

'71 ........ Italy. Failure of harrest.

'75 ........ Cape de Terde. Great famine-16,000 people perish.

'81-83 India. Famine in the Carnatic and the Madras settlement. "The Carnatic had been devastated by Hrder Ali's ineursions in 1780-81, and the settlement of Madras was reduced to great straits for food, as the whole country in its ricinity was suffering from a genernl scarcity. Early in 1781 the Gorernment of Madras took steps to regulate the supply of grain; and the distress continuing, in January, 1782, a public subseription was raised for the relief of the poor, to which the Goremment contributed. This was the origin of the institution for the relief of the native poor, known as the Monegar Choultry. Early in October the Gorernment deemed it necessary to take the supply of rice and food-grain into their own hands. The scarcity seems to hare come to an end in the early montlis of 1783."-DANreRs, 1877.

'82-84 India. Famine in province of Sind, including Thar and Parkar. "When the Kulhora drnasty ceased in 1782, and that of the Talpors commenced, a rery serere famine oceurred, which lasted for two and a-half years. During four months of this time not a grain of corn was procurable. This famine was caused by the burning of crops, and the suspension of eultication during a period of hostilities. There was also no rainfall for two years."-DAsrens, 1877.

'83-84 India. Famine in the north-west prorinees of the Punjab. "The disturbanee of the season of 1783 seems to have been general; but as the countries most affected were not then subject to British rule, rery little information therein is obtainable. There are reasons for beliering that the upper parts of Hindustan had been risited with extraorlinary dronght during the two prerious years. In September and October, 1783, there was an abnornal cessation of rain and extreme drought, and in the latter month a terrible famine was reported in all the countries from beyond Zahore to Karumnasa (the western boundary of Behar) ... and the famine had been already felt in all the western districts towards Delhi. 'To the northward of Calentta, the crops upon the ground had been scorched, and nearly destroyed."-Daxrens, 1877. By the middle of 178.1 the famine had abated.

'87-88 India. Famine prospects in Behar and north-west provinecs of Punjab, consequent upon aceess of rain and floods. The Government laid an embargo on the exportation of grain.

'89 ....... France. Grierous famine; province of Ronen.

'90-91 India. Famine in district of Baroda, and in many adjoining districts, in some of which, howerer, it was only partial and local. "Very little is known conecrning the famine in many of the distriets named, beyond the fact that in 1790 tradition records the occurrence of a very severe famine. An almost total failure of rain was the immediate cause, apparently, of the ealamity ; and suflicient information exists to prove that it was one of the most remarkable on record. So great was the distress that many people fled to other districts in search of food; while others destroyed themselves, 
A.D.

Table I.-Chronology of Famines-Contd.

1790-91 and some killed their children, and lived on their flesh. In India-Contd. Belgaum the scarcity was aggravated by people flocking into the district boarding on the Godavery."-DANvers, 1877.

In Kach, in 1791, a famine was caused by innumerable black ants which swarmed in almost all parts of the country, and destroyed vegetation. [This Kach, formerly Cutch, is in Bombay Presidency, situated south-east of the mouths of the Indus, and appears in later times to have become a terribly God-forsaken place: famines and plagues eonstantly!]

'90-92 India. Serious dearth in the northern districts of the Madras Presideney, and the pressure continned for about two years, from Norember, 1790, to November, 1792. "Nany deaths from starvation occurred. At an early period Government suspended the import and transit duties on all kinds of grain and provisions, and themselves imported grain from Bengal. In the latter part of 1791 the export of riee from Tranjore was prohibited, except to the distressed districts. Rice was distributed by Goremment, and relief was afforded by employing the poor on public works." DANVERS, 1877.

This was the first oceasion of the poor being employed on public works by the Govermment in India.

'95 ........ England. Scarcity of food severely felt.

1801.

United Kingdom. Great scarcity; flow obtained from America; Committees of both Ilouses of Parliament were appointed to inquire into means of supplying food.

'02-04 India. Famine in the Nizam's dominions (Bontbay Presidency). "This famine was cansed in the sercral districts affected by it by four distinct eauses, which operated apparently about the same time. In Kach the erops are said to lave been destroyed by locusts. In Pahlumpur, Rerra Kanta, Surat, Guzerat, Hyderabad, Belgaum, and Rutnagherry, the famine is stated to have been caused by want of rain. Candersh was overrum by the armies of Holkar; and the Pindaree bands sacked and burned villages in every direction, even destroying the grain standing in the fields; and the same fate attended the districts of Ahmednagar, Poona, and Sholapur: whilst the influx of starving people from other districts into Sattara, Kolapur, Dharwar, and Colaba, caused a scarcity of food in those districts."-DANvers, 1877.

'04-07 India. Scarcity in the Bombay Presidency, following the unfavourable scason of 1804 ; severe pressure on the poorer" classes. "In the latter part of the following year a general failure of crops appears to have occurred in most parts of the presidency, and the scarcity caused thereby had not passed over until October, 1807." -DANTERS, 1877.

'12 ....... United Kingdom. Great scareity in England and Ireland.

'12-13 India. Famine in parts of Sind and other neighbouring districts, attributed to failure of rain. "In Kach and Pahlumpore the loss was aggrarated by locusts; and in Kattywar it was followed by a plague of rats. Guzerat suffered most from scarcity caused by export of grain to the famine districts; and Almerdabad was overrun with starving immigrants. In Mahee Kanta the distress was caused by internal disturbances; whilst in Broach there was no failure of rain, but the crops, before they were reaped, were entirely devoured by locusts, which came in very large numbers, and spread all over the country."-Danvers, 1877.

'12-14 India. Scarcity in 'Madras Presidency, following unfavourable season of 1811 ; "but no serious distress appears to have been generally experienced throughout the presidency on this occasion, although the district of Madras suffered considerably." DANVERS, 1877. 


\section{TabLe I.-Chronology of Fumines-Contd.}

A.D.

1813

'13-14 then only partial.

'19 ......... 1877. Danvers, 1877. same. 1877.

Poland. Suffered from famine, consequent upon an inundation : also Droutheim (Norway), in consequenec of the intercepting of supplies by Swedell; 5,000 perished.

Iudia. Partial famine in many parts of the Agra district; the autumn erop of 1812 failed, and the havest of the following spring was indifferent. In 1813 the rains set in late, and were

India. Great scareity in the Allahabad and neighbouring distriets, under the following circumstances:- "The rains set in late, but when they did come they appear to have fallen in abundance. The land which had hitherto been so dried up by the heat that sowing had to be undertaken twice without any effeet, beeame so drenehed that a third sowing was not possible till the middle of September. In Bundelkhand the kharif of 1819 fniled extensively, and frost nipped the spring erops in the beginning of 1820."-DAxYers,

India. Famine in Upper Sind and neighbouring provinces, caused only partially by drought. "In 1819 there was a failure of crops in Ahmedabad, caused by unscasomable weather after the monsoon; whilst in Sawunt Warru it was oceasioned by a sudden and unusual fall of rain, accompanied by a terrific storm-the former destroying the ground erops, and the latter the bagayut produce."-

Ireland. Dreadful famine, produced by failure of potato crop.

"While, howerer, the agrieulturists of the continent were suffering from an abundance, a grievous famine arose in Ireland, slowing the anomalies of her situation, resulting either from the staple food of her population differing from that of surrounding nations, or the limitation of her commercial exehanges with her neighbours. Her distresses from searcity were aggrarated by the agrarian outrages, originating in the pressure of tythes and raek-rents on the peisantry and small farmers. Several of the ringleaders of these disorclers were apprehended by the eivil and military power, and greut numbers executed or transported."-WADE's Brit. Hist.

India. Famine in screral districts. In Delhi and neighbouring prorinees it was due to serere drought; in the Madras Presideney, and more particularly in the Carnatic and Western districts, the cause was failure of rains at the usual season. In Hindustan the

India. Famine in the north-rest provinees, occasioned by failure of rains; and scarcity in Sangor and Nerbada territorics caused by blight, and a succession of heary thunder storms.

India. Famine in parts of IFindustan. "The autumn of 1827 and the following spring were marked by drought across the Jumna. In Pergunnahs, Rancea, and Sirsa, the rains commenced auspiciously, but stopped abruptly carly in July, and did not begin again till the 22nd September. It was then too late to retrieve the misehief which the drought had already caused; and to add to the general distress, there was every cbance of a failure in the wheat. This was the staple rubbee crop in these regions, and its success was mainly dependent on the river Ganges orerflowing its banks, but on this oceasion the usual inundations did not oecur." - DANvers,

Ireland. Famine; Parliament granted 40,000l. for relief; 74,410l. subscriptions in England.

India. Scarcity in Poona and the southem Mahratta country, producing considerable distress, but hardly a famine.

India. Famine in some of the north-west provinces. "It is said that not a single shower of rain fell in Ajmir in 1832. In the following year the drought was most sererely felt in Lundelkland, 


\section{TABLE I.-Chronology of Famines-Contd.}

A.D. India-Contd.

1832-34 and in the southern pergunnahs of Campore; but in the per. gummahs bordering on the Ganges, the rubbee was good owing to the facilities for irrigation."-DANVERs, 1877.

'33 ...... India. Famine in the Guntoor and other distriets in the Madras Presideney; about 200,000 perished. Mr. Danvers says "this was the most serious famine which has occurred since the British occupation, and from the fearful loss of life which took place in the Guntoor district on this oecasion, the scarcity became generally known as this "Grmtoor famine." "

'33-35 India. Famine in Madras Presidency.

"In 1831 rain fell eopiously in Kach; grain was sown and eame up well; but locusts appeared and destrored all the erops and grass as well as the trees. In Ahmedabal there was excessive rain the same year, which rendered cultivation impossible, and lncusts also appeared in great quantities. In Broach the famine of 1835 was also eaused by excessive rain, which destroyed the spring crops, whilst the winter erops were also burnt up by intense cold. In the other districts named, the scarcity appears to have been eansed by failure of erops owing to drought." -DANYERS, 1877.

'37-38 India. Famine in north-west provinces, resulting from a general failure of rain. This was also felt in the lower provinees : for in Caleutta it is said the tanks were empty. Lord Auekland wrote in January, 1838: "The fall in the usual season of the rains last year was unusually late and scanty; and an absolute drought has followed up to the present time."

'38-39 India. Great seareity and eonsiderable distress, eaused by failure of rains in Surat and other distriets in the Bombay Presidency. Large numbers of people left these provinees in search of food elsewhere.

'45. Ireland. Famine; the Govermment expended $850,000 l$. in relief of sufferers.

'46 ....... Belgium. Serere famine; but relieved from supplies from neighbouring countries.

'46-47 Ireland. Great potato famine; Parliament advanced nearly 1 0,000,000l.; about 275,000 persons are supposed to have perished. The famine in the whole lasted over nearly six years; the population beeame reduced by about 2,500,000. The emigration to America was $1,180,409$, and $1,029,552$ are said to have died from starration and pestilenee eonsequent upon it. This is probably orer-stated. It is further said that about 25 per cent. of the emigrants died within twelre months of leaving. The Commeree and Navigation Laws were repealed.

'47 ....... France. Scarcity. Food riots. At Chateauroux a wealthy com merchant who defied the mob was set upon and beaten to death.

'53-5.4 India. Great searcity in the Bellary district (Madras Presideney). "The rains which usually fall in the months of October and Norember, ceased at an unusually early period in the ycar 1853; and the showers whieh usually fall in June and July, had been scanty. The grain harvests were eonsequently almost universally deficient, and considerable distress oceurred in sereral parts of this presidency. In Bellary district, the season had been exceptionally unfavourable: an average fall of only $9 \frac{1}{2}$ inches of rain having taken place during the year, against an arerage of about double that quantity in prerious years. The stocks of grain on hand were small : for serious damage had been oecasioned by a storm in 1851 to seceral of the irrigation works of the distriet; and in 1852 the falls of rain had been unseasonable, and the erops short."DANrers.

'60-61 India. "In 1859-69 the Delhi territory suffered from want of rain. The great Nujjufghur Jheel. beeame entirely dry-a thing nercr before known within the memory of man. The rains of $1860 \mathrm{com}$. 


\section{TABLE I.-Chronology of Famines-Contd.}

A.n.

1860-61

'61-62

'66

'68-70

'71-72

74

$74-75$

37

India-Contd.

pletely failed in the country between the Jumna and the Sutlej; and exeept where irrigation was avitilable, no autumn or spring erop could be sown."-1) Axrers, 1877.

India. Considerable seareity of food in Kach and varions other districts of the Bombily l'iesidency, owing to seanty and unseasonable rains in 1861 , and to short fall in the early part of 1862 .

Indire. Awful famine in the Lower Prorinces of Bengal, Orissa, Behar, \&e, ; 1,500,000 persons reported to hare perished.

"The total quantity of rainfill for the rear [1865] was not nnusually small in most of the districts of Bengal, but it fell abnormally and out of time. Nuch rain fell carly in the senson, before the usual tine for sowing, while the later mins, which are usunlly expected in the end of September and October, failed."DANTERS, 1877.

Great searcity also in Madras Presideney, through many districts.

India. Famine and scarcity in a considerable number of the northwest provinees, including Delhi, Mecrut, \&e. This was oceasioned by failume of the harvest of 1868, following upon the inferior crop of 1867.

Persia. Serere famine.

India. Bengal; famine arising from drought. The Gorermment took early measures, and at a cost of 6,500,000l. organised a system of relief. About $1,000,000$ tons of rice were carried into the distressed districts; and about 100,000 remained after relief concluded.

Mr. Danvers gires us the following details respecting this famine :"During three sucessive rears the weather in Bengal had been abnormal. In 1871 the rain was exeessive, but the erops wero good. In 1872 the rain was deficient, but although extraordinarily seanty, it was happily distributed both $\mathrm{m}$ time and place, and the erops were good in Bengal, and not bad in Behar. The year 1873 was again dry, almost beyond precedent, and what rain there was was unfortmately distributed. Soulh of the Granges it was exeessive; but in Nortli Behar, and almost the whole of Bengal, the rain was below the arerage. Coupled with defieient rainlall, the monsoon of 1873 was abnormally hot . . . . In January, 1874, it was reported that the frost and west winds were drying up the erops in Patna. The famine seached its eulminating point in April and May."

Asia Minor. Severe fumine; great efforts made by Turkey to alleriate; also subseriptions ritised in England. Deaths up to July, 1874 (Times, 31st Mareh, 1875), i 50,000.

India. Madras Presideney. One of the most extended famines on record. The eost to the Government of India, in remedial measures and loss of rerenue, is estimated at $10,000,000 l$. The aetual amount of mortality oceasioned is rlifficult to determine, the estimates vary so much. Cholern prevailed in some of the famine distriets, and added greatly to the number of deaths. The Mansion House Relief Fund, instituted by the lord mayor (Sir Thomas White), exeeded half-a-million sterling.

Mr. Danrers gires the following details regarding the meteorologieal ineidents associated with this famine: "The season of 187.1. was generally good, but in parts it was unfarourable. In 1875 tho season was in many places unpropitious. In 1876 the south-west monsoon, or summer rnins, were deficient throughont the greater part of the Madras Presideney, and in the Bombay district of Poona. In the northern portions only of the Madras Presideney ... was the rainfall ordinarily propitious. The north-east monsoon, or autumn rains, failed still more disastrously. In October the whole of the nine distriets of the Bombay Decein were threatenel with a scrious famine, nearly all the monsoon crops 


\section{TABLE I.-Chronology of Famines-Contd.}

A.

1877

77 ..........

'77

$77-78$ India-Contd. having perished, and there having been no later rains to admit of sowing the rabi. ... The spring and summer rains again failed in 1877. . . . and added to this, the rainfall was short almost all over northern India.

Egypt. Short rainfall and low Nile; great scarcity.

Morocco. Drought of preceding season produced famine.

Brazil. Great drought in northern provinces, and upwards of 200,000 of the population exposed to famine.

North China. A telegram dated 26th January, 1878, says : "Appalling famine raging throughout four provinces North China. Nine million people reported destitnte. Children daily sold in markets for [raising means to procure] food. Foreign Relief Committee appeal to England and America for assistance." Total population of districts affected, to millions. Mr. Fredk. H. Balfour, of Shanghai, said: "The people's faces are black with hunger; they are dying by thousands upon thousands. Women and girls and boys are openly offered for sale to any chance wayfarer. When I left the conntry, a respectable married woman could be easily bought for six dollars, and a little girl for two. In cases, however, where it was found impossible to dispose of their children, parents hare been known to kill them sooner than witness their prolonged sufferings, in many instances throwing themselves afterwards down wells, or committing suicide by arsenic."

"Lord Derby received a report drawn up by Mr. Mayers, Chinese Secretary of the Legation at Pehin, upon the distress which the drought of the last two years has caused in the northern and central provinces of China. This famine, it seems, has been most severely fell in the district furthest from the coast. With the exception of Chefoo, and, in a lesser degree, Tien-tsin, no foreign settlement has come directly into contact with the misery which has been described as existing in the interior, nor are any immediate traces of it visible in the neighbourhood of the capital. The apparent cause was disturbance in the usually unfailing regularity of the summer monsoons. The spring and summer of 1876 were marked in the southern maritime provinees, Kwangtung and Fuhkien, and in a less degree also along the coast as far north as Ningpo, by an excessire rainfall, cansing in the two prorinces aborenamed disastrous floods and much destruction of crops. In the north, on the contrary, from the Yangtsze to the neighbourhood of Pekin and thence eastward to the borders of Corea, an unusual drought was experienced."-Times, 13th March, 1878.

Further papers on this famine were presented to Parliament, 2nd July, 1878. The number of souls for whom relief is required is said to be between 3 and 4 millions. One point brought ont is the enormous cost of transporting supplies to the prorince of Shansi, where a mountain range has to be crossed and a distance of some hundreds of miles to be traversed by carts. Mr. Mayers says the reported cost of transporting these supplies to Shansi would be about four taels per picul, or, sar, I 2 l. sterling per ton. Mr. Hugh Fraser sends from Pckin, 18th January, the translation of a memorial addressed to the throne by Yen King-Ning, "Special High Commissioner for the Superintendence of the Arrangements for Famine Relief in Shansi. The commissioner dwells npon the painful scenes he hats witnessed at erery stage of his journey, in the course of which his chair has continually been surrounded by crowds of the famine-stricken population iuploring relief, to whom he has administered comfort in soothing words, assuring them of the Imperial sympathy. The roads are lined with corpses in such number's as to distance all efforts for their interment, while women and children, starring and in rags, know not where to look for the 


\section{TABLE I.-Chronology of Fumines-Contd.}

A.D.

North China-Contd.

means of keeping body and sonl together. The memorialist, his henrt wrung with despairing pity, cannot but ask why has a cahmity so awful as this been risited upon the people. IIe ean only ascribe it to his own failure in the dne discharge of his duty, and he feels that bis shorteoming admits of no excuse. In reply, the Grand Conncil has received a reseript expressing profomd sympathy with the sufferings of the people as reported in this memorial, and directing that all that is possible for their relief be done, in consultation with the governor of the prorince."

Note.-The Empire of China las long been subject to the most serions famines; but of these we have found no details available.

75

Morocco. A eorrespondent of the Jewish World, residing at Mogador, and earrying on business in that cit $y$ as a merehant, writes:- "I regret to say that from want of rain the southern part of Moroceo, comprising the provinces of Soos, Haha, Antuga, and the Moroceo districts, is suffering from famine, every description of food being exceedingly scarce, and the pauper population of Mogador, always disproportionately large, forming about one-third of its entire inluabitants, is being rapidly increased by numerous famished Jewish and Moorish fimilies from the adjacent districts. It is a fearful sight to see some of them-mere living skeletons. The Jews are beharing well, and hare collected large smms and distributes them; they bare now agreed to pay a tax of $3 \frac{1}{2} d$. on evely package of food and grain imported, and the money is being distributed weekly anong the Jewisl poor. The Moors, poor creatures, get no assistanee from the Government, and little or nothing from their co-religionists; they are mainly dependent upon the eharity they receire from the Jews and a few Christians. Unless this Gorernment quickly does something to assist the sufferers, I fear that the limted resources of the merelants here will necessarily fail under the continual drain, and render them mable to assist the inercasing number of poverty-stricken people. There is no kind of business now doing, except in articles of food, and consequently the working classes have nothing to do. They are selling their clothes and furniture to obtain food, and when these have gone the amount of destitution will be inercased. I fear, mnless relief comes from the Gorernment here, or from some charitably-disposed persons, that I shall hare to relate the most distressing aceounts. Alreadr some cases of actual starration have oceurred among the Moors. If rou conld sec the terrible seenes of misery-poor starring mothers, breaking and pounding up bones they find in the streets, and giving them to their famished chillen-it would make your heart ache. Raise a few pounds if you ean, and if yon ean do so lay it out in rice at the wholesale brokers, and liave it shipped by the steamers learing Englind."

'78 ....... Cashmere. Serere famine, regarding wlich, howerer, no exact details have come to hand.

It is seen from the preceding table (which includes in the whole over 350 famines in various parts of the world) that famines have given rise to several of our more important and distinctive institntions-as the Poor Law in England in 1586, and its equivalent in India in 1781-83; as to Government ReLIEF Works, vide famine in India in 1790-92, since followed ont in varions parts of the empire.

But in truth they gave rise to our Conx Laws, see first record of importation of grain during the famine, 1258. I expect to be able 
to show, in a later part of this paper, that famines gave rise to imperial restrictions on the price of FOoD as early as about the twelftl century. The literature of famines will be passed under review in the second portion of this paper. The subject of Indian famines, which occupy such a prominent place during the last century of the table, will be spoken of specially later in this paper.

\section{Dnumeration of the Cruses of Famines.}

A careful analysis of the preceding table, and of the authorities from which it is compiled, reduces the causes of famines to the following:-

1. RAIN, by excess of which, producing Froods, the soil becomes saturated, and decomposition of the seed is produced.

2. Frost, whereby either the process of sowing is retarded, or rendered impossible, or the ritality of autumn-sown seed becomes destroyed; whereby also the transport of grain was in former periods rendered impossible.

3. Drocaht, whereby the natural moisture essential to vegetable production is withheld from the soil.

4. Meteorocogtcal Phenomena, other than the preceding, as comets, hail, earthquakes (the latter frequently leading to irruptions of the sea, \&c.).

5. InsECTs, as locusts, grasshoppers, ants, \&c. Vermin, as rats, $\& c .$, destroying vegetation.

6. W $\mathrm{AR}$, whereby cultivation is prevented, or the crops wilfully destroyed, or, as to particular towns and localities, where a blockade has been established.

7. Defective Agriculture, arising either from ignorance, indifference, or unsuitability of climate or location.

8. Defective Traxspont, or bad roads, want of canals, or shipping, or wilful obstruction.

9. Legistative Interference, whereby the natural course of supply and demand has been interfered will or interrupted.

10. Currency Restrictions, including debasing the coin, whereby either direct or indirect influences may be brought into play.

11. Speculation, known technically as "engrossing," whereby the necessary supply of food for the people has been "forestalled."

12. Misappetcation of Grain, such as its excessive use in brewing, distilling, or by bnrning, whether wilfully or by misadventure.

At a first glance these causes arrange themselves into two entirely distinctive divisions:- 1 . Natural Caíses, or those bejond human control. 2. Artificial Causes, or those within human control. The first five canses named rank almost entirely nnder the first division. The remainder are all subject to human control, although 
not alrays immediately so, at least by those most affected at the moment. I shall deal with the natural or unavoidable causes first.

1. Rarv.-In temperate climates like our own, an excess of rain rery frequently leads to famine. The ground becomes sodden, and it is thus impossible to get upon it for purposes of efficient cultivation; or the seed having been deposited, is destroyed. Or again, if the rainfall be in the latter half of the year, the grain is not sufficiently ripened for the harvest; or if it shall have been cut, then it becomes stacked without being properly dried, by which means mildew is engendered, and it moulders aud spoils. It is remarkable to notice what a large proportion of the famines in the three divisious of the United Kingdom lare been occasioned by rains. Improved cultivation of the land, as good diaiuage, \&c., lessen these evils.

Unfortunately in this country we have no meteorological records by which the rainfall orer any lengthened period of iime can be ascertained. In the absence of these, I am driven to another expedient, and this is to bring into requisition a table of floods. The effect of this table is to widen our view of the causes from which famines may arise and have arisen. Many of the statistical details contained in this table have a value quite apart from any immediate bearing upon fumines. I have extended it to all parts of the world, in order that its range may be identical with that of the famine table.

TABLE II.-Of the Floods and Inundaiions of the World.

B.c. The Deluge, the first mention of which oecurs in Gen. iv, 7-22, where Date not is described the dircetions jeeeired by Noal relative to the construcfixed. tion of the ark. The commencement of the Flood is related in Gen. vii, 10-12. The waters inereased for 40 dars (v. 17), and remained upon the earth 150 days $(v .24)$, at the end of which time the ark rested on the mountain of Ararat (Gen. viii, 4). This was regarded by the narrators of, the event as a general delnge-a fact now very much doubted on seientific grounds. The date of the occurrence ranges according to the estimates of different authorities from B.c. 3246 down to B.c. 2104. - Townsend's Dictionary of Dates.

1760 ........ Attica (Greece). A flood known as the Deluge of Ogyges. It was occasioned by the sea being driven in by winds, and is sometimes spoken of as the "Second Delinge."

1504 ........ Deucalion (Greece). Great lood from rain, whieh extended all through Thessaly. It is sometimes spoken of as the "Third Deluge."

322 ....... Ephesus (Asia Minor) was destroyed by an inundation. Rebuilt on a more elerated site B.c. 300 .

241 ....... Rome. The orerflowing of the Tiber is said to have swept away all the houses and buildings in the lower part of the city. The river orerflomed again B.C. 54 and 27 . (See A.D. 15.)

A.D.

7..

England. Great flood in valley of the Thames; many persons drowned, and eattle destroyed.

9........... England. Great overflow of Humber, flooding the country all round. 


\section{TABLE II.-Of the Floods and Inundutions of the World.-Contd.}

A.D.

$56 \mathrm{t}$

570

575

579

580

590

634

619

669

684

685

690

693

717

719

730

733

818 or 520

834

840

856

$86 \mathrm{~L}$

861

876

885

912

918

918

935

942

$9+2$

952

959

968

973

989

1012

'13

'14

'16

'20

'31

'40

'45

'46

Fingland. Great rain floods.

Italy. Great rains and floods.

England. Parts of Essex, Suffolk, and Norfolk inmndated from tho sea.

France and Italy. Great rains and floods.

Anglesea (Wales). Much damaged by the sea.

Italy. Great lloods from tempest ; followed by plague.

Ireland. Floods in Munster.

Cheshire and Lancashire (England). Greatly damaged by inundations of sea.

Kent (England). The Medway orerflowed; great dimage.

Japan. More than 500,000 acres of land in the Isle of Sikokf swallowed up by innulation of the sea, following earthquake.

Ireland. Great inundation from the sea.

Italy, Venice, Liguria. Great lloxls from violent rain storms.

Ireland. Floods of rain in Leinster.

Rome. The Tiber greatly orerflowed from rains.

Ireland, A rainy summer ; great inundations of the sea.

Ediaburgh (Seotland). Great damage by riin or inundation.

Glasgoro. Great lloods; more than 400 families drowned. [Some authorities give the date 758 .]

Ireland. Great fall of rain, and consequent floods.

"A flood in Darinis."

Italy. The Tiber much flooded by rains.

England. Great orerflow of the Severn; 2,000 people and 7,000 eattle dromed.

France. Great rains and floods.

Northumberland. Tweed orerflowed and extended 30 miles round. Loss of life and euttle.

Germany. The Rhine flooded from rains.

England. Great rains and floods, followed by epidemie of quinsy.

Kent (England). Floods in Medway. Great loss of eattle.

England. The Humber again greatly flooled.

Saxomy. Great rains in June. Extended damage.

Cheshire. The Dee greatly overflown; many rillages injured.

Saxony. Flooded by rain, "after a eomet."

Scotland. Rains extending over five months; eonsequent floods.

Ireland. A great flood.

Southampton. Great floods; many people drowned.

England. Deeember. Great rains and floods, "after comet in November."

Ireland. Great flood of the Shannon.

Bagdad (Asiatie Turkey). Half the eity iuundated from great overtlow of the Euphrates.

Bagdad. Nearly three-fourths of the eity inundated from a serious overflow of the Euphrates.

Persian Gulf. Severe irruption following earthquakes. Several eities destroyed, and new islands formed.

England. Thames greatly orerflown; many people drowned.

$$
\text { " Floods all the winter. }
$$

and Germany. Great inundations of the sea.

Earthquake, floods, thunder, lightning, hurricane.

Great inmundations of the Linglish coasts; "a number of

,

" seaport towns demolished."

Ireland. Excessire rains and floods-produeing cattle mortality.

England. Great floods followed by plague.

" Extended general floods from rains.

Germany. Great floods.

Flanders. Inundations from the sea.

Severn Valley (England). Great rain floods; loss of cattle. 
Table II.-Of the Floods and Inundations of the World-Contd.

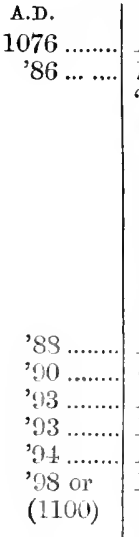

1099

Bagdad. The Tigris orerflowed and inundated Bagdad.

England. Heary lloods from rain.

"In the twenticth year [of William the Conqueror] there fell such abundance of rain that the river's did greatly orerflow in all parts of the Realn. The springs also rising plentifully in divers hills, so softened and decared the fondations of them, that they fell down, whereby some rillages were overthrown. By this distemperature of weather much cattle perished, mueh eorn upon the ground was either destroyed, or greatly impairel. Thereupon ensned first a famine, and afterwarks a miserable mortality of men " [Plague]Harleian Miscellany, iii, p. 167.

Bagdad. The Tigris again orerflowed and dit much damage. Constantinople. Great floods.

Ireland. "Great rains and inundations in summer and autumn."

England. Great floods. and aiterwurds serere frost.

Ireland. "Great inumlations in all Ireland."

English Chanizel. Earl Godwin's lands, exeeding 4,000 aeres, orerflowed by the sea, and an immense sand-bank formed on the coast of Kent, now known as the Godwin Sands.-CAPDEN.

$1100 \mathrm{or}$

Englund. Rains and sa floods, "fatal to much people and eattle." Thames muth flooded on festiral of St. Mintin.

Flanders. A terrible inmolation forced many of the inlabitants to 1105) leare the eountry. Some settled in England. Nearly the whole of this country is believed to have been corered by the sea in early times. On this oeeasion the town of Ostend was immersed.

05 England. Great flools, followed by famine.

'06 " Inundation from the sea.

'18 or' 10

$25 \ldots . . .$.

'33

34 ..........

$52 \ldots . . . .$.

, 56

ว7 0158

'61.

'62.

'65.

,

Constant floods all the ,ear; "no corn sown or reaped."

,

Great flood on St. Lawrence's Day.

France. Great lloods from rain.

Flaaders. Inundation from the sea.

Gerinany. Great floods on the Rline from rains.

Finlland. Rain floods, lasting all the harvest.

Haly. Great orertlow of the Tiber. Tomandy. Great floods.

Sicily. Inmmelation of the sea; drowned 5,c00 per'sons; "flools in many rivers, multitudes of pe ple lost." "(1165.)

70

Folicind. Inundation from the sea; many people and eattle lost.

Sicily. Irruption of the sea; 12,000 prejile drowned. (1161.)

Holland, Friestand, and Utrecht. Terrifie flood. In the latter province the water rose to so great a beight that the people were able to eateh fish with nets within the walls of the town.-DATiEs' Holland.

'71 ....... England. Inundation of the sea; harrest destroyed in many places.

$72 \ldots . . . .$.

Ireland. "Great floods destroyed numbers of men."

73

Germany. Great tloods on the Rhine.

36

Holland. Great flood [? inundation] which considerably extended the limits of the Zurcler-zee.

Lincolnshise (England). Inundation from the sea; also in Holland.

'79

387

England. "MIny floods from a most serere winter." - Sногт.

'88

'96

" Great lloods. eattle."

Great floods in March from rains.

England. Great floods in March from
$y, \quad$ Serions flools from rain.

?ด9

1208

France. Terrible rains and great floods, destroying briages, houses, \&c. "Greatest erc1" seen in France."-Snort.

'09

England. Great Hoods on St. Nicholas Eve, "after a tempest of thunder and lightuing." Décember. 


\section{TABLE II.-Of the Floods and Inundations of the World-Contd.}

A.D.

1210 or 12 Perth (Scotland). Great flood from overflow of Tay and Anan rivers: many houses washed down and people drowned. The king lost his youngest son and nurso in it; and twelve of the connt ladies were drowned. The king and his brother with great dificulty eserped in a boat.

'12 ....... Sicily. Inundation from the sea, "thousands of people swept away by it."

'18 ........ England. Great floods in the night in winter.

'19 ........ Nordland (Norway). "The St. Lawrence Lake broke out and drowned 36,000 people, besides eattle."

'20 ....... Poland. Floods from constant rains; Friesland, inmuations, Oetober.

'22 ....... England. High tides; great dimage. Also eontinuous rain storms. " In the "seventh yeare of Henry III, on Holy Rood Day, was a great thunder and lightning tempest thronghout all Englanil, and such great floods of water followed witl great wiuds and tempests, which continued till Candlemass, that the yeare following wheat was sold for $12 s$. the quirter."-PEnketminax.

'28 ....... Frieseland. Irruption of the sei, 100,000 people drowned.

'30 ........ Italy and France. Great overlow of the Tiber; floods in Franee.

$3 ?$ Austria. Great overtlow of the Damube.

'40 ........ England. The Thames greatly flooded from rains. Extended above 6 miles at Lambet].

'17-50 England. Sereral inundations of the sea; great losses.

'51 ........ ," Tides rise 6 feet ligher than usmal.

'51 ......... Treland. 29th June. Great inundation of the Shamnon.

, 57

' 60

'66

' 69 England. July. Great floods from rains.

Germany. Great floods on the Rlime.

Scotland. Great inundations of the Tay and Forth from the sea.

76 England.

February. Great floods from thaw.

76

77

78 , Great Hoods from the sea, and from rains.

Bagdad. The eity again inundated after appearance of red flame.

Holland. Great inmudations at Friesland, forming the Dollert Sea.

Italy. Great overflowing of the Tiber.

England. Great floods all the summer; espeeially in Angnst.

Winchelsea (England). Great inundation of the sea; more than 300 houses swept away. "Charter granted for erection of new port."

'86-87 Holland. A dreadful storm, laid the whole country on both sides of the Zuyder-zee under water. 'To such a height did the water rise that Count Florenee took advantage of the eireumstance to subdue the inland towns by armed ressels called "eogs."-DAviEs" Holland.

'87

England. Winter excessirely rainy; great floods. 1st June. Sea broke in from the Humber to Yarmontl, foreed by the winds. In December on Suffolk and Norfolk coasts. Plagne all the year.

'87 ...... Salandria (?). Fifteen islands submerged by the sea, i 5,000 people drowned.

'89 ........ England. Great hailstorm, followed by heary rains, greatly affeeting the next year's harrest.-Penketminas.

'91 ........ Damascus (Syria). Inundated by orerflowing of streams.

'99 ........ England. Flood after a comet. In November inundation from the sea, in the Thames. "In Decenber" great ealm, heat, and clearness."-SIIORT.

1304 Damascus. Again inundated.

'15 ........ England. Great rains and floods during harrest; mueh grain spoiled.

England. Heary rains; grain did not ripen; harrest not commeneed till Michaelmas.

'35

Florence. Norember. Great orerflow of the Arno.

England. Continued rain storms; corn spoiled. 


\section{TABLE II.-Of the Floods and Inundations of the World-Contd.}

A.D.

'39.

' 48 .......

'50

'65

'96

1404

'12

' 21 .........

86

'91

1501

'11

'15

'21

'23-26

'24.

26

England. Continnous rain from beginning of October to December.

" 22nd Mareh. Great flood in Tyne; many lives lost.

" Violent rains from Midsummer to Christmas, "so that there was not one day and night dry together."

England. "Floods, storms, tempests, and fiery meteors in the air."

Violent rain storms.

Holland. "Another deluge," which formed the Marsdiep, separated the islands of Texel, Vlielandt, and Wieringen from the mainland, and submerged other districts. "This first raised the commeree of Amsterdam."

England. An inmotation from the sea.

"12th October. "Sea flooded thrice without ebbing."

Holland. Dreadful and most destructive inundation, overwhelming serenty-two villages, $t$ wenty of which were never recovered. The loss of life [nearly 100,000 persons on some authorities] and property was immense; many noble families were reduced almost to beggary. By this inundation the Biesbosch was formed, and the town of Dordrecht separated from the mainland of Holland. [Some authorities give the date of this event as 1446.]

6 ........ Istula (? Tistula, Germany). Flood of the.-SHoRT.

England. The Serern overflowed during ten days, and carried away men, women and children in their beds, and covered the tops of many mountains; the waters settled upon the lands, and were called "The Great Waters" for a hundred years after."-Hotrns Hed.

Iieland. Great rain and floods all the summer; called the "Dismal Tear."

Germany. The Elbe orerflowed. 14th August. The Albis ditto.

Irelant. Great inundation, which produced considerable destruction.

Germany. "All Germany like a sea, and Craeovia flooded."-Sноrт.

Holland. 1st Norember." "A dire inundation of the sea, and 100,000 drowned."-SHORT.

Turkey. The rivers greatly swollen, and pestilential diseases prevalent.

Naples. Terrible inundation.

England. 18 Hemry VIII. "In Norember, December, and January fell such abundance of Reine that thereof ensued great Flouds, which destroyed Corne-fields, Pastures and Beasts. Then was it drie until the 12th April ; and from that time, it rained every day and might, till the 3rd June: whereby Corne failed sore in the yeare falling." - Old Chronicle.

'27 ....... England. Great flood.

'29 ........ Switzerland. June 13 or 14. Great flood at Basle. England, 2nd October. Great flood in Thames.

'30 ........ England. Great floods all the year. Rome. 8th Oetober. Great flood.

'32 ........ Holland. Great floods.

'34 ........ Poland. Extensive floods.

'47 ........ Tuscany. 12th August. Great floods.

49

England. 13th June. Severe rain floods.

'50 ........ " "The Thames flowed thrice in nine hours."-SHort.

'51 ....... Marpurg [? Marpod or Mariapod, Austria]. January and February. Great floods.

'52 ........ Budissina (Saxony). 13th August. Great floods.

'53 ........ Germany and Holland. 19th January. Great floods in the Rhine.

'54 ........ Ireland. Perpetual rain all winter; great floods.

England. 21st September. Great floods in the Thames.

France. 10th September. Floods near the district of Languedoc. 


\section{TABLE II.-Of the Floods and Inundations of the World-Contd.}

A.D.

1565

69

70

'70

71

'73

'74.

'79 ........ England. September and October. Great inundation from the sea

Louvain (France), Great inundation from the sea; wind.

Englani and France. Great floods.

England. 5th Oetober. Inumlation from the sea.

Holland. Inundation. A strong north-west wind occurring during the high tides, drove the sea with such riolence against the dykes that sereral of them were broken down. The waters rush in on every side, and rolling forward with resistless furs, snept away houses, trees, men, and cattle, in one universal ruin. Entire rillages were destroved. The number of lires lost in Frieshnd alone was estimated at 20,000 ; and was very extensive in other prorinces. "The damage to property incaleulable." The Spaniards (then at war with the Netherlands) imputed the flood, whieh oceurred on All Saints' Day, to the vengennce of God upon the heresy of the land ; the Netherlanders looked upon it as an omen portending some riolent commotions.

Flanders. August. Great floods; also in Fiance and Germany.

Holland. 1st September. Inundation from the sea.

Leyden (IIolland). A riolent equinoetial gale broke through the dykes. By this means the city, then besieged by the Spaniards, was sared. and from rains.

England. 36 Elizabeth. "In May fell many great showers of raine, but in June and July much more, for it commonly rained day and night till St. James's eve; and on St. James's-day in the aftermoon it began again, and continued for two days together. Notwithstanding there followed a fair harvest. But in September great raines raysed high waters, such as stayed the carriges, and bore down bridges, as at Cambridge, Ware, and elsewhere. Also graine grew to be a great price-a bushell of wheat at $6 s ., 7 s .$, or $8 s$., \&c., which dearth happened more through the merchants' overmuch transporting than the unseasonableness of the weather past."-PEnkethuaN.

'95 ........ Germany. Considerable floods.

'96 ........ England. "Floods all summer."-SnorT. '98 ........ Rome. Considerable floods.

'99

England. Norember. Floods.

" 29th March. General floods.

'The waters rose above the tops of the houses, and upwards of roo people perished in Gloucestershire and Somersetshire. Flood also in Corentry, which destroyed 257 houses.

The author of a rare tract, "God's Warning, \&c.," published this rear, sars :-

"Upon Tuesday, being the twentieth of Ianuary last past 1607, in diuers places, as well in the westerne parts of England, as also in diners other places of the realme, there hapened such an onerflowing of waters, such a riolent swelling of the seas, and such forcible breaches made into the firme land, namely, into the bosomes of these eounties following, that is to say, in the counties of Glocester, Sommerset, together with the counties of Munmouth, Glamorgan, Carmarthen, and diuers and sundry other places of South Wales; the like nerer in the menory of man hath ever bin seine or heard of; the suddayne terror whereof strooke such an amazed feare into the hearts of al the inhabitants of those parts, that eury one prepared him selfe ready to entertayne the last period of his lives distruction, deeming it altogether to be a second deluge, or an universal punishment by water."-Harleian Miscellany, iij, 61-5.

France. Tite Loire overlowed its banks and enused great destruction of property. 


\section{TABLE II.-Of the Floods and Inundations of the World-Contd.}

\begin{tabular}{|c|c|}
\hline 1614 . & Lincolnshire (England). The sea eame 12 miles inland. \\
\hline 16. & Manchester. "An extraordinary flood." \\
\hline '17. & Catalonia (Spain). Great floods; 15,000 people perished. \\
\hline '19 & Thuringia (Germany). July. Great rain floods. \\
\hline 20 & Germany. Norember. Great floods. \\
\hline$' 23$. & Austria, Hungary, \&e. The Daunbe greatly overflown. \\
\hline '26. & England. 6th Jume. Great floods. \\
\hline 27 & $\begin{array}{l}\text { Austria; Danube. Scptember. "A clond loaded with a sea of } \\
\text { water bust." }\end{array}$ \\
\hline 27 & Apulia (Naples). Great floods. \\
\hline 29 . & Mexico, city of, deluged from the mountains. \\
\hline June 20 & tinued for sereral rears. \\
\hline 1630 & Scotland. Great floods in the Clyde. \\
\hline 33. & $\begin{array}{l}\text { Cork (Ireland). A "prodigions flood of the sea" swept away some } \\
\text { of the public buildings and bridges. }\end{array}$ \\
\hline '37. & East Friesland. 1st September. Great floods. \\
\hline 39 & England. October. Great floods. \\
\hline 240 & Dresden. 23rd september. Great floods. \\
\hline '42. & $\begin{array}{l}\text { Kuifong [or Cai-fong-fon] (China). Besieged by the rebels, and the } \\
\text { embankments destroyed. It was eompuied that } 300,000 \text { perished } \\
\text { by this inumdation. }\end{array}$ \\
\hline 43 & Thuringia (Austria). Great floods. \\
\hline '44 & Spain and Holland. Considerable floods. \\
\hline '46 & $\begin{array}{l}\text { Holland, Friesland, Zealand, \&c. Great inumdations. Some autho- } \\
\text { rities state that as many as } 110,000 \text { persons were dromned. }\end{array}$ \\
\hline $37-48$ & $\begin{array}{l}\text { England. "This was a most excedingly wet year: neither frost nor } \\
\text { snow all the winter for" more than six dajs in all. Cattle died } \\
\text { ererrwhere of a murain."-Erwis's Diary. }\end{array}$ \\
\hline 49 & Englaind. Tery general floods. \\
\hline '55 & Januars. Considerable floods. \\
\hline 56 & Rome. Floods. \\
\hline '5S. & Faversham (Kent). Considerable floods. \\
\hline 60 . & England. 11th Norember. Great floods in Thames valley. \\
\hline '61. & Kent. Considerable floods. \\
\hline 65 & England. Great flooding of rivers; and iuundations from the sea. \\
\hline '66 & Oetober. Great floods. \\
\hline 70 & Bridgewater (Somerset). Great floods. \\
\hline 78 & Middlesex (England). Considerable floods. \\
\hline 80 & Oxford. Jume. Great floods. \\
\hline '80 & Ireland. "An inmudation near Londonderry." \\
\hline 82 & England. "Rain, hail, floods, all the summer."-Sногт. \\
\hline '86 & $\begin{array}{l}\text { Forkshire. A rock opened and poured out water to the height of } \\
\text { a ehureh steeple.-Philosophical Transactions. }\end{array}$ \\
\hline '87 & Ireland. Excessive rains; great flood in Dublin. \\
\hline 1705 & Flood at Limeriek ; \\
\hline 05 & Europe. Great rains and floods orer eontinent of Europe. \\
\hline דים & $\begin{array}{l}\text { England. Great inundation at Dagenham (Essex), Mav, continuing } \\
\text { orer several years. }\end{array}$ \\
\hline$' 11$ & $\begin{array}{l}\text { Mobile (U.S.A.). City almost destroyed by inundations at the } \\
\text { mouth of the Hobile riter. }\end{array}$ \\
\hline '17 & $\begin{array}{l}\text { Zealand; Hamburg. "Tundation from the sea in Zealand; 1,300 } \\
\text { persons dromned. "Ineredible clamage done in Hamburg." }\end{array}$ \\
\hline 20 & Northampton (England). A great flood clit considerable clannage. \\
\hline & $\begin{array}{l}\text { Adige (Italy). Terrible floods ocewred in the valley through which } \\
\text { this rirer (the ancient Athesis) runs. }\end{array}$ \\
\hline & $\begin{array}{l}\text { Torkshire. Extensive rains and great damage; known as "Ripon } \\
\text { Flood." (See 1771.) }\end{array}$ \\
\hline 23 & any persons of distinction drowned. \\
\hline 24 & Adige $(\mathrm{Ital} \overline{\mathrm{l}}) . \mathrm{G}$ \\
\hline 26 & Eurnpe. Great imundations and floods "all orer Enrop \\
\hline
\end{tabular}




\section{TABLE II.-Of the Floods and Inundations of the World-Contd.}

A.D.

1729

'30

'31

40

'40

' 42

'45

'52

'53

'53

54 ..........

'54.

'56

'61

'61

'61

'62

'62

' 62

'62.

'63

England and Ireland. Great rains and floods.

Chili. The eity of Conception inmulated.

Belper (Derbyshire). I flood carried away tho bridge over the

Derwent and did other damage.
England. Great lloods from the breaking up of frost and snow of the preceding serere winter.

Dublin. Heary rains and great floods; shipping at Dublin injured. Limerick (Ireland). Great flood; much diunage.

Dublin, Great flood; scrious damage to bridges, \&e.

Wales. 19th September. Great rim st orm : 10,000 sheep drowned.

Ireland. Great inundations through the country.

Germany; Holland. Great overllow of the Rhine.

Englanil and Scotland. Great rain storms in early spring.

Germany and Holland. Serious floods.

England and Europe. Great floods.

\section{," Great rilins and floods.}

Treland. Great floods; especially in Cork and Dublin.

Europe. Great rains and floods in south of Europe.

England. Great flood in the Thames Valley, and other parts of England.

Dublin. 21st October. Serious flood and much damage.

Spain. Great destruction at Lisbon.

Burhanpoor (in the Decean, Hindustan). The river Taptee greatly swollen in consequence of heary rains, and one-fourth of the city inmudated, and one-tenth of the houses destroyed.

'63 ........ England Great rains and floods. "A remarkable year for floods

and high waters." -WHITE's Selborne.
Ireland. Floods. "Above 200 persons perished on the river Nore."

In the Gentleman's MIagazine there are melancholy accounts of tho damage resulting from the thaw, after the six weeks' frost, and by the rains which followed:- "Rivers have overflowed their banks, and laid rast tracts of land under water, cattle in many places have perished, and in some are deprived of food; people have been forced to leave their dwellings, and take refuge in the neighbouring towns; in short, such a scene of calamity and distress as is to be seen in the counties of Lincoln and Cambridge has never been known in this island by the oldest man [in] it. Tho rast extent of meadow from the source of the Thames to the river's month is almost eovercd with water. The great bank between Peterborough and Wisbeach in Cambridgeshire has been broken down, and near 400,000 acres of land orerflowed. The river Welling in Lincolnshire las likewise broke its banks, and overflowed Porsend and Crowland fens. . . The river Severn has likewise risen to an uncommon height, and laid the meadows on each side its banks under water to an immenso extent. About Birmingham the floods aro ineonceirable. In short such general floods were never known." January.

'63 ........ Europe. Great floods.

'64.........

'65

Ireland. January. Great floods in Dublin, Cork, and other parts.

65 England and Europe. General rain storms and floods.

Ireland. Great floods thronghout the south.

'67

England. An apparent irruption of the sea. The tide rose so high in the Thames that the damage oecasioned was estimated at 50,000 . On the sca-board of Fisex sereral islands were submerged. At Aldborough (Suffolk) the sea flowed in at the windows of several houses, bore down a few, and damaged many. The inhabitants were driven to the greatest distress. Much damage done near Ipswich. Ayrmouth (Scotland), the sea brenched over many of the houses, the high street was like a sea, and tho consternation of the inhabitants inexpressible.-Gentleman's Magazine, Jan., 1767. 


\section{TABLE II.-Of the Floods and Inundutions of the World-Contd.}

A.D. England-Contd.

1767 ........ "The floods are every where out; but the most melancholy effects of these inundations are almost always felt in the fen counties, where a breach in the banks generally lays whole districts under water. By a breach in Dceping Bank, several thousand acres are now under water; and by the north bank of the Riser Glen giving way, the north fens are overflowed, by which the inhabitants of the villages between Peterborangh and Lincoln are reduced to the most deplorable circumstances: their cattle carricd away, and their houses three or four feet under water. Many other places have shared the same fate; and in short their consternation and distress is such as none can concejre but those who hare been in the like situation."-Gentleman's Magazine, Februars.

'67 ....... Wates. "No man living erer saw such floorls."

'67 ........ Scotland. The inundations on the breaking up of the snow did incredible damage. At Lorhinabar the waters of Annan came down with such rapidity as to take houses, cattle, com, and everything along with them.-Gentleman's Magazine, February.

'67 ....... Ireland. The waters of the Liffey orerflowed, doing great damage.

'68 ........ India. There were heary floods in Behar and the district (Bengal) in August of this rear. and then rery little rain for nearly two ycars. (See Famines, 1770 .)

'70 ....... India. Great flood in the Eastern Provinces (Bengal), by which much of the bencfit which would have followed a two years' drought was direrted.

"70-71 Holland. "Terrific floods, combined with an infectious disease rife among the cattle."-DAries' Holland.

'71 ....... Forkshire (England). A dreadful inundation, called the Ripon Flood. - Tincent; also in Northumberland, Newcastle bridge carried awas.

73

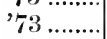

73 .........

73

$74 \ldots . . . . .$.

75

Freland. Great mountain torrents.

Tenice. A village carried away.

Naples. Great damage from the sea.

Calculta. Great destruction by rain and floods.

England. Great floods at Battersea and Chelsea.

Rotterdan (Holland). The Meuse orerflowed, doing considerable damage.

75-76 England. Wet antumn and winter. "The land-springs, which we call levants, break out much on the downs of Sussex, Hampshire, and Wiltshire. The country people say, when the levants rise, corn will always be dear; meaning that when the carth is so glutted with water as to send forth springs on the downs and uplauds, that the corn rales must be drowned; and so it has proved for these last ten or elcren zears past; for land-springs have nerer obtained more since the memory of man than during that period; nor has there been known a greater scarcity of all sorts of gram, consilering the great improvements of modern lusbandry. Such a run of wet seasons a century or two ago would, I am persuaded, have occasioned a famine. Therefore pamphlets and newspaper letters that talk of combinations tend to influence and mislead; since we must not cxpect plenty till Providence sends us more farourable seasons."-White's Sellborne.

${ }^{7} 76$........ kent. Great floods.

'76 ......... France. 25th April. Village of Bar le Due destroyed; and other damage.

'77 ....... Dublin. Great flood ; 6 feet of water in St. Patrick's cathedral.

England. Great flood of the Tyne. It was on this oceasion that the stock in trade of Bryson, the great Neweastle bookseller, whose shop was on the old bridge, was "washed out."-CuRwes's History of Booksellers, p. 452.

'82 ....... England. Great floods in Northumberland; Hexham and other bridges thrown down. 


\section{TABLE II.-Of the Floods and Inundutions of the Wrorld-Contd.}

A.

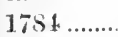

81

'85 .........

's5

' 86

87

'87

's7

's7-88

England. Great floods in Yorkshire; Tadeaster bridge thrown down, and several lives lost.

India. Some of the north-west provinees of the Punjanb suffered very seresely from floods after a great drought. December.

England. Great floods in September and October of this rear.

Germany. Extended floods and rast destruction of property.

Sussex. Irruption of the sea; block-house at Brighthehnstone washed down.

Manchester. A great flood did much damage.

Ireland. Great flood in most of the principal rivers of Ireland. Also in Dublin; 8 feet of water in the cathedral.

Nararre (Spain). September. Great torrents from the mountains; orer 2,000 persons lost their lives. May.

India. Floods in Behar and other north-west provinees of the Punjab; said to have cansed loss of 15,000 lives and 100,000 herd of cattle. "The rains commenced abnormally early in 1787, ancl continued for months ahuost withont cessation. In some of the districts of Bengal and in Behar it is stated that from the latter part of March to the latter half of Juls, they had continued with such riolence as almost to render cultiration impossible. There was a break in the rains about the end of July, but early in September the waters were out again as widely as erer in Sylhet, and similar complaints were made from Jesson, Nuddea, and Central Bengal. About 1st October a tremendous storm of rain and wind swept all over the western distriets of Bengal, which ended in a crclone of unexampled extent, which scems to lare swept across almost the whole of Bengal. By this disaster the late crops, which, after all previous disasters were fast getting into ear, were in a great measure destroyed orer larger traets of country." DANYERS, 1877 .

's8 ....... Scotland. The bursting in of the dam-dykes at Kirkwald caused great destruction.

'89 ....... England. Great rain storms in the north.

'91 ........ Cuhu. Great torrents of rain; 3,000 persons and II,700 head of cattle of varions kinds drowned.

'91 ........ England. The Don, the Derwent, and the Trent all greatly orerflowed.

'91 ........ Italy. Extended floods at Placentia.

'92 ......... Worcestershive. Extended flools near Broomsgrore (April).

'Y2 ........ Lancashire. Great tloods (August).

June 21. Retford (Notts.) Great floods which caused much damage to the

1795 town ; and in other parts of the comntry eansed by melting of snow.

1800

1800

'01.

02

02

West Indies. Great destruction at St. Domingo; 1,4,00 lives lost.

China. Great floods.

Holland and Germany. Great damage on sea coasts.

England. Great floods; much damage to shipping, etc.

1802

Dublin. Jamury and February. Great overtlow of the Liffey. "Immense damage."

April 14

Europe. In the soutl great rain storms.

Lorea (Mereia in Spain). A resersoir burst, which inmedated moro than 20 leagues, and drowned upwards of 1,000 persons, besides cattle.

1807 ....... Dublin. Great floods in the neighbourhood.

'08 ........ England. Floods in rarious parts.

'10 ........ Lincolnstire. Breaking down of sea-banks.

'11 ......... Pesth (Hungary). Orerflow of Danube, by which twenty-four April May rillages and their inhabitants were swept away.

October Lunelurg. Village of Wurgen swept away by overflowing of Elbe. 


\section{TABLE II.- Of the Floods and Inundations of the World-Contd.}

A.D.

$1813 \ldots$

Austria, Hungary, and Poland. Great floods from rain during the summer. Produeed famine in Poland; and eaused loss of 4,000 lives.

'13 ........ Viddin (Damube). September 14. Island near, on which were 2,000 Turkish troops, suddenly flooded; all drowned.

'13 ....... Silesia (Prussia). The floods eaused the death of about 6,000 inhabitants; and the ruin of the Freneh army under Maedonald was accelerated by the same cause.-TIXCENT.

'13

'14. America. Great orerflow of the Mississippi ; immense damage.

'14 Ireland. The Shamon again orerflowed and did great damage.

16 Bengal. Great orerflow of Narbudda river, sweeling away rillages, inhabitants, and cattle.

Jan. 2 Strabane (Ireland). The melting of the snow in the mountains

February

Mareh 21

April 22

June \& eaused most destruetive floods.

July $\}$

1818 . England. Great floods in Northumberland and Durham.

Germam. The Vistula overflowed; many villages submerged; great loss of life and property.

Angust

1818 .

$19 \ldots . . . . .$.

19

'21 ..........

'21 ..........

Tieland. Great fíoods at Londonderry.

Gesmany. Harrest greally endangered from continued rains.

England. Great quantities of rain fell; barrest much delayed. Also on eontinent.

Ireland. Great floods; waterspout in Clare.

England. June. Large traets of land flooded in the Fen Country.

Iieland. Great floods in the north.

England. Disastrous rains and hoods.

Ireland. August and September. Serions floods and rains throughout the west; not only was hay anl grain washed away, but the potatoes were swept up out of the ground. Oetober. Heary rains and floods. November. Incessant rains and floods; Shannon rose greatly. Also floods in Dublin.

'22 ....... Great Bitiain. January. Great storms and floods through British Islands generally.

'22 ....... Iieland. Great storms and inumlations at Wexford and Cork.

22

22

21

Geneve. Great floods; serious damage.

Nov. 19.... St. Petersturg (Russia). Flooded from the orerflowing of the Nera.

Haranna. Great deluge at.

Belfast (Treland). Great floods at. The ricer rose to the first story of the houses in this eity. Carriages and horses were swept away, and a regiment of Carabinecrs, who had climbed to the roof of their barracks, were drowned. At Cronstadt a 100-gun ship of the line was left in the middle of the market-place. In the two places more than ic,000 lives were lost, and property to the amount of mans millions of roubles was dest roved. The Nera had orerflown in $1728,1729,1735,1740,1742$, and 1777 ; but none of these occasions was equal to that of 1824 .

1825

Denmark. During a riolent storm the sea broke through the isthmus between the North Sea and Lymfiorl, thereby making the north part of Jutland an islanc.

'25 ........ Rotterdam (Holland). The Meuse orerflowed, doing eonsiderable damage.

'27 ....... Naples. Destuctire inmondations.

'28 ........ Irelant. Great rise of the Shanmon; Cork also flooded.

'29 ......... Dantzic. The Tistula broke through its dykes, by which some 4,000

April 9 houses were destrored and many of their oceupants drowned. About 10,000 head of eattle were lost.

Aug. 9 .... Scotland. The "Moray Floods" eaused by rainfall, when the Spey and Findhorn rose in some places 50 feet above their ordinary level, and eaused great destruction of property. Many lires were lost.Sir T. D. LAUDER.

1829

Ireland. Great floods in south of Ireland. 


\section{T.ABLe II.-Of the Floods and Inundutions of the World-Contd.}

A.D.

1830 .

'30.

'31

February

$1832 \ldots . . . .$.

'33 .........

October

1833

'34

'37

'40

Oet. 31

to

Nor. 4

1811

Jan. 16

Nor.

1842

'44

'45

46 .

Oet. 22

1848

'50

April

Ang.

$18 \div 0$

'51

'52

Feb. 5

1852

Sept.,Oct.

Nor.

1852 .

1853

July 9 .... Nor, 2 dwellings.

Tienna. February. Tho dwellings of 50,000 of the inhabitants were under water.

Coblentz (Prussia). In the spring the waters of the Mosello thawed before those of the Rhine, and being stopped by the iee, did rery considerable damage.

Ireland. Great floods in the Liffey; and waterspouts in rarious pillts of the comtry.

Coringa (IIindustan). Great and most destructive inundation.

Canton (China). Ineessant rains; about 10,000 houses were swept away, and 1,000 persons drowned. The rains extended to other parts of Clina.

Calcutta (India). A high tide in the Hooghly committed great destruction.

Gibraltar. Waterspout and great damage from floods.

England. Floods eaused by tliaw.

France. The Saone poured its waters into the Rhone, broke throngh its banks, and covered 60,000 acres. Lyons was inundated. In Arignon 100 houses were swept away, still a greater number at La Guillotiere; and upwards of 300 at Vaise, Marseilles, and Nismes. Many villages almost swept away. 'The Saone had not attained such a height for two hundred and thirty-eight years.

Middlesex. Great floods at Brentford and surrounding districts; many lires lost, and considerable destruction of property.

France. Great floods at Maçon and neighbourhood; immense damage done.

Ireland. Great floods at Limerick; waterspouts elsewhere.

, Extensire floods in the east and south.

China. Great floods. "Along the shores of the Yellow Sea the phenomenon took the character of a second deluge; whole provinces being submerged."

France. Orerwhelming inundations in the centre, west, and southwest; numerous bridges, with the viaduct of the Orleans and Vierzon Railway, swept away. The latter had cost 6 million francs [240,000l.]. The Loire rose 20 feet in one night. The total destruction was estimated at $4,000,000 l$. sterling.

Inverness (Seotland). Great overflow of the river Ness, which swept away the old bridge and did other damage.

Ireland. Great floods in County Kerry; bridges destroyed, \&e. August. Great floods in Limerick.

Belgium. Calamitous flood.

Khartonm (Eggpt). "An inundation oceurred."

rieland. Great and destructive floods alike in spring and autumn.

Holmfirth, near Huddersfield (Yorks). The reserroir burst, consequent upon a rain-flood. Between 90 and 100 persons perished; and property was destroyed of the ralue of $600,000 l$., consisting of woollen mills, houses, \&e., in the ralley.

England. 1)readful storms and floods in many parts of the country, more especially in the Severn valley; also in Derbyshire ; in Sussex, and in Scotland and in Dublin.

Switzerland and parts of Belgium, Franee and Germamy suffered sererely. For full details of floods at home and abroad this year, see Gentleman's Magazine.

South Wales. Great floods caused by rain. At Brecon the Houdda rose to a great height, and carried away the bridge. Many houses inmulated. People escaped by resorting to the upper parts of their

Nov. 2... Cork. Great overflow of the Lee. St. Patrick's bridge swept away, with many people on it. 


\section{TABLE II.-Of the Floods and Inundations of the World-Contd.}

A.D.
1855 ... ....

Jan. 1

$' 56$.

'56

'61

Jan., Feb. 1861

1862

$\mathrm{May} 4$

Oct. 4

1863

Dec.14-21

1864

Mar. 11

Oct. 31 ...

1866

Nov.

1868

'69.

70

'71

71

'72

July

October.

1872

74

April..

May 16....
Hamburg. An orerflow of the Elbe laid the greater part of the city under water.

France (South of). Great floods, occasioning loss of agricultural produce and other property to the extent of 140 million $\mathrm{frs}$. $(5,600,000 \mathrm{l}$.).

Prome (Burmah). Great overflow of the Irrawaddy nearly destroyed this town.

Holland. Great inundations. About 30,000 of the peasantry rendered destitute.

Ilontreal (Canada). Flood, oceasioned by the breaking of the ice of the St. Lawrence in the spring, laid the greater part of the city under water, and oceasioned the destruction of a large amount of property.

St. Germains (near King's Lynn). Great inundations through the bursting of the Middle Level Sluice. Some 10,000 acres of cultivated land submerged. Another marshland sluice burst; large tract flooded.

Melbourne (Australia). A flood, caused by the rising of the waters of the Yarra yarra 40 feet above their usual lerel, submerged the greater portion of the city and destroyed property to the value of $250,000 l$.

Bralfield Reservoir (near Sheffield). The embankment gave way at midnight; the water rushed in torrents through the neighbouring rillages. Great destruction of property, and 250 persons drowned. Arelas (France). The bridge of boats and much property destroyed by a sudden rising of the Thone.

France. September. Most extensive damage from floods.

England. Great floods in the north, especially in Yorkshire, Lancashire, and Derbyshire; farms destroyed, mills thrown down, railways stopped, and mines flooded. The towns of Leeds, Manchester, Preston, and Wakefield suffered much.

Baltimore (U.S.). 24th July. Great damage to the city by flood. Many lives lost.

Ireland. January. Great floods in Cork, Dublin, and other places.

Rome. December. Considerable floods, causing great distress.

England. Extensive floods. Mr. Alfred Haviland published a paper The Present Floods and the Cancer Fields.

Burmah. Great floods near Prome.

Manchester. The Medlock overflowed its banks and caused great destruction of property.

Italy. Great floods in north of Italy ; the Po and other rivers overflowed; thousunds of people unhoused. Mantua, Ferrara, \&c., suffered much.

India. Great floods in Khandeish and Nassick (Bombay Presidency). These floods were mainly attributable to the denudation of the hills of their forest trees. There was in consequence nothing either to absorb or arrest the rainfall, which descended the hills in torrents, destroyed dwellings, and oceasioned much loss of human life and cattle, as also great damage to the water courses and property generally; vide Administrative Report on Forest Department in Bombay Presidency, 1875-76. (See notes at end of Table of Droughts.)

London. March. Great damage on banks of Thames from rery high tide.

United States. Great floods in the Mississippi valley, mainly in Louisiaua. About 250,000 acres of cotton, 100,000 acres of corn, and 500,000 acres of sugar were submerged. New Orleans was in considerable danger for a time, part of the levees which protect that eity being broken down. About 25,000 persons were wholly or partially ruined.

Massachusetts (U. S.). Reserroir in Mill River Valley, near Northampton, burst. Sereral villages destrojed and about 40 lives lost. 


\section{TABLE II.-Of the Floods and Imundations of the World-Contd.}

A.D.

1874

July 2 t

„26...

1875

June.

9

July

,

$187 \%$

August ....

18375

Angust

Scpt.

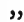

1875

Sept. 9

,

Oct.

1876

'76

Oet.

"

Nov.

Dec.

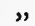

,

1877, Jan.

78
Nevada (U. S.). Great rainfall and waterspont. About thirty lires lost.

Pittsurg and Alleghany (U. S.). Great rain storm ; rivers seriously flooded and about 220 persons drowned.

This is one of the most generally disastrous years on record for floods. We shall endearour to gire a brief geographical record.

Fiance. Tremendons floods in the south; at Toulouse, Verdum, Se., many villages swept away; in the whole 6,yoo houses destroyed. About 1,000 lives lost. The loss, mainly oceasioned by the rising of the Garome, was estimated at from $12,000,000 l$. to 15,000,000l. Public subseriptions opened in England.

IIungary. Disastrous floods near Buda-Pesth; great loss of life and property.

England. Great floods in the midland and castern counties, West of England, Wales, and in Eastern Scotland.

Hungary. Another storm broke orer Buda-Pesth; great damage. Public subseriptions opened.

Silesia. Torrents of rain; great damage.

Germany. A waterspont burst near the town of Kirn; a number of persons drowned; mueh property destroyed.

United States. Great floods in the Central States; in Central Illinois, and in the Ohio and Mississippi valless; also in Arkansas. Burmah. Heary floods, exceeding those of 1871 .

India. Disastrous floods in the north-west prorinees; great loss of life and destruetion of property.

France. A gain great floods in the south of France, at Montpelier, \&c. Vineyards damaged.

Switzerland. Great floods in Canton Glarus. Holland. Great floods.

West Indies. At the Island of St. Vincent 19 inches of rain fell in twelve hours.

Texas. Great flood in Indianola, nine-tenths of houses destrojed, and mueh other damage. Publie subseription through the U.S.

England. Great floods in the Midland Counties, also in the northwestern counties at Dawlish.

Venice. A considerable flood; the Adriatic driren in by a gale.

France and Holland. March. Serere inundations.

China. Great floods in the northern prorinces.

Wales. Great damage in Soutl W Wales from orerflow of River Ebbw ; collieries damaged, \&c.

Bengal. Great inundation of tidal ware, consequent upon hurricane. Estimates of loss of life as high as 200,000; loss of property immense.

Scotland. Great floods in Perth and Forfar. Caledonian Railway much injured.

England. Floods generally throughout England.

Turkey. Deluge of rain round Adrianople; 1,000 houses said to be swept away; and other serions damage.

Spain and Poitugal. Great floods in Andalusia, and especially in Serille. Also in sonthem Portugal. Sce Times, 26th December.

London and England generally. Great damage done in the southern districts of London by ligh tide combined with floods; also in Thames Valley generally. Destruction cstimated at over 200,0001. A subseription opened by Lord Nayor for relief of poorer sullerers. Large sums raised. In the eastern, midland, and soutl-western counties great floods.

California. In the early months of this year great damage was sustained in the lowlands of this important grain-producing State. We draw the following summary from the letter of the (London) Times correspondent:-

"By the orerflow of the Sacramento and American rivers, the whole 


\section{TABLE II.-Of the Floods and Inundations of the World-Contd.}

A.D. $\quad$ California-Contd.

1878 ....... country around Sacramento was flooded, the water breaking through the levees that were built to protect the city from inundation, and the safety of the entire city was at one time imperilled. The river rose 25 feet $\mathrm{I}_{1} \frac{1}{2}$ inches above low water mark, and a rise of a few inches more would have completely swamped the eity. Fortunately the Yolo levees gave way in time, and allowed the water within the embankment to spread out over the Yolo and Solano plains. Immense exertions were made to repair the broken levees by means of sand bags, which were brought to the scene of disaster by a locomotive, followed by a train of flat cars. In the neighbouring town of Washington the water in many places stood 10 feet deep, trees were laid prostrate, and shanties and outhouses washed away. Although several houses were completely wrecked and a great deal of property destroyed, no lives were lost, though several persons had very narrow escapes. In other parts of the country the people were not so fortunate. Of the twenty-five islands which may be counted in the Sacramento Archipelago, scarcely one was to be seen during the inmudation, Union and Sherman Islands, both protected by levees, having been submerged. Boats and steamers were busy in every direction in affording assistance to the distressed, and moving among the islands and sloughs for the purpose of carrying off cattle and people to the mainland.

"In Sutter county the whole of the tule lands were overflowed, dwellings, barns, outhouses, and fencing completely destroyed, and a large amount of grain in bags carried away by the flood. The loss in live stock in many parts of the country has also been very severe. The area of land thus submerged embraces the richest and most productive portions of the State, sufficient to produce cereals for our entire population. Besides the immense amount of damage sustained in loss of property, the floods have left a deposit of silt, to do away with which will cause much trouble and expense to our farmers. What the amount of loss experienced in the Sacramento Talley is, I have not the means of ascertaining, but it is supposed to be several million dollars. The bed of the Sacramento has been elerated several feet, and the eleration increases in some places at the rate of about one foot a-year. The débris washed down from mining camps abore the Yuba River long since caused an orerflow of lands in the Marysville district, and the entire destruction of agricultural pursuits on those lands. The same causes are extending to and intluencing the Sacramento, and eren the harbour at Mare Island, the naral station of the Pacific, is said to be shoaling so much as to prerent freedom to navigation. The question as to whether mining tailings should be allowed to be shot into rivers, and, by filling them up, injming agricultural interests, has long bcen discussed by the legislature; but the consideration of impeded navigation and the serious destruction of property by excessive floods, will probably now turn the scale in favour of some restrictions on the mining interest, which has so long withstood any reform in this respect."

1878, Feb. Australia. "After the terrible drought which has afflicted the country, the abundant storms have been welcomed, bnt the parched earth has not been equal to carrying off such an enormous quantity of water suddenly poured upon it, and disastrous floods have followed, causing grent destruction of life and property. The railway at Campbeltown was flooded to a depth of 2 feet, mail carts have been washed away, numbers of trees, fences, walls, \&c., uprooted and thrown down, bridges destroyed, and other similar serious disasters have occurred. At Scone, near Sydney, $\mathrm{r}_{3} 33$ inches of rain fell in twenty-fire minutes. Some hailstones which accompanied the rain measured as much as $1 \frac{1}{2}$ inch in circumference. Serious 


\section{TABLE II.-Of the Floods and Inundutions of the World-Contel.}

\begin{tabular}{c|c} 
A.D. & Australia-Contd. \\
1878 ....... & damage has also been done by heary thunderstorms, many build-
\end{tabular}

February ings being struck and destroyed by lightning." During a stom in Sydney, as much as 10.88 inehes of rain fell in forty-eight hours.

1878 ....... Ceylor. "During the last four months Ceylon has been risited by a

Mareh succession of floods, which have cansed great destruction of property and seriously impaired the prospects of the coming eoffee eropl. In some districts as much as 50 inches of rain have been registered in tweuty days; and from the 1st of Norember to the 20th of Jammary last, I 30 inches of rain were gauged at Laggala. The natives express the opinion that the "sky is moth eaten, and heneo the constant leakage.' Up to the last advices from Galle the prospects of fine weatlier were as remote as erer. Rice and grain lave consequentiy increased enormonsly in price-from an exactly opposite eause to that which gare rise to the late famine in the adjoining eontinent, and which has also ereated such distress in Australia and at the Cape of Good Hope. In all these colonies prolonged droughts, which have only just broken, have prerailed to such an extent as to seriously interfere with business operations of all kinds." - Nesospaper Correspondence.

1878

March

France. "There were inundations in the Indre-et-Loire, and the Seine and other rivers were also very high. Snow is falling in the east, and frost has done some mischief in the south. At Vernay, near Tours, the flood swept away a bridge over a rirnlet, and part of a luggnge train fell into the water, the stoker and conductor being drowned."-Times Telegram.

1878 ....... England. Very leary fall of rain in and round London. Great April

Mas

1878

Mas

floods in Kent. At Lewisham (a suburb of London) all ordinary truffie was suspended, and the inhabitants were carried tlurongh the streets to the railway stations in boats, carts, \&e. A subseription was raised for the poorer sufferers.

This rainfall drew the following statement from Mr. Samucl Kinns, F.R.A.S.:-

"Perlaps the following calculation in refesence to the late fall of rain, which was said to amount to 3 inehes, may interest rour readers. This would equal 10,890 cubie feet, or 304 tons per aere, and taking the map of London generally published in the Post Office Directory to eontain 120 square miles, there must have fallen on that surface $836,352,000$ cubie feet, weighing 23,347,200 tons. This would be equal to the entire quantity of water contained in a canal 528 miles long, 30 feet broad, and 10 feet deep, bcing emptied upon London in twenty-four hours. The arerage annual rainfalls for the whole of England is estimated at 30 inehes, but the amount differs greatly in the eastern and western distriets. In Penzance it is 40 inches, and in London only $2 \mathrm{I}$ inches, therefore on the 10 th and 11th of April we had one-seventh of the average rainfall for a whole year. No wonder that the streets were flooded, the marrel is that so little comparatire mischief was done.

England. Great floods in the Thames valley.

HIong-Kong. A correspondent to the Times wrote hence, under date 31st May. "I have just been reading an account in your columus relative to an abnormal fall of rain in England. We in this distant tropical station may perhaps be allowed to smile when we compare 9 inches of rain in three hours, which we have just had, with the English fall of about $3^{\frac{1}{4}}$ inches in twenty-four hours. On the oecasion to which I allude, there was nearly 15 ineles in the twenty. four hours, an amount whieh very few of the gauges were competent to retain for registration."

June England. Great rainfall at Bath and other parts of the West of England. 
In this table will be found many details not strictly bearing upon famines; but as the table, it is hoped, will have other uses than that immediately before us here, I have desired to make it as perfect as the materials at command would permit.

The great frequency of Inundations from the sea will strike the careful reader of the preceding table. 'These inmudations are occasioned by three principal causes:-1. Unnsually high tides supposed to be occasioned by lunar infinences. 2. The tides acted upon by wind storms. 3. Undulation of earth's surface (in particular localities) from the subterranean influence of earthquakes. Table IV will, it is hoped, throw some light upon these incidents.

It is also seen from this table that the flooding of the Thames Valley is no new feature.

White in his "Natural History of Selborne," gives a reason why lands which are much flooded remain nnproductive :-

"Lands that are subject to freqnent inundations are always poor; and probably the reason may be, that the worms are drowned. 'The most insignifieant insects and reptiles are of much more influence in the economy of nature, than the incmions are aware of: and are mighty in their effeet from their mimteness, which renders them less an oljeet of attention; and from their numbers and fecundity. Earth-worms, though in appearance a small and despicable link in the chain of nature, yet if lost would make a lamentable chasm . . . worms seem to be the great promoters of vegetation, which would proceed but tamely without them, by boring, perforating, and loosening the soil, and rendering it pervious to rains and the fibres of plants; by drawing straws and twigs into it; and most of all by throwing up snch infinite numbers of lumps of earth ealled worm-casts, which being their exerement, is a fine manure for grain and grass. Worms probably provide new soil for hills and slopes, when the rain washes the earth away ... Earth without worms would soon become cold, hard-bound, and void of fermentation, and consequently sterile."

2. Frosts.-In temperate zones, frost is a deadly enemy to vegetation in sereral forms. In the matter of grain cultivation it may, by setting in early, prerent the efficient manipulation of the soil and the sowing of the antumn seed. Or by being protracted in the spring it will prevent spring sowing, or even seriously injure the young plants. Combined with rain it may even destroy the vitality of the seed while yet in the ground. And in the northern part of our island, it not unfreqnently destroys the grain before it is fully harvested. Efficient drainage of the soil is almost as effective against the ravages of frost as against the damage from rain.

\section{Table III.-The Gieat Frosts of History.}

\begin{tabular}{|c|c|c|}
\hline $\begin{array}{l}\text { A.D. } \\
134\end{array}$ & England. & Thames frozen orer two months. \\
\hline 153 & & Thames and all rivers frozen nearly thee months. \\
\hline 173 & & Three montlus' frost, followed by dearth. \\
\hline 220 & Britain. & Frost lasted fire months continnously. \\
\hline 250 & England. & Thames frozen orer nine weeks. \\
\hline $290-91 .$. & & Most of the rivers frozen for about six weeks. \\
\hline & $S_{e}^{2} O$ & also rery severe \\
\hline
\end{tabular}




\section{TABLE III.-The Great Frosts of History-Contd.}

\begin{tabular}{|c|c|}
\hline D. & \\
\hline 401 & Europe. The Euxine Sea frozen; also parts of Bosphorus. \\
\hline 47. & England. Frost with grent snow for four montlss. \\
\hline $507-8 \ldots$ & Britain. Rivers all frozen for about two months. \\
\hline $5: 5 \ldots \ldots$. & England. Thames laurd frozen for six weeks. \\
\hline 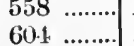 & $\begin{array}{l}\text { Eastern Europe. The Danube frozen over. } \\
\text { Scotland. Four months' frost, followed br deartll, also serere in }\end{array}$ \\
\hline $60.1 \ldots . .$. & $\begin{array}{l}\text { Scotland. Four months frost, followed by deartli; also serere in } \\
\text { England. }\end{array}$ \\
\hline $\begin{array}{l}670 \\
695 \ldots \ldots . . . . .\end{array}$ & England. "A fatal frost."-SronT. \\
\hline $695 \ldots . . . .$. & The Thames frozen over for six weeks. Trade earried ou \\
\hline $707 \ldots$ & Asia. Terrible frost. \\
\hline 759 & England. Frost from 1st October to 26 th February, 760 . \\
\hline $763 \ldots .$. & Constantinople. The two seas frozen. \\
\hline 821 & England. Great, after two or three weeks' rain. \\
\hline 827 & 'Thames frozen nine weeks. \\
\hline 856 & Poland. Great frost. \\
\hline 859 & Eastern Euorpe. Carriages were nsed on the Adriatie Sea. \\
\hline 860 & Meditermnean Sea frozen in virious parts. \\
\hline 908 & England. Most of the rivers frozen for about two months. \\
\hline 923 & The Thames frozen orer for thirteen weeks. \\
\hline 962 & "So grent as to cause a famine." \\
\hline 975 & Severe frost. \\
\hline $\begin{array}{lll}987 & \cdots . . . \\
998 & \ldots . . .\end{array}$ & A frost that lasted 120 days; began 22 nd December. \\
\hline $\begin{array}{r}993 \\
1020\end{array}$ & Thames frozen over five wceks. \\
\hline $\begin{array}{r}1020 \\
, 35\end{array}$ & " Very severe. \\
\hline '35 & $\begin{array}{l}\text { Frost on Midsummer Day; all gruss and grain and fruit } \\
\text { destrojed; a dearth.-SirorT. }\end{array}$ \\
\hline 59 & England. Great frost, and severe plague and famine after. \\
\hline '61 & Thames frozen seren weeks. \\
\hline '63 & Thimes frozen fourteen weeks. \\
\hline '66 & A great fro \\
\hline 70 & " \\
\hline
\end{tabular}

'76-77... " " Frost from 1st Norember to 15th April. "In the tenth year of his [William the Conqueror] reign, the cold of winter was exceedingly memorable, both for sharpmess and for continuance; for the earth remained hard frozen from the beginning of November until the midst of April then ensuing."-Marleian Miscellany, iii, p. 167 .

'86

England. "The weather was so inelement that in the unusual efforts made to warm the houses, nearly all the chief cities of the kingdom were clestroyed, including a great part of London and St. Paul's." -Fires, GReat, Insurance Cyclo., ir.

'95-99.... England. These winters all rery severe.

1114-15... ,, Great frost; timber bridges broken down by weight of ice. This year was the winter so serere with snow and frost, "that no man who was then living ever remembered one more severe; in consequence of which there was great destruetion of eattle."-Old Chronicle.

'21-22.... England. Killed grain erops, "and much people and eattle;" famine followed.

'28 ........ England. Very severe.

'49-50.... ", Frost continued from 10th December to 19th February.

'54 ........ " Great frost.

57 ......... Italy. Great frost in.

'76

England. Frost from Christmas to Candlemas.

1205

" Frost from 14th January to 22nd March. "Frozen ale and wine sold by weight."-SHonT. "In the seventh year of King John began a great frost, which continued till the 22nd March, so that the ground eould not be tilled, whereof it eame to pisse, that in the summer following a quarter of wheat was sold in many places 


\section{Table III.-The Great Frosts of History-.- Contd.}

A.D. $\mid$ England-Contd.

1205 ....... in England for a mark [20s.], whieh for the more part of the days of Henry II, was sold for 12d., and a quarter of beans and peas for a noble, and a quarter of oats for $3 s$. $4 d$., which were wont to be sold for $4 d$."-Penkethinan.

'07 ........ England. Frost extended over fifteen weeks.

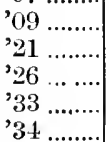

,"

, Serere.

Long and severe rinter, followed by dearth.

"Severe and snow.

"Frost "lasted till Candlemas."

" "18 Henry III was a great frost at Christmasse, which destroyed the eorne in the ground, and the roots and hearbs in the gardens, continuing till Candlemasse without any snow, so that no man could plougli the ground; and all the yeare after was unseasonable weather, so that barrenesse of all things ensued, and many poor folkes died for the want of rietualls, the rich being so bewitched with avarice that they eould yeild them no reliefe." Penkethinan.

The Mediterranean was frozen over in many parts, and merchants traded their merehandise with earts.

'41 ....... England. Deep snow; great frost after.

'41

'50

' 54

'63

'69

'80

'88.

'91

' 44

'96

1306

'23

' 37

38

'49

'53

' $63-64$

1402

'07

'08

'20

'26

'33

'34.

'38

'59

' 68.

1515

'23

'37

' 43

44

'48
St. Mark's night, frost and snow fatal to fruit trees.

Very severe.

1st January to 14th March, serere.

"On St. Nicholas we began a month's laard frost."

From 30th November to 2nd Febrnary.

Began on St. Tincent's Day and lasted fifty days, severe.

Great frost and snow.

Serere all the winter.

North of Europe, The Cattegat, or sea between Norway and Denmark, was frozen; and that from Oxlo, in Norway, traders travelled on the ice to Jutland.

Baltic. This sea corered with ice from Sweden to Gothland.

", This sea corered with ice for fourteen weeks, between the Danish and Swedish islands.

Baltic. This sea frozen and passable to travellers for six weeks.

England. Serere frost without snow.

, Serere frost for twelve weeks, after rain.

Baltic. This sea again frozen, and passable from Stralsund to Denmark.

England. 6th December to 12th Mareh. "Very eruel."

, 16th September to 6th April. "Very terrible."

Baltic. This sea frozen from Pomerania to Denmark.

England. Frost fourteen weeks; small birds perished.

Baltic Provinces. Severe frost.

Eastern Europe. The sea between Constantinople and Iskodar frozen and passable.

North of Europe. Ice-carried traffic from Lubee to Prussia.

Germany. Very serere.

England. 15th Norember to 10th February. Thames frozen down to Grar esend.

England. "Great and long."

North of Europe. The Baltic frozen from Mecklenburgh to Denmark.

Flanders. Very serere frost; wine eut with hatehets.

England. Carriages crossed the Thames from Lambetl to Westminster.

"Most serere."

,

Verg severe during December and January.

Great frost.

Flanders. Wine in easks frozen into solid lumps.

North of Europe. Oxen sledges travelled on ice from Rostock to Denmark. 


\section{TABJ.E III.-The Great Frosts of Ilistory-Contd.}

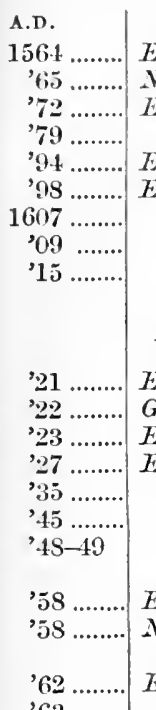

'63

\section{'61-65}

'67......

'69

'70

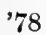

80

'8t
England. Diversions on the frozen Thames.

Netherlands. Scheldt frozen so as to bear laden waggons.

England. From 2nd Norember to 5th Jamury, hard; late spring. " "Most liard."

Europe. Rhine, Scheldt, and Adriatic at Veniee frozen.

England. Very severe in Jamuary.

Fires and diversions on the Thames-seren reeks.

"Severe and long."

,

From 17th January to 7th Mareh. There was uepublished in 1814, The Cold Feare: a Deep Snow in which Men and Caltle perished; written in Dialogne between a London Shopkeeper and "t Northcountryman. 1615. 4to.

England. Very serere from 2th Norember to 7 th December.

Greece. Ice covered the Hellespont.

Eastern Europe. The Damube frozen.

England. From 20th Jinuary to 12th February.

" From 15th December to 11th February, serere.

, Sth Deember to 17th Jauuary ; severe.

" "Now was the Thames frozen orer and horril tempests frown'd." 22nd Jamuary.-Erelyn's Diary.

England. From 1st Deeember to 10th Mareh, "north wind."

North of Europe. The army of Charles $\mathrm{X}$ of Sweden crossed the ice from Holstein to Denmark - horse, foot, and artillers.

England. 28th Norember: "A rery hard frost."-PEPr's Diary.

,28th January to 11th February: severe; "stl February being a rers hard frost; 28th Angust, cold all night and this morning, and a rery great frost, they say, abroad; which is much, having had no summer at all, almost." -PEPx's Diary.

England. 25th Deecmber to 7th February. 6tl February: "One of the eolkest days, they all say, ever felt in England."-PEPY's Diary.

England. 15th February to 19th March.

, Severe, with some remissions.

Prussia. The waters of the Rhine frozen at Coblentz from the 11t I to 17th January, so that the artifieers exercised their several trades upon the ice.

England. 9th December to 9th February, with one remission.

" Frost. "Long and hard."

, "Terrible frost of long continuance. Many forest trees split. In the severe frost of 1683-81, not only oaks, but elms and ash of eonsiderable bulk, and also walnnt trees, were rery much rent by the violence of the cold; oaks were most of all affeeted, and some split in such a manner as to be seen through, with a noise like the report of a gun. These elefts were not towards the same point of the eompass."-Gent.'s Mag. 1743, p. 144. There was published: Modest OLservations on the Present Extraordinary Frost, and of the most Eminent Frosts that have happened for many Hundred Years Past. By T. T[RYoN]. 4to. Very severe also in the North of Europe: ice in the harbour of Copenhagen 27 inches thiek.

'87 England. From 8th December to 30th January, with some remissions.

'91 ....... Europe. The sererity of the weather drore the wolves into the cities, Vienna, \&c.

'93 ....... Grermany and Italy. Serere in Norember and December.

'96-97
England. "Serere."

\section{1st January to A pril.}

" Great frost for three months, with snow, \&c. "That dreadful winter."-Wnite's Selborne. Mr. Derham supposed that this frost was greater than any within the memory of man.-Plil. Trans. Very little frost in Scotland or Ireland. 


\section{TABLE III.-The Great Frosts of History-Contd.}

A.D.

1711

'16

'18

'25

34

'37

40

'40.

'40

'41

'42

42 ...

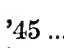

'54

'60

'63

England. Serere up to March.

A fair held on the Thames; oxen roasted.

"A short severe frost."

A month's serere frost.

Holland. Verr severe; but none in Sweden or Norway.

Italy and Spain. Tery serere frosts; none in Holland or Germany. England. Nine weeks' frost; coaehes plied on the Thames. "Will stand famous in history."-SHоRт. "I well remember after that dreadful winter, 1739.40, that cold north-east winds continued to blow on through April and May."-WIITE's Selborne.

Gent, the famous printer of $\mathrm{Yor}^{\mathrm{r}}$, in his life, tells how he set up a printing press on the river in that city during this frost, as follows:-

"In January 1739 [N.s. 1740], the frost having been extremely intense, the rivers became so frozen that I printed names upon the iee. It was a dangerons sport on the south side of the bridge, where I first set up, as it were, a new kind of press-only a roller wrapped about with blankets. Whilst reading the rerses I had made to follow the names-wherein King George was most loyally inserted, some soldiers round about that made great aeclamation, with other good people; but the ice suddenly cracking, they almost as quickly run away, whilst I, who did not hear well, neither guessed the meaning, fell to work, and wondered at them as mueh for retiring so precipitately as they at me for staying; but taking courage, they shorty returned baek, brought company, and I took some pence amongst them. After this $I$ mored my shop to and fro, to the great satisfuction of yonng gentlemen, ladies, aud others, who were very liberal on the oceasion." Pp. 192 and 193.

"This month (January) the frost, which began the 26th of last, grew more severe than has been known since the remarkable winter of 1715-16; so that many who had lived years at Hudson's Bay declared they nerer felt it colder in those parts. The Thames floated with rocks and shoals of ice. . . Bookstalls and printing presses were ereeted, and a frost fair held on it; multitudes walked over it, and some were lost by their rashness. Sereral perished with cold in the streets and fields in and about the city. All navigation being obstrneted, coals rose to $3 l$. $10 s$. per clualdron. Many forest trees were split up by the frost, as had been the case in 168.1."-Gentleman's Magazine, 1740, p. 35.

Denmark and Prussia. Vers intense frosts.

England. From 15th September to 1st February. "All frost or rain."

," Very serere for many weeks. "The frost having continued near three weeks, the streets in some parts of the city, though there had been no snow, were rendered rery incommodious, and several accidents happened."-Gentleman's Magazine (18th) December, 1742.

Rilsia. Unusually serere.

England. Very serere; especially at Bath and in south-west of England.

Gerimany. Very severe.

England. Frost lasted ninety-four days, and produced terrible effects. In the Gent.'s Mlag. for this year, it is stated that the frost set in on Saturda5, 25th December, 1762: "A most intense frost with easterly wind, which has since continued, with rer'y little intermission, until the end of January. Some experiments have been tried during the conrse of it, whieh prove that on some days it was no less severe than that of 1740 , though upon the whole it has not been attended with the same calamitous cireunstances. On Friday, 31st December, a glass of water placed upan a table in the open air, in six minutes froze so hard as to bear 5 shillings upon it; a glass of red port wine 
Table III.-The Great Frosts of ITistory-Conth.

\begin{tabular}{l|l} 
A.D. & England-Contd. \\
liaced upon the same table froze in two hours ; and a glass of \\
blandy in six, both with harl iec." In Cormeall, Wales, and \\
Ireland this frost was felt but slightly.
\end{tabular}

'63 ........ Germany. The frost seems to have set in sooner. On the lsth Dee. at eiglit in the morniug, the cold was $2^{\circ}$ Fahr. below zero-the same as in 1710 ; the next day half a degree more, "which answers exactly tho same degree of cold at Paris in 1739." - Gentleman's Magazine.

'63 ....... France. The olives and rines suffered much; the Seine and Rhone being frozen orel", the narigation was stopped, and provisions lose in Paris to famine prices.

'66 ....... England. February 1.th and 15th. Great min-storm in the S. and S.W. of England, whieh, by reason of a north. east wind, became frozen as it fell, and thus weighting down large timber trees, procheed terrible destruction. In the northern pirts of England there was snow, aceompanied by serere frost.- See Gentleman's Magazine, February.

'66 ........ Europe. At Ratisbon (Bararia) the frost was so serere that birds fell down dead with eold. On 13th Januny Reaumur's thermometer was $2^{\circ}$ lower than in the severe weather in 1709.

'66 ........ At Lisbon Reaumur's thermometer was $32^{10}$ below freezing-point.

' 66 ......... At Naples also the weather was so exeessively serere that the snow lay knee deep in the streets; Mount Vesurius was also eorered with snow, at the same time throwing up fire and black smoke, which made a most astonishing appearance-Gentleman's Magazine, February.

'67 ........ England. "Extreme frost."-Winte's Selborne. This was probably at the elose of the year: for in the Gentleman's Magazine under date 21st December, we find the following: "A serere frost set in from the E.S.E., which was followed by a deep snow, by which the navigation of the River Thames has been obstrueted, and the posts retarded all orer the kingclom." The frost was especially severe in the Wost of England.

'67 ....... Denmark. January. At Copenhagen the cold was reported to be as intense as it had been in 1740 . The Sound was frozen over, and there was communieation with Swedem. on the ice.

67.

Russia. January. The cold unusually intense; many, both rich and poor, perished; while many more were deroured by wolves in the forests.

'67

Prussia. January. In Berlin the cold was more severe than it was in 17.10. The Rhine was frozen near Coblentz-a cireumstance which the annals of that eity record as a memorable event. The artifieers again followed their sereral trades upon the ice.

'67.

Italy. January. The eold was so severe as to drive the poor from their habitations in the country; and some were said to hare perished.-Gentleman's Magazine. January and February.

'66 ........ France. 20th April. The frost was so serere in the provinee of Dauphing, that it destroyed the rines, and ent off the blossoms of the early fruit trees.-Gentleman's Magazine.

'68 ....... England. January. "We have had very serere frost and deep snow this month; my thermometer was one day $142^{\circ}$ below freezing point, within doors. The tender evergreens were injured pretty much. It was very providential that the air was still, and the ground well eovered with snow, else vegetation in general inust have suffered prodigionsly. There is reason to believe that some days were more serere than any since the year $1739 \cdot 40 . "-W n i t$ E's $^{\prime}$ Selborne. 


\section{Table III.-The Great Frosts of History-Contd.}

A.D.

England. "Dreadful springs." Frost and snow. - WHIte's Selborne.

The Gentleman's Magazine, 11th Februars, 1771, says, "Last night the frost was so intense that the thermometer was below $1^{\circ} 12$ dig. at about 11 o'clock. And this morning the barometer was $2^{\circ}$ lower than it was on 18th January last-consequently $2^{\circ}$ lower than it has been known for these nine years."-p. 92 .

'76 ........ England. The thermometer at Northampton was on 30th January at $9^{\circ}$, by 2 nd February it had risen to $40^{\circ}$. In the Phil. Trans. for this year (article $x l$ ) was a paper: Observations made during the late Frost at Northampton. By A. Fothergill, M.D.

'79 ........ England. Frost lasted 84 days.

'82 ........ Plymouth. 16th February. "The most intense frost almost ever known.. . . . The grass, which on Friday was as green and flourishing as if it had been midsummer, on Sunday morning seemed to be entirely killed. This is mentioned by our correspondent as very umusual in that part of the country; and the snow lay on the ground in many places."-Gentleman's Magazine, p. 93.

'82 ....... France. "On the night of the 11th Norember, it froze so hard at St. Pons, a district in France, during a heary shower of rain, so as to form a glazing as clear as crystal, and at the same time of the density of the most compact ice, and so thick that the tenderest twigs were in many places an inch thick. Hardly any trees were able to support the weight. Beech, asl, chestmuts, and oaks fell under it. Large branches were torm off, and some broke close to the roots. The most dismal prospect of desolation presented itself in the woods; and the most lamentable apprehensions of famine spread consteruation throughout the prorince. The potatoes were frozen in the ground, and the vines blasted in the vineyards. The hills in the diocese of St. Pons, Castres, and Lavour, have been most exposed to its rigour. The valleys and plains have suffered little, being covered with a very decp snow.'-Gentleman's Magazine, January, 1783, p. 24.

'83-84 England. Frost lasted 89 days. This frost commenced in December, and contimued through January and February, and even in March there was snow and cold cutting winds. This frost was very general, as may be seen by the rarious accounts in the Gentleman's Magazine. Thus in the February number, "From different parts of the country we have accounts of more persons having been found dead in the roads, and others dug ont of the snow, than ever was known in any one year in the memory of man." In the January number it was reported from Montrose: "This winter is likely to be still harder" on the poor man than the last, and the more so by its immediately succeeding it." But up to the November preceding the winter had been so unusually mild, that on the 4th "the cattle seek shade at noon from the heat." On the 17th the thermometer stood at $56^{\circ}$ indoors and out. On the 23rd and 24th there was frost and ice. On 30th November, "very hard frost." On 6th Jannary, "Thames not frozen quite over, but navigation stopped by ice." "Notıces of great sererity, especially at London, Canterbury, Salisbury, Worcester, Northampton, Barnard Castle, Edinburgh, Amsterdam, Mammeim, Rome, and Hungary. Frost especially severe from 10th to 20th of February. In the last days of the month the spring flowers were out, and the birds were singing. In March, frost, snow, and thick ice all through. Deep snow in Hampshire continued till 3rd April. Thames frozen and traffic crossed at many places.

On the fifth bell of the Tadcaster peal is recorded: "It is remarkable that these bells were moulded in the great frost, 1783. C. and R. Dalton, Fownders, York." 


\section{TABLE III.-The Great Frosts of History-Contd.}

A.D. $\quad$ England-Contd.

1784 ........ In the Gentleman's Magazine for February there is the following: "From 10th December, 1783, to this day it has been 63 days' frosi; of these it snowed nineteen, and twelre days' thaw, whereof it rained nine. Iial the frost continned at $13^{\circ}$, as on the 31 st December during the night, it would have frozen orer the Thames in twenty-four hours."-p. 1.17.

'St....... Southern Europe. There was serere frost in Tenice, Genoa, and Rome.

'85 ........ England. Serere frost. At Hinckley (Leicestershire), the thermometer registered on the last day of February, $19^{\circ} \mathrm{Fahr}$. below freezing point.-Gentlemen's Magazine, p. 194. There was mneh. snow.

'85 ....... Europe. This frost was severe throughont Europe; particularly in Holland.

'89 ........ England. Long and serere frosts.

'95-96 ", Winter very severe; Thames frozen. The Antiquarian Society of Newcastle recorded that the ice on the Tyne was 20 inches thick.

1812 ........ Russia. Very severe; Napoleon at Moscow.

'14 ........ When Louis XVIII was King, at Hartwell, his bill for coals on one Sunday when the Thames was frozen over in 1814 was $94 l .18 \mathrm{~s} .6 \mathrm{~d}$. at $5 s$. per ewt. There was also "a power of beer and spirits" for the coalheavers.- Tide Addenda to the Edes Hartwelliana, by ViceAdmiral W. H. Surthe.

'14....... Ireland. Winter very severe.

'15 ........ Canada. Frost at Quebec very serere.

'3s ........ England. 7th Jamuary. A serere frost commenced this day-one of the most serere in modern times-and continued for a month. It was rendered more remarkable by the eircumstance of its having been predicted in "Murphy's Almanack," which as a consequenee became rery popular. The doggrel of the period contained the following :-

\footnotetext{
"Murphy hath a weather eyeHe can tell wheneser he plenses, Whether it will be wet or diy,

When it thaws, and when it freezes."
}

'49 ....... Nonvay. Frost very severe.

'55 ........ England. Very serere between 14th January and 24th February; and very cold up to end of June. Fires on Serpentine in Hyde Park, and traffic established on ice in Lincolnshire.

'60-61 England. Very severe frost from 20th December to 5th January; many of the less hardy shrubs destroyed.

73

France. "The frost which scourged all the rineyards in France during the rights of the $24 \mathrm{th}, 25 \mathrm{th}$, and $26 \mathrm{th}$ of $A$ pril, when also snow and hail fell at intervals and often in abundance, has proved most fatal in Champagne. Now that the terrible eonsternation of first impressions has abated, and after having obtainech as correct information as possible respecting those vineyards which I have not personally inspected, I am able to estimate withont much clanger of exaggeration the extent of the damage inflicted. The disaster is more severe and more general on the right than on the left bank of the Marne. Thus, on the right bank, Damery, Cumieres, Hautvillers, Dizy, Champillon, Ay, Mareuil, have been hearily strieken; the loss in these rich vineyards, estimated at first at about fourfifths of the erop, is now considered to be about two-thirds. At and beyond Avenay the frost has caused less destruction, the loss at that place being one-third, while Bouzy and Ambounay have lost only one-fifth. The sererity of the damage, howerer, is resumed at Rilly, which it is calculated has lost two-thirds; but Chigny and Ludes, more faroured, lose only one-half. But the rich slopes of 


\section{Table III.-The Great Frosts of History-Contd.}

\begin{tabular}{l|l} 
A.D. & France-Contd. \\
1873 ........ & Mailly and Vernzenay are damaged to the extent of five-sixths of
\end{tabular} the crop, the vineyards of Vernzenay being, moreover, infested with the pyrale, which, before the frost, had already destroyed the young buis to a considerable extent. I have no reliable estimate respecting Verzy, which has, however, been sererely visited, As to the vineyards on the left bank of the Marne-Epernas, Pierry Mouss, Vinay, St. Martin, have lost about two-thinds of their crop. The valley from Vertus to Arize has been more spared than any other part of Champagne. At Trertus the loss is reduced to onefifth, at Le Mesnil to three-fifths, at Oger to one-fifth, at Arize to one-tenth, at Cuis to three-fifths. On the other side of the mountain of Arize, the slopes of Granres, facing dne south, have been completely derastated, and the vinerards of Mancr, Monthelon, Charot, have been searcely more spared. On the authority of the most trustworthy accounts from all quarters, it may fairly be reckoned that at present a proportion equal to two-thirds of the Champagne crop has been annihilated, and there are still before us all the clangerous contingencies of the five months which precede the vintage. This alarming situation, actual and possible, has given rise to considerable transactions. Wines in bottle, as well as wines in wood, have milergone very large advances in price, which, howerer, have not checked sales on the spot. The rare possessors of 1868's and 1870's in any considerable quantities, have now a fortune in their hands, and are in no hury to part with their stocks."-Wine Trade Review, May, 1873.

3. Drodght.-In all climates of a tropical character, drought plays an important part in retarding the development of vegetation. While combined with moisture, solar heat affords the most certain mcans of securing lnxuriance; withont the moisture, you have a barren wildermess! Our earliest biblical knowledge prepared our minds for this fact in the rising of the waters of the Nile, npon which erent the fertility of Egypt depends. In our table of famines, A.D. 1064, we see what has happened, when erents have not followed their natural course.

Eren in temperate climates like our own, long continued drought is very disastrons. Unfortunately again our meteorological records do not furnish systematic records. We have to seek our facts from fugitive sonrces.

Mr. E. L. Lowe, F.R.S., of the Highfield Observatory, Nottingham, says ("Notes and Queries," 5th series, riii, 507, 1877):-

"Cycles of the seasons are as certain as the laws that govern the heavenly bodies, though we have not yet been able to fix their periol. It is of atoms that the universe was made, so it will be the comlined work of mans that will enable us to arrive at those meteorological truths which it is so desirable to discover, and which may (when once discovered) prove of so great and lasting a benefit to mankind."

It has been generally remarked that the periods of the visitations of comets are marked by the prevalence of drought. Regarding this point I shall speak under another liead. 
TABLe IV.--Periods of Excessive Drought and Heat.

B.c.

138

138

A.D.

298

300 to 336

362

374

439

454

454

480

484

605

680

737

741

743

762

764

767

772

775

$850-51$

98S-89

1021 or 22

'64.

1102

13

'21

'30-31

'35

'37

'44

'49

'51

'52

'52

'59

'60

'85

'88

'91

'91

'94.

1321

Whole world. It is supposed that a great and general drought about this period gave rise to the fable of Phathon setting fire to the world.

Italy. Several screre dronghts are followed by plague.

Wales. Great dronght after comet.

Cyprus. Thirty-six years' dronght; expelled all the inlabitants.

England. "A prodigions drouglut."

," Drought, and then famine.

Britain. Drought after a comet.

Eastern Europe. Phrygia, Galatia, Cappadocia, \&c., great drought, then famine, then plagne.

England. Drought, July to September: Famine.

Scotland. Drought after comet.

Africa. Terrible.

England. Drought, with scorching heat.

" For three years.

Britain. Great, with searcity.

, Great, with scareity.

, Great, with an earthquake.

" "Long and terrible, with heat."-SноRT.

" After a long and serere frost.

Asia. Great drought.

Ireland. Great drought.

England. Drought and excessive heat, after great frost.

Italy and Germany. With famine.

England. Great drought, with heat, both years.

" Excessire heat, "yet marbles sweat profusely."-SHort.

Egypt. The drought which eaused the failure of the rising of the Nile for seven years, and hence the second seven years' famine.

England. With excessire heat.

" "So hot that corn, and some forests of wood, took fire."

England. All three spring months dry, and cxcessire heat.-SHorT.

," Greatest and hottest.

France and England. Great drought.

England. "General, with great heat: hence famine."-SHort.

" All harvest and long after.

Mas.-SHORT.

England. Dry and hot, harrest early and good.-SHonT.

" "13th Mareh to harrest, neither" rain nor dew. First, cold nights: frost, northerly winds; then greatest heat and dry, flies, gnats."-Short.

England. Great dronght.

, "Greatest drought all spring and summer" harrest, great rains ; in Oetober, and long after, drought again."-SnorT.

England. Drought in summer, and great plenty.

", "No rain all the year" to August; then moderate showers only; oats and barley lost."-SHORT.

England. "Sudden great darkness, then such drought and heat as killed most grain."-SHORT.

England. Heat and drought so intense as killed many; great deaths; plenty.

England. Drought all summer.

India. Great drought.

England. "Very great."

", "Greatest, with heat."

" After floods, storms, meteors, \&c.

, Drought. 
TABLe IV. -Periods of Excessive Drought and Heat-Contd.

\begin{tabular}{|c|c|}
\hline 1353 & Italy. Drought. \\
\hline $56 \ldots . .$. & England. Drought and heat. \\
\hline '61 ......... & " "Very grievous in summer." \\
\hline '75 ......... & Excessire, with heat. \\
\hline $1412-13$ & India. Great drought on the Ganges-Jumna Delta. \\
\hline $73-75$ & England. Great drought and heat after the two comets of 1472. \\
\hline $977 \ldots \ldots$. & " Drought, with great heat; caused plague. \\
\hline '98 ......... & "Very great." \\
\hline $1503 \ldots \ldots . .$. & Great drought in summer. \\
\hline '10 .... & Excessive heat. \\
\hline '16-17 & Hot and dry. \\
\hline $28 \ldots . .$. & $\begin{array}{l}\text { Drought from 1st February to 12th April, and all July } \\
\text { and August. }\end{array}$ \\
\hline '40 ..... & England. Great heat and drought. \\
\hline$' 58 \ldots . .$. & Drought whole year, and hot. \\
\hline '66 .... & All summer and larvest. \\
\hline '68 ....... & Excessive hot, with clearth of cattle. \\
\hline$' 83 \ldots . .$. & Excessive hot and dry summer.-Short. \\
\hline$' 90 \ldots . . . .$. & Drought all the year, and heat. \\
\hline$’ 92 \ldots . . . .$. & Extreme drought; want of water. \\
\hline '98 ......... . . & Great drought, with flies, gnats, \&c. \\
\hline${ }^{\prime} 99 \ldots . .$. & $\begin{array}{l}\text { " April and May cold and dry; June and July dry and } \\
\text { hot. }\end{array}$ \\
\hline $1600 \ldots . .$. & Russia. Great dronght. \\
\hline${ }^{\prime} 02 \ldots$. & England. Harrest and winter dry and cold; north winds. \\
\hline $07-08$ & Both summers dry and hot. \\
\hline '10 ......... & "Execssive hot and dry ; harrest inconstant."-SHORT. \\
\hline$' 12 \ldots . .$. & 1st Jamuars to 1st May, north wind; dry and cold. \\
\hline${ }^{\prime} 16 \ldots . . .$. & "Summer excessire hot and droughty."-SHoRT. \\
\hline$' 26 \ldots . .$. & The same. \\
\hline 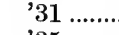 & India. Great drought; and throug \\
\hline '35 ..... & England. Summer and harrest dry and hot. \\
\hline 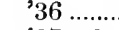 & Summer and harrest dry and hot; wind south or west. \\
\hline '37-38 & Hot and hy. \\
\hline $42-43$ & Excessive hot dry summer. \\
\hline '51-54 & Scorehing hot summer and dry years.-SHoRT. \\
\hline $57 \ldots \ldots$. & Scorching lot and dry. \\
\hline '61 ..... & India. Great dionght in the Punjaub. \\
\hline 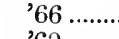 & England. Hot and dry ; east winds ; Great Fire of London. \\
\hline '69 ....... ( -.. & All the year dry. \\
\hline $78 \ldots$. & "All dry, hot, and clear." \\
\hline '80 & Dry hot summer. \\
\hline${ }^{3} 81$ & Dry all spring and summer. \\
\hline ' $84 \ldots . .$. & Spring dry and cold; summer very hot and dry. \\
\hline '86-89 & great drought. \\
\hline '91 ...... & Hot and dry. \\
\hline '93-94 & Hot and dry. \\
\hline ’99 ...... & Britain. Harrest hot and dry ; drought till following January. \\
\hline $704 \ldots . . .$. & England. Hottest and driest summer known for twenty years. \\
\hline , 16 & $" \quad$ Very dry till end of August. \\
\hline $17-19$ & Little rain, but rich dews. \\
\hline '23 ....... & Cold and dry after February. \\
\hline '82-83 & India. Province of Sind. No rainfall for two years.-Danvers \\
\hline '83-81 & $\begin{array}{l}\text { "In the north-west prorinces of the Punjaub, no rain for two } \\
\text { Jears.-DANrERs. }\end{array}$ \\
\hline '७0 ........ & $\begin{array}{l}\text { India. Great drought in district of Baroda, and in some adjoining } \\
\text { districts, resulting in serere famine. }\end{array}$ \\
\hline $1800 \ldots \ldots$ & $\begin{array}{l}\text { England. No rain fell for: serenty-four days, when on Tuesday } \\
\text { moruing, 19th August, "a glorious r'ain came down." }\end{array}$ \\
\hline
\end{tabular}




\section{Table IV.-Periods of Excessive Drought and Hcat-Contd.}

A.D.

$1803-04$

2.1

'32-33

' $37-38$

'60-61

'62

'66

73

$77 \ldots . . .$.

$77-78$

India. A total failure of rain in the "eeded districts" of Allahabad. "Not a shower fell after the 12th Angnst, 1803, and in September lot winds were blowing just as in May or June, and seorehed up the erops. The winter rains also failed. 'l'his drought was followed by heary hailstorms early in 1804."-DANrers, 1877.

India. Severe drought in the Delhi, and some other districts.

" Severe dronght in some of the north-west provinces.

" Serere dronght in parts of north-west provinees.

prorinces.

Cape Colony. Disastrous drought.

India. Severe drought in Orissa and parts of Madras.

" Serere dronght in Behar and parts of Northern Bengal.

" Serere dronght in Madras, Mysore, and parts of Bombay.

Australia. The intensity of the late drought in Australia may be judged, perhaps, by the simple ealeulation made by the inspeetor of stoek, that in New South Wales alone 4 million sheep were lost last year from the effeets of the dry weather. This estimate is generally admitted not to indieate the full extent of the losses, is it omits to take aecount of the last six weeks of the drought, which extended into the middle of February of this rear, during whieh time the effects of the lack of rain were daily intensifying in inereasing ratio. At least another million must be added to those figures to aceount for the losses of this year and for the loss suffered by small holders and others who were for rarions reasons omitted from the returns. Thus we hare 5 million sheep, valued at $2,500,000$. at least, destroyed, directly or indirectly, through the lack of pasturage eonsequent on the dronght. In 1576 the Australian Colonies possessed between them orer 45 million sheep, of which 20 millions belonged to New Sonth Wales. There is reason to believe that in Victoria and South Australia the effects of the dronght were quite as disastrous as in New South Wales, while in Queensland they were doubly serere. It is not, therefore, too mueh to estimate that at least the same proportion of the flocks elsewhere were destroyed as in New South Wales, and that in Austmia alone, omitting Tasmania and New Zealand, 9 million sheep perished in a single summer. If we extend our view to Cape Colony, which, with the whole of South Africa, endured a similar ealamity, we shall find that over 10 million sheep must hare suecumbed to the drought of $1877-78$, or nearly one-third of the number of sheep supported by the whole of the United Kingdom.-The Colonies and India.

Another account speaks of the expected failure of the grain crops, and adds, "The kangaroos and wallaby proved so numerous thint they alone consumed all that was left green. Water was carted in many cases from 10 to 12 miles."

Cape Colony. Intelligence from the interior of Cape Colony and the Orange Free State represents the eountry as haring suffered most sererely from the effeets of the prolonged drought. Galekas and Gaikas eombined are declared to be incapable at their worst of inflicting a tenth part of the injury on the country which has been eatused by the lack of rain. Not only are the cattle and horses described as becoming daily more attenuated, and dying from the want of food and water, but human beings have sueemmbed to starvation, and numbers of farmers have "trekked"-deserted their lands and homes in search of food for themselres and their flocks. The failure of crops threatened, at last adrices, a disast rous fumine unless rain speedily fell in abundanee. Netr the eoust the drought gare signs of breaking two months ago, but in the interior the roads were like iron, dams were dried up, springs were failing, 


\section{TARLE IV.-Periods of Excessive Drought and Heat-Contd.}

A.D. $\quad$ Cape Colony-Conta.

1578 ...... and not a eloud was to be scen in the skr. Of the fruit erops the grapes alone had been sared. Such a state of affairs has not been known since 1862, when a disastrous but less extensice drought occurred. The neeessity for works for storing water and for irrigntion purposes has been more than ever impressed on the colonists by the serions check wbich is thus placed on all commercial enterprise throughout the country. The Act passed last year for encouraging irrigation works will tend to the gradual relief, by artificial means, of the natural drawbacks of the eountry which, in this respect, resembles India or Egrpt, being dependent on the periodical pains, and consequent floods, for the production of its wonderfully fertile soil. April.

'78 ....... Barbary. Adrices from the coast of Barbary receired [May] at Gibrialtar, give a gloomy picture of the state of affairs in the town of Cusablanea, owing to the drought. Starration is staring the native tribes of Bedouins in the interior in the face. Their felds are completely parched, and they are in great distress for want of emplorment. Gaining their subsistence by tilling the ground and gathering in the crops whenerer chance offered, these poor Bedouins, who ried with each other in assisting their brethren of the Riff coast last year, are now as badly, if not worse, off than they were. The want of the rain which would enable them to raise fodder canses the lrolders of cattle to bring them into the town to be disposed of als best they can at any sacrifice. On the 10th bullocks were being offered at $s_{4}$ and 5 eneh and sheep at $8 \mathrm{rm}$., and on the 15 th thirty cows were sold for the paltry sum of six pesctas each, and the sheep at $5 \mathrm{rr} n$. Many heid of eattle in a lean condition remained unsold fur want of buyers, thongh offered at half the abore priee. Gruin is reported to be rery scaree, and the little that is to be seen in the market is rery dear. Rice and flom are being imported from England and France, but up to the present in small quantities. The prorince of Mogador is in a frightful state of misery owing to the want of rain. People, especially the Hebrews, flock into the town seeking the necessities of life from the charitable. At Tangiers some late showers have done much good by refreshing the fields for the benefit of the cattle.

'7s ....... Cinited States. Julr. For eleren days past the weather in the Mississippi Valley and in the North-Western States has been excessirely hot, the temperature areraging from $90^{\circ}$ to $102^{\circ}$ in the shade, in some places reaching eren $110^{\circ}$. In St. Lonis during this period 1,500 persons have been affected by the heat, of whom iso have died. Most kinds of public work and business generally were suspended during the first half of the present week or done at night. The letter-carrier serrice was also intermpted during the middle of the day. In many parts of Southern Missouri and Kunsas the harresting has been done by moonhight. At Fort Dodge, Iowa, the thermometer last Tuesday, at sunset, registered $101^{\circ}$, and in Milwankee on Wednesdar it ranged from $90^{\circ}$ to $100^{\circ}$ in the shade. One hundred and three cases of sunstroke were reported in Chicago on Werlnesdar, of which thirty-one resulted in death. The same das, throughout the Prorince of Ontario, in Canada, the thermometer ranged from $30^{\circ}$ to $103^{\circ}$ in the shade. The hot ware mored slowly eastward, and at Wheeling, West Virginia, the thermometer showed $101^{\circ}$ in the shade. On Thursday, in the cities on the Atlantic coast the temperature ranged from $88^{\circ}$ to $98^{\circ}$ in the shade. A cool ware from the north setting in after the torrid one reached Chicago on Thursday morning.

Note to this table.- Sinee the termination of Short's observations with the first quarter of the last century, we find no reliable records as to droughts in the United Kingdom. 
While upon the subject of dronght, it is impossible to ignore one of its principal causes, viz., the denuding the surface of the country of its forest trees. The rainfall in Britain has no doubt over a period of sereral centuries been gradually reduced in this manner, to the great benefit of the country generally. But when we turn to tropical conntries, while the same result of diminished rainfall is produced, it eannot be added that any benefit is conferred. In a recent State paper relating to southern India, I have seen it stated that much mischief is there resulting from this cause. Tho railways of India have required the timber as fuel for their engines. Is it not alike in the interest of the Government and the railway companies there, that steps be taken for planting forest trees in suitable localities? and there are plenty such available. For another reason in favour of planting, sce Table of Floods, 1872.

In another able State paper relating to India, and referred to more particularly hereafter, I note the following passage :-

" By proper attention to the replanting of forest trees at the sources of rivers, and by the other planting recommended, wherever it can be carried out, the first step will have been taken towards restoring the climate of India to its former state; regulating the rainfall of the country, rendering the minor rivers, which now often run dry, peremial, and putting an end to, or at least lessening the violence of the floods, which too often do great damage to crops growing in the vicinity of rivers, cause tanks to overflow, and burst their embankments, carry away railway bridges; render river navigation absolutely impossible during their continuance, and otherwise cause loss and lestruction, withont any compensating advantages whatever. As soon as the drainage of the comitry is thus brouglit under proper control, it will no doubt be perfectly practicable to construct. irrigation works in many parts where, either from the absence or want of continuous supply of water, they could not at present be introduced. The digging ditches and planting trees beside them is also recommended, and have the joint advantages of at once affording shade and collecting moisture."

In this connection it may be added that the French Forest Department in the Hautes and Basses Alpes are carrying out extensive planting operations to replace the forests formerly destroyed :-

"So great indeed were the devastations from which these Alpine districts suffered through the demolition of the monntain sides, and the consequent formation of torrents, that intervention of the most prompt description became necessary to prevent the destruction not only of the grazing grounds themselves, but of the rich valleys below them."

The replanting of these mountains has now been going on for some time :-

"Alrcady the beneficial effect of what has leen done is felt in the diminution of the violence of the torrents ... During the present summer (1875), where so much mischief has been done in the sonth of France by inundations, the Durance, which rises in the mountains east of Avignon, and which on former occasions has been the worst and most dangerous of all the rivers in the south of France, on acconnt of the inundations it has caused, has scarcely been heard of; and it is around the head waters of this river that the chicf plantation works harc, during 
the last ten years, been carried on."-(Extract from Proceedings of Forest Conference held at Simla, October, 1875.)

It is seen here, as in many other instances, that any rash interference with the economy of nature is attended with disastrous resnlts, not only in one direction, but in several. By the skilful management of the forests, it seems clear that the rainfall of a country may be at once regulated and controlled.

"The Japanese Govermment, which is making such rapid strides towards modern civilisation, has just awakened to the neeessity of preserving its forests, and stringent regulations lave been passed, which shall not only hinder the too rapid destruetion of the forests, but increase the area covered by woodlands." Nature.

4. Other Meteonologrcal Phenomena.-Under this head I propose to inelude comets, earthqualies, hurricanes, cyclones, violent storms generally, and heilstoms. These latter are usmally local in their effects, rarely extending beyond 60 miles in their greatest length, and some 6 miles in width, and generally are confined to mueh smaller limits. They are most destructice to grain and fruit produets of all kinds, when they oecur in serere form.

Comets are usually associated, if not with absolnte drought, certainly with seasons of excessive heat; but in temperate zones, this excessive heat is not necessarily prodnctice of deficient grain crops, while the fruit crops, and especially the vine, is frequently enhaneed not only in quantity but in quality.

Earthqualies would seem to have but little influence in prodncing famine, except in the immediate loeality of their devastation. Where howerer they have produced irruption of the sea, whieh has been not anfrequently the case, the damage has sometimes been very widespread.

Huricanes and storms frequently produce widespread damage in the localities they visit. They also lead to irruptions of the sea, and to the orerflow of rivers; but as a rule these oeenr at periods of the year when the grain and other erops are either not sufficiently advanced to sustain serious damage, or have been larvested.

Table V.-Comets, Cyclones, Earthquakes, Hailstoms, Hurricanes, and Violcnt Stoms generally, Chronologically Aranged.

B.C.

1491

Eg.upt. Among the plagues of Egrpt assigned at this date, as set ont in the Book of Exodus, chap. vii, viii, ix, and $x$, were: turning the river into blood; frogs were sent; and lice; a murrain of beasts; boils and blains; hail; loeusts; darkness.

'91 ....... Arabia Petra. An earthquake accompanied by thunder and lightning oceurred in Mount Sinai on the occasion of the delivery of the Law.--Exod. xix, 18.

'50 ....... Italy. An earthquake in central Italy, which swallowed up a city and produced Lilie Ciminus in its place. 
Table V.-Comets, Cyclones, Earthquakes, Iluilstorms, \&e.-Contd.

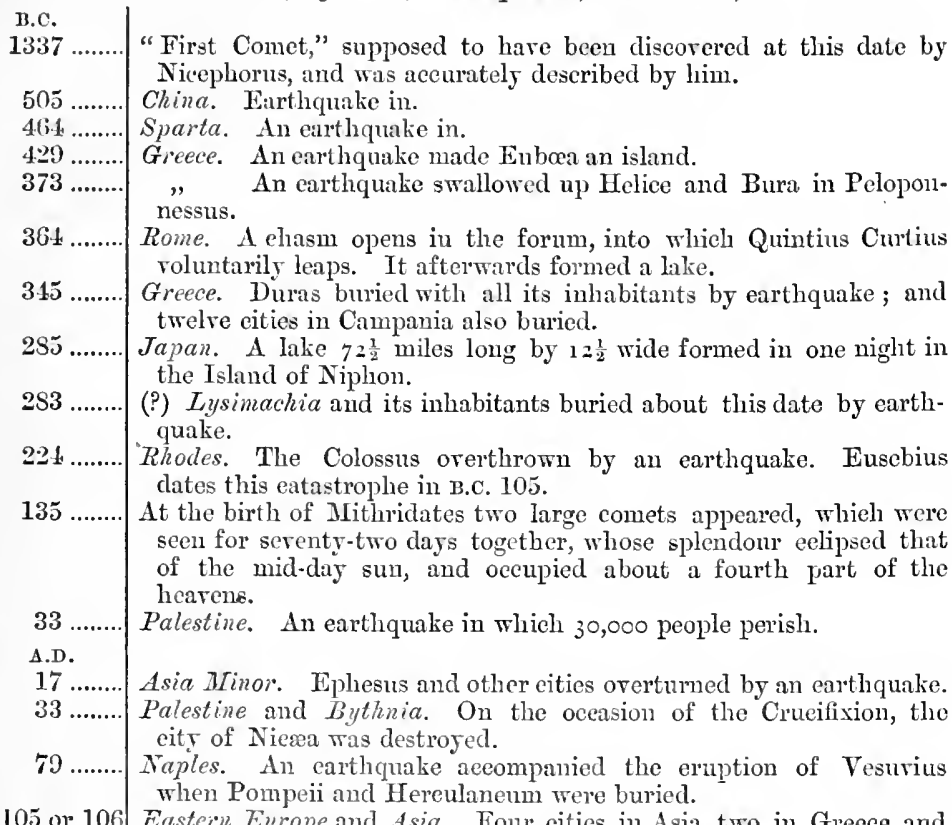

105 or 106 Eastern Europe and Asia. Fonr cities in Asia, two in Greece and two in Galatia orerturned by an earthquake.

115 Antioch (Syria) destroyed by an earthquake.

126 Asia Minor. Nieomedia, Cæsarea, and Nieea overturned by earthquake.

130 ........ England. Hailstorm; stones I 2 inches "about," fatal to people and cattle.

157 ........ Macedonia. Earthquake damaging 150 cities and towns; in Asia, the eity of Pontus and other plaees destroyed.

207 ....... England. Hail, "bigger than dueks' eggs."

262 ........ Italy, Asia Minor, fe. An earthquake attended by eclipse of the sun and inundations of the sea.

264 ........ Britain. Hail ; each stoue one pound or above in weight.

334........ England. Hail; "stones like goose eggs; fatal to people and cattle."

314....... England. Hailstorm ; "stones mueh bigger than hens' eggs."

358 ........ Asia Minor. Nieomedia again demolished by earthquake, and the inhabitants buried in the ruins; and 150 other cities more or less injured.

359 ........ Bithynia. The city of Nicomedia is destroyed by earthquake.

365 ........ Roman Empire. An earthquake.

459 ........ Britain. Hail in many parts of the country; stones 3 inehes in diameter. "Killed many men aud much eattle." Sparta. An earthquake.

Asiatic Turkey. The eities of Laodicea, Hierapolis, and Tripoli nearly destroyed by earthquake.

China. Earthquake in. 


\section{Table V.-Comets, Cyclones, Earthquakes, IIailstorms, de.--Contd.} A.D.

794

801

805

859

893

895

936

941

1007

29

'40

'48

'81

'89

'91

1111

'37

'39

'42

'58

'69

79

'86

1205

'13

'15

${ }^{\prime} 18$

'33

61

Constantinople.

A great many of the prineipal edifiees destroyed, and thousands of inhabitants perished by earthquake.

Asia and Egypt. Many cities overturned by earthquake.

? "Fiery hail burnt the ships, the sea boiling up."-Sirort. [? Voleanie seorix.]

Syria, Palestine, and Asia generally. Tremendous earthquake; more than 500 towns destroyed, and the loss of life surpassed all caleulation.

Italy. Earthquake at Trivisa; many lires lost.

Alexandia. An earthquake which orerthrew the Pharos.

France, Germany, and Italy. Serious earthquake.

South Wales. Hail; eaeh stone like hen's egg.

Syria. Upwards of I, 500 houses overturned by eartliquake in Antioch. Other towns suffer eonsiderably.

India. An earthquake destroys 180,000 lives.

Fork. Hail ; stones like ducks' eggs.

Gieece shaken. Constantinople overthrown by earthquake. [? 986.]

England. Great storm raged in and near London, whieh destroyed 1,500 honses.

Asiatic Turkey. Deinar orerthrown by earthquake, and 10,000 people buried in the ruins.

Asiatic Turkey. Ifalf of Damasens destroyed by earthquake.

Persia. Tabriz is redueed to ruins, and 50,000 of the inhabitants destroyed by earthquake.

England. Earthquake felt at Woreester, Derby, and other parts of England.

England. "In the 15th year [of William the Conqueror] a great earthquake happened in the month of April; strange for the strong trembling of the earth, but more strange for the cloleful and hideons roaring which it rielded forthe."-IIarleian Mris. cellany iii, p. 167.

England. Earthquake shocks felt generally.

"In sereral parts of the eountry. Great hurricane from the south-west. In London about 500 houses destroyed. 5th Oetober.

Syria. Antioeh, Aleppo, Jerusalem, and many towns destroyed by earthquake.

Sicily. Catania overturned by earthquake; 15,000 persons buried in ruins.

Persia. The eity of Gansana destroyed by earthquake, and 10,000 of the inhabitants buried in the ruins.

England. Earthquake sererely felt at Lineoln.

Syria. Much destruetion by earthquake; 20,000 people killed.

Sicily and Calcbria. An carthquake committed great derastation and billed some i 5,000 people.

England. Hail, with thunder, lightning; hurrieane. 5th June.

Calabria. One of its eities and all inhabitants orerwhelmed by earthquake, and engulfed in Adriatie Sea. September.

England. Hail, with thunder and lightning.

Much grain in like ducks' eggs; with thunder and lightning.

Mmeh grain in ficlds destroyed.

Italy: Hail like goose eggs.

English Channel. Great hurrieane off the eoast of Calais. A number of the Norman nobility on their way to assist King John against the barons were wrecked.

18 ....... Fiance. At Franche Comté a mountain opened and engulphed some 5,000 persons.

3 ....... England. Great tempests of wind, with rain and thunder for fifteen eonseeutive days.

A grand comet was seen; its tail was considered to extend $100^{\circ}$. (See 1556.) 
Tanle V.-Comets, Cyclones, Earthquakes, Hailstorms, dec-Contd.

A.D.

1268 ........ Cilicia (Asia Minor). Tremendous earthquake; orer 60,000 people perished.

"T.t........ England. Earthquake felt throughout; Glastonbury destroyed.

'S5 ........ " Great storm, "with violent liglt nings."

1318 .

'37.

53 A remarkable comet seen in England.-S'row.

59 ..........

Italy. An earthquake at Borgo-Sansepolero, and z,000 people perish.

France. "When Edward III was on his mareh, within tro lengues of Chartres, there happened a storm of piereing wind, that swelled to a tempest of rain, lightning and hailstones so prodigions, as instantly to kill 6,000 of his hor'ses and 1,000 of his best troops." Old Chronicle.

'82 ........ English Chamel. Great storm, which destroyed the ships from which Richard II's queen had just landed (from Bolsemia) and many others. January. (See 1396.)

'96 ........ English Channel. Another great storm, on the oceasion of the sccond Queen of Richard II landing.-HoLivgshed.

Note. - "When Richard II's first wife came [to England in 1382] from Bohemia, she had no sooner set foot on shore, but such a storm immediately arose as has not been seen for many years, when several ships were dashed to pieces in the harbour, and the ship in which the Queen eame was shattered and broken; and which was the more noticeable because his second wife brought a storm with her to the English Coast, in which the King's baggage was lost, and many ships of the Fleet east away."-Old Chronicle.

1456 ........ A comet appeared, and reappearing in 1682, as Hilley, the astronomer royal, had predieted, beeame known as Halley's comet. (See 1682.)

'56 ....... Naples. Great earthquake; 40,000 people perished. 5th December.

'79 ....... St. Neots (Huntingdon). Hailstorm, "when the stones measured 18 inches round."

'91 ........ Grecian Archipelago. Earthquake at Cos ; 5,000 persons perish.

1504 ......... India. Great earthquake in Agra. Every lofty building was levelled with the ground, and some thousands of people were buried in the ruins.

05 ........ India. Dreadful earthquake at Cabul, which laid most of the city in ruins.-Dow's Hindustan.

'09 ........ Constantinople. Earthquake, "thousands perished," 1,700 houses orerthrown. 14th September.

'10 ........ Italy. A hailstorm "which destroyed all the fish, birds, and beasts of the country."

'27 ....... Rome. Great hailstorm. 2nd December.

'28 ........ Ausburg. Great hailstorm. 19th July.

'31 ......... England. Great hailstorm. 16th December.

'31 ….... Lisbon. 1,500 houses destroyed by earthquakes, and abont 30,000 inlabitants buried in ruins. Sereral neighbouring towns enlgulphed. 26th February. (See 1755.) Also felt in Spain.

'35

'37 Zurich. Great hailstorm. 15th July.

' 46 Rome. Great hailstorm. 12th December.

.... Alechlin. Great hailstorm. Augist.

'48 ....... Louvain. Great hailstorm. 5th September.

'כ̃5 ........ London. Great hailstorm. 1st September.

'56 ........ The comet of 1264 was supposed to have reappeared, but with diminished splendour.

Note.-Tyeho Brahe demonstrated that comets are extrancous to onr atmosphere, 1557.

'63 ........ Cattaro. Suffered from earthquake.

'64 ........ Northamptonshire. Hailstorm, "when the stones measured 15 inches in circunference."

' 6.4 


\begin{tabular}{|c|c|}
\hline & \\
\hline . & Great hailstorm. \\
\hline '66. & Hailstorm destrojed 500 aeres of grain. \\
\hline ' 66 . & England. Great liailstorm. \\
\hline 78 & Brazil. Great hailstorm. 7th April. \\
\hline '80 & $\begin{array}{l}\text { London. Earthquake; part of St. Paul's and the Temple Clureh } \\
\text { fell. 6th April. Also felt in France and Belgium. }\end{array}$ \\
\hline '81 & England. Great hailstorm, "stones 8 or 9 inehes abont." \\
\hline '89 & London. Fresh hailstorms. 18th February ; 1st August. \\
\hline 90 & England. Hail, with thunder and snow. September. \\
\hline 96 & $\begin{array}{l}\text { Japan. Sereral eities destroyed by earthquake, and thousands of the } \\
\text { imhabitants perished. 2nd July. }\end{array}$ \\
\hline 206 & Wells. Great hailstorm. December. \\
\hline 602 & Janaica. Port Royal nearly destroyed by earthqnake. \\
\hline $24-28$ & $\begin{array}{l}\text { Azorés. An island more than a leagne and a half long raised near } \\
\text { St. Michael. }\end{array}$ \\
\hline ?26 & England. Great hailstorms, 29th March. 25th to 30th April. \\
\hline & $\begin{array}{l}\text { Naples. Eartluquake destroyed thirty towns and villages: } 70,000 \\
\text { lices lost. 30th Julv. }\end{array}$ \\
\hline '35 & Manila. Earthquake in. \\
\hline '36 & England. Hail, with rain, snow and thunder. \\
\hline '38 & $\begin{array}{l}\text { Calatria (Naples). "Awful earthquake." } 180 \text { towns and villages } \\
\text { injured. }\end{array}$ \\
\hline 11 & England. Hailstorms, 25 th June; 1 th and 19 th August, with rain. \\
\hline$\cdot 45$ & Hailstorm with rain. $3 \mathrm{r}^{\mathrm{d}} \mathrm{July}$. \\
\hline '46 & Angust. Hailstoms: 1th May; 11 th and 12th July; 17th \\
\hline '50 & Leicester. Hailstorm. 29th April. \\
\hline 31 & $\begin{array}{l}\text { Dorehester. Hailstorm; stones } 7 \text { inehes in cireumference. 23rd } \\
\text { August. }\end{array}$ \\
\hline '5s & $\begin{array}{l}\text { Europe. "The day that Oliver Cromwell died (3rd September) was } \\
\text { one [a storm] so riolent and terrible that it extended all orer } \\
\text { Europe."-MIORTrMer. }\end{array}$ \\
\hline ' 61 & England. Hailstorms. 11th April and 11th Oetober. \\
\hline 61 & London. Great hailstorm at Charing Cross. January. \\
\hline '66 & England. Serere hailstom and rain. 31st July. \\
\hline '67 & $\begin{array}{l}\text { Ragusa. City ruined by earthquake, 5,000 persons perislied. 6th } \\
\text { April. }\end{array}$ \\
\hline '67 & $\begin{array}{l}\text { Schrmaki (Sonthern Russia). Earthquake shoeks extending over } \\
\text { three months; } 80,000 \text { people perished. }\end{array}$ \\
\hline '69 & Eng!and. Great hailstorm with rain. 17th December. \\
\hline 72 & Rimini (Italy). Earthquake; 1,500 perished. 14th April. \\
\hline 78 & England. Great Lailstorm. 1Sth January. \\
\hline 39 . & $\begin{array}{l}\text { A comet whieh terrified the people by its supposed near approach to } \\
\text { the earth; was visible from 3rd Norember to 9th of March follow- } \\
\text { ing. Flom observations on this eomet, Newton demonstrated that } \\
\text { they are subjeet to the law of grasitation, and probably more in } \\
\text { elliptie orbits. }\end{array}$ \\
\hline '81. & England. Great hailstorm. 1st May. \\
\hline ' 82 & $\begin{array}{l}\text { Halley's eomet, so-ealled from his haring made observations suffieient } \\
\text { to establish its identity. He predicted its return in } 1759 \text {, and it } \\
\text { came. The revolution of this comet is supposed to occupy seventy- } \\
\text { five years. It reappeared in } 1835 \text {, and is due again in } 1910 \text {. }\end{array}$ \\
\hline '90 & Dublin. Serere shock of earthquake. 17th Oetober. \\
\hline & $\begin{array}{l}\text { Jamaica. Earthquake destroyed Port Royal, whose houses were } \\
\text { engulphed } 40 \text { fathoms deep; } 3,000 \text { perished. 7th June. }\end{array}$ \\
\hline ’93. & $\begin{array}{l}\text { Sicily. Earthquake orertumed } 54 \text { cities and towns, and } 300 \text { villages. } \\
\text { Of Catania and its } 18,000 \text { inhabitants not a traee remained; more } \\
\text { than } 100,000 \text { lives lost. September. }\end{array}$ \\
\hline & England. Great storm on the east coast ; 200 coaster: \\
\hline
\end{tabular}


Table V.-Comets, Cyelones, Eurthquates, Iailstorms, \&e.-Contd.

A.D.

1697

1703

'03.

'03.

' 16

'19

'20

26

27

'31

'32

'37

'45

46 .

'50

'50

'51

'52

'54.

55

'55

'55

55

'55

'55

Cheshire and Lancashire. "A storm of hail, \&e., whieh killed fowls and small animals, and knocked down horses and oxen; some of the stones weighing half a pomdl." 29 hl April.

IIertfordshive. II ilistones fell 14 inches in cireumference; destroyed trees and corn in a most dreadful nanner; the most terrible one that had ever been known in England; attended with flashes of lightning. 4th May.

Italy. Iquila ruined by earthquake; 5,000 perished. 2nd February. Japain. Jeldo rumed by earthquate; 200,000 perished.

England. One of the most terrible storms on record; known as the "Great Storm." The derastation on land was immense, while on the coasts and in the harbours the loss of slipping was terrible. The loss of life was very large, and sheep and cattle were drowned by thousands from the loods oceasioned, especially in the Severn and Thames ralleys. The loss of property in London was estimated at 2,000,000\%. Eddystone lighthouse was destroyed and its constructor (Winstanley) in it. On the coast of Holland great dimage was done. 26th and 27 th Norember.

$A b \cdots z \sim 0$ (Naples). Earthquake; 15,000 persous perished. 3rd Norember.

Algiers. Earthquakes ; 20,000 perished. May and June.

Sweden. Great snowstorm, wherein 7,000 Swedes, on their way to attack Drontheim, perished on the mountains.

India. On 20th Jume a fearful earthquake was felt in Old Delhi. During the day and night nine shocks occurred. Parts of the ramparts were thrown down and damaged, and many persons killed. "It was very wonderful that for a month and two days the shocks continued, and were felt four or five times in the twentyfour hours." - SIR H. Eltuor's History of India, vii.

Palermo. City nearly destroyed by earthquake; 6,000 lives lost. 1st September.

Persia. Tabriz overwhelmed by earthquake; 77,000 persons perish.

China. Pekin destrosed by carthquake; about 100,000 people swallowed up. 30th November.

Naples. Great destruction by earthquake; 1,940 persons perished. 29 tlı November.

Iudia. Great storm. "Many hundreds of ressels cast away;" a ficet of Indiamen greatly damaged. Some 30,000 persons are beliered to have perished. 11th October.

Forkshire. Hailstorm; stones 5 inches round. May.

South America. Lima and Callao demolished by earthquake; r 8,000 persons buried in the ruins. 28th October.

London. Slight shock of earthquake. 19th Febrnary.

Ionian Islands. At Cerigo $z, 000$ persons perish by earthquake.

St. Domingo. Portau-Prince destroyed by earthquake. 21st Norember.

Turkey. Adrianople nearly overwhelmed by earthquake. 29th July.

Egypt. Grand Cairo half destroyed by earthquake; about 40,000 of the inhabitants engulphed. September.

Egypt. The city of Grand Cairo completely destroyed by earthquake. April.

Kaschan (N. Persia) destroyed by earthquake; 40,000 perished. 7 th June.

Lisbon. The great earthquake of. In about eight minutes most of the houses and 50,000 of the inhabitants were swallowed up.

The cities of Coimbra, Oporto, and Braga (also in Portugal) suffered dreadfully, and St. Nebes was wholly orerthrown.

In Spain a large part of Malaga became ruins.

In Morocco one half of the city of Fez was destroyed, and 12,000 Arabs perished. 
Table V.-Comets, Cyclones, Earthquakes, Ilazlstorms, de.-Contd.

A.D.

1755

'55

'55

'59

'65

'66

66

${ }^{\prime} 67$

${ }^{9} 67$

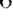

67

'68

'69

'69

'69

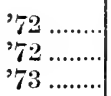

'73

73

Madeira. About half the island beeame waste.

In the Island of Metelene, in the Archipelago, abont 2,000 houses were overthrown.

This earthquake was felt as far as 5,000 miles away, and was distinctly experienced in Scotland. 1st November.

Syria. Shock of earthquake extended over 10,000 sqnare miles. Baalbee destroyed, and in this city 20,000 perished. 30th October.

Hungary. Comorn, Pesth, \&c., much damaged by earthquake. 2Sth Jume [? 1763].

Engiand. 15th February. Great snow storm in Nottinghamshire, which lasted fifty hours. In other parts of England rain storms, which froze upon the trees, and caused great destruction of timber; the immense weight breaking off the largest arms and branches.

England. Eartliquake shock in Glamorgamshire.

" "The snow was so deep throughout the whole kingdom that the like has not been remembered by the oldest man liring; many people hare perished; cattle and horses have been buried and dug ont; the stage waggons have been delayed; the postboys have been bewildered, and some frozen to death; in short the severity of the season is universally felt; and the distresses of the poor in many places are inexpressible."-Gentleman's Magazine, February.

France. Sth April. A dreadful storm of thunder and lightning did considerable damage at Prorence. The lightning set fire to the Royal Abbey of St. James's, by which one of the main beams in the steeple was burnt, so as to give way in the angle. Two other churches were set on fire in the neighbourhood; the bells of one melted, and the uther was entirely consumed.

Martinico. Damaged by earthquake; 1,600 perished. August.

Havannah. Dreadful hurricane; $4,0+8$ houses and many public edifices destroyed. About 1,000 inhabitants perished. 25th October.

England. "Last month [April] we had such a series of cold turbulent weather, snch a constant snceession of frost and snow, and hail, and tempest, that the regular migration or appearance of the summer birds was much interupted." - W HITE's Sellorne.

An IIstorical Narrative of the Great and Tremendous Storm which happened on $26 t h$ November, 1703. [This forms part of vol. ii of

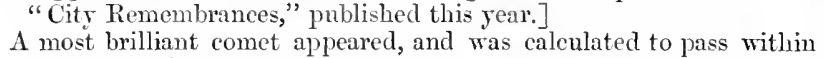
2 millions of miles of the earth. This comet was seen in London; it was moring with immense velocity, and its tail formed a luminous arch in the hearens, supposed to be $36,000,000$ miles in length.

Leeds (Yorkshire). Hailstones as Jarge as nutmegs. 20th June.

St. Jago (Cuba). Hailstones as large as oranges. 16th July.

"A riolent gale of wind (22nd February), made luarock among the shipping in the British Channel. It is more than twenty years since the like happened in this island."-Gentleman's Magazine.

26 th February. It blew a hurricane in London, by which the shipping in the Thames is said to hare sustained damage to the amount of 50,000 l. - Ibid.

Guatemala. Santiago with its inhabitants swallowed up by earthquake. 7th June.

Alengon (Franee). Hailstorm; stones measured 18 inehes round. 3rd August.

England. Awful storm in North of England; many ressels destroyed; four Dublin packets lost. 29th October.

IIolland, Antwerp, \&c. Hailstorm; stones as large as hen's eggs, and weighed three-quarters of a pound; horses killed, and the fruits of the earth destroyed. 11th June. 
Table V.-Comets, Cyclones, Eaithquakes, IIaitstorms, de.-Contd.

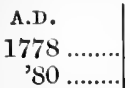

'82

'S2

'82

'82

'83

'83

'83

'84.

'84

's4

'84

' 81

'85

' 85

'86

'86.

'87 .

'88

' 88

's9

'91

'91

'91

'91

' 91

'93

Smyrna. Destruetire earthquake. 3rd July.

Tabriz (Persia). Earthquake; 15,000 houses thrown down, and multitudes of people buried.

India. Great storm at Surat; about 7,000 inhabitants destroyed. 22nd A pril.

Surat. "At Surat, a Dutch settlement lately taken by the English, a most dreadful hurricune arose, which carried all before it ; neither man, horses, nor sheep eould be saved. The storm began from the S.E. and ended N.W. with the same fury. The whirlwind swept into the sea more than 3,000 inlabitants, who in the first moments had taken refuge between Surat and Domus."-Gentleman's Magazine, January, 1783.

France. Hailstorm; stones weighed 8 ozs. 17th June.

Madrid. A violent hailstorm. "Some of the stones weighed a pound." $6,000 l$. of damage to windows.

Italy and Sicily. Messina and other towns thrown down by earthquake. "Thousands perished." 5th February.

Spair. 23rd December and seven days following. Dreadful storms, accompanied by rains, "so excessive as to treate impassable inumdations, so that many rillages and part of the flat countries have been reduced to the greatest distress." Floods particularly severe at Seville. Great number of shipwrecks on eoast.

England. Great storm of thunder and lightning in Hants and Wilts (25th Norember) ; also about this period great storms of wind and rain of "remarkable violence."

England. January and February. Great snow storms, espeeially in northern York, and in parts of the midland eounties. Barnard Castle and Northampton suffered severely. These storms were accompanied with iutense frost.

Scotland. Excessire falls of snow extending orer nearly a month daily.

France. 17th January. A violent storm at Rochelle, accompanied by an earthquake, thunder, lightning and hail; great damage done to houses and trees. The towns of Nantes and Roehefort much injured; and many ships lost on the coasts.

Europe. Storms and excessire cold were reported from Smyrna, Vienna, Nimegnen, Cologne, Naples (great floods), Leghorn, Rome, Lisbon, Amsterdam.

Pyrenees. Hailstorm; stones as large as hen's eggs, some weighing 23 ounces. 18th July.

Armenia. Exinghian (near Erzeroum) destroyed, and 5,000 buried in ruins by earthquake. 23rd July.

Paris. Severe hailstorm. 1st July.

France. Storm. "13 I villages and farms laid waste."

Italy. Hailstones as big as hen's eggs. 17th July.

North Shields. Great hailstorm. 16th August.

Normandy. Hailstones as big as hen's eggs. 4th August.

France. "Hail fell as large as a quart bottle; and all the trees from Vallence to Lisle were torn up or clestroyed." 13th July.

West Indies. St. Lucia destroyed by eartliquake; 900 perished. 12th October.

Tuscany. At Borgo di San Sepolero, an earthquake. Many houses and I,000 persons swallowed up. 30th September.

Italy. A riolent hailstorm. June.

England. Several violent hailstorms. June.

Calabria (Naples). Violent hailstorm; stones weighed one English pound; destroyed the vintage. September.

Sussex. Severe hailstorm. Oetober.

Thornton (Leicestershire). Hailstorm; great damage. 3rd August.

Japan. 1st April. Earthquake near the volcano Illigigama (which threw forth torrents of water), destroyed 53,000 persons. 
Table V.-Comets, Cyclones, Earthquakes, Hailstorms, \&c.-Contd.

\begin{tabular}{|c|c|}
\hline 50 & Jamaica. Hailstones as large as pigeon's eggs. 2nd July. \\
\hline & $\begin{array}{l}\text { South America. The whole country between Santa Fé and Panama } \\
\text { desolated by an earthquake. The cities of Cuzeo and Quito } \\
\text { destroyed, and } 40,000 \text { people buried, in what appeared but one } \\
\text { second of time. 4th February. }\end{array}$ \\
\hline & Naples. Vesurius overwhelmed the city of Torre del Greco. June. \\
\hline & $\begin{array}{l}\text { Britain. Great storm prevailed throughout; screral hundred sail } \\
\text { of shipping destroyed. 6th October. }\end{array}$ \\
\hline 20 & $\begin{array}{l}\text { Essex and Herts. A storm of hail whieh did great damage. 12th } \\
\text { Jume. }\end{array}$ \\
\hline & Asia ALinor. Earthquake; 1,500 lives lost. \\
\hline 20 & $\begin{array}{l}\text { Peru. Quite orerthrown by earthquake, burging 40,000 persons. } \\
\text { 4th February. }\end{array}$ \\
\hline 97 & $\begin{array}{l}\text { London. Hailstorm; did great damage to the gardens round the } \\
\text { MIetropolis. 6th MIas. }\end{array}$ \\
\hline & Lewes (Sussex). Serere and destructire hailstorm. 6th May. \\
\hline & $\begin{array}{l}\text { Another hailstorm; stones weighed from } 4 \text { to } 7 \text { or } \\
\text { 5th June. }\end{array}$ \\
\hline דים & Cumana (South America). Ruined by earthquake. 1.4th December. \\
\hline & $\begin{array}{l}\text { Orfordshire and Bedfordshive. Hailstorm at Heyford (Oxen); } \\
\text { irregnlar pieces of ice the size of hen's eggs fell. In Bedfordshire } \\
\text { liares and partridges were killed in the fields. 19th August. }\end{array}$ \\
\hline $1800 \ldots$ & $\begin{array}{l}\text { Constantinople. The Royal Palace and many buildings were } \\
\text { destroyed by earthquake. 26th Septenuber. }\end{array}$ \\
\hline 800 & $\begin{array}{l}\text { England. Great storm inflicting serious damage in rarious parts, } \\
\text { and especially in London. 3rd Norember. }\end{array}$ \\
\hline & $\begin{array}{l}\text { Eastern Europe. Earthquake shock extended from Cronstadt to } \\
\text { Constantinople. 26th October. The shocks were most violent in } \\
\text { the Danubian Principalities. }\end{array}$ \\
\hline '03 & $\begin{array}{l}\text { London. Dreadful hailstorm in Haymarket, and two or three } \\
\text { adjoining streets, withont the least appearance of hail in the other } \\
\text { parts of London." "A fire-ball fell in Oxenden-street which tore } \\
\text { up the parement." 9th Jume. }\end{array}$ \\
\hline & Holland. Serere earthquake shock. End \\
\hline & India. Sever \\
\hline & $\begin{array}{l}\text { Naples. Earthquake at Frosolone; 6,000 lires lost; also through- } \\
\text { out Calabila; } 20,000 \text { lires lost. }\end{array}$ \\
\hline & Piedmont. Earthquake shocks; and in ralley of the Rhone. \\
\hline & $\begin{array}{l}\text { Somersetshire. Great storm, accompanied with hailstones, measured } \\
6 \text { and } 7 \text { inclies in circumference. } 15 \mathrm{th} \text { Jul } \mathrm{S} \text {. }\end{array}$ \\
\hline '10.. & $\begin{array}{l}\text { Azores. A rillage of Las Casas, in the island of St. Michael's, sunk, } \\
\text { and a lake of boiling water appeared in its place. 11th August. }\end{array}$ \\
\hline '11 & $\begin{array}{l}\text { A remarkably conspicuous comet appeared. Its length on 15th } \\
\text { October Was estimated by Herschel to be } 100,000,000 \text { milcs. It } \\
\text { was visible all the autumn.* }\end{array}$ \\
\hline
\end{tabular}

* The vintage of 1811 has now acquired a peculiar celebrity, and the good wine produced that year all orer France has been generally attributed to the influence of the comet. It is strange that its excellence was not recognised at the time, but France was passing through too anxious a crisis to care much for choice wines, and these vintages were in the autumn of the following year freely sold at from 1,200 frs. a cask to 1,500 frs. a cask. In 1868 there was a sale of the cellars of Château Laflite, ineluding mueh of the eomet elaret. The auction took place on the 27 th October, and as these were the days of the luxury of the Second Empire high prices were realised. 'The lots were started at zo frs. a bottle, and the bidding went up to 121 frs., at which price an hotel keeper at Bordeaux bought a large quantity. Bottles of this wine were exposed in the windows of the hotel afterwards at the sensation priec of 150 frs. or about $72 l$. a dozen. In the meantime the comet claret has been growing -scarcer every 


\section{Table V.-Comets, Cyclones, Earthquakes, Hailstorms, \&c.-Contd.}

A.D.

1812

'13

'14.

'16

'16

'17

'18

'18

'19

'19

'19.

'19

21

'22

22

June 6

'29

'22

'22

'23

'24

'25

'26

27

'27

'28

'28

Tenezuela. The eity of Leon de Caraeas destroyed by earthquake; nearly 1 2,000 persons perished. 26th March.

Bedfordshire. Great storm of thunder, lightwing, and hail, with fire-ball nlich set fire to buildings. Oetober.

England and Ireland. A tremendous storm, by which great damago was oceasioned, and many ships wrecked. 16th and 17th Deeember. England. An awful gale, by whiel a great number of vessels wero lost, and mueh damage done on the coasts. 31st August.

Cumberland and Westmoreland. Great storm of wind and hail desolated these counties. August.

China. Chang-Ruh is orerthrown by earthquake; 2,800 persons buried in the ruins. April.

A comet appeared, which became known as Encke's. It makes its revolution in three years and fifteen weeks.

Turkey. The eity of Philipopolis said to be entirely engulphed by earthquake. March.

Inctia. Sereral earthquakes; distriet of Kuteh sunk, 2,000 persons buried. 16th June.

Italy. Genon, Palermo, Rome, and many other eities and towns greatly damaged by earthquakes; "thousands perished."

Greeee. Tostitza, the aneient Egium, destrojed by earthquake.

West Indies. Dreadful hurricane raraged Leeward Islands. At the Island of St. Thomas alone 104 vessels were lost. 20th-22nd September.

England. Great storm along the coast from Durham to Cornwall; many ressels lost. Norember.

Costa Rica. The town of Carthago overthrown by earthquake. 7 th May.

India. Great erelone in Bombay; as many as 100,000 of tho inlrabitants destroyed by the tidal wave, and probably an equal number of eattle. The loss of property in other respeets impossible of estimate.

Aleppo (Syria). Destroyed by earthquake; abore 20,000 perished. Shocks on 10th and 13th August and 5th September.

Chili. Coast permanently raised by earthquake. 19th Norember.

Ireland. Great storm and considerable destruction of property, particularly in neighbourliood of Dublin. 12th December.

England. Another eomet appeared.

Iranila. An earthquake in.

Algiers. This city and Blida injured by earthquake : 7,000 lives lost.

England. A comet known as Biela's appeared, and was remarkable for the nearness with which it approached, not the eartl, but the earth's patl. Its rerolution is performed in six years and thirtyeight weeks. It appeared again in $1838,1839,1815$, and 1852 , since whieh it has been seen no more.

India. Fort Kolitaran, near Lahore, destroyed by earthquake; about 1,000 lives lost.

Columbia (Sonth Ameriea). Some rery destructive earthquake shoeks: England. Awful storm on English coast; many ressels lost. 12th and 13 th January.

Gibraltar. Great storm; more than roo ressels destroyed. 1Sth February.

day, and at a great wine sale just coneluded (January, 1878) in Paris the "gems of the collection" were two bottles of the famous rintage. The price rose rapidly, and it was evident that many purehasers were eager to make an investment. At last the ultimate fate of the bottles rested between two restaurants, and the bidder at 620 frs. was declared the purchaser. That the proprietor of a café on the boulerards should pay nearly $25 l$. for two bottles of claret shows that the reign of luxury is not yet orer in Paris. 


\section{TAble V.-Comets, Cyclones, Earthquakes, Itaitstorms, dc.-Contd.}

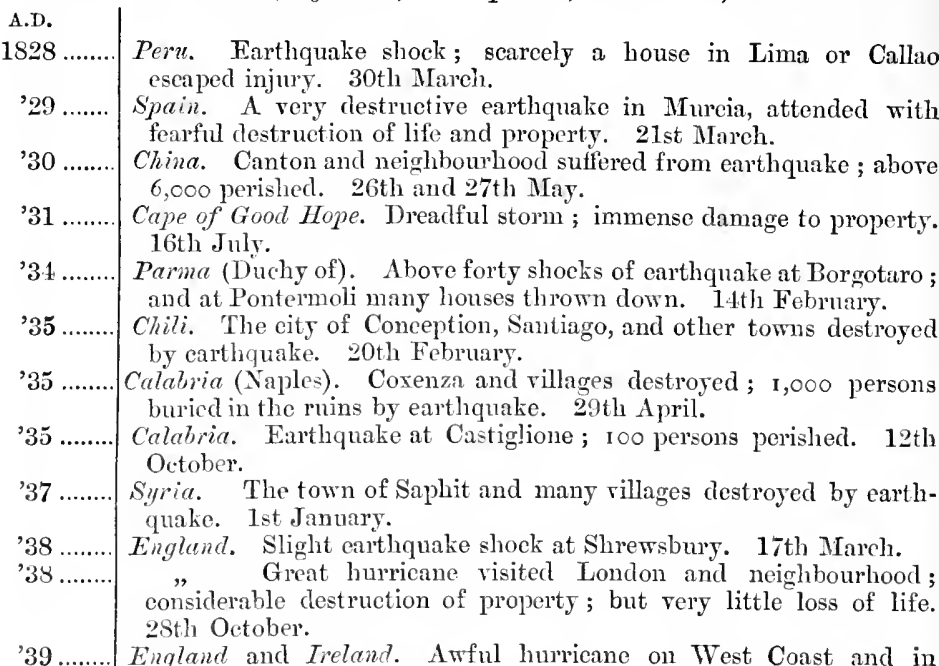
Ireland. Through Cheshire, Staffordshire and Warwickshire the damage immense. Many ressels wrecked, some of great valuc. In Limerick, Galway, Athlone, and other places, many houses destroyed; and the destruction was extended by fires. Dublin suffered much. The southern portions of England escaped. 6th and 7th January.

'39 ........ Martinique. Nearly half of Port Royal destroyed by earthquake; about 700 killed and the whole island damaged. 11th Jannary.

'30 ....... Ternate. The island laid waste by earthquake, and thonsands of lives lost. 14th July.

'40 ....... St. Domingo. Earthquake at Cape IIaytien, which destroyed nearly two-thurds of town; between 4,000 and 5,000 lives lost. 7th May.

'40 ....... Armenia. "Iwful and destrnetive earthquake at Mount Ararat; 3,137 houses orerthrown, and several hundreds of persons perished." 27 th July.

'40 ....... Zante. Great earthquake, many persons perished. 30th Oetober.

'42 ........ India. Earthquake destroyed fortifieations at Jellalabad. 19th February.

'42 ....... St. Domingo. Earthquake demolished the town of Cape Haytien, and destroyed not fewer than 10,000 lives. A fire broke out afterwards, blowing up the powder magazine, and with it the inhabitants who had escaped the first effeets of the earthquake. 7 th May.

'43 ....... England. Terrifie hailstorm in Norfolk, causing great devastation of the crops through the county. A voluntary county rate was made in farour of the sufferers. Out of these erents grew the General Hailstorm Insurance Society of Norwich.

'43 ....... West Indies. Destructire earthquake, destroying much property at Antigua, St. Thomas, and St. Christopher. Pointe-à-Pitre, Guadaloupe, was entirely destroyed, and many hondreds of persons buried in the ruins. 4th February.

'48 ....... England. Earthquake shocks in North and in Scotland. 10th March.

'43 ....... Germany. Earthquake shocks. 25th December.

'45 ......... Java. Severe earthquake shoeks. 8th February.

't5 ........ Hexico. The city is much damaged by eartliquake shocks. Tth April. 
Table V.-Comets, Cyyclones, Earthquakes, IIarlstoms, de.-Contd.

^.D.

1846 ..

'47.

'51.

'51.

$' 51$

'52.

'52.

52

'52-53

๊3 .........

'53 .........

'53.

54.

54

'54.

54

, 55

'55.

'55

'56

'56

'57

57

Norway. Earthquake more destructire in its consequences than any previously recorded. 14th November.

Mexico. The eity of Attixeo destroyed by earthquake, with great loss of life. 23rid October.

Rhodes and Macri. Earthquakes. A mountain fell at the latter place, crusling a village and destroying 600 persons. 28th February and 7 th Mareh.

Talparaiso. More than 400 houses destroyed by earthquake. Ind April.

Italy. Earthquake; mueh damage all throngh the Peninsula. Amalf almost laid in ruins, and 2,000 inhabitants orerwhelmed; 14,000 lives lost in various parts. 11.th Angust.

St. Jago (Cuba). Earthquake destroyed sonthern part of city and many inhabitants. 20th August.

Philippine Islanls. Manila injured by earthqnake. 16th-30th September.

England. Slight shock of earthquake in north-west; also felt in Ireland. 9th Norember.

England. In December and January many storms of great sererity, with mueh destruetion of property.

Persia. The eity of Shiraz destroyed by earthquake, abont 10,000 inhabitants orerwhelmed. 4th Miay.

Tenezuela (Sonth Ameriea). City of Cumana destroyed by earthquake. As many as 800 persons buried in ruins. An entire company of artillery, with Colonel Perey, perished in their quarters. 15th July.

Greece. Thebes nearly destroyed by earthquake, and shocks in other parts. 18th Angust.

South America. St. Salrador destroyed by earthquake. One-fourth of the inhabitants destroyed. 16th April.

Black Sea. Great storm, causing much loss of life and destruction of shipping and stores sent for allied armies in Crimea. 13th16 th November.

Japan. Anasaca and Simoda (in Niphon) destrojed by earthquake; Jeddo mueh injured. 23ri December.

North of Europe. Great storm ; considerable damage. 31st December. Turkey. Broussa nearly destroyed by earthquake. 2Sth February.

Central Europe. Sercial rillages destroyed by earthquake. 25th and 26 th $_{\mathrm{J}} \mathrm{July}$.

Japan. Jeddo nearly destroyed by earthquake, 30,000 inhabitants overwhelmed. 11th November.

Moluccas Islands. (On the Great Tanger.) Earthquake and roleanie eruption; nearly 3,000 lives lost. 2nd March.

Mediteranean. An earthquake extensive in its operation and destruetive in its effects, felt on the islands and eastern shore. In the city of Valetta searcely a building eseaped injury; at Cirita Vechi the dome of the eathedral was rent; at Thyree and Candia the ruined buildings took fire, and many lives were lost. Trifling damage at Cairo and Alexandria. 12th Oetober.

Scotland. Great storm on north-east coast; many fishing boats lost. 23rd Norember.

Naples (Italy). An earthquake, extending from the Mediterranean to the Adriatic, with varying violence, but inflicting the greatest damage at Calabria, in Naples. "Complete villages were engulphed in the yawning fissures." It was thought that as many as 10,000 lives were saerifieed. 16th December.

Note.-In the eourse of seventy-fire years, from 1783 down to this date, the kingdom of Naples lost at least 111,000 inhabitants by the effects of earthquakes, or more than 1,500 per annum, out of an arerage population of $6,000,000$.-LACAITA. 


\section{TABLE V.-Comets, Cyclones, Earthquakes, IIailstorms, dc.-Contd.}

A.D

1858

'58

'59

'59

'59

'59

'60

'60

'GI

61

'61

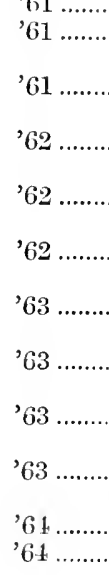

Corinth nearly destroced by earthquake. 21st February.

Donati's eomet appenred at Florence. It was beliered to be ncar eoming into collision with Tenus.

Quito (Ecuador). About 5,000 persons killed, and an inmense amount of property destroyed by earthquake. 22nd March.

Armenia. Earthquake at Erzeroum; thousands perished. 2nd June, 17 th July.

England. Dreadful storm on 25th and 26th October. The "Royal Charter," and many other ressels lost. Another great storm on 31st Oetober and 1st Norember.

59 ....... England. Slight shock of earthquake in Cornwall. 21st October. San Salvador. Many buildings destroyed by earthquake. 8th Decomber.

England. Sliglit shock of earthquake in Cornwall. 13th January. " Great storm in Channel, causing much loss of life and property. 1st January. Dreadful gales 26th-28th February, 28th May, and 2nd June.

Eingland. Great gales; part of Crystal Palace blown down; Chichester Cathedral steeple fell. 20til and 21st Februarp.

The comet of this year first discorered at Sydner, in Australia, is known as the "Great Comet." It was afterwards seen in France and England. It was supposed to trarel 10,000,000 of miles in twenty-fom hours. On 30 th June it was suggested that we (in England) were in the tail, there being "a phosphorescent auroral glare."

Sonth America. Earthquake; the cities of Mendoza, San Juan, and Sin Louis, all populons towns in the Argentine Republic, destrosed. The first and primeipal shock oceurred abont 8 P.x., succeded by other shocks which spread over the three following days. The total number of lires lost was at a minimum estimate put at 15,000 . Not only were the cities orerturned, but the entire district was broken up, ricers being tumed from their courses and roads and bridges broken up in one gencral ruin. In the Jesuit chmreh of Mendoza, where a large number liad gathered for erening scrrice, the roof and walls fell down, and enclosed the worshippers in one rast sepulchue. 20th-23rd March.

61

Italy. In Perucia, earthquake; several lires lost. 8th May.

Britain. Great stom. British coasts-I +3 wrecks, 2Sth Hay; and 13 th and 14th Norember, storm on north coast. Fifty weels.

Greece. North Morea, Corinth, \&c., injured by carthquake. 26th December.

England. Great hailstom, from 6 to 7 feet deep, at Market Larerton (? Somerset); much damage to crops. 2nd Scptember.

Fingland. Great storm on British coasts; many wreeks. 19th and 2oth October.

Guatemale. Earthquake destroyed 115 buildings and 14 churches. 19th December.

England. Extensire gales, accompanied by numerous wrecks. 19th January.

Rhodes. Thirteen rillages destrojed by earthquake. Abont 300 lires lost, and much cattle and property destrosed. 22nd April.

Philippine Islands. Inmense destruction of property at Manilla by earthquake; and about 10,000 persons perished. 2nd and 3rd July.

England. Central, west, and north-west, earthquake shocks. 6th October.

Mexico. Earthquake shock on 3rd October.

India. Great cyelone at Calcutta; immense damage done on land and sea; great part of eity laid waste; about 200 ships were reported to be lost, and abont 70,000 persons perished. Whole towns nearly destrosed. 5th October.

'6.1

Lisbon. Great hurricanc; much damage. 13th December. 
Table V.-Comets, Cyelones, Eurthquakes, IIailstorms, de.-Contd.

A.D. 1865 .

65

65

'66.

'66.

'66

'66

'67 mantled. 1st and 2nd October.

'67 ....... Cephulonia. Earthquake at Argostoti; abore 50 persons perished. 4th February.

67

'67

'67

'67

'68

'68

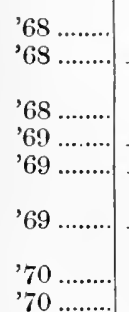

71

A fine comet appeared in the southern hemisphere, and was visible in South Ameriea and Anstralia.

Englaml. Sercre gales; great damage to shipping. 14th Jannary.

Sicily. Earthquake shock at Macehia, Bendinella, \&c. (on slope cf Mount Etna), 200 houses destroyed; 64 persons killed. 18th Juls.

England. Serere gales; many ressels and lires lost. 6th-11th Jannary.

Ronmelia. An earthquake orerthrew 200 houses at Arlona. March.

France. Slight earthquake shock near Tours and Blois. 14th September.

Great cyclone in the Bahamas, at Nassan, New Proridence; above 600 houses and many clrurches and other buildings thrown down; between to and 70 persons killed, and a great many ships disMitylene (Asia Minor). Earthquake; about 1,000 killed. 8th and 9th March.

Java. Town of Djocja destroyed by earthquake; abore 400 perished. 10th June.

West Indies. A dreadfnl hurricane off St. Thomas. The Royal mail steamers "Rhine" and "Wye" entirely wrecked. The "Conway" and "Derwent" and abore fifty other ressels driven ashore, and about I,, 000 persons lost their lives. 29th October.

67 ....... Calcutta. Another cyelone. Abont 30,000 natire huts swept away by the tidal ware; but only about 1,000 lires lost. 1st

Norember.
England. Destructive gales. 2nd-4th December.

"Serere gales and destruction of shipping. 22nd and 31st January and 1st February.

Central America. The cities of Arica, Arequipa, Iquique, Tacna, and Chencha, and many small towns in Peru and Ecuador, destroyed by earthquake; about 25,000 lives lost, and 30,000 rendered homeless. The sea in many places retired a space and then rushed orer the towns, destroying shipping and houses; loss of property estimated at $6 \mathrm{c}, 000,000 \mathrm{l}$. 13th-15th August.

Note.-About $11,000 l$. was collected in London to reliere the sufferers.

Culifornia. Earthquake shocks at San Francisco. 21st October.

England. Slight earthquake shocks felt at Bath, Swansea, and Leamington. 31st October.

Germany. Earthquake shock at Cologne. 17th Norember.

Indian and Pacific Seas. Serere carthquake shock. 15th January.

England. Great storms and loss of shipping. 11th and 12th September.

Ionian Islands. The town of Santa Mura destroyed by earthquake. 18th December.

Quebec (Canada). Slight earthquake shock. 20th October.

Calabria (Naples). Several rillages destroyed by earthquake. Early in October.

Darmstadt. Earthquake shock. 10th February.

England. Slight shock of earthqualic in nortl-west and Yorkshire. 22nd March.

West Indies. Cyelone desolated Antigua, St. Kitts, and other

islands; many buildings destroyed. 21st Angust.
England. Barometer very low; great storm; much damage. 24th January.

California. Several small towns destroyed by earthqnakes. 26th and 27th March. 
Table V.-Comets, Cyclones, Earthquakes, Hailstorms, dc.-Contd.

A.D.

1872

'72

72

"72

72

73

73

73

73

74

74

74

'74

74

' 74 .

75

75

75

15

75

'75

75

Sept. 9

1875

175 ........

Sept. 28

1575

$76 \ldots . . .$.

'76

76

Oct. 31

Antioch. Violent earthquake; shook foundations of city, again laying greater part in ruins. 3rd April.

India. Destructive eyclone at Madras; ships lost. 1st May.

England. After several days' intense heat, riolent storms, and delnges of rain in the milland and southern eounties. 24th-26th Jume. Other storms in July and Angust. Violent gale. 8th Deeember.

Europe. In the Mremoir of Alfred Smee, F.R.S., there occurs the following passage: "The intensity and riolence of the storms throughont Europe this summer naturally attract general attention."

India. Lehree, Eastern Catchi, Sind, destroyed by earthquake; abont 500 persons killed. 14th and 15 th December.

San Salvalor (Brazil) nearly destroyed by earthquake; abont 50 killed; the rest escaped through timely warning. 19th March.

North Italy. Earthquake shock; buildings destroyed and hives lost in Venetia. 29th Jume.

Scotland. "Awful storm ;" much loss of life and property. 22nd and 23rd July.

England. Grent storms in Lancashire and Yorkshire. 16th December.

Coggia's comet was discorered at Marseillcs. It gradually increased in brightness, but passed out of sight in Europe. It appeared very brilliant at Melbourne.

London. Awful storm; buildings fired by lightning; lives lost; railways flooded, \&c. 11th July.

Spain. At Azagra landslip produced by earthquake; killed 200 people. 22nd July.

Guatemala. Antigua and other places destroyed by earthquake. 3rd September.

Hong Kong. Great trphoon at Macoa. 22nd September.

England. Violent gales, with destruction of life and property. 21st Oetober, 29th November, 7th, 8th, 10th and 11th December.

Scotland. Severe snowstorms, loss of life. 1st and 3rd January.

Asia Minor. Karsa Hissa, and other places destroyed by earthquake; great loss of life. 3rd and 5th May.

Sinyma. Earthquake, many perish. 12th May.

Chili. San Jose de Cncuta, and other towns near Colombo destroyed by earthquake; abont 14,000 lives reported to be lost. 16th and 18th Nay.

Buda-Pesth. Destructive storms; about 200 persons killed. 26th June.

Geneva. Violent hailstorm; great destruction of glass and crops. 7 th and 8th July.

West Indies. The Isle of St. Vincent swept by a hurricane of umusual sererity. Much damage.

Texas. Great storm at Gaveleston, Indianapola, and other places; houses and villages washed away, and great loss of life. 15th-18th September.

England. Whirlwinds in Isle of Wight cause great destruction; also hưricane in Oxfordshire.

India. Lahore and ricinity sustained earthquake shock; property destroyed and lives lost. "12th December.

Tienna. Shocks of earthquake along banks of Dannbc. 17th July.

Sicily. Serere shocks of earthquake at Messina. 13th September.

India. Great cyclone in Bengal. A tidal wave, extending, it was estimated, over 3,000 square miles, being in many places more than 20 feet deep. The loss of life was estimated at 215,000 , while the destruction of property was incalculable. 
Table V.-Comets, Cyclones, Earthquakes, Ilailstorms, de.-Contd.

A.D.

1876

Nor. 7

2877

' 78

Jan. 15

1878

Feb. 7

1878

Mareh 29

$1878 \ldots . . . .$.

April

April 12

1878

April 19

1878

April 20

1878 ..........

May 14 $1878 \ldots . .7\}$ May 21$\}$ 1878

May 23

1878

May

June 27

1878 .........

June 30

India. The district of Baharganj (the delta thrown out by the united waters of the Ganges) desolated by a cyclone.

South America and Sandwich Fslands. Simultancous destruction of Iquiqua, Peru, and Hilso, Sandwich Islands, by an earthquake and tidal ware. loth Mas.

Indian Ocean. A cyelone derastated the island of Bourbon, and the next erops, it is feared, will show a considerable defieiency.

Takiti. A terrible hurricane, by which much property was destroyed, and about 120 lives lozt.

England. A tornado in south of England, followed by snow. It was during this that Her Majesty's ship "Eurydice" was lost off the Isle of Wight.

England. Terrible gale in the early days of this month. The East Anglian Daily Times, in describing the effects of the gale upon Lowestoft fishing boats, said that upwards of 200 lost every net they had on board, and out of 500 boats only 100 are now fit for sea.

Canton. A destructive hurricane, accompanied by two waterspouts, caused immense damage here to-day in the foreign concession and the native city. No lives are reported to lave been lost among the foreign population.

Turkey. An earthquake cansed considerable damage at Mondania, Sabandja, and in the eurirons of Bronssa and Ismid.

Bay of Biscay. Continuons storms. "During the recent hurricane about 150 fishermen from the neighbourhood of Bilbao and Santander were drowned."-Times Telegram.

Teneztela. Terrific earthquake at Cua; Gco persons killed; serere shock also at Caracas.

Hong Kong. Terrible thunderstorm, occasioning much damage.

United States. A terrific tornado erossed a portion of Winconsin, passing from the south-west to the north-east, and derastating a long strip of conntry, including the towns of Mineral Point, Mount, Vernon, Primrose, Oregon, and Paoli, while the feeble effects of the same tornado were felt at Madison, also as far south as Chicago. In the direet path of the storm ererything was demolished, and hundreds of buildings were destroyed. The débris was blown many miles. From reports thus far received it appears that 30 persons were killed and 50 injured. Several dead were carried to long distances by the whirlwind and then dashed to the ground. Those injured were generally in destroyed buildings. In one case a school house with the teacher and scholars were earried away several rods, three of the scholars being killed, but some eseaping unhurt.

Great Britain. During this month most severe storms, accompanied with lightning, oecurred in various parts of the kingdom. During the storm which passed over Perthsliire on 28th and 29th, the monument which was erected by $\mathrm{Mr}_{\mathrm{r}}$. Crieff in 1832 in memory of Sir David Baird, the hero at the storming at Seringapatam, was almost entirely destroyeci. The monument, which was a counterpart of Cleopatra's Needle, was 80 feet high, and cost $4,000 l$. to ercet. It was struck on the top; 20 feet of it was thrown to the ground, and the base was also injured by the electrie fluid.

Ireland. Great storm in south of Ireland; much damage oceasioned.

England. Very severe storms in rarious parts of the country, accompanied by lightning and torrents of rain. At Enfield (north of London) $3 * 0.7$ inches of rain was recorded during a thunderstorm. Hailstorms in west of England. 
Tarle V.-Comets, Cyclones, Eurthquakes, Hailstorms, dec.Contd.

\begin{tabular}{|c|c|}
\hline & A tornado, aecompanied by thunder, lightning, a \\
\hline & $\begin{array}{l}\text { hail, oceured at Pittsurg, Pennsylrania, inflicting great damage } \\
\text { within a radius of Io miles from that town. The lightning } \\
\text { destroyed the Vesta Oilworks, eonsuming } 80,000 \text { barrels of petro- } \\
\text { leum. Torrents of rain at the same time swept down the hills } \\
\text { into the Alleghany and Wonongahela rivers. One loonse was quite } \\
\text { swept away, and fise persons were drowned. The tornado burst } \\
\text { orer a party pienicing at Rossgrove, seren miles from Pittsbur, } \\
\text { mprooting five large trees, which fell upon a large number of people } \\
\text { who had souglit shelter beneath them, killing fourteen and injuring } \\
\text { thirty. }\end{array}$ \\
\hline $18 \pi$ & Southern Austria. Along the valley of the Sare, there was a few \\
\hline & $\begin{array}{l}\text { days ago a very serere hailstorm, which has done a great deal of } \\
\text { dimage to the crops. The hailstones are reportcd to have been } \\
\text { unusually liarge. The Nene Freie Presse describes them as being } \\
\text { of such a size that they broke the tiles on the roofs and sererely } \\
\text { injured several persons. }\end{array}$ \\
\hline $18 \pi$ & Switzerland. Great damage was done throughout Central and \\
\hline $\mathrm{Ju}$ & $\begin{array}{l}\text { Eastern Switzerland by a series of severe thunderstorms. Many } \\
\text { buildings were destroyed and set on fire by the lightning, ricers } \\
\text { overflowed their banks, and the Berne-Lncerne Railway received } \\
\text { injuries so serious that the traffic between those places has had to } \\
\text { be temporarily suspenderl. At the same time a heary hailstorm } \\
\text { derastated the erops and vineyards in the neighbourhood of Mon- } \\
\text { treux; and the hamlet of Thusinge, Canton Vaud, was almost } \\
\text { destroyed by a fire. }\end{array}$ \\
\hline $\begin{array}{r}1878 \ldots \\
\text { July }\end{array}$ & $\begin{array}{l}\text { England. During all the latter part of the month continued storms, } \\
\text { of great sererity. } \\
\text { Note.-The literature relating mainly to this table is very extended, }\end{array}$ \\
\hline
\end{tabular}

5. Insects, Vermin, Sic.-As to inserts, plagues of these appear to hare afflicted mankind from a very early period. Thas we read in the eighth, ninth, and tenth chapters of the Book of Exodus, of the plagues of Egypt, supposed to have occurred in the year 1491 B.c. There was first the plague of flies, and then of locusts; "15. For" "they covered the face of the whole earth, so that the land was " darkened; and they did eat every herb of the land, and all " the fruit of the trees which the hail had left: and there remained "not any green thing in the trees, or in the herbs of the field, through "all the land of Egypt." We are told "14. . . . . Before " them, there were no such locusts as they, neither after them "shall be such." But there have been some rery much like them, especially in the United States. I have endearoured to construct a table of such visitations. It must be regarded as very incomplete.

As to Vermin, such as Rats, Mice, \&c., destroying the crops, there are but few instances on record, and these are so scattered as to be by no means readily brought into tabular form. One or two instances will be found included in the following table:-- 


\section{TABLE VI.-Plagues of Insects and Vermin.}

B.c.

1491

A.D.

158

475

476

592

672

872

895-97.

1031

'90 or 91

'99

1101

'17

'41

'47

'52

'76

1266

' 86

1476

1575

'81

'98

1611

'12

'85

'87

1791

1802

'12-13

'33-35

'55.

'68

'74.

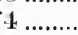

$7 x-77$

Egypt. The plagues of (inter alia) flies and loeusts.

Scotland. Infinite swarms of insects eat up all the grain and cause famine.

Northern Nations. Great swarms of locusts.

England. "Greatest swarms eat up grass, all grain, and fruits; famine."-SuOnT.

England. Locusts, with drought.

Syria and Mesopotamia. "Eaten up with them."

England. "A monstrons kind; hence famine and plague."-SHorT.

Ireland. Invasion of locusts, and famine.

England. Locusts and floods; famine.

Constantinople. Plague of inseets.

England. "Swarms of strange flies."-Sноrт.

Bavaria. Swarms of butterflies for three days, from Saxony.

Jerusalem. A plague of insects. Short gives the date 1120:

"Plague of mice and locusts."

England. "Clouds of small flying worms [? bugs] darken the sun." -Short.

England. "Swarms of butterflies sprinkled with blood."-SHoRT. , Plague of flies and gnats.

Germany. At Carinthia locusts eat up all ; famine and plague.

scotland. "Was eat up by palmer-worms."

Prussia. Infested with renomous worms.

England, Many insects.

Plague of flies and bectles on the Aron. 24th February.

",

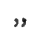

A plague of mice in Essex; but killed by owls.

". "Swarms of flies, fleas, and gnats."-SHonT.

(?) Spain. Insects and caterpillars, then flies, at Lusina (?) Luisiana, or (?) Lausanne (Switzerland).

(P) Austria. At Strigonium [? Striguo, in the Tyrol]. Clouds of grasshoppers diarkened the air.

France. At Languedoc, strange devouring grasshoppers.

England. Gnats, flies, and insects.

India. At Kach (Bombay Presidency) swarms of black ants ate up the erops.

India. At Kach swarms of locusts destroy erops.

", Crops destroyed in parts of Sind by locusts; in other localities by a plague of rats; and again in other districts by locnsts.

India. In Madras Presidency swarms of locusts.

United States. Great plague of locusts in Mormon settlements (Utah). Crops partially destrosed. Sea-gulls (never before or since seen in this locality) eame in great numbers and devonred the locusts, thus preventing absolute famine. This was regarded as a piece of divine intervention. This was told to the writer by the Mormon elders in $\mathbf{1 8 7 4}$.

United States. Locusts appeared in the Red River Settlements.

" The western plains were again ravaged by locusts. The writer passed through one of the distriets so visited in the early autumin; the devastation was complete.

In 1877 Mr. C. V. Riley, M.A., Ph.D., published in Chicago: "The Locust Plague in the United States: being more particularly a treatise on the Rocky Mountain Locust, or so-called Grassliopper, as it occurs east of the Rocky Mountains, with practical Recommendations for its Destruction." Illustrated.

United States. The Colorado (potato) beetle committed great derastation of the crops in various parts of the United States. It has since shown itself in Germany and in Great Britain.

8 ....... North China. The famine now raging began in one district by $\approx$ visitation of locusts. 


\section{TABLE VI.-Plagues of Insects and Vermin--Contd.}

A.D.

78

'78

June 9

1878

Spain. Locusts appeared (April) in fifty-three communes in the province of Badajoz.

Algeria. Dr. G. Hellmann, in the Austrian Jounal, 1st April, discusses the importance of an independent telegraphic organisation for the requirements of the western parts of the Mediterranean seaboard. He shows how reports from the Azores would be of the first importance to the district in question. Among other uses of the proposed intelligence system Dr. Hellmann suggents the possibility of locust warnings! The advance of these plagues over Algeria is at a regular rate, and it is quite possible to adopt precautionary measures for killing them if one knows they are approaching.-Academ.

Bosnia. 9th June. Locusts have appeared on the south side of the Neretva river, devastating the scanty crops there, which were the only hope of a resource from threatening famine.

India. In the Times telcgram, under date, Caleutta, 30th June, it is stated, "In Mysore locusts continue to cause damage." In the Times of India, at a later date, it was announced, "Locusts have appeared in great numbers in parts of the Madras Presidency." A later telegram, 25th July, sass, "Considerable anxiety is felt by the Madras Grorermment in consequence of the destruction caused by locusts. Request has accordingly been made to the Government of India for the immediate despatch to Madras of extra famine officers. Furloughs hare been completely stopped in Bengal. The Madras Government has issued instructions to all collectors to take energetic and vigilant measures for the destruction of locusts, and, on the appearance in any district of young locusts, to hire gangs of men to be emplosed under the famine officers in exterminating them. It is suggested that deep trenches should be dug, and the young locusts driven into them and buried."

\section{Literature of Meteorology as affecting Famines.}

I have found it of the ntmost ralue in dealing with historical questions, to reciew the special literature relating to the point or the period under consideration. It gives a much firmer grasp of any question to know what were the contemporary riews upon it, what was the degree of attention drawn to it: for this latter the literature at any period within the last three centuries is a certain guide. I venture to think that it is of no less value in regard to statistical inquiries such as the present. In this belief I have compiled the following chronological table of the literature of storms, \&c. It is supplemental to the preceding tables: it throws light upon them, which is occasionally of great ralue. That it occupies so much space, is simply due to the fact that I hare endeavoured to make it complete; and yet I am well aware that a critical examination will reveal some omissions. It is the first time such a table has been attempted, so far as I am aware. Subsequent labourers in the same direction may take heart that something is left for them to do.

The direct literature of famines will be best reserved for the second part of the paper. 


\section{TABle VII.-Literature of Earthquakes, Comets, Storms, de.}

B.c.

350

A.D.

1542

'66

71

91

'77.

78

' 80

' 80

' 80

'80

'80

'80

'80

'80

Among the worke of Aristotle was one on inundations of the Nile. It was republished in Paris in 1493, under the title of "De Inundatione Nile." 4to.

Heuy Nerres of an horryble Earthquake, which was in the Citie of Scarbaria, in this present yere of xlii, the xiii June; and also that a citie in Turkey is sonke. London. Printed by Richard Lant.

The great wonders that are chaunced in the Realme of Naples; with a great Misfortune happened at Rome, and in other places, by an Earthquake in the month of December last past. Translated out of the Frenche into Englishe by J. A. London. 16mo. Printed by Henry Denham.

A Declaration of such tempestuous and outrageous Flooddes as hath been in divers places of England, 1570. London. 8ro. This tract enumerates the loss and damage in the sereral counties, particularly in the Bishopric of Ely.-WATT.

A Goodly Gallery with a most pleasaunt Prospect into the Garden of Naturall Contemplation to beholde the Naturall Causes of all kind of Meteors, as well as fyery as ayery, as watry and earthly, of which sorte be blasing starres, shootinge starres, flames in the ayre, \&c., thonder, lightninge, earthquakes, \&c.; rayne, dew, snowe, cloudes, springes, \&e.; stones, metalles, earthes. To the glory of God and the profit of his creatures. By William Fulke [or Fulco), a celebrated English divine. London.

Of all Blasing Starrs in general, as well supernaturall as naturall; to what Country or People soever they appear. By Abraham Fleming. London.

A riew of certain "Wonderful Effects" of late days come to passe, and now newly conferred with the presignification of the Comete, or Blasing Star which appeared in the south-west, upon the 10th day of Norember last past. Written by T. T. London, 1578. 4to. Printed by John Jones.

The booke of the Earthquake, to the Good Deane of Paules. By Thomas Churchyard, poet.

A Godly Admonition for the time present; mote on oceasion of the Earthquake on the 6th April, 1580. Printed by Reginalde Wolff.

London. 4to.
Translation of Frederick Nauze, his generall Doctrine of Earthquakes. By Abraham Fleming. London. 8vo.

A Shorte and Pithie Discourse concerning the engendering Tokens and Effects of all Earthquakes in generall, particularly applyed to that 6th April, 1580. By Thomas Twyne, M.D. London. 4 to.

A Bright Burning Beacon, forcwarning all Wise Virgins to Trim there Lamps against the coming of the Bridgroom. Containing a General Doctrine of Sundry Signs and Wonders, especially Earthquakes. By Abraham Fleming. London. $12 \mathrm{mo.}$

Three proper and Wittie fumiliar Letters, lately passed betucene two Vniversitie men, touching the Earthquake in April last, and our Enghish reformed versifying, with a preface of a well-wisher to them both. By Gabriel Harvey, "A Caustic Wit." London. 4to. Black Letter.

A Discourse on the Earthquake that happened in England and other places in 1580. By Arthur Golding. London. 8vo.

A Warning to the Wyse, a Feare to the Fond, a Bridle to the Lewde, and a Glasse to the Good ; written of the late Earthquake chanced in London and other places, the 6th of April, 1580, for the Glory of God and benefit of men, that warcly can walke, and wisely can judge. Set forth in verse and prose, by Thomas Churcliyard, gentleman. Loudon. 8vo. 
TABLE VII.-Literature of Earthquakes, Comets, Storms, dic.-Contd.

A.D.

1580

94

(?) 1600

1607

'09

$2+$

'37 .........

'38............

'38

$' 50$

'61 ........ In Salusbury's Mathematieal Collection, puhlished this year (tome ii,

The Order of Praser and other Exereises to avert and turn God's Wrath from us, threatned by the late terrible Earthquake, \&e.; with a pracer to be rsed of Honseholders every Enening; a Godly Admonition ; and a Report of the Earthquake, which happened on Easter Wednesday, 6th April, 1580, somewhat before six of the Clock in the afternoon. 4to. London. Printed by, Christopher Barker.

Sorrowfull Song for Sinfull Sonles; composed upon the stronge and wonderful shaking of the Earth, on 6 of Aprill, 1580. By John Carpenter. London. 8ro.

Tersio et Annott ad Tarios Auctores de Meteorologicis Affeetionibus, seu de Causes et Signis Pluviarum, Ventorum, \&c. By Sig. Fed. Urbimus Bonarentnra. Venice. 4to.

De Tiberis Inundatione et Epidemia Romana. By Marsilius Cagnatus, an Eminent Physiean. Verona.

A Contemplation of Mysteries; contayning the rare effeetes and signifieations of eertayne Comets, and a briefe rehersall of sundrie Hystories, examples, as well Divine as Prophane, verie fruitfull to be read in this our age: with matter delectable both for the sayler and husbandman, sea and all traueslers by sea and lande, in knowing aforehand how dangerous tempests will sueeed, by the sight of the cloud eoming orer the head; and other matters fruitfull to be reade. Gathered and Englished by Thomas Hyll. London. 8 ro.

God's Warning to Iis people of England, by the Great Orerflowing of the Waters in Floudes, latels hapned in Soutl Wales and many other plaees; wherein is deseribed the great losses and wonderful danuges that hapned thereby, by the Drowning of many Townes and Villages to the rtter vndooing of many thousandes of people. Printed at London for W. Barlay and Io. Bayly, and are to be solde in Gratious Street, 1607. 4to. Black letter. 12 pages.See Floods this date.

Discorso sopria l'Inondatione del Tevere. Br Nic. Galli. Rome. 4to. Discorso sopra l'Inondatione dell Acque del Bolognese. By Sig. Alidosi. Bologna. 4to.

Drinke and Weleome; or the Famous Historie of the most of Drinkes in use now in the Kingdoms of Great Brittaine and Ireland; with an espeeiall Declaration of the Potency, Virtue and Operation of onr English Ale; with a deseription of all sortes of Waters, from the Ocean See to the Tears of a Woman : as also the Canses of all Sorts of Weather, Faire or Foule, Sleete, Raine, Haile, Frost, Snow, Fogges, Mists, Tapours, Cloudes, Stormes, Windes, Thunder, and Lightning. Compiled first in the High Duteh tounge bs the painefull and industrious Huldriehe Van Speagle, and now most learnedly enlarged, amplified, and translated in English Prose and Verse, by John Taylor, "the Water Poet." London. 4 to.

True and Terrible Narration of an Earthquake in Calabria. By Martin Parker. London. Sro.

Dreadfull News, or, a True Relation of the Great Fiolent and late Earthquake whieh oecurred on 27 th March at Callabria, in Naples, to the orerthrow of Eight Cities, Twent - -four Towns, and Fiftyfour thousand Persons, \&e. London. Simall 4to.

On Inundations. By Martin Schooehms, a learned Dutch writer. Date and place of publieation nucertain. p. 100), is ineluded: A Relation of the state of the Inundations, \&c., in the Territories of Bologna and Ferrara. By D. Corsini.

'65 ....... De Cometis ; or a Discourse on the Nature and Effects of Comets. By John Gadbury, "Astrologieal Imposture." London. Ito. 
Table VII.-Literature of Earthquakes, Comets, Storms, de.-Contd.

A.D.

1665

'66.

69

70

71

71

72

75

${ }^{9} 77$

79

'80

'S1

'82

'83

'83

'83

'84

'84

'86

'87

Geologica Norregica; or, a bricf Instructire Remembrancer, coneerning that rery great and spacious Earthquake, which happened almost quite through the south parts of Norway upon the zith day of April, 165\%. Translated by Dan. Collins. London. 12mo.

Accomt of an Earthquake at Oxford in 1665. By Dr. John Wallis, F.R.S.-Phil. Trans., 1666, abr. i, p. 59.

A Relation of the late Prodigious Earthquake and Eruption of Mount Etna. By Heneage Finch, Eall of Winchelsea. London.

Folio.
Theatrum Cometicum. By Stanislaus Zubrienietoki, an cminent Socivian divine. Amsterdam, 1666-68. Ludg. Bat., 1681. This is the most considerable of his works, and contains, among other things, the History of Comets from the Flood to 1665. "A work of great labour, containing a minute historical account of every comet that has been seen or recorded."-W -WTT.

Concerning the Origin and Property of the Wind, with an historical account of Hurricanes, \&c. By R. Bohun. Oxford, 1671 and 1693. 8 ro.

A relation of two considerable Hurricanes in Northamptonshire. John Templer of Braybrook.-Phil. Trans., abr. i, p. 593.

Concerning a strange Frost about Bristol.-Phil. Trans., abr. ii, p. 37.

To show that the Rain and Snow Waters are sufficient to make Foun-

tains and Rivers run perpetually.-Thil. Trans., abr. ii, p. 242 .
Letters, and Collections of Letters concerning Comets, \&c. Robert Hooke, M.D., F.R.S. London. 4to. Also Discourses concerning Earthqnakes. ? date.

On a Storm, and some Lakes in Scotland. By Sir George Mackenzie,

King's Adrocate.-Phil. Trans., abr. ii., p. 210 .
Account of the Signification of the Comet which hath been long

visible in England. By William Knight. London. 4to.
The Voice of the Stars. By William Knight. London. $12 \mathrm{mo.}$

A Judgement of the Comet which became first generally visible in Dublin, 13th December, 1680. By Edward Wettenluall, D.D., Bishop of Fienmore. London. 8vo.

Account of an Earthquake at Oxford, September 17th, 1683.

Tbree Papers upon Earthquakes. By Martin Lister, M.D.-Phil. Trans., abr. iii, p. 16.

Ondersock over de Kometci; that is, An Inquirv concerning Comets, occasioned by the Comet which appeared in 1680 and 1681 . By Balthazar Bekker. Leuward. 8vo. In this book, which was written in Low Dutch, he endeavoured to show that Comets are not the presages or forerumners of any evil.

84 ........ On the Effects of the great Frost of 1683 on Trees and other plants.-

Phil. Trans, abr. ii, p. 89.
Effects of the Great Frost on Trees and other plants.

Concerning a Discovery made by the Inundations of the Tcrore. BF Sig. Sarotti.-Phil. Trans., abr. iii, 340.

Tractatus De Cometis: Cometæ Amni 1680, et plurinm præcedentium ab Anno 843, et sequentium Uttriusque Testimenti et posterioribus Prophetiis cum Apocalipsi convenientibus. Concordatum in Remedium omnium Ecclesia Rom. adversititatum. Collectore, M. A. Malonoxio Vedasto-Novarillano Noso-comii D. V. Tornaci Pastore indigno. Leodii, Typis Gerardi Grison, in Antiquo Foro.

A Summary of the Causes of the Alterations which have happened to the Face of the Earth. By John Ray, F.R.S., Naturalist.

Practical Reflections on the late Earthquakes in Jamaica, England, Sicily, Malta, \&e. By John Shower, Minister of the Gospel. London. 8ro. 
TABLE VII.-Literuture of Earthquakes, Comets, Storms, dec-Contd.

A.D.

1693.

93

'93

'94............

34 .

'94

'94.

'94

'95

'95

'95

'95

'95

'96

'97

'97

'97

$' 97$

'98.

'99

1703

'03.

'03

'03

A Discourse of Eartlqquakes. By Robert Fleming, a Scotch Divine. London.

Account of the Earthquake in Sicily. By Martin Hartop.-Phil. Trans., abr. iii, 555. Author's account of the same. Ibid., 556.

Accomt of the Earthquakes in Sicily on the 9th and 11th January, 1692-93. 'Translated from an Italian Letter.-Phil. Trans., abr. ïi, 602. By Vincentus Bonajutus.

Earthquakes Explained and Practically Improved. Occasioned by the late Earthquake on September 8th, 1692, in London and many other parts of England, and beyond Sea. By Thomas Doolittle, M.A. "Jamaica's miseries show London's mercies. Both compared." London : printed for John Salusbury, at the Rising Snn, ores against the Royal Exchange, in Cornhill, 1693.

On a Whirlwind.-Phil. Trans., abr. iii, p. 660.

The General History of Earthquakes. By Richard Browne. London, 8ro. Sold by Nathaniel Crouch, Bookseller.

A Methodical Account of Earthquakes. By Leonard Christ. Sturmius, Professor of Plyysics and Mathematics, Altorf.

Account of the Earthquakes in Pern in 1687 and in Jamaica, 1687 and 1692. By Sir Hans Sloane.-Phil. Trans., abr. in, p. 624.

Account of a Volcanic Eruption in the Isle of Sorea in 1693.-Phil. Trans., 1695, abr. iv, p. 13. By Nicholas Witzen.

Further Account of the Horrible Burning of some Mountains of the Molueca Islands. Ibid., p. 163. By the same.

Course of some Rivers abont Tungarouse destroyed by an Earthquake. By Nicholas Witzen, Burgomaster of Amsterdam.-Phil. Trans., 1695, abr. iv, p. 502.

On the Production and Effects of Hail, Thunder, and Lightning. By Dr. John Wallis, F.R.S.-Phil. Trans., abr. iv, 196, 212, and 226.

An Essay towards a Natural History of the Earth and Terrestrial Bodies, especially in Minerals; as also of the Sea, Rivers, and Springs; with an Account of the Universal Deluge, and of the effects that it had upon the Earth. By John Woodward, M.D. 1695, 1702, 1723. 8ro.

Also a Treatise : Earthquakes caused by some Accidental Obstruction of a continual Subterranean Head.

An Extraordinary Hail. By Edmund Halley, F.R.S.-Phil. Trans., abr. iv, 171, 172.

A Note concerning an Extraordinary Hail in Monmonthsbie. By Edward Lhwyd, Antiquary.-Phil. Trans, abr. ir, 173.

Account of the Great Hailstorm in Hertfordshire. By Robert Taylor. Phil. Trans., abr. iv, 172.

Effects of a Violent Storm ou the Rivers of North America. M[r. Scarbrough.—Phil. Trans., abr. iv, 198.

A prognostication concerning the Frost. By M. Cassini, the French King's Astrologer, translated from the French. London. 4to. M. Geo. Domen. Cassini was the famous French Astronomer.

Concerning an Extraordinary Inundation of the Island of Mauritius. By Nicholas Witzen.-Phil. Trans.

Accomnt of what Rain fell in the years 1697-98; with some Observations on the Weather. By Richard Townley.-Phil. Trans., abr. iv, 350 .

The Storm ; or a collection of the most remarkable casualties which happened in the Tempest. Daniel de Foe.

On the storm; a Sermon on Psalm xlviii, 8. By Reverend John Cockburn, D.D., Rector of Northaw, Middlesex.

Observations on the late Great Storm. By Wm. Derham, D.D., Canon of Windsor.-Phil. Trans., abr. iv, 93.

Observations on the Weather for sereral years. By the same. Ibid., 60. 
TABLE VII.-Literature of Earthquakes, Comets, Storms, cec--Contd.

A.D.

1703

'04.

'04.

'04.

'0.

'04

0.1

ot

04

'Ot

'04

04

'0s.

'04.

'06

'08

'08

Aecount of the Weather for 1699. Phil. Trans., abr, iv, 483.

Poem on the late Storm. Jolm Crabb. London, folio.

A strange effect of the late Storm in Sussex. By Juln Fuller, Esq., -Phil. Trans., abr. v, 91.

A Fast Sermon on the Grent Storm, on Psalm Ixxxix, 32. By Rev. Jolm Griffith, Edensor, Derbyshire.

Fast for the Storm; on Joel ii, 12-13. By John Hoadby, Arcllbishop of Armagh. Norwich. 4to.

Sermon on the Great Storm, on Jolm iii, 8. B5 Joseph Hussey, Pastor of Cambridge. 4to.

Fast for the late Storm ; on Psalm exix, 120. Rev. Thos. Ley, M.A. Viear of Crecliton, Deron. 4to.

Sermon on the late Storm; on Isaiah xxvi, 9. By Rev. Thos. Manning, Bishop of Clichester.

Discourse on the late Storm; on Rev. xri, 9. By Rev. Symon Patrick, afterwards Bishop of Ely. $12 \mathrm{mo}$.

A Fast Sermon for a Storm; on Hosea viii, 7. By Benjn. Grosrenor, D.D., Dissenting Divine.

A Fast Sermon for Storm; on Isaiah xxix, 6. By Rev. W. Harris, D.D.

Experiments to show the canse of the descent of mereury in the barometer in a storm. By Francis Hauksbee, F.R.S.-Phil, Trans., abr. v, 147 .

Aecount of an Earthquake in the North of England. By Ralph Thoresby, F.R.S.-Phil. Trans., abr. iv, p. 104.

Raconto Istorico de Terremotti sentite in Roma, e in parte delle Stato Eeelesiastico e in altri luoghi la sera de' 14 di Gemnajo, e la mattina de' 2 di Febbrajo dell' anno 1753. By Lue Antonio Chracas. Rome, 1704. 4to.

An Account of a Storm of Rain that fell at Denbigh in Wales.-Phil. Trans., abr. r, p. 331.

Concerning the effeets of a Storm of Thunder and Lightning at Colchester. By Jos. Nelson.-Phit. Trans., abr. v, 432.

Miscellaneous Reflections occasion'd by the Comet which appear'd in Decenber, 1680, chiefly tending to explode Popular Superstitions. Written to a Doctor of the Sorbon[ne] by Mr. Bayle. Translated from the French. To which is added the Author's Life. In 2 vols. London: printed for J. Morphen, near Stationers' Hall. MDecril. In the Table of Contents of these rolnmes ocem (inter alia) the following sections :-9. "First reason against the presages of Comets, that 'tis very probable that they lave no virtue to produce anything upon earth." 14. "That the exhalations of the comets, even allowing they might reach as far as the earth, conld prodnce no effect there." 16. "That if eomets had the power of producing anything at all upon earth, they might as well produce good as evil." 17. "That Astrology, which is the foundation of partieular predietions from the Comets, is most ridienlons." 23. "That slou'd it be granted that Comets are always succeeded by signal Calamity's, yet we con'd not therefore infer that they have been either the signs or the causes of these Calamities." 24. "Tis false that nore Evils have happen'd in the years next sneceeding Comets than in other years." 29. "What are we to say in answer to those who bring examples to prove the presages of Comets." 35. "The year whirh suceeded the Comets of 1665, compar'd with the years preceding the Comet of 1652." 45. "That the general persuasion is of no weight to prove the Evil Influence of Comets." 50 . "The superstition of the Antients as to Eelipses." 56. "What has been said of Eclipses apply'd to Comets." 57. "If Comets were the presages of Calamity's, God must have wrought Miraeles for this Confirmation of Idolatry." 60. "A strange consequence which must follow 


\section{Table VII.-Literature of Earthquakes, Comets, Storms, \&c.-Contd.}

A.D.

1708

\section{Miscellaneous Reflections-Contd.}

from Comets being miraeulonsly produced." 72. "That the reasons why Comets cou'd not be the presages of Evil before the Coming of Jesus Christ subsist still." 74. "That Comets hare partieular characters upon 'em, which show they are not presages." 76 . "Tis false that people who are happy after the appearance of Comets, have merited this distinction by their repentance." 79 . "That the common opinion of Comets being the presages of Eril is an old Pagan Superstition, introduc'd and entertain'd among Christians by their prejudiee for antiquity." 84 . "How Christians came to be mder the sime prejudiee as the Heathens with regard to Comets." 95. "That when they make Comets the presages of the Death of Kings, they ne'er distinguish the Deaths which are prejudieed from those which are otherwise." 102. "First objection against the argument from Religion: God has form'd Comets, that the Pagans might acknowledge a Providenee, and not fall into atheism." 194. "That there's no example proving God has miraculously form'd prodigs's for the pretended conversion of any one to idolatry." 203. "Comets are produe'd without a miraele. God might work miracles among Infidels. God design'd to make himself known by the means of Comets. All aets of idolatry oeeasioned by Comets will render man more inexensable." 201. "If Comets were signs of what happens after their appearanee, 'tis necessary they shou'd be miraculously form'd." 205. "A list of several hypotheses which may be follow'd in reasoning on Comets." 206. "That neither of these hypotheses discorers any natural connection between the Comets and what happens upon Earth after their appearanee." 215. "A way of coneeiving Comets to be presages without being miraeles." 217. "That if Comets were miracles, they'd be of sueh a kind as God never rouclisafes to Infidels." 220. "The sight of a Comet renders us not more capable of knowing the nature of God." 220. "'Tis false that the true Gentiles were render'd inexeusable in not being converted to the true Grod by the sight of Comets." 229. "That 'tis impossible Comets shou'd be the effieient cause of the Calamity's they are supposed to presage." 233. "That the eharacters of true miracles belong not to Comets." 237. "That Comets have no part in exeiting the passions which eause the diversity of erents." 239. "Remarks showing that to make a judgment of "what shall happen after the appearance of Comets, there's no need of considering these Stirs, and that 'tis sufficient to have an eye to the situation of general affairs to the Inelinations and Interests of Prinees. An Essay of this method on the Comet of 1618 , and that of $1681 . "$

[It is eurious to be obliged to remember that the author of this Treatise was and is regarded as one of the greatest plilosophers Franee has produced!]

'09 ....... Winter Meditations on Frost and Snow ; on Psalm exlrii, 15-18. $\Lambda$ sermon. By John Shower.

'09 ....... On the Great Frost of the Winter of 1709. By. Wm. Derham, D.D., F.R.S.-Phil. Trans., abr. r, 553.

'09 ....... Comparison of the Weather and Rain at Zurieh and Upminster' (in Essex). Br the same. Ibid., 497.

'09 ........ An Account of some Inundations, Monstrous Birtlus, Appearanees in the IIearens, \&e. By Peter le Nere, F.R.S.-Phil. Trans., abr. v, 485.

'14 ....... Thanksgiring Ser.nons after the Storm; on John v, 14. By Rev. Elisha Smith, M.A. Leetures of Wishbeach.

'14 ........ Aeeount of the Rain which falls every rear' at Upminster, Essex, for eighteen sears. William Derham, D.D., F.R.S.-Phil. Trans., abr. ri, 45 .

'14 ....... Sermon on a Storm; on Nahum i, 3. By Rev. Gerard Degols, Rector of St. Peter's, Sandwich, Kent. 8vo. 
Table VII.-Literature of Earthquakes, Comets, Storms, dec-Contd.

\begin{abstract}
A.D.
\end{abstract}
1715

Meteorological Essays, conecrning the Origin of Springs, Generition of Rain, and Production of Wind, with an account of the Tirle. Edward Barlow. London. 8ro.

'18 ....... Account of a Fiery Metcor, scen in Jamaica to strike the Furth. On the weather, birthquakes, \&c., of that Iskand. By Henry Barham. Phil. Trans., abr. vi, p. 368.

'22 ....... On a violent Shower of Rain in Yorkshirc. By Ralpl Thoresby, F.R.S. Phil. Trans., abr. ri, 585.

'24 ....... Observations on a Comet, made at Witham in Esscx. By the Hon. Lord Paisley.-Phil. Trans., vii, 15.

'25 ........ Dissertation sur les Tremblemens de Terre, et les Epidémics qu'ils oceasionnent. By M. Charles Bagard, eminent French physician.

'25 ....... Curious and Uncommon Account of the Great Eelipse of the Moon, 10th October, 1725, with a new Theory of all the Orbs in the Hearens; also the Poetical Adrentures and Translations of fire months and odd days at the Rural Seat of Mons. de l'Aron. 8ro. plates.

'27 ........ At an Earthquake at Dartmonth in Kent. By Edmund Barrell. -Phil. Tians., abr. vii, p. 176.

'29 ....... Account of an Earthquake at Boston, New England. By Rer. Benjamin Coleman.-Phil. Trans., abr. vii, p. 34S.

'30 ....... Account of the Hurricane, May 20, 1729. Richard Bugden. London. 8vo.

? '30 ........ A Physico-chymical Explanation of Subterranean Fires, Earthquakes, \&c. By M. Lemery of the Academr of Sciences, Paris. ? clate.

'32 ........ A vindication of the Testimony of Phlegon, or an account of the Great Darkness and Earthquake at our Sariour's Passion rleseribed by Phlegon, in answer to a Dissertatian of Dr. Sykes upon that Eclipse and Earthquake. Br William Whiston, an English divine.

'34 ....... Account of some Rcmarkable Frosts. William Derham, D.D., F.R.S. -Phil. Trans., abr. rii, 448.

'34....... The Gencral History of Earthquakes; being an accomt of the most Remarkable and Tremendous Earthquakes that hare happened in divers parts of the World, from the creation to this Time; as they are recorded by Sacred and Common Authors; and particularly those latcly in Naples, Smyrna, Jamaica, and Sicily. With a description of the famous buruing Mount, Etna, in that Island; and the relations of the several dreadful Conflagrations and Fiery Irruptions thereof for many ages. Likewise the Natural and Material Causes of Earthquakes, and the usual signs and prognosticks of their approach; and the Consequences and Effects that have followed sereral of them. By R. B. [urton]. London. Printed for A. Battesworth, in Paternoster Row, and J. Hodges, on London Bridge. mDCCXxxir.

'35 ....... On a Storm; a Sermon on John iii, 8. By Andrew Gifford, D.D., F.S.A. 8vo.

'35

Account of sereral Earthquakes that have happened in $\mathrm{New}$ England. By Paul Dudley, F.R.S.-Phil. Trans., abr. viii, p. 22.

'36 ....... Account of the Earthquake at Havan in Sussex. By Dr. Edward. Bayly.-Phil. Trans., abr. viii, 96.

'36 ........ General History of Earthquakes. Burton.

'36 ........ Account of the Shock of an Eirthquake fell in Sussex, 25th October, 1734. By Rev. Joscph Wasse.-Phil. Trans., abr. riii, 96.

'36.

'37. On the same subject. Ibid., p. 98.

The Astronomical Year, or an account of the many remarkable Celestial Phenomena of the great year 1736 ; particularly of the Comet, which was foretold by Sir Isare Newton, and came accordingly. By Wm. Whiston, an English Divine. London, 8ro. Some Considerations of the causes of Earthquakes. By Stephen Hales, D.D., F.R.S. London. 8ro. 


\section{Table VII.-Literature of Earthquakes, Comets, Storms, dic. - Contd.}

A.D.

1740

Concerning an Earthquake at Naples. By Hon. Henry Temple. Phil Trans., abr. viui, p. 401.

'40 ....... Of the Volcanoes and Earthquakes in Peru. By M. Peter Bougner' of the Royal Academy of Sciences, Paris.

'41 ........ An Earthquake at Scarborough, 29th December, 1737. By Maurice Johnson.- Phil. Trans., abr. ruii, 511.

'42 ....... A Journal of the Shocks of Earthquakes felt near Newburg, in New England, from the rear 1727 to the year 1741. By Rer. Matthias Plant.-Phit. Trans., abr. viii, p. 552.

'44 ....... The Tatural Ifistory of Volcanoes and Earthquakes. By M. Buffon, of the Ropal Academy of Sciences, Paris. Also Theory of the Earth. 1714.

'48 ....... On the Weather in South Carolina, \&e. By John Lining, M.D.- Phil. Trans., abr. ix. 514.

'48.

Particular Relation of the Dreadful Earthquake which happened at Lima and at the Neighbouring port of Calloa, on the 28th October, 1746 , to which is added a description of Calloa and Lima, before their destruction; and of the kingdom of Peru in general, with all its inhabitants. foudon. Sro.

'49 ....... A surprising inundation in the valley of St. John's, ncar Keswick, in Cumberland, 22nd Angust, 1719. Br John Look, F.R.S.-Phil. Trans., abr. $\mathrm{x}, 18$.

'49 ....... Sermon on the Eartluquake, from Job. ix, 5, 6. By Samuel Chandler, D.D. London. 8ro.

'49 ....... The Natural and Moral Government and Ageney of God in causing Droughts and Rains; on Psalm crii, 33--35. A Sermon by Thomas Prince, M.A., Pastor of South Chureh, Boston, New England. 8ro.

${ }^{2} 50$........ On the occasion of a second shock of an Earthquake; a Sermon on Matt. xi, 23, 24. Br Rer. Philip Doddridge. 8ro.

'50 ........ On the Earthquakes, on Amos ir, 12. By Rer.John Mason, M.A: 8ro.

'50 ........ List of Earthquakes felt in England and other Countries, with their dates, \&e. By Cromwell Mortimer, M.D., Secretary of Royal Societr.-Phil. Trans., abr. x, p. 108.

'50 ....... On the Hot Weather in July, 1750. By William Arderon, F.R.S.Phil. Trans., abr. x, 94.

'50 ........ Letter to the Clergy and People of Westminster, on occasion of the late Earthquakes. Br Thomas Sherlock, D.D. London. 4to:

'50 ........ Some thoughts oceasioned by the late Earthquakes. By Benjamin Stillingfleet, Naturalist. London. 4to.

'50 ........ The Philosophy of Earthquakes, Natural and Religious. By Wm. Stukler, M.D., F.R.S. London. 8ro.

'50 ....... A Dissertation on Earthquakes. Roberts.

'50 ........ Juliana; or, a Discourse concerning the Earthquakes and Fiery Eruptions which defeated the Emperor's attempt to Rebuild the Temple at Jerusalem. By Wm. Warburton, Bishop of Gloucester. London. 8ro.

'50 ........ A Genuine Account of Earthquakes, especially that of Oxford in the rear 1695 [corrected in ink to 1683 ], and of another terrible one at Port-Royal, in Jamaica, in the year 1692, giving an account of the Nature and Cause of them, their dire Effects, and destructive Faculties; their Desolation and Depopulation: published for the Information and Instruction of the public in general, and collected from the best authors, and personal witnesses to the several fatal Occurrences. Loudon. Printed for Henry Slater, at the Goldenkey, the corner of Clare Court, in Drury-Lame. MDCcL. kenzie, M.D.-Phil. Trans., abr. x, 548.

'51 ........ A Poem in Blank Verse, on a Violent Storm, attended with Thunder and Lightning; to which is added a Poem on Death, \&c. Palmera. By Edward Stevens. London. 8ro. $2 s .6 d$. 
TABle VII.-Literature of Earthquakes, Comets, Storms, de.-Contd.

A.D.

1751

'53

54.

'54

'55

'55

'55

'55

'55

'55

55 ........

55.

'55

'55

'55

'55

'55

'55.

'55

'56

'56

'56

On the quantity of Rain which fell at Leyden in the year 1751. By

Wm. Van Hazen.-Phil. Trans., abr. x, 233.

of a Stom of Thunder and Lightning in Cornwall. By $\mathrm{Wm}$. Borlase, LL.1., F.R.S.-Phil. Trans.

On the quantity of Rain which fell at Charlestown in South Carolina, from Jannary, 1738, till December, 1752. By John Lining, M.D.

-Phil. Trans., abr. x. 400 .
Observations on the late serere cold weather. By Wm. Orderon,

F.R.S.-Phil. Trans., abr. $\mathbf{x}, 451$.
Of an Earthquake felt at York. By David Erskine Baker.-Phit. Trans., abr. ix, 597.

Of the Earthquake at Cadiz in 1755. By Benjamin Bewick.--Phil. Trans., abr. $\mathrm{x}, 662$.

An Account of the Earthquakes which liappened in Barbary, \&e.

Lord Viscount Royston, F.R.S.-Phil. Trans., abr. x, 663.
Agitation of the Waters in Cornwall. By Wm. Borlase, LL.D., F.R.S.-Phil. Trans., abr. x, 653.

Of the Earthquakes felt at Brussels. By Sir John Pringle, Bart., M.D.-Phil. Trans., abr. x, p. 696.

On the agitation of the Waters, 1st Norember, 1755, in Scotland and at Hamburgh. By the same.-Ibid., p. 697.

Serious Thonghts on the late Earthquake, \&c. A Letter from a Portugnese Officer to a Friend in Paris, giving an account of the late Dreadful Earthquake, by which the City of Lisbon was destroyed. Translated from the Portuguese. London. Cooper.

Aceount of an Earthquake felt at Glasgow and Dumbarton; also of a shower of Dust falling on a Ship between Shetland and Tceland. By Robert Whytt, M.D., F.R.S.-Phil. Trans., abr. x, p. 687.

An Account of an Earthquake felt in the Lead Mines in Derbyshire, 1st Nov., 1755. By Rer. Wm. Bullock.-Phil. Trans., abr. x, p. 656. Similar Aceounts from various parts of the Island, by different hands. -Ibicl.

Of the late Earthquakes. By Mons. Vernede, Pastor of the Wallon Chureh, at Mastricht.-Phil. Trans., abr. xi, 8.

55 ....... Account of the Earthquake at Madeira. By Charles Chambers.

-Phil. Trans., abr. x. 665.
Earthquake in Philadelphia. By Peter Collinson, F.R.S.-Phil. Trans., abr. x, p. 667 .

A Philosophical Diseourse upon Earthquakes, their eauses and consequences, \&e. London. Cooper.

Of an impression on a stone dug up in the Island of Antigua, and the Quantity of Rain fallen there for four years. By Rev. Francis Byam.-Phil. Trans., abr. x, 628.

Of the Earthquake felt 18th February, 1756, along the Coast of England between Margate and Dover. By Samuel Warren.-Phil. Trans., abr. $\mathrm{x}, 703$.

Earthquake in Genera. By Charles Bownell, F.R.S.-Phil. Trans., abr. $x, 687$.

A Further Account of Memorable Earthquakes to the present year 1756; whercin is inserted a short and faithful relation of the late dreadful calamity at Lisbon; together with an abstract of Father Goree's Narrative of the Rise of a New Island in the Bay of Santorini in the Arehipelago, in the year 1707. Being a continuation of a Tract entitled "A Chronological and Historical account of the most memorable Earthquakes which have happened in the world from the beginning of the Christian period to the year 1750." 'To which is added, by way of appendix, "A particular Account upon Auto-de-Fe, or act of Faith, at Lisbon. Taken from an author of good credit, who was himself an eye-witness thereof. By a Gentleman of the Unirersity of Cambridge." 
TABLE VII.-Literature of Earthquakes, Comets, Storms, \&c.-Contd. A.D.

1756 ........ On the Fast on account of the Earthquake at Lisbon; on Luke xiii, 2, 4, 5. Rev. Thos. Alcock, M.A. Oxon. 8ro.

'56 ........ A Sermon on the Earthquake; Genesis xix, 14. Rev. John Allen. 8ro.

'56 ........ Two Sermons on the Doctrine of the Divine Tisitation by Earth quakes; on Isaiah xxix, 6. By Rev. Wn. Dodwell. Oxford.

'56 ........ On the Euthquake at Lisbon; on Ezekiel xxri, 17, 18. Charles Bulkler, Dissenting Minister.

'56 ....... On Earthquakes; a Fast Sermon, on Psalm xviii, 7. By Wm. Stukley, M.D., F.R.S. Sro.

'56 ........ A Fast Sermon on the Earthquake; Luke xiii, 4, 5. Rer. Thomas Anguish, M.A., Deptford, 8ro.

'56 ....... Fast Sermon for' Eartliquake, on Luke xii, 4, 5. Rev. Wm. Bearcroft, M.A., Cliaplain to the Lord Mayor.

'56 ....... Fast Sermon on the Earthquake, on Luke xiii, 5. 8ro.

'56 ........ On the late Earthquake, \&e.: a Sermon on Jeremiah xvii, 7, 8. By a Rev. Divine. 4to.

'56 ....... Fast for Earthquake, on Ecclesiastes xxxri, 26. Rev. Wm. Totten, Hexlıam.

'56 ........ Fast for Earthquake, on 1 Peter, r. 6. By the same.

'56 ........ Fast Sermon, occasioned bs the Eartliquake at Lisbon; on

'56 ........ Serious call to Repentauce Orton, Eminent Dissenting Minister.

,56 Romans xi, 22. Rev. John Pennington, M.A., Prebendary of Lincoln. Fast Sermon on the Earthquake; on Jereniah xvii, 6-8. Rev. Gloucester Pidlley, D.D., Canon of Salisbury.

'56 ....... Earthquake, Fast Sermon: Psalm exxvii, 2. Rev. Arnold King, LL.B. Chaplain to the Lord Mayor. 4to. '56 ....... Earthquake; a Fast Sermon, on Psalm xlvi, 8. Rer. Geo. Lavington,
Bishop of Exeter.

'56 ....... Prayers for a time of Earthquakes and Violent floods. Rer. James Meyrick, M.A. English Divine and Poet.

'56 ....... A Fast for Earthquake, on Jeremiah xrïi, 7. By James Hallifax, D.D., F.R.s. 4to.

'56 ....... Fast Sermon, on the Earthquake, on Luke xïi, 2, 3. By Rev. James How, M.A. 8ro.

'56 ........ Earthquake : a Fast Sermon, on Isaiah xxvi, 20. Rev. J. Kidgell, A.M., Rector of Horne, surrer. 8 ro.

'56 ........ Earthinake : a Fant Sermon, on Matthew x, 29. Rev. James Kilner, M.A., Rector of Lẹdon, Essex. 4 to.

The Theory and History of Earthquakes, containing, I. A rational Accomt of their causes and effects; illustrated by experiments and observations on subterraneous rapours, and the manner of making artificial Earthquakes. II. A particular and authentic History of those which live happened in these kingdoms, and the more remarkable of those abroad, riz., in Sicily, Jamaica, and Lima, with the most considerable eruption of Tesuvius and Etra. III. Some seasonable reflections on the two late Earthquakes, with a pathetic address on that oceasion to the Inhabitants of London and Westminister. Humbly inscribed to the Right Rev. Thomas Lord

'56 Bishop of Canterbury. A pamphlet, pp. 62, with one leaf appendix. Plain account of the causes of Earthquakes; being a supplement to the Treatise on Fine. By John Ficke, F.R.S. London. 8vo.

'56

The General Theory and Phenomena of Earthquakes and Vuleanoes, \&e. ; to which is added a particular history of the Lisbon Earthquake. $\mathrm{B}_{y}$ an ingenious gentleman who was an eye-witness of that tremendous calamity. London. Owen. to a Treatise lately published on Fire. By the same author. London. 8ro. 
Table VII.-Literature of Earthquakes, Comets, Storms, de.-Contd.

A.D.

1756

56

'56

'56.

'56

'57

'57

'57

'57

'57

57

, 57

$57 \ldots$

'58

"s

, 59

The late Dreadful Earthquakes no proof of God's particular wrath against the Portuguese; a Fist Sermon on Luke xiii, 4, 5. Rev. Thomas Seward, Canon of Litehfield. London. 8ro.

A Satirical Reriew of the Manifold Falsehoods and Absurdities hitherto published eoncerning the Earthquake; to whieh is amexed an anthentie Aeeount of the late eatastrople at Lisbon, and the present state of that august Capital. By a Man of Business. London. 8ro.

Of an Earthquake felt at Cologne, Liege, Maestrieht, \&e., on 19 November, 1756. By Abraham Trembley, F.R.S.-Phil. T; ans., abr. xi, 56.

On Earthquakes, Polypes, Fossils, \&e. By the same, Ibid., 83.

The Christian's Duty and Confidence in times of Public Calamity; being four Diseourses oceasioned by the late Dreadful Earthquikes, and the apprehensions of a Freneh War. Rev. Benjamin Wallis, A.M., Minister of the Grospel in London.

Thoughts on the Earthquake whieh was felt on the 9th December, 1755, in Switzerland. By John George Zimmerman. 4to.

A Treatise on Places and Preferments, especially Chureh Preferments, with a Letter concerming the causes of Earthquakes. By Rev. William Webster; D.D. London. 8ro.

Of the Earthquake felt in New England and the neighbouring parts of Ameriea, Norember 18, 1755. Prof. John Winthorp, Cambridge, Mass.-Phil. Trans., abr. viii, 713.

The History and Philosophy of Earthquakes, from the remotest to the present time, colleeted from the best writers on the subject; with a partienlar aceount of the Phenomena of the great one of Norember the 1st, 1755, in various parts of the globe. By a member of the Royal Aeademy of Berlin. London. Nourse. 8ro. $5 s$.

Chronological Aecount of Earthquakes. By Rev. Zaehary Grey. Sro.

An Account of the remarkable Comet whose appearanee is expeeted at the end of this present year 1757, or at the beginning of $175 \mathrm{~s}$, \&e. The whole illustrated with reflections on the Generul Conflagration, \&e. London. 8ro. is.

A Diseourse on Comets; eontaining a brief description of the true system of the world, and an enumeration of all the diseorerics which hare been made yet eoneerning these temporary appearanecs. By John Todge Cowly, F.R.S., Mathematician. 8vo. $1 s$.

The Theory of Comets, illustrated, in four parts : 1. An Essay on the Natural History and Philosophy of Comets, being the substance of all that has hitherto been pnblished on the subject; 2 . Tables eontaining the elements of the 'Theory of a Comet's motion; 3 . The method of constructing the Orbit of any Comet, and eomputing its place therein; the method of Delineating the risible path of a Comet in the Heavens, on the surface of a celestial globe. The whole adapted to and exemplified in the orbit of the Comet of the year 1682, whose return is now at hand. By Benjamin Martin, Optieian and Mathematieian. Iondon. 4to. $2 s .6 d$.

Dissertatio de Frigore quatenus Morborum eausa. By William Butter, M.D. Edinburgh. 8ro.

Of an Earthquake felt at Lingfield, Surrey. By Sir James Burrow, F.R.S.-Phil. Trans., abr. xi, 235.

Observations on a slight Eartliquake, though very partieular, which may lead to the cause of great and violent ones, that ravage whole eountries and overturn cities. By Sicur de Peysonnel, M.D.Phil. Trans., abr. xi, 215.

On a Storm of Thunder and Lightning at Norwich. By Simucl Cooper.-Phil. Trans., abr. xi, 327. 
TABLE VII.-Literature of Earthquakes, Comets, Storms, \&c.-Contd.

A.D.

1759 An Explication of the canses of Earthquakes. By Edward Wortley Montague.

'59 ....... Accounts of the Fiery Meteor' which appeared on Norember 6th, 1768 , between 8 and 9 at night. By Sir John Pringle, Bart., M.D. -Plil. Trans.

'59 ....... Oratio de Generatione Metallorum, \&c. ; or, a Treatise on the Generation of Metals by Earthquakes. By Zomonozof, a celebrated Russian Poct.

'60 ........ Of the late Earthquakes in Syria. By Dr. Patrick Russell, M.D., F.R.S.-Phil. Trans., xi, 437 .

'60 ....... Observations on the Comet seen in Jamuary, 1760. By John Michel, B.D., F.R.S.-Phil. Trans., abr. xi, 428.

'60 ....... Conjectures concerning the Cause and Observations on the Phenomena of Earthquakes, particularly on the Earthquake at Lisbon, November 1st, 1755. By the same. Ibid., 447 .

'61 ....... Of a Meteor seen in New England, and of a Whirlwind felt in that Country. By Prof. John Winthrop.-Phil. Trans., abr. xi, 514.

'61 ....... Description of the Comet which appeared in 1744. By Zomonozof, the Russian Poet.

'61 ....... On the Phenomena of the Air, oceasioned by the Electrical Fire, with a Latin Translation of the same. By the same.

'61 ....... On the Origin of Metals by means of Earthquakes. By the same.

'61 ....... The two Hrdraulic Performances Jelatire to the Preserration of the Provinces of Ferrara and Raremna from the Inmulation of Rivers. By Paul Frisi, Philosopher and Mathematician. Lueca, 1762 .

'63

Of an Earthquake at Chattigaon. By Edward Gulston.-Phil. Trans., abr. xii, 12, 13.

'63 ....... Of the Earthquake in Siberia. Dy Weymaru.-Phit. Trans., abs. xii, 3 .

'63 ....... On the Rain fallen in a Square Foot at Norwich. By Rev. Wm. Arderon, F.R.S.-Phil. Trans., abr. xi, 678 .

'64 ........ A Description of a Storm that happened in the month of August, 1763. By Rer. John Hodges, Vicar of Tudily and Capella, Kent. London. 4to.

'64 ........ Theory of Lightning and Thunderstorms. By Andrew Oliver, Esq., of Salem, Mass.-Trans. Amer. Soc., ï, 74 .

' 64 ....... Theory of Waterspouts. By the same. Ibid., 101.

'61........ Of sereral Fiery Meteors seen in North America. By Prof. John Winthrop.-Plit. Trans., abr. xii, 142.

'67 ........ Rhenus. Br Manuel Lassala, a Spanish ex-Jesuit and Scholar. The subject of this Latin Poem is the inundations of the Rhine. Talentia; also Bologna, 1781.

'67 ....... Thoughts on Comets. By Prof. John Wintlrop,-Phil. Trans., abr. $x \ddot{i}, 405$.

'67 ........ Concerning Wind and Waterspouts, Tornadoes and Hurricanes. By John Morgan, M.D.-Trans. Amer. Soc., ï, 335.

'67 ....... Sermon, occasioned by the Earthquake. By the Right Rev. Beilly Porteus, afterwards Bishop of London. Clarks. 12mo.

'68 ....... On the history of the return of the famous Comet of 1682 ; with observations on the same. BF Matthew Maty, M.D., Seeretary of Royal Soeiet_.--Phil. Trans., abr. xii, 263.

'68 ....... A new Theory of Comets (Laws of Motion), \&e.; plainly showing that they are not solid, compact, fixed, and durable bodies, like those of the Planets, but that they are Solar Meteors or exhalations of the same nature with our smoke, which lying to a certain distance from the sun, thicken or draw together such a mass, that at last their own gravity forces them back into its blaze, where they 
TABLE VII.-Literature of Earthquakes, Comets, Storms, \&e.-Contel.

A.D.

1768

'69 .

'69

'69

31

71

71

72

73

73

73

75

76.

'77

'78

79

\section{A new Theory of Comets-Contd.}

no sooner arrive than they take fire, and are riolently thrown off in right lines through the Unirerse, till their own flames Lave exhluusted their substanee. By Miehael Wood, F.R.S. London. 8vo. is. An aecount of an Earthquake at Maeao, and a short description of a singular description of Monkeys without Tails, found in the interior part of Bengal. By Stephen de Visme.-Phil. Trans., abr. xii, 607.

Fall of Rain at Bridgewater and at Mounts Bay, 1769. By WVm. Borlase, LL.D., F.R.S.-Phil. Trans., abr. xii, 46 . The same as Mounts Bay 1770-71.-Phil. Trans., abr. xiii, 126 and 325.

Of the different Quantities of Rain which appear to fall at different lieights, orer the same spot of ground. By Wm. Heberden, M.I). -Phil. Trans., abr. x, 659 .

Method of determining the strength and duration of Earthquakes. Dr. David Wark, Minister of Haddington. Essays, Phys. and Lit., iii, p. 142.

Fall of Rain at different heights. The Hon. Daines Barrington. -Phil. Trans., abr. xiii.

The Inundation; or the Life of a Fenman. A Poem ; with Notes, critical and explanatory. By a Fen Parson. London. Baldwin. 4to. us. The principal Elements, or primary particles of Bodies inquired into, and found to be neither those of the Chemists, nor of the Natural Philosophers; but Earth, Water, Air, Fire, and Frost. Taken from the observance of nature and numerous experiments. London. 8ro. $2 s .6 d$.

Sermon on an Earthquake in Shropshire. By Rev. John Fletcher, Ticar of Madily, Yorks. London. Svo. Is.

On the effects of a Thunderstorm on the IIouse of Lord Tylney, at Naples. By Sir Wm. Hamilton, F.R.S.-Phil. Trans., abr. xiii, 453. (See 1783.)

In the Phil. Trans. of about this period will be found numerous papers by this nobleman on the Eruption of Vesurius, \&e.

The Naturalist's Calendar. By the IIon. Daines Barriugton. Contains an aceount of the Wars, Plagues, Earthquakes, Floods, Conflagrations, Thunder and Lightning, \&e., which happened from the

creation of the world to A.D. 416 .
There was reprinted by Wm. Benson Earle, from a searee pamphlet, an exact relation of the famous Earthquake and Eruption of Momt Etna in 1669; to which is added a Letter from himself to Lord Lyttleton, containing a deseription of the late Great Eruption of Mount Etna in 1766. London. 8ro.

Observations made during the late Frost at Northampton. By

Anthony Fothergill, M.D.,F.R.S.-Phil. Trans., abr. xir, 1 IG.
Aecount of the late Earthquake felt at Manchester. By 'Thomas Pereival, M.D., F.R.S.-Phil. Trans., abr. v, 201.

An Account of an Earthquake felt at Manchester and other places. By Thos. Henry, F.R.S.-Phil. Trans., abr. xir, 330.

The Universal System; or, Mechanical causes of all the appearanees and morements of the Visible Heavens; shewing the true powers that move the Earth and Planets in their Central Rotation. Witli a Dissertation on Comets, the nature, cause, matter, and use of their tails, and the reason of their long trajectories. Likewise an attempt to prove what it is that moves the Sun round its Axis. By Joln Lacy. London. 8ro. is.

'80 ....... Mémoire sur un Paratremblement, \&c., or, a Memoir concerning a Counter-Earthquake and a Counter-Volcano. By St. Lazare re Bertholon, a Freneh Philosopher. ['The anthor considered he had devised a method of presenting these convulsions in the bowels of the earth!] 
Table VII.-Literature of Earthquakes, Comets, Storms, \&c.-Contd.

A.D.

1781

'81

'81

'81.

' 81

'81

'81

'82.

'S3

'83

'83

'83

'S3

'S3

'81

'85.

'86

'88.

'88

'89

'90

'92

92.

An History of Jamaica and Barbadoes; with an Account of the Lires lost, and the damages sustained in each island by the late Hurricane, \&c. London. 8ro.

A General Account of the Calamities occasioned by the late Tremendous Hurricanes and Earthquakes in the iVest India Islands, \&c. By Wm. Fowle, M.D. London. Sro. is. 6d.
Account of an Earthquake at Hafodunas, near Denbigh. By John Loyd, F.R.S.-Phil. Trans., abr. xi, 151.

Account of several Earthquakes felt in Wales. By Thomas Pennant, LL.D., F.R.S.-Phil. Trans., abr. xr, 85.

Account of the violent storm of Lightning at East-Bourne in Sussex.

By Owen Salisbury Breraton.-Phil. Trans., abr. xr, 21.

Fatal effects of a Thunderstorm in Scotland. By Patrick Brydone,

F.R.S.-Phil. Trans., abr. xri, 186.
The Plionix ; or, Reasons for beliering that the Comet is the real Phœnix of the Aneients. By John Goodridge. London. 8vo. $3 s$. On a new kind of Rain. From the Italian of Chev. Joseph Gioeni, "an inhabitant of the third region of Mount Etna."-Phil. Trans., abr. xr, 165.

Quantity of Rain which fell at Barrowby, near Leeds. By George

Lloyd, Esq., F.R.S.-Phil. Trans., abr. xr, 193.
M. Dolomicu, a French Mineralogist. Pub. Voyage aux Isles de Lipari, fait en 1781, ou Notices sur les Eoliennes, pour servir a l'Histoire des Toleanos. Paris. 8vo. [Herein he gires a particular account of their Tolcanoes.]

Also Mémoire sur le tremblemens de terre de la Calabri. (This was in 17S4 translated into Italian.)

Of the Earthquakes which happened in Italy from February to May, 1783. By Sir Wm. Hamilton, F.R.S.-Phil. Trans., abr. xv, 373. (See 1773).

Account of the Earthquake in Calabria, March 28, 1783. By Count Francesco Ippolito.-Phil. Trans., abl. xr, 383.

Of a remarkable Frost on the 23rd June, 1783. By Rev. Sir

John Cullum, Bart., Antiquars.-Phil. Trans., abr. $x r, 604$.
De tffectibus Terræ. Iotus in Compore Humano; concerning the Effects of Earthquakes on the Human body. Bologna. 8ro.

On the Crooked and Angular appearance of Lightning in Thunderstorms. By James Logan, a Scotchman, residing in America.Phil. Trans., abr. vïi, 68.

Advertisement of the expected return of the Comet of 1532 and 1661, in 1788. By Nevil Maskelyne, D.D., F.R.S., astronomer.-

Phil. Trans., abr. xri, 147.
The Theory of Rain. Br James Hutton, M.D., F.R.S.E.-Trans. Soc. Edin., i, 41 (in 1792).

An Account of the Hurricane at Barbadoes on the 10th October, 1780. By William Blendy.-Ed. Phil. Trans., i, part first, 30.

The Frost; a Little Poem for Great Folks. London. Buckland. 8ro. $6 d$.

Sermon preached in the Low Chapel of North Shields, in the County of Northumberland, November 22, 1789, for the Benefit of the Orphans of the Unfortunate Seamen who perished in the riolent Storm off the East Coast of England, October 30 and 31. To which is prefixed an Account of the Gale, and a list of the ressels that were wrecked in it. By Rev. L. Gircle, of Newcastle-

upon-Trne. London. 8ro. 1s.
Theory of Rain, Prineiple of Fire, on the Power of Matter, \&c. James Hutton, M.D., F.R.S.E. Elinburgh. Ito.

A narratise of an Eartliquake felt in Lincolnshire and the neighbouring Countics. By Eimund Turner, F.R.S.-Phil. Trans., abr., xvii, 220. 
TAble VII.-Literature of Earthquakes, Comets, Storms, de.-Contd.

A.D.

1795

'96

97

'98

'98 .

'98

1803

'05

'07

'09

'10.

'11

'11.

'16

' 49

'77

Journal of the Thermometer, Hygrometer, Barometer, Winds, and Rain, kept at Windsor, Nova Seotia. Rev. William Cochrane.Trans. Irish Acad., ix, 133.

Aceount of an Earthquake felt in rarious parts of England; Norember 18, 1795. By Edward Whitaker Gray, M.1.-Phil. Trans., abr. xriii, 31.

The Iurricane; a Theosophical and Western Eelogue. By William Gilbert. London. 12mo.

The Storm ; a Drama. Jy George Holford, M.P. Of this only a few copies were printed.

Frost at Midnight. By S. T. Coleridge. London. 8ro.

The Dominion of Jesus Christ over the Elements of Nature; a Sermon upon the Storm of 1703. By the Rev. Robert Winter, D.D. 8ro.

Curious particulars respecting the Mountains and Volcanocs, and the effect of the late Earthquakes in Sonth America, \&c. Baron Inumboldt.-Nicholson's Journ., iii, p. 242.

Account of a Storm of Salt which fell in Jannary, 1803. By Richard Anthony Salisbury, F.R.S.-Trans. Limn. Soc., viii, p. 286.

Observations on the nature of the new celestial body discorered by Dr. Olbers; and of the Comet which was expected to appear in July last, in its return from the Sun. By William Herschel, LL.D., T.R.S.-Phil. Trans., abr.

A Narrative of the proceedings on board His Majesty's ship "Tharsus," from the 4th to the 15th September, 1804; being an account of a Hurricane which she encountered in the Atlantic

Ocean. Folio.
The Storm Improred, containing an interesting narrative of the loss of the "Liberty," of Kincardine, and the Substance of a Discourse delivered to the crews of the several vessels wrethed, with the Author, in the neighbourhood of Saltfleet. By John Clunie, A.M. $2 s$.

A Sermon, occasioned by the appearance of the Comet. By Josepl Jefferson, Dissenting Minister, Basingstoke. 8vo.

A short Account of the late Inumlation in the neighbom hood of Boston. By Saml. Partridge, MI.A., Vicar of Boston. 12mo. Account of the late Earthquake in Scotland. By Thos. Lauder Dick, F.R.S.-Annals Phil., viii, 364 .

The Progress of the Development of the Law of Storms and of Variable Winds, with the practical application of the Subject to Narigation; illustrated by charts and woodents. By Licut.-Col. Wm. Reid, C.B., F.R.S.

Note.-Mirs. Somerville stated sereral years since that about 255 earthquakes had occurred in the British isles, all slight. To aroid the effects of a shock predicted by a madman for the sth April, 1750, thousands of persons, particulariy those of rank and fortume, passed the might of the 7 th in their carriages and in tents in Hycle Park. -Tincent.

A Lecture on the Winds, Ocean Currents, and Tides, and what they tell of the System of the World. By Wm. Leighton Jordan, F.R.G.S.

Also by sime author, same jear: The Winds, and their Story of the World. 


\section{Object of Preceding Tables.}

The object of the preceding tables, is manifestly that of endeavouring to obtain a complete, or at all events a comprehensive view of the causes of famines, so far as they fall within the eategory of being the result of natural or nuavoidable causes. We see first from an analysis of the table of famines, the causes to which they are mainly attributed. We then follow ont these causes as a separate branch of inquiry. We suppose the facts presented in the sereral tables will aet and react upon each other in sach a manuer that the law of famines may be dedueed, at all events that the extent of cause and effect may be made in some degree apparent.

For the purpose of this analysis, it is neeessary to limit our range to some one conntry. We take our own, for instance, and apply the test of frosts. Famines in Great Britain have resulted from severe frosts. We take the table of frosts, which I believe contains something like a complete record of those which may be regarded as historical. From this table we turn to that of famines. Has a famine nsually resulted from intense frost? Here we must take into aeconnt a chronological incident. Under what is now designated the "old style," the year did not terminate until 25 th March. The ehange took place in 1752, which year began on 1st January. It is very important to keep this fact in mind in most chronologieal inquiries. In this instance it is especially so. The frost of one year would usually affect the crops of the next year, prior to 1752 . Where indeed the frost eame in very early, so as to affeet the larvesting of the grain-as is sometimes eren now the case in North Britain-it might be that the famine wonld arise in the same year as the frost. The same remark will also apply to floods. But I need not dwell upon these details: for I am compelled to admit that when critically examined in this manner, the facts in the one table do not, taken as a whole, at all coincide-to say nothing of presenting complete harmony-with those in the other. There are some correspondences, but these may be simple coineidences. The same admission has to be made with respect to the other tables. If you attempted to produce a table of the famines of Great Britain from the combined details of the eanses which are ustally credited as produeing famines, you would prodnce a result almost entirely out of harmony with aetnal reeorded facts.

That this discovery and consequent admission is very discouraging after the labonr bestowed is but too obvious. But we must not abandon all onr efforts in despair. The faets presented in the several tables as faets are, I hope I may say, of essential value. They have not lieretofore been presented in our Joumal. To the statistician, as to the scientific inquirer, all facts are of valuc. My duty now is 
to endeavour to account for this breakdown of a system of inquiry, which I veuture to think was logically as also theoretically correct. This may have been occasioned by the cumulation of several causes. The first and most readily suspected being that the data are incomplete: an incompleteness of data must necessarily imply in-harmony of results. The answer on my part is that I have had recourse to all known authorities. The next consideration is founded upon the well known want of harmony in the chronology of early recorded events. You consult any two or three of the early chronicles as to the occurrence of any known incident. You will not unfrequently find one year's, two years' or even three years' variation in the dates of the respective writers, occasionally very much greater and more perplexing discrepancies. Before unirersal calendars, or a settled chronology obtained, the mode of compating time was usually by reference to the year the reigning sovereign had occupied the throue, as third of Richard II, \&c., \&c. In this manner mistakes may well have arisen. We know that such discrepancies lave existed even as regards the date of particular Acts of Parliament - more than one chronological date being assigned to many of our more important legislative enactments. Still on the whole even these discrepancies may be harmonised, from the circumstance that great historical events do not usually happen in such immediate proximity, that the one may be mistaken for the other. In the ase of comparative tables, howerer, where cause and effect are sought to be established, this conflict of dates becomes very perplexing, and occasionally entirely misleading.

Again, in order to a complete understanding of the causes of famines in any given country, the operation of the artificial causes, as wars (including invasions and blockades), legislation (including limitation of imports, extent of import duty, or enforced restriction of prices). The effect of Pestilences, as resulting from tho neglect of the laws of public health, may be included in this category, althongh as a rule these lattcr are the results from rather than the occasions of famine. These will be considered in the second part of my paper.

Yet another consideration remains to be presented, and it is this, that it is more than probable that very frequently several causes combine to produce such a national calamity as famine, I mean a combination of natural causes. For instance, frosts following seasons of excessive rain, will be far more destructive of all vegetation than frost succeeding dry seasons. In this latter case the frost, often benefits the soil, and advances vegetation by destroying laz"gely its insect and reptile antagonists. And liere I am disposed to think my tables may be of real value, as affording means of comparison not otherwise readily available. 
I ought indeed at this point to notice the poetie, perhaps I had better say the dramatic, or even mythical aspeet of the subject. No one ean be familiar with the old ehronielers, from whom we necessarily draw so much of our historieal information, without being struck with the tendency of these persons to pile up the agony, so to speak, on certain great historical occasions. Comets in early times oceasioned great dread; eclipses of the sun, or moon, were deemed to be direet manifestations of the wrath of the Almighty; hurricanes, whirlwinds, waterspouts, were but lesser indications of the same divine vengeance; while earthquales formed as it were the grande fincle to the provoeation of erring man against his Creator. That the poets sbould seize upon stch events to give dramatic effect, and lend force to their creative outpourings, is but natural. They often deal with history as represented by popular tradition.

Thus Virgil in his "Georgies," speaks of comets and eclipses as appearing synchronously with great historical erents, such as the death of Cesar:

"Sol ctiam extincto miscratus Cæsare Romam, Quum caput obscurâ nitidum ferrugine texit."

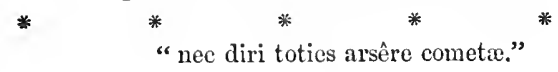

which may be rendered:

"The sun himself on Rome

Looked down with pitying eye when Cæsar fell, And hid his face in gloomy shrouds of night."

But that the ehroniclers, who were mostly ecclesiasties, should ever liave stooped to exaggerate their narratives with monsters seen in the heavens, with showers of blood, with sulphuric emanations, with unnatural eclipses, and with other most umeasonable horrors, and these too not unfrequently assoeiated with those historic personages who had incurred the displeasure of the Church-whieh perhaps is the only sort of excuse, but can be no justification-seems remarkable. It is loading listory with a perpetual lie, on the small pretext of affording an example to other heretics and offenders! It may be replied that the combined miseries of the plagues of Egrpt, afford at least a precedent for snch horrors; while the sun standing still on the command of Joshua, prepares one for all that may follow at any time or place. I am not of this opinion, and I have accordingly eliminated from my tables as far as possible the elements which I regard as purely mythieal. Two very mild instances of such exaggeration are given, the one under dates $1389-90$; the other 1658 .

But while endeavouring to exclude all hypothetical considerations from my paper, there yet remains to be considered a meteoro- 
logical solution of famines in various parts of the world, to which I have not in any way alluded at present, and this is the "sun-spot" theory, which is the most modern of all famine theories, and in the further elucidation of which several of the tables ineluded in this paper may yet be of value. It will of course be understood that in attempting to deal with this, "the newest scientific play"thing" as I have seen it called, I make no pretension to scientific knowledge. I shall deal here, as in other parts of the paper, with recorded facts, and shall only follow where these may lead.

\section{Indian Famines.}

In this connection our minds naturally revert to Asia, and more particularly to that important empire of India, with which we have so much concern. I have endeavoured to make my table of famines complete as to India in modern times.* The first great famine there of which we have any knowledge-many earlier ones of lesser magnitude have occurred-was that of $1769-70$, "when the "Government did not attempt to cope with the disaster; when the " people died of starvation by hundreds of thousands; and a "desolation spread over the country, the marks of which have not " wholly ceased." (Vide Col. George Chesney, "Indian Famines in "Ninetecnth Century," November, 1877.) We see in our table that it is estimated that three millions of the population then died of starvation, an cstimate I am not inclined to deem exaggerated; and we are told that Bengal has been subjected to famines periodically since-why since, as distinguished from previously, does not appear. In 1799 there was again a famine in Hindustan, and in 1803. In 1810 there was a famine in the North-West Provinces, and from 2 to 8 per cent. of the population died, 90,000 in one central district alone! In 1813-14 Hindustan again; in 1832 in Madras, when 200,000 perished in the district of Guntoor. In $1837-38$ in Northern India, "the worst famine of this century"-but this was written before the more recent famines we now have to record. In 1861 famine in North-West Provinces; in 1866, "awful famine" in Orissa, one million and a-half of the people, half the population of London, reported to have perished. In 1874, the Bengal famine, which cost this Government $6 \frac{1}{2}$ millions sterling, for an organised system of relief; and lastly that of 1877 , morc terrible perhaps than any during this century, over which our Indian experience extends, and which it is estimated will cost in all nearly ro millions sterling!

In all there have been thirty-four famines (above twenty on $\cdot$ at

* It is impossible for me to express too fully the obligations I am unruer t; Mr. F. C. Danvers of the India Office, for the assistance he has rerridured atd regarding the Famines, and Famine incidents of India. 
large seale) in India in just over a eentury. I mueh regret that I am not able to present more complete statistieal details as to some of these. Under the former Government of India, usually known as the Company's rule, statisties were not a feature. Many of the historical details which I have been able to give in my table of famines, are drawn from a most able report, prepared some little time since, but not yet made publie-much as its facts are needed just now-from some State rcason, or want of reason, which I do not profess to understand. If I lad found myself in possession of anything like complete metcorological data regarding India, I should have endeavoured to examine the causes of famines in that empire in mueh more detail.

MIr. F. C. Danvers says :-

"Famines in India have arisen from several different causes; but the most general cause has not been failure of the usual rains. Distress has also, however, been caused by hostile invasions; by swarms of rats and locusts; by storms and floods; and not unfrequently by the immigration of the starving people from distant distressed parts into districts otherwise well provided with food supplies; and occasionally by excessive exports of grain into famine-stricken districts; or by combinations of two or more of the above-named circumstances." Report, 1S78, p. 2 .

There is one peculiarity about the famines of India which deserves especial notice, and it is this: ecrtain districts only are so visited at any one period; and in India, taken as a whole, there is always produced food enough for all its inhabitants. The immediate question is therefore one of transport only; the ultimate question is of course the prevention of famines. This state of things has given rise to a somewhat fieree controversy between the respective advocates of railway and canal (or irrigation) extension. Into that controversy I do not propose to enter further than to say : for the purposes of Imperial Government one cannot bat admit that railways are of the first necessity. For the purposes of local and domestie government, canals (with which ean be combined irrigation), are at least in those districts most subject to famine droughts, of paramount importance on the seore of humanity. The soil of India nnder irrigation never fails to produce a erop. In some districts canals, as a means of transport, have been found to pay as a financial investment. In others they have involved immense loss, in the way of an unproductive lock-up of capital. In some parts of the empire, the country is naturally suited to canal and irrigation works; in others the physical or engineering difficulties are very great. The problem for the Government in the last-named eases is a very serions one. Irrigation where it can be successfully carried out, in fact is a preventative of famines. Railways afford the means of distributing food when famines arise; and in the meantime they aid greatly in developing the resources 
of the country. I know the anxious care which the present Government have bestowed npon this question. If tho near oceurrence of two such serere famines could have been foreseen, it would no doubt have been wise to have expended in irrigation works the I 2 or I 5 millions sterling which have been spent or lost by their occurrence, cven if this enterprise had not been pecuniarily productive. To meet probable future requirements, an extended and well-considered system of combined water carriage and irrigation must be devised. A return upon the outlay may be provided in the shape of a tax or water charge upon the districts benefited.*

This important question is ably discussed in an important paper by Colonel George Chesney, in the "Nineteenth Century," for" November, 1877.

\section{Sun-Spot Theorlj.}

When or by whom the sun-spot theory as applying to India was first observed upon, I need not stop to inquire. There seems to have been several independent inquirers, as is very often the case. The name of Mr. W. W. Hunter is notably associated with the inquiry; and in the "Nincteenth Century" for November, 1877, is an interesting article, the joint production of Mr. J. Norman Loekyer and Mr. Hunter, to which those who desire details beyond those here given may with advantage refer.

In the article named, after an explanation of the more recently observed phenomena connected with the sun, the writers proceed to state (p. 584):-

"All these phenomena ebb and flow once in eleven years. So that every eleven years we have the greatest activity in the production of nprushes, spots, and prominences; and between the period of maximum we have a period of minimum, when such manifestations are almost entirely wanting. In fact, the spots may be taken as a rough index of solar energs, just as the rainfill may be taken as a convenient indication of terrestrial climate. They are an index but not a measure of solar activity; and their ansence indicates a reluction, not a cessation of the sun's energy."

Now if the matter could have been reduced to as simple a problem as is here indicated, the effect of the variations of the sun's spots upon rainfall and other climatic conditions would have been easily within our reach, for even twenty-two years of meteorological

* In speaking of India it is always to be remembered that just as famines become obviated, and a regular food st ${ }_{\mathrm{r}}$ ply be obtained for the people, so will the population increase. All that is now done must therefore be considered in the light of the additional millions and tens of millions which will be planted upon that soil within the next half-eentury.

Sir J. Strachey had come to the conclusion that as a sort of insurance against future famines, he must have a surphs of some 2,000,000l. amnually.-Lord George Hamiltou in the House of Commons, 1878. 
observations would have shown us whether the results were perfectly uniform, or whether mueh variation was to be expected. Besides such regularly recurring results could not have escaped observation at an earlier period. A correspondent to the "Times" (14th December, 185 ), Mr. A. Cooper Ranyard, supplied the following important qualifications:-

"Will you permit me to draw attention to the fact that the periods of maximum and minimum of sun-spot development do not oceur at uniformly regular intervals of time, as some of your correspondents appear to assume? It is true that on the average sun-spot maxima occur at intervals of $\mathrm{II}^{\circ} \mathrm{I}$ years, but occasionally thirteen or fourteen years will elapse between two periods of sunspot maxima. In one instance in comparatively recent times-viz., between 1788.1 and 1804.2_-16.1 years elapsed; while, on the other hand, between the sun-spot maxima of $1829 \cdot 9$ and $1837 \cdot 2$ only 7.3 years elapsed. Dr. Wolf, of Zurieh, in a memoir which will shortly be issued by the Royal Astronomieal Society, shows that the divergence trom the mean period las during the last two centuries and a-lalf amounted on the average to 2.03 years. The data which he has made use of are derived from a very extensive series of manuseript and printed record of sun-spot observations dating from 1610 (shortly after the invention of the telescope) to the present time. An examination of these records shows that the irregularity in the development of sun spots is so great that only value prognostications can le made with regard to the time of an approaching maximum; for example, six months before the time assumed from the eleven-year law as a time of maximum development, it wonld be impossible upon examination of the sum to assert that the period of maximum development had just arrived, or whether it might be delayed for another two or three years. And what is true with regard to periods of maximam development is also true for periods of minimum development. It will thus be seen that if the newly-broached theory were fully established, the Indian Government would be as far as it is at present from being able to prediet a year or two beforehand whether any particular season would be a season of famine or no."

From this we also learn, what indeed was to be expected, that the theory will receive the most critical investigation and elucidation.

We have yet to understand the mode in which the changing aspeet of the sun makes itself felt on this planet. The "Nineteenth "Century" article thus enlightens us (p. 585) :-

"It was, perhaps, searcely necessary thus to clear the ground for the general statement, now an accepted fact of science, that with the exception of tide work, all our terrestrial energies come from the sun. In the great modern principle of the conservation of energy, we have not only proof that the actual energy stored up in our planet is eonstant, but that the solar energy is the great prime mover of all the changeable phenomena with which we are here familiar, especially in the inorganic world. That energy gives us our meteorology by falling at different times on different points of the aërial and aqueous envelopes of our planet, thereby producing ocean and air currents, while, by acting upon the various forms of water which exist in thos, envelopes, it is the fruitful parent of rain, and cloud, and mist. Nor does it stop here. It affects in a more mysterious way the electricity in the atmosphere, and the magnetism of the globe itself."

We are next told how it :s that these effects are variable, instead of being constant, as mo st of nature's operations are :- 
"If the energy radiated from the sun were constant, we should expect that the terrestrial conditions which depend on the amount of solar energy received at any one place would be constant too. The daily change in the earth's rotation, the yearly change bronght about by the earth's revolution would be there; but there the change would stop. The fire, as well as the air, earth, and water, wonld be constant quantities. But suppose the fire to be variable, in other words, suppose the solar energy to change in amount from year to year. To the daily and unusual changes of our terrestrial phenomena would then be added another change; a change absolutely irregular and unpredictable. if the variation in the amount of solar energy were sulject to no law; but a change as regular as the daily and the yearly one, if the variations in the amount of the solar energy were subject to a law. The period of the additional terrestrial change would agree with the period of the solar change, whatever that might be ; and to the laily and yearly response of the earth to the solar energy, there would be superadded an additional change, depending upon and coincident in the main with the period of the solar change. We have said coincident in the main, becanse it is easy to imagine in the case of meteorological phenomena dependent npon a long train of intermediate influences between the impact of the solir energy and the final result, that time would be taken for their development. In this case, although the dependence would be there, an exact coincidence would not. There would be a lagging behind, and this lagging behind would possibly not be the same at different latitudes."

I think we may now (thanks to our learned instructors) feel that we understand the rationale of sun-spot influences sufficiently for the purposes of this paper.

Reverting again more particnlarly to India, I desire to supplement what I have already said by the following able remarks communicated to the "Times" by Mr. Henry F. Blandford, of the Meteorological Association of Calcutta, under date 9th November, and put in that journal 4th December, 1877 :-

" Before concluding, I would say a few words on a subject which has been much discussed in the newspapers during the last few months, viz., the supposed recurrence of famines in Southern India at intervals of about eleven years, in accordance with the period of sun-spot variation. The idea that years of maximum sun spots are also years of abundant harvests, originally suggested by Sir William Herschel, bas lately been bronght into prominence mainly throngh the labours of Mr. Meldrum of the Mauritins, whose latest paper on the subject, published in the monthly notices of the Manritius Meteorological Society, gives figmres based on the rainfall statistics of a large number of stations in different parts of the world. These seem to show that the average rainfull of the globe is subject to a regular fluctuation through periods of about eleven years, and that at its maximum, which occurs about a year later than the epoch of maximum sun spots, the mean fall is about 15 per cent. greater than at its minimum, which precedes that of minimum sun spots by one or two years. 'The "Register of the Presidency 'Town of Hadras," lately published by Mr. Pogson, shows a greater fluctnation than this, apparently about 25 per cent.; but this seems to be quite local. Two other stations in Sontheru India, equally involved in the present famine (the only two I may mention, for which I have been able to obtain many [forty] years' registers), viz., Bangalore and Mysore, show a large irregular fluctuation, but scarcely an appreciable regular oseillation according to the eleven-year cycle; and the mean of seven stations, all situated in tropical India (inclnding Madras), gives a probable periodical fluctuation not exceeding 9 per cent. Such a fluctuation is, of course, quite insufficient to warrant the expectation of the regularly recurent famines. I cannot but think that some confusion has been unconscionsly introduced into the 
discussion, by the fact that the name of the town which shows the largest fluctuation is also that of the province, in one part or another, of which famines have occurred, for many of the famines which are supposed to illustrate the law of periodicity, have chiefly affected districts which receive their principal rainfall at a different season of the year from Madras itsclf and the Carnatic, and also from a different sonrce. That of 1866, for instance, is chiefly memorable as the Orissa famine; and while it involved certain distriets of Madras, the dearth also extended to Western Bengal and Behar, regions which, like Orissa itself, receive their rainfall during the summer monsoon-the latter chiefly from the west const, the former from the Bay of Bengal. That of 1854 was most severe in Bellary, which also depends mainly on the summer monsoon from the west coast. 'The law of famine recurrence even in southern India is, then, by no means so simple as one might be apt to infer from mmch that has lately been written on the subject; and it becomes still more complicated if we inclule northern India, which is a region of equal importance from an administrative point of view. The worst famine of this century was that of $1837-38,1837$ being a year of maximum sun spots, the highest in this century previous to 1870 ; and 1870 was preceded by the famine of Riajpootana and the North-W West Provinees in 1868-69, and followed two years later by great scarcity in Khandeish (in the Bombay Presidency), and again two years later by that of Buhar and the neighbouring districts of the North-West Provinces; the memorable famine of $\mathbf{1 8 6 1}$, in the upper North-West Provinces, also followed immediately on a year of maximum sun spots. Hy conclusion is then, that we are as yet far from laving liscovered the law of famine recurrence. As far as the evidence yet put forward ean be said to point to any law of periodicity, it is thisthat serere famines seem to tend to oceur more frepuently about the time of minimum sun spots in southern India, and alout that of maximum sun spots in northern Inlia; but the evidence is very imperfeet, and requires thorongh exanination. It is unquestionable that a great deficiency of rainfall in one region is in many cases attended by a great excess elsewhere. The rains which were withlield from Madras at the elose of 1876, were discharged over the Bay of Bengal, producing two severe eyclones; and while the North- West Provinces during the present smmmor lave suffered an almost entire loss of the erops of that season fron continued dronght, those of Pegu have been drowned and washed away by the extraordinary tloods of the Iranaddy."

\section{He adds :-}

"The law discovered by Mr. Meldrum is a most important one, and everyone must rejoice at the attempts which are now being made to trace out in the vicissitudes of the atmosplere the influence of the varying action of the sum. But no good will be effected by hasty and erude generalisation, and while much may be expected from a patient study of meteorological physics, the hasty promulgation of empirical laws, founded on insufficient data, ean only lead to disappointment. $\boldsymbol{\Lambda}$ prophecy that the rains would again fail this year in Madras, purporting to bear the authority of Mr. Pogson, the Govermment astronomer of Madras, las been largely circulated in the newspapers in England and India. Happily it has been falsified by the event."

I ought here to mention that two distinguished members of our own body have thrown some additional light on the sun-spot theory. Professor IV. Stanley Jevons, F.R.S., read a paper at the British Association meeting at Bristol in 1875 , on "The Influence of the "Sun-Spot Period upon the Price of Corn." This falls rather to be noticed in the second part of my present paper than here. Mr. Henry Jcula, who as Secretary of the late Statistical Committee at Lloyd's, lad extended mcans for olserving the inflnence of the 
seasons in relation to storms, in a letter published in the "Times" of 19 th September, 1877, furnishes some facts of much interest.* The following are the ehief passages of his letter:-

"The account given in the 'Times' of the 2Sth of March last, of Dr. W. W. Hunter's researehes into the Madras rainfall and its possible connection with sun spots, led me to throw together the scanty materials available relating to losses posted on Lloyd's loss book, to ascertain if any coincidence existed between the varying numbers of such losses and Dl. Hunter's results, for as the cycle of rainfall at Madras coincides, I am informed, with the periodicity of the eyelones in the adjoining Bay of Bengal, as worked out by the Government astronomer at Mauritius, some coineidence between maritime casualties, rainfall, and sun spots, appeared at least possible, and you may consider even so humble an attempt to enlarge the area of eomparison to be alike of some use and interest.

"I was only able to obtain data for two complete eycles of cleven yearsnamely, from 1855 to 1876 inclusive-while the period investigated by Dr. Hunter extended from 1813 to 1876 , and his observations related to Madras and its neighbourhood only, but the losses posted occurred to vessels of various countries, and happened in different parts of the workl.

"It was necessary to bring these losses to some common basis of comparison, and the only one available was the number of 'British registered vessels of the United Kingdom and Channel Islands'-manifestly an arbitrary one. I consequently cast out the pereentage of losses posted each year upon the number of such registered vessels for the same jear, and also the percentage of losses posted in each of the eleven years of the two eyeles upon the total posted in each complete cycle, thus obtaining two bases of comparison independent of each other.

“ The results were sufficiently remarkable to justify me in communicating my materials to Dr. Hunter, and he has most conrteously worked out with me a series of tables showing the final results; these would occupy too much of your space, but from them I hand you a short comparative one, which may be of some interest.

"The dates of the losses are those of report, not of occurrence, which would be earlier-sometimes considerably earlier-consequently they should lag somewhat behind the cycle, as they appear to do. The characteristics of Dr. Hunter's theory of cyclones have been so fully discussed by meteorologists, and are so clearly set forth in Mr. Buchan's letter in the 'Times' of the Sth instant, that I need only say the earlier and later years of the cyele show a minimum of sun spots and rainfall, while the years in the centre of the cyele show a maximum of both.

" Dividing the eleven years, as nearly as the number will allow, into three parts, and taking the percentages of losses posted, I find a coincident minimum periol of four years at the extremities of the eycle, a maximum period of three years in the centre of the eycle, and an intermediate period of four years lying between the maximum and minimum periods.

"The annexed table brings this elearly in view. For the figures relating to maritime casualties I am responsible; those referring to rainfall and sun spots have been kindly furnished me by Dr. Hunter, and for them lie is responsible. The sun spots are taken from a list previous to that just issued by Dr. Rudolf Wolf, of Zurich, but the differences in these lists, Dr. Hunter states, do not affect the general aspect of the case.

* I have only learned since this paper was prepared, that as far baek as 1846, another distinguished member of our Soeiety, Mr. Hycle Clar ie, prepared a paper: A Preliminary Inquiry into the Physical Laws Governing the Periods of Famines and Panics. This appeared in the "Railway Reporter" for that year; and I slall probably have oceasion to refer to it in some detail in the second division of my present paper. Again, in 1838, this learned gentleman lad contributed to "Ilerapatl's Railway Magazine" a paper On the Mathematical Law of the Cycle; leading up to the same line of observation. 
A Table showing the Mean Percentage of Losses Posted on Lloyd's Loss Book upon the Total Registered Vessels of United Kingdom and Channel Islands; also on the Total of the Losses Posted in each Cycle of Eleven Years, 1855-76 inclusive; Compared with the Eleven-Year Cycles of Sun Spots and Rainfall at Madras.

\begin{tabular}{|c|c|c|c|c|}
\hline & \multicolumn{2}{|c|}{ Mcan Percentage of Losses. } & \multirow[b]{2}{*}{$\begin{array}{c}\text { Average } \\
\text { Rainfall at } \\
\text { Madras, } \\
1813-76 .\end{array}$} & \multirow{2}{*}{$\begin{array}{c}\text { Average } \\
\text { Relative } \\
\text { Nnmber of } \\
\text { Sun Spots, } \\
1810-60 .\end{array}$} \\
\hline & $\begin{array}{c}\text { On Registercd } \\
\text { Vessels of } \\
\text { United Kingdom } \\
\text { and } \\
\text { Channel Islands, } \\
1855-76 .\end{array}$ & $\begin{array}{c}\text { On the } \\
\text { Total Posted in } \\
\text { each Cycle } \\
\text { of } \\
\text { Eleren Years, } \\
1855-76 .\end{array}$ & & \\
\hline $\left.\begin{array}{l}\text { Minimum Group- } \\
\text { Mcan of 1st, 2nd, 11th, and } \\
\text { 10th years of cycles........ }\end{array}\right\}$ & II 13 & $8 \cdot 64$ & $\begin{array}{l}\text { Inches. } \\
41 \cdot 58\end{array}$ & $14 \cdot 26$ \\
\hline $\left.\begin{array}{l}\text { Intermediate Group- } \\
\text { Mean of } 3 \mathrm{rd}, 4 \mathrm{th}, 9 \text { th, and } \\
\text { Sth years of cycles ......... }\end{array}\right\}$ & $11 \cdot 91$ & $9 \cdot 21$ & $5^{x} \cdot 37$ & $42 \cdot 46$ \\
\hline $\left.\begin{array}{l}\text { Maximum Group- } \\
\text { Mean of 5th, 6th, and } 7 \text { th } \\
\quad \text { years of cycles .................... }\end{array}\right\}$ & $12 \cdot 49$ & $9 \cdot 53$ & $5=\cdot 65$ & $64 \cdot 10$ \\
\hline
\end{tabular}

"In conclusion, permit me to express the hope that the great practical importance of Dr. Hunter's theory, if proved to be true, in relation not only to Indian famines, but, it would seem, to maritime commerce generally, will lead to a full and exhaustive examination of all the evidence bearing upon it."

A previous correspondent in the "Times" had suggested that the theory of rainfall and sun-spot connection should be condueted rather by a Fellow of this (the Statistical Society) than by a meteorologist. This was deemed by Mr. Jeula a sufficient justifieation for his entering upon the inquiry. I trust it may also be deemed a sufficient excuse for myself on this occasion.

The second part of my paper-which will treat of the "Artificial "Causes of Famines," as enumerated in the earlier part of this paper-will be presented to the Society whenever a favourable opportunity may arise; and I trust therein to show that the interest attaching to famines is by no means exhausted at present.

NoтE.-In finally revising this paper, I have brought the facts down several months later than the date at which it was read. The incidents of 1878 are in many respects important. I do not know -in the abseuee of systematie records - if they exceed those of other years, or whether the apparent increase is simply due to the more extended observation which the pursuit of the present investigation has induced me to make. 


\section{Discussion on Mr. Walfori's Paper.}

General Sir Artiuur Cotron confined his remarks to Indian famines, with which, he said, he was practically acquainted. Too mnch could not be said in favour of the Governor-General, who first attempted to grapple with the terrible evil of famines. It appeared astonishing that after having had experience of famines and having successfully grappled with them at one time that the administration should not have immediately proceeded to prepare for another. There was always abundance of time to prepare for a famine in India : therefore why should there not be a regular set of rules laid down as to what was to be done in the case of a famine aetually occurring. But why should not measures be taken so that their recurrence might be prevented altogether. There were at least thirty or forty districts in India as to which there was no possibility of famine, because the Govermment by their measures had already provided against it. What was the reason they had not extended their measures to other distriets? It was to his mind nnaccountable. But there is another point. There was always plenty of food in India, and therefore, as stated in the paper, the first thing to be considered was the mode of conveyance of food to a failing district from those districts that had abundance. This was the lesson he had learnt, and it had taken him many years to learn it. The point he wished to insist mpon was that notling but water in a country like India conld carry goods at such low prices, and in such vast quantities as were absolutely essential for the wellbeing of a country like India. There were actually at present before the Government plans for works which had been waiting to be earried into execution for tens and twenties of years, and it was imperative that these works should be carried out at once. There was nothing to hinder such a course being adopted. People said that India was already so poor that it could not be loaded with debts; but in saying so, they set aside the fact that irrigation works were thoroughly remmerative. The head of the irrigation department in the Indian Office had shown by plain figures this as a fact; and if the Government had accomplished these things during their apprenticeship, when they were finding their way to arrice at the knowledge of a matter which the natives had acquired hundreds of zears before, how much more should they hope to go on prosperously now that they had such immense experience to work upon. At the present moment I 5,000,000l. had been spent upon irrigation and navigation works. No doubt many mistakes had been made in the carrying out of the works, but experience would lead them not to repeat those mistakes, and it would rather be an encouragement to proceed still further. The principle of Mr. Fawcett and those of his school, was that a penny saved was a penny got, but his theory with regard to India was that every penny spent was a shilling gained, if judiciously spent, that is upon 
works really suited to the wants and circumstances of India, and he was sure the works that had been executed abundantly proved this. In dealing with this question in the House of Commons, every failure, however temporary or however partial, had been dwelt upen, but not one word had been said as to particular or general success. He was perfectly satisfied from his own experience that the whole of India could be made into a perfect garden, and from the knowledge and means they at present possessed, famines in Inclia could be put an end to for erer. The question was not so mnch what would be the profit of these works to the Treasury, but what would be the total effect they wonld have on the community. The $7 \frac{1}{2}$ per cent. profit stated by the head of the irrigation department, was a mere trifle compared with the actual total results. He could safely say that the general result of all the works that had been executed was 100 per cent. Mr. Henry Morris had lately published a book in which he gave an acconnt of the district with which he was connected for some time.*

Mr. F. C. Daxters (of the India Office) said that the paper was a most excellent and able one. With reference to the causes of famine he did not quite agree that what were called natural causes were beyond human control, becanse in the first instance, when the world was created, there was a certain economy in all parts of the miverse under which it was impossible that such things as drought or flood would occur to interfere with what was necessary for human existence. The inerease of population, the great demand for fuel, the desire to extend cultivation, cutting down forests withont due regard to where they were situated, and other causes, had tended in a great measure to bring about famines. If man had been instrumental in undoing the work of nature, it was only a

* His words are, " at the commeneement of our rule, the district composed part of a neglected provinee, and at one time it was brought into a state of extreme impoverishment and distress. It was desolated by famine, and misgoverned by the numerous landowners and their advisers. Since the introduction, however, of the admirable system of irrigation, it has brightened and revived. Famine is unknown. The people are prosperous and contented. It is the garden of the north province. 'The revenue instead of being reduced, as it once was, to the verge of bankruptey, is more elastic than it has ever been. Its population has more tham doubled; the universal prosperity of its inhabitants is proved by their being better fed, better clothed, and better edneated than formerly, its commerce has flourished, and its trade has developed in a murellous degree; and it may confidently be asserted that it is in as peaceful, happy, and prosperous a condition as any part of Her Majesty's dominions."

Mr. Morris gives the population in 1812 at 560,000 ; by the last census it was I,600,000. The revenue has increased from 230,000l. to $570,000 l$, the exports from 60,000l. to $800,000 l$., and the imports from 20,000l. to 200,000l., and the traftic on the main canal is 200,000 tons a-year. The mortality on the average preceding 1872 was under 2 per cent., and this included the upper feverish tuloohs; a strong proof of the healthiness of India where the water is regulated. Why should not the same be done for every district of Her Majesty's Indian doninions? Think of this district in the midst of the famine tract, instead of losing luundreds of thonsands of ber own people, as she formerly did, selling a full crop at famine prices, and saving hundreds of thousands of lives in the adjoining districts. 
question of time for man to restore the work of nature by planting and other processes, so that these droughts and floods would be put an end to or be modified. As to inundations, there were three causes given, 1st, Unusually ligh tides, supposed to be oceasioned by lunar influences; 2nd, The tides acted upon by wind storms, and 3rd, Undulation of the earth's surface in particular localities from the subterranean influence of earthquakes. He would suggest that the destruction of trees on hill-sides, which in many instances had been known to be followed by a rapid rush of water down the hill-side, filled the rivers beyond what they were able to carrs, and so cansed floots along their banks, very often destroying crops and causing temporary famine in small districts. To the list of periods of excessive drought which the author had given, he (Mr. Danvers) thought there might be some addition made in regard to Indian famines: one being in 1837-38, another in 1860-61, and a third which took place more recently in southern India, particulars as to which he should be happy to furnish Mrr. Walford with, if he desired them. The other day he had a correspondence with a French gentleman, as to what was the proportion of the area that shonld be covered with forest in different countries. In northern France it was considered to be 17 per cent. of the area; but in tropical countries it was considered desirable to have a much larger proportion; and investigation ought to be made with the view of ascertaining what were the correct figures in that respect. As regards Indian famines, the author had stated that the first great famine of which we had any knowledge was that of 1769-70. There was a record of several famines before that of which very little was known, and if the author wished it, he (Mr. Danvers) would supply him with the information of what was known as to these earlier famines. With regard to the famine of $1769-70$, the author stated, "in our table it is estimated that three millions of the population in Bengal then died of starvation," an estimate which I am not inclined to deem exaggerated; and we are told, that Bengal has been subjected to famines periodically since-why since, as distinguished from previously, does not appear. Now he (Mr. Danvers) thought that in all probability when the population increased, and where the laws of nature were interfered with in consequence of that increase, it might naturally be expected that as time went on, famines would increase nutil man had been sufficiently wise to replace what he had so wantonly destroyed in previous years. He had given a great deal of attention to the question of irrigation in India, and to a certain extent he agreed with Sir Arthur Cotton, that with regard to many parts of that country more might be done. It could not, howerer, be done all at once, because in many parts where the population were not aceustomed to irrigation, they were mwilling to take the water at first, and they must be educated to do so. While they were being educated, the Government were losing the interest, but this did not matter if they could be got to take the water eventually. In a great part of India such as the Deccan and southern India, in an ordinary season, tanks might be filled for the purposes of cultivating the land; but to incur a very considerable ontlay in those 
districts with a view to averting famine would be useless, but the benefit of such works in ordinary seasons would doubtless be great, as by enabling larger crops to be raised the ryots would be enriched, and therefore better able to meet the consequences of failure of crops in years of drought and famine. In northern India water conld be taken from those rivers which depended upon perpetual snow. With regard to water navigation, he did not think that water transit would answer for all parts of India, especially in those parts where there were railways.

Mr. Hrde Clarke said he did not wish to enter upon the disputed question of irrigation or canalisation in India. In reference to the question of climate and rainfall, it was a matter of consideralole importance to ascertain what proportion of these there should be in a conntry. It was a risputed point in forest science, but in this country there was not the information available for ourselves, and yet there were many forms in which it was desirable to collect the data. There were conntries where, for agricultmal purposes, the trees in the hedge rows were cut down, and the conseqnences of this had to be ascertained; but in this country there was a great variety of conditions. If they went to the other side of the Channel, they would find the whole country laid bare. IIe thought that more attention should be given to our scattered trees, because it was not a question merely of forest, but a question of distribution of trees; and attention being called to this subject, they might be able to bring it into a scheme for the preparation of agricultural statisties. He regretted he had not been able to put his hand on the diagrams he made in 1846 , to illustrate his former obserrations; but the mode in which he proceeded was a thoroughly economical one. As they all knew, there was a very long series of corn prices for six centuries, and he tabulated these, which gave the best exponent of mactical meteorological resnlts. The consequence was, he got the short ten years' period, but althongh it wonld go on very regularly for a long series, all of a sndden it would be missing; and in his opinion there was a period of fiftr-four or one hundred and four sears that operated, and besides that, there was a larger cjcle still; therefore apart from all the questions of the sun-spot theory, that had been subseqnently started, there was no possibility of foretelling the economical results of the phenomena so as to be of material use, and there was nothing in the discussions that had taken place, that in his mind held ont the hope that it would attain to results like that. At the same time it was a matter of very great importance to follow up the same subject, and the only way to do it was that in which Mr. Walford had begnn it.

Mr. R. H. Pattenson said he had been asked by Mr. Walford, to make a few remarks as to the great and terrible famines in China, which had been omitted in the paper. There was one going on at this moment in China, which was quite as bad as any of those which had occurred in our Indian Empire. Such famines have existed in that conntry, where they kept very accurate statistical 
records, from time immemorial. China in this respect differed somewhat from India. There was a double cause of famine in China, the one was tremendous inundations, the other was drought. The inundations were owing to the fact that at least two of the rivers in China were amongst the largest in the world. They flowed down from the vast snowy mountains of Central Asia, and, as almost always happened in those countries, the bed of these rivers was higher than the level of the surrounding eountry; consequently whenever the banks broke, whole provinees were submerged, and sometimes literally hundreds. of thousands of people were drowned. On the other hand, the famines were, like those in India, produced by drought. What seemed to him almost a special point in connection with Mr. Walford's paper was, that there was a number of records of terrestrial phenomena given, but what was wanted also, was a record of astronomical phenomena. So long as the configuration of the earth, the distribution of land and water, remained as it was, there conld not be any great changes in the conditions of the seasons, except from extra-terrestrial influence. It must be owing to the cosmical action of the surrounding orbs, of which the greatest actor was the sun. Hence the importance recently attached to the solar-spot theory. That theory was a thing of yesterday. Why? Because the statistical records of these things in Europe were but of yesterday. But it was not new in the old times. In Egypt and Babylon astronomieal phenomena were recorded for two thousand years; and not a few strange things that are told by Herodotas and others, as to the so-called powers of the priesthood, the Royal Society and the learned class of those days, were simply owing to the fact that science in some departments of knowledge means fore-knowledge. The aequirements of learned people in those days might be attributed by the masses, and even by themselves, to inspired knowledge or divination; but it might be better attributed to forecasting the future by the light of the past. If these learned classes had kept and compared terrestrial with solar phenomena for even five hundred years, they must have known (with all submission to our conceit), much more than the Royal Society yet does.

Mr. W. TAYLER after alluding to the value of the paper, said that famines were not unknown in ancient times, and were mentioned by Livy, and in modern times, by Voltaire, Usher, and others, but it was remarkable that none of the writers had suggested remedies for the prevention of farnines; we had now however the advantages of science to work upon, and if when $\mathrm{Mr}$. Walford, as promised in the latter part of his paper, gave another paper on the "artificial causes of famines," he would also give the means for their prevention, he would do a great service, not only to the Society, but also to the whole world.

Sir Rawson Rawson hoped that the paper would be productive of important consequences. The various facts had been collected with remarkable industry, but it was seareely to be expected that a complete list of these events could be made at the first attempt. 
He hoped that the paper would lead to the co-operation of others who had studied the matter, in assisting Mr. Walford to complete his tables; and he hoped that in the second portion of Mr. Walford's paper, a still further list of such remarkable events as he had described would be furnished. When he (Sir R. Rawson) was in Barbadoes, he arailed himself of the opportunity of ascertaining the fall of rain over a long series of years in that climate, and its influence upon the sugar crop; and he was happy to say that the report he had made had led to important local results. He was able to make the estimate that for about ten or twelce jears, each inch of rain in the antecedent year before a crop of sugar was worth about 800 hogsheads of that article. In the first year of the ten years it was about 800 ; in the last year it was about 800 , and on the average of ten years it was also about 800 . In the last three jears of his gorernment, there was a great advance, consequent, he believed, on an extension of the area under cultivation; and for each inch of rain it was 900 and upwards.

His reason for noticing this was that Lord Salisbury wrote and asked for a number of copies of his report, in order to send it out to India, with the riew of establishing a record of rain there, in order to anticipate a deficiency of the rice crop consequent on a deficiency of rain fall. That was one of the practical results of an observation of astronomical phenomena; and he beliered that if anybody would work out a comparison of the different erents noticed by Mr. Walford and others, they would be able to gather from a parallelism of these phenomena, some results which would be highly valuable and instructive.

Mr. E. H. Hall thought that there was not so much need with regard to this subject of scientific as of practical knowledge. What was wanted in case of famine was corn and rice for the people who were absolutely starring. He had been out in China. The provinces bordering on the Iang-tse river in the time of Polo were considered the garden of the world. But they could not be so considered now. There was no doubt that the great famines that had desolated northern China. were largely caused by the cutting down of the belts of timber in the momntain ranges and hills. He should like to call Mr. Walford's attention to an article that had appeared in the prerious week's "Saturday Review," which was prepared by some one very conversant with the subject, and which corroborated what he had learned when he was in China. He would recommend a perusal of those figures by MIr. Walford, because they supplemented in a valuable way what he had adranced as to the canse of famines. America was comparatively a new country, and therefore the rule to be applied with reference to the destruction of timber would be seen there more particularly than elsewhere. On the Missouri and Kansas and other great rivers, the destruction of timber not only materially affected the period of growth, but also the drought periods. It was well known that in China there had been difficulties almost as great as famines to contend with. There had been an epidemic of rebellion, and there had been in the central districts locusts, which were really the grasshoppers of that empire. In the 
sonth of China there were flonds; so that it might be said that there were three great plagnes intlicted upon them, and he conld not eonceive any more terrible spcetacle than that now presented in that vast empire. The condition of our fellow subjects in India must cause us even more conceru from onr connection with them. 'The Chinese we had bcen accustomed to consider as barbarians. He was happy to see that funds had been raised for their support, because to the Chinese this eountry owed very much, though not so much as to India; and they were never worse off than at the present time.

Mr. Abur-Fazl M. Abdur-Rahman, of Calentta, craved the indulgenee of the meeting to make a few remarks, as he came from a country (India) which in his opinion had suffered more than any other from the dreadful calamity of famine. In considering the subjeet of famines it might be divided into three parts, namely, the causes, the effects, and the means of preventing them. He would not enter into the eauses; and it was well known what terrible effects famines had on India and other parts of the world. With regard to the prevention of Indian famines, he was rather sorry that none of the speakers had made any reference at all to emigration. It was trne that Sir Arthur Cotton and some others had said something about irrigation and eheap railway system as means of preventing such calamities. The population of a country like India was very large, and tended to increase more rapidly than the food which was raised from the soil. They lived almost entirely upon agricnlture, and their labour prodnced only food enough for their annual subsistence. This was one obvious reason why the intensity of famine was so mueh felt in India. No provision had yet been made to accumulate erops for future purposes. With regard to emigration it was one of the most useful things in a country like India, where the population was so very large; but he thought it was utterly inapplicable to India, although he was not prepared that evening to give any reasons for it, but this much he could safely say that if the Mahomedans of India (of whom he was one) had now the same spirit which they once had, they would have left the country and gone to some other fertile part of the world. The Hindoos were naturally fettered to their country by their religion, and they could not for a moment even conceive the idea of leaving it for a better one. With regard to irrigation it was very effective where there was a natural defieiency of water, but it was also true that the Orissa Canal and the Madras Irrigation Company's Canal had failed, and the Government had lost about 4,400,000l. It would be found from Sir Arthur Cotton's pamphlets and lectures, and also from State papers, that irrigation works had done a great deal. Lord Salisbury himself admitted the great importance and value of such irrigation works. The Eastern and Western Jamna Canals, the Canvery Delta and the Godavery Delta liad given very good returns. It had, however, been said, that the want of education of the people caused them not to use the water. But such was not the case; the ráyat being the poorest man in India, being involved in heavy debts, was driven to still worse 
circumstances by famines, and if he at all survived the time of adversity, he tried by some means or other to recover his circumstances; when the Government came down upon him with a fresh $\operatorname{tax}$ to realise the expenses of irrigation, which the ráyat would naturally be unable to pay, and consequently be obliged to refuse water from the canal just completed. That was the real cause of failure of irrigations of which the Government complained. $\mathrm{He}$ strongly agreed with the views of Sir Arthur Cotton and those in favour of extension of irrigation works in India. If the Government were to continae to spend a certain amount of money on irrigation, and after the completion of such works, were to allow a certain number of years to the riyats to take water without any fresh payment until such time as they would be in a better position to pay fresh taxes in addition to numerous other taxes they were already paying, they no doubt would continue to take water and begin paying for it. They were all much obliged to Mr. Walford for giving such an elaborate exposition of the causes of famines, and he earnestly hoped that the next paper he gave would deal at length on the best methods and the best means for the prevention of the famines of the world in general, and famines of India in particular.

The Rev. Mr. Doxsey suggested that if the anthor wonld give a scale of the comparative density of the population in those parts of India where famine had occurred, it would greatly increase the value of his most excellent pajer.

Mr. Padr thought there was one point in the chronology of famines (Table I) which might be amplified. Between the years 1708 and 493 B.c. there were no records of famine given. He believed that there were records in the Scriptures of some eight or nine famines that occurred at intervals of one hondred years. The general remark at the commencement of the table might cover these; but perhaps MIr. Walford would supply the details. It was likewise instructive to notice that the famine in 1708, which was spoken of by Mr. Walford-the seven years' famine of Egyptextended so far across as to China, showing the great extent of the famine that existed at that time. There were, he believed, records in China which agreed very closely with the dates given by Mr. Walford with regard to Egypt.

Another important point in connection with the remarks made regarding drought, as to the cutting down of forests and the consequent influenee on the rainfall, was the gathering up of water in tanks or in dams. If water were spread over a swampy country, it was absorbed much more easily than if the same volume were collected in a tank or a dam; consequently, if by artificial means water were gathered at rarious points, the rainfall in the district where the water was su collected would be altered.

Mr. WALFord, in reply, said that he had felt the extreme difficulty of the subject, and none-was more conscions than himself of the deficiencies in the paper; but if he were to carry out the 
suggestions of some gentlemen, he did not know that he should ever live long enough to finish the task. He had found that the subject was inexhaustible; and if he had known what he now knew, he should hardly hare had courage to begin the paper; but he had become interested in the subject, and had pursued it, every day however becoming more discouraged: feeling that at least one of the objects he had in view steadily vanished from his grasp. He hoped to claborate the sun-spot theory, if such a theory could really be deduced; but he had made every table from independent sources, hoping that they would react on one another, with the view he had in his mind. He could by another mode of proceeding have made the tables fit with admirable accuracy, but if he had done so, he should not have been doing his duty, or have been carrying out the objects of the Society in pursuing statistical inquiries to the very end, regardless of everything but the facts. The facts here, as in other cases, were indeed the only safe means to an end. He should have been delighted to have heard Professor Stanley Jevons, Mrr. Jeula, and some others, who had studied the sun-spot theory more than himself, offer some remarks, if time had permitted. In the second part of his paper he did not propose to deal with the meteorological, or natural, but with the artificial causes of famine; and if he lived long enough to give a third part of the paper, he would pay some attention to the prevention of famines; but this was no part of the task he had set himself. $\mathrm{He}$ did not know how famines might be prevented. With regard to particular localities, no doubt the collected facts would teach something; but he had no doubt also that famines would continue. He regretted he had no data of the earlier Chinese famines; but whether it was owing to the density of the popalation, or other causes, famines were of very frequent occurrence in that empire. He found it was impossible to obtain authentic particulars. But for Mr. Danvers's able report he did not know where he should have been with regard to some of the Indian famines. He greatly appreciated what Mr. Danvers had done, and what he had promised to do. If he (Mr. Danvers) would revise some of the geographical boundaries, he had spoken of, and would point ont some of the more minute circumstances surrounding the localities wherein famines were found most to prevail, he would not only be doing a service to this Society, in its effort to supply correct information regarding important national events, but to humanity at large. He should take the earliest opportunity of presenting to the Society the second part of his paper. 



\section{FAMINES OF THE WORLD: PAST AND PRESENT.}

\section{PART II.}

[Read before the Statistical Society, 18th February, 1879.]

\section{CONTENTS :}

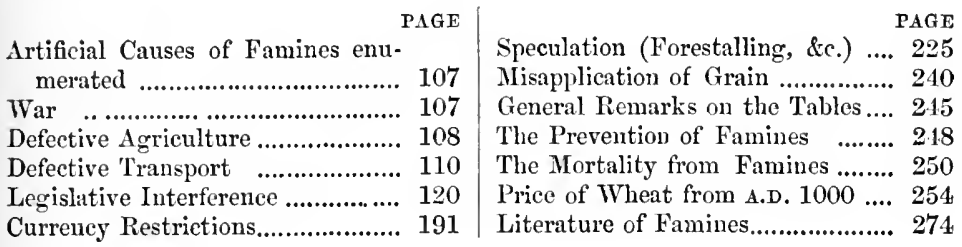

IN the first portion of my paper I considered the five "natural "causes" of famines, viz.:-RAIN (producing floods); (2) Frost ; (3) Drought; (4) Other Meteorological Phenomena; and (5) Plagues of Insects and Veruin; leaving the remaining seven causes, viz. (6) War ; (7) Defective Agriculture; (8) Defective Transport; (9) liegislative Interference; (10) Currency Restrictions; (11) Speculation (viz., "Ingrossing" and "Fore"stalling"); (12) Misapplication of Grain (as in brewing, distilling, \&c.), which I designated the "artificial causes" of famines, to be considered on the present occasion. I now proceed to this task; and shall deal with the several sections in the order above enumerated. It will be seen that in treating of these artificial canses, the range of observation will be more limited, being almost exclusively confined to the United Kingdom.

$$
\text { VI.-War. }
$$

That war has been in the past, and probably ever will (while it shall exist) be productive of famines, seems to be a self-evident proposition. Not only does it draw from their employments those who would be engaged in the cultivation of the soil; but it withholds the labour necessary to gather in the crops already prodnced; while by devastating the plains, as also in its endeavours to starve out the enemy, it wastes and destroys at every step that which has been already garnered in. At sea it blockades and diverts eargoes from their destinations; on land it cuts off armies, cities, districts, from their supplies. Still further, war breeds pestilence; pestilence cuts down the population who have escaped 
from its ravages; the land lies uncultivated; the live stock dies; and desolation proclaims itself. Hence the sword, pestilence, and famine are now, as they have been in all time, the three associated deadly enemies of the human race.

These truths need no selected examples for their illustration, they are too patent to all; but in the margin of Table XIV I have indicated periods of peace and war, as exercising a neverfailing influence on the price of grain, to which I shall call more minute attention in my observations upon that table.

But there is another manner in which war has deeply affected the food supplies of the people in this country, and this is by reason of the fiscal burdens which it has thrown upon onr country, and which have been defrayed, and could only be defrayed, by taxing continuously the necessaries of life required by the entire population. The progress of these burdens, as affecting grain, will be revicwed in Table $\mathrm{X}$.

\section{VII.-Defective Agriculture.}

That defective agriculture, asseciated with an increasing population, must conduce greatly to the probability of famines at recurring periods, is also a truth which requires no detailed elucidation. The fact that agriculture in England was very defective for at least a period of one thousand years after the Roman occupation (which brings us down to the middle of the sixteenth century), is a readily admitted truth. I mention the Roman occupation, because it is asserted, on what may be deemed good authority, that during that interesting period, grain was actually exported regnlarly from this island to support the imperial legions during their wars of conquest in other parts of Europe. Several famines in England are recorded during the Roman occupation (B.C. 55 to A.D. 449 ), but they become much more general during the Saxon period (A.D. 449 to 827); and still more so under the Anglo-Saxons and Danes (A.D. 827 to 1066). It was perhaps under the Normans (A.D. 1066 to 1154) that the agriculture of England fell to its lowest ebb. During the century of Norman rule, famines in England were almost chronic. Rents, too, were paid in kind, and not in money.

It is but too obvious that the continuous warfare which prevailed during the several periods last named must be incompatible with progressive agriculture. Not only was the face of the comtry devastated by the civil strife which prevailed at home, but the armies raised for our endless foreigu wars carried off the very flower of our yeomanry, and gave a martial rather than an agrarian tendency to the times. Under the House of Plantagenet (A.D. 1154 to 1399) matters were not much mended, except 
perhaps during the single reign of Edward I. The Houses of Lancaster and York, which reigned during the next century (1399-1485), bring up to the mind only memories of civil wars and extended desolation. Under the government of the Honse of Tudor (1485-1603) we begin to recognise the approach of a better state of matters; and this continued under the Stuarts, and through the Commonwealth and the Restoration.

At the Revolution of 1688 more than half the kingdom was believed to consist of moorland, forest, and fen; and vast common wastes covered the greater part of England north of the Humber. The numerous Enclosure Bills which begin with George II (1727) indicate that land was now growing into demand for the purposes of cultivation. This feature yet more especially marked the reign of his successor (George III). The drainage of the fen districts of England commenced about the middle of the last century; and by these means, combined with the other influences then at work in the same direction, the whole face of the country became changed. Ten thousand square miles of previously untilled land were added to the area of cultivation by the Enclosure Acts alone; so that betwcen the first and the last years of the eighteentin century a fourth part of England was redeemed from waste and brought under cultivation. But this is not all : the improvement of tillage had during the same period probably doubled the products of the land cultivated. This improvement in practical agriculture began with the travels and treatises of Arthur Young (the Suffolk farmer). It was followed up by the introduction of the large farm system of Mr. Coke, of Norfolk, rendering high farming a necessity. This again was succeeded by the development of scientific agriculture, in the early half of the present century, in the villages of Lothian; while he who has done more than any other man living to bring all these past teachings down to practical every-day adoption, is the enthusiastic John Joseph Mechi, of Tiptree Hall, the model Essex agriculturist ! *

Mr. Arthur Young, in his "Survey of the Eastern Counties " of England," vol. iv, page 458 (published 1771), estimated the exteut of land under crop in England (exclusive of Wales) at I 2,707,000 acres; but this was believed to be much too high. Mr. Sterenson, whose opinion was regarded as of high value, estimated the land under culture in England in 1812 as being 12,000,000 acres. Mr. Couling, land surveyor, laid before the Parliamentary Committee on Emigration in 1827, tables (since regarded as of high authority) wherein he estimated the arable and pasture land of England and Wales, exclusive of wastes,

* In Table XIV will be found many detailed facts bearing upon and illus. trating points associated with the periods embraced in this brief summary. 
forests, roads, rivers, \&c., at $28,7+9,000$ acres; * of which he supposed the cultivated land and gardens to make $11, \mathbf{I}+3,370$ acres. Mr. Middleton, Mr. Comber, and Mr. Stevenson (already referred to) regarded this latter estimate as being as much too low as Mr. Young's had been too high. Mr. M'Culloch ("British Empire," 1854, vol. i, page 548), supports this last view, and estimated the land under cultivation in 1846, at from 13 to $13 \frac{1}{2}$ millions of acres, cropped as follows :-

\begin{tabular}{|c|c|c|c|}
\hline Wheat & $\begin{array}{c}\text { Acres. } \\
3,800,000\end{array}$ & Beans and Peas & $\begin{array}{c}\text { Acres. } \\
500, \mathrm{cc0}\end{array}$ \\
\hline Barley & $\mathbf{I}, 500,200$ & 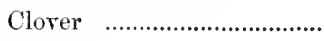 & $1,300,000$ \\
\hline Oats and $\mathrm{R}_{\text {fe }}$ & $2,500,000$ & 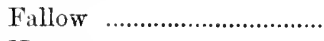 & $i, 500,000$ \\
\hline $\left.\begin{array}{c}\text { Potatoes, Turnips, and } \\
\text { Rape .............................. }\end{array}\right\}$ & $2,000,000$ & Hops & $\begin{array}{r}50,000 \\
\text { I } 50,000\end{array}$ \\
\hline
\end{tabular}

Tables prepared by Mr. Stevenson, from the returns made to the Board of Agricnlture, estimated the average produce of wheat in England in 1812-13, at from 20 to $2+$ bushels ( $2 \frac{1}{2}$ to 3 quarters) per acre; barley at 32 bushels, and oats at 36 bushels per acre. Mr. M'Culloch considered that little dependence could be put on these estimates, and he considered that even if they were correct when made, the produce of wheat had been so much increased by improved agriculture, as to be not less (in 1846) than 32 bushels per acre, a difference of yield on the $3,800,000$ acres of no less than $30,400,000$ bushels! The cultivated land in Scotland was estimated by $\mathrm{Mr}$. M'Culloch as being 5,043.450 acres, out of a total snrface acreage (exclusive of lakes) of 19 millions of acres. In Ireland the cultivated land (including towns and plantations) was estimated at $13,881,71$ I acres, out of a total of 20, I 77,446 acres.

\section{VIII.-Defective Transport.}

I said in the first portion of my paper, while speaking of India, that taking the empire as a whole, there was always (that is to say every year) enough food produced for the support of all its inhabitants, rast as that population is. If this be so of any one portion of the globe, it will certainly be true of the globe taken as a whole. It has often happened in our own little island, that while grain and other articles of food have been at famine prices on one side, or one end, or in one division, there has been an abundance and to spare in other portions of the land; how much more likely then is this state of matters to occur in vast continents such as India? This being duly considered, it is seen at once that one of the great problems in connection with famine is, facilities for transport.

* The entire acreage of England is now returned as 32,590,429 acres, and of Wales 4,734,486 acres, total for England and Wales 37,324,9 I 5 acres. 
As between nations there has existed from all time of which history takes note, the means of communication and of transport, by ships, i.e., sailing vessels. The countries of the earth have indeed too often made laws shutting out the supplies brought to them in the ressels of other nations; or only admitting them under exceptional and stringent conditions. As to the three divisions of our own kingdom it has rarely happened that famine has prevailed during any one year in them all; but each had so contrived, by legislation (presently to be reviewed) to shut out the products of the others, that starvation ensued before the artificial barriers so foolishly set up conld be removed; and only when removed to be set up again the moment the temporary occasion had passed away.

So as to the continent of Europe: we have always been within reach of supplies from thence, but from the obstructions of legislation, the circumstance of war, or the depreciation of our currency, these have not been always available.

But while we thus cut ourselves off from supplies from withont, did we take measures to facilitate the transport of the produce of our internal resources? It is clear that we did not. The condition of our internal communications until about the middle of the last century was such as can only be realised by detailed descriptions, drawn from contemporary sources. Even the great highways made for us during the Roman occupation-these Romans probably had learned the value of such roads from the famine visitations to which their own capital had been so often subjected-had been allowed to fall into a hopeless condition from sheer neglect.

It is seen from all this, that even in a small country like our own the means of internal communication are of the first consequence in periods of partial or general scarcity; how much more so must they be in vast and thickly populated continents like those of Asia or Africa? The grain may be transported from any part or from all parts of the globe to the ports; and the people may die of hunger long before it can reach them in the interior! this has happened so lately as to add a terrible emphasis to the facts here stated.*

I shall offer some observations later especially applicable to India; therefore I now propose to confine myself to the past experience of England in regard to transport; hoping that the lessons to be learned from these examples may be applied with effect elsewhere.

* As an important adjunct to the present increased facilities of transport must be mentioned the Electric telegraph, by means of wlich these facilities may be put promptly into motion. 


\section{Table VIII.-Defective Transport.}

B.C. 55

to

A.D. 449

$1247 \ldots$

' $85 . .$.

$1532-33$

The first roads, properly so-called, made in this country, was during the Roman occupation ; but unfortunately these were not kept up. ${ }^{*}$ Sir Charles Whitworth reviewing the price of grain, as increased from 1211, says, "so great a variation within so short time, in the same kingdom, indicates bad husbandry, and a want of proper conveyances both by land and water."

The first enactment relating to highways was 13 Edward I (The Statute of Winchester). "The highways to market towns shall be enlarged," which is not rery clear in its meaning.

"And further, it is commanded that highways leading from one market town to another shall be enlarged, whereas woods, hedges, or dykes be, so that there be neither dyke, underwood, nor buslu whereby a man may lurk to do hurt, near to the way, within 200 foot of the one side, and 200 foot on the other side of the way, so that this statute shall not extend nnto oaks, nor unto great trees, so as to be clear underneath. And if by default of the lord that will not abate the dyke, underwood or bushes, in the manner aforesaid, any robberies be done therein, the lord shall be answerable for the felony; and if murder be done, the lord shall make a fine at the king's pleasure. And if the lord be not able to fell the underwoods, the country shal. aid him therein. And the king willeth, that in his demense lands and woods within his forest and without, the wass shall be enlarged as before is said. And if perease a park be near to the highway, it is requisite that the lord shall minish his park, so that there be a boarder of 200 foot near the highway, as before is said, or that he make such a wall, dyke or hedge, that offenders may not pass in return to do evil."

This was not a widening of "lighwass" such as now understood, it was merely clearing the sides of highways, much as the sides of railways were cleared during the last rising in Poland. (See 1691.)

Br 24 Henry VIII, eap. 2-"An Acte for paring the highwaye betweene the Stronde Crosie and Charyng Crosse -" it is reeited :-

"In moost humble wise shewe and beseche your highnes, your poore subjects, the inhabitauntes dwelling in the parisshes of Seynt Nartine in the fielde next Charing Crosse, our lady at Stronde, and Sexnt Clement Danes without Temple Barre of London, in your comtie of Middlesex: that where the comon highway betweene Charinge Cross aforesaid, and the Strond Crosse is rery noyous and fowle, and in many places therenf rery jeoperdous to all your liege

* "The great Roman highwiys did not exceed is feet in breadth, and were sometimes a foot or two less [ 12 feet]. In constructing them, the earth was exearated till a solid foundation was obtained, or, in swampy places, a foundation was obtained by driring piles. Orer this, which was called the gremium, four conrses or strata were laid, namely the statumen, the rudus, the nucleus, and the pavimentum. The stutumen, which rested on the gremium, consisted of loose stones of a moderate size. The rudus or rubble-work orer this, about 9 inches thick, was composed of broken stones, cemented with lime. The nucleus, halfa-foot thick, was made with pottery broken into small pices, and also cemented with lime. Orer all was the parimentum, or parement, consisting of large polygonal blocks of hard stone . . . nicely fitted together, so as to present a smooth surface. The road was somewhat elerated in the centre, to allow the water to run off, and on each side were raised footpaths corered with gravel. At certain interrals were blocks of stone to enable a horseman to mount."

Roads so constructed are of such extraordinary durability, that portions of some more than 1,000 years old are still in a high state of preservation.-DrER's Rome (1865), p. 92. But in Britain the Roman roads were either intentionally destroyed or allowed speedily to get out of repair. 


\section{Table VIII.-Defective Transport-Contd.}

A.D.

1532-33

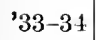

'55

people that wayes passing and repassing, aswell on horsebacke as on foote bothe wynter and in somer, by nyght and by day. 'The verry oceasion whereof hath ben and yet is that the landholders and owners of all the landes and tenents next adjoining on both sides of the seid common highwaye be and have been remisse and negligent, and also refuse and will not make and support the said highway with parying, every of them after the porcion of his grounde adjoyning to the same high waies: and forismoehe mooste gracious seuveraigne lord as the said highwaye is and hath ben of eontynuance greatly occupied aswell with your subjeetes and with their eartes and eariages reparinge to and from your eitie of London, frome dyrers parties of this your realue, as with your subjects passing and repassing to and from the towne of Westminster, aboute the nedes of your lawes their kepte in the term season, which waye if it were sufficiently pared and made after the maner of the parement of the strete betweene the said Stronde and Temple Barre it should not only then be a greate comforte to all rour subjects thereabouts dwelling, but also to all your other liege people that wayes passing and repassing."

It was then enacted that the owners of lands adjoining the said highway should pare the same, and keep the same pared. Justices at Michaelmas term each year to inquire into default.

In the following year there was an "Acte for paryng Holbourne," which recited that the street was the eommon passage for all "earyages earyed from west and nor-west parties of the realme," and that "the waye is soo noyous and soo full of sloughs and other incumbranees that of cen trmes many of yonr subjeets rydyog through the said strette and way be in joperdie of hurte, and have almost perysshed;" but here the road had before this time been a reasonably good one.

There was enarted 2 and 3 Philip and Mars, eap. 8-"An Act for the mending of highways"-which recited, "Being now both very noisom and tedions to travel in, and dangerons to all passengers and earriages;" and then enacted "that every parish within the ralm should, upon the Tuesday or Wednesday in Easter week, appoint two surveyors or orderers for one year, of the works for the amendment of the highways, in their parish leading to any market town." "And the said eonstables and ehurehwardens shall then also name and appoint fonr days for the mending of the said ways, before the feast of the Nativity of St. John the Baptist then next following, and shall openly in the ehurch the next sunday after Easter, give knowledge of the same four days; and upon the said days the parishioners shall endeavor themselves to the amending of the said ways," that is to say eertain some of the parishioners oeeupying land and owning horses, and also housekeepers, were to supply horses, carts, and labour during these days, under the directions of the said surreyor. (See 1562 and 1587.)

By 5 Elizabeth eap. 13, the Act of 1555 was continued, and authority was given to take material for mending the roads from any land eonvenient, so that the opening made for this purpose be not more than 10 yards over at the most; the same to be filled up again within one month; and it was recited:-

"5. And forasmueh as the high ways in sundry places of this realm be full of continual springs and water-eourses, by continned increase and sinking thereof into the ground, the side ways are not only very deep and dangerous, but also for the most part impossible to be amended and repaired in any good and sufficicnt manner withont some further remedy provided for the same."

Power was therefore given to turn water-courses into ditehes adjoining highways. (See 1576.) 


\section{TABLE VIII._Defective Transport-Contd.}

A.D.

1564

On the anthority of Stow, this is the year when coaches were first introduced, thus :-

"In the rear 1564, Gnilliam Boonen, a Dutchman, became the queen's coachman, and was the first that brought the use of coaches into England. After awhile, divers great ladies, with as great jealousy of the queen's displeasure, made their coaches, and rid up and down the countries in them, to the great admiration of all the beholders; but then by little and little thes grew usual among the nobility and others of sort, and within twenty years became a great trade of coachmaking."

IIardn sars coaches were first introduced into England in 1553 [it is recorded that Charles of Anjou's Queen entered Naples in a earêtta about 1282], while another anthor asserts that a Bill was brought into Parliament in 1601 [reign of Elizabeth], to prevent the effeminancy of men riding in coaches; and that it was repealed in 16.5. We do not trace either of these me:sures.

Stow also says that at this date long waggons travelled on some of the high roads in the south of England. (see 1605.)

'76 .... Br 18 Elizabeth, cap. 10, "An Act of addition unto the former Acts for amending and repairing of highways." This Act gires the fullowing account of the condition of a road in the Isle of Sheppy, in the county of Kent, then muchl in use :-

"And forasmuch as the nsual high way leading from the market town called Widdleton, to the said ferry, is presently in such decay, that neither man nor beast without great danger is able to pass, whatever necessity should suddenly happen for men to repair into or out of this said isle, and the parish where the same lieth is not able to repair the same."

It was therefore enacted that the imhabitants be taxed for the repair of the sane.

'7t .... The Rer. William Harrison, who wrote an historical description of the Island of Britain, prefixed to Holingshed's Chronicle, published at this date-being in many things, a shrewd observer, "thought it would be good if it were enacted that exch one should keep his next market with his grain, and not to run 6, 8, 10, 14, or 20 miles from home to sell his corn, where he doth find the highest price." such were the notions of this period.

'87 ... Br 29 Elizabeth, cap. 5, the Act of 1555 was continued, "all which Acts abore mentioned [including inter alia this] are by proof and experience tried and found to be rery neccsary and profitable for the commonwealth of the reahn."

1603 .... The queen died at 2 o'dock in the morning of Thursday, 24th Mareh, and James was procluimed king in London the same morning. But the news did not reach the eity of York until Sunday, 27th March. Contimuation of Stow's Annals.

'05 .... Long waygons for passengers and commodities travelled from London to Canterbury and other large towns.-STow.

'09 .... At this time the communication between the north of England and the unirersities was kept up by carriers, who pursued their tedious but uniform route with whole trains of pack horses. To their care were con-igned not only the packages but frequently the persons of young scholars. It was through their medimn also that epistolary colrespondence was managed; and as they always visited London, a letter conld scarcely be exchanged between Yorkshire and Oxford in less time than a month.-Tide The Historian of Craven.

'21 ... Navigable rivers. - The Thames was made navigable to Oxford. This is the first noticcable step in inland narigation in Great Britain. We bare to wait another century and a quarter for the introdnction of canals, which completed the means of water communication through the interior of the country. (See 1759.) 


\section{Table VIII. - Defective Transport-Contd.}

A.D.

$1635 \ldots$

In riew of facilitating communication, Clarles I resolved this year upon the establishment of the home post oflice. He says in lis proclamation, that there has been no certain communication between England and Scotland; and he therefore commands a running post to be established between Landon and Edinburgh, to go thither, and come back again in six days; and for other roads there was promised the same adrantages.

'59 .... From the diary of Sir William Dugdale, it appenrs that he this year set furward to London in the Coventry coach on the 2nd Mar, and arrived on the 4th May, three days.

'60 .... The General Post Office was established by Aet of Parliament, and all letters were to be sent through this oflice, "except such letters as shall be sent by eoaches, common known earriers of goods by carts, wargons, and pack-horses respectively." The Postmaster-General and his deputies, under this statute, and no other persons, "shall proride and prepare houses and furniture, to let to hire unto all throngh posts and persons riding in post, by commission or without, to and from all and every the places of England, Seotland, and Ireland, where any post roads are." The postmaster was to furnish a guide with a horn to such as ride post.

'62 .... The 14 Charles II, cap. 6-"An Aet for enlarging and repairing of common highways" - which recites, "whereas the former lawes and statutes for the mending and repairing of the common and publick highways of this realm have not been found so effectual as is desired, by means whereof, and the extraordinary burthen carried upon waggons and other earriages, diverse of the said highwayes are become very dangerous and almost impassable." It then prueeeds to apply remedies, much on the same lines as the former Acts. It contained the following:-

"VIII. And be it further enaeted by the authority aforesaid, that from and after the 29th September which shall be in the yeare of our Lord 1662, no travelling waggon, wayn, eart, or carriage wherein any burthen, goods or wares are or shall be carried or drawn for bire (other than sueh earts and carriages as are employed in and about husbandry and manuring of lands, and in the earrying of hay, straw, corne unthreshed, coal, chalk, timber for shipping, materials for building, stones of all sorts, ammunition or artillery, as shall be for His Majesty's service) shall att any one time travel, be drawn, or go in any eommon or public highway or road with abore searen horse beasts, whereof six shall draw in pairs, and not with abore eight oxen or six oxen and two-horse beasts, nor shall at any time earry above 20 hundredweight between the 1st day of October, and 7th May, nor above 30 hundredweight betweene the 1st May, and the 1st Oetober (except sueh particulars as aforesaid), nor abore 5 quarters of wheat, meal, mesline, rye, pease, beans, and tares, nor abore 8 quarters of barley, malt, or oats, and after that proportion; nor shall any waggon, wayne, eart or earriage for the uses aforesaid be employed, the wheels whereof are lesse in breadth than 4 inches of the tyre."

Upon penalty of $40 s$. Then follow powers of rating for repair of highways, \&e. Owners of ironworks, and persons within the wilds of Surrey, Sussex, and Kent were not to be exempted from the operations of this Act. (See 1741.)

'63 .... Turnpikes.-These were first set up this year; and this indieates a new era in the nuatter of improved highroads. Tolls had been previously levied by lords of manors, as one penny for every waggon that passed through; but this does not appear to hare implied any obligation to keep up a road; probably its only justification was that some trespass was committed. The innovation, although based on reason, was long unpopular, and turnpike roads did not become at all general until after the peace of Paris in 1763. 


\section{Table VIII.-Defective Transport-Contd.}

A.D.

1663

'67

Mr. Edward Parker, writing to his father, who lired near Preston, says, "I got to London on Saturday last. My journey was no ways pleasant, being forced to ride in the boot all the way. The company that eame up with me were persons of qualits, as kuights and ladies. My journey's expense was jos. This trivel hath so indisposed me, that I am resolved never to ride up again in the coach." - Archaologia $\mathrm{xx}$.

Antony à Wood records in his diary that this rear he traselled from Oxford to London in the eoach, and was two dass aceomplishing the journes.

By 2.2 Charles II, eap. 12-" An additional Act for the better repairing of highways and bridges"-whieh recited, "for the better repairing and amending of the highwars, now generally spoiled by the extraordinars and unreasonable loading of waggous, and other carriages, and the neglect of repairing and preserring the same," the sereral Acts in foree relating to highways were to be carried into exeention. The elause in the Aet of $166^{\circ}$, as to the width of wheels was repealed. Traveling waggons, wains, \&e., carrving goods were to be drawn with but fire horses at lengtl. It also recites:-

"XIII. And whereas in the counties of Chester and Lancaster there are many and sundry great and decp rirers; which run across and through the common and publick highways and roads within the said counties, which many times cannot be passed over without hazard and loss of the lives and goods of the inhabitants and travellers within the said counties, for want of convenient post and sufficient bridges in the said highways and roads, to build and erect which there is no law now in force."

It was then enated that bridges were to be built in these counties within ten sears. There were speeial provisions as to the Usk and Bassolegg bridges.

It appears that the longest journess which were made in England at this date were to Exeter, Chester, or York.

The diary of a Yorkshire clergrman shows that in the winter of this year a journes from Nottingham to London in a stage-coach occupied four whole days. Quoted in Aichaologia xx.

The 3 William and Mars, eap. 12-"An Act for the better repairing and amending the lighways, and for settling the rates of carriage of goods "-recites :-

"Whereas the free and easy intercourse and means of conreying and carrying goods and merchandises from one market town to another, constitutes very much to the advaneement of trade, increase of wealth, and raising the value of lands, as well to the ease and convenience of the subjects in general; for which ends divers good and necessary laws have been heretofore made for the enlarging, repairing, and amending the highways and common roads of this kingdom. Notwithstanding which laws, the same are not in many parts sufficiently amended and repaired, but remain almost impassable; all which is occasioned, not only by reason of some ambiguities in the said laws, but by want of a sufficient prorision to compel the execution of the same."

It was then enacted that all laws about highways were to be put in excution. Trees, bushes, and shrubs were to be pruned, so as not to hang orer the highways.

" $X V$. And be it enacted by the authority aforesaid, that the surreyors of the highwass shall and are hereby required to make every cartway leading to any market town, 8 feet wide at the least, and as near as may be even and level."

Horse causeways not to be less that " 3 feet in breadth."

By 8 and 9 William III, cap. 16- "An Act for enlarging common highways"-powers were given for carrying out the requirements of 


\section{Table VIII.-Defective Transport-Contd.}

A.D.

$1697 \ldots$

1700

25

'3t

'41 ....

the Act of 1691. Justices at quarter sessions should have powers for making highways 7 feet wide, and to order timber to be cut down for such purpose. Stones or posts were to be ereeted at eross roald, with name of next market town thereon.

"Till the beginning of the eighteenth century, we were almost wholly an equestrian people." - Kxight's Once upon a Time, p. 110.

The stage coach journey from London to Exeter oceupied four summer days. The passengers were aroused every morning at 2 o'clock, left their inns at 3 , dined at 10 o'clock A.M., and finished their day's journey at 3 in the afternoon.- Tide Mrs. Manley's Journey.

The 7 George II, eap. 9 - "An Act to explain and make more effectual the laws in being, to oblige the possessors of lands adjaeent to common highways to eut and keep low such hedges as are adjoining to the said highways" - reeites :-

"Whereas the making the common highways as commodions as may be, tends greatly to the ease and safety of his majesty's subjects, and to the advantages of trade and commerce; and whereas in many places the eommon highways are greatly damaged by the hedges adjoining thereto being of such height as to hinder thereby the advantages which would otherwise acerue to the said highways by sun and winds; and whereas some doubts have arisen, whether in such eases the laws in being hare provided a sufficient remedy."

Surveyors were therefore anthorised to eut bedges within 3 feet of the bank on owner's refusal to do so. The Act was not to alter the laws with regard to timber trees growing in hedges, nor any law for amending the highways.

'39 .... Mr. Andrew Thompson, of Grasgow, with a friend, left that city to ricle to London. There was no turnpike road until they eame to Grantham, within 110 miles of the metropolis. $U_{p}$ to that point they trarelled on a narrow causeway, with an unmacle soft road on each side. As strings of pack-horses met them from time to time, they were obliged to plunge into the side road, and had often difficulty in serambling up again upon the eanseway.-CLELAND's Glasgow.

"There is no such conveyanee as a waggon in this country (Scotland), and $\mathrm{m} y$ finances were too weak to support the expense of hiring a horse. I determined therefore to set out with the carriers, who transport goods from one place to another on horseback; and this seheme I accordingly put in execution on the first day of Norember, 1739; sitting upon a pack-horse between two baskets, one of which contained iny goods in a knapsack. But bs the time we arrived at Neweastle-upon-Tyne, I was so fatigued with the teclionsness of the carriage, and bentmbed with the coldness of the weather, that I resolved to travel the rest of my journey on foot rather than proceed in such a disagreeable manner."-SHoLLEJT's Roderick Random.

The 14 George II, cap. 42-"An Aet for the preservation of the publick roads in that part of Great Britain ealled England "recited that the highways of this kingdom were "greatly damaged and made ruinous by the excessire weights carried thereon." Weighing machines might be crected at tollgates, and carriages and goods might be weighed, a fine of $20 s$. a hundred for all above $6,000 \mathrm{lbs}$. weight, and applied to mending the roads. There were many exceptions to which this Act was not to apply.

By 16 George II, cap. 29, carts were allowed to be drawn with four horses.

The Duke of Somerset, who died this year, was always compelled, by the badness of the cross-roads, to sleep at Guildford on his way from Petworth to London. A letter of one of the Duke's servants to another servant, announces his master's intention to arrire at 


\section{Table VIII. - Defective Transport-Contd.}

A.D.

1748

Petworth from London, and adds direetions that "the keepers and others who knew the holes and slonghs, must eome to meet his grace, with lanthorns and long poles, to help him on his way."

50

The only road to the honses of parliament at this date (reign of George II) was through King-street and Union-street, "which were in so miserable a state, that fagots were thrown into the ruts on the days on which the king went to parliament, to render the passage of the state eoach more easr." Again, the present St. Margaret's Street was formed ont of a thoroughfare known as St. Margaret's Lane, which was so narrow that "pales were obliged to be placed 4 feet high between the footpath and the coach-road, to preserte the passengers from injurs, and from being covered with the mud whieh was splashed on all sides in abundance."-Switn's Hestminster, pp. 261 and 262.

50-70 "This rapid growth of manufactures brought a corresponding improvement in the means of communication throughout the country. Up to this time these had been of the rudest sort. The roads were for the most part so wretched that all cheap and rapid transit was impossible, and the cotton bales of Manchester were earried to Liverpool or Bristol on pack-horses. One of the great works of this period was the covering England with a network of splendid highways. But roads alone could not meet the demands of the new commerce. The engineering genins of Brindley joined Manehester with its port of Lirerpool in 1761 by a eanal which erossed the Irwell on a lofty aqueduet, and the suecess of the experiment soon led to the universal introduction of water-carringe Canals linked the Trent with the Merser, the Thanes with the Trent, the Forth with the Clyde."-Green's Short History of the English People, p. $76 \mathrm{~S}$.

'51 ... By 21 George II, cap. 43-" An Aet for the more effectual preservation of the turnpike roads in that part of Great biitain called England, \&e." - it is reeited :-

"Whereas great sums of money have been expended in amending and repairing the turnpike roads of this kingdom, ret the said roads eamnot be kept in sufficient repair, and are in many p'aces become ruinous by the great and excessive weights which the number of horses now allowed by law to draw waggons and other carriages enable carriers and other persons using the said roads to carry upon the same."

For remedy whereof certain stringent regulations were imposed; and there was a penalts for driring waggons out of turupike roads to aroid tolls.

'56 .... Canals.-Mr. Josial Tucker, in the fourth edition of his "Essay on Trade," published this year, strongly adrocated the entting of canals between the great trading towns of the kingdom "for the conveniency and cheapness of carriage." He consiciers these much preferable to making rivers narigable. "They are kept and repaired at a mueh easier rate. They are not subject to inundations, or the shifting of the sand or gravel, and are generally much shorter and straighter. But what is above every other consideration, a boat laden with merehandise in a canal may be drawn by a single horse, on a full trot, as in Folland, up or down stream, whether there be flood or not; and require: but two men to guide it." $A$ eanal between Reading and Bath "would make an easy and eheap communication between the two prineipal cities of the kingdom, London and Bristol. Goods and passengers might be carried at one quarter of the present expense . . . . if the like situation had been in Franee, a canal lrad been made long ago." 


\section{Table VIII.-Defective Transport-Contd.}

A..D

1759

'63

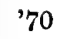

'81.

France had antieipated us by three parts of a century. The Cinermarthenshire canal was opened in 1756 , and the Droit wieh eanal

the same cear.
There was a coach once a month from Edinburgh to London, whieh was twelve to fourteen days on the road.

Mr. MCulloel says, "It was not till after the Peaec of Paris in 1763 , that tumpike roads began to be extended to all parts of the kingdom, and that the means of internal communication began, in consequenee, to be signally improred."-Account of the British Empire**

Mr. Gr. R. Porter, in the Companion to the British Almanack (1837), writing of this same period, says :-

"A gentleman now living at Horsham, in Sussex, has stated on the authority of a person whose father earried on the business of a buteler in that town, that in bis time the only means of reaching London was either by going on foot or on horseback; the latter method not being practicable at all periods of the year, nor in every state of the weather; and that the roads were never at that time in such a condition as to admit sheep or cattle being driven upon them to the London markets: for which reason the farmers were prevented sending thither the produce of their lands, the immediate neightourhood being in fact their only market. Under these circumstances the quarter of a fat ox was commonly sold for about ${ }_{15} 5$., and the price of mutton. was $1 \frac{1}{4} d$. per pound."

'70 .... In Arthur Young's Tour in the North of England, published this year, there is the following statement as to the condition of the turnpike road between Preston and Wigan :-

"I know not in the whole range of language terms suffieiently expressive to deseribe this infernal road. To look orer a map and pereeire that it is a principal one, not only to some towns, but eren whole counties, one would naturally conelude it to be at least decent; but let me most seriously eantion all trarellers who may aceidentally propose to travel this terrible connty to avoic it as they would the devil: for a thousand to one but they break their neeks or their limbs by overthrows or breakings down. They will here mect with ruts whieh I aetually measured ${ }_{4}$ feet deep, and floating with mud only from a wet summer; what therefore must it be after a winter? The only mending it in places receives is the tumbling in some loose stones, which serve no other purpose but jolting a earriage in the most intolerable manner. These are not merely opinions, but facts, for I aetually passed three earts broken down in these 18 miles of exeerable memory."

Dr. Johnson-"the great Dr. Johnson"-was visited at this clate by the Right Honourable William Windham, at Asliboume (Derbrshire), where he had gone for the benefit of his health, and Mr. Windham made a note of various points in the eonversation, amongst whieh is the following :-

"Opinion about the effect of turnpike roads. Every place communicating with each other. Before there were cheap places and dear places. Now, all refuges are destroyed for elegant or genteel porerty. Disunion of families, by furnishing a market to each man's ability, and destroying the dependence of one man upon another."

* Mr. Porter in his Progress of the Nation states that when it was in contemplation to extend the turnpike roads from the metropolis to more distant points than those to which they had been before carried, the farmers in the metropolitan counties petitioned parliament against this plan, fearing lest their market being invaded by so many eompetitors, who would sell their produc more cheaply, they should be ruined!-Book II, section 3 . 


\section{Table VIII.-Defective Transport-Contd.}

A.D.

1812

Steamboats.-The first steamboat-the Comet-sailed upon the Clyde, 18th January this year. This was the initiation of a world-wide system of rapid transit.

'30 .... Rrilroads.-The opening of the Liverpool and Manchester Railway on 15th September this year marks the practical commencement of the new era in locomotion in the United Kingdom. In a few years they made the country one in the matter of food supplies.

'64 .... There was a famine in Mexico this year, arising from drought and the consequent scareity of maize. Mr. Bullock (Across Mexico, 1864-65) says, "The plain of El Bajio is emphatieally the garden of Mexieo, and might become the grinary of the whole country but for the absence of roads, which renders the transport of grain in large quantities an impossibility. As it is, the great towns can only be supplied from their own immediate enrirons, which is a bad look ont for the city of Mexico, surrounded as it is by unproduetice marshes. In consequence of this lamentable state of things, which railway communication alone can remedy, famine may be raging in the capital, while the farmers of the Bajio-less then 200 miles distantare at their wits' end to know how to dispose of their superabundant harrest."

Tramways.-These are regarded as modern appliances, but as early as 1602 tramways (with rails of wood) were construeted from :o ne of the collieries round Neweastle-upon-Tyne down to the river. 'The first accurate deseription of these which we have met with is that given in the life of Lord Keeper North, published 1676 .

"The manner of the carriage is by laying rails of timber from the eolliery to the river, exaetly striight and parallel, and bulky earts are made with four rollers fitting those rails, whereby the carriage is so easy that one horse will draw four or fire chaldron of eoals, and is an immense benefit to the coal merchants."

At Whiteharen as early as 1738 iron rails were substituted for those of wood. Here was the germ of our future railways. But these incipient projects did nothing to help forward the canse of internal locomotion, and it is a century later that we must look for their aid in this respeet.

Tramways are only arlapted to the thickly populated districts, and for purposes of transport of food products eannot compete with canals or railroads.

\section{IX.-Legislutive Interference.}

Nothing was more naturai in early times and under a monarehial form of govermment, than that arbitrary measures should be taken in view of lessening if not of averting calamities in regard to the food supply, althongh nothing was more certain than that in the end these would prove utterly fallacious. The first idea would be that as one section of the people required food products which another section had in superabundance, that the latter should be made to supply the former, and in so doing not to take any undue advantage of their necessities. This wonld lead up to the dogma of fixed prices for various articles of ordinary requirement; in the expressing of which many principles of natural justice would certainly be outraged.

The first location wherein such experiments would be tried would probably be in the vicinity of the royal residence, where 
the king's purreyors would speedily learn of scarcity, and of consequent advance of prices.

In an insular situation like our own we should not long remain uninfluenced by external supplies, and hence a system of regulating imports and exports would become necessary; for if the holders of supplies here could make a market for them elsewhere, they would seek to avoid the restrictive influence of fixed prices at home. So also if a superabundance of supplies prevailed in neighbouring conntries, rendering it advantageons ${ }^{\circ}$ to bring these in and sell them at the fixed prices, or below them, confusion or dissatisfaction would arise. This would necessitate legislative restrictions as to our external commerce.

There would thus come to be two sets of legislative restrictions in operation; and it would be certain that in different parts of the kingdom different influences as to supply and demand must arise, and hence the system might become furtler hampered with local or municipal regulations.

But jet another difficulty might and would arise. It would become apparent that periods of scarcity would necessarily cause some relaxation of the most stringent rules as to prices; hence the owners of non-perishable products would resort to storing these away in view of securing the enhanced price consequent upon periodical scarcity. But this process carried on by a number of persons would be certain to affect prices, and complaints would ensue. This would lead to the adoption of further legislation; and forestallers, and engrossers, and regrators would be restrained in their practice by the strong arm of the law.

Here we should have another, a third, link in the chain of legislation: 1. Holders of consumable produce at home must sell to consumers at home at fixed prices; 2 . There must be no selling to or buying from persons abroad, for that would upset the notion of fixed prices; 3. Further, the produce must be consumed pari passu as it is produced-there must be no saving up for a rainy day, because that too upsets fixed prices, opens, indeed, the door to speculation.

But this is all "fine weather" legislation; what is to be done when supplies fail at home? Answer, open the ports and invite the foreigner to come in; English money will speedily bring him to our gates. So it has often happened.

Again, periods of scarcity pass away, abundant harvests prevail; there is a plethora of grain. Further, other countries are in want of supplies, and the money which would be so obtained would be of service here. What now is to be done? Our ships are freighted, a good price is obtained, the trade is found profitable to all concerned, and it increases rapidly. By means of this new outlet, 
a stimulus is given to our agriculture; the prosperity of the country is seen to be rapidly developing; and finally (1688) we begin to pay a bounty to our own growers for every quarter of grain they send away from our shores.

It must not be supposed that the process last detailed has gone on smoothly during the several centuries which are embraced in this introductory review. There were frequent intervening periods of scarcity. During some of these the ingenuity of parliament was taxed to the uttermost to devise a remedy suited to the occasion, and yet not calculated to overthrow the purely artificial system which the legislature in its want of wisdom had set up. The solution was found in the adoption of a graduated scale of prices; when grain rose beyond a certain indicated price here (at home) no more was to go out; but if the pressure were extreme, the ships of the foreigner might come in. When grain fell below a certain fixed price, the ships of the foreigner must be barred from our ports, while our own might sail away freely.

It is but too apparent that nnder such a makeshift system of legislation all commerce was a system of restriction, evasion, and compromise, resting upon the fallacious belief that one nation's gain was another's loss, and that commercial advantage was only to be measured by the balance of coin received for commodities, and not by the exchange of the useful products of industry, varying with the peculiar soil, climate, and manners of the exchangers.

Nor was this all. There were our continental neighbours looking on, and we may be sure looking on to their own advantage. The Dutch, ever keenly alive to their own interests, and deeply skilled in finance and in many of the other problems associated with successful commerce; and this too almost centuries before ourselves. Those Dutchmen many tines stored the wheat which the gorernment bounty to our growers enabled them to sell at a cheaper rate than the average European price, and sold it to us again in dear seasons at a large profit!

But it was not only the Dutch with whom we were playing at cross-pnrposes. There were portions of our own kingdom, to wit, Scotland and Ireland, against whom we set up legislative barriers of the mostrestrictive character, and they appear frequently to have retaliated upon us in kind. The mass of legislation which ensued as a consequence was simply appalling. I have not been able to make an exhanstive analysis of the Scotch and Irish Acts as bearing upon grain imports and exports, but I have reviewed perhaps enough of them to indicate their general scope. It is however, to be noticed that the first example of legislative wisdom in encouraging exports of which we find any record occurred in Ireland in 1323-24; and still further, the inhabitants of some of 
the islands of the English seas, as that of Man, Jersey, Guernsey, \&c., which depended upon parts of this country to a greater or lesser extent for their grain supplies, stood in great peril of being starved, by reason of our constantly changing laws and regulations regarding exports. Special provisions had to be made for their sustenauce; nor were they always loyal to us, for grain which was shipped in view of their benefit was sometimes reshipped to those countries from whom we had excluded ourselves by our legislation, to the great pecuniary advantage of the parties concerned.

It will be observed that I nowhere contend that in periods of emergency the legislature should not step in and endeavour to deal with the necessities of the hour. We have high examples of such temporary restrictive regulations in connection with the more enlightened nations of antiquity.* My remarks are entirely directed to the folly, in my judgment, of attempting to regulate commerce to the subversion of the great principles of supply and demand. The extent to which this species of adverse legislation has been resorted to in past times (and there are some who wonld now have ns try our hand at it again), can only be realised by reference to such detailed summaries as are given in the tables which follow. See especially Tables IX, X, and XII.

Ont of the desponding maze of legislation just reviewed, we suddenly emerge into a bright and cheering prospect. It was in 1776 that Adam Smith published his "Wealth of Nations," a book that deserves to live, and will live as long as the luman race shall last. A few sentences of its teachings are sufficient to dispel the illusions of all the legislation which had beset this question of famines (as also many other economic questions) during as many preceding centuries. Labour, he contended, was the one source of wealth; and it was by suffering the worker to procure bis own interest in his own way, that the public wealth would best be promoted. Any attempt to force labonr into artificial channels, to shape by laws the course of commerce, to promote special branches of industry in particular countries, or to fix the character of the intercourse between one country and another, is not only a wrong to the worker, or the merchant, but actually hurtful to the wealth of the State. $\dagger^{\dagger}$ There was an undergraduate at Cambridge who

* B.c. 350_-"The Selybrians were in want of money; and as there was a law among them not to export corn in a season of famine, and they had stores of corn of the preceding year, they passed a decree that private persons should give up their corn to the State at a fixed price, each leaving behind a year's supply; then they gave leave to any one who chose to export it, affixing to it such a price as seemed good to them."- "ARistotLe's Econonics" (Boln's translation), p. 312.

+ There were indeed several previous writers who had enforced like views, but had not reduced them to a science. See especially Table XI, date 1669 (Mun). 
read this book; who became instilled with its philosophy; his name was IVilliam Pitt. When he became prime minister, and while he so remained, the statute book ceased to be loaded with snch "Acts" of folly, as we have grown weary of recording. But it took yet another half-a-century to beat down the barriers of prejudice, and set up in their stead the electric illuminations of free trade as applied to the food of the people, and to commerce in general.

The details of the various legislative enactments of the English Houses of Parliament, of which the preceding ontline is but a reflex, will be found amplified, with I hope sufficient exactness, in the three tables already referred to (IX, X, and XII), but in No. X more especially. This table I had hoped to supplement by a statistical return of the amount of grain and grain products collectively imported into, or exported from this kingdom, from the earliest date (1697) when any snch returns are accessible; but I have found it impossible to obtain the required data, furnished on a uniform plan. It will be useful here to take a condensed view of the effect of the legislation embodied in Table $\mathrm{X}$, as follows:-

The several laws enacted previously to the year 1765 formed a system for regulating the grain trade upon the principle of restraininy importation, and encouraging exportation. In 1765, and each of the eight following years, laws were made prohibiting the export of grain, and allowing the import duty free. In 1773 a law was passed (13 George III, eap. 43) which established a new system with regard to the corn laws. The laws underwent further changes in each of the years 1791 and 1804. In 1815 an entire alteration took place in the system; foreign corn had previously been admissible to home consumption for several centuries, on the payment of duty, but this was now entirely prohibited. Wheat might indeed be brought in free of duty when the price was over 80 s. per quarter; but at other times it could only be brought in and warehonsed, to be used when the above limit of price was reached (with an exception in favour of the British Colonies in North America). In 1822 the same system was continued, the regulating price for wheat being lowered to 708 , and the consumption price for other kinds of grain was correspondingly reduced.

The effects resulting from the various systems enumerated (omitting the free interchange with Ireland, see Table X, 1806), are shown in the following figures; which, however, can only commence with the date of the first returns available: 


\begin{tabular}{|c|c|c|c|c|c|}
\hline $\begin{array}{c}\text { Dates } \\
\text { inclusive. }\end{array}$ & Periods. & lmports. & Exports. & $\begin{array}{l}\text { Excess } \\
\text { of lmports. }\end{array}$ & $\begin{array}{c}\text { Excess } \\
\text { of Exports. }\end{array}$ \\
\hline $1697-1764 \ldots$ & 68 years & $\begin{array}{c}\text { Qrs. } \\
\mathbf{I}, 723,818\end{array}$ & $\begin{array}{c}\text { Qrs. } \\
34,926,825\end{array}$ & Qrs. & $\begin{array}{c}\text { Q's. } \\
33,203,007\end{array}$ \\
\hline $1765-73 \ldots \ldots$ & $9 "$ & $3,151,020$ & $1,468,092$ & $1,682,928$ & - \\
\hline $74-91 \ldots \ldots$ & $18 "$ & $11,945,822$ & $5,419,625$ & $6,526,197$ & - \\
\hline '92-1804.... & $13 "$ & $18,577,612$ & $1,832,515$ & $16,745,097$ & 一 \\
\hline $1805-14 \ldots \ldots . .$. & $10 "$ & $7,6_{97}, 86_{3}$ & $1,430,938$ & $6,266,925$ & - \\
\hline '15-25......... & $11 "$ & I I , I $38,44^{8}$ & $2,007,991$ & $9,130,457$ & - \\
\hline
\end{tabular}

Note.-The returns for 1813 are estimated at the mean of $1812-14$-the records of the custom house having been destroyed by fire.

Another estimate made about this date, brought down to the year 1800 , was as follows :-**

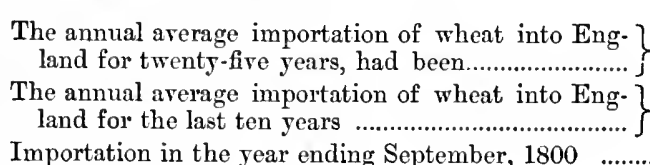

Quarters.

162,000

400,000

900,000

These 900,000 quarters were sold in our markets on an average at $95 s$. per quarter, making.

$£$

$4,275,555$

Flour, rye, barley, and oats imported during the last year, amounting in value to upwards of

$1,724,445$

Making a total of

$6,000,000$

It was estimated by the late Mr. J. R. McCulloch in the "Edinburgh Review" (1820), that a repeal of the restrictions on the importation of foreign corn would of itself, by permitting the consumers to import food from the cheapest markets, lead to a saving of 25 millions a-year in the purchase of the most indispensable of all the necessaries of life! Coming down to our own period, we now rely mainly upon imported grain supplies. The "Statis"tical Abstract" states the imports of wheat and wheatmeal and flour into the United Kingdom in the year 1876 at 5 I,904,433 cwt. :namely, 44,454,657 cwt. of grain, and 5,959,82 I cwt. of meal and flour, to which last item an addition is made on the principle that I cwt. of wheat flour is equal to $1 \frac{1}{4} \mathrm{cwt}$. of wheat in grain, so that the total is shown in weight of grain. This total was a larger quantity than in any previous year except 1875. Of this total no less than 22,223,403 cwt. came from the United States, being more than in any year except 1874 and 1875 . The import from Russia in 1876 reached only 8,91 1,788 cwt., a quantity smaller than in any of the preceding ten years except 1874, and only about half the quantity of 1872. The "Statistical Abstract" does not distinguish 
the amount of wheat imported from Austiatia or from India, but these sonrees of supply are rising into importance. Mr. Juland Danvers, Government Director of the Indian railways, observes in his railway report (1877) that it would hardly have been thought possible twenty years ago that a grauary for England would have been found in the valleys of the Ganges, Jumna, and Indus; but, notwithstanding their distance from a seaport, there had been, dnring the last two years, a rapidly inereasing production of grain in the provinces watered by those rivers, and a large export trade springing up. In 1871 the export of wheat was 248,522 cwt., in 1876 it was $5,5^{8} 3,33^{6} \mathrm{cwt}$., which was sent ehiefly to England. Mr. Danvers says :-

"When the fibres of Russia were denied to us during the Crimean war, India stepped in and supplied us with jute, and has continued to do so to an inereasing extent ever since. 'The same may now happen with respect to wheat, balley, \&c. A country with a soil and elimate capable of producing corm, tea, and tobacco, as well as coffee, opium, sugar, indigo, and cotton, must possess powers which, with the assistance of regular and cheap transport, will be realy to meet any demand that may be made upon it."

It seems an anomaly that, with her famives on hand, India is able to supply food for other parts of the world; but it has to be remembered that the natives there subsist very much on rice, and on inferior eereals designated as "dry erops," of which we know nothing in this conntry; and then there is the internal transport difficulty.

The following table gives some important details regarding the quantity and source of a chief item in our food supplies:-

The Supplies of Foreign Wheat and Flour brought into the United Kingdom during the Ten Years 1869-78, Reduced to Quarters.

\begin{tabular}{|c|c|c|c|c|c|}
\hline $\begin{array}{l}\text { Contributed by } \\
\text { the following Countries. }\end{array}$ & 1869. & 1870. & 1871. & 1872. & 1873. \\
\hline & Qrs. & Qrs. & Qrs. & Qrs. & Qrs. \\
\hline Russia ............................ & $2,113,46_{1}$ & $2,369,814$ & $3,606,692$ & $4,117,071$ & $2,214,945$ \\
\hline Denmark ................... & I 26,879 & 75,673 & 30,085 & 99,502 & 69,636 \\
\hline 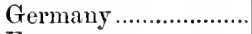 & $1,738,470$ & $1,032,980$ & 980,162 & $1,198,479$ & 693,398 \\
\hline 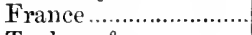 & 507,509 & 212,870 & 41,735 & $1,039,355$ & 747,078 \\
\hline Turkey, \&e................. & 549,209 & 112,943 & 327,435 & 193,401 & 84,804 \\
\hline Egypt .......................... & 231,802 & 24,219 & 204,091 & 539,355 & $290,86 \mathbf{I}$ \\
\hline United States- & & & & & \\
\hline $\left.\begin{array}{c}\text { Am. Atlantic .... } \\
\text { Pacifie....... }\end{array}\right\}$ & $3,530,743$ & $3,468,844$ & $3,606,275$ & $2,198,496$ & $5,007,640$ \\
\hline Chili & 130,870 & 138,308 & $126,8 \mathrm{I} 4$ & 330,951 & 359,337 \\
\hline $\begin{array}{l}\text { British N. America .. } \\
\text { Other countries ........ }\end{array}$ & 782,329 & $\begin{array}{l}783,995 \\
239990\end{array}$ & 872,178 & 493,722 & 996,448 \\
\hline $\begin{array}{l}\text { Other countries ......... } \\
\text { Austrian territories .. }\end{array}$ & $\begin{array}{l}307,524 \\
237,8=2\end{array}$ & $\begin{array}{r}239,990 \\
13,955\end{array}$ & $\begin{array}{r}381,783 \\
55,187\end{array}$ & $\begin{array}{r}723,102 \\
12,630\end{array}$ & $\begin{array}{r}1,398,159 \\
6,860\end{array}$ \\
\hline re & & & & & \\
\hline Total ..... & $10,242,338$ & $8,503,597$ & $10,232,540$ & $10,946,064$ & $11,869,166$ \\
\hline
\end{tabular}


the World: Past and Present.

Supplies of Foreign Wheat and Flour into the United Kingdom-Contd.

\begin{tabular}{|c|c|c|c|c|c|}
\hline $\begin{array}{l}\text { Contributed by } \\
\text { the following Countries. }\end{array}$ & 1874. & 1875. & 1876. & 1877. & 1878. \\
\hline Russia....... & $\begin{array}{l}\text { Qrs. } \\
1,318,728\end{array}$ & $\begin{array}{c}\text { Qrs. } \\
2,306,606\end{array}$ & $\begin{array}{c}\text { Qrs. } \\
2,023,675\end{array}$ & $\begin{array}{c}\text { Qrs. } \\
2,501,076\end{array}$ & $\begin{array}{c}\text { Qrs. } \\
2,084,522\end{array}$ \\
\hline Denmark.... & 38,604 & 113,907 & 60,581 & 17,033 & - \\
\hline Germany... & 919,371 & $1,523,510$ & 802,189 & $1,613,147$ & $1,500,756$ \\
\hline France ............................. & 257,747 & 799,853 & 377,252 & 887,867 & 201,458 \\
\hline Turkey, \&c.................. & 152,232 & 301,877 & 511,898 & 289,158 & 55,408 \\
\hline Egrpt …....................... & 67,818 & 483,196 & 285,888 & 564,856 & 50,191 \\
\hline United States- & & & & & \\
\hline Am. Atlantic .... & & $4,084,710$ & $3,639,828$ & $3,376,373$ & $6,664,199$ \\
\hline ,, Pacific..... & & $1,979,707$ & $1,515,54^{\circ}$ & $2,047,170$ & $1,058,405$ \\
\hline Chili & 444,307 & 207,895 & 226,758 & 169,848 & 11,670 \\
\hline British India & - & 308,063 & 756,897 & $1,408,832$ & 419,839 \\
\hline Aust & - & 264,676 & 601,330 & 98,237 & 336,888 \\
\hline British N. America.. & 989,822 & 934,337 & $6,8,390$ & 744,811 & $68+, 955$ \\
\hline Other countries ......... & 903,823 & 370,528 & $5+0,903$ & 886,293 & 662,126 \\
\hline Austrian territories .. & 649 & - & - & 一 & 一 \\
\hline Total & $10,5 \circ 6,064$ & $13,678,895$ & $11,942,672$ & $14,604,707$ & $13,730,422$ \\
\hline
\end{tabular}

Note.-For this table I am indebted to Mr. Henry M. Paul, a Fellow of this Society, who has drawn most of his data from the "Statistical Abstract."

It is estimated that a good grain harvest in the British Empire and dependencies, and in those countries from which we draw our food supplies, means an aggregate bounty of some 200 millions sterling, "poured from the heavens into the earth's treasury."

Turning to other articles of food, in 1875 the inhabitants of the United Kingdom consumed I,I86,64 I cwt. of beef from imported live cattle; 454,007 cwt. of mutton from imported live sheep ; 7 1,927 cwt. of pork from imported live swine ; 3, I I 4,809 cwt. of imported dead meat-i.e., bacon, pork, hams, cured beef, \&c.; I 5,820,006 cwt. of home-grazed beef; 8,70I,45 I cwt. of home-raised mutton; and 4,348,944 cwt. of home-bred pork; the total consumption of meat (exclusive of poultry, game and other meat not classified with butcher's meat) of the United Kingdom being $33,697,785 \mathrm{cwt}$. A reduction of $2 d$. per pound (the lowest estimated present rate of overcharge by retail traders to their customers) on this vast quantity of meat would result in a yearly saving to the whole country of $3 \mathrm{I}, 45 \mathrm{I}, 264 l .2 s .8 d$.

The value of the imports of meat and provisions in 1854 was $5,782,164 l$; of grain and flour $21,760,282 l$. - total $27,542,447$ l. In 1878 the value of meat and provisions imported reached $30,364,853 l$; of grain and flour $58,372,624 l .-$ total $88,737,477 l$.

All this is but a mere glance at the interesting problems associated with our modern food supplies. 
TABLE IX.-(Internal Regulations). Imperial and Municipal Restrictions on the Price of Food and Dealings therein.

Corn has provided a common article of food from the earliest ages of the world; and the baking of bread was known in the patriarchal agcs.-See Exodus xii, 15.

A.D.

1203

3 John. The first statute in England regilating the sale of bread, as to its weight and price, was the Assisa Panis of this jear. The chief justiciary and a baker commissioned by the king had the inspection of the assize.-MatTheW PaRis.

We have never met with an authentic copy of this reported statute, and we therefore prefer to fall back upon that of A.D. 1266 (51 Henry III) as giren in the Statutes of the Realm.

'66 .... The statute we find under this date is usually designated the Assisa Panis et Cervisie (the assize of bread and ale), and mostly embodies the following introductory paragraph, "The king, to whom all these presents shall come, greeting: We have seen certain ordinances of the assize of bread and ale, and of the making of money and measure, made in the times of our progenitors, sometimes kings of England in these words." Then follows the enactment, as translated from the Latin.

When a quarter of wheat is sold for xii $d$. then wastel bread of a farthing shall weigh vil. and $x \nabla j s$. But bread cockit [of a farthing] of the same coin and bushel, shall weigh more than wastel by ii $s$.; and [cocket bread] made of corn of lower price shall weigh more than wastel by $\mathrm{r} s$. Bread made into a simnel shall weigh ii $s$. less than wastel [because it is twice baked]. Bread made of the whole wheat shall weigh a cocket and a half, that is to say, a cocket shall weigh more than a wastel by $\mathrm{v} s$. Bread of treet shall weigh ii wastels. And bread of [all sorts of common] shall weigh two great cockets.

When a quarter of wheat is sold for xriii $d$. then wastel bread of a farthing, white and well baked, shall weigh iv $l$. $s$. viii $d$.

When for ii $s \ldots \ldots . .$. iii $l i$. viii $s$.

\begin{tabular}{|c|c|}
\hline ", & ii $s$. vi $d . \operatorname{liv} s$. iv $d . o b . q$. \\
\hline 9 & iii $s . . . . . . . .[$ [xlviii $s]$. \\
\hline " & iii s. vid. [xlii s.] \\
\hline " & iv $s \ldots \ldots \ldots[\operatorname{xxx}(s]$. \\
\hline ", & iv $s$. vi $d . \operatorname{xxx} s$. \\
\hline$"$ & $\nabla s \ldots \ldots \ldots$. xxvii $s$. ii $d . o b$. \\
\hline " & vs. vid. xxivs. vili $d . q$. \\
\hline " & vi $s \ldots \ldots \ldots \times$ xxil $s$. vill $d$. \\
\hline$"$ & vi $s$, vi $d, x \times s$, xi $d$. \\
\hline$"$ & vii $s . . . . . . . \operatorname{xi} s . .[\mathrm{i} d]$. \\
\hline " & rii s. vi d. xvili s. id.ob. \\
\hline " & $\begin{array}{l}\text { vill } s . . . \ldots . . . \text { xvil } s . \\
\text { viii } s . \text { vi } d . \text { xvi. }\end{array}$ \\
\hline "' & vills. v1d. xvi. \\
\hline$"$ & 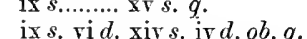 \\
\hline$"$ & 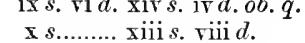 \\
\hline$"$ & x $s$. vi $d$. xii $s$. xi $d . q$. \\
\hline , & xi $s . . . \ldots . .$. xii $s$. iv $d . q$. \\
\hline
\end{tabular}

When for xi s. vi $d$. xi $s . \mathbf{x} d$.

\begin{tabular}{|c|c|c|}
\hline " & $11 s .$. & \\
\hline$"$ & xii s. vi $d$. & $10 s .10 \frac{1}{2} d$ \\
\hline$"$ & xiii $s . . . . . .$. & 10 s. $5 \frac{1}{2} d$. \\
\hline , & xiii $s, \operatorname{vi} d$. & $10 s,-\frac{3}{4} d$ \\
\hline ," & xiiii $s, \ldots . . . .$. & $9 s .8 d$. \\
\hline "' & xiiii $s$. vi $d$. & . $\quad 9 s .2 \frac{3}{4} d$ \\
\hline$"$ & XV $s . . . . . . .$. & $9 s .2 d$ \\
\hline$"$ & vi $d$. & $8 s \cdot 9 \frac{1}{2} d$. \\
\hline$"$ & .......... & $8 s .6 d$. \\
\hline$"$ & xvi $s$. vi $d$. & $8 s .2 \frac{3}{4} d$ \\
\hline$"$ & xpil $s, \ldots \ldots . .$. & $8 s$. \\
\hline$"$ & xviil $s$. vi $d$. & $7 s \cdot 9 \frac{1}{2} d$. \\
\hline ,' & xviii $s . . . . . . .$. & $7 s .6 \frac{3}{4} d$ \\
\hline " & $\mathbf{x v i i i} s$. vi $d$. & $7 s \cdot 4^{\frac{1}{4}} d$. \\
\hline " & 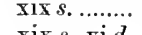 & s. $2 d$. \\
\hline$"$ & $d$. & $6 s, 0$ \\
\hline , & & \\
\hline
\end{tabular}

Gain to the Baker.-And it is to be known, that then a baker in every quarter of wheat, as is proved by the king's bakers, may gain vid. and the bran and two loves [for advantage], for three servants $i d$. $a b$., for two lads $a b$, in salt $o b$, for kneading $o b$., for candle $q$, for wood [ii $d$.] for his butel $o b$.

Assise of Ale.-When a quarter of wheat is sold for iii $s$. or iii $s$. iv $d$., and a quarter of barley for $\mathbf{x x} d$. or ii $s$., and a quarter of oats for xvi $d$., then brewers in cities ought and may well afford to sell two gallons of beer or ale for a penny, and out of cities to sell 


\section{TABLE IX.-Restrictions on the Price of Food-Contd.}

A.D. 1266

iii [or iv] gallons for a penny, and when in a town iii gallons arc sold for a penny, out of a town they ought and may sell four; and this assise ought to be holden throughout all England.

Punishment of a Baker or Brewer Transgressing the Assise.-And if a baker or brewer be convicted that they have not kept the foresaid assises, the first, second, and third time they shall be auncred according to the quantity of their offence; and that as often as a baker shall offend in the weight of a farthing loaf of bread not above ij $s$. weight, that then he be amerced as before is said; but if he exceeds ijs. then [he is to be set upon] the pillory without any redemption of money. In like manner shall it be done if he offend oftentimes and will not amend, then he shall suffer the judgment of the body, that is to say, the pillory if he offend in the weight of a farthing loaf under two shillings weight as is aforesaid. Likewise the woman brewer shall be pumished by the tumbrell, trebuchit, or custigatorie, if she offend divers times and will not amend.

In the Judicium Pillorie (the judgment of the pillory) which is usually dated back to this year (1266) is contained the following clauses :-

"First, they shall inquire the price of wheat, that is to wit, how a quarter of the best wheat was sold the last market day, and how the second wheat, and how the third, and how a quarter of barley and oats.

"After, how the baker's bread [in the court doth agree], that is to" wit, wastel and other bread after wheat of the best, or of the second, or of the third price.

"Also upon how much increase or decrease in the price of [a quarter of] wheat a baker ought to change the assise and weight, of his bread.

"Also how much the wastel of a farthing ought to weigh and all other manner of bread after the price of a quarter of wheat that they present."

Edward I. Besides Acts of parliament, passed in regular form, there were many other modes whereby the commands of the sovereign and his advisers were promulgated. These were severally by Charters, Acts of Grace, Letters Mandatory, Ordinances, and Proclamations (the latter becoming in due course more popular), severally issued on special emergencies. We shall have to glance at these: for the statute book is seen to be an incomplete authority to follow. The king at this date commanded the mayor and aldermen of London to make statutes for governing the hucksters of fish and fowl. A record of what was done under it is to be found in the horn book of the Corporation of the city under the title of "Statuta de poletria et pisce facta tempore Mairoratus Henry de Waleys," viz.:

Tempore Henrici de Waleys, \&c., i.e. in the time of Heury de Walss, maior of London, Nicholas de Winton, Henry de Corentre, sheriffs by the command of the lord the king, with the assent and consent of the great men of the kingdom and citizens aforesaid, it was ordained that no huckster of fowle [mango avium] go out of the city to meet them that bring poultry, to the city, to make any buying from them; but buy in the city, after the buyers of the lord the king, of the Darons, and the citizens, have bought and had what shall be needful for them, namely, after 3 o'clock and not before. And then let them buy thus: That they may afford an hen of the better sort for $3 d . a b$. And two pullets of the better sort for $3 d$. $a b$. And one capon of the better sort for $2 d . o b$. And from Easter to Whitsuntide a better homefed goose for $5 d$. And from Whitsuntide to St. Peter's ad Vincula, for $4 d$. And from that festival throughout the whole year always, one of the better sort for $3 d$. Also for a wild goose of the better sort, $4 d$. Three young pigeons of the better sort 


\section{TABLe IX.-Restrictions on the Price of Food-Contd.}

A.D. 1276

for $\mathrm{I} d$. One mallard for $3 d . o b$. And two cercels for $3 s$. And two wydeh [wild ducks] for $3 d$. ob. And four begaters $1 d$. And a dozen larks $1 d$. One better feasant $4 d$. One better botor for $6 d$. A better beron $6 d$. One better corlume $3 d$. One better plover $1 d$. One swan for $3 s$. One better crane for $3 s$. A better peacock for i $2 d$. A better coney with the skin $4 d$. And without the skin $3 d$. The flesh of a good hare $3 d . o b$. One kid from Christmas to Lent, of the better sort, for $10 d$. At other times of the year for $6 d$. One better lamb between Cliristmas and Lent for $6 \dot{d}$. And at other times of the year for $4 d$.

It is also ordained that no huckster of fish, or fishmonger who sells again to others, go out to meet those that bring or earry in fish to the eity, to make a forestal thence; nor have any partnership with a stranger, who brings from the sea to the city; but let them seek for fish in their own ships, and permit foreigners to bring it, and to sell when they are come in their own ships. Beeause by such partnership they who are of the eity, and have known the state of the eity, and the defect of rictuals, will hold the fish at a greater dearness than foreigners who shall not have known it. And also that they who are of the eity, when they eannot scll as they will, lay it up in eellars, and sell dearer than the strangers would do if they eame without partnership, and knew [not] where they might be harboured.

Nor let them buy any thing in the eity until the king's serrants, \&e., have bought, and not before 3 o'clock. And if they who have brought fish shall come after 3 o'clock, let them not sell that day, but let them sell on the morrow morning. And if they expeet more, let the fish be taken into the lord king's hand, and let them keep no fish, exeept salt fish, beyond the second day of their coming. Which, if it shall happen to be found let them lose their fish, and be at the meres of the Lord the king [to fine them].

And thus let the hucksters, i.e. the fishmongers, buy, that they afford,

A better plaise for $3 d$. $o b$., a middling one for $1 d$, and others less, as consequently they seem to be worth.

Also twelve better soles for $3 d$., and others as they are worth. Also, a better eonger for $12 d$, others as they may be worth.

$A$ better turbot for $6 d$., and others as they are worth.

A gallon of oysters for $2 d$.

A better fresh salmon between Christmas and Easter for $5^{s}$. And after Easter for $3^{s}$. And others middling and less as they are worth.

One lampred of nauntes, in their first coming, and of the better sort, for a month, for $16 d$. And after a better lampred for $8 d$. And after Easter for $6 d$.

Also, one better fresh lamprey, of Severne or Thames, between the purification of the Blessed Virgin Mary and the middle of Lent, for $t d$. And after the middle of Lent to Easter for $2 d$.

And let the lampreys of nauntes be sold in the publie market wherein they are aceustomed to be sold, and not in houses, unless they be hid by night.

And let merchant strangers come to the city, make there abode there, and do as they have been wont to do.

I luave greatly curtailed the list of fishes enumerated in the ordinance, partly on the ground of spaee, and especially because the names they bear therein are now unknown to us.

'85 .... In Statum de Pistoribus, \&c. (statute concerning bakers, \&c.), sometimes attributed to 51 Henry III, but appearing more probably to belong to this reign, 13 Edward I, is contained the following :

"Here begineth the rule for punishing the infringers of the assise of bread and ale, forestallers, cooks, \&c." 


\section{Table IX.-Restrictions on the Price of Food--Contd.}

A.D. 1285

'86

'90

"The assise of bread shall be kept aceording as it is contained in the writing of the Marslalsey of our lord the king, delivered unto them, after the sale of wheat, that is to wit, the better, the worse, and the worst. And well wastel bread, as other of what sort soerer they be, slatl be weighed, aceording as it is said [of the sale of the meaner wheat]. Neither shall the assise of weight of [wheat] be changed [more than 6d. increasing or deereasing, as it is in the sale of the quarter].

"A baker, if his bread [be foumden a farthing weight laeking in] $2 s .6 d$., or under, shall be amereed; and if it [pass the same number] he shall suffer punishment of the pillory, which shall not be remitted to the offender either for gold or silver; and every baker shall have a mark of his own for [each solt of) bread."

Then the following:

"A buteher that selleth swines flesh meazled, or flesh dead of the murrain, or that buyeth flesh of Jews, and selleth the sime unto Christians, after he shall be conviet thereof, for the first time, he shall be grierously amerced; the second time he shall suffer judgment of the pillory; and the third time he shall be imprisoned and make fine; and the fourth time he shall forswear the town. And in this manner shall it be done [of all that offend in the like case].

"And if any presume to sell the meal of oats adulterated, or in any other deceitful manner, for the first offence he shall be grievously punished; for the second he shall lose all his meal; for the third he shall undergo the judgment of the pillory; and for the fourth he shall abjure the town."

In this statute it was also prorided that "every pillory or stretchneck, must be made of convenient strength, so that execution may be done upon offender's without peril of their bocties."

90 ... At this date, and probably for some time earlier, the bakers who supplied London with bread mostly lived at Stratford-le-Bow, Essex, probably on aecount of its proximity to Epping Forest, where they could obtain firewood at small cost. At a later date Bromley (Bremble), also by Bow, but nearer to London, was the seat of many bakeries. The bread was taken to the eity, to the market in Bread Street in carts, and was often seized on its way for being of light weight or made of unsound materials.

Note.-It seems that the bakers of Southwark were not allowed to rend bread in the eity, because they were not amenable to the city laws. In the Horn Book, under date 1293, is the following entry: "Item, that no regrators shall come from below London Bridge, for the busing and preparing of bread in the city ; becanse the bakers of Southwark are not permitted by the statutes of our city to come from without the eitr." (See 1302.)

26 Edward 1. A mandate for the preservation of peace within the eity was issued by the king, acldressed to Hemry le Galeys, mayor, which reeites and ordains as follows :

"Edward by the grace of God, \&e., to the mayor and sheriffs of Loncton, greeting. Forasnuch as we have heard that the bakers, and brewsters and millers, in the city aforesaid, do frequently miseonduct themselves in their trides. . . . We of our counsel, wisling to apply a fitting remedy to all the preunises, and to strike both them and others with fear of so offending, do command you, and strictly enjoin, that you will so ehastise such bakers, brewsters, and miscloers, with corporal punishments, and so risit the other offences, at your discretion, that they may excite in others in like case a fear of so offending. And that all eorn to be ground at mills within the city aforesaid, and without, shall be weighed by the miliers, and that such millers shall answer in like weight in the flour coming therefrom. And to the matters aforesaid, and all other things which unto the 


\section{Table IX.-Restrictions on the Price of Food-Contd.}

A.D. 1295

1302

office of the mayoralty of the same city, and to the preservation there of our peace, do pertain, you are to cause to be inviolably observed. Witness myself at York, the 28th day of May, in the twenty-sixth sear of our reign."

30 Edward I-The bakers of London were first allowed to sell bread in their own shops this year. Preciously all the bread was sold in Bread Street (off Cheapside).-Stow. The London Bakers Company was incorporated 1307 .

Edward II. In the hom book of the corporation of London there is (p. 234) under the title of:

Incipiunt statuta et provisiones civium, Tondon, de assiza panis, the following :

"Secundem consuetudinem civitatus, London, \&c.-According to the custom of the city of London, an assay ought to be made of bread every year, after the feast of St. Michael, by four discreet and sworn men, chosen for this purpose : and according to the proportion of the common weight of that assay, the bakers ought to bake their loares throughout the whole rear: namely, so that if afterwards bread can be sold dearer than it was at the making assay, then the bread ought to be of less weight than it weighed in the assay. And if it were of less price, then it ought to weigh more. Only we ought cautionsly to prorille that accordingly to the quantity whereby the corn increaseth in price or decreaseth, the bread increase or decrease in weight."

The exact manner of making the assay, we learn from the same anthority, was as follows:

"That the said four sworn men should buy three quarters of bread corn [or meal] in the sack upon the parement in the three markets: one at Grassechurch, another at St. Botolph, Billinsgate, and the thind at Queenhith. Of which they were to make a wastell, and another loaf less fine (which I think they called coket), and after they had baked these lores with the greatest diligence, then they went and presented them hot before the maior and aldermen in Guild-IIall. And thus hot they were weighed. And then (saith the statnte) the buring of the bread corn shall be considered: and $8 d$. for every quarter slall be allowed to the baker for his charges. The selling alsu of the bxamn shall be considered, and shall be withdrawn out of the sum that the meal was bought for. And if [after dirers exact rules for weighing the bread] there be more loares in number than there shall remain halfpence in the sum of the meal bonght, when the charge is allowed, then let there be a partition of the weight of those loves remaining and above. And so every loaf shall be made of just weight. And if these be fewer loaves than the number of halfpence in the sum the meal was bouglit for when the charge is allowed, then let it be withdrawn from the weight of each loaf equally, so far until there result so many loares of equal weight, as there are halfpence in the number of the sum the meal was bonght at when the charge is allowed.

"If there slall be more loaves than the number of halfpence, let the part exceeding be taken from the number of loares, and see the how manieth part it will be to the number of halfpence; and according to that proportion let the weight of each loaf be augmented. For example sake, if there be 20 halfpence and 24 loaves, every loaf at the weight of fos., then the number of loares increaseth above the number of halfpence, which are but 20 ; and it is the fifth part, since 5 times 4 make 20 . Therefore the weight of every loaf increaseth by the fifth part of its weight; and the weight of the loaf was $40 s$., whose fifth part is $8 s$. Therefore 20 loaves shall be each loaf of the weight of $48 s$. And so each loaf shall be of just weight. 


\section{TABLE IX.-Restrictions on the Price of Food-Contd.}

A.D.

1307

'14....

"If there were more halfpence than the number of loares, we must sce the how manieth part was the number increasing of the number of loares; and if it were a third part, a fourtl part is to be lessened from every loaf; and if it were a fourth part, a fifth part is to be lessened. "For example, if the number of halfpence were 24 and the number of loares 20 , then is the number increasing to as before, which is the fifth part of 20 . Therefore cach loaf decreaseth of a sixth part of its weight. If the weight therefore shall be $40 s$., it shall be $3 i s .4 d$. And so the number of loaves is equalled to the number of halfpence, and the weight is the same."

While this explanation helps us in regard to certain quotations which arise in the denomination of valucs in this paper, it has not the adrantage of making itself elear to the understanding of any orlinary reader. We must be content to take it as we find it. It is quite certain that the actual weight of the coins mentioned in each case was used to determine the weight of bread in the preceding assise. We next adrance to another stage of the proceedings taken by the city authorities in the matter of bread.

There were four principal halimotes in the year, when all the city bakers were bound to meet together: whereof the first was kept after the first of St. Michael, for the profit of the city and the kingdom. That the bakers assembled together take and know their new sheriffs and retain in their memories the statutes of the city belonging to the bakers, and receive the assay of bread.

The second halimote was held after the nativity of our Lord: that if there be any transgression made in the first term of the year it may be there without difficulty more fully amended.

The third halimote was acenstomed to be ealled together after the close of Easter : as well for the coming of the king as of the nobles of his kingdom; lest their might scem to fall out a want of this kind of serrice-that is, in a convenient supply of the city and inhabitants with good bread.

The fourth halimote was after the natirity of St. Joln Baptist: that what should be solemnly appointed by the common council and providence (sic) of the city in the first three terms, in this fourth term might be profitably confirmed. So that the goodness of so great a work might not run to disprofit by ignorance or by negligence.

To these four halimotes all the bakers must come. And if they come not, nor excuse and essoin themsclves reasonably, they forfeit to the sheritf 2 id .

8 Edward II. At this period the king agnin attempted to come to the resene of the city, by setting a "reasonable price" on flesh and fowl, in the ordination which follows:-

Edwardus Dei Gratia, \&e.-Edward by the Grace of God, King of England, Lord of Ircland, Duke of Aquitan, to the Sheriffs of London, greeting. "We have heard the complaint of the arch bishops, bishops, earls, barons, and others of the commonality of our kingdom, by their petition exhibited before us and our council: containing that there is a great and, as it were, intolerable dearth, in these days, of oxen, cows, sheep, hogs, geese, capons, hens, chickens, pigeons, and eggs; to the no little loss and grievance of them and all others dwelling within the same kingdom. For which they hare besought us instantly that we would take care to provide upon this concerning some suitable remedy.

"We therefore yielding to the aforesaid supplication for the common profit of the people of the said kingdom, as it seemed expedient to us, have ordained, with the counsel and assent of the prelates, earls, barous, and others, being of our council, in our last parliament held at Westminster :

"That a better sort ox, alive, saleable, fat, not fed of grain, be sold 


\section{Table IX.-Restrictions on the Price of Food-Contd.}

A.D.

1314

for the time to come for $16 s$, and not abore. Or that if it be fed with grain, and be fat, then to be sold for $24 s$. at most.

"And that a better sort of cow, alice, and fat, be sold for $12 s$.

"A hogg, two years old, and fat, for 4 od.

"A sheared mutton, fat, for $14 d$.

"A fat goose for $2 d . o b$. In our city aforesaid for $3 d$.

"A capon, good and fat, for $2 d$., and $2 d . o b$.

"A fat hen for a $1 d$., and $1 d$. ob.

"Two chickens for $1 d$., and $1 d$. ob.

"Three [four overwritten] young pigeons for $1 d$.

"Twenty eggs for $\mathrm{i} d$.

"And that if it happen to be found, that any persons, or any one person, will not sell these salcable things for the price appointed, as is before set forth. then the said saleable things shall remain forfeited to us. And we will that the aforesaid ordination from this time be firmly and inriolably observed in our silid eity.

"Ve command, firmly enjoining you, that in our city aforesaid, and suburb of the sime, where ye shall see it to be expedient, that the aforesaid ordination be publickly and distinctly proclaimed; and that ye cause the same from time [sic] to be inviolably observed in all and each its articles, moler the aforesaid forfciture, throughout, the whole bailifwic. And this omit by no means, as you will avoid onr indignation, and preserse rourselves without blame. Witness mrsclf at Westminster this 1th day of March in the eighth year of our reign."

This ordination was afterwarls extended through the whole kingdom, in all cities, boroughs, rillages, \&e. "But (in the langnage of STow) the ling was fain the next year to send a brief of reclamation of his former ordination, finding it did more harm than good." It was as follows:

"The king to the sheriffs of London, greeting: Although we lately comminded you that in each plice in the aforesaid city, where it shoukt seem to you to be best expedient, ye should cause it to be publickly proclaimed, that oxen, eows, hogs, sheep, geese, capons, heus, chickens, pigeons and eggs should be sold at a certain price: Because, nerertheless, we have understood that such a proclamation, which at the time we believed would be for the profit of the people of our realm, redounds to their greater damage than profit: We eommand you that in the said sereral places fe cause publickly to be proclaimed, that oxen, cows, hog, sheep, geese, capons, hens, chickens, fom pigeons and eggs be sold for a reasonable price, as was accustomed to be done before the said former proclamation; certifying all and singular that the former proclamation was not mate by virtue of the ordination late made by the prelates, earls, and barons, and nobles, of the same realm, and by us accepted, nor was contained in them. Witness nyself at Lincoln, the 20th February, in the ninth year of our reign."

This frumk confession of errors in judgment, and outstretching of anthority, in the matter of gorermment, has a novelty about it to which we moderns are not aecustomed.

10 Edwand II.-Gilbert Parry was indicted and eonvieted for selling maslin halfpenny loaves of short weight in the city, "and because it was found that he had been twice drawn on the hurdle, and was now for the third time found in defant, it was adjudged that he should be drawn now for the third time, and should then forswear the trade of a baker in the city for ever. And he did abjure it before the mayor and aldermen in full court, \&c."-Memorials of London, p. 123. "Marlin" bread was componnded of wheat and rye flour combined. The designation is still current in the north of England. 


\section{Table IX.-Restrictions on the Price of Food-Contd.}

A.D.

1336 .... By 10 Edward III, statute 3, it was enacted that none should be served at any neal with more than two courses, except at certain festivals. But this enactment appears to fall within the pale of the sumptuary laws, and not to liave been the result of any special searcity of food.

'48 .... 22 Edward III. Pikc, in his History of Crime in England-a work of the highest authenticity - writing of the punishments of delinquents at this period, says:-

"Turn where he might, the traveller could hardly fail to light upon some group which would tell him the character of the people he had come to see. Here, perhaps, a baker with a loaf hung round his neck, was being jeered and pelted in the pillory, because he had given short weight; or because when men had asked for bread, he had giren them, not a stone, but a lump of iron inclosed by crust. There perhaps an oven was being pulled down, because a baker had bcen detected in a third offence, and had been compelled to abjure trade in the city for ever. If there were no bakers to be punished on any particular dar, the pillories could never have been all without occupants. They were used to punish the sellers of bad meat, poultry, and fish, . . . of oats good at the top of the sack and bad below, . . . and the petty pilferers of every kind."

For some rerification of this see RiLEr's Memorials of London. (1S5s), p. 498.

49 .... By the 23 Edward III, cap. 6, "Victual shall be sold at reasonable prices," it is enacted as follows :-

"Item-That butchers, fishmongers, regrators, hostlers, brewers, bakers, ponlters, and all other sellers of all mamer of rictual, shall be bound to sell the same victual for a reasonable price, having respect to the price that such victual be sold at in the places adjoining so that the same seller have moderate gains, and not excessive, reasonably to be required according to the distance of the place from whence the said rietual be carried. (2) And if any sell such victuals in any other manner, and therefore be conviet in the manner and form aforesaid, he shall pay the double of the same that he so received to the party damnified, or, in default of him to any other that will pursue in this behalf. (3) And the mayors and bailiffs of cities, boroughs, merchant towns, and others, and of the ports of the sea, and other places, shall have power to inquire of all and singular which shall in anything offend the same; and to levy the said pain to the use of them at whose suit such offender shall be convict."

"If the mayors, bailiffs, \&e., were themselves engaged on their duties in this regard they were to be grievously punished."

'50-51 By 25 Edward III, statute 2, cap. 1, it was enacted that carters, ploughmen, drivers of the plough, shepherds, swineherds, deies, and all other servants, should take liveries and wages, accustomed in the twentieth year of this reign: "so that in the country where wheat was wont to be given they shall take for the bushel tenpence, or wheat at the will of the giver till it be otherwise ordained."

'57 .... By 31 Edward III, statute 1, eap. 10, it is enacted as follows :- "Item. Because that the fishers, butchers, poulterers, and other sellers of rictuals of the city of London by colour of some charters and by evil interpretation of some statutes, made in advantage of the people, that every man may freely sell his victuals without disturbance, and that no mayor, sheriffs, or other minister ought to meddle of the sale; it is accorded and assented, that every man that bringeth victuals whatever they be to the said city, by land and watcr, may freely sell the same to whom it shall please him, without being interrupted or impeached by fisher, butcher, pouiter, or any other; and that the mayor and aldermen of the said city may rate and redress the defaults of fishers, butehers, and poulters, as they do of 


\section{Table IX.-Restrictions on the Price of Food-Contd.}

A.D.

1357

those that sell bread, wine, or ale, notwithstanding charters of franchise, and statutes, customs, or other privileges made or used to the contrary: And that the said mayor and aldermen do the same and put it in execution, upon the pain late ordained touching the eity of London, so that the punishment of such be not made in respect of any singular profit.'

By the 31 Edward III, statute 2- "An ordinance made concerning the selling of herrings," after certain provisions against forestalling, which will be found in Table XII, proceeded to enact that the "hundred" of herrings should consist of six score, and the "last" of ten thonsand, proceeds :-

"And that the merehants of Yarmonth, of London, or elsewhere, shall sell the thousand of herrings to the people after the rate of the price of the last; and that two lasts of shotten-herring fresh shall be sold for the price of the rate of the buying of a last of full herring. And that the people of Yarmouth sell the last of led herring bought for $40 s$. fresh, or for less than $40 s$. for half a mark of gain and not above. And that the people of London, at such fain, shall bring the last from Yarmouth to London for one mark of gain and not abore.

In this sear also was promnlgated, "An ordinance concerning the salt fish of Blakeney," which recites:-

"Whereas it is shown to our lord the king by the commons of his realm of England, in his parliament holden at Westminster the Monday next after the week of Easter, in the year of the reign of our lord the king, that is to say of England, the 31st, and of France the 1Sth, that salt fish of Blalieney, and of the coasts adjoining are, and heretofore have been sold at too high and excessive price, to the great damage of our lord the king, of the great men, and of all the people of the said realm, whereof the said commons do pray a remedy; our lord the ling desiring to make amendment therein, for relief of his people... . hath ordained and established concerning the sale of the said fish in mamer following."

Then follow the enactments:-

"1. First, it is ordained that all the ships called doggers and lodeships, pertaining to the Haven of Blackney, and coasts thereunto adjoining, that is to say, Saterley, Wineton, Clay, Salthouse, shiringham and Crowner, shall deliver or discharge their fish within the Haren of Blackney only, betwixt Renord and Hogfleet, and in none other place, upon pain of imprisonment at the king's will, and forfeiture of the same fish. And that no fish be delivered nor carried out of the ship to any house, nor elsewhere before that the owner of the ship wherein the said fish is charged, and the merchant that shall buy the fish, be agreed of the price of the same by clear dav."

2. (In abstract). The buyer only shall handle the fish. The price of dogger fish was to be settled at the beginning of Blakeney finir. Fish was not to be kept in houses to be sold by retale. "And that no man buy nets, hooks, nor other instruments pertaining to fishing, in the county of Norfolk, but owners, masters, and mariners of ships that use the mystery of fishing, and which have to do with such things, upon pain of imprisonment, and to be ransomed at the king's will, and to forfeit the things so bought." Six ehosen men were to be present at the delivery of the fish, "to search for orgeys," \&c.

'60-61 By the 35 Edward III-"An ordinance of herring" - the ordinance of 1357 was modified after the following recital of the causes therefore, "beeause that the hosts of our town of Great Yarmouth would lodge the fishers coming there with their herring in the time of the fair, will not suffer the said fishers to sell their herrings, nor to meddle 


\section{TABLE IX.-Restrictions on the Price of Food-Contd.}

A.D. 1360-61

'62

with the sale of the same, but scll them at their own will, as dear as they will, and give the fishers that that pleaseth them, so that the fishers do withdraw themselves to come there, and the herring was set at a greater dearth than it was before." And again, "because it is showed to us and our council by petition in this present parliament, that the sale of herring is much decayed, and the people greatiy endangered by the points aforesaid [the provisions of the ordinance of 1357], that is to say, that many merchants coming to the fair, as well as labourers and servants, as other do bargain for herring, and every of them by makce and enry increasc upon other, and if one prefer $40 s$, another will prefer $10 s$. more, and the third $60 s$, and so every one surmounteth other in the bargain, and such profers extend to more than the price of the herring upon which the fishers profered it to sell in the beginning; and when every man who claimeth his part of the herring for the price accorded, shall have his part, and the herring be so divided amongst them that the fisher is so much grieved and delayed in the gathering of his money, that he should demand of so many persons, that he looseth his tides, and the adrantage of his fishing; and also herein, that no fresh herring is put to sale but from the sun-rising till the sun going down, and not before nor after, which is to the great loss of fishers, and appairing of the herring, and damage of the people that shall buy the same, for the fishing is more by night than by day, and often it chanceth that the fishers be so distant and so laden that they come to the town after the sun going down, or little before, so that they cannot sell their herring in the tine for the sale limited, so that they must abide all the night and day after upon the sale of their herring, and lose many tydes and the profits of their fishing; We perceiving the mischiefs and grierances aforesaid, granted that all persons might buy herring openly, not pricily; no man was to interrupt another in a bargain of herring, nor bid upon him, and fishermen might sell their herring as soon as they arrived; in fact matters got back to much as they were before the first ordinance of herring, except that there was to be no competition in the sales, otherwise the price could not remain fixed!

2 .... An Act regulating the price of poultry was passed, viz., 37 Edward III, cap. 3, which was as follows:-Item. For the great dearth that is in many places of the realm, of ponltry, it is ordained, that the price of a young capon shall not pass iijd., and of an old iiijd., of an hen ij $d$., of a pullet $\mathrm{j} d$., of a goose iiij $d$., and in places where the prices of such victuals be less, they shall hold without being enhanced by this ordinance ; and that in the towns and markets of uplands they shall be sold at a less price, according as may be agreed betwixt the seller and the buyer; and justices shall be thereupon assigned by commission to put the thing duly in execution.

During part of this reign a quarter of corn sold in certain localities for $2 s$.

By 37 Edward III, cap. 8, the diet and apparel of servants was regulated. We quote in brief. Item.- "For the outragions and excessive apparel of divers people, against their estate and degree, to the great destruction and impoverishment of all the land; It is ordained, that grooms, as well servants of lords, as they of mrsteries, and artificers, shall be serred with meat and drink once a day of flesh or of fish, and the remnant of other victuals, as of milk, butter and cheese, and such other victuals, according to their estate. . . ."

By 36 Edward III, cap. 2, the Act of the preceding session (37 Edward III, cap. 5), restricting merchants to deal in one sort of merchandise only [see Table XII] was repealed as follows:-

"Item-To that which was ordained at the last parliament, of living and apparel, and that no English merchant should use but one mer- 


\section{TABLE IX.-Restrictions on the Price of Food-Contd.}

A.D.

$1363-61$

chandise. It is ordained that all people shall be as free as they were at all times before the said ordinance, and, namely, as they were in the time of the king's grandfather and his other good progenitors; and that all merchants, as well aliens as denizens, may sell and buy all manner of merchandise, and freely cary them out of the realm, paying the eustoms and subsidies therefore due, except that the English merehants shall not of the realm with wool or woolfels; and that none carry ont of the realm gold nor silver, in plate nor in money, saving the victuallers of fish that fish for herring and other fish, and they that bring fish within the realm in small vessels, which meddle not with other merchandises; and that aceording to the arbitrement of the chaneellor."

'65 ... 39 Edward III. An ordinance was promulgated, "as to the sale by hostelers and herbergeours of bread, and horse-bread," \&e., which recites :-

"Whereas many grieranees and damages hare been done heretofore unto divers folks repairing to the city of London, for that the hostelers and herbergeours of the same city have made horse-bread to sell in their houses, at their pleasure; the which has been of no assise, and not of the ralue that it ought to be; and also some hostelers and herbergeours do go into Southwark and elsewhere, where they please, to buy horse-bread, and there buy it dry, and at the rate of 18 loares for 12 , and then sell it to their guests at one halfpenny the loaf, whereas 4 such loares are really not worth a penny; to the great scandal of the said city, and to the great damage of the conmmon people.

"Therefore the maror and aldermen, with the assent of the commons, by way of remedr, ordered that the persons aforesaid shall buy bread for such guests, and for their horses, of the common bakers of the said eity, each loaf being stamped with the mark of the baker of whom the same was bought; that so, every one may see that the bread is of the right assise, and of the real value that it ought to be."-Memorial of London, p. 323.

'82 ... By 6 Richard II, statute 1, cap. 10, it is enacted as follows:- "ItemIt is ordained and accorded, that all manner of foreigners and ahens, being of amity of the king, and of his realm, and coming within the said city of London, and other cities, boronghs, and towns within the said realm, as well within liberties as without, with fish and all mamer of other victuals, there carrsing and going again to their own countries, shall from henceforth be under the safeguard and the special protection of our said lord the king; and there it shall be lawful to them and every of them, and by force of these presents, they may from beneeforth eut their fishes and victuals aforesaid, without impeachment or denying of any man, in prices, and in part, or in all, at retaile, or in grosse as to them best sball seem, to sell and make their profit; any charters, statutes, or ordinanees, privileges, or customs made or had to the contrary notwithstanding.'

'89-90 By 13 Richard II, statute 1, cap. 8, it is ordained and assented (inter alia), and in the right of rictuallers it is accorded, that they shall have reasonable gains, aceording to the diseretion and limitation of the said justices, and no more, upon pain to be grievously punished according to the discretion of the said justices where no pain is limited in eertain before this time upon the said vietuallers. And the sheriffs, stewards of lords of franchises, mayors and bailiffs, and all others that hare assise of bread and ale to keep, and the correction of the same, shall take no amercement or fine for any default touehing the assise, for the which a man or woman by the law ought to have bodily punishment, aceording as it is another time ordained by statute . . . and all other that hare the order and survey of victuals in cities, boroughs, market towns, and elsewhere, where 


\section{TABLE IX.-Restrictions on the Price of Food-Contd.}

A.D.

1389-90 rictuals be sold in the realm, shall find the statute made, the twenty-third year of the reign of king Edward, grandfat her to the king that now is, whiel begimneth, "Beeanse a great part of the people," touching the estate of victuallers and hostellers, and other sellers of rictuals in due execution; and that no hosteller make horse bread in his hostry nor without, that bakers shall make it, and the assise thereof shall be made so that the weight be reasonable after the price of the corn in the market; and that the same hostellers shall sell hay and oats after a reasonable price, so that they take not for the bushel but one halfpenny over the common price in the inarket.

'91 .... The 15 Richard II, cap. 4-"There shall be but 8 bushels of corn striked to the quarter," recites as follows :

"Item-Whereas it is ordained by divers statutes that one measure of corn, wine and ale should be througliout the realm, and that 8 bushels striked make the quarter of eorn; nevertheless, because that no pain is thereupon ordained in the said statutes, divers people of divers eities, horoughs, towns and markets, will not take, neither buy in the said eities and sell in none other place, but 9 bushels for the quarter: and if they eamnot buy in that mamer, they arrest it as forfeit to the great damage and oppression of all our people, and manifestly against the statute aforesaid."

Whereupon it was orlained and assented that the said statute should be firmly kept and holden as well in the eity of London, and in every other place throughout the realm, and that as well by water as by land, notwithstanding any usage in times past to the contrary.

'99 .... By the 1 Henry IV, cap. 17-"Strangers may buy and sell within the realm victuals in gross or by retail," the Act of 1352 is recited, and it is then set fortls as follows: "Our lord the king, considering the same statute to be very profitable in many ways if it were put in execution, by the assent of the lords and commons aforesaid, hath ordained and established, that the said statute be firmly holden, kept and duly executed after the form and effect thereof, notwithstanding the letters patent late granted to the contrary to the fishmongers of London by the said late King Richard upon lis last royage towards Ireland."

1400 .... 2 Henry IV. It will be useful to give at certain stated periods as we proceed, short schedules of the prices of the leading articles of food, and in contrast therewith the price of labour at the same date. We commence at this clate; but it must be remembered that the prices varied greatly in different localities, in consequence of the difficulty of transport.

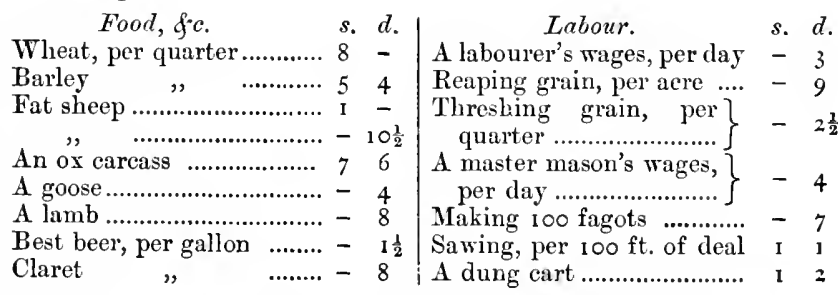

'01 .... By 4 Henry IV, cap. 8, the enactment of 13 Richard II, statute 1, eap. $8(1389-90)$, was confirmed, regarding the price to be eharged by hostelers for horse bread and oats.

'17 .... 4 Henry $V$. On the 4th February it was ordered that in time of Lent simnel loaves [i.e., loaves of the finest wheaten flour] should not be made, nor yet any other white loares, that are called painman, maincherin, \&c.; but only three kinds, namely tourte, bis [brown bread known also as trete] and white. 


\section{TABLE IX.-Restrictions on the Price of Food-Contd.}

A.D.

1424

By 3 Henry VI, cap. 2-"Sheep shall not be transported beyond the sea without the king's license." This enactment was not in view of food supplies, but related to the export of wool.

'35 ... By the 14 Henry VI, cap. 6-"That none disturb an alien that bringeth in rictuals to sell in gross or retale," the Act of 1382 was re-enacted.

29 Henry VI. The prices of food and labour as given by Doubleday-The True Law of Population (1841) - at this date were as follows :-

\section{Food, \&c.}

Wheat (plentiful), per qr.

Finest

Oats

$A$ lean ox ........................... 1

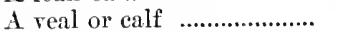

A lamb

A goose

Eggs, per 100

Red wine, per gallon

s. $d$.

Labour.

s. $d$.

5 4 4 A weeder, per day............... - 2

$8-$ A reaper, with diet ............ - 3

2 I A mower , , ........... - 4

3 - A labourer, per three days 1 1 4

2 - A sawyer................................ 6

I -

$-3$

$-5$

A tiler

A tiler and man.

A master carpenter

A man and cart.

Edward IV. Robert Brook and Thomas West, Esqres., were at this date clerks of the market, and in a MS. book of theirs there is recorded the following :-

"Memorandum.-The baker shall be allowed in every quarter of whete bakyng, as it is proryd by the kyngis bakers, as it shal appere hereafter.

"First, he shal have $4^{d}$. and all his branne to arauntage; and two lofis for fornage; and three halfpence for three servauntes; and for coles $a b$. and for reste $o b$. and for salt $o b$., and for wood $3 d$., and for bultelle [bolting the meal] $o b$., and for the sealing $o b$., and for candele, q. summ $11 d$. q. beside his branne, and the two loves.

"This is proved by the statutis: and also by an Acte in William Conquerours tyme: and the tyme of Henry the III; and in the tyme of King Edward the III : and never reversid sithen.

"Memorandum, it is ordayned bi statute, that alle manner of bakers dwelling out of cities and burgh townes, as bakers dwelling in villagis and upon Londe, their peny lof, what corne so ever it be, be it white or browne, it shall wey more than the peny lof in the town or city by $x$ s., and the halfpenny lof by $v$ s. beeause they bere not suche chargis as bakers in the eities doon, and townes. And yet they shal kepe the assize truly according unto the statute upon perne of $6 s .8 d$. for his offenee, as often as he doth the contrary, beside his mersement for brekyng of the size, if his lof wey nat as they do in cities and burgh townes. And in likewise shal the ferthing lof wey after the statute."

Then follow the "assize of brede" as follows:-

"This is the assize of al maner of brede of whete, and of what eting corne soever it be. It shal be weied after the ferthing wastell; for the ssmonell shal weje less than the wastel than $2 s$. because of the sething.

"The ferthing white lofe, called the cockct, shal wey more than the wastcll by $2 s$. because of the bakyng.

"The halfpeny wheten lofe, that is to say, the halfpeny cribel lofe, shal wey three ferthing white lofys.

"The lofe of al maner of corn, that is to say the horse lof, shal wey two halfpeny white lofis."

In this same book there was also contained the assise for other branches of trade connecter with food of the people: thus for the "myller," the "brewer," the "bocher," the "fyssher," \&c. 


\section{Table IX.-Restrictions on the Price of Food-Contd.}

A.D.

1472

$1500 \ldots$

It was also the custom at this early period to have an assise of liquors, embraced under the general teru "Victuals," concerning which we learn many details from the 20 Edward $1 V$, eap. $8-$ "An Act for annulling of Letters Patents male to Searchers and Surveyors of Vietuals," enacted this year, and which recites as follows:

"Item-Whereas the gorernors, that is to say m.lyors, bailiffs, and other like governors of every city, borough and town of substance within this realm of England, for the most purts have courts of leets and views of frankpledge, holden yearly within the same cities, boroughs, and towns, and surreying of all victuals there, and correetion and punishment of the offen lers and breakers of this assise of the same, to be presented and amerced if any default be found in the said courts, or by their surreying, which by reason ought not to be contraried, nor the victuallers there by the law ought to be surcharged or oppressed; (2) as now, and of late, divers persons daily intending their singular avail and profit, to oppress the said victuallers, and to enter and break the liberty of divers places in this realm, having franchises and sulveying of all victuallers, and correstion of the same, have purehased letters patent of our sorereign lord the king, to be surveyors and correctors of all such victullers within divers cities, boroughs, and other places of this reilm of England, as of a'c, beer, wine, and other such victuals, by which pretence and unlawful office, they do commit divers and muny extortions and oppressions, among t the king's liege people, taking of them unlawfully divers great finss and ransoms to the danger of the king's liege people, and also wrongful derogation of the libertics and frunchises of divers of the said cities, boroughs, and towns."

It was therefore enxeted that all letters pateut granted to persons for searching or surveying of victuals should be void, and the chief gorernors of cities, towns, \&e., appointed to search and survey the same. The other Acts and authorities ou this branch of the inquiry, which we do not intend to pursue in detail here, are:-4 Inst., 262; 51 Henry III, statute $6 ; 12$ Edward II. statute 1, cap. $6 ; 10$ Edward III, statute 3; 23 Edward III, cap. 6; 31 Edward III, statute 1, cap. $10 ; 6$ Richard II, cap. 10 ; 13 Richard II, statute 1, cap. 8; 1 Henry IV, eap. 17 ; 3 Henry VIII, cap. 8 ; 25 Henry VIII, cap. 2 ; 2 and 3 Elward VI, cap. 15 ; 2 ' an 123 Car. II, cap. 19 ; 31 George II, cap. 28 ; and 32 George II, cap. 1.

15 Henry VII. The prices of food and labour this year are recorded as follows:-

Food.

Wheat, per quarter ........... 74

Malt $\quad, \quad$.............. 28

A cow .................................... 8 -

A lamb

A pig

Carcass of a neat ............... -

Eggs per 100 ......................... - 9

Wine, per gallon

"

s. $d$.
A woman labourer, per day - $2^{\frac{1}{2}}$

A carter, per day ................ - 3

A reaper $\quad, \quad$................ - 3

A mower " $\quad$................... -4

A carpenter, with diet perday - 6

A plumber ", 6

A tiler or joiner ", $\quad-6$

Lesser crafts, without diet $\}$

By 22 Henry VIII, cap. 7, whoever should convey any horses, geldings, mares, or sheep, to any parts beyond the sea, without the king's license, save for the victualling of Calais, was to forfeit 40 s. for every poll. (See 1562.)

By the 23 Henry VIII, cap. 3, "An Acte for Fleshe to be sold by weight," it was enacted that any person who should sell by himself or any others, the carcasses of beefs, pork, mutton, or veal, or any part or parcel thereof after the 1st August then next ensuing, should sell the same by lawful weight, called haberdupois, and none other 


\section{Table IX.-Restrictions on the Price of Food-Contd.}

A.D.

1532 .... wise ; the said flesh to be ent out in reasonable pieces, aceording to the request of the buyer, in like fashion as afore that time was used, without fraud or covin; and that every person who by himself or any other should sell any flesh of the said earcasses, should have with him where he should make sale of the said flesh, suflicient beam scales and weiglits, sealed, called haberdupois, for true serving of the buyers. And that after the said 1st day of Angust no person should take, or cause to be taken for any pound weight of flesh of the carcasses of beef or pork, above the price of one half peny and half farthing upon pain of forfeiting $3 s \cdot 4 d$. "Proryded always, that the heedes, neckes, inwardes, purtynances, legges, nor fete shiall not be connted no parte of the carcasse afore said, but such be solde for a lower price." The lord chancellor and justice of assise, justice of peace, mayors, bailiffs, \&c., might fix lower prices, and special power's for "towns and Unirersities of Oxforde and Cambridge."

In this year there were three enactments bearing upon food supplies, viz.:--

1. The 25 Henry VIII, cap. 1, which enacted that the governors of cities and market towns upon complaint to them made of any butcher refusing to sell victual by weiglit according to the statute 24 Henry VIII, cap. 3, might conmit the offender to ward until he had paid all penalties limited by the said statute; and might sell or eause to be sold for money all such rictual for realy money to be delivered to the owner, and if any grazier, farmer, breeder, drover, refuse to sell his fat cattle to a butcher upon such reasonable price as Ine may retail it at the price assessed by the statute, the justices of the peace, mayors, and governors, should eause indifferent persons to set the prices of the same, which if the owner refuse to accept them, the same justices, \&e., slould bind him to appear the next term in the Star Chamber, to be punished as the king's counsel should think good.

2. The 2: Henry VIII, cap. 2, see Table XII.

3. The 25 IIemry VIII, cap. 13-" Concerning the number of sheep one should kcep," the preamble of which is rel'y remarkable:

"Forasmuch as diver's and sundry persons of tlie ling's subjects of this realm, to whom God of his goodness hath disposed great plenty and abundance of movable substance, now of late within few years hare daily studied, practised, and inrented ways and means how they might accumulate and gather together, into few hands, as well as great multitudes of farms as great plenty of eattle, and in special sheep, putting such lands as they ean get to pasture, and not to tillage, whereby they have not only pulled down churches and towns, and enhanced the old rates of the rents of the possessions of this realm, or else brought it to such excessive fines, that no poor man is able to meddle with it, but also have raised and enhanced the prices of all manner of "om, cattle, wood, pigs, geese, hens, chickens, eggs, and such other, almost double above the prices which have been accustomed; by reason whereof a marvellous multitude and number of the people of this ralm be not able to provide meat, drink, and clothes necessary for themselves, their wives and children, but be so discouraged with misery and poverty, that thes fall daily to theft, robbery, and other inconveniencies, or pitifully die for hunger and cold, and as it is thought by the king's most humble and loring subjects, that one of the greatest oceasions that moveth and provoketh those greedy and coretous people so to aceumulate and keep in their lands such great portions and parts of the grounds and lands of this realm from the occupying of the poor husbandmen, and so to use it in pasture and not in tillage, is only the great profit that cometh of sheep, which use be come to a few person's hands of this realm in respect of the whole number of the king's subjects 


\section{TABLe IX.-Restrictions on the Price of Food-Contd.}

A.D.

1533

'35

'36

'42-43

'41 ... By 33 Henry VIII, cap. 11, "An Act for butcher's to sell at their

that some hare 24,000 , some 20,000 , some 10,000 , some 6,000 , some 5,000, and some more, and some less, by the which a good sheep for victual, that are accustomed to be sold for $2 . s .4$. or $3 . s$ at the most, is now sold for $6 s$., or $5 s$., or $4 s$. at the least; and a stone of clothing wool, that in some shires of this realm was accustomed to be sold for 18 pence, or 20 pence, is now sold for $4 s$, or $3 s .4$. at the least ; and in some countries [counties], where it hath been sold for $2 . s .4 \%$, or $2 s$. $8 d$., or $3 s$. at the most, it is now sold for $5 . s$, or 4 . at least, and so are raised in erery part of this realm; whieh things thus used be principally to the high displeasure of Almighty God, to the decay of the hospitality of this realm, to the diminishing of the king's people, and to the let of the cloth making, whereby many poor people have been accustomed to be set on work; and in conclusion, if remedy be not found, it may turn to the utter destruction and desolation of this realm, which God defend."

Wherefore it was enacted of the king's " most gracious and godly disposition, that from and after the feast of St. Michuel the Archangel, 1535, no man should keep, occupy, or have in his possession abore 2,000 sheep at one time, upon penalty of $3 s .4 \%$ per liead for all besond; lambs under one year old not to be counted as sheep; grace of one year given as to sheep coming by executorship, or marriage; with special provisions as to sheep bequeathed by will to a child under age."

Then follow a series of clauses which reroke a good deal of the foregoing, viz., that the owner of land may on his inheritance keep as many sheep as he will; it was only the farmer who was to be so limited to 2,000, and eren he mi ht have additional slieep for the maintenance of his houselold. And inasmuch as the number of 100 sheep in every county be not alike, 6 score were to be counted I00. No man was to take abore two farms.

By the 27 Henry VIHI, cap. 9, butehers were permitted to sell flesh for two years, as they did before the making of the statutes 24. Henry VIII, eap. 3 (1532), and 25 Henry VIII, cap. 1, and notwithstanding these enactments.

By 28 Henry VIII, eap. 14-“"For prices of wines," it was enacted "That no person or persons shall sell any Gascoin, Geryen, or Freneh wines abore riijd. the gallon, that is to say, a penny the pint, twopence the quart, fourpence the bottle, and eightpence the gallon, upon pain of forfeiture for every pint sold abore that price if ird. . . And that no Malmesys, Romneys, sacks, nor other local wines shall be sold by retail above xijd. the gallon, vid. the pottle, iij $d$. the quart, i $d$. ob. the pint, upon pain, \&e." The prices of wines sold in the gross were to be assessed by the king's great officers, riz., the Lord Chancellor, Lord Treasurer, and Lord President of the Council, \&e. liberty by weight or otherwise," it is recited at the instance of the masters and fellowslip of butchers, and of other butchers within the realm, that if the Acts of 1533 and 1535 "should hereafter be put in execution, and your said orators compelled to sell flesh by weight ... . . should be to the utter undoing of your said orators for ever." Wh reupon it was enaeted tliat it might "from theneeforth be lawful unto all your said subjects to sell their rictuals from time to time by themselres, their wives and scrvants, to all manner of persons that will buy the same in like manner and form as they might have done before the making of the said estatntes or any of them."

The 34 and 35 Henry VIII, cap. 9-"An Act for the preservation of the River Severn," recites :-

"Whereas dirers persons, as well as inhabitants, farmers and dwellers near unto the stream of Severn, and unto the creeks and 


\section{TABLE IX.-Restrictions on the Price of Food-Contd.}

A.D.

$\mathbf{1 5} 12-43$ piles of the same, from Fingrod upwards toward the city and town of Gocester, conveyeth and earrieth grain and corn out of the realm of England, nnto the parts beyond the sea where grains are very dear, and now of late time hare made picards, and other great boats, with foremasts, of the burthen of $15 \mathrm{tun}$, and some to $36 \mathrm{tun}$; and by reason thereof, wheat, rese, beans, barley, malt, and other kinds of grain by stealth are conveyed into the utter parts beyond the sea, so that thereby the king's maj"st $F$ is not only deceired of his subsidy and custom for the same, but it eauseth at such times wheat, grain and other kind of corn as is aforesaid, to be at high prices; and by the same means the inhabitants within the said city or town of Bristol are often and sundry times destitute and scant, mas have grain or corn to serre the king's obedient subjects there dwelling and inhabiting; and also by redson of having the said great boats or vessels, oftentimes divers ships, as well of the parts beyond the sea, or other of English ships lying in Kingrod and IIungrod (being ports or havens of the city or town of Bristol aforesaid distant 5 miles or thereabonts from the said town of Bristol) awaiting and tarrying there the coming of the said boats with eorn and grain down Severn, who there dischasge the grain and corn abroad the said ships at Fingrod, by reason where of the said ships and other ressels there tarrying for the receipt of the said grain and corn, do then east out their ballast of stones, and other roble of ballast of their said ships and ressels into the said roads and harens, to the great destruction, and in continnance to the utter undoing of the said roads and havens, in that the month and whole channel of the sajd haven is so heaped and quarried with stones and roble of ballast of the ships and boats there arriving, that great ships which use the course of merchandise to the said town of Bristol from the parts beyond the sea, and from the tow laden with merehandise unto the nitter parts, may scantly $01^{*}$ safely come in unto the king's said port and town of Bristol and the river of the same, and so from the said port and town of Bristol unto the said Sovern, without great danger and peril; and by that means ships of great burthen are like to be destroyed and utterly to be cast away; and if redress be not the sooner had therein, it will be to the utter destruction of the hasen and port of the said town of Bristol, which said town of Bristol is chiefly maintained by course of merchandise."

It was therefore enacted (in addition to penalty for casting ballast) that none should load any corn in any vessel by the water of the Severn to transport until the same should be submitted to the king's "customers" at Bristol there to pay the export duties, and then only to cary so much grain as his license permitted, upon pain of forfeiture of ressel.

'45 .... Br a statute enacted this year, we learn that trades-unionism is not a new feature - that is new in our own time: this measure is the 2 and 3 Edward VI, cap. 15-"The Bill of conspiracies of victuallers and craftsmen," which recites :-

"Forasmuch as of late diver's seller's of rictuals, not contented with moderate and reasonable gain, but minded to hare and to take for their victuals so mueh as list them, have conspired and covenanted together to sell their victuals at mressoriable prices; $(2)$ and likewise artificers, handicraftmen and labonrers have made their confederalls and promises, and hare sworn mutual oaths, not onl that thes should not meddle one with anotlier's and perform and finish that another hath begun, but also to constitute and appoint how much work they shall do in a-day, and what hours and times they shall work, contrary to the laws and statutes of the realm, and to the great hurt and imporerishment of the king's majest $y^{\prime} s$ subjects." 


\section{TABLE IX.-Restrictions on the Price of Food-Contd.}

A.D.

1548

For reformation whereof, it was enacted-" That if any butchers, brewers, bakers, ponlterers, cooks, costermongers or fruiterers, shall at any time from and after the lst day of March next coming, conspire, covenunt, promise, or make any oaths, that they shall not sell their victuals but at certain priees... . shall forfeit for the first offence $10 l$. to the king's highmess, or twenty days imprisonment on bread and water; and for the second offence $20 l$., or the pillory; and for the third offence $40 \mathrm{l}$., and the pillory, with loss of one of his ears, and also shall at all times after that be taken as a man infamons, and his saying, depositions on oath, not to be credited at any time in matters of judgment." If any such conspiracy were entered into by the Company of Victuallers, then their

corporation to be dissolved.
3 Edward VI. Prices were as follows :-

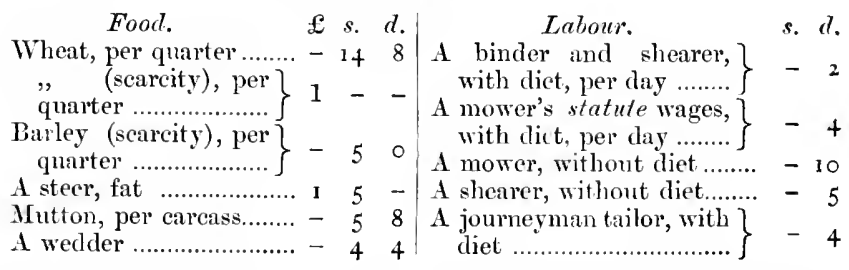

The 5 and 6 Edward VI, eap. 14, "An Act against Regrators, Forestallers, and Ingrossers," and which will be noticed in detail in Table No. XII, contained the following:-

V1II. And it is also further enacted, "Tlrat if any person or persons after the said 1st day of May next coming, having sufficient corn and grain for the prorision of his or their own house or honses, and sowing of their grounds for one year, do buy any corn in any fair or market, for the change of his or their seed, and do not bring to the same fair or market the same day so much corn, as he shall fortune to buy for his seed, and sell the same, if he can, as the price of corn their goeth in the said market or fair, that then "very such person or persons so buying corn for seed, shall forfeit and lose the double value of the corn so bought." . . .

Also this :-

XII. "Provicled always . . . . That it shall be lawful to every person or persons which shall be assigned and allowed by three justices of the peace of the comnty where he shall thereunto, by (otherwise than by forestalling) corn. grain, or cattle, to be transported or carried b." water from any port or place within this realm of Wales, unto any other port or place within the said realm or dominions, if he or they shall without fraud or covin ship or embark within three score [other editions have it forty] days next after he or they shall have bought the same, or taken covenant or promise for the buying thereof, and with such expedition and diligence as wind and weather will serve, to carry and transport the same to such port or place as his or their cockets shall declare, and there to disbark, unlade and sell the same, and do bring a true certifieate thereof from one justice of the peace of the county, or mayor or bailiff of the town corporate, where the same shall be unladen, and also of the customer of the port where snch unlading shall be, of the place or day where the saicl corn or cattle shall be disbarked, unladen and sold, to be directed unto the customer and comptroller of the port, where the same wesc embarked; anything mentioned in this Act to the contrary notwithstanding."

This Act was made perpetual by 13 Elizabeth, cap. 25 . 


\section{Table IX.-Restrictions on the Price of Food-Contd.}

A.D.

1562

In the 5 Elizabeth, cap. 5, "An Act touching Politick Constitutions for the maintenance of the Nary," but which was in reality an Aet to encourage fisheries and the mercantile marine, in view probably of drafting foung fishermen into the royal nary, there was contained the following clauses:

XIV. "And for increase of provision of fish by the more usual and common entering thereof, be it further enacted by the authority aforesaid, that from the feast of St. Michacl the Archangel, in the year of our Lord God, 1564, every Wednesday, in every week, throughout the year, which herefofore hath not been by the law and customs of this realm used and observed as a fishday, and which shall not happen to fall on Christmas week or Easter week, slall be hereafter observed and kept, as the Saturday in every week, be or ought to be. (2) And that no manner of person may eat any flesh on the same day, otherwise than ought to be upon the common Saturlar." 1593.

Under pain of the penalties therein provided, sce further hereon, There was enacted, 8 Elizabeth, cap. 3-"An Act against carrying over seas, Rams, Lambs, or Sheep, alive." This was probably in the interest of the woullen trade.

0 .... By 13 Elizabeth, eap. 13-" An Aet for the increase of Tillage, and maintenance of the Nars," it was set forth when corn might be exported and when not. It might be exported out of certain ports, in certain specified tasses of ships, when the prices be allowed "reasonable." Before any grain was transported under this Act, the justices of locality from which export was proposed to be made had to be notified to the queen or her council, and then allowed or otherwise. The custom to be paid for grain transported under this Act was specified. The queen by prochunation might prohibit export. sir Lionel bucket, masor. This year there was "imprinted on a sheet, by J. Dar, the eity printer," a tariff of the prices of poultry, with a preface as follows:

"Forasmuch as through the greedie conctousnesse of the poulters, the pricee of all poultrie wares within the citie and the liberties thereof are growen to be axcessive and unreasonable, not only to the perillons cximple of all manner of people throughont the whole realme that do sell poult rie wares, but also to the great charges of all noblemen, men of worship, and gentlemen, that do keepe any honses withm this citie, or neere the sime;

"For reformation whereof, it is ordered by my lord maior and court of aldermen, that all maner of persons, as well poulterers as others, that shall after this present 5th day of Apri], in the xiiij year of the queenes maiesties reign, sell any poultry wares within this ('itie and the liberties thereof, shall observe and keep these prices following."

Then follows detailed list of prices to be charged in "shops" and

in the "markets."
By the 27 Elizabeth, cap. 18, so much of the Statute 5 Elizabeth, cap. 5 (1562), as concerneth the eating of fish, and restraineth the eating of flesh upon Wednesdars, was repealed. "Sea-fish might be sold any day in the week saring Sunday. Victuallers were to issue no flesh in Lent, nor upon Fridays or Saturdays."

86 ... In riew of preventing a dearth in the city of London, certain of the city companies "were, by the lord maior's means, to buy each of them a quantity of com, and to lay it up in the Bridge-House."STow.

3 .... By 35 Elizabeth, cap. 7-"An Act for reviving, continuing, explaining, and perfecting of divers statutes"-this Act of 1562 was amended as follows:- 


\section{Table IX.-Restrictions on the Price of Food-Contd.}

A.D.

1593

'94

"XXII. Provided also, and be it further enacted by the authority aforesaid, that every person eating any flesh upon any fish-days, contrary to the Form of the said statute mate for the maintenance of the navy [1562], shall forfeit only $20 s$, or else suffer only one month's close imprisonment without bail or mainprize; and erery person or persons within whose house any sneh offence shall be done, and being privy or knowing thereof, and not effectually publishing or disclosing the same to some public oflicer, having authority to punish the same, for every such offence to forfeit only $3_{3} s .4 d$, anything in the said statute contained to the contrary notwithstanding."

94 .... "And such a dear year was that of 1591, Sir John Spencer, maior, who therefore (it being now winter time) called upon the companies, riz., those of them that had not laid in their proportion, to do it within so many days; corn being then brought in from foreign parts."--STow.

Reign of Elizabeth.-There was published by John Powel, sometime clerk of the market: The bolie of the assyse of breade, \&c., " corrected and enlarged." There were many other editions of this work, but we propose here to quote from the edition of this date, which we believe eontains the text as confirmed by the Lords of the Privy Council ("Christoph. Ifatton, Canc.") about this period as follows :-

"Ancient Laws, Customs and Good Ordinances, set down for Bakers, in making, sizing, and selling all sorts of Lawful Bread, which by the Laws are vendible unto the Queens Subjects in the Commonwealth retailing the same.

"First-That no manner of person or persons shall keep a common bakehouse in eities and corporatice towns, but such persons as have been apprenticed into the same mystery and brought up therein for the space of seven years, or else otherwise skilful in the good making and true sizing of all sorts of bread; and shall put his own mark or seal upon all sorts of his man's bread, which he or they shall make or sell as before is mentioned.

"Item-That no baker or any other persons do make, bake, utter and sell any kinds or sorts of bread in the commonwealth, but such which the stitutes and antient ordinances of this realm do allow him to bake and sell : that is to say, they shall bake and sell symnel bread, and wastel, white, wheaten, household, and horse bread ; and none other kinds of bread, to put to sale into her Majesty's subjects.

"Item-They must make and bake farthing white bread, halfpenny white, penny white, halfpenny wheaten, penny wheaten bread, penny household, and twopenny household loaves : and none of greater size, upon pain of forfeiture, unto poor people all such great bread, which they or any of them shall make, to scll of greater size (the time of Christmas always excepted).

"Item-They shall not utter and sell to any innholder, or victualler, either in man's bread or horse bread (which shall retail the same) but only ${ }_{1} 3 d$. worth for $12 d$., without any poundige or other advantage.

"It em-They shall sell and deliser unto innholders and rictuallers in horse bread but 3 loaves for a penny, and 13 pennyworth for $12 d$. (as aforesaid), every one of the same three horse loaves weighing the full weight of a penny white loaf, whether wheat be good, cheap, or dear.

"Item-That no baker or other person or persons shall at any time or times hereafter make, utter, or sell by retail, within or without their houses, unto any the queen's subjects, any spice cakes, buns, bisket, or other spice bread (being bread out of size, and not by law allowed), except it be at burials, or upon the Friday before Easter, or at Christmas; upon pain of forfeiture of all such spice bread to the poor. 


\section{TABLE IX.-Restrictions on the Price of Food-Contd.}

A.D.

1595

98

1601

'15.

${ }^{\prime} 07$.... James I. The lord mayor of London addressed a letter (dated

"Item-Whereas there are in cities and corporative towns, common bakers using the mystery of baking there, and within the same towns, common bakers which come into the nurliet with their bread to be sold, they shall not only bring with them such kinds or sorts of sized bread as the law and ordinances do allow to be made and sold, as aforesaid, but also shall keep and obserre this order in the weight of their bread, as hereafter followeth. Beeause the said foreigners do not bear and pay within the same cities and towns, such scot and lot as the bakers of the same towns do.

"First-The foreigner's halfpenny white loares shall weigh half an ounce more in every loaf than the bakers of the same towns halfpenny white loaves do.

"Item-Their penny white loares shall weigh one ounce more to every loaf than the bakers of the same towns penmy white loaf do.

"Item-Their halfpenny wheaten loaves shall weigh one ounce in erery loaf more than, \&c.

"Item-Their penny wheaten loaves shall weigh 2 ounces more than, \&e.

"Item-Their penny household loares, \&c.

"Item-Their twopenny household loaves shall weigh 4 ounces more than, \&c.

"Provided always, that the clerk of the market of Her Majesty's household, his deputy or deputies, maiors, bailift's and other offeers of citics, corporative towns and liberties, shall look into, have diligent care and respect unto the due performance and excrution of these articles, and they shall and may from tine to time freely give and distribute all such unlawful bread as shall be hereafter macle, and put to sale, being contrary to these articles before mentioned, unto poor prisoners, or any other poor people. Willing and requiring all justices of peace, constables, bailiff', and other otlicers to be aiding, assisting, and helping all the aforesaid officers in the due execution thereof, as they will answer to the contrary at their perils."

There was published John Stow's Surveys of the Cities of London and Westminster, and in Book V. Will be found chapter xxr, with the following heading: "Antient Assize and weight of bread: an Ordinance for it, according to the price of wheat. Old Orders for Bakers. Ifow the Assize of Bread was made each ycar. The Bakers Halimotes [? Hallmotes]. Assay of Bread according to the Regale of England. Laws and Charges for Bakers. Miller, Baker, Brewer, Butcher, Fisher, Cook, Innholder, Tavener, Tallow-chandler, Spicer, Wearer, Tanner, Cordwayner, Carrier, White Tawyer, Mercer, \&c., Forestallers. All their Assizes. Standard for Wirghts adjusted. Measure for Seaconl and other things measurable upon the Thames." Wherein will be found much that is of interest on the questions treated of in this article. We have lere quoted from the edition of 1713 , which had passed through many hands after its original author.

By 48 Elizabeth, cap. 7, justices of the peace were direeted to compel those who cast down growing corn to make satisfaction. 19th March) to the lords of the council, reporting that on account of the exceeding high price of com, and the scarcity, the bakers were scarcely able to keep 11 ounces weight in the wheaten penny loaf, and requesting that license might be granted to those who will bring corn to the port of London, and that if such quantities as should be brought in were not vencled or uttered there, it might be lawful for them to ship the same out again without paying customs.

About this date the said J. Powel, elerk of the market, reported to James I and his council that "divers bakers and other persons taking upon them the mystery of baking and uttering of bread unto the king's majesty's subjects in the commonwealth, for their own prirate 


\section{Table IX.-Restrictions on the Price of Food--Contd.}

A.D.

1615

'16. Chine of beef gown, is. tid. stalling.

lucre and commodity, did not only make and sell to the subjects, breads of odd sizes, made by their own inventions, but also divers kinds and sorts of bread; which were both repugnant to the laws and good ordinances of the realm, and likewise hurtful to the commonwealth." Further orclers and regulations were thereupon issued, and the master and wardens of the company of bakers were especially ordered "to look into and liare diligent cure and respect unto the due performance of these articles."

The price of indoor labour at this date is indieated by the following tailor's bill : For making a suit of eluthes, 4 s.; for making a cloak, I $s .6 d$; f for making a morning gown, $\mathrm{s} s .8 d$.; for making a black

23 .... See Table $\mathrm{X}$, this date, as to relaxation of prohibitions against fore-

7 .... By 3 Car. I, cap. 4. (5) - " An Aet for continuance and repeal of divers statutes" - the 3 and 4 Edward VI, cap. 19 and 21 ; the 5 Elizabeth, cap. 5 ; the 21 James I, cap. 22 ; and other Acts mentioned in this

$32 \ldots$ The cxpense of living in the metropolis is stid to have increased considerably about this time. The poor's rates in the country also went up. These incidents were attributed to the nobility and gentry living constantly with their families in Lonton. In the following year several regulations were made by the Star Chamber for bringing down the priees of provisions and of horse meat in London and Westminster. The wretchelness of the poor was in some degree ascribed to the fraudulent practices of bakers. Ordinaries were limited to $2 s$. a-head for dimner (wine included), and to $8 d$. a-head for a serrant attending his mister. Respecting innkeepers, it is said that, "considering the present price of hay and vals, $6 d$. a night for hay and stable-room, and $6 d$. a peek for oats were suffieient, without anything being allowed for litter."-Rru FED., xix, 476.

Commonwealth. The prices of food and labour had ranged during the half-century now ending as follows :-

\begin{tabular}{|c|c|c|c|c|c|}
\hline Food. & $£$ & & ". & Labour. & \\
\hline Wheat, per quarter..... & I & 14 & - & Labourers, ordinary, per day & \\
\hline$\ldots .$. & 2 & - & - & 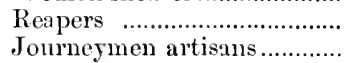 & \\
\hline A fat ox .......... & 9 & 10 & - & 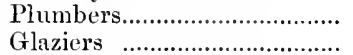 & \\
\hline veal & - & 17 & - & 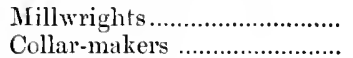 & \\
\hline Mut ton, per stone of $8 \mathrm{lbs}$. & - & 2 & 3 & 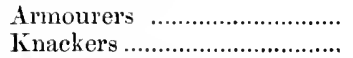 & \\
\hline A lamb .............. & - & 6 & 8 & 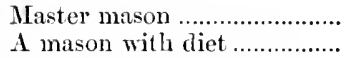 & \\
\hline Tongues, cure & & I 2 & - & 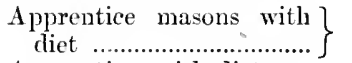 & \\
\hline ee & & & & Apprentices with diet . & - \\
\hline
\end{tabular}

70 .... By 22 Charles II, eap. 8-." An Aet for aseertaining the measures of corne and salt "-it is reeited that there was a great variet $y$ of measures existing in the "several countyes, eittyes, burrougles, ports, and other places of this realme for the measureing, buying, and selling of all sorts of graine, salt and other commodityes usuilly bought and sould by the bushell, to the great defrauding and oppressing of the people, contrary to the great charter," \&e. It is therefore enaeted that the "Winchester measure" only be used, under a penalty of $40 s$. 


\section{TaBle IX.-Restrictions on the Price of Food-Contd.}

A.D.

1670

And to the end that there might be "a just and certaine measure," so as to determine all eontrorersies, there was to be aflixed before the $29 t h$ of September this year within the cities, borough and market towns, "one measure of brasse prorided and ehained in the market place upon paine of forfeit and loose for every person soe neglecting respectively the smmme of 5l." Constables to search for other measures and to break them. (See 1391).

By 22 and 23 Car. II, cap. 12 (2), corn, \&c., was not to be sold without measuring.

1701 ... B 1 Inne, eap. 26-"An Act for the relief of the masters of hoys and other ressels carroing eorn and other inland provisions within the port of Jonton"-it is recited that certain officers of Her Majesty's customs had for their own profit and here required and exicted great fees for transires and coequets, "to the great discouragement of the county famers, and oppression of the said hormen," all of which was ovdered to be discontimed. The rights of the ports of Sumbich and Ipswich [described in the Act as being locaterl in the connties of Kent and Essex!] reserved.

By another Act of the same year, riz., 8 Amne, eap. 19-" An Aet to regulite the Price and Assize of Bread "- it is recited :- -

"Whereas by the statute made in the one-and-fiftieth rear of the reign of hing IIfmry the Third [intituled Assisa Punis et Cervisice], prorision was make, amongst other things, for sottling the assise of bread; but the saick statute is expressed in terma so obscure and impracticable in these times that many doubts and diffeulties have arisen, and daily to arise, in the construction thereof, whereby little or no obsersance hath in many places been made, either of the due assise, or reasonalble price of bread; and eoretous and evil-disposed prems, taking adrantage of the sime, hase, for them own gain and hure, deceived and oppressed Her Mirjestr's subjects, anl more especially the poorer sort of people; for remedy whereof for the future, and that a plain and constant rule and method may henceforward be duly obsersed and kept, in the making and assising of the several sorts of breact made for sale be it enacted, \&e."

So much of the said statute as relates to the assice of bread is then repealed, and it was enacted that after 1st May, 1710, the lord mayor and aldermen of London, and the mayor and baitiffs, aldermen or other chief masistrates of other rities and towns, and the justices of the peace in ylaces where there was no mayor, \&c., should set the assise and weight of all sorts of breat, hasing respect to the price of grain, \&t., no person to sell brad other thim such as shonld be licensed by the lord mayor, and other anthorities nimed. Bread to be made according to a scale in the Act, regulating weight aceording to quality of the flour and the price of eorn. All bread to be marked. Bakchouses might be searthed, \&c.

This Act was amended and continued by varions Acts at different periods, as will be shown in what follows.

'14.... There was enacterl 1 George I (statute 2), eap. 23 - " In Art for continuing sereral laws therein mentioned, relating to coals, hemp and thix, Trish and Scotch linen, and the assise of Brend; and for giving power to adjoum the quarter sessions for the count $y$ of Anglesea, for the purposes therein mentioned." After 1st September, 1715, bakers making bread deficient in weight should for erery ounee forfeit $5 s$, for lesser deficiencies $2 s .6 d$.

'18 ... By 5 George I, eap. 25-" An Act for continning the Act made in the Sth year of the late Queen Amne, to regulate the price and assise of Bread; and for continuing the Act mide in the twelfth year of His late Majesty's reign, for the better encouragement of the making of sail cloth in Great Britain" - the Act of Ame, as amented, con. tinued for five years. 


\section{Table IX.-Restrictions on the Price of Food-Contd.}

A.D.

1723 .... By 10 Gcorge I, cap. 17-"An Act for continuing Acts for preventing theft and rapine upon the northern borders of Enrlind; and for better regulation of pilots; and for regulating the price and assize of Bread; and for better encouraging of the making of sail-cloth in Great Britain "- the det of Ame, as amended, was extended for seven years.

'30 .... By 3 Gcorge II, cap. 19-"An Act for continuing and amending an Iet for regulating the price and assize of Bread"-ic., which recites the Act of 1709 , "And whereas the said Act haring been by subsequent Acts further continucd, was found rery useful and beneficial, but the same is now near expiring." It was now contimued to 25 th March, 1738.

"II. And whereas the court of lord mayor and aldermen of the city of London and some other" magistrates, have thought fit to set down and ascertain the price for which half-peck and quartern loares ought to be sold; wlich prices the bakers have sometimes complied with, but at other times have refused to do so, to the deceit and oppression of His Majesty's subjects, especially of the poorer sort of people. And whereas some doubts hare arisen :ouching the penalty ther have incured for such their refusal, for remed whereof be it enacted, that from and after the 25th day of Jume, 1730, if any baker or other person or persons baking or making bread for sale, or exposing bread to sale, shall sell any peck, half-peck, or quartern loaf or loaves at any greater or higher price than shall be set and ascertained by the said court of lord mayor and aldermen, or by the lord mayor of the said city for the time being, by order of the said court or by the mayor, bailiffs, aldermen, or chief magistrate for the time leing of any other city, town corporate or borough, or by any two or more justices of the peace in such towns and places where there shall be no such mayor, bailiffs, aldermen, or chiff magistrate, he, she, or they so doing, being thereof lawfully convicted, shall for. every such offence forfeit the sum of $10 s$.; the said forfeiture or forfcitures to be given to the informer or informers, \&c.

"III. Provided always, that before any reduction is made in the assise of bread by the court of lord mayor and aldermen, a copy of the prices delivered in by the meal weighers for the said city for the time being, shall be left at the common hall of the Bakers Company by the space of twelve hours before any such reduction, to the intent thit the said company shall have an opportunity to be heard thereupon before the said court."

'39 ... Bs 12 George II, cap. 13-"An Act for continuing the Act made in the eighth year" of the reign of Her Majesty Qneen Anne, to regulate the price and assise of Bread, \&e."-which recites, "Whereas the laws hereinafter mentioned (which have by experience been found useful and beneficial) are near expiring," and the Act of 1709, as amended by that of 1714 , is continned, with amendments as follows :-

"II. And whereas several doubts and difficulties have arisen touching the powers of the magistrates of burghs and corporate towns, and of the powers of the justices of the peace in such other towns and divisions where no magistrates are, in that part of Great Britain called Scotland, tonching the regnlating of the price and assise of bread; be it therefore declared and enaeted by the authority aforesaid that the said det of [1719 as amended] . . . . does extend, and shall be with all the powcrs, provisions, clauses and declarations, extended to that part of Great Britain called Scotland."

'42 .... In the Dublin News Letter of Sth May this year', was the following regarding the prices of food in Ireland: "We hear from Derry that provisions are as eheap there as they were ever known; there being 20 lbs. of meal for $9 d$., $20 \mathrm{oz}$. of butter for $2 \frac{1}{2} d$., 18 eggs for $1 d$., and potatoes for $3 d$. a-bushel." 


\section{Table IX.-Restrictions on the Price of Food-Contd.}

A.D.

1749

By 22 George II, eap. 49-"An Act to eontinue several laws . . . . . and for regulating the price and assise of Bread," and which eontinues the Act of 1709 (as annended by the Aets already reviewed) to 14th June, 1757 , and proceeds :

"XXI. And whereas it is often very diffieult for the magistrate or justice, or justices of the peace before whom bread is complaincd of, to know under what denominations the bread ought to be weighed, pursuant to the direetions of the said Aets" . . . . "Be it enacted ... That every common baker, and every person who shall make bread or bake for sale, or any wars expose to sale, any sort of bread whaterer, shall from and after the 1st day of August which shall be in the year of our Lord 1749, fuirly imprint or maik, or cause to be imprivited or maiked on ever"y loaf so by him made or exposed for sale, the letters hereinafter-mentioned (that is to say), upon every loaf exposed to sale as wheaten bread, a large Roman $\mathrm{W} \mathrm{H}$, and upon every loaf exposed to sale of household bread, a large Roman $\mathbf{H}$, and every person selling or exposing to sale not marked as aforesaid, shall forfeit and pay the smo of 20 . to the informer. . . . . "

" P'rorided always that nothing in this Act was to extend, or be construed to extend, to any sort of bread but that mentioned in the said tets of 1709 and the amending Acts."

There was enacted 31 George I1, eap. 25-"An Act for establishing a free market for the sale of Corn and Grain within the City and Liberty of Westminster" - which recites, "Whereas the establishment of a free market for the sale of corn and grain within the eity or liberty of W'estminster, would be rery advantigeons to the inlabitants of the said city and liberty, as well as adjacent parts; but sueh market eamot be established without the aid of parliament," there was to be a toll paid to the trustees of the said market of $i d$. for erery sack of corn, grain, malt, meal, or flomr, and $\frac{1}{2} d$. for every bushel of seed.

[Note. At this date all the other markets were under greater or less restrictions.]

The same rear there was enacted 31 George II, eap. 29-"An Aet for the due making of Bread; and to regulate the price and assise thereof; and to punish persons who shall adnlterate Meal, Flonr, or Bread"-which recites (inter alia): "And whereas it is expedient to reduce into one Act the several laws now in force relating to the due making, and to the price and assise of bread, and to make some alterations in, and amendments to the same." From 29th September, 1758 , the Aets of Henry III and of Anne were repealed; and there was enacted a "General Orimance for setting an assise and priee of bread." The assise was to be regulated by the price grain, meal, and flour bore in the market (with detailed maehinery for ascertaining the same), and " the profit to be allowed to the baker." All this was set out in tables appended to the Act, supplemented by regulations, worked out with the most elaborate care, and there was included the following :

"IL herein contained, shall extend or be eonstrued to extend to prejudice the ancient right or enstom of the two unirersities of Oxford or Cambridge, or either of them, or of their or either of their elerks of the Market, or to praetice within the several jurisdietions of the said Universities, or cither of them used, to set, aseertain and appoint the assise and weight of all sorts of bread to be sold or exposed to sale within their several jurisdictions, but that they, and every of them, shall weigh severally and respectively, from time to time, as there shall be oceasion, set, aseertain and appoint within their several and respective jurisdictions the assise and weight of all sorts of bread to be sold or exposed to sale by any baker or other person whatsoever, within the limits of their several jurisdictions, and shall 


\section{TABLE IX.-Restrictions on the Price of Food-Contd.}

A.D.

1757

and may require and punish the breach thereof, as fully and freely in all respects as they used to do, and as if this Act had never been made; anything herein contained to the contrary thereof notwithstanding." See Table XII (15j̃5).

Under section 25 of this Act, magistrates might enter premises of susperted miller or baker and search for arlulterated meal.

58 .... By 32 George II, cap. 18-"An Act to [inter alia] . . . . appropriate certain penalties mentioned in an Act made in the last session of parliament for the due making of Bread; and to regulate the price and assise thereof; and to punish persons who shall alulterate Meal, Flour, or Bread"-one-half of the penalty went to the prosecutor; the other half as the magistrate should direct.

There was enacted 32 George II, cap. 61 - "An Act for discharging the inluabitants of the town of Manchester, in the county palatine of Lancaster, from the custom of grinding their com and grain, except malt, at certain water corn mills in the said tom, called the School Mills; and for making proper recompense to the feotlees of such mills." This although contained in the schedule of the statute at large as a public Act, is regarded as a local and private Act, and its

title alone is printed.
Br 3 George III, cap. 6-.." An Act for explaining and amending an Act made in the thirty-first year of the reign of his late Majesty, George II, intituled an Act, \&c.; so far as the same relates to that part of Great Britain called Scotland; and for rendering the said Act more effectual in that part of the United Kingdom." The regulations of procedure were rery minute, for instance, the magistrates and justices were to inquire into and take proof of the prices which the sereral sorts of bread, corn, meal, and flour, sold for in the public markets; and where there were no public markets, then to tako proof of the present or last selling price thereof, so as to ascertain the price the same costs the baker; they giving previous notice to the deacon of the baker's compans, or to two reputable bakers, to attend the taking of such proof. 'This evidence was to be engrossed in a book, and signed by the witnesses and the magistrates taking the same; and the respective prices to be declured, and entered in the said book, which was to be free to public inspection. The assise and weight of bread for sale to be ascertained according thereto; and was not liable to be raried, but to continue in force till a new one was made.

Upon application and proof offered of a sufficient variation of the price of any species of the said grain, by any two inhabitants or bakers, since the last assise, fresh eridence was to be taken of the current price, and a new assise to be made conformable thereto.

In the same session was also enacted 3 George III, cap. 11-"An Act for explaining and amending an Act made in the thirty-first year of the reign of his late Majesty George II, intituled an Act for the due making of Bread, and to regulate the price and assise thereof ; and to punish persons who shall adulterate Meal, Flour, or Bread," wherein it is recited that the Act of 1757 (cap. 29) " is deficient in several of the provisions thereby made, when an assise of bread is not set pursuant to directions of the said Act." For remedy whereof, it was enacterl that no "assised" and "prised" bread were to be made at the same time in the same place. Justices at any general quarter sessions, or petty sessions, might appoint which of the sorts of assise, or prised loaves, and what other sorts of bread, and of what grain, should be made for sale; they causing an entry to be made of such order, which was to be free forinspection, and a copy thereof to be set up in some market or public place, or published in the county newspapers. "No justice within their respectire jurisdiction shall at any time allow the naking for sale or selling any sorts of assise bread made of the flour 


\section{Table IX.-Restrictions on the Price of Food-Contd.}

A.D.

1762

or the meal of wheat, other than and besides wheaten and household bread, and loaves of white bread of the price of $2 d$. or under." A like proportion as to weight was to be kept between the white and wheaten bread and the wheaten and household assise bread, all of which was set ont in detail.

A proportion in the price was to be kept in the peek loaf and halfpeek ; and its other sort divisions, both in the wheaten and in household bread; and the household was to be one-fourth eheaper than the wheaten. The weights which the peck loaf, and its sub-dicisions, were to be of in every sort of bread, are set out in cletail. The weight if elallenged to be taken before a justice within twenty-four lours after being baked, sold, or exposed for sale, and fines imposed, unless deficieney should be satisfactorily accounted for. Bread of an inferior quality to wheaten not to be sold at a ligher price than household. A large Roman $W$ to be imprinted on all wheaten bread made for sale, and a large Roman $H$ on all houschold bread. Bread marle of any other grim than wheat to be impressed with such letters as the juitices should orler, thes calusing an entry of the orter to be made for inspection. Where no sueh order wade by justices, the baker to mark every loaf with two distinct capital letters. Justices might enter the houses of bakers, and scarch for, examine and weigh all bread made for or exposed to sale, and bread found defeetive in weight, or not duly marked, or wanting in due baking or goodness, or being flaudulently mixcl, אc., might be seized and given to the poor. The rights of the two unirersitien were reserved. This measure consisted of twenty-five scctions, many of them very complex.

'66 ... By 6 Gcorge III, cap. 17-"An Act for explaining and amending so much of an Act made in the first year of the reign of James II [1685], intituled, \&e, as relates to the eity of London"-it is enacted that the same duties whieh are to be performed by justices in quarter sessions under the Aet of 1685 (and that of 1670) are to be performed in London by the lord mayor and aldermen; but in January and July, as woll as in April and October.

"The magistrates of Edinluigh and Glasgow hare put a stop to the exportatiun of grain, tallow, and butter, in their respective jurisdictions; a power which the magistrates of London do not seem to possess."-Gentlemen's Magazine, February.

'67 ... "At a court of aldermen held on purpose to inquire into the state of the meal trade in London, it appeared that a very small quantity of flour was then in town ; that the principal part of the flour destined for the supply of the London market was on board barges and other ressels, whiel could not come down on aecount of the eommunieation being stopyt by the frost; and that unless some provision was made for defraying the extraordinary expense of unshipping, and bringing it by land earriage, there wonld be a want of bread. It also appeared that one great reason of the present short stock of flour at the London market was, that the riots and tumults in those counties from which London was principally supplied, had prevented the nsual quantity of meal being made for the London market. Bread ruse on this inquiry to $2 s$. $10 d$. a-peck."-Gentlemen's Magazine, February, 1767.

73 .... By 13 George III, cap. 62-"An Act for better regulating the assise and making of Bread "-it is recited:

"Whereas according to the ancient order and custom of the realm, there hath been, from time immemorial, a standard wheaten bread, made of flour, being the whole product of the wheat whereof it was made; and whereas by an Act passed in the 31st rear of the reign of George 1I, intituled, \&e. [alreads mentioned], and by an Act passed in the 3rd year of the reign of his present majesty, for explaining and amending the said recited Act, two sorts of bread made of 


\section{TABLE IX.-Restrictions on the Price of Food-Contd.}

A.D. 1773

wheat only are allowed to be made for sale (that is to saly), wheaten and household; whereby the flour, being the whole produce of the wheat, is so divided in the making of bread for sale, as that this standard wheaten bread made according to the ancient order and custom of the realm could be no longer nade for sale; and whereas household bread, such as is intended by the said Act of George II, to be made for sale, is not generally made for sale, whereby and for want of the said standard wheaten bread continued, many inconreniences have arisen, and many of the inferior classes of the people, more especialls, have been under the neeessity of buying bread at a higher price than they could afford, to their great hurt and detriment; for remedy whereof, \&e."

And it was enacted that after 2.3th September, 1773, standard wheaten bread be allowed to be made, baked, and sold. The weight, price, and proportion of the different loares were again placed under regulation; and standard wheaten bread was not to be sold as "prised loares" at one and the same time with "assised loares" of the same wheaten bread.

The weekly bill of mortality published Tuesday, 16th August, this sear, contained the following :-

\section{BULL, MAYOR.}

LONDON, $\{$ The assize of Bread, set forth this 16th day of to wit. $\{$ August, 1777 , by the order of the court of mayor to wit. $\{$ and aldermen of the said eity, to commence and take place on Thursday next, and to be observed and kept until the further order of the lord mayor of the said eity, or the said court of mayor and aldermen, by all persons who shall make, or bake for sale, any bread within the jurisdiction of the said court of mayor and aldermen, that is to say :

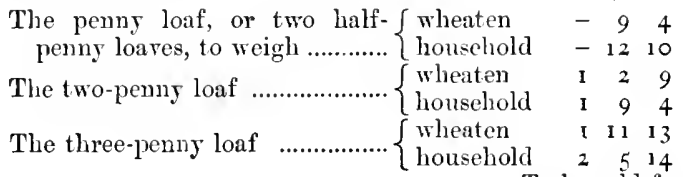
lb. oz. dle.

lb. oz. dr.

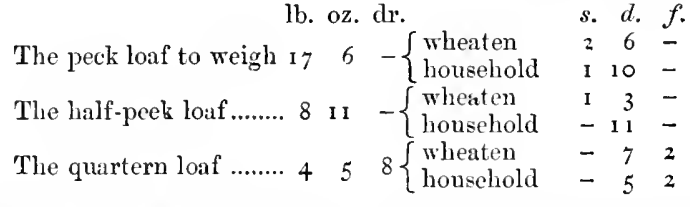

Note-All loares, if complained of, must be weighed before a magistrate within $t$ went $y$-four hours after baking or exposing thereof to sale, and must be according to the respective weights in the above table.

Six drams make an oumee, and sixteen ounces a pound.

Item.-It is hereby ordered and appointed, that no person, within the jurisdiction aforesaid, shall, after Wednesday next, until the further order of the lord mayor, or of the said court of mayor and aldermen, make, or bake for sale, or sell or expose to or for sale, within the jurisdietion aforesaid, any half-quartern loaves.

And the better to distinguish and ascertain the two sorts of bread hereby orlered to be made, one from the other, there is to be imprinted and marked on every loaf of bread which sliall be made, sold, carried ont, or exposed to or for sale within the jurisdiction aforesaid, as wheaten bread, a large Roman $W$, and on erery loaf of 


\section{Table IX.-Restrictions on the Price of Food-Contd.}

A.D.

1773

bread, which shall be made, sold, carried out, or exposed to or for sale within the jurisdiction aforesaid, as household bread, a large Roman H. And the penalty of every omission is $20 s$.

The price of salt, set by order of the court of lord major and aldermen, dated the 21 st of October, 1735 , is $5 s$. the bushel ; $56 \mathrm{lbs}$. to the bushel, and so in prop rrtion for any lesser quantity; and whosoever shall sell at a higher price, or shall refuse to sell at the price afuresail, forfeits $s l$.

There was enacted the 36 George III, cap. 22-" An Act to permit bakers to make and sell certain sorts of Bread," which recited"Whereas it is expedient, in order to diminish the consumption of wheit, that bakers should be permitted to make and sell in all places various kinds of mixed bread, and such kinds of wheaten bread as they eamnot now sell in places where an assise is set: And whereas it is not experlient to apply to such sorts of bread the restrictions contained in this table of the assise and price of bread now by law establisherl." And it was then enacted that loaves might be made of wheat, deducting only $5 \mathrm{lbs}$. of bran per bushel, or mixed with any grain or potatoes, and sold at such prices as should be deemed reasonable. All such mixed bread to be marked to distinguish the sorts. If such bread were found deficient in weinht aceording to the assise prescribed by 31 George I I, cap. 29 , or was not marked, or had any mixture not denoted by the mark, \&e, the offender was to be liable to the penaities of that Act. This Act was not to infringe upon the rights and privileges of the city of London, or of the Worshipful Company of Baker's of the said city.

By 37 George 111 , cap. 98-"An Act to anend and render more effectulal an Act made in the thirty-first year of the reign of his late Majesty King George II, intifuled 'An 'Aet, \&c.' [already reeited in full], so fin as the same relates to the assise and making of Breal to be sold in the eity of London and the liberties thereof, and within the weekly bills of mortality and within 10 miles of the Ruyal Exchange--" corn meters were to enter in a book at the corn meter's office every Monday accounts of the wheat worked and delivered by them respectively in the preceding week. And many other minute regulations were laid down.

There was enacted, 38 George III, cap. 62-"An Act to empower magristrates and justices of the peace, in setting the assise of Bread, to make allowance on account of the additional duty on Salt." In setting the assise of bread, $5 s$. per quarter was to be added to the arerage price of wheat, on account of the additional duty on salt.

Same session there was enacted 38 George III. cap. Ir (local and private), "An Act for amending an Aet made in the last session of parliament, intituled 'An Act to amend, \&c.' [1797], which recited that it had been found necessary that certain additional regulations should be made, and further powers given for rendering more effective the Aet of 1797." It is also further recited :-

"And whereas in setting the assise of bread in conformity to the directions of the said Act of the thirty-serenth year of the reign of his present Majesty, it frequently happens that the arerage price of wheat or of flour returned does not agree with any of the prices specified in the table atfixed to the said Act, from which the assise of bread is direeted to be set, and the assise is then set from the price in the said table nearest the said arerage price returned, by reason whereof the assise and price of bread is at times higher than by the said tet is intended, to the injury of the public, and at other times not so ligh, to the injury of the baker."

For remedy whereof an account of the differences was to be kept in a book at the cocket office till they amounted to half an assise, 


\section{TABLE IX.-Restrictions on the Price of Food-Contd.}

A.D. 1798

1801 .... There were sereral enactments in the session of parliament helu this year, which fall to be reviewed here:-

1. In the first session, the $4 \mathrm{l}$ George III, eap. 16 (Great Britain) "An Aet to prevent until the 16tl day of November, 1801, and from thence to the end of six weeks from the commencement of the then next session of parliament, the manufacturing of any fine flour from wheat or grain, and the making of any bread solely from the fine flour of Wheat; and to repeal an Aet passed in the thirty-sixth year of the reign of His present Majesty [36 George III, eap. 22], for permitting bakers to make and sell certain sorts of bread, and to make more effectual provision for the same," which recites "whereas there is just ground to expect that the supply of good and wholesome bread will be materially angmented, and the price thereof redueed by preventing the consumption of bread made from fine flour." Whereupon it was enacted that from 17th January, 1801, in London or within 40 miles thereof, and from 24 th $\mathrm{Jul}_{\mathrm{u}}$ in every other part of Great Britain, no meal shall be dressed finer than throngh certain speeified wire machines or eloths, nnder penalties ranging from $5 l$. down to 10s. per bushel. This measure consisted of twenty-two sections, many of them rery complex.

2. In the second session, the 41 George III, cap. 1 (United King(tom) - "An Aet to suspend until the 15th day of Mareh, 1801, so much of an Act made in the last session of parhiament, intitnled . . [41 George III, eap. 16 (Great Britain) ], as relates to other Grain and Wheat; and for indemnifying persons who have dressed, sold, and used any Meal or Flour of such other Grain finer than is preseribed by the said Act."

3. The 41 George III, eap. 2 (United Kingdom) - "An Act to repeal an Aet made in the last session of parliament . . . [41 George III, eap. 16 (Great Britain)], and to indemnify millers and others persons who have dressed, or used any Meal or Flour of a finer deseription than allowed by the said Act." The indemnity consisted of being held free from all actions for infringement of former measure now repealed, we presume, as unworkable.

4. Br the 41 George III, cap. 12 (United Kingdom), intituled, \&c., the 36 George III, eap. 22, was amended, the recital being:-

"Whereas br an Aet made in the thirty-six year of the reign of His present Majests, intituled 'An Act,' \&e., all persons are allowed to make and sell in any place, under certain provisions and restrictions, the sereral sorts of loares in the said Aet partieularly described, made of the whole produce of the wheat, deducting only $5 \mathrm{lbs}$. weight of bran per bushel; or macle of any sort of wheaten flour, mixed with meal or flour of barley, rye, oats, buckwheat, Indian corn, pease, beans, rice, or any other kind of grain whatsoever, or with potatoes, in such proportions and at sueh prices, for the said loaves respectively, as the maker and sellers thereof shall deem proper and reasonable, whether any assise of bread shall be set in sucli place or not: and whereas it is desirable to encourage the making of good and wholesome bread, containing a larger proportion of the produce of wheat than is contained in the bread upon which the assise is usually set, and for that purpose to extend the prorisions of the said Act, so far as the same relate to the making and selling of whenten bread, \&e."

For ali of which directions in minute detail were giren.

The 42 George III, cap. 14-" An Act to repeal an Act. . . 


\section{Table IX-Restrictions on the Price of Food-Contd.}

A.D. 1802

'2t ... Br 5 Creorge IV, eap. 50-" An Aet for amending an Aet passed in the 53rd rear of the reign of His late Majesty King George III, intituled an Aet [already eited in full] - the allowance made to bakers under the Act of 1413 was to be reduced in manner herein mentioned." Then the following :

"II. And be it further enacted, that neither this Act nor anything herein contained sliall extend or be consirued to extend to prejudiee the ancient right or custom of the two universities of Oxford or 


\section{TABLE IX.-Restrictions on the Price of Food-Contd.}

A.D.

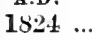

'36....

Cambridge, or either of them, or of their or cither of their clerks of the market, or the practice within the sereral jurisdietions of the said universities, or either of them, used to set, ascertain and appoint the size and weight of all sorts of bread to be sold or exposed to sale within their several jurisdictions; but that they and every one of them shall and may sererally and respectively from time to time, as there shall be oceasion, set, ascertain and appoint, within their several and respective jurisdictions, the assise and weight of all sorts of bread to be sold or exposed to sale by any baker or other person whateoever within the limits of their several jurisdictions : and shall and may inquire into and punish any brach thereof fully and freely in all respects as they used to do, and as if this Aet had never been marle; anything herein contained to the eontrary thereof notwithstanding."

There was enaeted 6 and 7 William IV, cap. 37-" An Act to repeal the several Acts now in foree relating to Bread to be sold out of the eity of London and the liberties thereof, and beyond the weekly bills of mortality and 10 miles of the Royal Exchange; and to provide other regulations for the making and sale of Bread, and for preventing the adulteration of Meal, Flour, and Bread bejond the limits aforesaid." This is therefore the first modern measure of general application to the country; and it recites (inter alia):

"And whereas it is deemed expedient that the several Aets of parliament now in foree relating to the making and selling of bread, or to the assise and price thereof, or to the adulteration of meal, flour, or bread, beyond the limits aforesaid, should be altogether repealed, and that in lien thereof the regnlations, provisions, and penalties hereinafter eontained, and which are similar to those eontained in the said reeited Aet [3 George IV, eap. cri, 1822], shonld be substituted. Bnt inasmueh as the purposes aforesaid cannot be effected without the aid and anthorit $y$ of parliament. Be it, \&e."

It is then enaeted that it should and might be lawful for the several makers and sellers of bread outside the limits of the eity [as those inside the city had been authorised by the reeited Act] to make and sell bread made of flour or meal of wheat, barley, rye, oats, buckwheat, Indian corn, peas, beans, riee or potatoes, or any of them, and with any eommon salt, pure water, eggs, milk, barm, leaven, potatoes, or other yeast, and mixed in such proportions as they should think fit, and with no other ingredient or matter whatsoever, subject to the regulations in this Act contained. And the bread might be made of any weight or size; but was to be sold by weight only, except as to certain fancy bread and rolls. There were heavy penalties for adulteration; and bakehouses might be searehed.

By 1 and 2 Vietoria, eap. 28- "An Act to repeal the several Aets now in foree relating to Bread to be sold in Ireland, and to provide other regulations for the making and sale of Bread, and for preventing the adulteration of Meal, Flour, and Brend in that part of the United Kingdom ealled Ireland"-it is reeited :

"And whereas it is deemed expedient that the several Aets now in force relating to the making and selling of bread, or to the assise and priee thereof, or to the adulteration of meal, flour, or bread, in that part of the United Kingdom ealled Ireland, should be altogether repealed, and that in lieu thereof the regulations, prorisions, and penalties, hercinafter contained, and which are similar to those contained in the said reeited Act [of 1836] should be substituted."

The clauses following conform to those of 1836 ; so that the whole of the United Kingdom was now brought under a uniform law in these matters, for the first time.

Note-The only Acts relating to bread (other than the statute upon adulteration) are those of 1824 and 1836 . 


\section{TABLE IX.-Restrictions on the Price of Food-Contd.}

A.D.

At length came the time and the man. The food of the people was no longer to be made the pretext for "unnatural legislation." Sir Robert Pecl swept away the whole fabric of failures which his predecessors had built up, and which we have here passed in review; and the poliey of "free trade" in the essential portion of the food of the people was for once, and, so far as the United Kingdom is concerned, for ever proclaimed!

In the preceding table, under date 1336, I have quoted a law of Edward III, that none should be served with more than two courses at any meal. This was a period of scarcity; but it was also the period of sumptuary laws. There were other laws in the same direction. See 1368, 1562, and 1593. There is a remarkable incident associated with the scarcity which prevailed at the commencement of the present century. In 1800 the inhabitants of Westminster, or many of them, entered into a compact known as "The Engagement," of which the following is an exact transcript :-

"We, the inhabitants, housebolders of the parish of St. Anne's, within the Liberty of Westminster, being earnestly desirous of giving the most steady effect to his majesty's late proclamation, and of affording all possille relief, under the present pressure, do sincerely engage, and solemnly bind ourselves, that we will practise the greatest economy and frugality in the use of every species of grain; that we will use our utmost endeavours to rednce the consumption of bread in our respective families, by at least one-third of the quantity consumed in ordinary times; and that we will in no case suffer the same to exceed one quartern loaf for each person per week; and that we will alstain from the use of flour in pastry, and noreover restrict the use of it, in all other artieles than bread. And further, that sneh of us as keep horses, and especially loorses for pleasure, will, as far as om respective cireumstances will admit, carefully restrict the consumption of oats, and of other grain, for the subsistence of the same. And we further solemnly pledge ourselves, that we will use the strictest economy in every other article of food, and take the greatest possible care, that neither a profusion be allowed, nor a waste committed in our respective honseholds.

"To which solemr engagement, not less important to us individually than to the general welfare of the contry, we have affixed our hands, this 17 th day of December, 1800."

Nor was this all; another step remained to make the morement complete, and this was to try and reach and teach the household domestics, a by no means easy task at any time. This was attempted to be accomplished as follows :-

"And as it is equally the duty and interest of servants, as of their employers, that this engagement should be carried into entire effect, it is expected that all servants will jeadily, and with a hearty good will, unite with their respective families in this necessury measure; should, however, the contrary in any instance occur :

"It is resolved, that any servant, refusing to concur in the olyject of this engagement, and in consequence, quitting a place, or being discharged, slall not be received by us into our homes, nor, as we have reason to believe, will they be received by any of our friends."

Further resolutions were passed for assisting the poor in the present emergency. 
TABLE X.-(External Regulations.) Legislutive Restrictions and other Provisions on the Export or Import of Grain from or into the United Kingdom or Parts thereof.

A.D.

1323-24 By 17 Edward II, cap. 3-" Ordinance made for the state of the land of Ireland"'-it is enaeted as follows:-

"Moreorer that our said justiees, nor any of our other ministers, by colour of their offiee, shall arrest ships, nor other goods of strangers of our own people; but that all merchants and others may earry their corn, and other rictuals and merchandises forth of our realn of Jreland unto our realm of England, and unto our land of Wales (exeept in the eases after-mentioned), paying the eustoms due and used; so that they make good security that they shall not go unto, nor eommerce with our enemies of Scotland, nor other of our enemies, if any shall be. And if any justice or other officer do the eontrary in the things aforesaid, and be therefore attainted, he shall sutisfy the plaintiffs double dimages, and shall also be grierously punished on our behalf."

'29 ... By 3 Edward III, the importation of wheat, rye or barley into this realm [England] was prohibited, unless the priee of wheat exeed $6 s$. $\delta d$. the quarter" rye 4 . ; barley $3 s$, at that port or place where the same should be brought in, "upon paine of forfeiture thereof."

'60 .... By 34 Edward III, cap. 20, no eorn was to be transported [exported from England] but to Calais and Gascoign.

'93 .... By 17 Richard II, eap. 7, it is enaeted as follows :-

"Item. The king, at the request of the eommons to him made in this present parliament, hath granted license to all his liege people of his realm of England, to ship and carry eorn out of the said realm, to what parts that please them, exeept to his enemies, paying the subsidies and duties thereof due; notwithstanding any ordaining, proclamation, or any defence made before this time to the contrary; nerertheless he will that his couneil may restrain the said passage when they should think best for the profit of the realm."

1425-26 This last named statute was confirmed by 4 IIenry VI, eap. 5.

'36 .... By 15 Hemry VI, eap. 2, it was enacted, "corn being at small priee, riz., wheat at $6 s .8 d$. and barley at $3 s$. the quarter, may be carried forth of the realm without licence," the following reasons being giren :-

"Item. Forasmueh as by the law it was ordained that no man might earry nor bring eorn ont of the realm of England without the king's license, for eause whereof farmers and other men who use manure. ment of their land, nay not sell their eorn but of a low priee, to the great damage of all the realm: our said sorereign lord the king, willing in this case to provide remedy, hath ordained by authority aforesaicl, that it shall be lawful to every person to exry and bring com out of England, and the same to sell to whatsoever person that he will, except all only to the king's enemies, as often and as long as a quarter of wheat or barley is so shipped; and that without suing any license for the same: all other statutes before this time thereof made to the entrary notwithstanding. Provided always that the king be contented of his eustoms and money. And this ordinance shall endure till the next parliament."

' 11 .... The last-named det was eonfirmed by 20 th of same reign (1441).

'44 .... The Act of 1436 made perpetual by 23 Henry VI, cap. $\tilde{5}$.

'63 .... By 3 Edward IV, eap. 2, it was enaeted :-

"Whereas the labourers and oceupiers of husbandry within this realm be daily grievously eudangered by bringing in of eorn out of other lands and parts into this'realm, when corn of the growing of $t \mathrm{l}$ is realm is at a low priee: our said sovereign lord the king consdering the premises, by the adviee, assent, and authority aforesaid hath ordained and established, that no person from the feast of St. John the Baptist 


\section{Table X.-Restirictions on the Export or Import of Grain-Contd.}

A.D.

1463 .... next coming shall bring or convey into any place or port of this realm, by way of merehandise or otherwise, any wheat, rye, or barley, which is not of the growing of this land, or of any isle pertaining to the same, or of the growing of Ireland or $W^{2}$ ales, at any tume that the quarter of wheat loth not exceed the price of $t s$. od., the quarter of rye 4 ., and the quarter of barley $3 s$. of lawful money of England, within the place or port where snch wheat, rye, or birley shall happen to be brought; upon pain of forfeiture of the said wheat, rye and barkey, the one-half to our said sovereign lord the king, and the other half to him which shall happen to seize any such wheat, rye or barley : provided always that this aet extend not to any wheat, rye or barley taken by any of the king's liege people upon the sea without fraud or corin."

'f $1-65 \mathrm{~B}_{y}+$ Edward IV, cap. 5, the importation of an merelrandises except provisions from the comntries of the Duke of Burgundy (which then extended over Burgundy, Lot rike [? Utrecht], lirabant, Luneburgh, Flanders, Artuis, Henault, Holland, Zealand, Xassau, the markship of the Ifoly Empire, Friesland, Meynes, de.), was prohibited.

72 ... An Act of the parliament of lielend, 12 Edward $[\mathrm{T}$, cilp. 3-"An Act thạt no grain be laden out of the reahn, unless the same be at a eertain price" - was as fullows:-

"Item-At the request of the commons, for that there is so great lack of money in this land, and also the grain are enhanced to a great price beciuse of great lading from dity to day used and continued within this realne; by the which great dearth is like to be of graines, withoul some remedy be ordeyned in the said parliament. Whereupon the premises considered, it is orderned, enacted, and established, by the antlority of the said parliament, that no person or persons late no (sic) grain out of the sidid land to no other parts without, if one peck of the said grains exceed the price of ten pence, upon pain of forfeiture of the said grain or the value thereof. And also the owner of the ship within the which the said graines are laden shall forfeit the said ship (that is to say), the one moyety to the party that seize or take the said grains on ship."

$1533 . .$. In the 25 Henry VIII, cap. 2- "Proclamations for the prices of vietuals, riz., the prizing of them, and proclaiming the prices" quoted in some detail in Table $\mathbf{X}$, there is contained the following :-

"IV. And be it further enacted, that no person or persons, unless it be by hicense under the king's great seal, from henceforth shall carry or convey, or cause to be carried and convejed, any corn, beefs, muttons, reals, porks, or any other of the above suict victuals, to any the parties [? parts] beyond the sea, except only for victualling of the towns of callis, Guisnes, Hammes, and the marches of the same, and except for victualling of masters, miners, and merchants of ships passing the seas; and also except barrelled butter and meal to be carried to the parties of Ireland, as hath been accustomed; upon the pain of forfeiting of the value of the thing conveyed and carried into the parties of beyond the sea contrary to this Act, the one-half thereof to the use of our sorereign lord the king, and the other half to the prorty who will sue for the same," \&e.

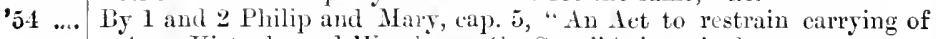
Com, Tictuals, and Wood over the Seas," it is recited:-

"Whereas sundry good estatutesand laws have been madewithin this realm, in the time of the Queen's IIighness most noble progenitors, that none should transport, carry or conrey ont of this realm into any place in the parts beyond the seis any corn, butter, cheese or other rictual (except only for the victulling of the towns of Calice, Hames aud Guisnes, and the marehes of the sanre) upon divers great pairs aurl forfeitures in the same contained. That notwithstanding, many and snndry coretous and unsatiable persons, seeking their own lneres 


\section{Table X.-Restrictions on the Export or Import of Grain-Contd.}

A.D.

1554

and gains, have, and daily do cary and eonrey, innmmeruble quantity as well of eorn, cheese, butter and other rictual, as of wool out of this realm into the parts beyond the seas, br reason whereof the said eorn, victual and nood are grown into a wonderful dearth and extreme prices, to the great detriment of the common wealth of this your highness realm, and your faitliful subjects of the sime."

In future no such exports to be made withont license, exeept when prices should not exceed the following: wheat, $6 s .8 d$. per quarter; rre, $+s$. ; barley, $3 s$.; then it should "be lawful to erery person and persons to eary and transport over the sea to any place beyond the seas at their pieasure, any of the said kinds of eorn, so that it be not to the king and queen's enemies."

By 1 Elizabeth, cap. 11- "An Aete lymiting the tymes for layeing on Lande Marhandise from beronde the Seas, and tunehing Customes for Sweete Wynes"-it was provicled -

"XI. . . . That it shall be lawful to ship, lade and transport into the parts berond the seil, all mamner of corn and grain out of the counties of Norfolk and Suffulk, and either of them, at such places as herctofore lath been acertstomed, and between the hours in this Act appointed [in the disclight and in an open place], when the same com and grain shall not exeed the several prices mentioned in this statute, 5 and 6 Edward VI [1552, Table No. XII], entituled 'An Act against regrators, Se.', the customs and subsidies therefore due be well and truly paid; ansthing in this Act or any other Act to the eontrary notwithstanding. Prorided that nothing herein was to be 'prejudicial or hurtful to the isle of Anglesea, the shires of Carnarvon and Flint in North Wrales; but that the indrabitants thereof, and every of them, may receive, lade, and discharge, aeeording to their old aneient uses, eustoms, or libertics granted to them, or any of their predecessors, by the late king, of famons memory, king Ilemry the VIII, or any other her progenitors. So that they and every of them pay the eustoms and subsidies that shall be due, and discharge and load within the tines and hours before-mentioned."

62 .... By 5 Elizabeth, eap. 5-" An Acte towching certayne Politique Constitutions made for the maintenanee of the Narye"-see. 17, it is enaeted that corn might be exported by British subjeets in English ships at eertain ports, when not exeeding the following prices, viz., wheat ros., rye, pease, and beans, $8 . s$, and barley or malt $6 s .8 d$. per" quarter; and then-

"XXVI. And be it further enaeted by the authority of this present parliament, that from and after the Feast of St. Michael the Archangel next coming, it shall be lawful to all and erery person and persons, being subjects to the queen's majesty, her heirs and suecessors, only out of sueh ports and creeks as by the queen's majesty's proclamation hereafter shall be published and appointed, and not elsewhere, to load, carry, or transport any wheat, barley, malt, peas, or beans into any parts beyond the seas to sell as merchandise in ships, crayers, or other vessels, whereof any English born subjects then shall be the only owners, so that the price of the said corn or grain so earried or transported exceed not the prices hereafter following, at the times, havens and places, where and when the same corn or grain shall be shipped and laden, viz., the quarter of wheat at $10 s$.; the quarter of rye, peas, or beans, at 8. ; the quarter of barley or malt at $6 s$. $8 d$. of current money of England; any law, usage, or statute made to the contrary hercof in anywise notwithstanding."

By 13 Elizabeth, eap. 13-“" An Acte for the Encrease of Tyllage," \&e.-it is enacted that corn might be exported to friendly eountries by British subjects, from certain ports, in eertain ships, at all times when proclamation was not made to the contrary, on the price of 


\section{TaBLE X.-Restrictions on the Erport or Import of Grain-Contd.}

A.D.

1571 ... corn being ascertained yearly in the several comntries. A duty of $12 d$. per quarter imposed on all corn exported. The queen might prohibit the exportation of com by proclamation at all times.

'93 .... By 35 Elizabeth, eap. 7- "An Aete for continuing of diverse Statutes" -it is enacted by seetion 17 that the export of corn may be prohibited either generally throughont the whole realme, or in any of the comnties individunly, having sea-ports; and further--

"XXIII. Prorided alwatys . . . Thit when the price of corn or grain exeeedeth not the rates herenfter following, at the times and harens, and places where and when the same corn and grain shall be shipped or loaden, riz., the quarter of whent at 20s.; the quarter of ree, pease, and beans at $1_{3} s .4 d$.; the quarter of barley or malt at i $2 x$. of eurrent English money; that then it shall be lawful for all and evers person or persons being subjects of her majesty, her heirs or successors, to loar, earry, or transport any of the said com or grain in such manner and form as in the saicl Act made for the maintenance of the nary is limited and appointed.

The queen was to receire for custom and poundage for every quarter of wheat so exported $2 s$, and of other grain $1 s, 4 d$, in full satisfinetion.

1604 .... By 1 James I, cap. 25-"An Aete for eontinuynge and revivinge of divers Statutes, and for repealinge of some others"-the following legulitions eame into foree-

"XIVI. Prosided also, ind be it further enacted by the authority of this present parliament, that when the prices of corns or grains, exceeding not the rates hereinafter following, at the times, havens, and plices where or when the same corn or grain shall be shipped or londed, riz., the quarter of wheat $26 s$. $8 d$.; the quarter of rre, pease, and heans at $15 . s$; the quarter of barley or malt at $14 \%$ of current English moner; that then it shall be lawful for every person and persons being subjects of the king's miljesty, his heirs or surcessors, to transport of his own, and to buy and transport any of his said eorns and grains into any parts beyond the seas in amity with his majesty to sell as merchandise in ships, cravers, or other vessels whereof any English born subject or subjects shall then be the owner or owners, any law, usage, or statute to the contrary hereof not withstanding."

The custom or pounlage to the Crown being as. per quarter for wheat, and $1 s$. od. for the other grain enmerated.

The king might br proclamation prohibit the exportation of grain either from the whole or any part of the kingdom.

'23 .... By 21 James I, ap. 28- " In Aet for contynewing and reviring of divers statutes, and repeal of dyrers others,"-it was enacted--

"III. Prorided also . . . that when the prices of corn or grain exced not the rates hereinafter following, at the times, hasens, and places when and where the same corn or grain shall be brought, shipped, or landed, riz., the quarter of wheat at $32 . s$, the quarter of rye at $20 s$, the quarter of pease and beans at $16 s$, the quarter of barley or malt at 16. . of eurrent English moner, that then it shall and may be hawful for all and erery person or persons being subjeets of the king's majesty . . . to carry and transport of his own, and to buy to sell again in markets and out of markets, and to keep or sell, or cary and transnort any of the said corn and grain from the places where they shall be of such prices into any parts beyond the seas in amity with his majesty, as merchandise in ships, erays, or other ressels whereof any English born subjeet or subjeets then shall be the owner or owners; or the same to carry, and sell in other parts within this realm or dominions thereof, any law, usage, or statute to the contrary not withstanding."

The king's custom or poundage to be $2 s$. per quarter for wheat, and 


\section{TABLE X.-Restrictions on the Export or Import of Grain -Contd.}

A.D.

1623 transportation of grain.

Br this Act there was repealed a considerable number of the preceding Aets named in this table.

227 .... The Act of 1623 was confirmed by 3 Car. I, cap. 4 (5), section 24.

'60 .... By 12 Car. II, cap. 4-"A subsidy granted to the king of lom "Age and poundage, and other sums of money payable on merchandise exported and imported "-it was cnacted:-

" II. It shall and may be lawful, immediately after the passing of this tet, for any person or persons to ship, earry out, and transport, by way of merchandise, these several sorts of goods following, that is to say - . . and wheat, rye, pease, beans, barley, malt, and outs, beef, pork, bacon, butter, cheese, candles, when the same do not exceed in price at the ports from whence ther are laden, and at the time of their lading, these prices following, that is to say, wheat, the quarter, 4os.; rre, beans, and pease, the quarter, $24^{s}$; barley and malt, the quarter, $20 s . ;$ oats, the quarter, I $6 s$.; beef, the barrel, sl.; pork, the birrel, 6l. Ios.; bacon, the pound, $6 d$.; butter, the barrel, 4 . Ios.; cheese, the hundred, I $l$. ros.; eandles, the dozen pounds, 5s., paying the respective rates appointed by this Aet and no more, any former law, statute, prohibition, or custom notwithstanding. As a specimen of the seale of duties-Exports, beef, the barrel, $3 l .:$ Imports, beef, the barrel, $1 l . "$

'63 ... B 15 Car. II, cap. 7-" An Act for the encouragement of Trade" it is recited :-

"Forasmuch as the encouragement of tillage ought to be in an especial manner regarded and endearoured; and the surest and effectual means of promoting and adrancing any trade, ocenpation or mystery, being by rendering it profitable to the uscrs thereof; (2) and great quantities of land within this kingdom for the present lying in a manner waste, and yiclding little, which might thereby be improred to considerable profit and advantage (if suffieient encouragement were given for the laying out cost and labour on the same), and thereby much more com produced, great numbers of people, horses and cattle employed, and other lands also rendered more valuable."

And it is then enacted that when the price of whent did not exceed at the place from which it was to be exported $4 \delta s$. per quarter Winchester measure, barley or malt $28 . s$, buckwheat $28 s$., oats $13 s .4 d$., rye $32 s$., peas or beans $32 s$. of English money, then the same might be exported to places beyond the seas. And when the prices did not exceed those named at the place of import, there might be imported wheat upon paying a customs duty of $5 s .4 \%$, rye $4 s$. , barley or malt $2 s$. $8 d$, buckwheat $2 s$, oats is. $4^{d}$., and peas or beans $4 s$.

And it was further enacted, that when the prices of corn or grain, Winchester measure, did not exceed the rates above stated at the markets, harens, or places where the same should be bought, that then it should "be lawful for all and cvery person and persons (not forestalling nor selling the same in the same market within three months after the buying thereof) to buy in open market, and to lay up and keep in his or their granaries or houses, and to sell again, such corn or grain of the kinds aforesaid as without frand or covin shall have been bouglit at or under the price before expressed, without incurring any penalty; any law, statute or usage to the contrary notwithstanding."

By this Act it is recited :-

" XIII. Whereas a great part of the richest and best land of this kingdom is and cannot so well be otherwise employed and made use of as in the feeding and fattening of cattle, and that of the coming in of late of vast numbers of cattle already fatted, such lands are in many places much fallen, and bkely daily to fall more in their rents 


\section{Table X.-Restrictions on the Export or Import of Grain-Contd.}

A.D.

1663

and ralues, and in consequence other lands atso, to the great prejudice, detriment, and imporerishment of this kingdom."

"And it is thus enacted, That for erery head of great cattle (except such as are of the breet of Scotland) that shall be imported and brought into England, Wales, or the town of Bervick-upon-Tweed after the Ist day of July and before the 2uth day of December in any fear ; and for every head of great cattle of the breed of Scotland that shall be imported or bronght into England, Fales, or the tomn of Bervick after the 24th August and before the 20th December in ans year, there shall be paid to his majecty, his heirs and successors, the sum of zos, and the stum of $10 s$. to him or them that slull inform and seize the same."

For every sheep so imported there was to be paid the sum of 10. . The Act, so far as it reluted to cattle and sheep, was not to eome into force before the 1st Julr, 166t, nor to continue longer than the end of the first session of the next partiament. (See 1665).

section 18 of this det is a follows:- "Prorided also and be it elacted that it shall and may he lawful to import catle of the breed of the Isle of Mam not exceeing 600 in any one rear. And corne of the growth of that island out of that island into England, soe as the said catle be landed at Chester, Lirerpoole, or Wilewater, ançtling in this Art to the contrary thereof in any wise notwithstanding."

Adam sunith observel of this measire, that with all its imperfertions, it had done more to promote plenty than any other law in the statute book.

By is Car. II, cap. 2-"An Aet against importing Caitle from Lielund and other parts besond the Seas, and Fish taken by Foreigners"-after reciting the Act of 1663 (sec. 13) it is enacted"That such importation from and after the end February in the present rear 1666, is a public and a common nusance, and shall be so adjudged, deemed, and tuken to be to all intents and purposes whatsoever;" and further:-

"That if any great cattle, sheep, or swine, or any beef, pork, or bacon (except for the necessary provision of the respective ships or ressels in which the same shall be? bronght, not exponing the same or any part thereof to sale) shall from and after the said and February, by any wise whaterer be imported or browght from bryoud seas into this hingdom of Emgland, dominion of Hales, or town of Berwickupon-Tweed, that then it shall and nay be lawful for any constable, tithing man, heal horough, dhurchwadens, or orerseers of the port, or any of them, within the respective liberties, parishes, or places, to take and seize the same, and keep the same during the space of fortyeight hours in some publiek or convenient place where such seizure shall be minle, within which time if the owner or owners, or any for them or him, slatl make it appear unto some juatice of the peace of the sane county where the same shall be so seized, by the oaths of two ardible winesses, that the same were not imported from Ireland, or from any other place beyond the seas not hereinafter excepted, after this saiti and day of Februtry, then the same upon the warrant of such justice of the peace shall be delirered without delay; but in default of such proof and warant, then the same to be forfeited: one-half thereuf to be disposed to the use of the poor of the parish where the sime shall be so found or seized; the other half to be to his own nse that shall so seize the sane.

"And for the better encouragement of the Fishery of this kingdom, be it further enacted by this anthority afuresaid, that if any ling, herring, cod, or pilchard, fresh or salted, dried or bloated, or any silmons, eels, or conpers, talen by any foreigner, aliens to this kingdom, shall be imported, uttered, sold or exposed for sale in this kingdom, that then it shall and may be law ful for any person or 


\section{Table X.-Restrictions on the Export or Import of Grain-Contd.}

A.D.

1665

persons to take and scize the same; the one-half thelenf to be disposed of to the use of the poor of the parish, de. [as before].

"Provided always, that nothing in this Aet shall be construed to hinder the importation of cattle from the Isle of Mun in this kingdom of England, so as the number of the said eattle do not exeed 600 head yearly; ind that they be not of any other breed than of the breed of the Iste of. Iran; and that they be loaded at the port of Chester, or some of the members thereof, and not elsewhere."

This Aet was to continue until the end of seren yours. It was made perpetual by 32 (ar. II, cap. 2 , sec. 2 (1680).

The 20 Car. 1I, cap. 7, "An additiunal Act aga'nst the importation of Foreign Cattle," all oflicers who had seized my cattli, sheep, swine, beef, pork, or bacon, were saved harmless; while those who neglceted to seize were made liable to a penalts of 100 .

70 .... By 2.2 Car. II., eap 13-"An Act for the Improrement of Tillage and the Breed of Cattle"-It was enacted that it should be lawful after the 24th June of this year for all and every person or persons, native or foreignes, at any time or times, to ship, lade, earry, and transport as merehaudize all sorts of corn and grain, "althongh the prices thereot shall exceed the rates set down" in the det of 1663 , paying for the same the rates stated in the subsidy of 1660 . But when the rates did not exeed those following, then there should be paid the custom and poundage fol'owing, riz., for wheat when the same shall not exeed the price of $53 s .+d$. per quarter, $16 s$; and when the price of wheat exceeded the price list naned, but did not exceed $80 s$., the sum of $8 s$.; for every quarter of rye when the price did not exceed $40 s ., 16 s$; fur barley or malt when it dist not exceed $32 s ., 16 s$.; for buckwheat the same; for oats not exceeding $16 s$. per quarter, $5 s .4$; for peas and beans not exceeding + s. per quarter, I6s.; eacle quarter to contain 8 bushels, and each bushel 8 gallons and no more.

This Act also contained the following :-

"III. And for the further encouragement of French or pearl barley in this kingdom, there shall be paid for the eustom of every ewt. . . the sum of $5 s$.

"IV. And for the further encouragement of breeding ancl feeding of eatile of all sorts, be it enacted that from the 2.thl June which shall be in the year of our Lord God 1670, and from thenceforward, it shall be lawful for every person or persons, native or foreigner, at any time or times, to ship, lode, and transport [export] by way of merehandise these sorts of goods following, that is to say, beef, pork, baeun, butter, ehecse, and candles, thongh the same do exceed in price at the ports from which they are la len, and at the time of their lading, the prices set down and limited in the aforesaid [1660] . . . or any other law, statute, usage, or other prolibition to the contrary thereof in anywist notwithstanding; paying for the same the respective lates effected by the said Act, and no more," with eertain enumerated exceptions. It was also made lawtul to export eows and heifers, swine or hogs, herses and mares.

Further provisions hereto were made by 3 William and Mary, cap. 8.

The 31 Car. II, cap. $2-"$ " An Act prohibiting the importation of cattle from Ireland"-while making the Act of 166.5 perpetual, "foras. much as, by long experience, the said law hath been found to be very beneficial to this kingdom," eontains further enactments in the same direction.

"VIII. And whereas the present laws do not sufficiently provide against the importation of mutton and lamb out of lreland and other parts berond the seas into this kingdom, but that great quantities thereof are daily imported and sold, to the great loss and prejudice of this lingdom. Be it therefore enacted, that from and 


\section{'TABre X.-Restrictions on the Export or Import of Grain-Contd.}

A.T.

1680 .... after the said Ind February, no mutton or lamb shall be imported into this kingdom from the kingdom of Ireland or any foreign parts; and all mutton and lamb imported from Ireland, or beyond the seas, or that shall be exposed to sale within this kingdom, shall be subject to the like seizure, and the importers and sellers thereof respectively in the like penalties, as are provided and appointed by any former law against any importer or seller, or importation of any beef, pork, or bacon, from the lingdom of Ireland or any foreign parts.

"IX. And whereas the present laws do not suffieiently provide against this importation of butter and cheese ont of Ireland into this kingdom, but that great quantities thereof are daily imported and sold to the great loss and prejuclice of this kingdom; be it therefore macted, that from and after the said and February no butter or cheese shall be imported into this kingdom from the kingdom of Ireland; and all butter and aleese imported from Irelund, or that shall be exposed to sale within this kingdom, shall be subject to the like seiznres; and the importers anct sellers thereof respectively to the like penalties, as are provided in any former law against any importer or seller, or importation of any beef, bacon, or port from the kingdom of Ireland."

As to cattle, it wis further provicled that the seizure might be made in any parish to which the same might be remored.

'S5 .... Iy I James II, cap. 19-“ An Additional Act for the Improvement of Tilluge"-the Act of 22 Car. II, "of ever blessed memorr," eap. 13 $(167(1)$, is recited, but inasmuth as 10 provision was made by the said Act for ascertaining and determining the prices therein set forth, "by reason whereof several great quantities of foreign eorn and grain have been imported without paring the respective duties by the said Act appointed, contrary to the true intent and meaning of the said Act." it was now determined that justices of the peace upon the coast have power, "upon the oaths of two or more honest and substantial peroms of the respective counties, being neither merehants nor ficturs for the importing of corn, nor anywars concerned nor interested in the corm so imported, and ach of them haring a free. hokl estate of 201 . per ammun or a leaschold estate of 501 . per annum above all charges and reprizes, and being skilful in the priee of corn," Se., to determine the prices for the purposes of the said recited A.t.

'88 .... There were two enaetments this year, the first cmbodying quite a now feature, that of bounties on export.

1. The 1 William and Mary, statute 1, cap. 12 - "An Aet for the encouraging the exportation of Com"-wherein it is recited: "Foras. much as it hath been found by experience, that the exportation of corm and grain into foreign parts, when the price thereof is at a low rate in this kingdom, hath been a great advintage, not only to the owners of land, but to the trade of this kingdom in general," \&e. It was therefore enacted that when malt or barles, "Winchester measure," should be at or under 24 . per quarter, rye at or under 32s., and wheat at or under $48 s$. per quarter, the masters and crews of British ships exporting the same should reeeive a bounty on a seale set forth in the said Act. Precautions taken not to allow such grain to be reslipped into Great Britain.

2. 1. William and Mary, eap. 24.- In exeise Aet-contained the following :-

"XVIII. And be it enacted, that when malt or barley of English growth, Irinchester measure, shall be at, $24^{s}$. by the quarter, or under, rye, of English growth, at $32 s$. by the quarter, or under, and whent, of English growth, at 48 s. by the quarter, or under, in the town or port of Berrick-upon-Tueed; every merchant or other person who shall pat on shipboard in English shipping, the master 


\section{TABLE X.--Restrictims on the Export or Import of Grain-Contd.}

A.D. 1688 .... and two-thirds of his mariners at least being their Majesties' subjects, any sorts of the corn aforesaid, from the said port or town of Berwick, with intent to export the said corn into parts beyond the scas, and shall pursue all and every the methods and things prescribed and appointed in that behalf, in and by the said Act made in this present session of Parliament, intituled ' $A_{n}$ Aet for encouraging the exportation of Com, shall have the benefit and advantage of the said Act, and of everything therein contained, as fully to all intents and purposes as if the said corn had been put on shipboard from any port or ports of this kingdom or dominion of Wales.

"XIX. Provided alwass, and be it enacted, thit if any merehant or other person whatever shall put on shipboard any corn of the growth of Scotland, out of the sail port of Berwick-upon-Tweed, that all such corn shall be forfeited (that is to say), one-third part to their Majesties, one-third part to the informer, and the other third part to the poor of the said town of Berwick."

'97 ... By 8 and 9 William III, cap. 22, a duty of $6 d$. per bushel was laid upon malt.

'98 .... Grain and other articles of food were afterwards the subjects of fiscal burdens by indirect enactments wherein they are nowhere speeifically named. Thus, in the 9 and 10 William III, cap. 23-" An Act for granting to his majesty a further subsidy of tonnage and poundage towards raising the yearly sum of $700,000 \mathrm{l}$. for the service of His Majesty's Honsehold, and other uses therein mentioned, during His Majesty's life "-a duty of $12 d$. in the $\mathscr{L}$ on the value of all goods and merchandises imported was imposed. This was held to apply to grain, and accordingly raised the duty then payable thereon.

'98 .... By 10 William III, cap. 3-"An Act to prohilit the Exportation of any Corn, Malt, Meale, Flour, Bread, Biscuit, or Starch for one yeare from the 10th February, 1698 "- it is recited that the price of corm in the kingdom of England, dominion of Wales, and town of Berwickupon-Tweed was at this time excessire; and that in several other parts of Europe it was "scarcer" and dearer that in England ; hence no corn, \&c., was to be exported except under the provisions of this Act. The eommissioners of customs might seize all ressels unduly laden with corn for exportation, even to Scotland, and take the same to the king's warehouse. Bat corn might be exported for sustenance of erews and passengers of ships, and for British ports and colonies, and for the benefit of English fisheries, and malt to the Channel Islands, also carried coastwise, and on narigable rirers. And on decrease of price the king might by proclamation permit exportation before expiry of this Act.

'98-99 Br 11 William III, cap. 1-“" An Act for taking away the Bounty Money for exporting Corn from the 9th February, 1699, to the $29 t_{1}$ September, 1700 " - the purposes for which the said bounties had been instituted are recited, and then: "But forasmuch as it appears that the present stock and quantity of corn in this kingdom may not be sufficient for the use and serrice of the pcople at home, should there be too great an exportation into parts beyond the seas, which many persons may be prompted to dee for their own private advantage and the lucre of the said bounty or allowance-moncy," it was suspended accordingly for one year.

1. By 11 and 12 William III, cap. 20-." An Act for taking away the Duties upon the Woollen Manufactures, Corn, Grain, Bread, Biseuit and Meal Exported"-it was enacted :-

"IV. And for the greater encouragement of tillage, be it further enacted by the authority aforesaid, that from and after the 30th day of March, 1700, the subsidy and all other duties whatsoerer payable for or upon the exportation of wheat, rye, barley, malt, beans, peas, and other sorts of corn and grain whatsoerer, ground or unground, and 


\section{Table X.-Restrictions on the Export or Import of Grain-Contd.}

A.D.

1700

'03 .... By 2 and 3 Amne, cap. 9- An Act for granting to ITer Majesty an additional subsidy of tomage and poundage for thrce years," Se.the increase of duity on all grin and other merchandise imported was increased by one-third.

'03 .... By the 9th Aet of the parliament of Scotland, holden by Queen Anne this rear, intituled, "An Aet discharging importation of Irish Victual, Beef and Cattle," the importation of rictual from Ireland or anc other places beyond the seas into Scotland was restruined and prohibited, mnder several penalties contained in the said Act, and in other Acts of the Parliament of Scotland therein referred to. But with this prosiso, that when, by reason of dearth, the prices of rictual should exceed the rates specified in the said Aet, the Lords of Her Majesty's Priry Council of Scotland should liare power, after due trial by them taken of the prices of rictual, to suspend and diselarge the execution of the said prohibitory Aets for such space of time as the exigencies of the said dearth should require.

'04 .... By 3 and 4 Anne, eap. 5-"An Aet for granting to Her Majesty a further subsidy on wines and merchandises imported "- -an additional poundage equal to two-thirds of that imposed by 9 William III, eap. 23 , was imposed. The effect of this and the precious as also of later Acts of the same character upon the duty leviable upon imported wheat, will be shown in a table given by way of supplement to the present table.

'06 .... In the Treaty of Union between Fngland and Scotland, made this rear, it was provided by Article VI, that the prohibition as then in force by the law of Scotland against the importation of rietual from Ircland, or any other place beyond the seas, into Scotland, should, after the union remain in the same force as it then was, until more proper and effectual ways should be prosided by the parliament of Great Britain for discouraging the importation of the said rictual from beyond the sea. This treaty was confirmed by 5 Anne, cap. 8 .

Sime session, by 5 Amme, eap. 29 , parliament desiring "that there unay be as great an equality of trade as possible" among all Her Majesty's subjects, enacted (by section 15) that exporter's of malt male of wheat slonld be entitled to $5 s$. per quarter bounty money (in confornity with 1 William and Mary, statute 1, eap. 12 (1682).

'09 .... By S Anne, eap. 2-"An Aet to prolibit the exportation of Corn, Malt, Meal, Flour. Bread, Bisenit and Starch, and Low Wines, Spirits, Worts, and Wash drawn from malted Com "- -it is recited :-

"Whereas the price of corn at this time within the kingdom of Great Britain is become very great, and (in some parts thereof) excessire, which tends to the imporerishment of many of Her Majesty's good subjects, espeeially of poor manufacturers and otbers of a mcaner condition, and by reason that corn in sereril other parts of Europe is scareer and dearer than in Great Britain, it is likely that sereral persons for their prisate advantage or luere will not only export or convey great quantities of corn from this kingdom, but likewise distil excessive quantities of low wines and spirits from malt, corn and grain, in order to export the same to foreign parts, whereby the price of corn will be further enhanced, to the detriment of Her Majesty's good 


\section{TABLe X.-Restrictions on the Eevort or Import of Grain-Contd.}

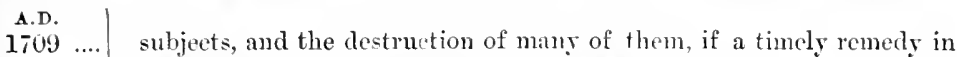
this behalf be not provided. Be it therefore," \&c.

It was then enacted that from $29 t h$ September, 1710 , no exportation of the articles named be made other than as therein provided. Export might be permitted by proclamation. No limit of price named.

Same session, br 8 Amne, cap. 11-" An Aet to explain so much of the Act for prohibiting the exportation of Corn, Malt, Meal, Flonr, Bread, Bisenit, and Stareh, and Low Wines, Spirits, Worts, and Wash drawn from Malted Corn ; by which Act the said commodities are almitted to be carried from the Isle of Wight to several markets; and for giving liberty to export certain quantities of Oatmeal for the uses of the British Hospitals berond the seas "-it was permitted after 2nd March, 1710, to export corn of the growth of the Isle of Wialit, to Southampton, fe., in any resel whatever, but not elsewhere, taking such coequets, \&e, as by the former Act. After 1.t March, 1710, any person having a licenee from the queen might export oatmeal, not exeeeding too bushels, for Holland, not exceeding 200 bushels to Barceiona, and not exeeeding the like quantity to Lisbon, for the use of British troops in those places.

'29 .... There was enacted 2 George II, eap. 18-" In Act to ascertain the custom payable for Corn and Grain imported; for better aseertaining the price and quantity of Com and Grain, for whieh a bounty is parable on exportation," \&e., \&c. Powers were giren to justices at quarter sessions to determine the priee of grain.

'32 .... The 5 George II, cap. 12, amender the det of 1685 regarding the mode of "determining the common market price of middling English corn and grain," which "had been found ineffectual;" and the natter was now to be determined by the oath of the grand jury assembled at quarter sessions, on a presentment made in open court. This mode was not to extend to London.

'38 ... By 11 George II, cap. 2.2-"An Aet for punishing such persons as shall do injuries and violences to the persons or properties of His Majesty's subjects, with intent to hinder the exportation of Corn" it is reeited :-

"Whereas many disorderly and evil-minded persons have of late frequently assembled themselves in great numbers, committed great riolences, and done many injuries to the persons and properties of His Majesty's subjects, with intent to hinder the exportation of corn, wherebs many of His Majesty's subjects hare been deterred from buying of corn and grain, and following their lawful business therein, to their great loss and damage, as well as the great damage and prejudice of the farmers and landowners of the kingdom, and of the nation in general."

It was then enacted that, "for the better presenting such wicked and disorderly practices," persons using violence to hinder the purchase and carriage of eorn, should on conviction he imprisoned and publicls whipped. The "Hundred" was made liable to the extent of $100 l$. for corn destroyed :-

'41 ... 1. Br 14 George II, cap. 3-"An Act to prohibit for the time therein limited the exportation of Corn, Grain (Rice excepted), Meal, Malt, Flour, Bread, Biscuit, Starch, Beef, Pork, and Bacon, the exportation of which may at this time be greatly prejudieial to His Majesty's subjects;" and was therefore restrained up to the 31st December. But His Majesty might nevertheless grant power to export thesc things.

2. There was enacted, 14 George II, cap. 7-"An Act for licensing the importation of Vietual from Ireland and other parts beyond the seas into Scotland, in time of dearth and scarcity." (See 1703 and 1706.) 
Table X.-Restrictions on the Export or Import of Grain-Contd.

A.D.

1748 .... By 21 George II, cap. 2-" An Act for granting to His Majesty a subsidy of poundage upon all goods and merchandises to be imported into this kinglom," \&e.-au additional duty of $12 d$. in the $£$ was imposed.

'51 ... By 24 George JI. cap. 56-"An Act for ascertaining the admeasurement of Wheat, Meal, or other Corn or Grain ground, for which a bounty is parable on exportation," \&e.-it is stated that doubts had arisen, and these the present Act now solved.

'53 .... B 26 George II, cap. 15 - "An Act for allowing interest upon certain debentures for the bounty granted on the exportation of Corn "-It appears that at certain ports whereat the collectors had not in hand at the time of export sufficient funds to pay the bounties prorided by some of the Acts cited for the export of com, certificates were to be given, and these certificates, with debentures attached, were to be presented for payment to the general receiver or eashier of the customs; but the amount of corn exported had been so large that the funds for the purpose were exhausted, and it was therefore now enacted that all debentures six months or more overdue carry interest at the rate of 3 per cent. per anmm. Notice was to be given when treasury could pay off debentures.

'5f .... There were several cnactments this year which require to be reriewed:-

1. The 30 George II, cap. 1-"An Act to prohibit for a time, to be limiterl, the exportation of Corn, Malt, Meat, Flour, Bread, Biscuit, and starch"-it is enacted that the exportation of the same be greatly prejulicial to His Majesty's subjects, and is therefore prolibited from Great Britain and lreland up to 25 th December the next ensuing; exception in favour of grain earried coastwise, and to certain Britisl Isles.

2. The 30 George II, cap. 7- "An Act to discontinue for a limited time the duties upon Corn and Flour imported; and also upon such Corn, Grain, Meat, Bread, Biscuit and Flour, as have been or shall be taken from the enemy, and brought into this kingrom."

3. The 30 George I1, cap. 9-"An Act to prohibit for a limited time the exportation of Com, Grain, Meal. Malt, Flour, Bread, Biscuit, Starch Beef, Pork, Bacon, and other Tictual (except Fish, Roots and Rice, to be exported to any part of Europe sonthward of Cape Finisterre) from His Majestr's colonies and plantations in America, unless to Great Britain or Liveland, or to some of the said colonies and plantations, and to permit the importation of Corn and Flour into Great Britain and Ireland in neutral ships; and to allow the exportation of Wheat, Barles, Oats, Meal and Flour from Great Britain to the Isle of Man, for the use of the inhabitants there."

4. The 30 George II, cap. 14-"An Act for continning an Act of this present session of parliament, entituled, 'An Act to discontinne for a limited time the duties upon Corn and Flour imported; and also upon such Corn, Grain, Meal, Bread, Biscuit and Flour as hare been or shall be talien from the enemy, and brought into this kingdom." Recited Act contimued to 15th Norember, 1757.

There are sereral enactments also this year:-

1. The 30 George 11, cap. 7- "An Act to discontinne for a limited time the duties upon Corn and Flour imported; and also upon such Corn, Grain, Bread, Biseuit and Flour, as have been or shall be taken from the enemy, and brought into this kingdom." simply recites"Whereas the discontinuing of the duties for a limited time upon corn and flour imported into this kingdom, and also upon such corn, grain, meal, bread, biscuit and flour, as have been or shall be taken from the enemy and bronght into this kingdom, mas be of adrantage to His Majesty's subjects," and it is therefore enacted accordingly. 


\section{Table X.-Restrictions on the Export or Import of Grain-Contd.}

A.D. 1757 whereas by an Aet passed this present sesion of parliament, entituled, 'An Aet to prolibit,' \&e. [30 George II, cap. 1] . . . it was enacted that no person at any time before the 25th December, 1757 , should export or curry out of or from the kingdoms of Great Britain or Ireland, any sort of corn, malt, meal."

3. By 31 George II, cap. 1, each of the two last Acts were continued in foree to 21 th December, 1758 ; and all duties upon grain imported were discontimued; with an exception in favour of His Majesty, "with advice of priry council, to order and permit the exportation of such quantities of the commodities aforesaid as may be necessary for the sustentation of any forces in the pay of Great Britain, or of those of His Majesty's allies acting in support of the common cause." The parment of bounts during the continuance of this Act prohibiter.

4. The 31 George II, eap. 28-"An Act to permit the importation of Salted Beef, Pork and Butter from Treland for a limited time, viz., for five months."

5. The 31 George II, eap. 37-"An Act to permit the exportation of certain quantities of Malt now lying in His Majesty's storelonses; and to allow the bounty upon such Corn and Malt as was shipped and cleared for Ireland, on or before a limited time; and to authorise the transportation of Flour, Meat, Bread and Biseuit to the islands of Guernsey and Jersey, for the ne of the inhabitants there, in lien of the Wheat, Malt or Barley which may now, by law, be transported to those islands." By this enaetment the merehants of Forwich and Yarmouth were permitted (sec. 1) to export to Holland, within a limited time 200 lasts of long malt, lying in the king's storehouses, whieh were entered for exportation on or before 31st Jannary, 1757, they giving security for the due loading, se., to Holland; and (see. 4) the inhabitants of Lynn and Wells (Norfolk) were permitted to export to Holland, under like regulations, 350 lasts of malt, lying in the king's storehouses; while libcrty was also granted (see. 6) of exporting from the port of Southampton within a limited time, and in limited quantities, meal, flour, bread or biscuit, for the use of the inhabitants of Jersey and Guernsey; $70 \mathrm{lbs}$. avoirdnpoise weight to be deemed equal to a bushel.

There were again sereral enaetments bearing upon the importation and exportation of food, grain, meat, \&e. :-

1. The 32 George II, eap. 1, "An Aet to contime for a limited time the det marle in the last session of Parliannent, entituled, 'An Act to permit the importacion of Salted Becf, Pork and Butter from Ireland, for a limited time, and to amend the said det." "This Act in its second reeital says, "And whereas doubts have arisen whether all kinds of salted pork, and hogmeat, may be imported from Ireland by virtue of the above recited Act," and it was therefore enacted that ail kinds of salted pork and "hogmeat," might be imported.

2. The seareity of grain being still felt, the Acts of last session were continued in foree by 32 George II, eap. 2 , "An Act to continue for a further time the prohibition of the exportation of Corn, Mall, Meal, Flour, Bread, Biscuit, and Starch," till the 24 th Dceember, 1759 , "unless the term should be abridged by parliament, or proelamation, or Order of Couneil."

3. But in the meantime, as grain beeame abundant in quantity, and reduced in price in a corresponding degrce, there wis cnacted 32 George II, eap. 8, "An Act for taking off the prohibition on the exportation of Corn, Malt, Meal, Flour, Bread, Biscuit, and Starch."

4. "An Aet to permit the free importation of Cattle from Iielaind for a limited time, viz., for five years, from Ist May, 1759, duty free."

The det for diseontinuing the duties on grain imported was allowed to expire. 
TABLE X.-Restrictions on the Export or Import of Grain-Contd.

A.D.

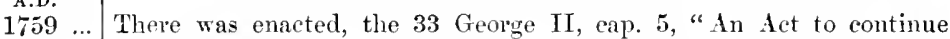
for a limited time the importation of Salted Beef, Pork, and Butter from Ireland."

'60

There was enacted, 1 George III, eap. 4, "An Act to contmue for a limited time the importation of Salted Beef, Pork, and Butter from Ireland," and the time was continuel to 21 th Deeember, 1761.

Note.-Mr. Comber estimated the arerage annmal produce of wheat at this date in Great Britain at 3,800,000 quarters, of which about $3,500,000$ were requiled for home consumption; and 300,000 quarters were left for export.

There was enacted, 2 Georqe III, eap. 6, "In Aet for the Importation of Salted Beef, Pork, and Butter ints the Kingdom from Ireland, for a limited time, for the suppls of His Majestr's Ships, Transports, and other Ships and Vessels in His Majesty's service and par."

There was enacted, 4 George III, cap. 25, "In Act to enable His Majestr, with the adrice of his plisy council, to order the importation of Proxisions from Ireland during the next recess of Parliament mder eertain restrictions and regulations tlerein mentioned;" the preamble whereof recites, "Whereas the price of prorisions is at present high, and may become higher; that it greatly alfects the poor people, and will tend to hurt the trade and manufacture of this kinudom if not timely prerented," therefure IT is Majests was enabled, with the adrice of his priry council, to order the importation of salt proxisions from Ireland during the recess of Purliament; and all persons were exempted from duties and from penalties on account of such importation, otler than the following duties to the commissioners for the duties on salt, riz.. $3 s .4 d$. per barrel on beef and pork, and $1 s .3^{d}$. per cwt. for all dried beef, neats' tongues, and hogmeat, and $4 d$. per cwt. for salted butter; to be paid into the exchequer as part of the duties on salt.

The $n$ casmles before parliament on the food question this year were:-

1. The 5 George IIT, eap. 1, "An Act for importation of Salted Beet, Pork, Pacon, and Butter from Ireland for a limited time, riz., fur twelve months from date of Aet, on paring salt Duties."

2. The 5 George III, cap. 10, "An Act to permit the free importation of Cattle from Ireland." This importation was to continue for seren sears without payment of duties.

3. 5" George III, cap. 31 , "An Act to diseontinue for a limited time the duties upon Wheat and Wheat Flour imported, and also the bount y parable on exportation of Wheat and Wheat Flour."

4. The 5 George III, cap. 32, "An Act to enable His Majesty, with the atrice of his Priry Council, to prohibit the exportation of Wheat, ITheaten Mcal, Flowr, Bread, Biscuit, and Starch, during the next recess of Parliament, at such time aul in such mammer as the necessity of the time may require, and he, in his wisdom, shall think convenient and needful."

'66 .... The following Acts formed part of the legislation of this session :-

1. The 6 George III, cap. 1, "An tet to continue an Act made in the last session of Parliament, intituled 'An Act for importation of Salted Beef, Pork, Bacon, and Butter from Ireland for a limited time." ",

2. The 6 George III, cap. 3, "In Aet for allowing the importation of Corn and Groin from His Majesty's Colonies in America into this Kingdom, for a limited time, free of duty."

3. The 6 George III, cap. 4, "An Act for allowing the importation of Oats and Oatmeal into this Kingdom, for a limited time, dnty free."

4. The 6 George III, cap. 5, "An Act to prolibit the exportation of Corn, Grain, Malt, Meal, Flour, Bread, Biscuit, and Starch for a limited time." 


\section{Table X.-Restrictions on the Export or Import of Grain-Contd.}

A.D. 1766

5. This last Act was amended by an Act of the same session, 6 George IV, c. 40 , to the extent of allowing wheat to be exported from Sonthampton and Exeter for the use of the inhabitants of the Isle of

Man, but not to exceed in the whole 2,500 quarters.
The legislation of this year embraced the following :-

1. The 7 George 1IL, cap. 1, "An Act to continue an Act made in the

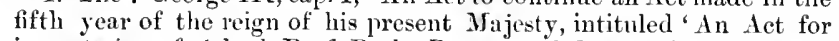
importation of Salted Beef, Pork, Bacon, and Butter from Ireland, into this Kingdom for a limited time.",

2. The 7 George III, cap. 3, "An Act to prohibit for a limited time the exportation of Corn, Gruin, Meal, Malt, Flour, Bread, Biscuit, and Starch, and also the extraction of Low Wines and Spirits from Wheat and Wheat Flonr."

3. The 7 George III, cap. 4, "An Act for allowing the importation of Wheat and Wheat Flour from Ilis Majesty's Colonies in America, for a limited time, free of duty."

4. The 7 George III, cap. 5, "An Act for allowing the importation of Wheat and Wheat Flour from any part of Europe into this Kingdom, for a linited time, free of duty."

5. The 7 George III, cap. 8, "An Act for allowing the importation of Oats and Oatmeal, Rye and Ryemeal, into this Kingdom, for a limited time, free of duty."

6. The 7 George III, cap. 11, "An det for allowing the importation of Wheat and Flour, free of duty, from any part of Europe, for a further time than is allowed by any tet made in this session of par. liament, and for permitting the tree importation of Barley, Barleymeal and Pulse into this Kingdom, for a limited time."

7. The 7 George III, cap. 22 , "An Act for further allowing the importation of Wheat and Wheat Flour, Barley, Barleymeal, and Pulse, free of duty, into this Kingdom, from any part of Europe."

8. The 7 George III, cap. 30, "An Act for allowing the free importation of Rice, Sago Powder and Vermicelli, into this Kingdom from His Majesty's Colonies in North America, for a limited time."

9. The 7 George III, cap. 36 , "An Act to continue so much of an Act made in the thirty-third year of the reign of his late Majesty, as relates to the free importation of Cochineal and İndigo, and for allowing the Bounties granted by any Acts of Parliament now in being upon the exportation of Corn and Malt declared or made for exportation, and Barley steeped and entered at the Excise Office to be made into Malt for exportation, for a limited time."

10. The 7 George III, cap. 45, "An Act for encouraging and regulating the Trade and Manufactures of the Isle of Man, and for the more easy supplying of the inhabitants there with a certain quantity of Wheat, Barley, Oats, Meal, and Flour, authorised by an Act made in the last session, to be transported to the said Island."

11. The 7 George III, cap. 54, "An Act (inter alia) for empowering His Majesty, with the advice of his Privy Council, to permit the importation of any sort of Corn or Grain, duty free, into this Kingdom, for a longer time than is permitted by any Act of this session of Parliament."

But this was not all. Owing to the high price of food and the riots and tumults that ensued, the privy council, on the 26th September, before the meeting of parliament (which usually then assembled at the commencement of the winter season) issued a proclamition, laying an embargo on the exportation of wheat and flour, and prohibiting the use of that grain in the distilleries. By this exercise of the dispensing power, under the plea of its being impracticable to take the advice of parliament-whilst the meeting of parliament had been by a like proclamation postponed from 16 th September to 11th 


\section{TABLE X.-Restrictions on the Export or Import of Grain--Contd.}

A.D. 1767

-

'68...

The legislation of this year consisted of :-

1. The 8 George III, cap. 1-"An Aet to continue and amend the Aet made in the last session of Parliament, to prohibit, for a limited time, the exportation of Corn, Grain, Meal, Malt, Flour, Bread, Biseuit and Stareh, and also the extraction of Low Wines and Spirits from Wheat and Wheat Flour."

2. The 8 Geurge III, cap. 2- "An Act to comtinue sereral Aets made in the last session of parliament, for allowing the importation of Wheat, Wheat Flour, Barley, Barley Meal, Pulse, Oats, Oatmeal, Rye, and Rre Meal, duty free; and also so much of an Act made in the same session, as relates to the free importation of Rice, from His Majestr's eolonies in North America; and to allow the importation of Wheat and Wheat Flour from Africa, for a limited time, free of duty."

3. The 8 George III, cap. 3-"An Act for the free importation of Indian corn, or Maize, from any of His Majesty's eolonies in America, for a time therein limited."

4. The 8 George III, eap. 4-" An Act to continue and amend an Act made in the fifth year of the reign of $\mathrm{His}$ present Majest 5 , intituled, 'An Act fur importation of Salted Becf, Pork, Bacon, and Butter, from $I r+$ land, for a limited time ;' and for allowing the importation of Salted Beef, Pork, Bacon, and Butter, from the British dominions in America, for a limited time."

5. The 8 George III, eap. 24- An Act to permit the exportation of eertain quantities of Malt, belonging to certain merchants, in the counts of Norfolk, and which were made for exportation between the 15th Norember, 1876, and the passing of this Act of last session for prohibiting the exportation of Malt."

6. And in a special session held in May, of the 8 George III (sess. 1), cap. 1-"An Act for further eontinuing certain laws, to prohibit for a limited time, the exportation of Corn, Grain, Meal, Malt, Flour, Bread, Biscuit and Stareh, and also the extraetion of Low Wines and Spirits, from Wheat and Wheat Flour; for further allowing the importation of Wheat and Wheat Flow, Barles, Barley Meal, and Pulse, free of dut $y$, into this Kingdom, from ans part of Europe; and for allowing the importation of Oats and Oatmeal, Rye and Ryemeal, into this hingdom, for a limited time, free of duty, and also for eontimuing such other laws as will expire before the beginning of the next session of Parliament."

'69....

1. The 9 George III, eap. 1-"An Act to prohibit for a further time the exportation of Corn, Grain, Meal, Malt, Flowr, Bread, Biscuit and Starely; and also the extraetion of Low Wines and Spirits from Wheat, and Wheat Flour."

2. The 9 George III, eap. 4-"An Aet to allow for a further time, the free importation of rice, into this Kingdom from His Majesty's colonies of North America."

3. The 9 George III, eap. 9-" An Act to continue an Act made in the eighth rear of the reign of His present Majesty, intituled [8 George III, eap. 9], "An Aet for importation of Salted Beef, Pork, Baeon and Butter from Ireland, for a limited time; and for allowing the importation of Salted Beef, Pork, Bacon and Butter from the British dominions in America for a limited time."' 


\section{Table X.-Restrictions on the Export or Import of Grain-Contd.}

A.D. Again there were sereral measures relating to exportation and importation of grain, \&e.

1. By 10 George III, cap. 1-“An Act for continuing an Act'made in the last session of Parliament, to prohibit, for a further time, the exportation of Corn, Grain, Meal, Malt, Flour, Bread, Biseuit, and Starch; and also an extraction of Low Wines and spirits from Wheat and Wheat Flour."

2. By 10 George III, cap. 2, the right to import eertain salted prorisions from Ireland and the British dominions in America was continued to 1st March, 1771.

3. The 10 George III, cap. 10-" An Act to permit the exportation of Malt."

4. A new feature, that of statistical returns of exports and imports, was introduced by 10 George III, cap. 39- " An tet for registering the prices at which Corn is sold in the sereral counties of Great Britain, and the quantity exported and imported"-it is recited: "Whereas a register of the prices at which cor"n is sold in the sereral counties of Great Britain will be of publie and general adrantage." It then enacts that justices at quarter sessions were to order weekly returns to be made of the prices of wheat, rye, barley, oats, beans, and bigg from not less than two or more than six markets in each county ; and to appoint persons to make such returns. Meal-weighers in London to make return. An aecount of the quantities of corn exporter and imported, and of the bounties and duties paid and reeeived, was to be transmitted anmually to the Treasury by the commissioner's of customs.

This year there was enacted rarious measures relating to food supply.

]. The 11 George III, cap. 1- "An Act to eontinue the prohibition of the exportation of Corn, Grain, Meal, Hlour, Bread, Biseuit, and stareh, and also of the extraction of Low Wines and Spirits from Wheat and Wheat Flour for a further time; and also to prohibit the exportation of Walt for a limited time."-There were exceptions made in farour of ressels laking such stores as were necessary for their royages; also for His Majesty's ship; of war, \&e., forces or garrisons; ulso as to such rietuals earried constwise; also for exportation from Ireland to Great Britiin, or vice versa ; or to Gibraltar, America, or British colonies in Ameriea, or to the British fishery there; also exception for beans exported to the British forts in Afrien, or as to any of the said commodities exported by the East India Company to their forts; also as to wheat, flour, malt, barley, bread, biseuit, or peas exported from Southampton to Jerser, Guernsey, and Aiderney, \&e., for the use of the inhabitants there only, not exceeding 5,000 quarters in the whole; and for wheat, barley, oats, and meal or flour from Whiteharen or Liverpool to the Isle of Man for the use of the inhabitant there, not exceeding in the whole 2,500 quarters, of which equal moieties were to be shipped trom Whiteharen and Liverpool ; also for bread and biscuit, not exceeding fifteen tons, sent by the Committee of African Merchants to their forts, \&c., in Africa. The commissioners of eustoms to return aceount to parliament of all eorn, \&c., so exported. There was to be no prohibition against exporting rice. This measure, in fact, nainly eonsisted of exceptions to the rule it laid down, and so indicates that difficulties were being felt.

2. B5 11 George III, eap. 8, the importation of salted prorisions from Lreland and America was permitted until 1st Mareh, 1772.

3. A new feature was now introdueed. By 2 George III, eap. 37"An Act to prohibit the exportation of Live Cattle and other Flesh Provisions from Great Britain for a limited time"-viz., to the twentieth day after the commencement of the next session of parliament, 


\section{TABLE X.-Restrictions on the Export or Import of Grain-Contd.}

A.D.

1771

with certain exceptions in farour of ships of war, and in favour of cattle, \&e., sent to Gibraltar, Minorca, or America.

There were again sereml measures this year.

1. The 12 George III, cap. 1, continued the Act against exportation, chapter 1, of last session, over to next session, with certain slight amendments.

2. The 12 George III, cap. 2, continued the Act permitting im. portation of salt provisions from Ireland and America till 1st Mareh, 1773.

3. The 12 George III, eap. 60, allowed the importation of rice from the British plantations into the ports of Bivistol, Liverpool, Lancaster, and Trhitehaven "for immediate exportation to foreign parts."

4. See Forestallers, \&c., Table No. 12, for another Act of this year. There were again several important measures as to importation and exportation of food.

1. The 13 George III, cap. 1-"An Aet for allowing the importation of Wheat, Wheat Flour, Rye, Rye Meal, Barley, Barley Meal, Oats, Oatmeal, Peas, Beans, Tares, Callivancies, and all other sorts of Pulse from ans part of Europe or Africa into this lingdom for a limited time, fiee of duty"-riz., at any time bufore 1st January, 1774. Entry to be made of all such imports in the form heretofore in use, otherwise such wheat, \&c., should be subject to duties previously parable.

2. The 13 George III, eap. 2-"An Act for allowing the importation of Wheat, Wheat Flour, Indian Corn, Indian Meal, Biscuit, Pease, Beans, Tares, Callivancies, and all otleer sorts of Pulse from His Majesty's Colonies in America into this Kingdom for a limited time, free of duty"-riz., from 1st December, 1772, to 1st January, 1774 . Entry to be made as formerly, or duties to be eharged. Such grain might be earried coast wise.

3. The 13 George III, cap. 3-" An Act to prolibit the exportation of Corn, Grain, Pease, Beans, Meal, Malt, Bread, Biscuit, and Starch, and also the extraction of Low Wines and Spirits from Wheat Flour for a limited time" - vi of this Act all grain loaded on any ship for exportation to be forfeited. The exceptions were much the same as in 11 George III, cap. 1.

4. The 13 George III, cap. 4, continued the license to import salt provisions from Iieland and America till 1st Mareh, 1774.

5. The 13 George III, eap. 7- "An Aet for allowing the free importation ol Rice into this Kinglom from any of His Majesty's Colonies in America for a limited time, and for encouraging the making of Starch from Rice" - riz., at any time before 1st Mar, 1780.

6. The legislature began to grow weary of such hand-to-mouth measures as had now continued over quite a series of years, and hence there was enacted the 13 George III, cap. 43- "An Act to regulate the importation and exportation of Corn." It is recited as fullows:-

"Whereas the several dets of parliament heretofore madeconcerning the duties and bounties respectirely payable on the importation and exportation of corn and grain have greatly tended to the adrancement of tillage and nirigation; yet nevertheless it having been of late years found necessary, on account of the small quantities of corn and grain in hand, and of the shortness of the crops, to suspend the operations of those laws by temporary statute, whereby the benefits derived from the said Aets of parliament have been during such emergencies withheld and suspended; and whereas the regulating the importation and exportation. of corn and grain by a permanent law, under such generul rules and provisions as might render for the time to come such temporary laws umecessary, would afford encourage- 


\section{TABLE X.-Restrictions on the Export or Import of Grair-Contd.}

A.D.

1773 ment to the farmer, be the means of increasing the growth of that supuly to the poor, and preventing abuse in that article of tricle. May it therefore please Your Majesty, \&c."

It was then enacted that no British wheat be exported when at $44^{s}$. per quarter; rye, peas, or beans when at $28 s$.; barley when at $22 s$.; nor oats when at I 4 . per quarter, under penalty of forfeiture of $20 s$. per bushel, and the ressel in which the same should be carried. There were exceptions as to export to Ireland and to certain British forts and islands specified with great precision.

After 1st July, 1774, as in 11 George III, cap. 1, the former scnle of bounties for exports were to ccase, and a new scale to take eflect.

7. The 13 George III, eap. 72 - "An Act to permit the free importation of Cod Fish, Ling, and Hake caught and cured in Chaleur Bar, or any uther part of the Gulf of St. Laurence, or on the coasts of Labrador."

The produce of wheat in Great Britain was stated in the House of Commons to be 4,000,000 quaters, of which the whole, and abore 100,000 imported quarters, were consumed.

7. ... By 14 George III, cap. 64-"An Act to explain so much of an Act made in the last session of Parlian:ent (intituled, \&c.), as relates to the method of ascertaining the prices of Corn "- it is set forth that after 1st Jume this year the prices of corn, grin, \&e., should mean the "arerage prices" under the regulations therein stated. In cases where the prices of grain rose within the probibited schedule within twenty days after entry at custom house, the shipping might proceed.

... By 15 George III, cap. 1-“ An Act to allow the importation of Indian corn and maize, under certain restrictions "- it is reeited :-

"That under the Act of 1773 (cap. 43), the mention of Indian corn was omitted," and it was therefore now enacted that this might be imported, paying $I d$. per quarter, under the like regulations as barley in the Act of 1773 .

.... By 19 George III, cap. 25-" An Act for granting to His Majesty additional duties upon the produce of the sereral duties under the management of the respective companies of the Customs and Excise of Great Britain "-an additional duty of 5 per cent. of the former duty was laid on all goods imported into, or exported from, or carried coast wise in Great Britain.

The 20 George III, eap. 31- "An Act for allowing a bounty on the exportation of British Corn and Grain in ships, the property of persons of any kingdom or State at amity with his majesty"recites :-

"Whereas much of the shipping of this kingdom, built in times of peace for the purposes of commerce, is now at the present time of war and hostilities, employed in transporting your majesty's troops and stores, and many ships and ressels, through the spirited exertions of your majesty's subjects, are converted into prirate ships of war, as also great number's of seamen, taken from the merchant serrice, are in like manner employed, and whereas, from these and other effects of the war, the exportation of corn and grain from Great Britain is so far interrupted, that it cannot now with advantage to the farmer and merchant, notwithstanding the bounty granted thereon, be exported in British shipping, the master and two thirds at least of the mariners being your majesty's subjects."

It was therefore enacted that exporters of British corn in ressels belonging to any State in amity with his majesty, were to be allowed half the usual bounty. The said bounty to be paid under the like conditions, and as for corn reported in British shipping.

This Act was to continue until 25th March, 1781; but it was 
TABLE X.-Restrictions on the Export or Import of Grain-Contd.

A.D.

further contimed by 21 George III, eap. 29, and 22 George III, cap. 13, until 25th March, 1783.

1731 ... By 21 George III, eap. 50-." An Act for further regulating and ascertaining the importation and exportation of Corn and Grain, within several ports and places therein mentioned "- -so mueh of the Acts of $1685,1732,1766$, and 1773 as related to determining the price of miduling English wheat in Kent, Essex, and London was repeated, and the prices in these plices were in future to be regulated by the prices ascertained in the city of London by the inspector of the returns of the factors in the corn exchnnge.

'82 ... By 22 George III, cap. 66-" An Act for granting to His Majesty additional duties upon the produce of the several duties under the management of the respective commissioners of the Customs and Exeise in Great britain "-from 25th July this year an additional duts of 5 per cent. of former duties was laid upon all goods imported into, or exported from, or carried coastwise in Great Britain.

'87 ... The 27 George III, eap. 13, wis an A.t for repealing the several duties of customs and excise, and grunting other duties in lieu thereof. Under this Act a rery small addition was made to the former duties on grim imported or exported. See supplemental table at end of this table.

'89 .... Br 29 George III, eap. 58-"An Act for better regulating and ascertaining the importation and exportation of Corn and Grain; also for the better regulating the exportation of Starch and the importation of Rape seed"-the regulations of the Act of 1781 were modified to the extent that the inspector of corn returns was to receive from esery com factor in Lonton and the suburbs a weekly return of the corn brought into the Thames eastward of London Bridge which was sold by him during the preeeling week. One halfpenny was to be charged on every "last" contained in such returns, or $1 d$. if foreign corn; with many other most elaborate details.

"G1 .... There was enacted 31 George III, cap. 30-"An Act for regulating the importation and exportation of Corn, and the payment of the duty on foreign Corn imported, and of the bounty on British Corn exported"-which recites:

"Whereas the laws nuw in force regulating the importation and exportation of corm, and the parment of the duty on foreign corn imported, and of the bounty granted on Britisb com exported, require amendment; and it is expedient that certain parts of the said laws should be continued, and new provisions male, and that the same should be comprised in one Act of Parliament."

It therefore enacted the repeal of the Acts of $16 \div 5,1658,1732$, $1770,1773,1781,1789$, and all other Acts relating to the importation of grain of all kincls. The prorisions of the Aet of 1663 as to buying corn to sell again, and hyying it up in granaries, were also repealed. Then follow a long series of most elaborate regulations in riew of the purposes of the Act, extending in all to $9+$ sections, now long since happily repealed. Permission was given to export from the port of Southampton to the Channel Isles 9,800 quarters of grain, meal, \&c., within two sears, and no more. Malt made for export exempted from operation of Act.

'92 ... By an Order in Council, under date 9th Norember this year, the exportation of wheat or Hour was prohibited until 1st March, 1793.

'93 ... In consequence of the last step, the formula of 1767 had to be repeated, and there was enacted 33 George III, cap. 3-" An Act for indemnif ring all Persons who have been concerned in advising and carrying into execution an Order in Couneil respecting the exportation of Wheat and Wheat Flour, for presenting suits in consequence of the same, and for making further provisions relative thereto; and 


\section{Table X.-Restrictions on the Export or Import of Gircin-C'ontel.}

A.D. 1793

also for anthorising ITis Majesty to prohibit the exportation of Corn, Meal, Flour, Bread, Biseuit, and Potatoes, and to permit the importation of Corn, Meal, or Flour on the low duties" -which r"ceites, "And whereas the said Order eamnot be justified by law, but wes so much for the service of the public, and so necessary for the safety ant preserration of His Majesty's subjects, that the same ought to be justified by an Act of parliament, and all persons issuing, adrising, or acting under or in obedience to the said Order respectively indemnified." All of which was aecordmgly done. Until 1st Marcli, 1793 , all wheat, \&e., exported out of Great Britain, or shipped with that intent, to be forfeited, as also the vessel. There were exceptions in eonformity with 31 George III, cap. 30.

93 .... B5 33 George IlI, eap. 65. The same session there was enated an Aet to amend the Act of 1791 , whereby many of the provisions of that Aet are repealed and others substituted, in reurard to the receirership of "Corn returns," from which to deduce the weckly prices. This Act eonsisted of twenty-one sections, some of them very eomplex.

95 .... There was enacted 35 George III, eap. 4-"An Act for enabling IIis Majesty to prohibit the exportation, and to permit the importation of Corn, and for allowing the importation of other artieles of provision, for a limited time, without payment of duty." His Majesty might order the taking out foreign eorn from wareliouses for home eonsumption. Certain aricles might also be imported into Great Britain from any place, in British ressels, or ressels belonging to places in amity with His Majesty, duty free. The artieles enumerated in this Aet eonstitute the following extended list, in acidition to the various kinds of grain, viz., beans, ealled kidney or Freneh beans, tares, lentils, eallivancies, and all other sorts of pulse; and also bulls, eows, oxen, calves, sheep, lambs and swine; beef, pork, mutton, real, and lamb, whether silted or otherwise ; bacon, hams, tongues, butter, eheese, potatoes, rice, sago, sago powder, tapioea, vermicelli, millet seed, poultry, fowlo, egirs, game, and sour-crout.

There were several measures relating to food supplies, one embodying an entirely new feature, viz., Bounties on Imports.

1. The 36 George III, eap. 3-"An Aet to prohibit the cxportation of Corn, Meal, Flour and Potatoes, and to permit the cmportation of Corn, and other articles of provision for a limited time in any ships whatever, without payment of duty." There was no new feature.

2. The bounty system was now to be tried in relation to imports, by the 36 George III, cap. 21-" An Aet for allowing bounties for a limited time, on the importation into Great Britain of any Wheat, Wheat Flour, Indian Corn, Indian Meal, and Rye." It was, howerer, specified what maximum quantities might be so admitted from different parts of the globe, as :

$a$. From Europe, sonth of Cape Finistere, from the Mediterranean, or Afriea, not exceeding 400,000 quarters (of $2 \frac{1}{2}$ ewt., avoirdupoise, per quarter), at a bounty of $20 s$. per quarter.

b. From other parts of Europe to the extent of 500,000 quarters (same weight) a bounty of $15^{s}$. per quarter, or 4 . $6 d$. on every ewt. of wheat flour.

c. From His Majesty's colonies, 500,000 quarters (same weight), a bounty of $20 s$. per quarter, or $6 s$. per cwt. on wheat flour.

On all quantities in exeess of those speeified the bounties were to be Ios. per quarter only. A bounty of $5 s$. per quarter on Indian eorn and meal, up to 500,000 quarters, and then reduced bounty; and a bounty of $10 \mathrm{~s}$. per quarter on rye, up to j00,000 quarters, and then reduced. 


\section{TABLE X.-Restrictions on the Export or Import of Grain-Contd.}

A.D.

1796

There were again several enaetments on food supply-one suspending the Bounty det of last session.

1. The 37 George III, (ap. 7-_An Aet to eontime for a limited time, and amend an Act made in the last session of parliament, intituled an Act $[36$ George III, cap. 3]; and for permitting Wheat, Wheat Flour, and Meal, imported in order to obtain the bounties granted by an Act of the last session of Parliament, but whieh have not been found fit for making Bread, to be used in the manufacture of Stareth, Hair Powder, and BIue, or in the distillation of Low Wines and spirits." This right to be extended to 1st February, 1797.

2. The 37 Gcorge III, eap. 15- "An Act for granting to IIis Majesty certain duties of customs on goods, wares, and merehandise imported into, exported from, or brought and earried constwise within Great Britain, exeept wines and coals"-an additional duty of 5 per cent. on former duties on goods imported, including grain (and Io per cent. on certain other goods), was imposed.

3. It scems that the bounty had done its work effectively, while the harrest prospects were also probably good, for by the 37 George III, eaj. 83-"An Act to repeal so much of an Act jussed in the present session of parliament, as prohibits the exportation, and permits the importation, duty free, of several sorts of Corn, and other arti les made trereof" -And which received royal assent 18 th June, it is recited, "and whereas since the passing of the said Act the prices of sererul of the sorts of corn therein mentioned, have been considerably diminished," therefore, after 16th Jume, "so much of the said det as relates to importation and exportation, and the earrying constwise of barley, beer or bigg, pease, oats, or any meal, flour, bread, tiscust, or malt made thereof, shall be, and the same is bereby repealed." No such articles entered for exportation before 6 th February, 1798, to be entitled to bounts.

4. The 37 George III, eap. 125-" $\mathrm{An}$ "Act for authorising His Majesty to permit the exportation of an additional quantity of Wheat, Wheat Meal, or Flour, Rye, Barley, or Malt, or Bread, Biscuit, or Pease, to the Islands of Guernsey. Jersey, and Alderney, for the sustenance and use of the inhabitants of the said islands, for a limited time"-recited that it was expedient to allow a greater quantity of corn and other articles to be exported to the Channel Islands than had been provided for moler the Aets of 1791 and 1793 (cap. 65), and the quantity was extended to 10,000 quarters.

.... There was enacted 38 George III, cap. 10-"An Act to contimue until 


\section{TABLE X.-Restrictions on the Export or Import of Gruin-Contd.}

A.D.
1797

'99

1800

the expiration of six weeks from the commencement of the next session of parliament, so much of an let passed in the session of parliament of the 36 th and 37 th years of his present Majesty, cap. 7, viz., on the 11th Norember, 1796, as relates to the exportition and carrying eoastwise of Wheat and Rye, and to the importation of sereral articles of provisions." It prorided that foreign wheiat or rye, or the flour, \&e., thereof, arriring at any port in Great Britain by 31st December, 1797, might be imported duty free, if proved to have been ready for sea at certain periods. During the recess of parliament His Majesty might suspend the provisions of this Act.

By another Aet of this same session, 37 Gcorge III, cap. 110, an additional duty of 5 per eent. upon former duties upon grain, \&c., was imposed.

There was enacted : 1. 39 George ILI, eap. 87-"An Aet for enabling His Majesty to prolibit the exportation, and permit the importation of Corn, and for allowing the importation of other articles of provision, without payment of duts, to contimue in force until six weeks from the commencement of the next session of parliament." But this power was not to extend to foreign corn warehoused on the conditions of 31 George III, cap. :30, and not taken out for home consumption. Copies of any order of council to be laid before parliament.

2. The 39 George III, cap. 88-"An Act for erecting the County of Edinburgh into a separate district for the purpose of regulating the importation and exportation of Corn." This was a modification of the provisions of the 33 George III, cap. 65.

This year was prolific of legislation on the famine question.

1. The 39 and 4.0 George III, c. 9 - "An Act to continue . . . . . until 30th September 1800, an Aet of the last session of parliament for enabling His Majesty to prohibit the exportation of Corn, and for allowing the importation of other articles of provisions withont payment of duty."

2. The 39 and 40 George III, cap. 29-"An Act for granting bounties on the importation of Wheat, Whenten Flour, and Rice until the 1st day of October, 1800." This bounty was to be paid according to the price of wheat as adrertised in the Gazette. (See cap. 91.)

3. The 39 and 40 George III, cap. 35-" An Act for granting a Bounty on the importation of Oats until 1st October, 1800." 'This Bounty to be under the management of the Commissioners of Customs.

4. The 39 and 40 George III, cap. 53- "An Act for granting a Bounty on the importution of Rye until the 15th day of October, 1800." Bounty to be regulated by the average price of rye.

5. The 39 and 40 George III, cap. 58-" An Act for further continuing and amending an Act made in the last session of parliament for enabling llis Majesty to prohibit the exportation and permit the importation of Corn; and for allowing the importation of other articles of provisions without payment of duty." The Act to be continued for forty days after commencement of next session.

6. The 39 and 40 George III, cap. 91-"An Act to prohibit until the 15 th day of October, 1800, the exportation of Rice." (Sec cap. 22.) No rice was to be exported after 15th July this year.

7. The 39 and 40 George III, cap. 107 " An Act to permit until six weeks after the commencement of the next session of parliament, the importation of Swedish Herrings into Great Britain."

Same year, in the autumn session of parliament, there were enacted :-

1. The 41 George III, cap. 1-“An Aet to prohibit until the 1st day of Norember, 1801, exportation of Rice; and to indemnify all 


\section{TABLE X.-Restrictions on the Export or Import of Gruin-Contd.}

A.D. 1800

persons who have been eoncerned in the prerenting the exportation thereof, or in the non performance of any contracts and agreements that shall not have been performed in consequence thereof."

2. Here we have a more comprehensive measure than any of the preceding, as it applics to fool generally. The 41 George III, cap. 2 - "An Act to authorise His Majesty from time to time to prohibit the exportation of Provisions or Food." His Majesty was allowed by Order of Council, from time to time to prohibit the exportation of any article used as food by man. There were certain exceptions not material to mention now. All such orcicrs to be laid before parliament.

3. The 41 George III, cap. 5-" An Act for continuing, until the expiration of fort y dars after the commencement of the first session of parlament that shall be begun and holden after the 1st day of September, 1801 , severil laws relating to the prohibiting the exportation, and permitting the importation of Corn and other articles of Provisions, withont payment of duty.... [See Table XIII] in that part of Great Britain called Scotland."

4. The 41 George II1, (ap. 10-"An Act for granting Bounties on the importation of Wheat, Barley, Rite, Oats, Pease, beans, and Indian Com, and of Larley, Rye, Oat and Indian Meal, and Whaten Flour mal Rice." The bounty was to be paid for grain importa between 1st Deceniber, 1800, and 1st October, 1S01, in British ressels, or ressels belonging to States at amity with $\mathrm{His}$ Majesty. The butunties were to be regulated aceording to average price in Guzette; and every corn factor in London or the suburbs was to make returns of prices and quantities of his purchases in forms provided under the Act. These to be sent to the lord mayor. This was a highly terhnical Act, consisting of 29 clauses and sohedule.

5. The 11 George III, cil]. 11-"An Aet to permit, until the 1st day of Oefober, 1s01, the importation of Ilerrings and other Fish. The prodnce of the fishery carried on in Noca Scotir, Tew Brunswick, Newfonndland, and the coust of Labsalor, into this Kingdom without paynent of cluty."

6. The 41 George IIl, cap. 12- "An Aet for making letter provision for the maintenmee of the poor, and for diminishing the consmmption of Breat Corn, by lirecting the manner of applying Parish Reliff, until the Gth chy of November, 1s'1, and from thence until the errl of six weeks after the meeting of the then next session of parliament."

7. In the rotes for supplies this rear, 11 George III, eilp. 14, was inchucled one for 50,000l., for laying in stores of fish and distributing them throughout the kingdum.

8. 'The 41 George 1Il, cup. 18, authorising the importation of Swedish herrings into this kingdom until 1st October, 1801.

9. The 41 George I1I, cap. 19-" An Act to remove donbts arising upon the construction of an Act of this session of Parliament, intituled [the 41 George IIl, eap. 10]." All grain was to be inspeeted to see if merchantable before bounty paid.

Note.-As the result of the legislation of this year, we have here given sixteen separate measures relating to food supplies, and under sercral other tables (especially Nos. 10 and 13) will be found other enactments directly the result of the then system of legislating on fumines.

'01 .... There were several measures relating to food supplies enacted this session, the first of the parliament of the United Kingdom, which causes some confusion in the numbering of the Acts: we shall add " (United Kingdon)" after-Acts of this session.

1. The 41 George 1[I, cal. 13 (United Kingdom)-"An Act for increasing the bounties grunted by an Act of the last, session of par- 


\section{TABLe X.-Restrictions on the Export or Import of Grain-Contd.}

A.D.

$1801 \ldots$

$02 \ldots$

liament, on Flour imported from America, in ships which shall hare been eleared ont between certain periods." These bounties were on a sliding scale, regulated by the price of the grain.

2. We have the new feature of granting bounty on fish. Thus, by 41 George III, eap. 77 (United Kingdom) - "An Act for allowing until the 1st day of August, 1802, the importation of certain Fish from Newfoundland and the const of Labrador, and for granting a bounty thereon." Salted salmon and cod might be imported by "British subjeets," a bonnty of 3 s. per quintal or ewt. being paid. Acts for securing duty on sait not to be affected.

3. The 41 George [II, cap. 77 (United Kingrlom) eontinued the sereral laws relating to encouraging the fisheries of Newfoundland, \&c.

4. The 41 George III, e. 99 (United Kingdom) - An Act for granting bounties for taking and bringing Fish to the eities of London and Westminster, and other places in the United Kingdom," extended the system of bounties, which, however, were not to exceed $500 \mathrm{l}$. to any one ressel, or $30,000 \mathrm{l}$. in the whole. An account to be laid before parliament.

There were again sereral enactments on food supplies, two of which fall to be noticed in this table, viz. :-

1. The 42 George III, cap. 13-“An Act to continue until the 1st day of January, 1803, and amend an Act of the 39th year of the reign of His present Majesty, for prolibiting the exportation and permitting the importation of Corn, and for allowing the importation of other articles of provision without payment of duty; and to continue for the same period an Act of the last session of parliament for prohibiting the exportation from Ireland of Corn and Potatoes, or other provisions, and for permitting the importation into Ireland of Corn, Fish, and provisions without parment of duty." Under which IIis Majesty in conncil might probibit the exportation of any article of provisions.

2. The 42 George III, eap. 35-"An Act for regulating, until the 15th day of February, 1803, the prices at which Grain, Malt, and Flour may be exported from Great Britain to Ireland, and from Ireland to Great Britain." The right to export or import being regnlated by the prices, as ascertained according to 3 L George III, cap. 30.

This year produced sereral new measures, viz.:-

1. The 43 George III, cap. 12-" An Act to continue until the 1st day of January, 1804, several laws relating to the prohibiting the exportation and permitting the importation of Corn, and for allowing the importation of other articles of provision without payment of duty."

2. The 4:3 George III, c. 13-"An Act to continne until the 1st day of January, 1804, so much of an Act made in 41st year. of the reign of His present Majesty, as relates to the prohibiting the exportation from Ireland of Corn and Potatoes, or other provisions, and for permitting the importation into lreland of Corn, Fish, and provisions withont payment of duty."

3. Here we have a further refinement of legislation in the 43 George III, eap. 14-“ An Act for continuing until the 1st day of July, 1803, an Act made in the 42nd year [42 George III, c. 35]; and to permit from and after the passing thereof, until the said 1st day of Jnly, 1803, the exportation of Seed Corn from Great Britain to Ireland, and the importation of Malt into Great Britain from Ireland." Seed corn, of British growth, might be exported from Great Britain to Ireland, in British or Irish ships, whatever might be the average price of corn; with certain special regulations when the average priee of corn should be higher than that at which corn was then allowed to be exported to Ireland. 


\section{TABLF, X.-Restrictions on the Export or Import of Grain-Contd.}

A.D.

1803

4. By 43 George III, cap. 68-" An Act to repeal the duties of customs payable in Great Britain, and to grant other duties in lieu thereof" - a slightly increased duty was imposed upon grain imported.

5. And by another Act of the same session, 43 George III, cap. 70 - "An Act for granting to His Majesty, during the present war and until the ratification of a definite treaty of peace, additional duties on the importation and exportation of certain goods, wares, and merchandise, and on the tonnage of ships and ressels in Great Britain," under which slightly additional duties were imposed on grain. Sce table at end of this table.

6. By the 43 George III, cap. 78, the Acts of 12 George III, cap. 35, and 43 George III, cap. 14, were continued until 1st July, 1804 .

7. By 43 George III, cap. 105-"An Act to permit the exportation, for two years, of a certain quantity of Corn, Grain, Meal, Flour, Bread, Biscuit or Pulse, to the Islands of Guernsey, Jersey and Aldiney, from other Ports in England, as well as the Port of Sonthampton, under certain restrictions"-it is enacted that, while the places of shipment mar be increased, the total quantity of 9,800 quarters is not to be exceeded.

1. Br 41 George III, cap. $53-$ "An Act for granting to His Majesty during the present war, and for six months after the expiration thereof by the ratification of a definite treaty of peace, additional duties on the importation of certain goods, wares, and merehandises into Great Britain, and on goods, wares, and merehandise brought or carried coastwise within Great Britain"-the increased duties on grain were considerable. See table at end.

2. Py 44 George III, cap. 4, the 39 Greorge III, cap. 82, was further continued until 25th March, 1705.

3. By 44 George III, cap. 109-"An Act to regulate the importation and exportation of Corn and the bounties and duties payable thereon," so much of the Act of 1791 as related to the prices at which corn might be exported or imported to Great Britain, \&e, was repcaled, and new regulations as to the arerage prices at which importation and exportation should be permitted were enacted. This was not to extend to the intercourse of corn between Great Britain and Irelund.

1 Br 45 George III, cap. 29-“ An Act for granting to II M Majesty additional duties within Great Britain on certain goods and merchandize imported into or brought const wise "-a further adcition was made to the duty on grain. See table.

2. By 45 George III, cap. 63, the Act of 1803 (cap. 105) was made perpetual.

3. By 45 George III, cap. 86-"An Act to explain and amend the Act mitde in the last session of parliament to regulate the importation and exportation of Corn, and the bounties and duties payable thereon," some of the regulations of the Act of 1504 were repealed, and it was enacted that the importation and exportation of corn, \&c., into and from Great Britain should be regulated by the average prices of the twelve maritime clistricts of the east and west as ascertained by the returns required by the Act of 1791. Orders in Council as to importation of corn from British colonies in America to continue in force for six months.

1. By 46 George III, cap. 42-"An Act for granting to His Majesty during the present war and for six months after the expiration thereof by the ratification of a definitive treaty of peace, additional duties on certain goods, wares, and merchandise imported into and exported from, or brought or carried coastwise witbin Great Britain "- further additional duties were imposed upon grain imported, more especially when the price here did not exceed $60 s$. per quarter. See table. 


\section{Table X.-Restrictions on the Export or Import of Grain-Contd.}

A.D. 1806

'09

'13

2. By 46 George III, cap. 97-"An Aet to permit the frec interchange of every species of Grain between Great Britain and Ireland," it was reeited," Whereas it is expedient that the free importation and exportation of all corn and grain, meal, flowr, bread and biscnit, reciproealls to and from Great Britain and Ircland should be allowed, and that all restraints, duties, and bounties relating thereto should cease;" whereupon it was cnicted that all bounties and duties payable on interehange of corn between these two divisions of the kingdom should cease.

By 49 George III, cap. 98-" An Act for repealing the several duties of eustoms chargeable in Great Britain, and for granting other duties in lieu thereof," under "coln," in the schedule of this Aet was given the duties chargeable on each variety of grain imported, with a column of "temporary or war duty" in addition, ranging from $8 s .4$. down to $z d$. per quarter for wheat, and for other grain in proportion.

A select parliamentary committee was appointed this year to inquire into the state of the laws affecting the corn trade. This committee recommended in its report (dated 11th Mas) a vers great increase of the prices at which exportation was allowable, and when importation free of duty might take place. It will be seen by Table XIV that the home price of corn was now very high, and hence this committee exhibited a marked solicitude to exclude all forcigners from competition witl home growers. Parliament happily did not indorse this view.

By 53 George III, eap. 33-" An Act for granting certain additional duties of eustoms [on goods, \&c.] imported into, and exported from Great Britain" - a very considerable addition was made to the duty on imported grain when at priees not exceeding $65 s$. liere. See table at end of this table.

14... This rear a more enlightened policy was inangurated in a series of resolutions roted by the House of Commons, declaring that it was expedient to repeal the bounty on exportation of grain, to permit the free exportation whatever might be the home price, and to impose a graduated scale of duties on the importation of foreign corn. Com imported from Canada, or from the other British eolonies in North Ameriea, only to pay half the duties of that from other places. Two Bills embodying these provisions were introduced to the House, but one only was passed, viz. : 5 \& George III, cap. 69-"An Act to permit the exportation of Corn, Grain, Malt, and Flour from any part of the United Kingdom, without payment of duty or receiving of bounty." See 1827 .

15 ... By 55 George III, eap. 26-"An Act to amend the laws now in force for regulating the importation of Corn," it is recited: "Whereas it is expedient to amend the laws now in force relating to the importation of and trade in corn," and then enacted that foreign corn, meal, or flour might be respectively imported into the United Kingdom "for home consumption," under and subject to the provisions and regulations then in force, without payment of any duty, whenever wheat should be at or over $80 s$. per quarter, rye, peas, and beans, 50s., barley "bere or bigg" 40 s., and oats 27s. per quarter. There was, however, an exception in farour of the importation of corn, \&c., from the "British Colonies in North America." From thenee wheat might be brought in when the price was at or above $67 s$. per quarter, rye, pease, and beans, $44 s$, barley, bere or bigg, $33^{s}$., and oats, 22s. per quarter. At other times, indeed, foreign corn, \&c., might be brought in and warehoused; but it could only be taken out of warehouse for consumption when the prices were at or above those stated. This was known as Mr. Robinson's Act. There was much public disturbance while the measure was before parliament.

'17 .... By 57 George III, cap. 27-"An Act for repealing the duties of 


\section{TABLE X.-Restrictions on the Export or Import of Grain-Contd.}

A.D.

1817

customs on Buckwheat imported into this kingdom, and for granting other duties, until the 25th day of Iarch, 1821, in lien thereof "the former duties were repealed, and instead thereof a new duty of Ios. per quarter, irrespective of the price of the grain. This wheat might be warehoused, and duty paid when taken out for consumption.

By 1 and 2 George $I V$, eap. 87-"An Act to repeal certain Acts, \&e., for regulating the importation and exportation of Corn, Grain, Meal and Flour, into and from Great Britain, and to make further provisions in lien thereof," the Acts of 1791, 1793, 1804, and 1805 were repealed, and a new mode of obtaining weekly returns of the price of corn from one lundred and forts-eight forms specified in the statute was enacted. This Act consisted of fifty sections. No ground corn (except wheat, meal, or flour and oatmeal), nor malt, to be imported.

.... BY 3 George IV, cap. 60_" An Act to amend the laws relating to the importation of corn," an attempt was made to meet the rise or fall in prices of grain consequent upon importation and exportation under the previous Acts, more especially that of 1815 .

1. Br 6 George IV, eap. 6 L An Act to alter for one sear, and until the end of the next session of parliament, the duty on Wheat, the produce of the British possessions in North America," under which all duties upon the saue were suspended.

2. The fi George IV, cap. 65-" An Act to allow until the 15th day of August, 1825, the entry of warehoused Corn, Grain, and Wheaten Flour for home consumption, on pament of duty"-enacted that foreign corn warehoused hefore 13th May, 1822, and wheaten flour warehoused under 5 George $1 V$, cap. 70 , might be taken out for home consumption, at the times mentioned in the Act, notwitbstanding the 55 George III, cap. 26.

3. Ly 6 George IV, eap. 111-_An Act for granting duties of customs"- -duties on buckwheat and Indian corn were imposed, viz., buckwheat I $^{s}$. per quarter, aud Indian corn per scale.

Br 7 and 8 George IV, cap. 3-" An Act to confirm an order in council for allowing the Importation of foreign Oats, Oatmeal, Rye, Pease and Beans; to indemnify all persons who have advised or acted in execution of the same; and to permit the importation of such articles until 15th February, 1827," we arrive at a more complete idea of the inextrieable contusion which was resulting from modern attempts to regulate the pice of food by Act of parliament.

1. By 7 George IV, cap. 70-" An Act to permit foreign Corn, Meal and Flour warehoused, to be taken out for home consumption, until the 16th dar of Angust, 1836," and grain (although not adnissible under 3 George $I V$, cap. 60), warehonsed, \&e., on or before 2nd May, might be entered for home consumption, until 16th August, $18: 6$; but not more than one-half might be entered before 1st July, 1826 ; and not more might be entered after this day than was entered before it.

2. Ly 7 George IV, eap. 71-“An Act to empower His Majesty to admit foreign Com for home consumption under certain liabilities until the 1st duy of Julr, 18:7, or for six weeks after the commencement of the then next ensuing session of parliament, if parliament shall not then be sitting." His Majesty by order in council might admit warehoused wheat or flour for home consumption on payment of such duty as shall be therein declared, as to what was warehoused before 2nd May; duty nor to exceed that paid by 3 George IV, cap. 60.

By 7 and 8 George IV, cap. 57-" An Act to permit until the 1st May, 1828, certain Corn, Meal, and Flour to be entered for home consumption," it was recited: 


\section{Table X.-Restrictions on the Export or Import of Grain-Contd.}

A.D. 1827

"Whereas it is expedient to permit for a limited time certain cor" grain, meal, and flour to be entered for lome consumption, npon payment of the respectire duties hereinafter mentioned, althongh sueh corn, grain, meal, or flour may not, at the time of suclientry, be admissible for home consmmption under the provisions of the liw now in force for regulating the importation of corn, or may be admissible only on payment of higher duties."

Thus when the price was $62 s$. and under $6 \xi s$. per quarter, the duty was to be $1 l .-s .8 d$; and for every $\mathrm{I} s$. of advance in price the duty was to be decreased $2 s$. , until at the priee of $72 . s$. the import duty would only be $1 s$. per quarter. But when the price was under 62s., the duty was to be $1 l .2 s .8 \mathrm{~d}$. Barley and oats were regulated in a like manner. This was really a trial trip for the new sliding seale of 1828. [The first "sliding scale" as to duties on grain was introdueed in 1660.]

In the same year there was enacted 7 and 8 Greorge IV, eap. 58"An Act to make provision for ascertaining from time to time the average priee of British Corn," by which the Act of 1821 is repealed (except in so far as it repealed the Acts named therein), and weekly returns of the priees of British eorn were to be made from a long list of towns therein mentioned. A eomptroller was to be appointed, and a deputy if necessary ; and an inspector and deputy in London, who were not to be millers or dealers. The average prices when aseertained as the Aet direets were to be published in the London Gazette. The Act had forty-two clauses, with a full measure of penalties for non-compliance.

By 9 George IV, cap. 60-"An Act to amend the laws relating to the importation of Corn-" there came into force wliat was long designated as the "sliding seale," whereby wheat was allowed to be imported from any foreign country on payment of a duty of $1 l$. $5 s .8 d$. per quarter, whenever the averuge price of all England was under 62s. and not uuder 61s. When the price was $62 s$. and under $63 s$. , the duty was to be $1 l .4$ s. 8 d.; and thence it gradually reduced as the price rose, until it fell to $1 s$. when the average price was $73 . s$. and upwards. A scale was also applied on the same prineiple for barley, oats, rye, pease, beans, meal, \&e. This was the beginniug of the end. This Act repealed the Acts of 1815, 1822, the seeond Aet of 1827, and so much of the Aet of 1825 as related to buckwheat and Indian corn. There was a special seale of duty for grain imported "from any British possession in North Ameriea, or elsewhere out of Europe," viz., when wheat was mder $67 s$. per quarter, the duty was to be $5 s$. ; when above, $6 d$. Barley under $34 . s$. per quarter, $2 s .6 d$. duty; above, $6 d$. Oats up to $25 s$. per quarter, $2 s$.; over, $6 d$. Rye, pease and beans up to 4 is., duty $3 s$.; over, $6 \lambda$. There were new regulations for ascertaining average prices. The Act consisted of forty-eight sections and a sehedule.

By 5 and 6 William IV, eap. 13-" An Act to regulate the importation of Corn into the Isle of Man-" it is made manifest that whereas the produce of the Isle of Man could be imported into the United Kingdom without payment of any duty (and none of the many Aets recited had levied any duty upon foreign grain imported there), that a pretty brisk trade liad resulted in the shape of importation to, and exportation from thenee to other parts of the United Kingdom. This "weak plaee" was now stopped-the duties were extended to it.

This year, on the 18th September, the Anti-Corn Law Leagne, whieh sprang from rarious metropolitan and provineial associations, was founded in Manchester. Its first actire supporters were Charles Villiers, Riehard Cobden, John Bright, \&e.

42 .... By 5 and 6 Vietoria, cap. 14-" An Aet to amend the laws for the importation of Corn" - the Act of 1828 was repealed, and new pro- 


\section{Table X.-Restrictions on the Export or Import of Grain-Contd.}

A.D. 1812

risions made in lieu thereof. This was known as the "reduced sliding scale Act." The duty on wheat imporied from any foreign countr, when the price was under 5os. in the United Kingdom, was to be il., reducing $1 s$. as the price adranced up to 73 . and beyond, when the minimum dut $y$ of 18 . per quarter was reached. For barley when under $26 s$. a duty of 1 is., reducing with the advance of price up to $37 . s$, when $1 s$. minimum duty. Oats under $19 s$. duty of $8 s$, reducing with advance of price until $27 s$., when the minimum duty became $1 s$. For rye, peas, and beaus under $30 s$., duty i $s .6 d$., reducing with increase of price to minimum of is. Meal, \&e., correspondingly graduated. But when grain was imported from Britisl posses.ions, wheat under $55 \mathrm{~s}$. paid a duty of $5 \mathrm{~s}$., $58 \mathrm{~s}$. and upwards, $1 s$. Barler moler $28 s$., duty $2 s .6 d$, graduated to $6 d$. when price $31 s$. and upwards. Oats under 22s., $2 s$. dut 5 , graduated to $23 s$. when duty $6 d$. Rre, pease and beans, under 30 s., duty $3 s$., graduating to 34 s, when duty $6 d$. Meal, \&c., correspondingly graduated. Additional regulations as to corn returns; oflicer's of excise to act as inspectors; and where any foreign country shouk unfuirly surcharge British ressels arrying grain, \&e., IIer Majesty might prohibit importation from sich country. Accounts of com imported, and of duty, and rates of duty, to be published monthly. An exception in farour of the unirersities of Oxford and Cambridge as to appointment and dismissal of inspectors of corn returns for those places (section 14). There were forty-five clauses and two schedules to this Act.

The end was now near at liand. The failure of the potato crop in Ireland it this period lent a force to the free-trade morement in grain which vear's of mere controversial argument would not have given it ; and finalls this year there was enacted:

The 9 and 10 Victoria, eap. 2.2 - "An A.t to amend the laws relating to the inportation of Corn" -it was enacted that on and after 1st February, 1819, the duties upon all foreign corn imported into Great Britain and the Isle of Man shonld be is follows:-mpon wheat, barles, bere or bigg, outs, rye, pease, and beans, $1 s$. per quanter; and upon meal from any of the same $4^{\frac{1}{2}} d$. per cwt. But until that date the duty on wheat imported "from any foreign country" was to be as follows: when the arerage price under 48. ., duty ics., decreasing as the price increased to $53 \mathrm{~s}$. and upwards, when the minimm duty of 4 . per quarter came into force. A similar scale of gracluation for other kinds of grain.

By 32 Victoria, cap. 14-" An Act to grint certain duties of customs and inland revenue, and to repeal and alter other duties of customs and inland revenue"-nuder section 4 the duties and cuntoms chargeable upon con and meal in all its numerons varieties, including arrowroot, cassava powder, mandioca fluur, hair powder, scmolina, tapioca, rermicelli, \&c., \&c., were for erer swept away, as if in rengeance for the barbarities legislation in their assumed behalf had previously inroked. The remaining "shilling duty" on grain, left under the Act of 1846 , was the principal item affected. So long as it remained, a host of rexations in regard to the food substances already named, and many others, still cropped up. The full measure of free trade in food was only now realised.

Fote.- We have fult that the record of famine legislation could never be rendered complete by any means short of recording, as we have done, the titles and substances of the Acts enumerated in this and the preceding tables. What a mass of wasted legislative energ. is here represented; and now every line of it has been swept off our statute book! - thanks to the labours of the Statute Law Rerision Commission. 
TABLE X.-Restrictions on the Export or Import of Grain-Contd.

A.n.

1869 .... The following short summary of the effect of such of the statistics, in the preceding table, as make the duty payable on foreign wheat imported chepend upon the price of wheat at home, will supplement the information in the table, which was often curtailed in view of space, and of prerenting seeming repetition.

Supplement to Table X.

Rates of Duty per Imperial Quarter on the Importation of Foreign Wheat when the Price of British Wheat per Quarter was at

Acts. a

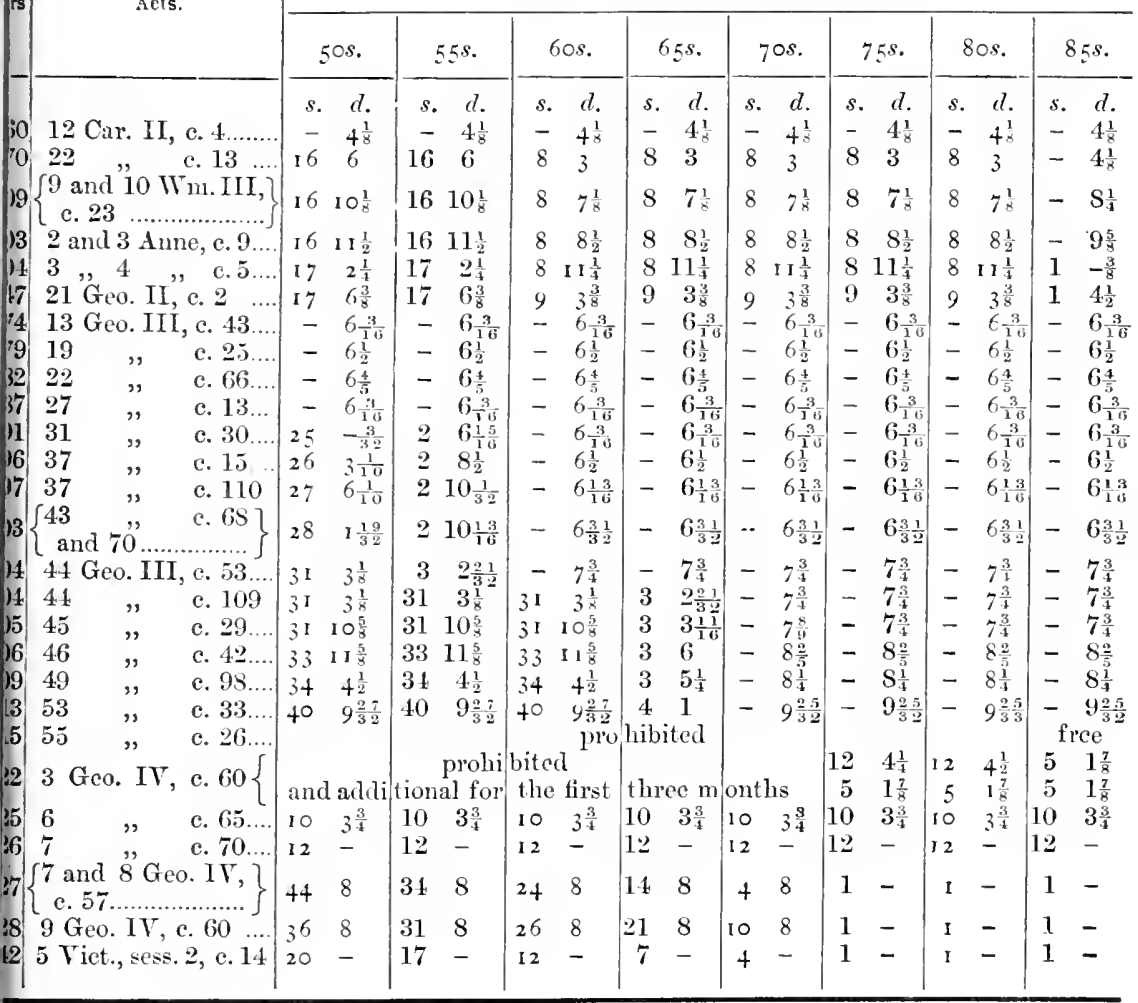

\section{X.-Currency Restrictions.}

In my Table of Famines there are sereral attributed directly to the debasing of the coinage, more particularly those of A.D. 1124, 1248,1390 , and 1586, while most authors who have written upon food supplies or upon prices, have laid great stress upon the effects of a restricted or abundant currency. Table XIV in the present paper frequently attributes the high price of wheat to the scarcity of money. 
Aristotle, in his "Economics," written B.c. 350 (Book II, chapter 24), gives an account of the manner in which Timotheus made a coinage of brass answer the purposes of his army until victory had secured a supply of silver from the conquered; but I have not been able to discover any analogy between the operation there described and the events which have occurred in our own country.

There are indeed several obvious modes in which a debased coinage may operate to the disadvantage of its holders, more especially in times of scarcity. Internally, bread being in the ordinary way purchased with coinage of small value, which is very rarely debased, when, from scarcity, it rises to a price which calls arger coinage into play, if this latter shall have been unduly debased it will not realise its nominal value in the purchase of food. It has been with silver coinage of various denominations that the trouble has nearly always risen. Externally, a more obvious sense in which debased coin (silver or gold) may operate in periods of scarcity, is that its purchasing power in all external dealings is lessened not only in the degree to which it has been debased, but even to a greater extent by the prejudice, or want of confidence its known debasement has inspired. Thus a British merchant seeking to buy grain abroad, where the coinage value will have to be measured in relation to some coin of the country wherein the purchase is made, or in relation to the standard value of the precious metals in such country, it is certain that the coin tendered will only have a purchasing power in exact relation to its intrinsic character. This latter view leads at once to the consideration of the modes by which a currency may be debased, These are four:-

1. By employing the smaller amount of pure metal in manufacturing coin having a nominal fixed value-as for instance making: 20s. currency out of silver of the value ${ }_{1} 5^{s}$. only, or any sum less than the current denomination of the coin.

2. By mixing an undue proportion of alloy (originally spelled allay) with the pure metal in any given class of coin, by which the weight is maintained, but the value deteriorated.

These may be denominated the imperial mode of producing a debased coinage. They have each been adopted on many occasions in this country.

3. By means of clipping, filing, drilling, sweating, and otherwise lowering the value of coin originally produced of the standard value.

4. By counterfeiting, i.e., by making coin of inferior metals so as to pass current for those of ordinary value, a process which has been largely applied to our coinage on many occasions. These last divisions have each to be spoken of historically.

First. Originally, as we all know, the sum which we now call a 
pound actually represented a pound troy, or 12 ozs. of standard silver, which latter consisted of 1 I ozs. 2 dwts. of pure silver, and I $8 \mathrm{dwts}$. of alloy, so that $1 l$. paid in silver money would be one pound weight of standard silver. In the year 1087 this pound troy was divided into 20 shillings exactly; by 1347 it was made into $22 \frac{1}{2}$ shillings, i.e., $\mathrm{r} l .2 s .6$ l. By the middle of the fourteenth century it was made into $25 \mathrm{~s}$; by 1412 into $32 \mathrm{~s}$. ; and ten years later, or by 1422 , into $37 s .6 d$; by 1505 into $408 . ;$ a few years after into $45 \mathrm{~s}$; and by 1543 into $48 s$. In another century no less than $72 s$. were made out of the same weight of silver; and this was the highest point ever reached, i.e., the greatest measure of debasement (in this form) to which the English coin has ever been redueed. From this extreme, a few years later, the pound troy came to be coined into 6os., and during the seventeentl and eighteenth centuries into $62 s$.

Second. The proportion of alloy remained precisely the same from the Conquest for a period of five hundred years, viz., down to 1532 , viz., $8 \mathrm{dwts}$. to the pound of silver-this alloy being of tin, and was serviceable in hardening the coin, and hence of making it more durable; but in 1543-reign of Henry VIII-the proportion was increased to 2 ozs., so that in a pound weight of standard silver there was ro ozs. only of pure silver but a few years later the standard was lowered to half alloy, i.e., 6 ozs. of pure silver, 6 ozs. alloy; and the worst had not yet come. During the greater part of the reign of Edward VI the proportion of pure silver was only one-third, viz., 4 ozs. against 8 ozs. alloy. After going up again to one-half in 1549 it descended in 1551 to one-fourth, i.e., 3 ozs. of pure silver to 9 ozs. of alloy. The ounce of standard silver thus became debased from 5 s. $2 d$., where it had remained until 1532, down to $1 s .10 \frac{3}{8} d$. in 1548 , and to $1 s .4 \frac{3}{4} d$. in 1551 , and in like manner the ounce of pure silver became increased from Is. $9 \frac{5}{5} d$. in 1087 to $24 \mathrm{~s}$. in 1551 . Bat we have seen in the previous paragraph that while all this debasement was going on, the pound of standard silver was all the time being coined into larger numbers of shillings, until at length in 1551 the shilling only weighed less than one-third of its original weight, and this reduced quantity of metal was only of one-fourth the purity of the original English coin. Herein is seen a twofold, nay, about a tenfold reason why the purchasing power of the coin should be of small avail in periods of emergency!*

* I ought, as a matter of patriotism, to add that the standard of coin has been less degraded in England than in many, perhaps most, of the European nations. In France, the livre, or pound in tale contained in the reign of charlemagne precisely a pound weight of pure silver; but, by successive degradations, it contained at the commencement of the French Revolution only one-sixth of an ounce, or one 
Happily we are left in no doubt regarding the facts here indicated. The mint has stood in relationship to the Crown as a department acting under well defined contracts from time to time renewed. These contracts have always defined the "standard" of silver to be employed in the coinage. Sir Charles Whitworth, M.P., whose name frequently occurs through this paper, and who was one of the highest statistical and financial authorities living in the last century, in the preparation of his "Inquiry into Prices" (published in 1768 , without his name appended, but with the authorship well known) took the trouble to make reference to these mint indent ures, and to ascertain the standards therein prescribed. From these, as his base, he deduced the following :-

seventy-second part of a pound of silver. The Spanish maravedi, which in 1220 weighed 84 grains of gold, and was worth about i 4 slillings of our present money, has now become degraded into a small copper coin of the value of about one-sixth of the English penny! But, as the Acts of Parliament say, in that part of the United Kingdom called Scotland, the pound weight of silver, which had previously to 1296 been coincd into one pound, or 20 slillings, was in 1601 coined into thirty. six pounds, or 720 shillings.

The depreciation of the currency is not, however, the only means by which rulers have in past times defrauded their subjects. The appreciation has sometimes been quite as eflective a weapon and has been used in modern times. The first instance of this kind which I find recorded oecurred in Roman history. The Roman citizens being bound to pay into the Imperial treasury, not a certain weight of gold bnt a certain number of pieces of gold, or anrei, the Emperor Heliogabalus, whose vices have become proverbial, in order to inercase his means of dissipation without appearing to add to the weight of the taxes, increased the quantity of metal contained in the aureus, thus obtaining by dexterity what he might never have obtained by open dealing. In this, however, he was probably only enlarging upon a hint obtained from Licinius, a freedman of Cæsar's, who in his govermment of the Gauls under Augustus, livided the year into fourteeu months instead of twelve, because the Gauls paid a certain monthly tribute! See Dion Cassius, lib. 72 . 
Table Exhibiting the Standerd Weight, Value and Comparative View of English Silver Money from Willium the Conqueror down to 1765.

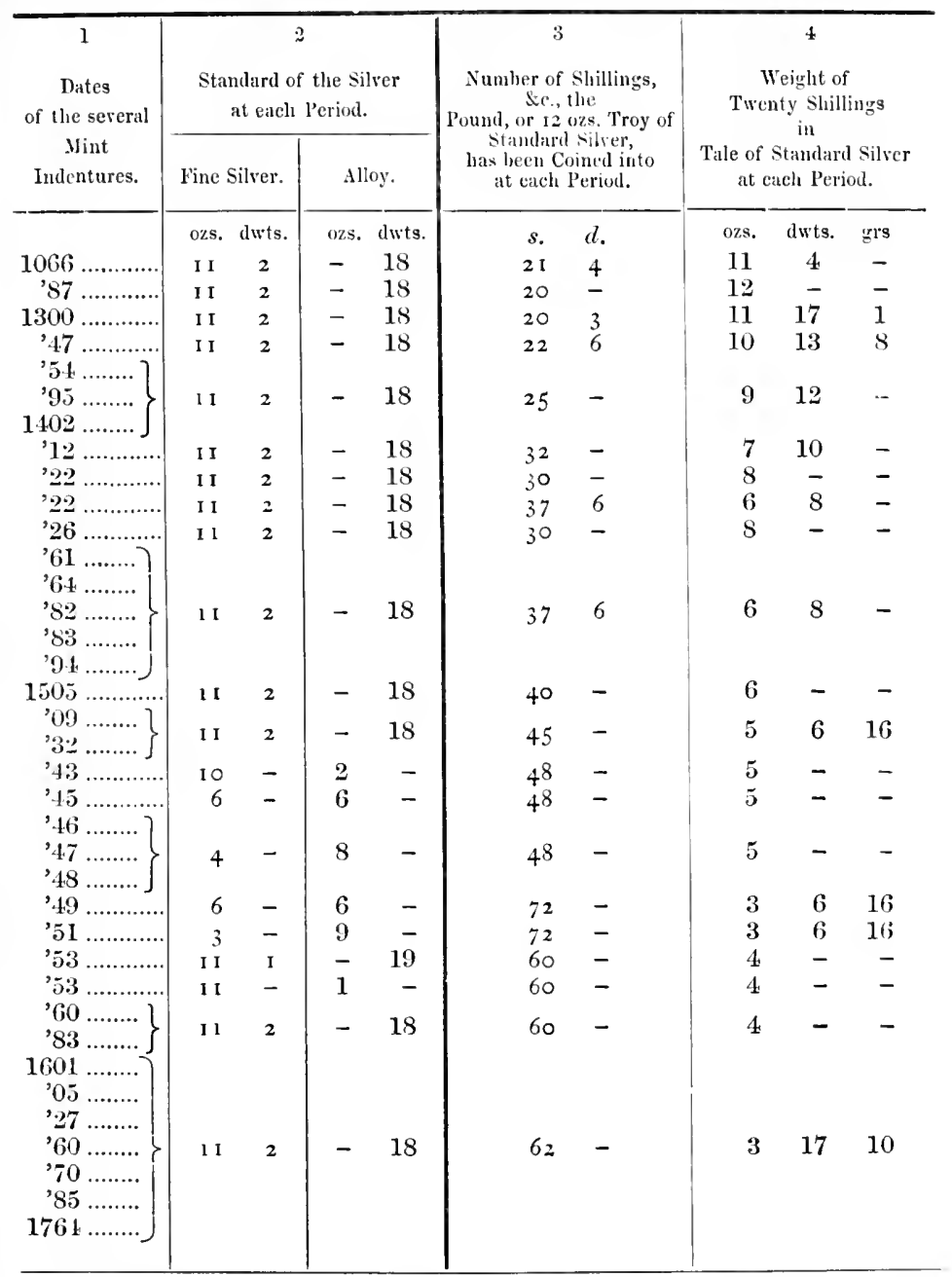

Note.-Mr. Tooke considers that from this date the intrinsie value of English coinage has substantially remained unelianged, "Itistory of Prices," vol. ir (1857), p. 487. The table confirms this riew; but some of the works referred to in Table XI, eonvey a different impression. 
Table of the Standard Weight and Value of English Silver Money-Contd.

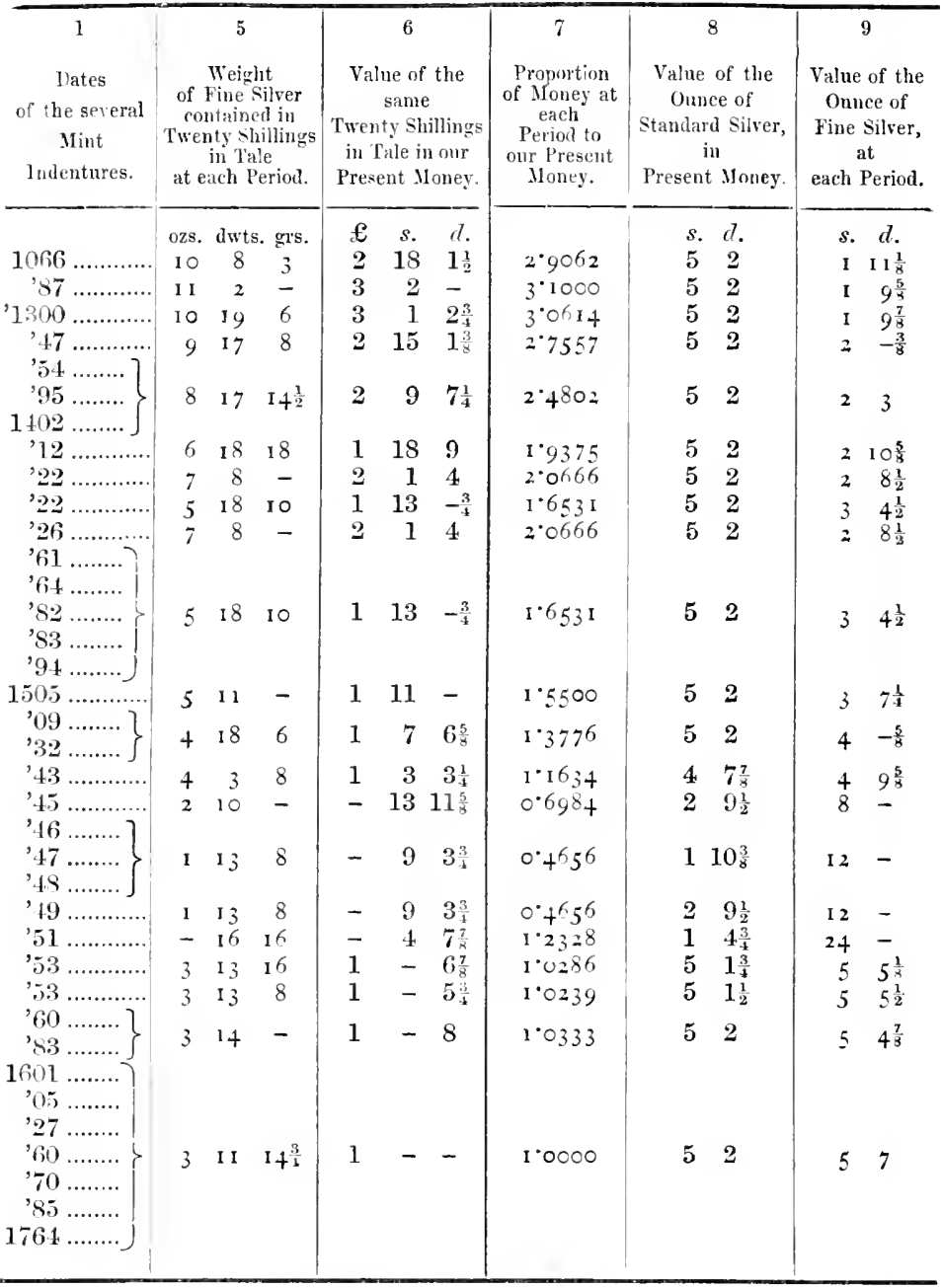

From this valuable table we learn not only the faets I have already recited, but may of others of the first importance in estimating the depreciation to which our silver coinage has been subjected.

It must be distinctly nuderstood that the only values in this paper which have been adjusted in conformity with the silver values here indicated are those in column 3 of Table XIV. It has been essential in quoting Acts of Parliament and other public documents, to adhere to the exact prices they furnish; but when 
such prices are brought into comparison over a long series of years, theu they require to be adjusted in the light of the variations in the value of the eurreney which has oecurred during the period under review.

Third. In considering the question of clipping of coin, which prevailed so extensively during the thirteenth, fourteenth, and fifteenth centuries, we must carry our minds back to the form of the coinage, more particularly of the silver coinage, during that period. It was prodneed from strips of metal cut from the sheets into which it had been moulded after leaving the melting-pot. These strips or thin bars were eut with shears into pieces of exact weights, according to the denomination of coin intended. Thesc square pieces were formed into a round shape by a hammer, after which they were made white by boiling; lastly, they received an impression from a hammer, and were then put in cireulation.

It is easy to understand how these band-made coins might be cut down and hammered out so as to approximate to the original size, which was the usual guide in ordinary dealings, and it was only when they were brought together in the mass and placed in the scales that their real deficiencies became known.

Filing and drilling were usually applied to the larger silver coins, and occasionally to those of gold, and very considerable depreciation may be effected without altering the gencral appearance.

The sweating process is usually applied to gold coinage only. It consists in putting a number of new coins into a bag and moring them rapidly, the friction eausing minnte particles to come off, which are aggregated by consuming the bag in the melting-pot.

The produeing of coins with raised milled edges-a most effective protection against clipping-is usually attributed to Cromwell, during the Protectorate, 1653-58, but it is certain that some were put in cireulation by Henry VII; see Table XI, date 1503 (19 Henry VII, cap. 5).

Fourth. The counterfeiting of coins is simply a matter of mechanical ingenuity, and the rougher the original manufacture the more easily the process of imitation. The difficalty always lies in passing the counterfeit coin into circulation. But in early times, before bills of exchange came into practice in this country, and before banks were known, our dealings with foreign countries were necessarily through the medium of coin. Foreign merehants seeking to buy wool, woollen cloths, or other merehandise here, bronght over the eoin of their own or of some other country to present in payment. Our merchants going over to the continent to purehase grain, took our coinage with them for the purpose of making payment. Thus the coinage of all the trading nations 
became common in each, and the facilities for counterfeiting were multiplied in like proportion.

Coinage generally.-In order that the full measure of coinage complications through which this country has passed may be comprehended in all its bearings, I have had reconrse to the statute book, and for a period of fully five centuries there is here exhibited such a record of struggles and defeats as could be accurately pourtrayed by no mere method of verbal deseription. For the first three centuries of this period there was a bona fide struggle to keep up the purity of the coin; for the next two the struggle was to keep up the nominal value, while the actual value was being rapidly debased.

It is more than probable that the high standard our eoin maintained in the early period eaused it to be sought after largely on the continent of Europe, and hence its frequent scarcity at home. The conntries of the continent sent us an inferior standard of coinage, which for a time did dnty here, but for purposes of external dealings conld never be made fully available by us.

In order to elucidate the effects of a depreciated enrrency npon our food supplies, I have quoted from anthors of acknowledged authority. Frequently the legislation of the period confirms their surmises and conclusions; but oceasionally the very opposite appears to be the case. I have not attempted to harmonise such discords.

The difficulties appeared to lessen gradually from the early part of the eighteenth century-reign of Queen Anne-but I have continued my Table XI up into the present century, as illustrating currency effects upon several of our later famine periods, and I have made very especial reference to the use of toliens as tending to elucidate the sufficiency, or otherwise, of the currency at different periods.

The latest instance of a scarcity of coin producing a famine is that of Ireland, and we quote the words of Mr. Delahunty (the member for Waterford), as given in the "Times," 21st March, 1878, debate on Money Laws (Ireland) Bill. "In Ireland, in 1822 and 1823, the banks failed, and the result was that fumine stallied through the lanh, and provisions could be had for half the price they previously fetched. (A laugh.) The people starved because the circulating medium did not exist, and there was no employment." 
Table XI.-Currency Restrietions, Legislutive and Otheruise, especially including Debusing the Coin, whereby either Direct or Indirest Influences bearing upon the Price and Supply of Provisions have been brought into Play.

B.C.

55 to The Romans coined money at Camalodumum (Colchester). This was A.D. 419 the first money in the British Isles.

827 to The Anglo-Saxons coined silver; and it has been supposed that they 1013 Ind a copper coinage also.

'15 .... "The coin was observed to be greatly elipped, from whence every kind of provision became so dear that multitudes perished."'-SIR CHARLES WHITWORTH, M.P.

'49 .... "All the great men of the realm, the bishops, earls, and barons, coined their own monies; this increased the price of provisions; and was attended with many impositions and losses to the nation in general; but more especially to the trading portion."-SIR CHarLes WH ITWORTH.

'55 .... Henry II repaired the coin, and ordered that his money only should be current in the kingdom.

's0 .... The king again called in the debased coin.

$1202 \ldots$ The current coin was again debased.

'16 .... Coin was made sterling at this date; previously rents were mostly paid in kind; and money was found only in the coffers of the barons.STow.

'27 .... "The pope having extorted great sums of money from the English clergr, it is probable as the coin of the kingdom became scarce, the price of prorisions could not rise."-Sir ChaliLes Whitworti.

'46 .... "'The eurrent coin being egregiously clipped, so that without any other reason assigned we find wheat and prices consequent of a famine."Sir C. Whitworth.

'50 .... "About this time money was so shamefully clipped, that by an order it was enjoined to be taken only by weight; which order (it's said) produced a great obstruetion to trade for some time."-Јон SuIth's "Memoirs of Wool," \&c.

55 .... "The extortions of the pope, and the sums obtained by the Earl of Cornwall, raised the interest of money to $50 l$. per eent. 1t was computcd they took of the kingdom $2,170,000 /$. in real specie, for paper currency was then unknown: this oceasioned a general decay of trade; which was aggravated by a famine."-SiR CharLES WHITwORTH.

'72 .... Some 280 Jews were executed for clipping the current coin of the realm.

The statuta de moneta (statutes concerning money) is attributed to this date, 20 Edward I, and contains the following :-

"Against the perils and damages which are of late come, and which hereafter may come of the money of England. It is thus ordained, that it be cried and defended on the ling's behalf throughout the whole realm, in all the merchant towns, that no men upon grierous forfeiture be so hardy to dispend, receive, or send money of other coin than of the coin of the king of England, Ireland, and Scotland.

"And also that it be cried and commanded on the king's behalf, that if any find money coined of any other coin than that of the coin of the king of England, Ireland, or Scotland, or elipped money, that he break the same; and that none be so hardy to gainsay the same upon pain of grievous forfeiture; and he whieh findeth the same false, shall break the same, the broken money shall be given to him which oweth it, and the false money shall be pierced without restoring it; and the body of him in whose hands the false or clipped money appeareth to be found, be taken and holden until such time as he can find surety, if he be a suspieious man.

"And because that many of the poor and rich people cannot know 


\section{Table XI.-Currency Restrictions, Legislative and Otherwise-Contd.}

A.D.

1291-92 the light and clipped money from the other, now it is ordained, that hereafter he which ought to receise or pay mones, shall receive and pay the same by weight of $v$. s. of even weight by the tumbrel, delirered by the warden of the exchange marked with the king's mark as the measures are; and it shall be lawful to any man to pieree the moner which shall not pass the tumbrel; and the money of other coin than of the coin of the king of England, Ireland, and Scotland, the weight shall be as well delirered and marked by the warden of the exchange, as the tumbrel.

"The riewer and the warden of the money which shall come from beyond the sea, when he shall have any, he shall have regard unto the age thereof, and shall weigh the same. And if he find of the new mones, that the pound weigheth not $x x^{\prime}$, by the number of iiij pence, then he shall hare regard by the tumbrel where the default shall be; and if there be money which is much used, if in the whole pound of $x x^{\prime}$, it want but rjd, then it shall be delicered to him who bought the same without gainsaying; and if it want more, it shall be done of them as of the rest. And let the warden aforesaid take good heed that he take no gift nor allowance to spare any one, nor make any extortion, nor give any manner of clelay, as he will save himself and his goods."

The following clauses, although usually printed in this same statnte, are believed really to belong to another, probably of later date (say Edward II) ; but it is eonvenient to take them next :-

"These be the things which arise on this side of the sea and on the other, to the great damage of our lord the king and of his people, to the great corruption of his money of England.

"First, they make there abroad, a money of silrer, with a mitre; $20 s$, of which money weighs only $16 s .4 \%$. of the mones of England.

"Also they make two other sorts of money with lions, whereon there are heacls on the one money, and not on the other, but which are as light as the money with the mitre.

"Also they make as well on this side of the sea as on the other, a sort of false money, which is merely of copper, and is wightened, and when it is new it resembles the mones of England.

"There is also another sort of money which is made in Germany, under the name of Edward, king of England, which weighs as little as, or less than, the money with the mitre, and that cannot be distinguished, mless it be by weight.

"The other deceit which they make in the money is, that there are some who bring plates of pewter, or of lead, in the form of a penny, then they lut them between two leares of silver, and afterwards insert them into coin or into copper, when another penny well forged hatli been struck.

"Orhers, as well on this side the sea as on the other, do elip the good and lawful money to the damage of the whole community. Those moness which are made and clipped out of England are bronght by passengers, and especially by merchants. And because they know that seureh is made for then at Dorer, they put them into cloths and bales; then they come not to Drer or Sandwicl, but they come to London or into Essex, or into Suffolk, or into Norfolk, or to Hull, or into Lindsay, or to some other ports of England, where they expect to find no hindrance; the which things if they should be long permitted to be so would oring the money of England to nothing."

Edward I "caused the wooll and leather to be stayed in England, and there followed great dearth of corne and wine."-РелкетнмaN.

'99 .... "Much base money was eurrent. Trade was in great deeay. The king ordered new monies to be coined, and half-pence of silver."Sir Chamles Whitworth. 
'TABLE XI.-Curreney Restrictions, Legislative and Othervise-Contd.

A.D

1299

1311

'19

Accordingly this year there was enacted the 27 Edward III"A statute concerning false money" - which recites :

"Whereas our kingdom and the other lands of our sorcreignty are filled with divers bad monies known by the numes of pollards and crockirds, and by other names, which are brought and left in the said kingdom and elsewhere within our jurisdiction by divel's persons coming from abroad, and therein diversely dispersed, to the great damage of our people." It is then enacted that henceforth such monies shall not be imported under forfeiture of life and goods; and "Forasmuch as this ordnance cannot arail if it be not well maintained; it is ordained that good and strict wateh be kept in all places upon the open coast, at the ports and elsewhere, where there is any coming from abroad, by good and lawful sworn men, who shall arrest those who bring such or other bad monies, together with the monies and everything belonging to them." These officers were known as "wardens of the ports." It is further recited: "Whereas we have been informed that the good sterling is counterfeited in foreign parts with base and false metal, to the great damage of our realm aforesaid;" persons bringing "stirlings" from abroad were to deliver them up to the wardens to be assaycd, "and the said wardens shall also send their bodies with the money, safely and courteously." If money good, to be given up and persons released; if bad, money and bodies to be retained at "our pleasure."

In confirmation, part of the palace of Westminster being destroyed by fire, a parliament was held by Edward I, in the house of Henry Wallis, mayor of London, at Stebenheth, "when crockards, pollards, and rosaries coyned in foreign parts beyond scas, and uttered for sterlings, were cried down."--STow's English Chronicles. By 5 Edward II, cap. 30, it is enacted, "Forasmuch as at all times when an exchange of money is made in the realm, the people are greatly aggriesed in many manners, we do ordain that when need be, and the king willeth to make an exchange, that he do it by the common council of his baronage, and that in parliament."

To this year, 12 Edward II, is attributed the following: " Edward, by the grace of God, King of England, Lord of Ireland, and Duke of Aquitaine, to the sheriff of Lincoln, greeting: Bceause that strange merchants, and also some merchants denizens of our realm, from day to day bring into the same our realm, from the parts beyond the sca, our money elipped, and other money of divers coins counterfeited and mingled with our money, trafficking and buying with the same money, to the great loss of us and all onr people, and also the subrersion of all our money. We hereupon willing to provide a remedy, unless peradventure by longer sufference a greater danger might ensue, command you that in your full county, and in all your cities and merchant towns of the same county, you do cause strictly to be forbidden and openly proclaimed, that no strange merchant, nor any other from henceforth, bring into the realm any such money of ours rounded [clipped], or any other counterfeited of strange coins, or else use the same in buying or trafficking; and if they do, at the first time wherein they shall be taken therewith, they shall lose such rounded money, or any other counterfeit; and if the shall be again found in the like offence, they shall lose such money and other goods found with them; and if the third time they commit the like offence, and be taken therewith, their bodies and also all their goods and chattels shall be forfeited unto us. But others who shall not be merchants, and shall have such rounded money, or other counterfeit money, shall presently pieree the same and send it to our exchange to be new coined under our coin; or otherwise in whose hands such money shall be found, the same shall be unto us wholly forbidden. Provided moreover that all pennies of money clipped or 


\section{TABLE XI.-Currency Restrictions, Legislative and Otherwise-Contd.}

A.D.

1319 couneil."

counterfeited, when by forfeiture of others the same shall come to onr hands, shall be in like manner pierced and sent to our exehequer. Witness the king at York, the 2ud day of February. By the

'23-24 By the "Assise of Weights and Measures," attributed to this date, it was enaeted-

"By consent of the whole reahm the king's measure was made so that in English penny, which is called the sterling, round without chipping, shall weigh 32 grains of wheat, dry in the midst of the ear. 20 pence make an ounce and I 2 ounces make a pound." [Note-"London to wit, 20 shillings of sterlings."]

It was the silver penny obsiously which is here referred to.

"By the same statute it. was enacted that 7 pounds made a gallon of wine; 8 gallows of wine make a bushel of London, which is the ejghth part of a quarter." [Note-" And 12 pounds and a-balf make the stone of London."]

Ifere is an inclication alike as to mone $\mathrm{and}$ measures that the ralnes relate to London; but as to money, it seems to have been intended that the statute hould apply to the entire kingdom.

'35 .... The 9 Edwird 111, statute 2, cap. 1, enacted as follows :-

"Edwart, ly the grace of God, King of England, \&e., to the sherift of York, greeting: Because we have perceised that disers people bevond the sea do endearour themselves to connterfeit our sterling moner of England, and to send into England their weak money, in teceit of us, and damage and oppression of om people, if remeily be not proviched; we willing to prevent and let all such deceits, dannges, and oppressions, and to this that our good money be increased in our realm, and other countries within our power, to the profit of ns and our subjects; by the assent of the prelates, earls, baroms, and ofluer great men of our realm, at onr parliament holden at Jork, the morrow of the Ascension last passed, there assembled, have ordained and established these things ensuing in the manner underwitten:

"I. First. It is provicled that from henceforth no religious man [pilgrim], nor other shall earry any sterling out of the realm of England, nor silver plate, nor ressel of gold, nor of silver, upon pain of forteiture of the mones, plate, or ressel that he shall so carry without our especial lieenvie.

"II. Item-lhat no filse mones or counterfeit sterling be brought into the realm, nor elsewhere within our power, upon forfeiture of such money.

"IIJ. Item-That no sterling halfpenny nor farthing be molten for to make ressel or any ofler thing by goldsmiths nor others, upon forfeiture of the mones so molten.

"IV. Item-That all mamer of blank money which hath been commonly current of late in our realm and obseisance, be utterly excluled, so that none such shall be eurrent after a month next after the cry thereof made, upon pain of forfeiture of the same money.

"VI. It 'I -That the rizor's and bailiffs of erery port where merchants and ships be, shall take the oath of the inerehants and masters of the ships going and coming again, that they shall do no fraud against this provision in any point."

Searchers were to be appointed at the ports of the kingdom to guard against the earriage of money or plate from ont the kingdom.

In 1336 the complaint of a scarcity of money was so great that the king was allowed to export 20,000 sacks of wool to Flanders, the value of which was 918,000 l.-Sir Charles Whitworth.

"Item-It is aceorded to make money of good sterling in England of 


\section{Table XI.-Curreney Restrietions, Legislative and Otherwise-Contd.}

A.D.

1313

the weight and allay of the ancient sterling, which shall be enrent in England between the great men and the commons of the land, and the which shall not be earried out of the ream of England in any manner, nor for any canse whatsoever; and in ase that the Flemmings will make good money of silver groats, or other, according in allay with good sterling, that such money shall be current in England between merchant and merehant and others who of their own accord will receive the same; so that no silver be arried ont of the realm."

By 13 Elward III, statute 2, cap. 6, it was enacted :-

"Item-That no man be compelled to take the new money of gold and silver which our lord the king hath ordained, to go in payment at a certain price, within the sum of 2os. And also that money of gold and silrer be made in the eity of York, and elsewhere, where the king will it ordain, in the manner as it is made in the Tower of Loucton; and exchanges shall be ordained in the great towns, aecording as it best shall seem to our sorereign lord the king, for the profit of lim, aud arse of his people. And that it be ordained in a certainty, what thing shall be given in exchange for every piece of gold."

In conformity with the preceding statute, the king, by adrice of his combeil, eommanded florius of gold to be coined, to pass for $6 . s$, half florins for $3 s$, and quarter florins for $1 s$. 6 $l$. money of that time. "But Edward aiming at too mueh profit, had set too high a value upon these pieces, whieh prevented their curreney. To remedy this, he coined that same vear, nobles, half nobles, and farthing noblesthe noble to pass for $6 s$. $8 t$., and the gold of the first coinage to be brought to the mint, and sold for its real value. In the first coinage a pound of gold was rated at $15 l$. of silver, in the sceond at only ${ }_{13} l .3 s .4 \%$. The noble was so ealled either on account of its value and beauty-being the largest and finest then known-or on aeeount of the honourable occasion on which it was struck, the great naval victory orer the Freneh, obtained by Edward in person in 1340 ; for on that coin Edward appears eompletely armed, in a ship, with a naked sword in his right hand. These nobles, half and quarter nobles, continued to be the chicf gold coins to the end of the fourteenth century."-WADE's British Ristory.

"Edwadd III made a material alteration in the state of the coin, by commauding 22s. 6t. to be coined ont of the Tower pound of silver. $\mathrm{Br}$ this regulation the weight of the silver penny, which was still the largest real coin, was redueed from $22 \frac{1}{2}$ to 20 troy grains, and the pound to $51 \mathrm{~s}$. $8 d$. of our moner."-WADE's British Ifistory.

"The king made a still greater change this year by coining silver groats and half groats, the groats weighing $7 \geq$ troy grains; and ho of these groats made a nominal pound sterling, and containing therefore a restricted value as against earlier periods, bcing about as mucl silver as $46 s$. $6 d$. of our present money."-WADE's British History.

By the 25 Edward III, statute 5, cap. 2, in an enumeration of the offences which are to be adjudged treason, is this: "And if a man bring fulse money into this realm, counterfeit to the money of England, as the money called Lushburgh, or other like to the said money of England, knowing the money to be false, to merchandise or make payment in deeeit of our said lord the king and of his people."

By 25 Edward III, statute 5, eap. 13, it was enacted :-

"Item-It is accorded that the money of gold and silver which now rumeth shall not be impaired in weight or allay; but as soon as a good way way be found, the same slall be put in the ancient statute as in sterling."

By the "Ordinanee of the Staples," 27 Edward III, statute 2, eap. 15, it was enacted:- 


\section{Table XI.-Curreney Restrietions, Legislative and Otherwise-Contd.}

A.D.

1353

'73

'90

'81-82 By 5 Richard II, cap. 2, it was enacted :-

"Item-We have ordained, that all merehants, priry and strangers, may safely earry and bring within our said realm and lands, plate of silver and billets of gold, and all other manner of gold, and all money of gold and silver to our bullion and our exchanges, which we shall canse to be ordained at our said staples, or elsewhere, taking the money for our eoin of gold and silver conveniable to the value; and if any will take good money of gold and silver of other coin than ours in payment, he shall take the same without impeachment, so that none be thereunto compelled if he will not take it of his goodwill.

"Prorided always, that no money have common eourse within our said realm and lands, but the money of gold and silver of our coin; and that none carry out of our said realm and lands the old sterling nor other money but our new money of gold and silver, except the merchants strangers, that bring to our said realm and lands any manner of money, and will not employ this money within our realm and lands; whom we will that they may reearry into their country all this money, or so much as shall remain thereof not employed withont impeachment."

Search was to be made at the ports " to the intent that no merehant shall carry more beyond the sea than he brought into the same realm and lands."

By 47 Edward III, eap. 2, it was enacted as follows :-

"Item-For that the people of Scotland by their subtlety have drawn the good silver money ont of England, and have uade their coin of less value than the moner of England is, and so it passeth in payment in the said realm of England, to the great damage and deceit of the king and of the great men and of all the commonalty. It is ordained and accorded that the Scotch groat shall be current of the value of iijd. $[3 d$.$] and of less money according to the quantity ;$ and if per ease this Scottish money be impeired, the money so impeired shall be set at a less priec, after the qunntity of the impeiring." (Sce further 1390.)

"Item-For the great mischicf which the realm suffereth, it long hath done, for that gold and silver, as well in money, ressel, plate, and jewels, as otherwisc by exchanges, made in divers manners, is carried out of this realm, so that in effect there is none thereof left, whieh thing if it should longer be suffered would shortly be the destruction of the same realm, which God prohibit; it is assented and aceorded, and the king enjoineth all manner of people, merchants, clerks, and others, as well strangers as denizens, of what estate or condition they be, upon pain of as much as they may forfeit, that none of them upon the said pain, pririly nor openly, send nor carry, nor cause to be sent or carried out of the said realm, any gold or silver in moner, bullion, plate, or ressel, neither by exehanges to be made, nor in other manner.

"Except for payment of king's forts beyond the sea, and by the king's license by exchanges in England to pay beyond sea."

No person (with eertain specified exceptions) was to depart ont of the kingdom withont the king's license, and then only at certain specified ports.

By 14 Richard II, cap. 12, a further abatement was made in the ralue of Scoteh money as follows:-

"Item-That the groat of the mones of Scotland $\mathrm{rmn}$ in the value of only $2 d$. English: and the half groat of Scotland, of a penny English; and the penny of Scotland, of a half-penny English ; the half-penny of Scotland, of a farthing English. And if the money of Scotland be impaired, that the value thereof be abridged after the rate, and that commissions be made through the realm to 


\section{TaBI. XI.-Currency Restrictions, Legislative and Otherwise-Contd.}

A.D.

1390

inquire of them that have brought or sent the money of England into Scotland, to make bullion or money of Scotland, in prejudice and damage of the king and his realm."

'93-94 The 17 Richard II, cap. 1, after reciting the 9 Edward III, statute 2, cap. 3, against melting of money, extended that statute to groats and half-groats, and then proceeded:-

"And moreorer it is ordained and assented that no gold nor silver of Scotland, nor of other lands beyond the sea, shall rum in any manner of parment within the realm of England, but shall he brought to the bullion, there to be molten into the coin of England, upon pain of forfeiture of the same, and of imprisomment, fine, and ransom of him which doth eontrary; and that no man shall send any English money into Scotland, to change the same in money, or for money of Scotlaud, upon the pain next aforesaid."

1400-01 The 2 Henry IV, eap. 5, after reciting the 5 Richard III, statute 2, cap. 1, touching the exporting of gold and silver, proceeds :-

"Our lord the king, for to prevent the subtilty of them that will do fraud, or deceit to him in this behalf, hath ordained and established that if from heneeforth any seareher of the king mas find gold or silver in coin, or in mass, in the keeping of any that is passing, ${ }^{*}$ upon his passage, in any ship or ressel to go out of any port, haven, or ereek of the realm, without the king's special license, all that gold and silver shall be forfeited to the king, saving his reasonable expenses, which he shall be obliged to confess, and discover presently after, that he is warned and charged to do so by the same searcher, or else all the said money so concealed shall be forfeit to the king. Provided alwars, that the merchant strangers that do sell their merchandise within the realm of England; and the one half of the money of England received for the same merchandises, do employ upon other. merchandises of the realm, may freely carry out from the same the other half of the said money by the king's license, according to the statute thereof made."

This somewhat obseure passage means that foreign merchants selling say zocl. of goods, might carry ont goods of the ralue of $100 l$., and the other $100 \%$. in eoin, upon the king's license. It then proceeds :-

"Item-for the great deeit that is in this money of gold and silver of Flanders and Scotland, that doth commonly run in payments, made in parments, made in divers parts of the realm, to the great damage of the king and his people; It is ordained and. established, that all the money of gold and silver of the coin of Flanders, and of all other lands and countries beyond the sea, and also of the land of Scotland, shall be voided out of the realm of England, or put to coin to the bullion within the said realm, betwixt this and the feast of Christmas next ensuing, upon pain of forfeiture of the same; and that all the merchants and others of Calais, which do reeeive any such gold or silver of the coin of Flanders or of other lands and countries beyond the sea, or of the land of Scotland, shall post the same to bullion at Calais, without bringing it in coin within the realm of England."

Search was to be made at Calais, as well as on this side of the sea.

By the 4 Henry IV, eap. 10, it was enacted :-

"Item-For the great scarcity that is at this present within this realm of England of half-pence and farthings of silver, it is ordained and established, that the third part of all the money of silver which shall be brought to the bullion, shall be made in halfpence and farthings; and that of this third part, the one-half be made in half-penee, and the other half in farthings; and the same to do and perform the coiner shall be sworn in special; and that no goldsmith nor other person, whosoerer he may be, cause to be 


\section{TABLe XI.-Currency Restrietions, Legislative and Otherwise-Contd.}

A.D. 1402

'07 .... The base eoin imported from Genoa was prolibited.

'09-10 Bs the 11 Henry IV, eap. 5, it was enacted as follows:-

"Item-Because that gally half-penee do eommonly run in this realm for payment, in derogation of the king's crown, and in great deeeit of the common people, it is ordained and established that the said galley half-penee shall never be current in payment nor in other manner within the realm of Englasd, upon pain of forfeiture thereof. And moreover that the gally half-pence in whose lands soever they be found within the realm, shall be forfeit to our sovereign lord the king, after the two months next ensuing the proclamation of this statute; and also the same our lord the king will, that all the statutes or ordinances makle before this time by him, or by his noble progenitors, not repealed, as well of the money of Seutland, as of the money of other realms and parts beyond the sea, be holden and kept, and put in due exeeution."

'11 .... The statute of $1409-10$, as to gally half-penee, eonfirmed by 13 Henry IV, eap. 6.

New money was eoined.

'15... By 3 Henry VI [cap. 1] it was enacted :-

"That gally lialf-pence, and the money called suskin and dotkin, and all manner of Scottish money of silver, shall be utterly put out and not be current hereafter for any payment in the realm of England. Joined to the same, that prodamation be made through all the eounties of England within framehises and without [within eities and boroughs], and elsewhere, that all that have gally halfpenee, suskins and dotkins, shall bring them to the King's Exehanges betwixt this and the feast of Easter next ensuing, there to be broken, and that that is found good silver, there to be striken and eoined in English half-penee." *

And all they that offended against this statute were to be deemed felons; with further prosisions for discorery, \&e.

'15-16 The 4 Henry $V$, eap. 6 , is as follows:-

"Item-Because that before this time great doubt and ambiguity hath been, whether that elipping, washing, and filing of the money of the land, onght to be jutged treason, or not. Forasmueh as no mention thereof is made in the declaration of the artieles of treason

* King's Exchanges.-The origin of these King's Exchanges has quite a little history, and dates baek to Edward III. It was at this period no easy matter sometimes to exchange gold and silver eoins for each other; and therefore Edward, and afterwards sereral of his successors, took the office of exchangers into their own hands, as well to prevent extortion as for their own adrantage. They performed it by appointing eertain persons, furnished with a eompetent quantity of eoin, in London and other towns; these to be the only exchangers of money, at fixed rates. These royal exchangers had also the exclnsice privilege of giving the current eoins of the kingdom in exchange for foreign coin, to aeeommodate merchant strangers; as also of purchasing light money for the use of the mint We have seen that sereral laws were in force against exporting English eoin. The King's Exchangers at the sereral ports furnished merehants and others who were going abroad with the coin of the eountries to which they were going, in exchange for English money, according to a table which hung up in their office for public inspection. By these rarious operations they made considerable profits, of which the king had a share. The house in whieh the Royal Exehanger kept his office was ealled "The Exehange," from whence the origin of Exehange or Royal Exchange, a place for merehants and strangers to meet to transact business. - Vide WADE's British History. 


\section{Table XI.-Currency Restrictions, Legislative and Otherwise-Contd.}

A.D.

1415-16

'16 ....

$20 \ldots$

'21 ....

made in the parliament holden in the 25 Edward III [statute 5, cap. 2], the same our lord the king, willing to decide such doubt and to put the same to ecrtainty, hath declared in this present parliament that such clipping, washing, and filing shall be adjudged for treason, and they which do so elip, wash, and file the money of the land, shall be judged treason to the king and the realm, and shall incur the pain of treason."

The circulation of base coin again prohibited, and a now coinage struck.-W $\mathrm{ADE}$.

"The coinage of IIenry V (1416), became not sterling; and there was a great scarcity of coin." -WADE.

By the 9 Henry $\mathrm{V}$, statute 2 , the statutes concerning money were confirmed. A signorage upon coinage of money was imposed, viz., for gold, $5 s$. "for the pound of the Tower," and upon silver is. $3^{d}$. "for the pound of the Tower;" while those who would not subject their money to be coined into English were to be charged after the rate of $1 d$. for the noble, $\frac{1}{2} d$. per half-noble, $\frac{1}{4} d$. per quarter noble, "with the signorable and coinage as afore is said."

It was further enacted :-

"Item-That the king's mint be coined and made at Calais, in the mauner as it hath been made and governed at the Tower of London.

"VI. Item-That all the money of gold and silver that shall be made at the Tower of London and at Calais, or elsewhere in the realm of England, by authority royal, shall be made of as good weight as it is now made at the Tower.

"Item-That the king do to be ordained good and just weight of the noble, half-noble, and farthing of gold, with the rates necessary to the same, for every city, borough, and market town, of the realm, to be delivered by the chancellor of England to them that will have them, to the intent that be not deceired by false connterfeits, and them that use false weight in deceit of the people."

By 2 Henry VII, cap. 9, it was enacted:-

"Item-It is ordained, that proclamation be made through all the counties of England within frawchises and without, and within cities, towns, boroughs, and elsewhere, that all the money called blanks shall be wholly out and roided out of the realm before the feast of St. John Baptist next coming; and moreover, that no man after the said feast pay or receive for payment in any manner within the said realm, the said money called blanks, upon the pain contained and ordained by a statute made 3 Henry V, and other to our lord the king's agent all that pay or receive for payment the money called gally halfpence, suskins, and dotkins within the realm."

By 2 Henry VI, c. 16, it is recited and enacted :-

"Item-Forasmuch as great scareity of white moner is within the realm, because that silver is bought and sold not coined at the price of xxxijs. the pound of troy, whereas the same pound is no more of value at the coin [mint] than xxxijs. abated for the coinage twelvepence; It is ordained and established for the increase of the said white money, that no man, of what estate or condition he be, within the realm, shall buy or sell no silver in plate, broken nor in masse, being as good of allay as the sterling, above $30 s$. in the pound of troy, over the fashion upon the pain of forfeiture of double the value of as much as he buyeth or selleth contrary to the ordinance."

The words "over the fashion" which occur in this Act may be read "beyond he cost of workmanship" :-

"Here's the note how much your chain weighs to the utmost carat,

The fineness of the gold and charge tor tashion."-SHAk ESFEABE.

This Act was repealed in 1623-24 by 21 James I, cap. 28, sec. 11 . 


\section{Table XI.-Currency Restrictions, Legislative and Otherwise-Contd.}

A.D. 1463

'64

'77-78

An Act of the parliament of Ireland, 5 Edward IV, cap. 3-"An Act against clipped money"-is as follows :-

"Also at the request of the commons, that inasmuch as the groat, the half-groat, and the peny, and other coins are lost and destroyed by divers and many clippings; It is ordained and established, and enacted by the authority of the said parliament, that money clipped shall not be taken in and by no manner of payment after the feast of the Purification of our Lady next ensuing, but that it be after the said feast utterly void, dampmed, and determined no coyne of the king; and that it shall be lawful to every man to refuse the same, and that thereupon a proelamation slall be made in the said parliament, and upon the same proclamation, writs shall be directed to the sheritt's, mayors, bayliffs, sorercigns, portrisses, and all other officers and ministers within the said land of Ireland, to make proclamation upon the present Act. And thereupon proclamation was made in the said parliament according to the said Aet or ordinance."

Edward IV ealled in the base money. - W ADE.

By the 17 Edward 4, cap. 1, the Acts of 1335 and 1400-01 are recited, and it was then further recited :-

"And now so it is that of late, and at these dass counterfeit and false mones of such countries, in poys [weight] figures and alay as groats and pence made in Ireland in part like to the groats and halfgroats, four pens and two pens of this realm, in such a great multitude be daily brought into this reahm, out of Ireland and other places, and put in payment in this realm, which if it should long endure, it should not only destroy the good money of this realm, but also cause the good money of silrer of this realm made within the same, to be trimslated and turned into the said false and counterfeit money made in Ireland and other plaees, and also should cause a great part of the plate of silver to be carried out of this realm, and to be coined into the said false and eounterfeit money, wherefore.

it is orlained that after the feast of Easter next eoming, none of the same moness of Ireland shall run in payment within this realm, Wales, Calais, or the marches of the same; nor that no person after the said feast put any of the same moneys, nor the same receire in ary payment within this realm and npon pain of forfeiture of the same money.

By 4 Henry 7, cap. 18, "Forgsnge and countrefeyting of gold and silrer of other londes supposed to renne in this realme is made treason."

"Item-For as moche as by the krngis sufferaunce dyverse coigne of golde and silver, whiche be not of the krngis proper coigne of Englande, be currante in payment within this reame, dyvers and many eryll disposed persones, percesring that the forgyng and counterfetyng of suche coignes is neither folonye nor treason, prestme and take upon theym for their araile and prefyte to counterfyt and forge such coynes; to the grete hurte and prejudice aswell of the kyng our sovereyne lorde as to the hurte of all the kyngis subgettes; it is therefore orderced and established by auctorite of the said parliament, that the countrefeytyng and forgyng of every such eosne be adjudged treison, as it is of the countrefytyng of the proper coignage of the kyng of this realme."

The 4 IIenry III, cap. 23 , rerired the 27 Edward IV, cap. 1, prohibiting the exportation of money, plate and jewels; and it was enacted that no one should dehrer by way of exchange to strangers, any gold coin or plate, bullion, \&c., npon pain of forfeiture of the

double the value thereof.
Columbus discorered America: "The quantities of gold and silver this continent furnished within a short time after, greatly influenced the landed and trading interests of Europe."-Sir CHARLES Whitworth. 


\section{TaBLe XI.-Currency Restrictions, Legislative and Otherwise-Contd.}

A.D.

1492

A gain the same writer says, under date 1508, "Before the discorery of Ameriea the price of labour and provisions were but low . . . . . but this sudden plenty of moner enhanced the price of labour and prorisions; the ralue of estates increased, and the landowner was in the end most adrantaged; such were with as the first effects of Perurian riches."

The 19 Henry VII, eap. 5, reeites as follows:-

"The king our sovereign lord, seeing evidently that lis coin, and especially of silver, is sore impaired, as well by elipping thereof, as counterfeiting of the same, and by bringing into this his realm the coin of Ireland, by occasion whereby great rumour and variance daily increaseth among his subjects for outing and refusing of the same."

"It is then enaeted that all manner of gold of the eoins of a sovereign, half-sovereign, royal, half-royal, and the fourth part of a royal, the angel, the half-angel, and every of them being gold, whole and weight, should go and be eurrent in payment through all this his realm for the sum that they were eoined for ; and also that as well all manner of groats of English eoin, and of the coins of other lands now eurrent in this realm for groats, or for ivd. being silver, and not elipped, minished, or otherwise impaired, exeept reasonable wearing (albeit they be cracked), as all manner of half groats, or for $\mathrm{ij} d$. not elipped, minished, or otherwise impaired, being silver (howbeit they be cracked) shall in likewise go and be eurrent through all the same realm for the sum as they were eoined for. And over that, that all manner of pence being silver, and having the print of the king's eoin, shall have course and be current for payment, as well to him in all his reeeipts, as to all his receirers, and to all other lords spiritual and temporal and their receivers, and to all other within this his realm, withont any manner refusal or eontradiction except only pence bearing spurs, or the mullet, to have eourse for half-pence and not alone."

Any person refusing to take such eoins in payment for the values aforesaid, to be liable to punishment at the decision of a justiee ; then

"That all manner of groats and half groats . . . as well English coin as coin of other lands, elipped, minished, or otherwise impaired, exeept reasonable wearing, shall not go or be in any wise current for payment within this realm, but utterly to be refused and forsaken in payment from henceforth. And that notwithstanding it shall be lawful to any person having any such groats or pence of ijd. elipped or diminished, to bring the same to the king's mint, there to be ehanged after the eustom of the same mint or convert the same into plate, bullion, or otherwise sell or employ it to his use or profit or advantage within this realm, any other Act or Acts to the eontrary in any wise notwithstanding.

"And in eschewing and avoiding of such clipping in time to come, the king .... hath eaused to be made new eoins of groats and pence of ijd., and that every pieee of the same eoin shall have a eircle about the utter part thereof ; and also all manner of gold hereafter to be eoined within this his realm shall have the whole seripture about every piece of the same gold, without lacking of any part thereof, to the intent that his subjeets hereafter may have perfeet knowledge by that eircle and seripture when the same eoins be clipped or impaired."

No one hereafter was to earry into Ireland more than $6 s .8 d$. of bulilion, plate, or eoin, or to bring in more than $3 s .4 d$. of Irish coin. The 1 Henry VIII, eap. 13, inhibited the exportation of money, plate, or jewels, until next parliament.

'11 .... The 3 Henry VIII, eap. 1, also extended the inhibition, under penalty of double the value, until next parliament. 
Table XI.-Currency Restrictions, Legislative aad Otherwise-Contd.

A.D.

1523 .... By 14 and 15 Henry VIII, cap. 12-"An Act eoneerning eoyning of money" - the proportion of coins to be struck from $100 l$. worth of gold or silver respeetively was defined. The tenth part of any money coined for any person was to be in halfpenee and farthings (to supersede the eoins of these respective denominations then in currency, which were of the sime size [i.e. equal] or thereabouts, causing deceit). This Act not to affeet the mints of York, Durham and Canterbury.

'42-43 By 34 and 35 Henry VIII, eap. 27, it was enacted (sec. 25), that the lords of the exchequer and collectors night for the "space of oone hole yere nexte folowing take and not refuse in any payment, any ducates, erownes, erusadoros, or any other golde corned in the parties beyond the sea, bearing their true weight aeeording to suche value as was limited by the laste proclamation thereof, made the xxvijth daie of Marche in the xxxth yere of the reigne of our saide soveraigne lorde the king."

'H .... Stevens in his "Mistory of Taxes," (second edition, 1733, p. 209), openly accuses Henry VIII of eoining base money, "against the honor of a prinee."

'45 .... By 37 Henry VIII, eap. 25, the like coins as speeified in the Act of 15.2-43, might be received in parment of subsidics.

'47 ... Henry ViII had during the latter years of his reign suffered his coin eontimually to be debased-so that his shillings at this date (1 Edward VI) passed for $9 d$. and afterwards for $6 d$. only.WHITWORTH.

'51 .... BY 5 and 6 Edward VI, eap. 12-"An Aete towehinge the exchanges of golde and sylver" - a penalty was inflicted for giving more for gold or silver eoin than the value of its currency as provided by proclamation for the time being.

[Note.-'The objeet of this measure was elearly to prevent the sale of coin simply as bullion for purposes of transport and exchange.]

52 ... At this date the eoin of the realm was three-fourths alloy.-WhitWORTH.

'52-53 3y 7 Edward VI, eap. 6- "An Aete reviving a statute made in the xrijth yere of King Edwarde the Fourthe, touching the earrieng of golde and sylver out of the realme"-The Aet of 1477-88, whieh had been continned by the Aet of 1488.89 for twenty years, was revived, it being recited that "Sithin the whiehe $\mathrm{xx}$ years sooe expired, the golde and sylver of the eoggne of this realm hathe and daily ys and been carried and eonveighed into France, Flanders, Normandye, Brytayn, Irelande, and other parties beyonde the sea, aswell by merehant strangiers, as by denizens, to the great impoverishing of this realme, and greater $y$ s lyke to bee oneles remedye therfr spedelye be provided." The revived provisions to continue for twenty years from this date.

'53 .... By 1 Mary, statute 2, eap. 6, the eounterfeiting foreign coin eurrent in the realin was declared bigh treason.

Queen Mary restored the coin to very nearly its proper standard.WHITWORTH.

'5f .... By 1 and 2 Philip and Mary, cap. 11, the importation of eounterfeit foreign eoins current in this realm, with a view to the uttering the same here, was declared high treason.

' 60 .... The base eoin ealled in and genuine coin issued.

'62 ... By 5 Elizabeth, eap. 9-"An Act against the elipping, washing, rounding, and filing of eoins," it is recited :-

"Whereas the offences of elipping, rounding, washing, and filing of monies or eoins of this realm, was deelared by an Aet of parliament, in the time of King Henry V, to be treason to the king and the realm; and aceording to the said Aet the same offenees were and did continue treason until the 1st May, at which time the pains and penalties due 


\section{TABLE XI. -Currency Restrictions, Legislative and Otherwise-Contd.}

A.D. 1562

$75-76$

'51 .... The Commonwealth's sixpences were the first milled coin in England.

$' 53$.... Private persons had liberty to coin their own pennies.

'js .... Cromwell coined the first English milled crown-piece.

'61 .... 'This year there was published a book whieh engaged some attention, and has continued to attract attention ever since, viz., "England's Treasure by Forraign 'Trade: or the Ballance of ow Forraign Trade is the Rule of our Treasure." By Thonias Mnn, of London, merchant. In this little book is contained (I liere quote from the third edition, 1669) ehapters bearing the following titles:-IV. The 
Table XI.-Currency Restrictions, Legisiative and Otherwise-Contd.

A.D.

1661 .

'62

'66 ...

72

72

'\$5.

'8s

Exportation of our Moners in Trade of Merchandise is a means to increase our treasure. VI. The Spanish Treasure cannot be kept from other Kingdoms by any prohibition made in Spain. VII. The Enhancing or Debasing our Honies cannot enrich the Kingdom with Treasure, nor hinder the Exportation thereof. VIIl. A Tolleration of Foreign Coins to pass current here at higher rates than their ralue with our Staniard, will not increase our Treasme. XI. It will not increase our Treasure to enjoin the Merehant that exporteth Fish, Corn, or Munition, to returu all or parts of the raluable in money. It would hare been well if our statesmen and legislators had paid regard to these truths when they were so proclaimed.

"The current coin of the realm had for yeirs been so clipped as to lose half its value ; one reason why provisions sold at greater rates."Whiтworth. Milled money now began to be generally coined.

By 14 Car. If, cap. 31- "An Act to prevent the inconvenience arising br melting the silver corn of this realm"-it is recited that the Acts made in this belalf (9 Edward III, statute 2 , eap. 3 ; and 17 Richaril II, cap. 1) liad been evaded; and it is now enacted that the penalty for melting the current coin of the realm was disfranchis. ment and imprisonment.

By 18 and 19 Car. II, cap. 5, it is recited as being obvious "that the plenty of current connes of gold and silver of this kingdome is of great adrantage to trade and commerce," and it is then enated that for ercry pound troy of gold or silver brought there was to be delivered a pound troy of current coin; and more or less as the bullion exceeded or was less than the fineness of the standard. The cost of the coinage was to be defrased by a new impost on certain liquors, riz., wine, rinegar, csder, and beer imported-10s. per tun. Proviso for Lady Villiers (under letters patent) to be paid zd. by toll of evers pound weight troy ol silver moneys conied for twenty-one rears, but not to exceed $60^{\circ} \mathrm{l}$. in any one year. (Spe 167.2.)

By 25 Charles II, cap. 8-"An Aet for continuing a former Act coning cornage "- it is recited :-

"Fonsmuch as great adrantage hath acerewed to this kingdome by one A.t of this present parliament . . [1666]. . for that vers great quantities of gold and silcer have been bronght into this realine, and eonverted into the current coynes thereof by reason of the "neouragement giren thereto br the said Act."

The recited Act, which was to continue till 20th December, 1671,

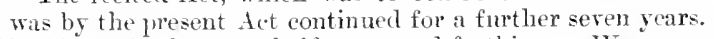

The king comed copper half-pence and farthings.-WHitwortu. (See note, 1697, Tokens.)

By 1 James II, cap. 7 , the Acts of 1666 and 1672 were continued for seven rears further.

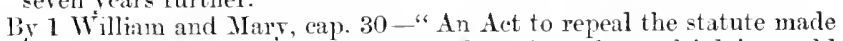
in the fifth rear of King Henry IV, against the multiplying gold and silver," which recited that it was "amongst other things" [in the said 5 Henry IV, aip. 4] "enacted in these words or to this effect namely, that none from henceforth should use to multiply gold or silver or use the craft of mutiplication; and if any the same do, they shall incur pain of felonr."

"And whereas since the making of the said statute, diverse persons have by their studs, industry, and learning, arrived at great skill and perfection in the art of melting and refining of metalls, and otherwise improring them and their ores (which rery much abound within this realm), and extracting gold and silver out of the same, but dare not exercise their said shill within this realm, for fear of falling umder the penalty of the said statute, but exercise the said art in foreign parts, to the great loss and detriment of this realm."

The said recited Act was now repealed, and it was enaeted that 


\section{Table XI.-Currency Restrictions, Legislative and Otherwise -Contd.}

A,D.
1688 .

dominions.

'91 .... There was published Sir Dudley North's “Discourse upon Trade, principally directed to the Cases of the Interest, Coynage, Clipping, and Increase of Money."

'94 .... Br 6 and 7 William and Mary, cap. 17-"An Act to prevent counterfeiting and elipping the coin of this kingdom "-it is recited :-

"Whereas it is manifest that of late years the current coin of this kingdom hath been greatly diminished by elipping, rounding, filing and melting the same, and likewise many false and counterfeit coins hare been elipped for the better disgnising thereof. And forasmuch as it is apparent that these prinetices of diminishing the current coin is rery much occasioned by those who drive a trade of changing broad money for elipped money, and by other arts and devices.

"It was therefore enicted that from and after 1st Mas, 1695, if any person or persons whatever, shall at any one time or payment, exchange, sell, borrow or buy, receive or pay any broad silver money, or silver money unclipt of the coin of the kingdom, for more in tale, benefit, profit, or advantage, than the same was coined for, and ought by law to go for, be lent, sold for, borrowed or bought, received or paid, shall forfeit the sum of $10 l$. for every 20 s. that shall be so exchanged," \&c.

It was given in exidence before a committee of the House of Commons this rear, that five pounds current silver specie was searce worth $40 s$. sterling. Besides an infinite deal of iron, brass and copper, washed over or plated, passed for money.

There was published, "A Sermon against Clipping [the coin], preached before the right honourable the lord mayor and court of aldermen, at Guildhall chappel, on 16th December, 1691. By IV. Fleetwood, chaplain in ordinary to their majesties [afterwards bishop of Ely]. London: printed by Tho. Hodgkin, and are to be sold by John Whitlock, near Stationer's' Hall. 169.4." Dr. Fleetwood was the author of Chronicon Preciosum.

The silver coin was now so much debased and clipped that one guinca was equal to $30 s$. current coin.

The nation generally was alarmed at the circulation of "artificial wealth," such as bank notes, exchequer tallies, and government security. Bank notes were at zo per cent. dis.ount.-W нгтшокт.

The condition of the eurrency had again become serions.

1. By 7 and 8 William III, cap. 1- "In Act for" remedying the ill state of the coin of the kingdom "- it is reeited :-

"Whereas the silver coins of this realm (as to a great part thereof), doe appear to be exceedingly diminished by such persons who (notwithstanding several good laws formerly provided, and many examples of justice thereupon), have practised the wicked and pernicions crime of clipping, until at length the course of the monies within this kingdom, is become difficult and very much perplext, to the unspeakable wrong and prejudice of His Majesty, and his good subjects in their affairs as well publick as particular, and no sufficient remedy can be applied to the manifold erils arising from the clipping of the moneys without recoining the clipt pieces.

"Now to the end a regular and effectual method may be observed and put in execution in and for the recoining of the said clipt moneys, whether the same be sterling silrer, or bee silver of a courser allay than the stanclard. And to the end the loss upon the said money soe to bee recoined (to wit), the quantity of silver that is clipt away or deficient in the said moneys may be better known and 
Table XI.-Currency Restrictions, Legislative and Otherwise-Contd.

A.D. $1695 \ldots$

adjusted in order to the making satisfaction for the same by a public charge or contribution."

On or before 1st February, 1695, returns of clipt money in the Treasury were to be entered in a book; and up to 4th May, 1696, clipped sterling mones was to be reeeived at same rate as if unelipped, in orler of being made into new coin. Sixpenees not being clipped within the inmermost ring, to be kept in cireulation.

2. Same session. By 7 and 8 William 1II, eap. 13- "An Act for taking off the obligation and encouragement for coining guineas for a certaine time therein mentioned," wherein the Acts of 1666,1672 , and 1655 are recited, under which coin, plate, or bullion taken to the mint might be eoined into eurrent coin of the realm without any charge or abatement for waste :-

"And whereas great quantities of gold hare lately been imported from foreign parts, which being coined here as aforesaid into guineas, have been (on oceasion on the present ill state of the silver eoins) taken and aecepted by the subjects of this realm, at rery high and unusual rates and prices, tending to the great damage and loss of the public. The eontinuance of which practice (unless speedily prevented), will rm the mations vastly in debt to foreigners, for the repayment, whereof the silver money of this kingdom, must inevitably be exhausted on terms of great disadrantuge."

Therefure "to present the growth of so great an eril," the mint until 1st. July following, was not obliged to receive or coin gold.

The wine dutics were to be applied to the coinage of silser. There was a proriso for eoinage of gold brought to the mint by the royal African eompany. The importation of guineas or half-guineas from beyond the sea, "which may prore very prejudieial to this kingdom in the present juneture," was prohibited on pain of forfeiture.

3. Same session. By 7 and 8 Willi:m IJI, eap. 19-" An Act to encourage the bringing plate into the nint to be coined, and for the further remedying the ill state of the coine of the kingdome "-it is recited :-

"Whereas severall persons haveing wronght or manufactured plate or silver in ressell are or may bee willing and desirous, having a suitable encouragement given them, to bring such plate or vessels into IIis Majesty's mint or mints to bee coyned into the current coines of this realme, which will tend to the publick benefitt ;" it was therefore enaeted that persons bringing plate, \&e., to the mint to be coined, might have the same assayed, \&e., without any charge, and for every pound troy of sterling or standard silver, there should be delivered out a pound troy of lawful moneys, together with a reward after the rate of sixpence per ounce, upon the quantity brought in.

After 4th May, 1696, no tarern keeper was to expose any silver article (exeept spoones), for public use, in his use, on pain of forfeiture. All persons having presses for eoinage, taking the same to the mint would be paid for the same; but after the 3rd May, if found in the possession of any person they would be forfeited, with penalty of 500 . There were heary penalties for shipping bullion without certificate that the same was of foreign cwnership.

4. Same session. In William III, cap. 30, is contained a clanse which sets forth the relations between the corporation of moneyers and the mint, regarding the coinage of small silver moneys.

5. By another Act of the same session, 7 and 8 William III, ca]. 31, preeautions are taken (section 84) regarding paying the $6 d$. per onnee reward npon silver plate brought to the mint to be coined; and a penalty was imposed for unduly tendering plate for coinage.

It is stated that the cost of reforming the coinage at this date was $1,200,000 l$. 


\section{TABLe XI.-Currency Restrictions, Legislative and Otherwese-Contd.}

A.D.

1695

'95

"A great want of money in specie, but this was remedied by issue of new coin."-Wh IтWORTH.

It is reported that during this reign a commission, eonsisting of Lord Somers, Sir Isaac Newton and Jolm Locke, was appointed to reform the coinage, from whenee probably much of the legislation of this year proceeded.

There was published "Lownde's Essay for the Amendment of the Silver Coin." 8ro.

There was published "A Discourse concerning coining the new Money lighter, in answer to $\mathrm{Mr}$. Lock's considerations about raising the ralue of money." By Nicholas Barton, Esq., London. Printed for Richard Chiswell, at the Rose and Crown, in St. Paul's Churchyard, Mdcxcvi ; also, "Regulating the Silver Coin made Easy and Practicable." 8 ro.

By 8 and 9 William III, cap. 1-“ An Act for importing and coining guineas and half-guineas," which after reciting the Act of last session (cap. 13), further recites :- "But the said price of guineas being now reduced to, or neare the standard, and sundry persons being desirous to coine gold, and also to import great quantities of gnineas and half-guineas, which may be rery beneficial to the trade and commerce of this kingdome;" these coins were permitted to be freely imported.

2. By another Act of this session, 8 and 9 William III, cap. 2-"An Act for the further remedying the ill state of the coin of the kingdom "-it is recited as follows :-

"Whereas great mischief and inconreniences hare fallen upon this kingdome by the frequent counterfeiting, clipping, and other unlawful diminishing of the current coine of this lingdome, for the remedying whereof for the future it is thought necessary that all the hammered silver coin of this kingdom shonld be recoined by the mill and presse, which will be less subject to those pernicious and destructive methods of elipping and counterfeiting; and that in the meantime, to put a stopp to the further clipping such hanmered money, the same should not be current in payment, otherwise than is hereafter mentioned.

"For the incouragement therefore of all persons to bring in their hammered silver money into His Majesty's minte to be recoined, be it enacted," \&c. That all such hammered silver money elipped or unclipped, as shonld be brought by any person, at any time after the 4th Norember, 1696, and before the 1st July, 1697, should be received at $5 s .4 d$. per ounce; hammered coin to be taken for taxes on loans at $5 s$. $8 d$. an ounce.

3. After 1st December, 1696, no hammered silver coin to be current, except by weight; broad hammered money to be received till 1sth November, by tale for taxes, \&c. All the hammered money to be melted down and coined by the mill.

4. By a later Act of same session, 8 and 9 William III, cap. 6, it is enacted (section 106), that tender of hammered silver at rate of 5s. $2 d$. an ounce, after 1st February, 1696.

By another Act of the same session, 8 and 9 William III, cap. 7"An Act for granting to His Majesty several duties upon paper, vellum, and parchment, to encourage the bringing of plate and hammered money into the mint to be coined "-such duties were so imposed, in order to bear the charge of the recoinage, apparently estimated at 125,000 l.

5. And by yet another Act, 8 and 9 William III, cap. 8- "An Act incouraging the bringing in wrought plate to be coined"-it was enacted that persons bringing in such wrought plate to be coined between the 1st July, 1696, and 4th Norember, 1697, should be paid for the same at the rate of $5 s .4 d$. per ounce, in the new moneys 


\section{TABLE XI.-Currency Restrictions, Legislative and Otherwise-Contd.}

A.D. $1696-97$

$97-98$

of the realm, "no deduction for solder, unless in any bottom part of the plate."

6. Ihere was also enacted the 8 and 9 William III, cap. 26-"An Act for the better preventing the counterfeiting the current coin of the kingrlome." (See 1702 and 1708.)

There was enacted 9 William III, eap. 2-" An Act to prevent the further curreney of any hammered silver coine of this kingdome, and for re-coining stich as is now in being, and for the making out new exehequer bills, whether former bills are or shall be filled upp by endorsement." From 10th July, 1697, no hammered silver coin to be eurrent, nor the tender thereof a good tender, nor the refusal thereof refusal of lawful coin.

2. By another Act of same session, 9 William III, cap. 21-"An Act for the better preventing the counterfeiting, clipping and other diminishing the coine of this kingdom "-there is some glimmering of legislative wistom. It recites: "Whereas the preventing the currency of clipt and mulawfully diminisht and counterfeit money is a more effectuall meanes to preserre the coine of this kingdom entire and pure than the most rigorous laws for the punishment of suein as diminish or comterfeit the same;" and further, "the former and ancient laws being grown into disuetude, whereby unlawfully diminisht and counterfeit mones or currency, and wieked and trasterons persons are encouraged to diminish and eumterfeit the same; now to the end, the kingdom, after so rast a charge and expense for the reformation of the silrer eoine, and restoring it to its due weight and purity, may not relapse into the same evil from which it hath been so latel." delivered with great difficulty and hazard, and that counterfeit and unlawfull climinisht money, which already begins to increase, may be defaced and destroyed, be it declared," sc.

And it was declared and enacted that persons to whom unlawful money was tendered might break or deface the sanne; and if counterfeit, the persons tendering the same were to bear the loss. Silver moners for duties, de., to be taken by weight.

3. There was another Act of the same sestion, 9 William III, cap. 36 - "In Act to stop the coining farthings and half-pence for one sear" - which recited: "Whereas, hy reason of the great quantities of copper firtlings and half-pence which have lately been coined and uttered, the same are at present become a burtheu and inconrenience to miny of his majesty's subjects in several parts of the kingdom." The coinage of these and of "tokens to go for farthings and half-pence," was stopped ; and an arrangement was anthorised to be made with the contractors for farthings of copjer to supply farthings of tin.*

* Tokens.-For many centuries, down, in faet, to Charles II (1672), the only authorised current coin in the realm was of gold and silser (except that perhaps the earliest inhabitants of our island had nsed eopper). The silver pence and half-pence had gradually beeome rednced in size until by reason of their smallness ther had become inconvenient. To remedr this, and also to provide ehange for the inerease of retail trade, and abore all as a means of adrertisement, tokens came to be issued by tradesmen. They were mostly coins of small denominations, and were first issued about the reign of Ifenry VII. They were rariously composed, originally of lead, tin, latten, and even of leather; later on, of copper. In the reign of Elizabeth ther greatls increascd; and though the silver farthings coined by James I and charles $\dot{I}$ for a time supplied the want of small coin, yet in the eiril wars the prirate tokens multiplied to a great exeess; and erery petty tradesman had his pledges for a half-penny, redeemable in silver or in goods to bearer on demand at his shop ; upon the credit of whieh it therefore depended whether they should circulate 


\section{Table XI.-Currency Restrictions, Legislutice and Otherwise- - Contd.}

A.D.

1700

$1700-01$

Abundance of French money in England.-Wнитwовтн,

By 12 and 13 George III, eap. 11, seetion 12 , the statute of 1666 (eontinued by several subsequent Acts) was further extended for a period of seven years.

Note.-The current eash of the kingdom computed to be I 2 millions.

'02 .... By 1 Anne, eap. 1, the Art of 1696-97, cap. 26, which " hath been found of good use for suppressing the counterfeiting the eurrent eoin of this kingdom by such tools and instruments as are therein prohibited," eontinued in furce till 25th March, 1709.

The town of Neweastle-npon-Tyne was appcinted for assaying and marking wrought plate for coinage, and the silversmiths inhabiting there were constituted into and incorporated as the Company of Goldsmiths of the said town.

The rules for marking and assaying wrought plate were as in 12 and 13 William III, eap. 4.

By the Act of union of the two lingdoms of England and Scotland, 6 Anne, cap. 11 [Ruffhead, 5 Anne, eap. S], artiele xri, it was enaeted:-

"That from and after the union, the coin shall be of the same standard and value throughout the United Kingdom as now in England, and a mint shall be eontinued in Scotland, under the same rules as the mint in England," \&e.

And by artiele $x \mathrm{r}$ it had been agreed that the losses "which prirate persons may sustain by reducing the eoin of Scotland to the standard and value of the eoin of England may be made good," out of a fund which had been provided for various purposes of adjustment (see 1711).

The 7 Anne, cap. 42-"An Aet for continuing the former Aet for the encouragement of the eoinage, and to eneourage the bringing foreign coins and British or foreign plate to be coined, and for making provision for the mints in Scotland, and for the prosecuting offenees concerning the coins in England "-continued the statute of 1666 and that of 1672 . It then authorised the master and worker of the mint to offer bounties, at $2 \frac{1}{2} l$. per ounce (and not exceeding in the whole 6,000 l. so to be expended), for foreign coins of standard silcer brought into the mint between 20th April and 1st December, 1709; the same to be coined into money of this realm.

through one or two streets, a whole town, or some little distance in the eountry round. The tradesmen on old London Bridge were famous for their tokens.

The "London Gazette" for 25th July, 1672, and 23rd February, 1673, contained proelamations against these tokens, and of the jssuing of the first farthing coinage-referring to "the Farthing Office in Fenchureh Street" as the place of exchange.

Again, in 1781 , in eonsequence of the debased condition of the authorised copper coinage, there commenced a general striking and issue of provineial and tradesmen's tokens, foremost amongst which was the now famous Anglesey penns of this date.

The inseriptions or impresses upon these tokens consisted generally of names, residences, initials, and the trade signs of their owners, by whom they were issued and guaranteed. The quantity used in London at one period was so great, that Sir Robert Cotton supposed in 1612 that there were no less than 3,000 persons who issued leaden tokens of the amount of 5 l. annually on an average, of which ther had not one-tenth remaining at the sear's end.

Not only did private persons issue tokens, but at a later date some of the more public institutions, as the Bank of England, the Bank of Ireland, \&e., issued them, as will be seen by referenee to the statutes given later. See 1804 to 1825, this table. 


\section{Table XI.-Currency Restrictions, Legislative and Otherwise-Contd.}

A.D.

The 10 Anne, eap. 7 [cap. 3 in some editions of statutes] - "An Act for eharging and continumg the duties upon malt, mum, eyder and perry for the service of the year 1712 ; and for applying part of the coinage duties to pay the deficiency of the value of plate coined, and to pay for the recovering the old money of Scotland"-tells its own tale sufficiently in its title except in one particular, as to which it is recited as follows:-

"And whereas by the accounts that have been given of the charge of reeorering of the money in that part of Great Britain called Scotland, pursuant to the articles of union in that behalf, there appears to be due and owing to the prorost and moniers of the mint in the Tower of London, a eonsiderable sum of money on the sereral rates and allowances agreed to be paid theln for and upon aecount of the said recoinage; and some doubt hath arisen whether the sum or sums so due and owing may legally be taken out of the money arising by the comage duties, and as the said duties now stand. . . . . "

And it was enacted that a sum not exceeding 2,700l. $5 s \cdot 3^{\frac{1}{2}} d$. might be so applied.

The gold coinage at this date in Great Britain was estimated at 12,000,000l.-DATENANT.

'42 ... By the 15 George II, cap. 28-"An Aet for the more effeetual prerenting the counterfeiting of the current coin of this kingdom, and the uttering and paring false or eounterfeit coin"-it was made high treast $\mathrm{n}$ to gild silver coin in riew of making it resemble gold. This Act recited :-

"II. And whereas the uttering of false money, knowing it to be false, is a erime frequently eommitted all orer the kingclom, and the offenders therein are not deterred, by reason that it is only a misdemeanor, and the punishment very often but small, though there be great reason to believe that the common utterers of such money are either themselres the coiners, or in confederaey with the coiners thereof."

It was therefore again made felony for the third offenee, imprisonment for the first and second.

'59 .... There was published The Analysis of Trade, Commerce, Corn, Bullion, Banks, and Foreign Exchange. By Philip Cantillon, late merchant of Purden (WatTs). MeCulloch says, "late of the city of London, merchant."

'62 .... The gold coinage was estimated at 16,000,000l.-Anderson.

'73 ... We now find that the gold coinage was being subjeeted to similar treatment to that which had been so long experienced by the silver coinage.

By 13 George III, cap. 71-" An Act for the better prerenting the counterfeiting, clipping, and other diminishing the gold coin of this kingdom" - wherein it is reeited :-

"Whereas the prerenting the curreney of clipped and unlawfully diminished and counterfeit money, is a more effectual means to preserve the coin of this kingdom entire and pure than the most rigorous la $\pi$ s for the punishment of such as diminish or counterfeit the same; and whereas, by the known laws of this kingdom, no person ought to pay, or knowingly tender in payment, any counterfeit or unlawfully diminished money; and all persons may not only refuse the same, but may, and by the ancient statntes and ordinances of this kingdom have been required to destroy and deface the same, and more particularly the tellers in the receipt of the exehequer, by their duty and oath of offiee are required to reeeire no money but good and true; and to the end that the same might be the better discerned and 
TabLe XI.-Currency Restrictions, Legislative and Otherwise-Contd.

A.D.

1773

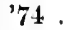

'86

'98

1800

known by the ancient course of the said receipt of the exchequer, all money ought to be receired there by weight as well as tale."

It is then enacted that persons to whom gold noney should be tendered, diminished otherwise than by reasonable wearing, or appearing to be counterfeit, might cut or deface such money ; disputes to be settled by mayor's of cities or justices of the peace.

The gold coinage brought into the mint by proclamation was $1,556,359 l$.; the expense of collecting, melting and recoining it was $754,019 l$.

The 14 George III, eap. 42-"An Act to prohibit the importation of light silver coin of this realm from foreign countries into Great Britain or Ireland; and to restrain the tender thereof beyond a certain sum"-recites :-

"Whereas considerable quantities of old silver coin of this realm, or coin purporting to be such, greatly below the standard of the mint in weight, have been lately imported into this kingdom, and it is expedient that some provision should now be made to prevent a practice which may be carried on at this time to the very great detriment of the public."

After lst June this year all coin purporting to be Britisl coin, not of the standard weight, prohibited from being brought into this kingdom, and might be seized and melted down. See 1798.

The gold coinage estimated at 20,000,000l.-ChaLMERs.

The 38 George III, eap. 49-"An Act to revise and continue until the 1st day of January, 1799, an Act [14 George IIX, cap. 42 (1774)] . . . . and to suspend the coinage of silver-" leeited :-

"And whereas his majesty has appointed a committee of his privy council to take into consideration the state of the coins of the kingdom, and the present establishment and constitution of his majesty's mint; and inconvenience may arise from any coinage of silver until such regulations may be framed as shall appear necessary; and, whereas, from the present low price of silver bullion, owing to temporary eireumstances, a small quantity of silver bullion has been brought to the mint to be coined, and there is reason to suppose that a still further quantity may be brought, and it is therefore necessary to suspend the coining of silver for the present."

It was therefore resolved to suspend the coinage of silver until 9th May, 1798 [royal assent, 21st June].

There was published, "The cause of the present threatened famine traced to its real source, viz., an actual depreciation of our circulating medium, occasioned by its paper currency, with which the war, the shock giren to public eredit in 1794, the stoppage of the bank in 1797 , the bankrupteies of Hamburg in 1799, inundated the country, to accommodate government, and enable the merchants to keep up the price of their merchandize. Showing by an arithmetical calculation, founded on facts, the extent, nay the very mode of the progress which the paper system has made in reducing the people to paupers, with its only apparent practical remedy. By Common Sense." 8 vo., $28 \mathrm{pp}$. Motto on title page, "Depreciate the value of my money" and you take from me the means of subsistence to that amount. That is the gist of the argument of the author.

The gold coinage of the kingdom was estimated at 37,000,000l.Puillips. [Evidently an over-estimate, see 1830.]

Also a pamphlet, "Cause of the present threatened famine traced to its real source, viz., an actual depreciation of our circulating medium by paper currency." 8vo.

There was published, "Profusion of Paper Money, not defieiency in Harrests; Taxation not Speculation; the principal causes of the Sufferings of the People." By a Banker. 8ro.

04 .... By 44 George III-cap. 71, "An Act to prevent the counterfeiting of 


\section{Table XI.-Currency Restrictions, Legislative and Otherwise-Contd.}

A.D. 1804

silver coin issued by the goremor and eompany of the Bank of England, ealled dollars, and silver coin which may be issued by the gorernor and eompany of the Bank of Ireland, called tokens; and to prerent the bringing into the United Kingdom, or uttering any eounterfeit dollars or tokens "-it is recited :-

"Whereas the governor" and esmpany of the Bank of England hare for the convenience of the publick, lately cansed to be coined or stamped, and eireulated, a large quantity of silrer dollars, containing on the obrerse side there of an impression of his majesty's head, and the following words and letters, videlicet, 'Georgius III Dei Gratia Rex,' and on the reverse side thereof the impression of 'Britannia,' and the following words and figures, videlicet, 'Fire shillings dollar Bank of England 1804.' And whereas the gorernor and company of the Bank of England are preparing and intend to issue for the conrenience of the publick, in that part of the United Kingdom called Ireland, a quantity of silver coin denominated tokens, containing on the obrerse side thereof the same impression, worls, and letters as the said dollars, and on the reverse side thereof the impression of Hibernia, and the following words and figures, "Bank of Ireland Token 1804, Six Slillings.' And whereas for the security of the publick it is expedient to prevent the connterfeiting of the said respective eoins."

It was therefore enacted that persons counterfeiting the said dollius or tokens should be guilty of felony, and persons uttering or vending counterfeits were to be liable to six montlss' imprisonment.

There was enacted, 45 George 11 , eap. 12 - "An Act to extend the provisions of an Aet made in the last session of parliament for preventing the counterfeiting of certain silver coin issued by the banks of England and Ireland respectively, to silver pieces, which may be issued by the goremor and company of the Bank of Ireland, ealled tokens; and to promote the cireulation of the said tokens" - which reeited :-

"Whereas the goremor and eompany of the Bank of Ireland are preparing and intend to issue for the eonvenience of the publie, in that part of the United Kingdom called Ireland, a quantity of silver pieces denominated tokens, of the common standard of Spanish pillar dollars, eontaining on the obrerse side thereof an impression of his majesty's head, and the following words and letters, videlicet, 'Georgius III Dei Gratia' and on the reverse side thereof the following worls and figures, 'Bank Token Five-pence Irish 1805,' each such token for frepence containing in weight one-thirteenth part of the common weight of the Spanish pillar dollar, and each such token for tenpence eontaining two sueh thirteenth parts. And whereas for the security of the publiek it is expedient to prerent the counterfeiting of the said respective tokens."

And the like punishments as under the former Act were enaeted. Such tokens issued during restrictions on Bank of Ireland to be received in payment of the revenue.

The 48 George III, eap. 31-"An Aet to extend the provisions of an Act made in the forty-fifth sear of his present majesty's reign, for preventing the counterfeiting of eertain silver tokens, to eertain other tokens, which may be issued by the governor and company of the Bank of Ireland, and to promote the eirculation of the said lastmentioned tokens" - recited that the Bank of Ireland was preparing and would issue in Ireland a "Bank Token xxx penee Irish," eaeh such token containing in weight six-thirteenth parts of the common wcight of a Spanish pillar dollar; also that the eoins mentioned in the Act of 1805 had been issued with the figures 1806, instead of as deseribed in the At. Persons counterfeiting these coins or any of them to be guilty of felony. New eoins to be taken in payment of rerenue. 


\section{Table X1.-Currency Restrictions, Legislative and Otherwise-Contd.}

A.D. 1811 silver pieces denominated tokens, intended to be issued and circulated by the governor and company of the Bank of England, for the respective sums of five shillings and sixpenee, three shillings, and one shilling and sixpenee; and to prevent the bringing into the kingdom or uttering any such eounterfeit pieces or tokens"-it is reeited :-

"Whereas the gorernor" and company of the Bank of England, with the approbation of his majesty's most honourable privy council, are preparing to make and stamp, and intend to issue and eireulate for the convenience of the public, a quantity of silver pieces, denominated tokens, for the respective sums of five shillings and sixpence, three shillings, and one shilling and sixpenee.

Then follows a detailed deseription of the coins; and penalties for counterfeiting or bringing counterfeit tokens into the kingdom. Powers of searehing suspected houses.

11 .... The 51 George III, cap. 127-"An Act for making more effeetual procision for preventing the current gold coin of the realm from being paid or accepted for a greater value than the current value of such coin; for preventing any note or bill of the governor and company of the Bank of England from being received for any smaller sum than the sum therein specified; and for staying proceedings upon any distress by tender of such notes"-sufieiently expresses its purpose in its title. It was passed in a period of scareity of grain.

12 .... By 52 George III, eap. 157 - "An Act to prevent the issuing and eireulating of pieces of gold and silver, or other metals usually ealled tokens, exeept such as are issued by the Banks of England and Ireland respeetively," - -it is reeited :-

"Whereas various piees of gold and silver, and mixed metals composed in part of gold or silver, usually denominated tokens, hare lately been and are issued and eireulated by persons residing in various parts of the United Kingdom, in great quantities, for nominal sums of money usually expressed therein, much above the real value of the metals of which the same are composed. And whereas it is expedient that the further making and issuing of sueh tokens should be prohibited, and the eirculation of those already made or issued should also be prohibited for a limited period."

No tokens already made to be issued, and none to creulate after 25th March, 1813; but they might be presented for payment to original issuer, who was not to be relieved from payment by the operation of this Act. Aet not to apply to Banks of England and Ireland.

13 .... There were several enaetments this year:-

1. By 53 George III, cap. 19, "An Aet to amend an A et of the last session of parliament to prevent the issuing and cireulating pieces of gold and silver or other metal usually ealled tokens, except such as are issued by the Banks of England aud Ireland respectively." The period at whieh the eireulation of tokens (other than those of the Banks of England and Ireland) was to cease was extended to 5th July, 1813.

2. The 53 George III, eap. 106-"An Aet to extend the provisions of an Act made in the forty-fifth year of his present majesty's reign, for preventing the counterfeiting of certain silver tokens, to certain other tokens which have been or may be issued by the governor and company of the Bank of Ireland"-recites :-

". . And whereas the governor and company of the Bank of Ireland have issued, or are preparing to issue in Ireland, for the eonrenience of the public, a quantity of silver pieces denominated tokens, of the common standard of Spanish pillar dollars, for thirty pence, Irish eurrency, each 


\section{TABLE XI.-Currency Restrictions, Legislative and Otherwise-Contd.}

A.D. 1813

Then follows a detailed description of the coin, as also of a new issue of tenpenny and fivepenny tokens dated this year. Then there are penalties for counterfeiting. These tokens might be received in payment of revenue.

3. The 53 George III, cap. 114, "An Act to continue and amend the Act of the present session, to prevent the issuing and circulating of pieces of gold and silver or other metals, usually called tokens, except such as are issued by the Banks of England and Ireland respectively"-extencled the period at which the circulation of tokens was to cease until six weeks after the commencement of the next session of parliament.

4. By 54 George III, cap. 4, the period for staying the circulation of tokens (other than those of the Banks of England and Ireland) was extended to six weeks after the commencement of the then next session of parliament.

Mr. S. T. Galton published, "Chart, Exhibiting the relation between the amount of Bank of England notes in circulation, the rate of Foreign Exchanges, the Prices of Gold and Silver, Bullion and Wheat."

There was also published, Further Considerations on the State of the Currency. BF Lord Lauderdale. 8vo., Edinburgh.

There was published, "Cobbett's paper against gold, containing the history and mistery of the Bank of England, the funds, the debt, the sinking fund, the bank stoppage, the lowering and the raising of the value on paper money, and showing that taxation, pauperism, poverty, misers, and crimes have all increased and ever nust increase with a funding system."

16 .... There was enacted 56 George III, cap. 68-" An Act to provide for a new silver coinage, and to regulate the currency of the gold and silver coin of this realm" - which recites :-

"Whereas the silver coins of the realm have by long use and other circumstances become greatly diminished in number and deteriorated in valuc, so as not to be sufficient for the payments required in dealings under the value of the current gold coins, by reason whereof a great quantity of light and counterfeit silver coin and foreign coin has been introduced into circulation within this realm; and the evils resulting therefrom can only be remedied br a new coinage of silver money to be made and issued under proper regulations for maintaining its value and preserving the same in circulation."

The Act of 1666 was then in part repealed, and also so much of 1695-96 (cap. 1) ; "and also so much of all and every other Act and Acts as declare, enact or provide that the weight and trueness prescribed by any indenture therefore made with his majesty's master and worker for making of silver monies at the Tower of London shall be and remain to he the standard of and for the lawful silver coin of the kingdom."

It was enacted that the pound troy of standard silver, 1 I ounces 2 pennyweights fine silver, and i 8 pennyweights of alloy might be coined into $60 \mathrm{~s}$. Also that the old coinage of the realm brought to the mint might be exchanged for its full nominal value in new silver coin.

1. By 57 George III, cap. 46-"An Act to prevent the issuing of pieces of copper or other metal, usually called tokens"-it is recited :-

"Whereas various pieces of copper and mixed metals composed in part of copper, usually denominated tokens, have lately been, and are issued and circulated, by persons residing in varions parts of the United Kingdom, in great quantities as money, and for a nominal value of the metals of which they are composed; And whereas it is expedient that the further making and issuing of such tokens should be prohibited, and that the circulation of those already made or issued should also be prohibited after a limited period." 


\section{Table XI.-Currency Restrictions, Legislative and Otherwise-Contd.}

A.D.

It is then enacted that from and after the passing of this Act, no picce of copper or nixed metal composed in part of copper, of whatever value the same might bc, should be made or manufactured, or originally issued as a token for money, or as purporting that the bearer or holder thereof was entitled to demand any ralue denoted thereon, either by letter's, words, figures, marks or otherwise, whether such value was to be paid or given in money or goods, or in any manner whatsoever. And penaltics were imposed upon the circulation of any such tokens after 1st January, 1828. It was further recited :-

"III. And whereas certain tokens made of copper or of a mixed metal composed partly of copper, and bearing the subscription 'Sheffield Penny Token,' were issued from time to time during the rears $1812,1813,1814$, and 1815 , by the orerseers of the poor of the township of Sheffield, in the county of York; and whereas the immediate suppression of the circulation of the aforesaid tokens would bc attended with great loss to the said tornship of Sheffield, and to the holders thereof, who are for the most part labourers and mechanics, as well as with great inconvenience to the inhabitants of the town of Sheffield and the neighbourhood thereof."

These Sheffield penny tokens were therefore to be allowed to circulate until 25th March, 1823. And it was further recited:-

"VI. And whereas certain other tokens made of copper, or of a mixed metal composed partly of copper, and bearing the superscription 'Birmingham One Penny,' were issued from time to time during the years 1812-15, by the orerseers of the poor of the parish of Birmingham, in the county of Warwick; and whereas the immediate suppression of the circulation of the aforesaid tokens would be attended with great loss to the said parish of Birmingham, and to the holders thereof, as wcll as great inconvenience to the inhabitants of the town of Birmingham and the neighbourhood thereof."

All such tokens to be called in before 25 th March, 1820 .

2. By 57 George III, cap. 113-"An Act to prevent the further circulation of dollars and tokens issued by the gorernor and company of the Bank of England, for the conrenience of the public "-the Acts of 1804 and 1811 are recited :-

"And whereas, in consequence of the recent circulation of the new current silver coin, it becomes unnecessary any longer to continue the said dollars and tokens in circulation, and it is expedient to prohibit further circulation thereof after a time to be limited."

The circulation was therefore to ccase after 25th March, 1818; but they might be presented to the Bank of England for payment up to 25th March, 1820, and might be disposed of for old silver at the current price of silver.

The Act of last session (chapter 113) was by 58 George III, cap. 14, altered to the extent that the tokens might be employed up to 5 th April, 1819, in payment of government dues, taxes, \&c.

A series of tables, exhibiting the gain and loss to the fundholders arising from the late fluctuations in the value of the currenes from 1800 to 1821. By Robert Musket, Esq. Second edition. London.

Mr. J. C. McCulloch contributed to the Edinburgh Review a paper, "On Pernicious Effects of Degrading the Standard of Money," Article XI, July, 1821. A most excellent article, from which I have drawn some contributions for this paper.

The 6 George IV, cap. 98-"An Act to prevent the further circulation of tokens issued by the governor and company of the Bank of Ireland, for the convenience of the public, and for defraying the expense of exchanging such tokens"-recites the issuing of the said tokens under the anthority of the Acts already reviewed:-

"And whereas in consequence of the recent issue of a new current 


\section{Table XI.-Currency Restrictions, Legislative and Otherwise-Contd.}

A.D.

1825

26

$30 \ldots$ The Duke of Wellington estimated the gokt coinage at $28,000,000 l$, and the remainder of the metallic currency at 13,000,000l.; total, $4^{1,000,000 \text { l. }}$.

31 .... An II istorieal Inquiry into the Production and Consumption of the Precious Metals. BY William Jacob, Esq., F.R.S. 2 vols. "Though perlaps the best on the subject, the work is rers defective." MeCUldoch.

37 .... There was published, "Money and its Vicissitudes in Value, as they affect National Industry and Peeuniary Contracts; with a Postscript on .Joint Stoek Banks." (See 1857.)

40 .... Mr. James Wilon published, "Influence of the Corn Laws, as affecting all Classes, and particularly the Landed Interests." 8ro. Second edition.

'40 .... There was published, A Letter' to Firkman Finlay, Esq., on the Importation of Foreign Com, and the Value of the Precious Metals in Different Countries. By James Pennington, Esq. London. 8 ro.

The Philosophy of Trade- An examination of the principles which determine the relative value of Corn, Labour, and Currency. By Patrick James Stirling. Sro.

'53 .... Mr.William Newmarch, F.R.S., published, "The new Supplies of Gold: Facts and Statements relative to their actual amount, and their present and probable effects."

'56 .... Mlr. Charles Jellicoe contributed to the Assurance Magazine, of which he was then editor, a short paper, "Comparative Value of Gold in different Countries," wherein he points out that while the onnee of standard gold is ralued at $3 \%, 17 s .10 \frac{1}{2} d$, one-twelfth of it being allog, the ounce of pure gold will be worth one-eleventh more, making $8+977 s$.

'57 .... There was published, "Money and its Vieissitudes in Value, as they affect Industry and Pecuniary Contracts," by the author of a " C'ritical Dissertation on Value," \&c. Svo. (See 1837.)

'59 .... There was published a now widety known work, "On the probable Fall in the value of Grold: the eommercial and social consequences which mar ensue, and the measures which it inrites." By Michael Chevalier, translated from the French, with preface by Richard Cobilen, Esq.

'63

There was published by Professor Jerons, "A serious Fall in the Value of Gold ascertained, and its Local Effects set forth." With two diagrams.

'65 .... There appeared in the Journal of the Statistical Society of London, rol. xxviii, p. 294, a paper" On the Variation of Prices and Talue of the Curreney since 1782." By W. Stanley Jerons, \&c.

'66 .... Mr. Charles Willich published is table showing (inter alia) the price of consols, the bank rate of discount, and the price of wheat from July, 1844 (passing of Bank Charter Aet) to May, 1866.

'69 .... "Letter on the Value of Gold." Economist, 8th May. Reprinted in the Statistical Journal, rol. xxxii, p. 4tin. 


\section{XI.-Speculation.}

In my remarks upon legislative interference (in section 9 of this paper), I have shown how it became incumbent to enact laws against "speculation" in grain and other food stuffs, known technically as forestalling, engrossing, regrating, \&c. It was a necessary prop to uphold a tottering and unsound system of legislative interference with commercial affairs. These laws were in their nature arbitrary, and could only be tolerated because they appeared to be made in the interest of the people. That their design was in this direction is manifest, and it seems clear that the people so regarded them, or they never could have been continued throughont so many centuries; and would not have been renewed, extended, and supplemented as they were from time to time in parliament. It must be always assumed that any legislation which appears to secure cheap food for the people will be popular with the masses, however unjust and tyrannical as against individuals or classes.

It may indeed be that there were in operation in the past causes, which, while we cannot realise them now, seemed to justify even all these laws attempted to accomplish; or it may simply be that such laws, originated in defiance of all known principles of political economy, were allowed to continue in a like spirit of defiance. It is certain that Adam Smith and his followers did kill them out, althongh they died a very hard death, as reference to the concluding portion of Table XII will make apparent.

I have looked with curiosity, bordering upon anxiety, for a writer who should defend these laws on any principle of rational argument; but have not found one. In my search, however, I did discover a document-nothing less than a report by a select parliamentary committee of the House of Commons, from which I propose to quote certain passages for the edification of all whom they may now concern or interest.

"A report from the committee who (upon the 8th day of February, 1764) were appointed to inquire into the causes of the present high price of provisions, with the proceedings of the house thereupon. Published by order of the House of Commons." (Folio pp. 6.) From this document I take the following passages :-

"Mr. Winter, Orton and Jones, agreed in stating the present price of the best beef to be $3 d$. per pound to the vendor, which is about one $\frac{1}{2} d$. dearer than beef of the same goodness has usually been in the month of March for some years past; to which point the committee brought all the witnesses in giving their evidence: imagining it to be necessary, in determining a comparative price, to adhere to the same month, and to meat of the same goodness.

"The witnesses stated the present price of the choice pieces of the best beef to be, to the customer, $4 d$. and $4 \frac{1}{4} d$. per pound; the best pieces of inferior beef $3 d$. or $3 \frac{1}{4} d$; and the coarser pieces of beef in general from $1 \frac{3}{4} d$. to $2 \frac{1}{2} d$. and $2 \frac{3}{4} d$. which is $\frac{1}{2} d$. dearer than the same have usually been in the month of March. . ." 
"The same witnesses admit the present price of mutton also to be higher than it used to be in March, but they state the increase differently from $\frac{1}{4} d$. to a $\frac{1}{2} d$. per pound."

In riew of discovering the causes of this increase of price, the committee examined several "eminent" meat salesmen, who alleged, first, the inereased demand in London, which on being pressed they could not sustain, next:-

"They then accounted for this increase of the price of meat by the want of pork at market, proceeding from the great plenty of acorns in 1762, which incluced all the Feeders to Fatten their whole Stock of Hogs in that year, which extraordinary slaughter they allege is not yet replaced; and that the want of one article in the General Provisions of so populous a City as London has necessarily atranced the Prices of other Species. The whole Demand acting upon the whole Quantity of the different sorts of Provisions as upon one and the same Subject.

"They added also, that the wet season had much lessened the Weight of even Fat Cattle; that the great Scacity of Fodder in 1762, had reduced the Breed and Stock; and that the failure in the Crop of Turnips in sereral Counties this year, had prevented those Counties fattening the usual quantities of Beasts. They assigned atso the low price of Hides and Tallow as an additional Reason. But upon further examination, all the salesmen and Butchers admitted that the present High Price is not entirely or exclusively the effect of Natural Causes, but an Artificial Price, resulting from Combinations, and the want of better Regulations for the sale of Cattle in Open Markets."

They fell back upon the evils of engrossing and forestalling, and on this point $I$ have already quoted from this same report in the following table.

Note.-In 1362 (36 Edward III) a petition was presented to the king, which complained "that great mischief's had newly arisen, as well to the king as to the great men and commous, from the merchants Grocers, who engrossed all manner of merchandise vendible, and who suddenly raised the price of snch merchandise within the realm; putting to sale by covin and by ortinances made among them. selves in their own society, which they called the "Fraternity and Gild of Merchants,' such merchandises as were most dear, and keeping in store the others until times of dearth and scarcity." The "Fraternity" here complained of is now the famous "Company of Grocers" in the city of Loudon, originally a "Craft Gild."-English Gilds, p. exxiii. 
TABLE XII.-Speculation in Grain and Other Articles of Food, known as "Engrossing," "Forestalling," and "Regrating."

A.D. 1266

In the Judicium Pillorie (the judgment of the pillory), attributed to this date (51 Henry III), is contained, among the offences for which persons are to "suffer this judgment of the body," the following :-

"And also forestallers that buy anything afore the [due and accustomed hour] against the regulation [good state and weal] of the town and market, or that pass out of this town to meet such things as come to the market [and buy] out of the town, to the intent that they may sell the same in the town more dear to regrators [that utter it more dear] than they would that bought it, in case they had come to the [town or] market."

The Liber Albus declares (inter alia), the following to be articles of ancient usage, in the eity of London, "that ought each year, after the feast of St. Michael, to be proclaimed throughout the said city."

Of Forestallers. "And that no dealer, denizen, or stranger, whoerer he may be, shall go to meet dealers coming by land or by water with their merchandise and victuals towards the city, to buy or to sell, until such time as they shall have arrived at the said city, and have put ap their merchandise for sale; under forfeiture of the article sold, and pain of imprisomment. . . .

"And that no merchant, denizen, or stranger, whoever he may be, shall go to the pole [i.e. Pool, from the tower to Limchouse], or any other place in the 'Thames, to meet wines or other merchandise, or go on board of vessels to buy wines or other things, until such time as they shall have come to land, under pain of losing the article."

Of Regrators. "And that no regrator" of corn, of fish, or of poultry, shall buy provisions for resale, before the hour of prime rung at St. Paul's; or before the substantial men of the land and of the city shall have bought their provisions, under pain of losing the article bought.

" And that no market shall be held upon London bridge, but [only] elsewhere in the city where they are established, under pain of losing the article [sold].

"Also it is forbidden that if any one shall be so daring as to go on board of ressels or boats that bring scallops, mussels, welks, and cockles, or any other victuals, when they have arrived, for the purpose of regrating the same, uuder pain [of losing] the article. But the same shall stand for common sale by him who shall have bought such wares, that so the community may be served without regrators ; and under this pain of losing the article. And if any such person shall be found, he shall be heavily punished."

In the Statutum de Pistoribus (statute concerning bakers, \&c.), sometimes attibuted to 51 Henry III, but more generally to 13 Edward I, which latter we adopt, is contained the following, defining forestallers and awarding their punishment :

"But especially be it commanded on the behalf of our lord the king, that no forestaller be suffered to dwell in any town, who is an open oppressor of the poor people, and [of all the commonality, and an enemy of the whole shire and county, who, for greediness of his private gain, doth prevent others in buying grain, fish, herrings, or any other thing to be sold coming by land or water] oppressing the poor and deceiring the rich [who carrieth away such things intending to sell them more dear], the which come to merchants, strangers, that bring merchandise, offering them to buy, and informing them that their goods might be dearer sold than they intended to sell; and [by that means unjustly goeth about to sell the things much dearer than he who brought them] an whole town or county is deceived by such craft and subtlety.

"He that is convict thereof, the first time shall be [amerced], shall lose the thing so bought, and that according to the customs and 


\section{Table XII.-Speculation in Grain and Other Articles-Contd.}

A.D. 1285

\section{8}

ordinance of the town; he that is eonviet the second time shall have julgment of the pillory; at the third time he shall be imprisoned and make fine; the fourth time he shall abjure the town. And this judgment shall be given upon all manner of forestallers, and likewise "1pon them that have given them counsel, help, or farour."

By 12 Edward II (Statute of [Ebor] Fork), cap. 6, no officer in any city or borough, who ought by his office to keep assise of wine and victuals, should trade therein during his term of office.

There is understood to hare been an Act passed either in this or one of the preeeding reigns, intituled, "No forestaller shall be suffered to dwell in any town."

The 23 Edward III, eap. 6, eontains some provisions indireetly affecting regrators (see Table $\mathrm{IX}$ ).

By 25 Edward III, statute 4, cap. 2-"The penalty of him that doth forestall wares, merehandise, or victual "-it is enacted:

"Item-And it is accorded and established, that the forestallers of wines and other rictuals, wares, and merchandise that eome to the good towns of England by land or water, in damage of our lord the king and his people, if they be thereof attainted at the suit of the king, or of the party, before mayor, bailiffs, or justices, thereto assigned, or elsewhere in the king's court; and if they be attainted at the king's suit by indietment, or in any other manner, the things forestalled shall be forfeited to the king, if the buyer thereof bath made free to the seller; and if he hare not nade free of all, but by earnest, the bujer shall incur the forfeiture of as mnch as the forestalled goods do amount to, after the value as he bought them, if he have whereof; and if he hare not whereof, then he shall have two years' imprisonment and more, at the king's will, without being let to mainprise, or delivered in other manner; and if he be attainted at the snit of the party, the party shall have one-half of such things forestalled and forfeit, or the price, of the king's gift, and the king the other half."

By 27 Edward III, statute 1, cap. 3 , it was enacted:

"Item-For" the great and outrageous dearth of rietuals which hostelers, herbingers, and other regrators of victuals make through the realm, to the great clamage of the people paying through the realm, it is aceorded and established, that the justices, learned in the law, who be good and eonvenient, shall be newly chosen to inquire of the deeds and ontrages of such hostelers, regrators, labourers, and all other comprised in the statute another time thereof made and them to punish, and moreorer to do right to the king and his people; saring always to every lord and other their franchises in all points."

Chapter 5 of the same statute made it felong to forestall, or ingross Gascoin wine.

Same year the 27 Edward III, statute 1, eap. 11, enaeted as follows:-

"Iten-We have ordained and established that all merchants, aliens, and denizens, and other that do bring wine and other wares, or merchandises whatever they be to the staples, cities, boroughs, and good towns, or to ports of the sea, within our said realm and lands, may safely and without challenge and impeachment to any, sell them in gross or at retail, or by parcels at their will, to all manner of people that will buy the same; and that no merehant, priry, nor stranger, nor other of what condition that he be, go by land nor by water to encounter such wines, wares, or merehandises, eoming into our said realm and lands, in the sea, nor elsewhere, to forestall or buy them, or in other manner to gire earnest upon them, before that they eoxe to the staples, or to the port where they shall be dis. eharged, nor enter into the ships for sueh cause, till the merehandise be set to land to be sold, upon the pains and forfeiture eontained in the same third article aforesaid." 


\section{TABLe XII.-Speculation in Grain and Other Articles-Contd.}

A.D. 1353

The penalties imposed by the third ehapter of this Aet were "life, and member," i.e., life and limb.

By the 28 Edward III, cap. 13, it was enacted-

"And that no manner" of ship. which is frumght towards England or elsewhere, be compelled to conie to any port of England, nor here to abide, against the will of the master and minriners of the same, or of the merchants whose the goods be; and if such ships come of their own good will, or be driven by tempest or other misfortume or mischief, to any port in England, and the masters, mariners, or merehants of the same ships will sell or delirer part. Part of their merchandise, with their good will, it shall be lawful for every man to buy such merehandise freely withont impeachment in the port where such ships shall come, albeit the said merchandise be not put to land to sell; so alwags that no merchant nor other shall go by land nor by water to meet such ship eharged with merehandise to forstall the same merchandises, or to give earnest upon them by way of forestalling."

The 31 Edward III, statute 2-" An ordinance made coneerning the selling of herrings," recited as follows :-

"Forasmuch as the commons of the realm of England, at the parliament holden at Westminster on Monday next after the week of Easter, the year of the reign of our lord the King Edward III of England xxxi, and of France xriii, have complained them to our lord the king beeause that the people of Great Yarmouth do eneumber the fishers bringing herring to the said town in the time of the fair, and do buy and forestall the herring before they do come to the town; and also the hostelers of the same town that lodge the fishers coming thither with their herring will not suffer the said fishers to sell their said herring, nor meddle with the sale thereof, but sell them at their own will as dear as they will, and give to the fishers that pleaseth them, whereby the fishers do withdraw themselves to come thither; and so is the herring set at much greater price than ever it was, to the damage, to the great damage of our lord the king, of the lords, and of all the people: wherefore our lord the king seeing the mischief in this behalf, by the assent of the great men and all the commons, hath ordained and established remedy upon the said mischiefs, in the form as followeth :-

"I. First, that no herring be bonght or sold in the sea, till the fishers be come unto the haren with their herring, and the cable of the ship be down to the land.

"II. Item-That the fishers be free to sell their herring to all that come to the fair of Great Yarmonth withont any disturbance of their hostelers, or any other; and when the fishers will sell their merchandises in the port, they shall hare their hostelers with them, if they there will be, and in their presence, and in the presence of other merehants, openly shall sell their merchandises to whomsoever they please; and if any other nerchants present are willing to have part, let erery one who claims have his part for the price, after the rate of the same merchandise so sold; and the said sale shall be made from the sun rising till the sun going down, and not before and not after, upon forfeiture of the same merchandises: and that the said fishers be free to buy their vietuals, and that which they need, where it shall please them. And that no hostelers, nor other, buy any herring for to hang in their houses by covin, nor in other manner at an higher price the last than 40 s.; but less in as much as he may, ascording as he may agree with the seller; and that no hostelers nor any of their servants, nor any other whatsoever be be, coming to the said fair, shall go by land nor by sea to forestall herring privily nor openly, but the herring shall come freely unsold into the haven: nor that any rover make buying of fresh herring in the houses of Yarmouth, 


\section{Table XII.-Speculation in Grain and Other Articles-Contd.}

A.p.

'60 herring were to be sold, as given in Table IX.

'60 .... The last-numed ordinance was very mueh modified this year, see Table IX.

'63 .... The 37 Edward III_-“A statute coneerning diet and apparel," recites :-

"V. Item-For the great misehiefs that hare happened as well as to the king, as to the great men ancl commons, of that that the merchants, called grocers, do ingross all mamner of merchandise vendible; and suddenly do enhance the price of such merehandise within the realm, putting to sale by covin and ordinance made betwixt them, ealled the Fraternity and Gild of Mercluants, the merchandise which be most dear, and keep in store the other, till the time that dearth or scarcity be of the same: it is ordained, that no English merehant shall use no ware nor merehandise by him nor by other, nor by no manner of corm, but only one, which he shall choose betwixt this and the Feast of Candlemas next ensuing."

Surveyors, consisting of "good people and lawful of every merchanclise," were to be appointed to see to the due earrying out of these provisions.

The Act of this rear was repealed by 38 Edward III, eap. 2 (1363-64), under which all buying and selling was declared free, with certain reservations mentioned in Table $\mathrm{X}$.

'78 ... By 2 Riehard II, statute 1, cap. 2, it was ordained and established that the statute made in the time of King Edward, the grandfather, the twenty-fifth year of his reign, of forestallers of wines, wares, and merchandise which come to the good towns within the realm by land or by water, should be loolden and firmly kept at all points, and put in dize execution, for the common profit of the said realm.

Item. - It is ordained, that all manner of hosts, as well in the city of London, and the towns of Great Yarmouth, Scarborough, Winchelsea, and $R_{y}$, as also in certain other towns and places upon the coast of the sea and elsewhere through all the said realm, as well within the liberties as without, shall from henceforth utterly cease to be amoved from the noyance and wicked deeds and forestallings; and in especially they be inhibited by our sovereign lord the king, that they nor none of them, upon the pain that belongeth, shall any further intromit to embrace herring or any fish or other rictuals, under the colour of any custom, ordinance, pririlege, or charter before made or had to the contrary, which by tenour of these presents be utterly repealed; or privily or aferlty do, or procure to be done any inpediment to any fishers or victuallers, denizens or aliens being of the king's country, whereby they or any of them be compelled to sell their fish or other victuals, but where and when, and to any person whatsoever they will within the said realm at their pleasure. And moreover, it is especially inhibited to all and singular the said hosts, that none of them upon the pain aforesaid intromit from henceforth [of buying, selling, or corenenting] any manner sea fish fresh to the use of any fishmonger, or other citizen of the said city of London; and likewise it is inlibited to all fishmongers and other citizens of the same city of London, that none of them mpon the same pain, far from the city or near the same, from henceforth by any sea fish fresh, nor of the fresh 


\section{TABLE XII.-Speculation in Grain and Other Articles-Contd.}

A.D.

$1461 \ldots$

$1503 .$.

watcr, to sell again in the same city except eels fresh and luees and pykes, which shall be and remain in eommon as well to denizens as foreigners, to buy or sell, so that nevertheless the denizens shall in no wise let the foreigners within the same eity, to sell such fish, as often as ther shall bring or eause to be brought the same fishes to the said eity.

Other statutes against the forestalling of fish will follow.

There was an Aet of the parliament of Ireland, 8 Edward IV, eap. 2"An Act against engrossers and regrators of Corn," as follows :-

"Whereas direrse persons baving themselves great abundanee of all manner of com, have used to buy to the common market great store of corn to granell up the same to sell upon a dearth, and also diverse other persons ealled badgers, have used to goe to one market and have bought great store of wheat and corne at one price, and shortly after have taken the same corne into another market, and hare there sold at a more deer price by two pence or four penee in the bushel, which hath been the greatest means of dearth within this land, and the great and intolerable hurt of the poor inhabitants of this land of Ireland. Thercfore it is ordained and established by the authority of the said parliament, that no man having sufficient store of corne of his own, shall buy any manner of corne in the common market, nor that no other person nor persons ealled badgers shall buy any manner of corne in the form aforesaid, upou such payn as is made against the regrators in the king's market, and they and every one of them to be judged in the law as common regrators in the market. Also that it shall not be lawful to no man (sic), of whaterer condition soever he be, which will buy any mamer of corne in the common market to sell the same againe in the same market, nor in no other market, upon pain to be adjudged in law as a common regrator in the market."

There was enacted in the parliament of Scotland (cap. 31), a statute "of malt mekaris in Burrow Towns," understood to be direeted against engrossing.

2. The 25 Henry VIII, cap. 2, "Proclamations for the prices of vietuals, viz., the prizing of them, and proclaiming the prices," which recites: "Forasmuch as dearth, scarcity, good, cheap, and plenty, of cheese, butter, capons, hens, chickens, and other victuals necessary for man's sustenance, happeneth, riseth, and chanceth of so many and divers occasions that it is very hard and difficult to pat any certain prices to any such things (2), and yet nerertheless the priees of such victuals be many times enhaneed and raised by the greely coretousness and appetites of the owners of such victuals, by ocea-ion of ingrossing and regrating the same, more than upon any reasonable or just ground or eause, to the great damage and imporerishing of the king's subjects."

For renedy whereof it was enacted that the king's councillors, justices, and officers, should have power and authority from time to time as the case shall require, to set and tax reasonable prices of all such kinds of victuals above specified, how they shall be sold in gross, or by retail, for the relief of the king's subjects; and that after such prices set and taxed in form aforesaid, proclamation shall be made in the king's name, under the great seal, of the said prices in such parts of the realm as should be convenient for the same. Then the following :-

"II. And be it enacted, That all fermors, owners, broggers, and all other victuallers whatsoever having or keeping any of the kinds of victuals afore rehearsed, to the intent to sell, shall sell the same to such of the king's subjects as will buy them, at such prices as shall be set and taxed by the said proclamation, upon the pains to be expressed and limited in the said proclamation, to be lost, forfeited, and levied to the king's use, in such wise as by the same proclamation shall be declared. 


\section{Table XII.-Speculation in Grain and Other Articles-Contd.}

A.D.

1503

'35

'40....

"III. Provided always, that this Act or anrthing therein contained, shall not be hurtful to mayors, sheriffs, bailiffs, or other officers of cities, boroughs, or towns corporite, or to any other person or persons, or bodies politick, having authority to set prices of such victuats, or of any of them; but that they and every of them may set prices thereof as if this Act had never been had nor made."

Then there is a provision against transporting rietuals out of the realm without license. See l'able $\mathrm{X}$.

An Act of the parliament of Scotland, eap. 26, was passed this year and entituled "off forstallaris."

There were several Acts made in the parliament of Scotland this year being against forestalling, \&e., viz. : 1 (cap. 16), "For esehewing of dearth of wittallis, flesehe and fysche." 2 (eap. 18), "For stanching of derth and priees of wyne, salt, and tynmer." 3 (eup. 32) "Anentis forstallaris."

49 .... The 3 and 4 Edward VI, cap. 19-"An Aet for buying and selling of rother beasts and cattle," enacted as follows :

"Be it enacted by the authority of this present partiament, that no person or persons at any time from and after the Feast of the Annmeiation of our Lord next eoming, shall buy or commence and conelude to buy any mamer of oxen, steers, ronts, kine, heffiers or calres, but only in the open fair or market, when the same shall happen to be brought and put to sale, and not sell the same again alive at and in the market or fair where he bought the same, during the time of the said fair or market, upon pain of forfeiture of the donble ralue of such cattle bought or sold contrary to the tenor of tlis present Act."

By clause 2 there was exeeption in farour of persons buying for their household, farm or dairy; then

"And be it further enaeted by the authority aforesaid, that no person being a buteher, and using the craft or mystery of butchery, shall at any time after the said feast buy any fat oxen steers, ronts, kine, heifers, calres or sheep, and sell or cause to be sold the same again alive, upon pain of forfeiture of erery such ox, \&e., bargained or sold contrary to the form of this present Act."

Butehers might buy fat oxen. \&c., in open market at their free will, but were not to sell the same again alive (see 1663).

By the 3 and 4 Edward VI, eap. 21- "An Act for the buying and selling of Butter and Cheese" -it was enacted, "that no person or persons after the Feast of the Ammunciation of our Lady next coming, shall buy or sell again any butter or eheese, nnless he or they sell the same again by retail in open shop, fair or market, and not in gross, upon pain of forfeiture of the double value of the same butter and cheese so sold eontrary to the tenor of this present Aet.

2. "Provided alway, that this Act or arithing therein eontained shall not extend to any innholder or rictualer for such butter or cheese as shall be spent or uttered by retail in any of their houses."

3. "Prorided always . . . that the said word of retail mentioned in this Aet shall be expounded, deelired, and taken only where a waye of cheese, or a barrel of butter, or of less quantity and not above, shall be sold at any one time to any person or persons in open shop, fair, or market, and that to be done without fraud or eovin.'

This Aet was eontinued by 2 James I, cap. 25, section 3 (1604).

The 5 and 6 Edward VI, eap. 14-"An Acte againste regratours, forestallers, and engrossers," recited, "albeit, divers good statutes heretofore made against forestallers of merehandise and vietuals, yet for that good laws and statutes against regratours and engrossers of the same things have not heretofore sufficiently made and provided, and also for that it hath not been perfeetly known what person should be taken for a forestaller, regrator, or engrosser, the said 


\section{Table XII.-Speculation in Grain and Other Artides-Contd.}

A.D.

statutes had not taken good effect," wherefore these were severally defined to be-1. Forestallers, persons buying goods or victuals on their way to a market or port; or contracting to buy the same before actually brought for sale; or endearouring to emhance the price, or prevent the supply. 2. Regrators, perscns buying corn, rictuals, \&e., and reselling them in the same narket place, or within 4 niles thereof. 3. Ingrossers, persone buying growing corn, or buying rictnals to sell again. But under section 10 persons, might " engross" corn, "not forestalling" it, if at or moler certain prices per quarter, viz., wheat $6 s .8 d$. , barley and milt $3 . s$. 4 ., onts $2 . s$, pease and beans $4 s$., rye, $\{c ., 3 s$. By section 12 , inhabitants within one mile of the sea might buy fish fresh and salt to resell. Seetion 13, drovers might buy cattle, to resell them in markets 40 miles clistant; being annually licensed by justices of the peace.

Many of the prorisions of this statute were very remarkable, and deserve a more detailed analysis than our space here will allow (see 1570).

By 2 and 3 Philip and Mary, cap. 15-_"An Aet that purneiours shall not take rictuals within fine miles of Cambridge and Oxford"--the preamble of which is as follows :-

"Hrmbly sue to your maiesties, the societies, colledges, and companies of your true and faithfull subjects, and daily oratours, the scholers and students of both your maiesties rninersities, Cambridge and Oxford, that where it hath bcene aceustomed time out of mind, that both the said market townes of Cambridge and Oxford, wherein the said two rninersities be set, and the cireuit of fiue miles next adjoyning, hath beene free from any charge or molestation of any common takers, or purueiours for rictuall, whereby the said markets were more plentifully serued with victuall, and the poore estate of a great multitude of scholers, having rery bare and small sustentation, thereby reliened, and now by the meanes that contrary to the same laudable custome, diuers purueiours and takers hane of late excessiuely frequented the same market, and thercby given occasion to make victuals more skant, and much dearer, to a notorious decay of scholars, which also daily in this great dearth is like to inerease, and be more lamentable, to the hindrance of God's seruice, the dishonour of the realme, and discomfort of all good and holy men louing learning and nertue.

"II. It may therefore please your Maiesties, of your great pitie and abundant fanor and loue towards your said two vninersities, being the very two onely nurses of good learning in the realme, with the assent of the Lords spirituall and temporall, \&c., \&c."

And it is then enacted " that from hencefoorth, no manner of purueiour, taker, lodger, or other minister, mar, or shall take or bargaine for any kinde of rictuall or graine, in any of the said markets or townes of Cambridge, and the eitie of Oxford, nor shall take or bargaine for any rictuall within the compasse of fiue miles thereto adjoyning, without the consent, agreement or goodwill of the owner or owners, neither shall attempt to carrie, take awaie, or bargaine for any manner of graine, or other victuall brought or prouided within the said space of fiue miles, by any common minister of any colledges hostell, or hall, to bee spent within any of the said collerlges, hostels, or hals, vpon peine of the forfeiture of the quadruple ralue of any such maner graine or vietuall so taken or bargained for ;" and for any sueh offence should suffer imprisonment "for the space of three moneths, without baile or maincprise." The finding might be by jury empanelled by the "Chancellour, Uiceehancellour, or his commissarie for the time being," with two "iustices of the peace of the countie wherein the vniversaries be set."

"III. Prouided, that this Act shall not be put in execution at any 


\section{Table XII.-Speculation in Grain and Other Articles-Contd.}

A.D.

1555

time or times, whensoeuer your majesties, or the heires or successors of sour majestie our Sonereigne Ladie, shall please to come to any or both the said rniuersities, or within seuen miles of either of them, but shall be in suspense during that time onely and no longer."

Nothing in the said Act was to be in any wise "preiudiciall or hurtfull to the maior, bayliffes and communaltie" of the said eities and borough. See Table IX (1757).

There was also an enactment made in the parliament of Scotland this year (cap. 35), "Anent the disposition of wyne, salt, ane symmer brocht into the realm."

'70 ... By 13 Elizabeth, cap. 21, it was again enacted that purreyors should not take away grain, corn, or rictuals, within 5 miles of Cambridge and Oxford.

And by 13 Elizabeth, cap. 25-"An Act for reviving and continuance of certain statutes"-it was enacted (see. 21) "that the Act 5 and 6 Edward VI, eap. 15, was not meant to extend, nor should extend to any wines, oils, sugars, spices, currans, nor other foreign rictuals, brought or to be brought into this realm from beyond the seas ; fish and salt only excepted."

79 .... There was an Act of the parliament of Scotland (eap. 26), "For punishment of regrataris and forstallaris."

'89 .... By the 31 Elizabeth, eap. 5-"An Aet concerning informers" - it was enacted that for any offence comprised in any statute made or to be made against engrossing, regrating, or forestalling, where the penalty should appear to be of the valne of $2 \mathrm{cl}$. and abore, erery such offence might be laid in any county at the will of the informer.

'92 .... There was an Act of the parliament of Seotland (cap, 70) intituled, "Aganis foirstallers and regraittaris."

1608 .... "The king, on account of the high prices of corn, issues out good orders against monopolists, who bought up and engrossed grain of every species."-Sir Charlis Whitworth.

'23 ... Regarding the change of policy in now allowing grain to be purchased and sold again either in the markets of the kingdom or elsewhere, see 21 James I, eap. 28 , sec. 3 , already quoted in some detail in Table X. See also 1663.

'61 ... There was an Act of the parliament of Scotland (cap. 280), intiluled "An Act protecting of inanufactories," which was directed against forestallers.

'63 ... The 15 Car. II, cap. 8-"An Act to prerent the selling of lire fatt Catle by butchers"-after reciting of the Act of 1549, proceeds :-

". ... Which law hath not wrought such effectuall reformations as was intended by reason of the difficultie in the proof of such buying and selling, being for the most part at places far distant if not in sererall countyes, by meancs whereof the parties soe offending have eseaped unpunished. Be it therefore enacted, \&c., That noe person using the trade of a butcher shall at any time from and after the Feast of St. Michaell the Arch Angell next ensuing, sell, offer, or expose to sale in any market or elsewhere, either by himselfe or any servant or agent whatsoever, any fatt oxen, steers, runts, hine, heifers, calves, sheepe or lambes alive, upon paine to forfeite the double value of the cattle soe sold, or offered or exposed for sale as aforesaid."

See further 1670-71.

'70-71 By 22 and 23 Car. II, cap. 19, "An Act to prevent fraudes in the buying of and selling of eattell in Sunithfeild and elsewhere," the Acts of 1549 and 1663 were revired and continued, with the following addition :-

"And bee it further enacted by the authority aforesaid, That noe jobber, salesman, or other broker or factor, which doe or shall cumningly buy or sell cattell for others be allowed or imployed 


\section{Table XII.-Speculation in Grain and Other Articles-Contd.}

A.D.

either for buying or selling any fatt eattell other than swine or calres by or for any butcher, or other person or persons whatsocrer, within fowcrscore males of the cityes of London and Wcstminster, upon paine of the forfeiture of the value of the said cattell soe bought or sold for him or them as aforesaid, to be paid by the owner of the said cattell. And upon further paine, that all and every person and persons taking upon him or them to nse or exereise the said employment of a jobber or broker, or of a salesman or factor for the buying or selling of eattell contrinry to this present Act, sball forfeite for every such offence the ralue of all such cattell soe bought or sold or exposed to sale by him or them as aforesaid.

"And be it further enacted, that if any person or persons excrcising the trade of a butcher within the cityes of London or Westminster, or within 10 miles thereof, shall buy any fatt cattell and sell the same againe either alive or dead to any person or persons exercising or useing the same trade, that the seller thereof shall forfeite for ercry such offence the value of such cattell soe bought and sold as aforesaid."

This clause was repealed in 1672 , by Car. II, cap. 4 .

By an Act of the parliament of Ireland, 2 Amne, cap. 15-" An Act to prohibit butcher's from being graziers, and to redress sereral abuses in buying and selling of cattle, \&c."-it is recited, "Whereas great inconreniences happen in this kingdom by butchers following the trade or occupation of graziers, and by their engrossing cattle into their hands to sell again to other butchers, and by buying of cattle in fairs and markets, and selling them again in the same fair and market." For remedy whereof it was enacted that no butcher should be a grazier, or keep in his possession or in trust for lim above 20 acres for cattle, and that no butcher in Dublin, or within 5 miles, should sell fat oxen, \&c., to any other butcher, either dcad or alive, nor expose any alive for sale within 20 miles of where bought, no cattle or sheep bought in any market or fair to be sold or expozed for sale in the same place the same day. See 1710.

The 5 Anne, cap. 34-"An Act for continuing the laws therein mentioned, relating to the poor, and to the buying and selling of cattle in Smithfield and for suppressing piracy"- contained the following :-

"And whereas there is, notwithstanding the provisions of the aforesaid Act a pernicious practice, now in use, for one butcher to buy a greater quantity of fat cattle or sheep than he can rend, unless by selling them again to other butchers, which reduces the number of buyers in Smithfield, and may be a very great inconvenience both to the graziers and housekeepers, by subjecting both the one and the other to such price as they shall think fit to gire or demand, be it therefore enacted by the authority aforesaid, that from and after the 29th September, 1707, no person using the trade of a butcher shall sell, or offer for sale, in any market or elsevehere, either by himself or any servant or agent whatsoever, within the cities of London and Westminster, or within 10 miles thereof, to any person or persons exercising or using the trade of a butcher, any fat cattle or sheep, either alive or dead, upon pain to forfeit the ralue of the cattle or of each sheep so sold or offered to sale as aforesaid."

This Act is explained by 7 Anne, cap. 6, to the effect that one butcher might sell to another any dead calres, sheep, or lambs.

By an Act of the parliament of Ireland, 9 Anne, cap. 7, the Act of 1703-" which Act by experience hath been found to be in most parts of it a good and profitable law in the kingdom-" was continued and made perpetual (see 1741 and 1757).

1 .... By an enactment of the parliament of Ireland, 15 George IT, cap. 9, the Act of 1703 was amended after the following recital: "And whereas divers evil-minded persons exercising the trade of a butcher do buy 


\section{Table XII.-Speculation in Grain and Other Articles-Contd.}

A.D.

1741

${ }^{\prime} 56$

'57

'49 .... By the 22 George III, cap. 49 "An Act for making a fish market for

and engross into their hands upon the roads leading to the city of Dublin, and in the markets thereof, greater numbers of the best oxen, shecp. steers, cows, calres, lambs, and swine, than they can sell by retail to the inhabitants of the said city at their shops or stalls, and with intent to sell the carcases and joints of such oxen, sheep, steers, cows, calces, lambs, and swine to other persons using or exereising the same trade or mystery of a butcher, to be sold again in the markets of the said eity and liberties adjoining, whereby considerable gain doth arise to themselves, the best of meat is ingrossed into few hands, the price of rictuals greatly cubanced, and the true intent of the said former Act is eluded." It was therefore enacted that no butcher in Dublin or within 5 miles should sell a carcass or any kind of beef, \&c., to a butcher in the market, nor expose the same for sale not haring boneht and had the oxen, \&c., in their possession alive. Penalty (inter alia), public whipping tliree market days through the district where such offence lad been committed. the sale of Fish in the eity of Westminster, and for preventing the forestalling and monopolising of Fish, and for allowing the sale of Fish under the dimensions mentioned in a clause contained in an Act of the first year of his late Majestr's reign, in case the same are taken with a hook" - it is retited: "Whereas a free and open market for fish in the city of Westminster would greatly tend to increase the number of fishermen, and improve and encourage the fishery of this kingdom;" and the right to establish such a market is enacted in a measure of twenty-one clauses. Those relating to forestalling are as follows (section 9): "All contracts between fishermen and fishmongers made before 29th September, 1749, are declared roid, except (section 11) as to fresh salmon, soles, oystcrs, and salt and dried fish," which were to subsist.

"XIT. And lest fishermen and other persons employed in catehing, importing, or vending of fish, should bring fish to Queenborough, Gravesend, or some other place or places in the river Thames, and there keep it for a considcrable time, and send only small quantities from time to time to market, with a riew to keep up the price of the sereral species of fish, which such person or persons respectively import or trade in, which practice will not only tend to cnlance the value [? price] of fish, but also to render it umwholesome food to the consumer, as well as the fishery in general."

Wherefore a penalty was enacted against fishermen not selling their fish within eight days after their arrival on the coast between Yarmouth and Dover.

By 39 George II, cap. 39, the Act of 1749 is explained, amended, and made more eflectual, and it is herein recited . . . " And whereas many difficulties liave arose (sic) in putting the said Act in execution."

There was an enactment of the Irish parliament, 31 George II, cap. 8"An Act to prohibit salesmen from bcing graziers, and to redress sereral abuses in buying and selling cattle or meat," which was in fact a re-enactruent in another form of the Act of 1703, after an admission in the recital that the last-named Act had "not answered the good end for which it was intended," it is then further enacted that no butcher in Dublin or other person for his use, should buy or contract for calves or lambs in the county or roads to Dublin; calves and lambs to be retailed in meat markets should be sold openly at times appointed.

The English House of Commons after an inquiry into the distress prevailing among the poor, recommended the enforcement of the laws against forestallers and regrators.

'61

There was enacted the 2 George III, cap. 15-"An Act for the better supply of the citics of London and Westminster with fish, and to 


\section{Table XII.-Speculation in Grain and Other Articles-Contd.}

A.D.

reduce the present exorbitant price thereof, and to protect and cneourare fishermen." The scheme of this Aet was to allow any person, though not a fishmonger, to buy at any mirket, sea cuast or river, \&e., any fish in season and sizeable, paying the accustomed dues at the place of purchase, and to sell the same again in any fish or flesh market, paying the aceustomed dues, Covent Garden Market, and the precinets thereof excepted. But such fish were not to be resold by the first purchaser before the same were brought to London or Westminster, or to where consigned, under a penalty of $20 l$. Special waggons, designed "fish machines," were to be employed in the carriage of such fish, without being liable to the duty on common stage waggons. They were to pay only the same tolls as post chaises, and might run with narrow wheels; they might travel on Sundays and holidays. If the driver should suffer any passenger, game, or other thing than fish to be carried he should be tined $40 s$. Bulk not to be broken before exposed for sale in the market, or iol. penalty. It was to be exposed for sale the next morning after arrival in London (except Sundays), and the selling any part by retail before it reached the market incurred a fine of $\mathbf{r}$. " Mackerel brought up by such carriages might be sold on Sundays.

All contracts made for fish, except salmon or lobsters, were to be vacated after 1st May, 1762, and parties discharged from the penalties to their contracts, and parties contracting to buy up fish after that date (except salmon and lobsters) before the same should be exposed in the market, to be liable for penalty of $50 \mathrm{l}$., and contraet cleclared void. After 1st May, 1762, no contract for salmon and lobster to extend beyond one year, and after same date no person might be engaged to buy fish in the markets of London or Westminster, to divide among fishmongers, and no person to buy fish but for his own sale or use, under penalty of $20 l$. No person to refuse to sell to particular persons, under penalty of $20 l$. And all fish of respective sorts specified in the Act brought into the London markets for sale, should be openly sold at first hand, and in no greater quantity in a lot than is preseribed; and every lot to consist of one kind of fish only. No fish to be sold or exposed for sale again in the market wherein it was bought during the same day, under penalty of $10 l$. An account of the quantities and sorts of each fish brought to marliet to be posted in legible characters on the fish stand, "flounders, plaice, and dabbs excepted;" penalty for defacing such aceount before sale concluded, $4 \circ s$. No fisherman to destroy any fish (not being unwholesome) after market over; penalty not exceeding two months' hard labour. Fishermen engaged in this business to be exempted from impressment into the king's service. Any parties concerned in contracts contrary to this Act giving first information and convicting others, to be himself indemnified, and entitled to moiety of penalty.

This specimen of free trade legislation in fish contains in the whole thirty-seven seetions, and is one of the most penal measures in the statute book. I well remember these fish machines running daily from Yarmouth to London up to the date of the opening of the

Great Eastern Railway.
A parliamentary committee was this year appointed to inquire into the high price of provisions. In its report the committee quote the evidence of several prominent salesmen and butchers that the high prices were not exclusively the effect of "natural causes;" and then oeeurs the following passage :-

"In support of this opinion, they informed the committee of a method now practised of buying large quantities of sheep and oxen upon the road to market, in order to forestall the market of that day, and fix the price by the will of a few engrossers; of another species 


\section{TABLE XII.-Speculation in Grain and Other Articles-Contd.}

A.D.

1764

87

of forestallers, who buy great numbers of sheep and oxen, and, after slaughter, sell the carcases whole to the lesser butchers, and thereby set the market price to them, and advance the retail price; and all the witnesses concurred in declaring that if these combinations and arts for gaining and keeping the command of the markets in a few hands could be obviated and prevented, the summer and winter price of meat of all sorts would be more reasonable.

"They were clearly of opinion that at this very time there is no want of fat eattle, and they urged with great force, in support of that judgment, that through the whole month of March, when provlsions have been so very dear at London, beef, mutton, and real, have been at a moderate and usual price in the markets of the several counties within 30 miles around the metropolis."

Upon the whole matter the committec came to the following conclusion :-

"Resolved, that in the opinion of this committee the high price of prorisions of late, has been oceasioned partly by circumstances peculiar to the season, and the year, and partly by defect of the laws in force for convicting and punishing all persons concerned in forestalling cattle in their passage to market."

2 .... A change came over the scene. There was enacted the 12 George III, cap. 71-"An Act for repealing sereral laws therein mentioned against badgers, engrossers, forestallers, and regrators, and for indemnifying persons against prosecutions for offences committed against the said Acts" - which contains this very candid recital :

"Whereas it hath been found by expcrience that the restraints laid by several statutes upon the dealing in corn, wheat, flour, cattle and sundry other sorts of victuals, by preventing a free trade in the said commodities, have a tendency to discourage the growth, and to enhance the price of the same; which statutes, if put in execution, would bring a great distress upon the inbabitants of many parts of Loudon and Westminster."

It was therefore enacted that the abore recited Acts of 1549, $1555,1579,1663$, and 1706 , as also "all Aets made for the better enforcement of the same, being detrimental to the supply of the labouring and manufacturing poor of this kingdom, shall be, and the same are hereby declared to be repealed."

And all informations, \&c., commenced under the said Acts were to cease and determine.

By an enactment of the parliament of Ireland, 13 and 14. George III, cap. 22-"An Act for paring streets within the eity and county of the city of Dublin" - section 73 anthorises a market jury to seize provisions or victuals in the hands of any forestaller, regrator, or engrosser.

By an enactment of the parliament of Ireland, 27 George III, cap. 46 - "An Act for establishing market juries in citıes"- - section 3 anthorises and empowers certain market juries to seize prr visions and victuals found in the hands of forestallers, regrators, and engrossers.

A corn dealer named Rusby was this year found guilty of having purchased by sample in the corn market in Mark Lane, 90 quarters of wheat at $4 \mathrm{I} s$. per quarter, and having sold 50 of them in the same market, the same day, for $44^{s}$., Lord Clief Justice Kenyon in sentencing lim, said to the jury, "You have conferred, by your verdict, almost the greatest benefit of your country that was ever conferred by any jury." It would hare been diflicult after this to obtain a conviction against any of the persons who had gutted this ill-used man's residence in Blackfriars Road. No punishment was inflicted, as some of the judges donbted whether regrating were really punishable at common law. See Table $\mathrm{XV}$, this date.

Again, on 13th July, two butchers were tried at Hicks's Hall on an 


\section{Table XII.-Speculation in Grain and Other Articles-Contd.}

A.D.

1800

indictment for forestalling, by buying cattle on the road to Smithfield Market, when it was stated that the practice was a common one. Being found guilty, defendants were ordered to pay $20 l$. each, or be imprisoned for three months. This was considered a light punishment, and would hare been more serere had not the defendants been "the first examples since these sort of prosecutions fell into disuse."

1800 .... There was published, A Short Inquiry into the Nature of Monopoly and Forestalling. By Edward Morris, Esq. Third Edition, with additions. London, 8ro.

1800 .... Also. An Address to the Good Sense and Candour of the People in behalf of the Dealers in Corn, with observations on a late Trial for Regrating. By Sir Thomas Turton, Bart. London, Svo.

1800 .... Observations on the pernicious eonsequences of Forestalling, Regrating, and Ingrossing; with a List of the Statutes, \&c., which have been adopted for the Punishment of those Offences, andProposals for New Laws to Abolish the Ssstem of Monopoly ; Remarks on the Impolicy of the Consolidation of Small Farms, \&c. By J. S. Girdler, Esq., London. 8ro. 6s.

'44 .... There was enacted 7 and 8 Victoria, eap. 34-" An Act for abolishing the offences of forestalling, regrating and engrossing, and for repealing certain statutes passed in restraint of trade "-wlich recited :

"Whereas divers statutes have been from time to time made in the parliaments of England, Scotland, Great Britain and Ireland respectively, prohibiting certain dealings in wares, rictuals, merchandise, and rarious commodities of the names of badgering, forestalling, regrating and engrossing, and subjecting to divers punishments, penalties and forfeitures, persons so dealing; and whereas it is expedient that such statutes, as well as certain other statutes made in hindrance and in restraint of trade, be repealed . . . . and whereas, notwithstanaing the making of the first recited Act [12 George, cap. $71(1772)]$, persons are still liable to be prosecuted for badgering, engrossing, forestalling, and regrating, as being offences at common. law, and also forbidden by divers statutes made before the earliest of the statutes thereby repealed."

It was therefore enacted that after the passing of this Act the sereral offences named "be utterly taken away and abolished, and that no information, indictment, bail, or prosecution shall be either at common law, or by virtue of any statute, or be commenced or prosecuted against any person for or by reason of any of the said offences or supposed offences." This Act extended specifically to Scotland and Ireland.

Note.- "Besides attempting to lower prices by prohibiting exportation, our ancestors attempted to lower them by proscribing the trade carried on by corn dealers. This most useful class of persons were looked upon with suspicion by every one. The agriculturists concluded that they would be able to sell their produce at higher prices to the consumers were the corn dealers out of the way; while the consumers concluded that the profits of the dealers were made at their expense; and ascribed the dearths that were then very prevalent entirely to the practices of the dealers, or their buying up corn and withholding it from market."-McCoLlocH, Literature of Political Economy. 


\section{XII.-Misapplication of Grain.}

It was but natural that when grain products were scarce, and the people starving, that attention should be drawn to any process or processes whereby the supply, or any material proportion of it was being absorbed. Hence the measures indicated in the following table fall into the natural order of things, and demand no speeial eomment.

It would be interesting to note the proportion of the grain produce which at different periods of our history have been applied to these purposes; but the statisties upon the point are limited.

In 1765, Mr. Charles Smith, author of "Tracts on the Corn "Trade," made many curious investigations, with a riew to diseover the mean annual consumption of corn; and redncing it to the standard of wheat, he found it to be at the rate of about a quarter for each individual, young and old. He took the population of England and Wales for this year to be 6,000,000, and reckoned the consumers of each kind of grain, the quantity consumed by each individual, and hence the whole consumed by man, as follows :-

\begin{tabular}{|c|c|c|c|}
\hline Population. & Consumers of & $\begin{array}{l}\text { Average } \\
\text { Consumption } \\
\text { per Head. }\end{array}$ & Consumed by Man. \\
\hline $\begin{array}{r}3,750,000 \\
739,000 \\
888,000 \\
623,000\end{array}$ & 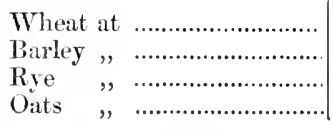 & $\begin{array}{ccc}1 & \text { qr. each } & \ldots \ldots \ldots \\
1 \frac{3}{8} & , & \ldots \ldots \ldots \\
1 \frac{1}{8} & " & \ldots \ldots \ldots \\
2 \frac{7}{8} & " & \ldots \ldots \ldots\end{array}$ & $\begin{array}{r}3,750,000 \text { qrs. } \\
1,016,125 \quad " \\
999,000 ", \\
1,791,225 \quad "\end{array}$ \\
\hline \multicolumn{3}{|c|}{ 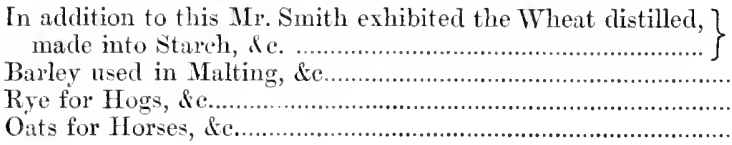 } & $\begin{array}{r}7,556,350 \\
90,000 \text { qrs. } \\
3,417,000 \\
31,000 \\
2,461,500 \quad,\end{array}$ \\
\hline \multicolumn{3}{|c|}{ 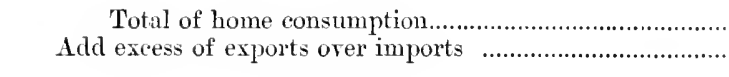 } & $\begin{array}{r}13,555,850 \\
398,924\end{array}$ \\
\hline \multicolumn{3}{|c|}{ Add seed (one-tenth) } & $\begin{array}{r}13,954,474 \\
1,395,447\end{array}$ \\
\hline \multicolumn{3}{|c|}{$\left.\begin{array}{l}\text { Total growth of all kinds of grain in England and Wales } \\
\text { in } 1765\end{array}\right\}$} & $15,349,921$ \\
\hline
\end{tabular}

This estimate did not include either Scotland or Ireland, and later inquiries have rendered it probable that the population was under-estimated by nearly one million. It seems also that at that date the proportion for seed ought to have been one-sixth, certainly not less than one-seventh. 
Regarding the estimated consumption per head, this estimate has been eonfirmed by a variety of subsequent researches in varions parts of England and in France. In this latter conntry the consumption was found to be about ten bushels per liead; but the French consume more bread and less animal food than the English.

In 1814 Dr. Colquhoun made the following estimate of the consumption of grain in the United Kingdom, i.e., England, Scotland and Ireland :-

\begin{tabular}{|c|c|c|c|c|c|}
\hline $\begin{array}{l}\text { Species of } \\
\text { Grain. }\end{array}$ & $\begin{array}{l}\text { Consumed } \\
\text { by Man. }\end{array}$ & $\begin{array}{c}\text { Consumed } \\
\text { by Animals. }\end{array}$ & $\begin{array}{l}\text { Used } \\
\text { in Beer and } \\
\text { Spirits. }\end{array}$ & $\begin{array}{c}\text { Used } \\
\text { in Varions } \\
\text { Manutactures. }\end{array}$ & $\begin{array}{c}\text { Total } \\
\text { Quarters. }\end{array}$ \\
\hline 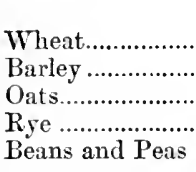 & $\begin{array}{c}\text { Qrs. } \\
9,000,000 \\
1,875,000 \\
6,750,000 \\
625,000 \\
500,000\end{array}$ & $\begin{array}{c}\text { Qrs. } \\
\ldots . \\
2 \mathbf{1 0} 0,000 \\
10,200,000 \\
59,000 \\
1,360,000\end{array}$ & $\begin{array}{c}\text { Qrs. } \\
\ldots . \\
4,250,000 \\
\ldots . \\
\ldots . \\
\cdots\end{array}$ & $\begin{array}{c}\text { Qrs. } \\
170,000 \\
\ldots \\
\ldots \ldots \\
1,000 \\
\ldots\end{array}$ & $\begin{array}{r}9,170,000 \\
6,335,000 \\
16,950,000 \\
685,000 \\
1,860,000\end{array}$ \\
\hline Total .................... & $18,750,000$ & $11,8 \geq 9,000$ & $4,250,000$ & 171,000 & $35,000,000$ \\
\hline
\end{tabular}

I am not aware of any complete estimate of this character of later date; but the amount of barley made into malt had increased from 4,525,68 I quarters in 1825 to $7,876,959$ quarters in 1875 .

Under this head falls to be named those wanton acts of waste, such as burning grain-stores, firing ricks, and other acts of wilful destruction of grain which have too often occurred during periods of scarcity, and the only effect of which must be to add to the calamities of the moment. The incendiary fires which took place in Kent and in Suffolk in 1830, and in Cambridgeshire in 1853-54, are happily about the latest instances of such folly. 


\section{TABLE XIII.-Misapplication of Grain by its Excessive Use in Brewing, Distilling, or by Misadventure.}

A.D.

1250 .... The art of distillation of spirits from grain became known in England about this date (reign of Henry III); it having been introdueed into Europe by the Moors about a century previously.

1302 .... The failure of the English wine crop in 1298 led to a eonsiderable inerease in the brewing of ale, which became the subject of complaint, as affecting the price of grain.

'15 .... "The Londoners the same yeare, considering the wheat was mueh consumed by the eonverting thereof into mault, ordained that from theneeforth it should be made of other graine; and also that a gallon of the better ale should be sold for 3 halfe pence, and of small ale for one penny, not above." This order was afterwards extended by the king through the whole kingdom.-Penketriman.

1532 .... By 24 Henry VIII, cap. 10-" An Acte made and ordesned to destroye choughes, crowes, and rookes" - it is reeited :- -

"Forasmuch as innumerable number of rooks, crows, and choughs, do daily breed and increase throughout this reahn, which rooks, crows, and ehoughs do daily destroy, derour, and consume a wonderful and marrellous great quantity of corn and grain of all kinds, that is to wit, as well in the sowing of the same corn and grain, as also of the ripening and kernelling of the same, and orer that a marrellous destruction and decay of the corertories of thatehed houses, barns, reeks, stacks, and other such like. (2) So that if the said crows, rooks, and choughs should be suffered to breed and continue, as they have been in certain years past, they will undoubtedly be the cause of the great destruction and consumption of a great part of the eorn and grain which hereafter shall be sown throughout this realm, to the great prejudiee, danger, and undoing of a great number of all the tillers, hwsbands, and sowers of the earth within the same."

It was therefore enaeted that all persons in the possession of lands should do their best to destroy crows, \&e. Every town, hamlet, \&e., was to provide and maintain erow nets during ten years, during which period farmers, \&c., to meet and take orders for destroying young crows, \&c. The takers of old crows, \&c., were to be rewarded at $2 d$. per dozen.

$1630 \ldots$ In a letter from the lords of the conneil, dated "from Whitehall, the xiii of June, 1630," and addressed to "the maior and burgesses of the cittie of Wells," in riew of an expected famine, there is the following passage :-

"That the lawes prorided as well againste the breweinge or spendinge of strong ale or beere in inns or alehowses be strietly put in exeention, as likewise against ingrossers, forstallers of corne, and for the regulatinge of the market for the prices of grarne; and that you eause the grayneries of those to be risited or noted for ingrossers, to see that they may supply marlietts accordinge to the lawes-and generally that you will rse all other fitt courses and remedies, either provided by lawe, or w'ch you by y'or experience knowe best, or can finde ont for the preservacon and well-husbandinge of the grayne within y'or jurisclicon."

'46 .... At this period it seems that the nsual bread-corn of the poor was barley. The king (Charles I) arailed himself of this eireumstance, in order to establish a new monopoly, by subjecting the brewers and maltsters to a royal lieense. His reasons for this measure were deelared to be, for the relief of the poorer sort of his people whose usual bread was barley; and for the restraining of innkeepers and vietuallers, who made their ale and beer too strong and heady. Rym. Fæd., xix, 102 ; $\mathrm{xx}, 157$.

1701 ... By 9 Anne, eap. 14-“ An Act for eneouraging the consumption of malted corn, and for the better presenting the running of French and foreign brandy"-it was recited:- 


\section{TabLe XIII.-Misapplication of Grain-Contd.}

A.D. 1701

'09

"Whereas the making of English brandy and strong waters from malted corn, hath becn enconraged by several Aets of parliament, whereby great quantities of the worst sort of malted corn, not useful to the brewers, hath been yearly eonsumed by those who set up works for that purpose: and whereas the consunption of English brandy and strong waters, hath of late years been greatly hindered, as well by the running of French and other foreign brandies, as also by a clanse in an Act made in the twelfth and thirteenth years of his late majesty . . . whereby all distillers and tradesmen who sell brandy and strong waters by retail, are compelled to take out licenses, as common alehouse keepers."

It was therefore enacted that all French brandy landed before the dity was paid shonld be forfeited.

See (S Anne, cap. 2) Table $\mathbf{X}$, this date.

There was enacted, 30 George II, cap. 10- "An Act to prohibit for a himited time the making of low wines and spirits from wheat, barley, malt, or any other sort of grain, or from any meal or flour"-and such distillation was accordingly prohibited for two months.

Same session there was enacted 30 George II, cap. 15-An Act for continuing an Act of the present session of parliament entituled, \&c. [the preceding Act], and the Act was extended to 11th December this year, with a proriso empowering his majesty by proclamation, or order of council, to suspend the Act and permit distillation from wheat, \&c.

There was enacted 32 George II, cap. 2-"An Act to contimue . . . . . and also to continne for a farther time the prohibition of the making of low wines and spirits from wheat, barley, malt, or any other sorts of grain, or from meal or flour; and to prohibit for a limited time the making of low wines and spirits from bran." The Act of 1757 to remitin in force until 24th December, 1759.

There were enacted two measures of restriction this year:-

1. The 33 George II, cap. 4, "An Act to continue for a further time the prohibition of the making of low wines and spirits from wheat, barley, malt, or any other sort of grain, or from meal, flour or bran." The Act of 1757 was continued to 24 th December, 1760 , unless the continuation thereof be shortened by any other Act of this session.

2. The 33 George II, cap. 9, "An Act for prerenting the excessive use of spirituous hquors, by laying additional duties thereon, for shortening the prohibition of making low wines and spirits from wheat, barley, malt and other grain, and from meal, flour and bran; and for enconraging the exportation of British made spirits ; and for more effectually securing the duties payable upon spirits, and preventing the fraudulent relanding and importation thercof;" from the preamble of which it appears that an unexpected good had resulted from the famine necessities of the original measure, thus :-

"Whereas the high price of spiritnous liquors hath been a principal cause of the diminution of the home consumption thereof, and hath thereby greatly contributed to the health, sobriety and industry of the common people: and whereas it is therefore of the utmost importance to the public welfare, that some timely provision should be made for preventing the return of all those mischiefs which must unaroidably ensue, in casc such spirituous liquors should again be suffered to be sold at as low a rate as formerly; and forasmuch as the most effectual and expedient method of continuing the high price of spirituous liquors, will be by laying a large additional duty on such spirituous liquors," \&c.

This is as neat an excuse for raising the rerenue as is often to be found. Additional duties were laid as from 21st April, 1760. The prohibition against extracting spirits from the grain mentioned was 


\section{TABle XIII.-Misapplication of Grain-Contd.}

A.D.

1759

price of wheat should excecd for two successive market dafs $48 s$. per quarter in the port of London, in which ease the king might by proclamation continue the prohibition.

'68 ... By 8 George III, eap. 1, "An Act to amend an Act made in the last session of parliament, to prohibit for a limited time the exportation of corn ..... and also the extraction of low wines and spirits from wheat and wheat flour."

'69 .... By 9 George III, cap. 1, "An Act to prohibit for a further time the exportation of corn .....; and also the extraction of low wines and spirits from wheat and wheat flour."

70 .... By 10 George III, cap. 1, The prohibition was extended to twenty days after the commencement of the next session.

'71 .... By 11 George III, cap. 1, The like prohibition again extended to twenty days after commencement of the next session.

'73 .... By 13 George JII, cap. 3, The like prohibition again extended to 1st January, 1774 .

'95 .... There was enacted, 35 George III, cap. 11-“ An Act for granting to his Majesty additional duties of excise on worts, wash, and other liqnors, made in Eugland, for extracting spirits for home consumption; and for preventing distillers from making use of wheat or wheat flour in making wash for extracting spirits."

'96 .... By the 36 George III, cap. 7 , it was permitted that certain wheat, wheat flour, and meal, which had been imported under the provisions of 31 George III, cap. 3, "and which had not been found fit for making bread" might be used (inter alia) in the distillation of low wines and spirits.

1800

There was enacted-

1. The 39 and 40 George III, cap. 7- "An Act to prohibit, until the 1st day of March, 1800 , the making of low wines or spirits from wheat, barley, malt, or other sort of grain, or from any meal, flour, or ans bran, in that part of Great Britain called Scotland."

2. The 39 and 40 George III, cap. 8, "An Act for recheing until the lst day of June, 1800 , the duties upon spirits distilled from molasses and sugar, or any mixture therewith; for prohibiting the distillation of spirits from wheat flour; and for reducing until the 20 th day of September, 1800 , and better collecting the duties payable on the importation of starch."

3. The 32 and 10 George III, eap. 25, "An Act to prohibit, until the 1st day of October, 1800 , the use of wheat in making starch."

This extension of prohibition to starch was a new feature.

4. The 39 and 40 George III, cap. 6.2, "An Act to allow for nine month after the passing this Act, the use of sugar in the brewing of beer."

In the autumn session of the same year there were enacted other measures, riz. :-

1. The 41 George III, cap. 3, "An Aet to prohibit until the 1st day of January, 1802, the use of corn in distilling of spirits and making of starch."

2. The 41 George III, cap. 6, "An Aet for continuing until the expiration of forty days after the commencement of the first session of parliament that shall be begun and holden after the 1st day of September, 1801, several laws relating . . . . . to the allowing the use of sugar in the brewing of beer... . . . and to the prohibiting the making of low wines or spirits from wheat and certain other articles, in that part of Great Britain called Scotland."

3. The 41 George III, cap. 6-"An Act for shortening, until the 25th day of March, 1801, the time of keeping in steep for malting barley damaged by rain in the last harvest."

01 .... There was enacted 42 George III, cap. 5, "An Act to continue until the 


\section{TABLE XIII.-Misapplication of Grain-Contd.}

A.D.

1st day of January, 1802, so much of an Aet made in the thirty-ninth and forticth years of the reign of his present majesty as relates to the reducing the duties upon worts or wash brewed or mide from molisses or sugar, or any mixture therewith, or to any distiller or distillers, or maker or makers of spirits; for reriving and continuing for the same period so much of the said Act as relates to the reducing and better collecting the duties payable on the importation of starch, and for continuing for the same period an Act made in the same session of parliament for prohibiting the making of low wines or spirits from wheat, barley, malt, or other sort of grain, or from any meal, flour, or grain in Scotland; and so much of an Act made in the last session of parliament as relates to allowing the distillation of spirits in Scotland from molasses or sugar at a lower rate of duty."

And same session there was cnacted the 41 George III, cap. 16 (United Kingdom), "An Act to prohibit, until the 25th day of March, 1802, the making of malt and the distilling of spirits from corn or grain in Ireland."

There was enacted-

1. The 42 George III, eap. 5, "An Act to continne until the 1st day of January, 1802, so much of an Act made in the thirty-ninth and fortieth years of the reign of his present majesty, as relates to the reducing the duties ipon worts or wash brewed or made from molasses or sugar, or any mixture therewith, or to ans distiller or distillers, or maker or makers of spirits; for revising and continuing for the same period so much of the said Act as relates to the reducing and better collecting the duties payable on the importation of starch; and for continuing for the same period an Act made in the same session of parliament for prohibiting the making of low wines or spirits from wheat, barley, malt, or other sort of grain, or from any meal, flour or bran in Scotland; and so much of an Act made in the last session of parliament as relites to the allowing the distillation of spirits in Scotland from molasses or sugar at a lower rate of duty." The title tells its own tale without reference to the Act itself.

2. The 42 George III, cap. 14, "An Act to permit until the 1st day of July, 1802, the making of stareh from rice or potatoes, or any mixture thereof, and the importation of any such starch from Ireland free of duty."

An Inquiry into the Policy and Justice of the Prohibition of the use of Grain in the Distilleries. By Arehibald Bell, Esq. Edinburgh. 8vo. "An able pamphlet, strongly opposed to prohibition."McCulloch.

\section{General Remarlss upon the preceding Tables.}

In the preceding Tables (VIII to XIII inclusive), and the observations accompanying them, is presented an outline of the causes, distinguished in this paper as the "Artificial Causes," of famines. And as to several of these, this enigma presents itself, that the very remedies which have been adopted to prevent, or to mitigate the severity of, these periodical visitations, have by some reflex action, apparently, either aided in producing them, or at least added very much to the severity of the results flowing from them. Famine is the result of a scarcity of the food necessary for the sustenance of a community. It is clear that the actual occasion of such scarcity may be either of several sets of circumstances 
acting singly or combined. 1. It may be from a failure of crops, from war, pestilence, neglect, or from the density of population being so great that the area at disposal for cultivation is insufficient for the requirements of the numbers depending on it. 2. It may result from the circumstances that while there is food sufficient in the country, it is still too far removed from the location of those requiring it, and there may be no efficient means of transport to bring the food to the people.* 3 . It may result from a want of means to purchase food, which with such means could be obtained in abundance. But it was not the plan of this paper to deal with theoretical causes, or even to group the causes under any very scientific arrangement. The inquiry took for its basis actual facts. There had been many hundreds of famines in our own country and in others. These had been recorded as to time, location, and reported canse. I songht out those records, reduced them to chronological order, and made a summary of their reported causes, twelve in number. The five "Natural Causes," i.e., causes beyond human control, have been examined in Part I. The so-called artificial causes were left for like treatment on this occasion; and these I have had to deal with here in the order in which they were presented by the original investigation.

It became apparent in the first portion of the paper that the investigation was of a very complex character; that the elements which went to make up the aggregate of the reputed causes of famine were diverse in the extreme. But this was no argument against the proposed investigation; it was in truth very much the other way. Problems with obvious, or very simple, conclusions, stand much less in need of elucidation than those wherein the considerations are multifold. If I had foreseen the labour involved in the task I liad set myself, that would have been a very good reason for leaving it in the hands of some person having fewer demands upon his time than myself. But having once entered upon it, there has been no course open to me but to pursue it, and to endeavour to do this thoroughly. I might have shirked certain stages of the inquiry on the simple grouud of the laboxr involved; but the mere question of labour, where historical truths, or statistical results, are in view, is not to be allowed to have weight; I have therefore followed it through to the end, leaving no stone unturned to make the inquiry reasonably complete.

To determine the mode of treatment best adapted to the inquiry has caused me no small degree of anxiety. To make each

* On various occasions when the Thames has been frozen over for several weeks, the price of provisions in the metropolis has been greatly enhaneed: although there was no scarcity whatever in the country. It was solely a question of trarsit. See Table IX (1767). 
branch of inrestigation reasonably complete in itself, and yet in harmony of treatment with the whole, has been the object in view. That the method I have pursued is the best that could have been devised I am very far from contending; it is simply, on the whole, the best which has presented itself to my mind.*

I here desire to refer to an objection which has been made to the first part of the paper, and to which perhaps the present portion is equally or even more open. It is said the facts presented are facts in history, and are not statistical in the sense ordinarily understood. I admit there is some force in the objection; but I reply, these are the bases of statistical inquiry; historical facts reducerl to the form and order of statistical tables. No surmises or generalisations, which may mean something or nothing, as they are rendered or understood; here you have the very words of the record, the time and place and mode of recording. The many hundreds of Acts of parliament embodied in the tables here given have been carefully read and condensed from the "Statutes of the Realm" and the "Statutes at large," and in order to make the understanding of their legislative clauses more clear, I have, wherever it appeared desirable, quoted the very reasons assigned by the legislature for the particular enactment. Let me further say, while on my defence, that not one Act of parliament, nor one book, tract, or record of any kind, has been quoted which does not in my judgment bear directly upon the question of famines, or which has not been designed to du so.

Acts of parliament are not light reading; and the language employed in them is not always redundant either with grace or clearness. The rules of grammar are not to be flaunted in the face of the assembled legislature. The title of an Act is frequently the only part of it which commends itself to the ordinary understandiug; but even the titles do not always convey a very conclusive indication of the contents. In a word, the study of the results of legislative deliberation does not inspire one with the highest ideal of legislative wisdom!

I have said that the anomaly presents itself in respect of several of the tables here given, that while the measures they recount were intended to avert the occurrence of famines, there is reason to believe that they have frequently had the very opposite effect. This is particularly the case as to the legislative enactments in Tables IX, X, XI, and XII. Instances of more perverted

* For my owu information I have made a chronological table of all the events and incidents contained in the entire fifteen tables embraced in this paper and the former one. It perhaps shows the logical sequence of events more fully than they are here shown; but I donbt if that form would have been so suitable to the pages of our Journal, or the information conveyed so useful to general readers, outside the subject of Famines. 
ingenuity than are to be met with in these legislative efforts it is not possible to conceive. An ukase to compel water to run up bill would have been as reasonable, and in many cases, not, in effect, very dissimilar; while the tradition of the Pope's bull against the new moon has at least the advantage of humour in the comparison!

And here I pass from niy legislative review.

\section{Supplemental Observations.}

It has become clear in the progress of this inquiry that the twelve canses of famines indieated in the original table in Part I, do not cover the entire considerations which belong to the history of famines. Accordingly I propose to add a few remarks upon points of direct interest, viz., 1. The prevention of famines in the future; 2 . On the mortality occasioned by famines; 3 . A table (No. XIV) of the price of wheat in England from the year A.D. 1000 down to the present time; 4. And finally a table (No. XV) of the literature of famines.

\section{The Prevention of Famines in the Future.}

It was no part of my original desigu to discuss the prevention of famines, but it was intimated on the former occasion that I should be expected to say something hereon. When we speak of the prevention of famines in the future, that expression must necessarily be understood in the sense, not of changing the course of the seasons, but the rather of understanding their course, and of being prepared for the emergencies such teaching may indicate; or at all events for those contingencies which a knowledge of the past must lead us to expect in the future. It is indeed to be hoped that continued improvements in agriculture and the extension of irrigation, will avert the frequeney of the occurrence of famine : but on these we must not place too much reliance: they are at the best only aids, and slow of development.

That famines will occur in times to come is but too certain. The practical point we have to consider under this division of our subject is what can best be done to avert or mitigate their consequences?

If any one fact be made more clear than another from a study of the data contained in the tables in this paper, it is that famines cannot be averted by legislative action! Neither can this effectively restrain the operation of prices, which alone are and must always be regulated by supply and demand. And yet, because legislation has so signally failed in the directions in which it has been in the past most persistent, is that to be taken as an argument against all legislative measures in the future? Certainly not. One of the oljects most prominent in my mind during the whole course of investiga- 
tion for the purposes of the present paper, is that towards the legislation which will certainly follow the present inquiry, by commission, into the famines of India, and in which one of the most distinguished Fellows of this Society (Mr. James Caird, C.B.) is engaged-the facts here brought together will assuredly contribute. These facts go to show that the canses of famines are manifold: too much rain as freqnently as too little; storms, and pests of insects and vermin. They go also to show what legislation cannot do, and therefore they simplify the problem of what it can do. This latter then is the point which we now have to consider.**

The function of legislation, as we now understand it, is to supply the people governed with the facilities for protecting themselves, and only to step in and attempt actual protection, pending the realisation of this process. In India people require the means of inland communication, and they require a curreney adapted to the circumstances of their daily life. On the latter point I am not fully competent to speak. As to the former, I have already spoken in the first portion of this paper. It is a question between canals and railways-canals for cheapness of transit and for combining irrigation facilities, where practicable; railways for communication with distant provinces, for passenger transit, and for transit of perishable commodities. Canals and irrigation, unless based upon well-considered plans, are liable to break down when most needed, namely, in seasons of great drought. $\dagger$

During the famine which terminated last year, the government tried an experiment which probably will never be repeated. It caused 30,000 tons of rice to be purchased; fearing, I suppose, that the ordinary laws of prompt supply where urgent demand arises wonld not there be equal to the emergency. In that view (if it were the official view) it was soon discovered they were mistaken. In future the conrse seems plain-give timely warning of approaching scarcity; leave the rest to mercantile enterprise. Of course, as to the conveyance of grain inland, help must be

* In India there lave been many governmental restrictions regarding food supplies, and the mode of dealing in these; but regarding their details $I$ am not sufficiently informed.

† Kaye remarks in his "History of Indian Progress," that the preciousness of water crops up incidentally in the oldest Hindoo writings extant. In the laws of Manu, at once the Noah and Solon of Indian myth, the breaker of a dam is sentenced to long immersion under water. Timur, too, whose invasion in 1398, together with the subsequent reign of four officers, the Sayids, as his viceroys, forms a marked feature in Indian history, ordained, whoever undertook the cultivation of waste lands, or built an aqueduct, or made a canal, or planted a grove, or restored to culture a deserted district, that in the first year nothing (in the way of taxes) should be taken from him, and that in the second year whatever the subject voluntarily offered should be received, and that in the third year the duties should be collected according to the regulation. 
given, pending completion of the modes of transport; and upon this question of transport I do not propose to invoke any discussion on this occasion, knowing that the question is under imperial consideration.

In all I have said regarding India, I beg to disclaim any idea of imputing censure on the Government. A snccession of great calamities in the way of famines have fallen upon that empire: the Government and its officials have struggled nobly with the difficulties presented; and but for these efforts the suffering, as also the mortality, would probably have been ten-fold. My point is, that hereafter we are to devise measures of permanent security, rather than rely upon temporary expedients, however energetically these may be executed. I have already indicated that the only mode of permanent prevention lies, in my belief, in improved means of cultivation, if practicable, and of transport as a necessity.

\section{On the Mortality Occasioned by Famines.}

In my table of famines, I have stated (wherever such estimates were found to exist) the mortality resulting from the particular famine under notice. It is only in exceptional cases that such estimates are given; and if they were given in every case, I fear they would mostly be panic estimates, and therefore not entitled to implicit credence.

But beyond the directly known, or calculable loss, I suspect there is a vast mortality occasioned by periods of scarcity which can only be arrived at by approximation. I am not about to attempt any detailed inquiry into this branch of the subject, which indeed might be found sufficient for a paper full of interest in the hands of any industrious member of this Society seeking for a subject. I propose simply to put on record some facts which have come before me almost incidentally in the progress of this inquiry.

It has been remarked that nearly all the great epidemics of fever, more especially of typhus, have occurred during seasons of scarcity and want. They are in fact associated with famine. In some instances the famine has been general, owing to failures of the crops, and the epidemics have been widespread: while in others the scarcity has been the result of artificial causes, such as strikes, commercial failures, sieges, \&c., and the epidemics have been circumscribed. But whatever may have been the cause of the scarcity, it has been a common observation in manj epidemics that the fever has raged among the poor in a degree proportionate to the privations they have endured. It was especially observable during the Irish potato famine: those persons who had been reduced by insufficient food were invariably attacked. 
1802.-The seasons of 1799 and 1800 were "bad," and the consequent dearth in 1801 and 1802 produced great distress. Parliamentary committees inquired into the means of supplying people with food. Before one of these committees the following return was made :-

\begin{tabular}{|c|c|c|c|}
\hline Year. & $\begin{array}{l}\text { Arerage Price of the } \\
\text { Wincliester } \\
\text { Quarter of Wlieat, } \\
\text { Windsor Prices. }\end{array}$ & Corn Returns. & Burials in England. \\
\hline 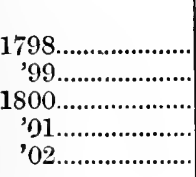 & $\begin{array}{rc}s . & d . \\
54 & - \\
75 & 8 \\
127 & - \\
128 & 6 \\
69 & 3\end{array}$ & $\begin{array}{rr}s . & d . \\
50 & 3 \\
67 & 6 \\
113 & 7 \\
118 & 3 \\
67 & 5\end{array}$ & $\begin{array}{l}187,531 \\
189,586 \\
208,063 \\
204,434 \\
199,889\end{array}$ \\
\hline
\end{tabular}

1804.-A writer in the "Edinburgh Review" (1829) instituted the following comparison: The year 1801 was a year of extreme scarcity. The number of births registered in England and Wales was 237,000, and the number of registered burials 204,000; whereas in 1804, which was a year of plenty, there were no fewer than 294,000 registered births, and only i 8 1,000 registered burials; being an excess in the latter year of 57,000 births, and a diminution of burials, although out of a larger population.

1841.-Mr. Thomas Doubleday published, "The True Law " of Population, shown to be connected with the Food of the " People."

1841-42.- In a valuable paper read before the Philosophical Society of Glasgow this year by Dr. R. D. Thomson (and published in the transactions of the Society for the fourteenth session), after noticing the number of deaths in England by starvation, or purely from want of food, the author says, "how many persons die by piecemeal starvation, or by disease engendered by bad food, or want of it, has not yet been pointed out by statistical data." He also said :-

"We trust the day is fast approaching when the light of science will enable the guardians of the poor to manage our poverty-stricken fellow men by precise and definite rules, and will teach all classes of the community that the quantity of vital air supplied by the Creator to man is based on fixed laws which require the imbibition of a certain amount of food. An adult consnmes every day $30^{\frac{1}{2}}$ ounces of oxygen or vital air from the atmosphere. To consume this and to convert it into carbonic acid, he requires, according to Liebig, about 13 ounces of carbon in the form of food. If the food is withheld, the carbon must be supplied from the muscles and substance of the body ; the latter becomes thinner and wcaker, and likc an expiring taper is extinguished by the influence of the 'most trivial causes."

1842.-The Report of a Committee of the British Association for the Advancement of Science : On the Vital Statistics of the Large 
Towns of Scotland, published this year, contained the following passage :-

"Though we may not be able to trace the effects of destitution in its different stages on the increase of disease and death, yet by the improvenent of registers, and by greater attention to the vital statisties of different localities, and of different classes of the people, more certain knowledge may be obtained on this most important subject. 'I'he proof, however, which the preceding tables afford that the mortality for the different towns is in proportion to the amount of the poor and destitute in these towns, is supported by the amount of burials which take place in them at the public expense."

1842.--In Professor Liebig's Report on Organic Chemistry applied to Physiology and Pathology-of which an abstract made by Dr. Lyon Playfair appeared in the report of the British Association for this year-there is the following :-

"Food is either applied in the increase of the mass of a structure (i.e., in nutrition), or it is applied in the replacement of a structure wasted (i.e., in reproduction). The primary condition for the existence of life is the reception and assimilation of food. But there is another condition equally important-the continnal absorption of oxygen from the atmosphere. All vital activity results from the mutual action of the oxygen of the atmosphere and the elements of food. All changes in matter proceeding in the body are essentially chenical, although they are not unfrequently increased or diminished in intensity by the vital force.

1846.-The Registrar-General, in his ninth annual report, reviewing the scarcity of food at this period, occasioned very much by the failure of the potato crop in Ireland, pointed ont why such disasters were not so fatal to the people as was formerly the case :-

"The quantity of food which a country imports does not depend merely on its wants; it depends on its ability to pay for food from abroad; the ability itself varying with the people's powers of production and the prices of commodities in the foreign market. A purely agricultural ill-cultivated country such as England was in the mildle ages, and such as parts of Ireland and France are, suffers more from the failure of a crop than a population like that of England now, whose income is derived from the several sources of agriculture, manufactures and commerce. It is not the less true that the partial destruction of the crops is an immense loss to the country."

In the same year (1846) Dr. Farr read before the Statistical Society of London a most valuable paper: The Influence of Scarcities and of the High Prices of Wheat on the Mortality of the People of England [Statistical Journal, vol. ix, p. 158], whercin he says:-

"If we may judge from the habits of the best and most vigorous races, man would appear to be able to live on great varieties of food; but in respect to the quantity of nutritive matter, the law of his system is less flexible. In the cold, or engaged in hard work, he requires a large quantity of nutriment, and he socn becomes unable to take active exercise if the supply fall below a given point. Dalton--and subsequently Liebig-have shown that a certain number of ounces of carbon is burnt in the body, to keep up its slightly-varying temperature; and that nitrogenous matter is required to replace the particles destroyed in the evolution of sensation, muscular actions and other functions." 
After reviewing the periods of scarcity in the history of Great Britain, and the prices of provisions at various periods, he proceeds :-

" The causes of a high mortality are various, but the greater number of known causes may be referred to five heads-1. Excessive cold or heat. 2. Privation of food. 3. Effluvial poisons gencrated in marshes, foul prisons, camps, cities; and epidemic diseases, such as typhus, plagne, smallpox, and other zymotic diseases. 4. Mechanical and chemical injuries. 5. Spontaneous disorders to which the structure of the human organisation renders it liable. The first three classes of independent causes vary in intensity from year to yeir' and as each will separately produce the effect which we are investigating, nannely, an inerease of deaths, it nust be evident that this effect will not always vary as privation, or as any one of the elass of causes. For instance, the sweating sickness, said to have broken out in Richmonl's camp, spread through England and destroyed great numbers. It was a poison in the air, and, like other poisons, its fatal action was not stopped by abundance of food, although its ravages, if aided by fimine, might have been rendered more deadly. So of the black death in 1318, the plague of 1665 , the cholera of 1832 .

"Then, low prices do not always denote plenty, nor high prices scarcity. And if high prices inerease the mortality, any great mortality has a tendency to increase the price of provisions. Thus in 1349 'the price of every kind of cattle was much reduced; they wandered about in herds without iserdsmen. Corn of all kinds was so abundant that no one gathered it.' Workmen were scarce, a 'great part' of them baving been destroyed, and demanded high wages.

"These great disturbing causes and the imperfections of the returns require, for the elimination of their effects, a series of observations extending through a century. The concurrent evilence of the seventeenth and eighteenth centuries appears to me to justify' the inference that high prices of wheat-I mean relatively high-irrespective of the other necessaries of life, had then a tendency to increase the mortality of London."

\section{Much other information of interest is contained in Dr. Farr's} paper.

1862.-An inquiry was made by direction of the Privy Council into the nourishment of the distressed operatives of Lancashire and Cheshire-distressed by reason of the "cotton famine" then prevailing. This inquiry was conducted by Dr. Edward Smith, M.D.; and in his report was contained a theoretic estimate of the minimum quantity of food on which human life could reasonably be expected to subsist; and that estimate formed the scientific basis for such adrice as was given to the cotton towns on the subject of their allowances for the poor. Its purport was, that in order to avert starvation-diseases an average woman's daily food ought to contain at least 3,900 grains of carbon, with I 80 grains of nitrogen, i.e., for the woman about the same quantity of the nutritive elements as is contained in 2 lbs. of good wheaten bread; and for the man about one-ninth more.

1867.- In the thirteenth detailed report of the Registrar-General for Scotland, Dr. Stark, in reporting on the deaths, \&c., of this year, says:- 
"In comtries where the mass of the population is dependent for then sustenance on the crops which they raise, and where they have little or no external trade, it is the crops which are the great regulators of the mortality, after the weather. For if the crops partially or wholly fail, the price of the food rises so high as to be beyond the power of purchasing by the lower classes. In such countries, therefore, the amount of sickness and death almost invariably rises and alls with the price of the provisions. When provisions are abundant, and consequently cheap, the amount of sickness is small, and the death-rate low; but a failnre of the crops almost invariably brings a high amount of sickness, and the death-rate becomes excessive."

In Scotland, during the operation of the Registration Act, he had not found this law in operation.

\section{Price of Wheat in England.}

The following Table (XIV) is added in view of bringing into one focus the results (as affecting one principal article of food) of all the efforts, legislative and general, which have been made during the last eight centuries to counteract the effects of recurring periods of scarcity in England. If it had so chanced that in this country (as in the case in the West Indies, and perhaps in some few other portions of the globe) the supply of food had always been fully equal to the wants of the population, there would have been no necessity for any legislative restrictions at all. We may fairly say then that all the mass of legislation which we have reviewed has been designed to prevent the occurrence of undue fluctuations in the supply of food, and hence will necessarily have exercised its influence upon the prices embraced in the following table. It follows therefore that at least since legislative influences were brought into play the prices recorled in the table are not those which have resulted naturally; but that they are artificial prices, modified to a now unknown extent by the influences we have recorded; and some of these are stated to have existed long before the dates at which they became recorded in our statutes. The regulations indeed (or some of them) detailed in the preceding tables had been proclaimed orally from the market cross as being by the command of the sovereign. When written laws came into fashion, these were made to cmbody those yet earlier ordinations.

I confess it would be to me a matter of much interest to know the extreme range of prices which any famine has produced, where matters have simply been allowed to run their natural course. It is seen however that in such a case it is the poor who must be of necessity sacrificed, as their resources for purchasing food would be the sooner exhausted, and that therefore the wealth of the country, i.e., its monetary resources, must always be an important element in the consideration of the influence of famines. Where money will not bring food, and a scarcity continues, the people must all 
die out, anless such as have the means migrate forthwith to some land better supplied. I suspect in the eastern nations migrations have often been enforced by scarcity of food. With pastoral tribes the migration recurs with the change of seasons; the inhabitants are always following up their food supplies. A stationary population is of course always dependent for its sustenance upon the food supplies it can either produce or purchase. With such a people the price of food must always be regulated by two main factors-the seasons and the facilities or otherwise for obtaining foreign supplies.

In the preparation of the following table it has been necessary, in order to make the comparison of price consistent throughout the entire period over which it extends, to adjust the prices actually recorded (in the currency of the period) to the standard of present values. In this I have availed myself of the labours of several who have given much time to the subject-they are all named in notes appended, in relation to the particular part of the table resulting: from their labours. I fear there may be a little disjointedness consequent upon treatment by several hands, but it is probably not very material on the whole.

I have sought by means of explanatory notes to draw attention briefly to the causes of the rise and fall of price at different periods. Reference to the preceding tables at the corresponding lates will complete this comparison, and in a certain sense reduce all that is contained in this and the previous part into one chronological whole.

By the term "price of wheat" too must be understood the average price as far as this has been capable of ascertainment. I think as illustrating the exact conditions and circumstances of the country at each period, a record of the highest and lowest prices would have been of more valne; but these would be almost. impossible of systematic compilation within the required space.

Again, I have prefixed an almost never-failing canse of disturbance in the price of grain, I mean the advent of "peace" or "war." The occurrence of the latter has in almost every instance driven up the price-realising the meaning of the old phrase, "war "prices."

I think this table will be useful in the pages of the Joumal of the Society for many purposes beyond that immediately before us.*

* Up to this date (1877), at least during the present generation, (and we have not the means of going furtler back), the price of food has been regarded and proclaimed as the ruling factor in determining the marriage-rate in England and Wales. But the Registrar Generil in adjusting his account with Hymen and Co., now discovers that " the price of coals" is becoming a ruling factor in watrimony; for the marriage-rate perceptibly declines in those districts where coal mining has been less prosperous and remunerative; but this only (I assume) because the wage earning power is diminished. 
TABLe XIV.-The Price of Wheat in England and Wales from the Year A.D. 1000 (intermittent during the First Two Centuries and a Half), with a Statement of the Probable Causes Affecting the Price, as Peace or War, Abundance or Scarcity, Legislative Tnterferences, $d c$.

Note.-The values in column 3 are giren in moner of the present day. By "Winchester measure" is meant a quarter of 8 bushels of 8 gallons each.

\begin{tabular}{|c|c|c|c|c|c|}
\hline \multicolumn{2}{|c|}{$\begin{array}{l}\text { Peace or } \\
\text { War. }\end{array}$} & Year. & \multicolumn{2}{|c|}{$\begin{array}{c}\text { Price } \\
\text { of Wheat per } \\
\text { Quarter, } \\
\text { Winchester } \\
\text { Measure. }\end{array}$} & $\begin{array}{l}\text { Notes, Expla natory, \&c. } \\
\text { [The money ralues in this column are not enlarged, hut are } \\
\text { quoted as given by the respective authors cited.] }\end{array}$ \\
\hline War & .... & 1000 & $\begin{array}{ll}£ & s \\
- & \mathrm{I}\end{array}$ & & 1000. Ethelred II, an Anglo-Saxon king, was \\
\hline & .... & ’01 & $-\mathbf{I}$ & & now on the throne. The purchasing price of \\
\hline Peace & .... & 32 & $-\mathbf{I}$ & 6 & land was from $5 d$. to is. $3^{d}$. per acre; a horse \\
\hline War & $\cdots$. & 03 & -1 & 6 & was worth $1 l$. I $7 s .6 d$. ; a mare $1 l .5 s . ;$ a cow $6 s$. ; \\
\hline Peace & $\cdots$. & 204 & -1 & 6 & a sheep $1 s .3 d . ;$ a goat $2 s .9 d$. ; a mule $15 s . ;$ an \\
\hline & $\cdots$. & $\begin{array}{l}05 \\
06\end{array}$ & $\begin{array}{ll}- & I \\
- & I\end{array}$ & 6 & ox $7 s .6 d$. The price of wheat as here given is \\
\hline War & .... & 07 & $\begin{array}{l}-1 \\
-\quad I\end{array}$ & $\begin{array}{l}6 \\
6\end{array}$ & conjectural. \\
\hline & $\cdots$ & ’08 & -1 & & 1003. A Land Tax \\
\hline eace & $\cdots \cdot$ & ’99 & - & & $\begin{array}{l}\text { 1003. A Land Ta. } \\
\text { land first imposed. }\end{array}$ \\
\hline$"$ & $\cdots \cdot$ & 10 & 一 & & \\
\hline War & $\cdots$. & $\begin{array}{l}11 \\
\prime 12\end{array}$ & 二 & & . \\
\hline$"$ & .... & '13 & - & & 1008. Each 310 hydes of land were taxed to \\
\hline$"$ & $\cdots \cdot$ & 14 & - & & furmish a ship ready for war; and every 8 hydes \\
\hline$"$ & $\cdots$. & 15 & 一 & & one horseman. England was computed to \\
\hline$"$ & $\cdots$. & $\begin{array}{l}16 \\
17\end{array}$ & - & & contain 243,600 hydes. \\
\hline Peace & .... & '18 & - & & nded the English \\
\hline " & $\ldots$. & 19 & 一 & & throne. \\
\hline$"$ & $\cdots$ & 20 & - & & \\
\hline$"$ & $\cdots$ & 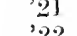 & -1 & 6 & 1014. Canute succeeded Sweyn on the throne. \\
\hline$"$ & $\cdots$ & 23 & $\begin{array}{ll}- & 1 \\
- & 1\end{array}$ & 6 & 1017 Canute beo \\
\hline$"$ & .... & 21 & 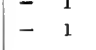 & 6 & $\begin{array}{l}\text { 1017. Canute became king of England. He } \\
\text { levied a Dane-gelt of } 216,000 l \text {.; but this was not }\end{array}$ \\
\hline$"$ & $\cdots \cdot$ & '25 & - & & collected till 1039 . \\
\hline$"$ & $\cdots$. & ' & 一 & & Note-The Saxons and Danes at this period \\
\hline " & $\cdots$ & $\begin{array}{l}3 \\
2 \\
298\end{array}$ & 一 & & ive under fendal laws; they \\
\hline$"$ & $\cdots$ & '28 & 一 & & cted to arms and chivalry ; and \\
\hline " & $\cdots \cdot$ & ' 29 & 一 & & ed arts and agriculture to the \\
\hline$"$ & $\cdots$. & $\begin{array}{l}30 \\
31\end{array}$ & 一 & & hem. \\
\hline$"$ & .... & ' 32 & $\longrightarrow$ & & 103 \\
\hline$"$ & $\cdots$. & '33 & - & & \\
\hline$"$ & $\cdots$. & '34 & 一 & & 1039. Hardic \\
\hline$"$ & $\cdots \cdot$ & '35 & 一 & & The collection of the Dane-gelt caused an in- \\
\hline$"$ & $\cdots$ & ( & - & & nention \\
\hline$"$ & $\cdots$. & $\begin{array}{l}37 \\
38\end{array}$ & 二 & & \\
\hline$"$ & .... & 39 & 一 & & $\begin{array}{l}\text { 1041. Edward the Confessor, } \\
\text { ascended the throne. }\end{array}$ \\
\hline$"$ & $\cdots$ & 40 & - & & \\
\hline 争 & $\cdots \cdot$ & 41 & -15 & $3^{\frac{1}{2}}$ & 1041-43. Wheat dearer than it had been known \\
\hline$m$ & $\cdots \cdot$ & 43 & 5 & & within the memory of man. Famine caused by \\
\hline$"$ & .... & '44 & 13 & 2 & ning burning grain in the field ; followed by \\
\hline - & .... & 45 & - & & \\
\hline & & & & & \\
\hline
\end{tabular}


TABLE XIV.-The Price of Wheat in England and Wales-Contd.

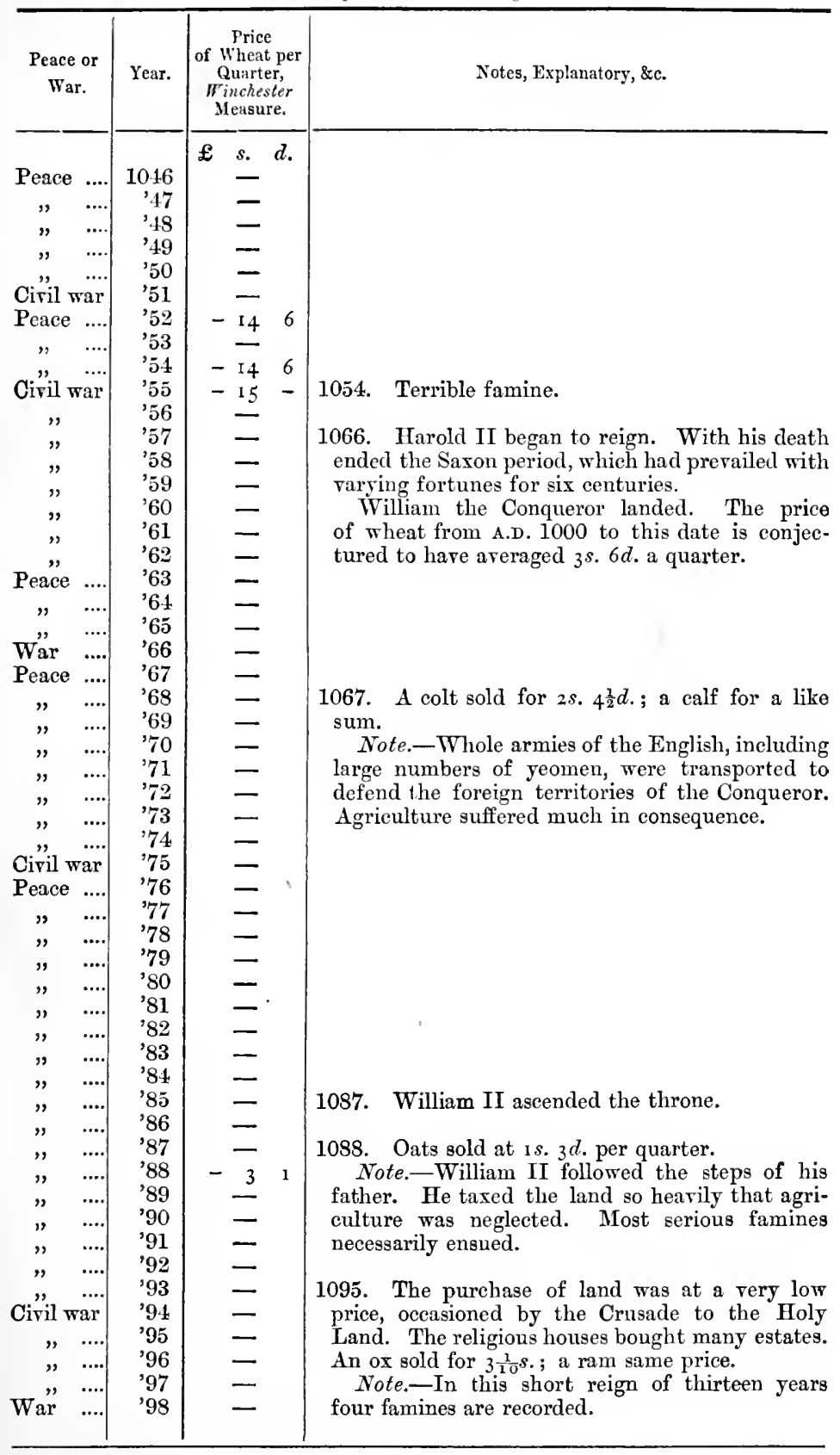


Table XIV.-The Price of. Wheat in England and Wales-Contd.

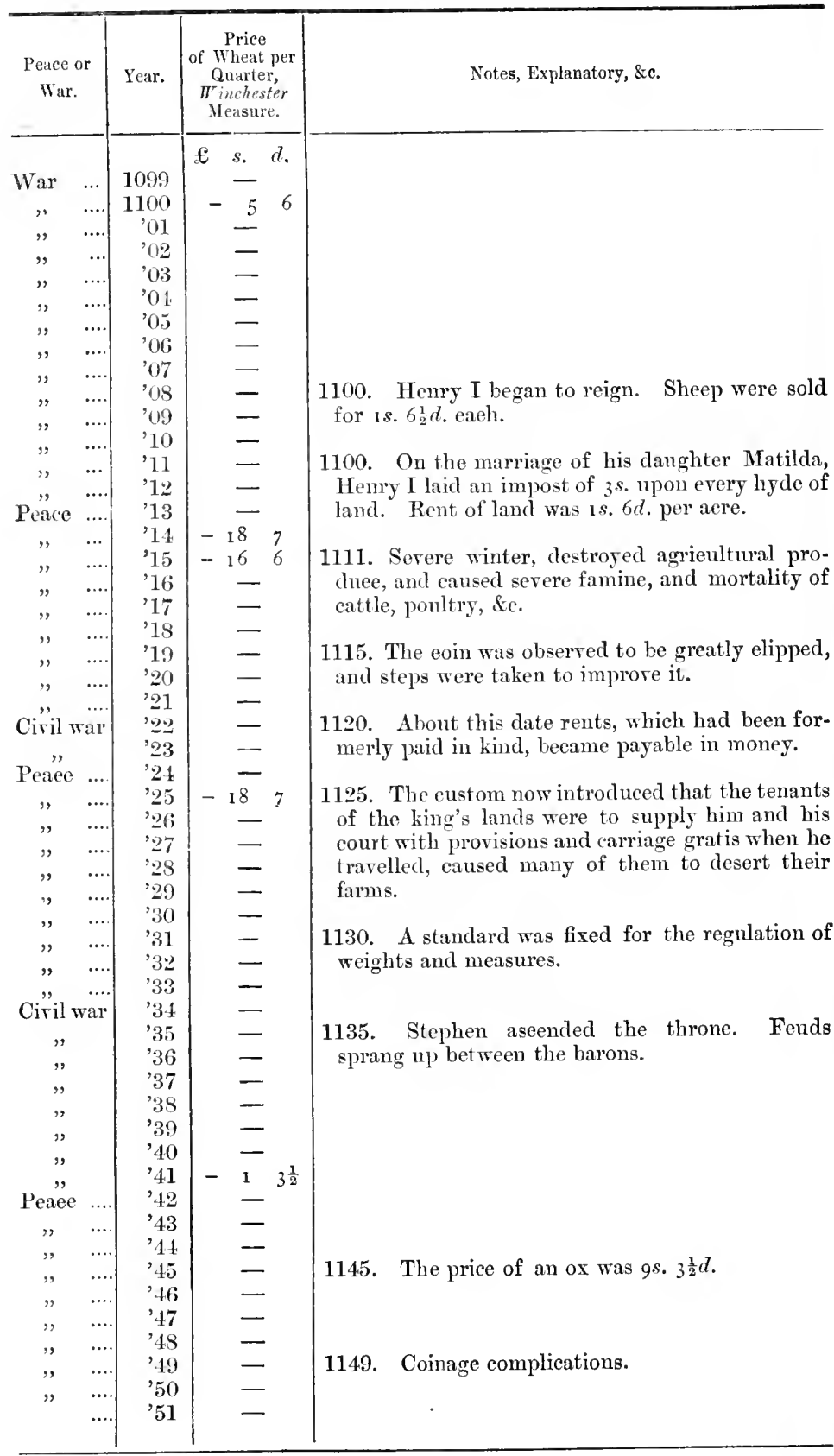


Table XIV.-The Price of Wheat in England and Wales--Contd.

\begin{tabular}{|c|c|c|c|}
\hline $\begin{array}{l}\text { Peace or } \\
\text { War. }\end{array}$ & Year. & $\begin{array}{c}\text { Price } \\
\text { of Wheat per } \\
\text { Quarter, } \\
W^{\text {inchester }} \\
\text { Measure. }\end{array}$ & Notes, Explanatory, \&c. \\
\hline $\begin{array}{cc}\text { Peace } & \ldots . . \\
, & \ldots \\
, & \ldots\end{array}$ & $\begin{array}{r}11,52 \\
, 53 \\
, 54\end{array}$ & $\begin{array}{c} \pm s . \\
- \\
-\end{array}$ & $\begin{array}{l}\text { 1154. Henry II ascended the throne-first of the } \\
\text { Honse of Plantagenet. }\end{array}$ \\
\hline
\end{tabular}

1155. The king repaired the coin, and ordered that his money only should be current. Oats sold for $1 s .-\frac{1}{2} d$. per quarter.

1164. The carcase of a fat ox sold for $3 s$. $1 \frac{1}{2} d$., a fat sheep for $1 s .-\frac{1}{2} d$.

1177. A fat ox sold for $3 s .4 d$; a fat sheep for $1 s .-\frac{1}{2} d$.

1180. Debased coin called in.

1184. (30 Henry II.) Madox, in his Baronia Anglica (c. 14), records that in this year 33 cows and 2 bulls cost but $8 l .7 \mathrm{~s}$. money of that age; 500 sheep, 22l. $10 s$., or about $10 \frac{3}{4} d$. per sheep; 66 oxen, 1 $8 l .3 s$; ; 5 breeding inares, $2 l$. 1 $2 s .6 d$.; and 22 hogs, $1.2 s$.

1188. A new Crusade was proclained. A tax of one-tenth on all movable goods was imposed.

1189. Richard I ascended the throne; he remitted the Dane-gelt.

1191. Labourcrs' wages at Croyland was $4 \frac{1}{7} d$. per day.

1193. A $\operatorname{tax}$ of $15 s .6 d$. laid on every hyde of land.

1196. One hundred acres of land were let for 3l. 2s.; an ox sold for $12 s .5 d$.; a labouring horse I $2 s .5 d$.; a sow $3 s$.; a sheep with fine wool $2 s .7 d$.; with coarse wool $1 s .6 \frac{1}{2} d$. A law enacted that there should be but one weight and one measure throughout the land; unhappily not enforced.

1199. John ascended the throne. The price of wheat during the period 1066-1199 probably averaged $3 s$. $1 d$. per quarter.

1200. Beer more generally brewed, principally for the use of the gentry. It was employed before this date in the administration of the Sacrament. The Council of Winchester this year substituted wine. Red wine was is. $6 \frac{1}{2} d$. per gallon.

1202. Coin again debased. 
Table XIV.-The Price of Wheat in England and Wales-Contd.

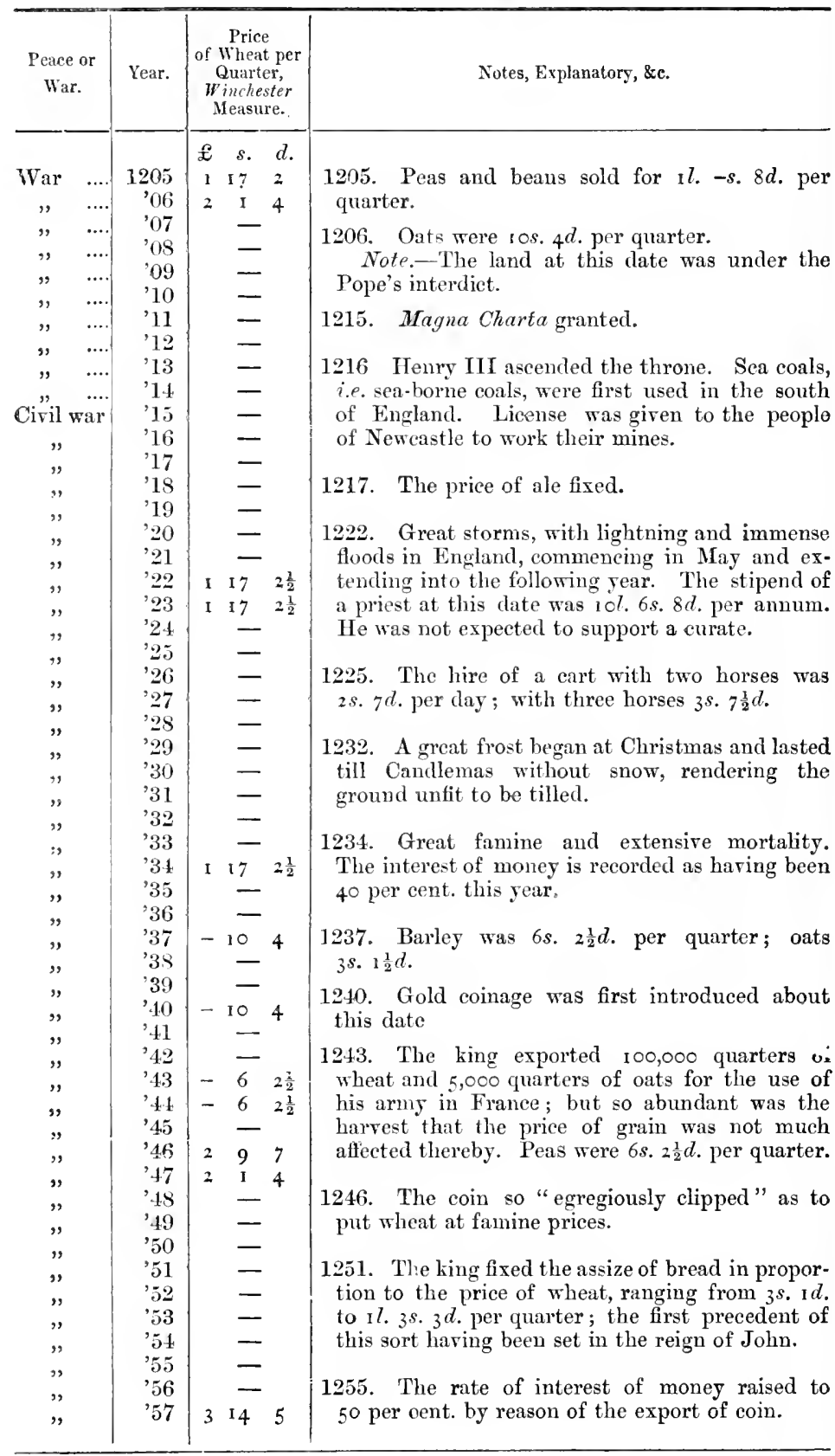


TABLE XIV.-The Price of Wheat in England and Wales-Contd.

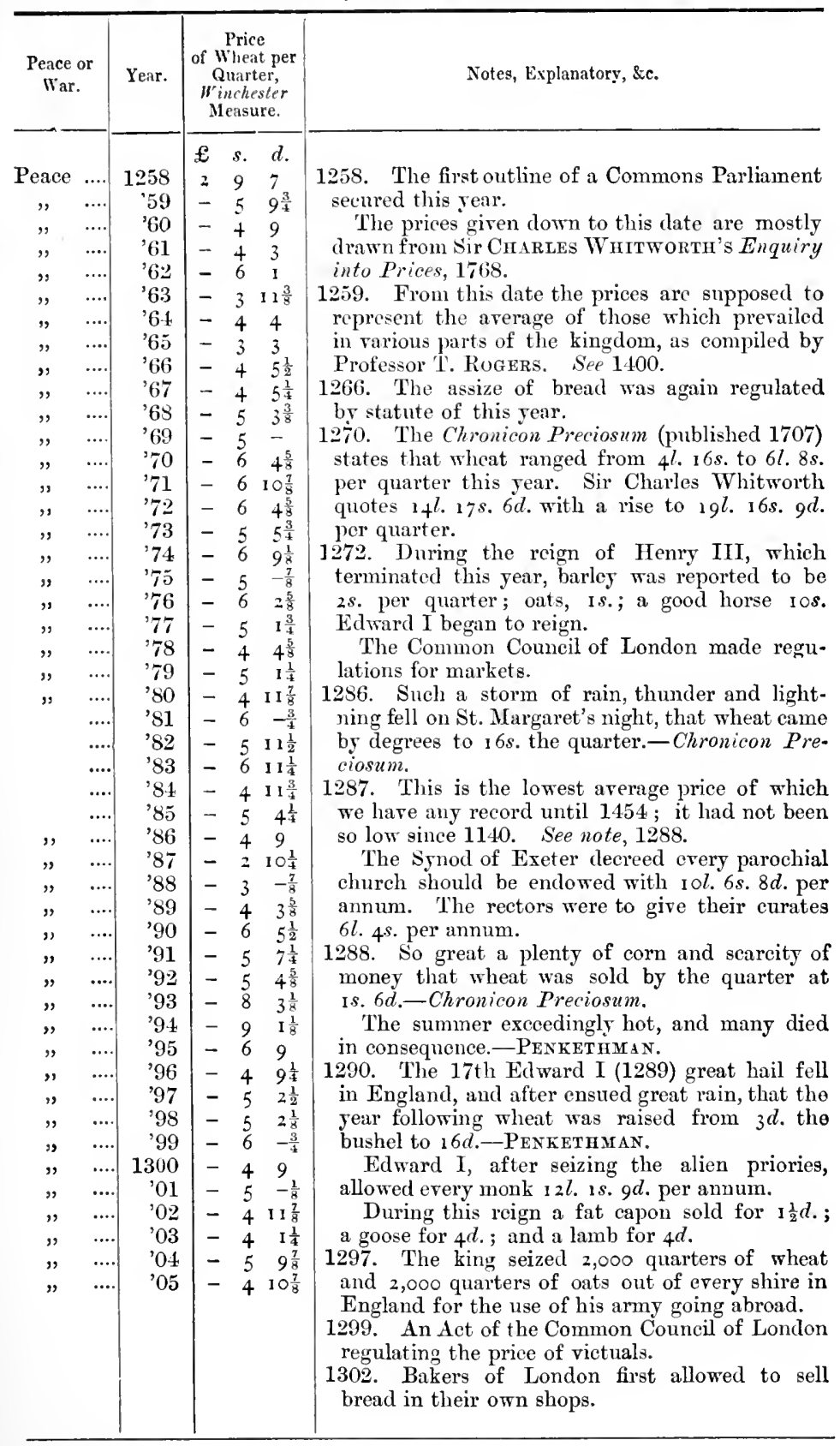


Table XIV.-The Price of Wheat in England and Wales-Contd.

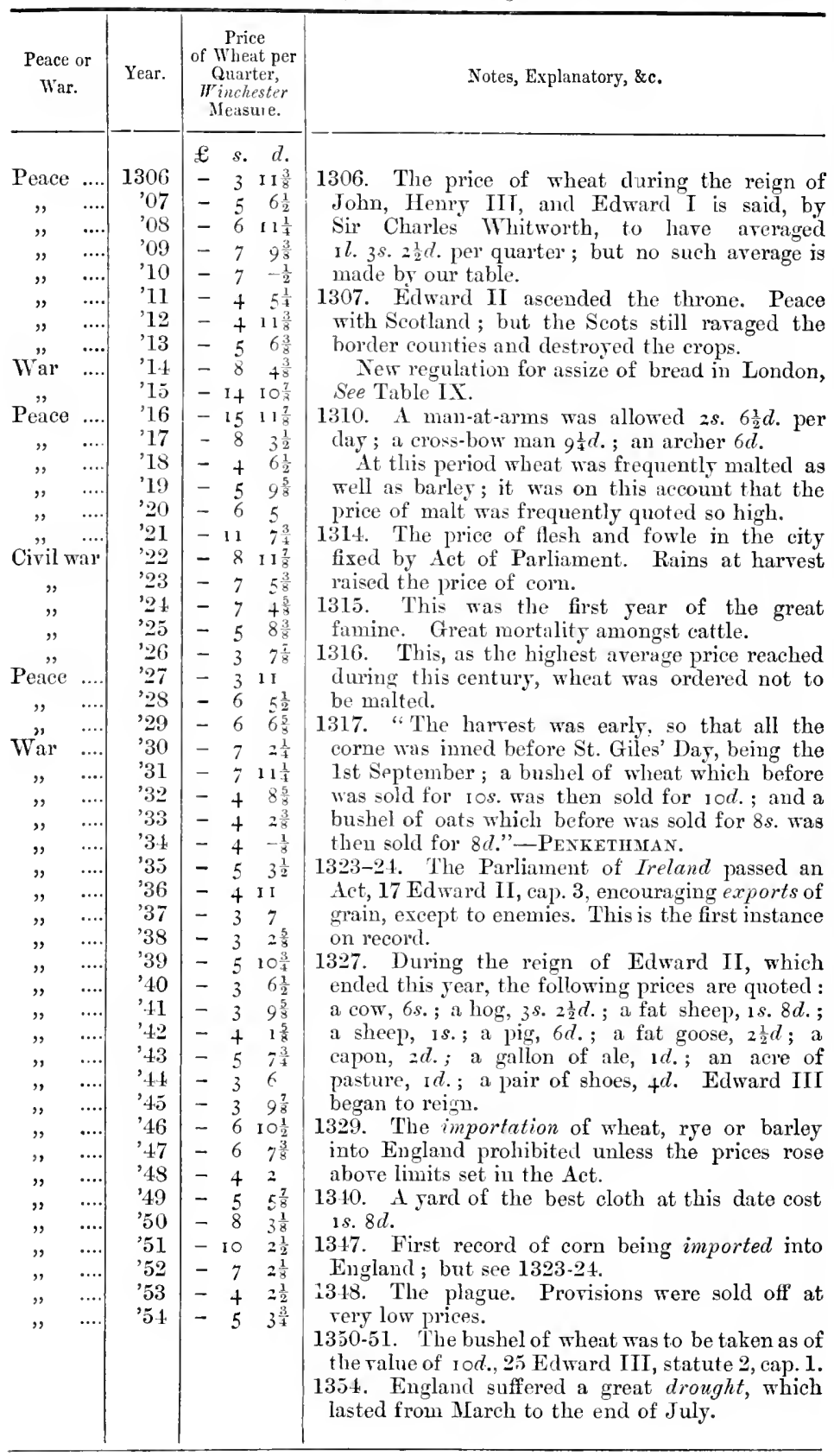


Table XIV.-The Price of ITheat in England and Wales-Contd.

\begin{tabular}{|c|c|c|c|c|}
\hline \multicolumn{2}{|c|}{$\begin{array}{c}\text { Peace or } \\
\text { War. }\end{array}$} & Year. & $\begin{array}{c}\text { Price } \\
\text { of Whicat per } \\
\text { Quniter, } \\
\text { Winchester } \\
\text { Measure. }\end{array}$ & Notes, Explanatory, \&c. \\
\hline War & $\cdots$ & 1355 & $\begin{array}{lll}\mathfrak{E} & s . & d . \\
- & 5 & 11 \frac{3}{8}\end{array}$ & 1355. Considerable scarcity; grain imported from \\
\hline$"$ & .... & '56 & $-6-$ & Ireland. \\
\hline$"$ & $\cdots$ & 57 & $-610 \frac{3}{4}$ & \\
\hline$"$ & ... & , & $-56 \frac{1}{2}$ & 1360. Exportation of corn forbidden, except to \\
\hline Peace & $\ldots$. & '60 & $-63^{\frac{1}{2}}$ & \\
\hline " & $\cdots$ & '61 & $-54^{\frac{3}{4}}$ & 1361. The stipends of the clexgy were reduced to \\
\hline , & $\cdots$. & '62 & -7 & 8l. 5 s. per annum by the Archbishop of Canter- \\
\hline " & $\cdots$ & 63 & -86 & bury. The wages of artificers were increased. \\
\hline " & .... & '64 & $-75 \frac{3}{8}$ & \\
\hline " & $\cdots \cdot$ & '6ã & $-6-\frac{3}{8}$ & 1362. Act regulating the price of poultry.- \\
\hline " & ‥ & 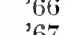 & 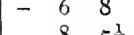 & 37 Edward III, cap. 3. \\
\hline " & $\cdots$ & 67 & $\begin{array}{l}-87^{\frac{1}{2}} \\
-\quad 67 \frac{8}{8}\end{array}$ & $\pi$ \\
\hline "” & $\cdots$. & '69 & $-11 \quad 10 \frac{1}{4}$ & $\begin{array}{l}\text { 1363. Servants to eat flesh or hish but once a-day. } \\
-37 \text { Edward III, cap. } 8 .\end{array}$ \\
\hline 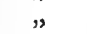 & $\cdots$ & '70 & $-94 \frac{5}{8}$ & \\
\hline
\end{tabular}

1365. An ordination promulgated in London regarding sale of horse bread.

1376. The value of land, as also the rent of it, very much reduced by depression of trade.

1377. Richard II ascended the English throne.

1379. The 3 Richard II, "A bushell of wheat was sold for $6 d$; ; a gallon of white wine for $6 d$.; of red for $4 d . "$-PENKETHMAN.

1387. The 10 Richard I, "In the beginning of the year at Leicester, 100 quarters of barley were sold for roo shillings."-PENkETHMAN.

1391. The measuring of grain to be made uniform throughout the realm.-15 Richard II, cap. 4.-Grain imported by lord mayor for the people.

1393. Export of corn freely permitted.-17 Richard II, cap. 7.

1399. Henry IV (first of the House of Lancaster) ascended the throne.

1400. The prices down from 1259 to this date are obtained from Professor T. Rogers's table in History of Agriculture and Prices, 1866. The arerage price during the whole period of i 40 years was $5 s .10 \frac{3}{4} d$. per quarter.

1401. The prices from this date are those given by Sir Fred. M. Eden (History of the Poor).

1407. Great plague; 30,000 persons died in England. 
Table XIV.-The Price of Wheat in England and Wales-Contd.

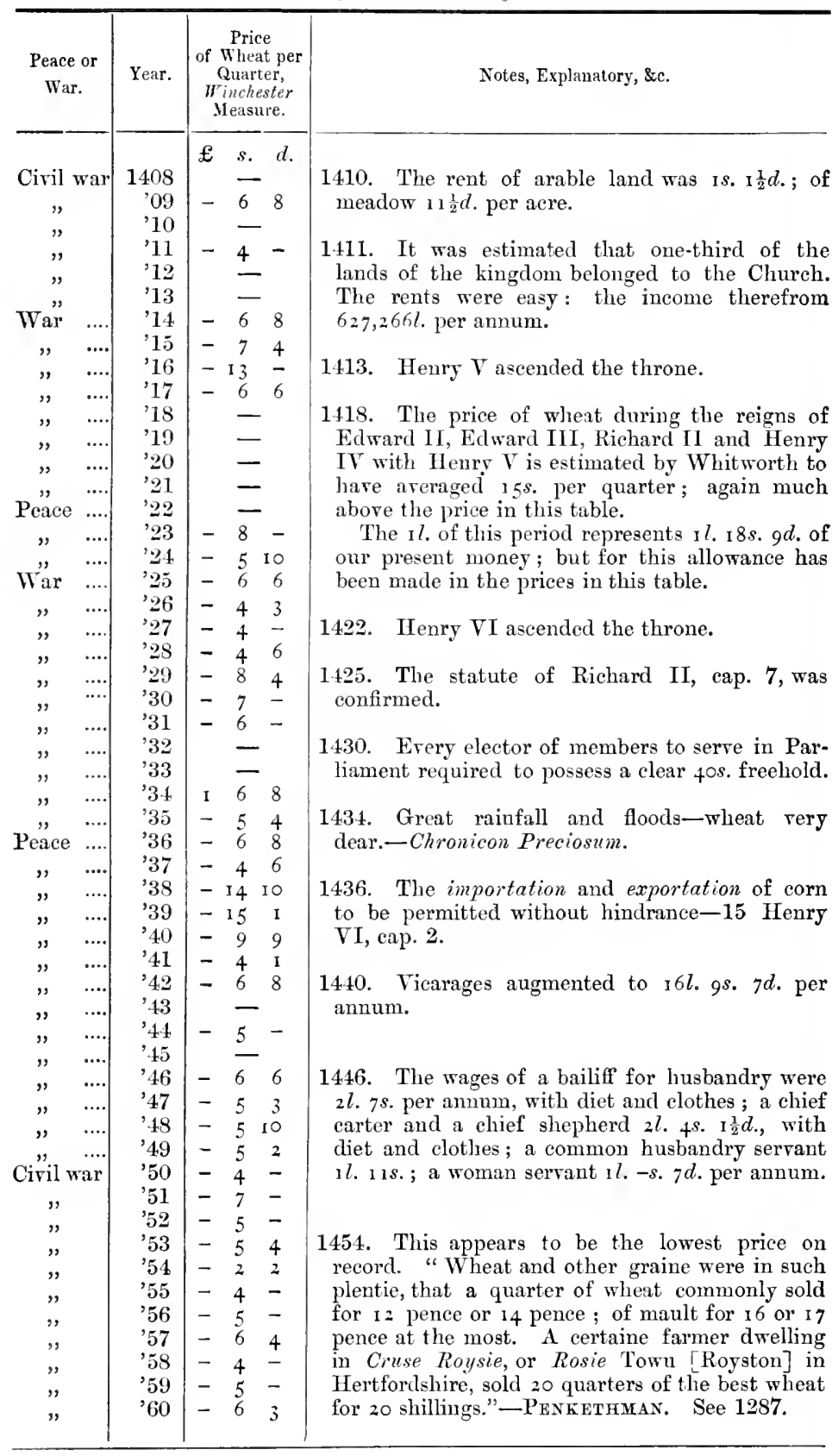


the World; Past and Present.

TABLe XIV.-The Price of Wheat in England and Wales-Contd.

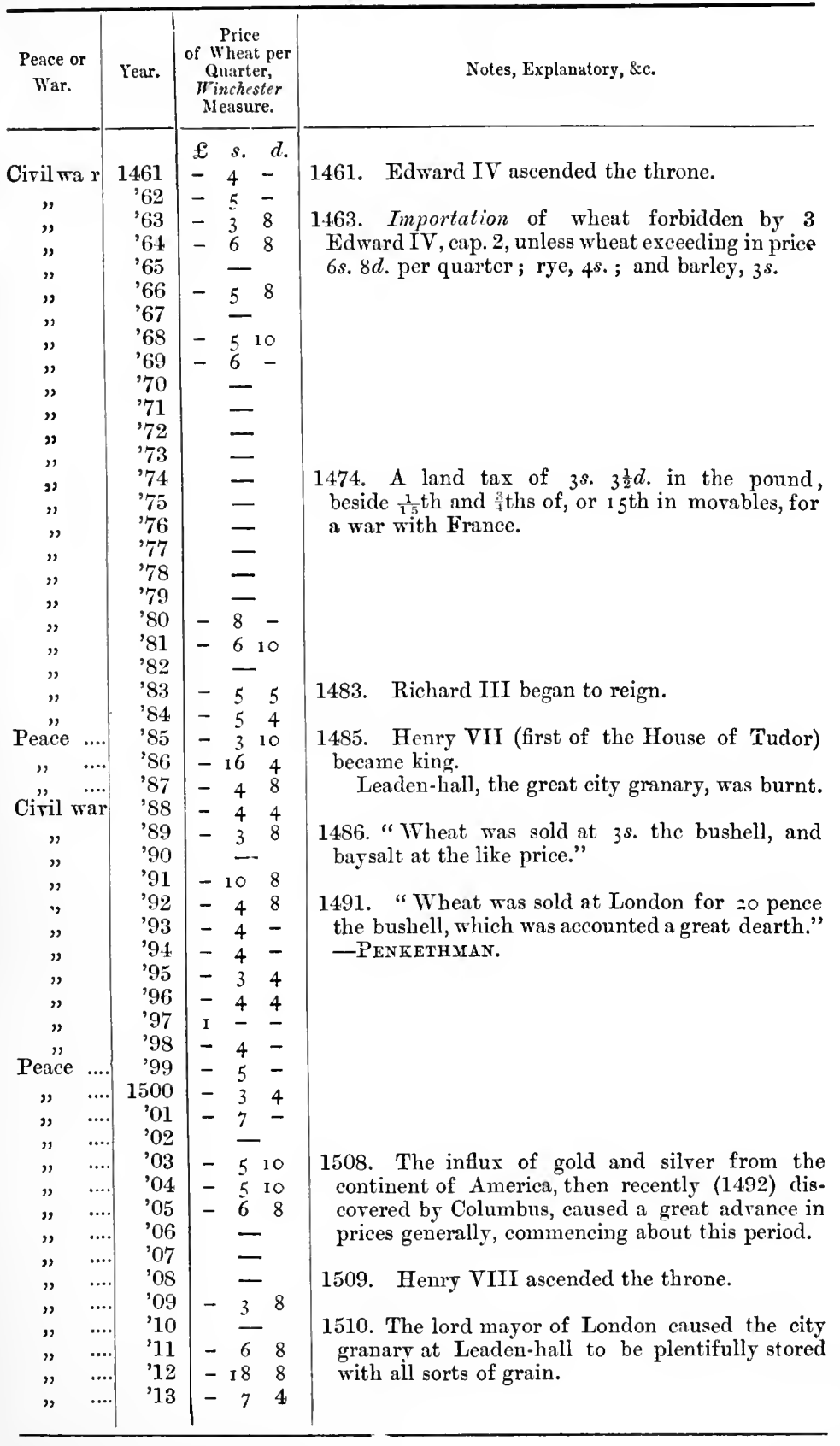


Table XIV.-The Price of Wheat in England and Wales-Contd.

\begin{tabular}{|c|c|c|c|c|c|}
\hline \multicolumn{2}{|c|}{$\begin{array}{c}\text { Peace or } \\
\text { War. }\end{array}$} & \multirow[t]{2}{*}{ Year. } & \multicolumn{2}{|c|}{$\begin{array}{c}\text { Price } \\
\text { of Wheat per } \\
\text { Quarter, } \\
\text { Winchester } \\
\text { Measure. }\end{array}$} & \multirow[t]{2}{*}{ Notes, Explanatory, \&c. } \\
\hline Peace & & & $\begin{array}{l}£ \\
-\end{array}$ & $d$ & \\
\hline 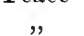 & & '15 & -6 & - & $\begin{array}{l}\text { 1014. The wages of master masons, carpenters, } \\
\text { rough masons, bricklayers, tylers, plumbers, }\end{array}$ \\
\hline , & ..... & '16 & -8 & 4 & glaziers, carvers, and joiners, without diet, $8 \frac{1}{4} d$. \\
\hline$"$ & .... & 17 & - & & per day; common labourers $5 \frac{1}{2} d$. \\
\hline$"$ & $\cdots \cdot$ & '18 & -13 & - & 1516. The king in council order an assay of bread. \\
\hline$"$ & $\cdots$ & '19 & -10 & 3 & 1520. The purchase price of land at this period \\
\hline$"$ & $\cdots$ & 20 & $\rightarrow \quad 8$ & - & $\begin{array}{l}1520 \text {. The purchase price of land } \\
\text { was ten years' rental. }\end{array}$ \\
\hline$"$ & $\cdots$ & 21 & $\begin{array}{ll}1 & 3 \\
- & 0\end{array}$ & 4 & Was ten years rental. \\
\hline$"$ & $\cdots$. & 20 & -9 & 4 & 1521. Famine, war, and pestilence, las \\
\hline " & $\cdots$ & 23 & & & but inflicting less mi \\
\hline , & $\ldots$ & 24 & -13 & 4 & s did in earlier times. \\
\hline$"$ & $\cdots$ & , & -10 & 2 & 1524. Hops first cultirated in England, and lead- \\
\hline " & $\cdots \cdot$ & 20 & & 7 & ing to great increase in consumption of malt \\
\hline$"$ & … & 28 & -18 & I & liquors. \\
\hline$"$ & $\ldots$. & 29 & -18 & - & 1526. Considerable quantities of grain imported \\
\hline , & $\ldots$ & 30 & -5 & 4 & from Dantzic. \\
\hline , & $\ldots$ & 31 & & & 1527. Much want in London. The \\
\hline$"$ & $\cdots$ & 32 & & & present of 1,000 quarters of wheat to the city. \\
\hline$"$ & $\cdots$ & 33 & & 4 & The price of rictuals attempter \\
\hline ", & $\cdots$ & 35 & & 7 & lated by Act of Parliament. See Table IX. \\
\hline " & $\ldots$. & 36 & - & & 1534. The Reformation. Church lands forfeited. \\
\hline " & .... & 37 & -13 & 4 & 1536. Act for promoting tillage by erecting farm- \\
\hline " & .... & '38 & -17 & 4 & houses to everv 50,40 , or 30 arres of land; this \\
\hline " & $\cdots$ & ’39 & -13 & 4 & led gradually to it considerable rice in rents. \\
\hline$"$ & $\cdots \cdot$ & 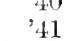 & $\begin{array}{l}-13 \\
-18\end{array}$ & $\begin{array}{l}4 \\
8\end{array}$ & 1545. For the war with Scotland a land tax of \\
\hline " & $\cdots$ & 42 & -14 & 8 & Is. $4^{\frac{3}{4}} d$. was imposed. \\
\hline " & .... & 43 & $1-$ & - & 1547. Edward VI begau to reign. \\
\hline , & $\ldots$ & 44 & I 5 & 4 & for \\
\hline " & $\cdots$ & 45 & -18 & & engrossers. See Table XII. \\
\hline " & $\cdots$ & 46 & - & & 1553. N Tarr began to reign. "Victuals \\
\hline$"$ & .... & 46 & $-\overline{6}$ & 8 & 1553. Mary began to reign. "Victuals were so \\
\hline ", & $\cdots$ & 45 & -0 & & $\begin{array}{l}\text { plentifun, that a barrell of beere was sold for } \\
6 d . \text { with the caske, and }+ \text { great loaves of bread }\end{array}$ \\
\hline$"$ & … & 49 & $-1+$ & I & 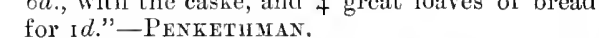 \\
\hline$"$ & … & 50 & $\begin{array}{ll}-17 \\
-11\end{array}$ & - & \\
\hline ," & ... & 01 & $\begin{array}{l}-11 \\
-17\end{array}$ & 6 & al without license \\
\hline, & $\cdots \cdot$ & 22 & $\begin{aligned}-17 \\
-\end{aligned}$ & 7 & rohibited.-1 \\
\hline 3 & $\cdots$ & 5 & -11 & - & 1557. Wheat was sold before harvest for 4 marks \\
\hline 77 & $\cdots$ & '55 & -9 & 8 & the quarter, but after harvest for $5 s$. "So that \\
\hline , & $\ldots$ & 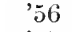 & & 5 & a penny loaf, which weighed in London this last \\
\hline " & $\ldots$. & 57 & -18 & - & yeare but 1 I onnees troy, weighed near 26 ounces \\
\hline ( & ... & '58 & & 9 & troy."-PENKETHI \\
\hline " & $\ldots$ & '59 & -12 & - & All the wheat and other provisions whic \\
\hline " & $\ldots$ & ' 60 & 118 & 5 & e found in Norfolk or Suffolk this year, were \\
\hline & $\ldots$ & 61 & & 7 & \\
\hline & .. & 62 & -17 & 6 & 1558. Elizabeth ascended the throne. Corn ruight \\
\hline " & .... & '63 & & 6 & from Norfolk and Suffolk.-1 Eliza- \\
\hline & .. & 64 & & & $1+1$ \\
\hline " & $\cdots$ & 65 & $\begin{array}{l}-18 \\
-17\end{array}$ & 5 & ight be exported by British subjects \\
\hline " & & & & & ritis \\
\hline
\end{tabular}


Table XIV.-The Priee of Wheat in England and Wales-Contd.

\begin{tabular}{|c|c|c|c|c|c|}
\hline \multicolumn{2}{|c|}{$\begin{array}{l}\text { Peace or } \\
\text { War. }\end{array}$} & \multirow{2}{*}{$\begin{array}{c}\text { Year. } \\
1567\end{array}$} & \multicolumn{2}{|c|}{$\begin{array}{c}\text { Price } \\
\text { of Wheat per } \\
\text { Quarter, } \\
\text { Winchester } \\
\text { Neasure. }\end{array}$} & Notcs, Explanatory, \&c. \\
\hline Peace & .... & & $\begin{array}{l}\mathbb{E} \\
-\end{array}$ & $d$ & f interest for money w \\
\hline$"$ & $\cdots$ & '68 & -13 & 4 & $\begin{array}{l}\text { to } 6 \text { per cent. } \\
1570 \text {. This was a year of scarcity, and wheat was }\end{array}$ \\
\hline$"$ & $\ldots$ & $\begin{array}{l}69 \\
' 70\end{array}$ & -16 & - & $\begin{array}{l}16 s \text {. per quarter. Labourers' wages, without diet, } \\
\text { were } 5 d \text {. per day. The lord mayor laid in a } \\
\text { stock of } 6,000 \text { guarters of wheat in the Bridewell }\end{array}$ \\
\hline$"$ & $\cdots$ & '71 & & & public granaries. \\
\hline$"$ & ... & $\begin{array}{l}72 \\
' 73\end{array}$ & $\begin{array}{ll}1 & - \\
1 & 12\end{array}$ & 6 & $\begin{array}{l}\text { tries. Export duty of } 12 d \text {. per quarter imposed } \\
\text { by } 13 \text { Elizabeth, eap. } 13 .\end{array}$ \\
\hline$"$ & $\cdots$ & 74 & 14 & - & $\begin{array}{l}\text { 1573. "Ahout Lammas wheat was sold for } 3 \text { s. } \\
\text { the bushell, but shortly after it was raysed }\end{array}$ \\
\hline$"$ & $\ldots$ & $\begin{array}{l}75 \\
76\end{array}$ & $\begin{array}{l}1- \\
-16\end{array}$ & - & $\begin{array}{l}\text { to } 4 s ., 5 s ., 6 s . \text {, and before Christmas to a noble } \\
\text { and } 7 s \text {., which so continued long after ; yet there } \\
\text { was no want to him that wanted not money." }\end{array}$ \\
\hline$"$ & $\cdots$ & T7 & . & & $\begin{array}{l}\text { Penkethman. The rise in price was attributed } \\
\text { to orer exportation of grain to the Netherlands. }\end{array}$ \\
\hline , & $\ldots$ & '78 & -18 & - & 1580. The end of the Eden prices. \\
\hline , & ... & $\begin{array}{l}' 79 \\
' 80\end{array}$ & $\begin{array}{r}-16 \\
18\end{array}$ & 3 & $\begin{array}{l}\text { 1582. From this date down to } 1770 \text { the prices } \\
\text { are those ascertained by the audit books at Eton }\end{array}$ \\
\hline$"$ & $\cdots$ & '81 & & & mensure. The baker and brewer of the College \\
\hline ", & $\ldots$. & '82 & $\begin{array}{l}-18 \\
-17\end{array}$ & 2 & $\begin{array}{l}\text { preceding Lady-day and Michach } \\
\text { record of the highest prices that wheat and malt }\end{array}$ \\
\hline$"$ & .. & '84. & & $8 \frac{1}{2}$ & $\begin{array}{l}\text { were sold for on these days. These records, alike } \\
\text { for prices and fixed measure, hare long been }\end{array}$ \\
\hline " & .. & '85 & I I & $-\cdot \frac{1}{2}$ & famous. \\
\hline$"$ & $\ldots$. & '86 & I & - & famine, by order of the lord mayor. \\
\hline$"$ & $\cdots$. & '87 & 1 & IO & 1588. The price of sea-coal was by a combination \\
\hline War & .. & 's8 & -14 & $2 \frac{1}{2}$ & $\begin{array}{l}9.3 d \text {. per chaldron. }\end{array}$ \\
\hline$"$ & .. & ' 89 & & 6 & $\begin{array}{l}\text { 1593. Export of corn might be prolibited gene- } \\
\text { rally or locally. }-35 \text { Elizabeth, cap. } 7 \text {. }\end{array}$ \\
\hline$"$ & .. & '90 & I 3 & I & 1594. Dearth oceasioned by excessive exportation. \\
\hline$"$ & $\cdots$ & '91 & & 2 & $\begin{array}{l}\text { The rapid and continued rise in the price of } \\
\text { wheat from this date onward was considered to }\end{array}$ \\
\hline$"$ & $\cdots$ & '92 & -16 & 7 & be the result of sereral combined causes, of which \\
\hline , & ... & '93 & -18 & $4^{\frac{1}{2}}$ & $\begin{array}{l}\text { the chief was believed to be spcculation in the } \\
\text { way of monopoly. }\end{array}$ \\
\hline$"$ & & & & - & The lord mayor of London enjoined the people \\
\hline$"$ & .. & '95 & 118 & 6 & of the city to lay in provisions of grain. The \\
\hline$"$ & $\ldots$ & $' 96$ & 26 & 3 & $\begin{array}{l}\text { Bridge house was then a common granary for } \\
\text { the city. }\end{array}$ \\
\hline$"$ & .. & 97 & 216 & $10 \frac{1}{2}$ & $\begin{array}{l}\text { 1595. New regulations as to the assize of bread } \\
\text { issued in London. }\end{array}$ \\
\hline , & $\cdots$ & & I 17 & I 1 & 1596. Dearth oceasioned by great rain \\
\hline$"$ & .. & '99 & 1 & $8 \frac{1}{2}$ & 37 Elizabeth, "In August, September, October, \\
\hline$"$ & & 1600 & 19 & $-\frac{1}{2}$ & in meale was sold at London for ros. the bushell; \\
\hline$"$ & .. & '01 & I & 8 & yet thro' the diligent carefulnesse of 'Thomas \\
\hline 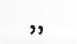 & & 02 & & $3 \frac{1}{2}$ & sion was \\
\hline
\end{tabular}


TABLe XIV.-The Price of Wheat in England and Wales-Contd.

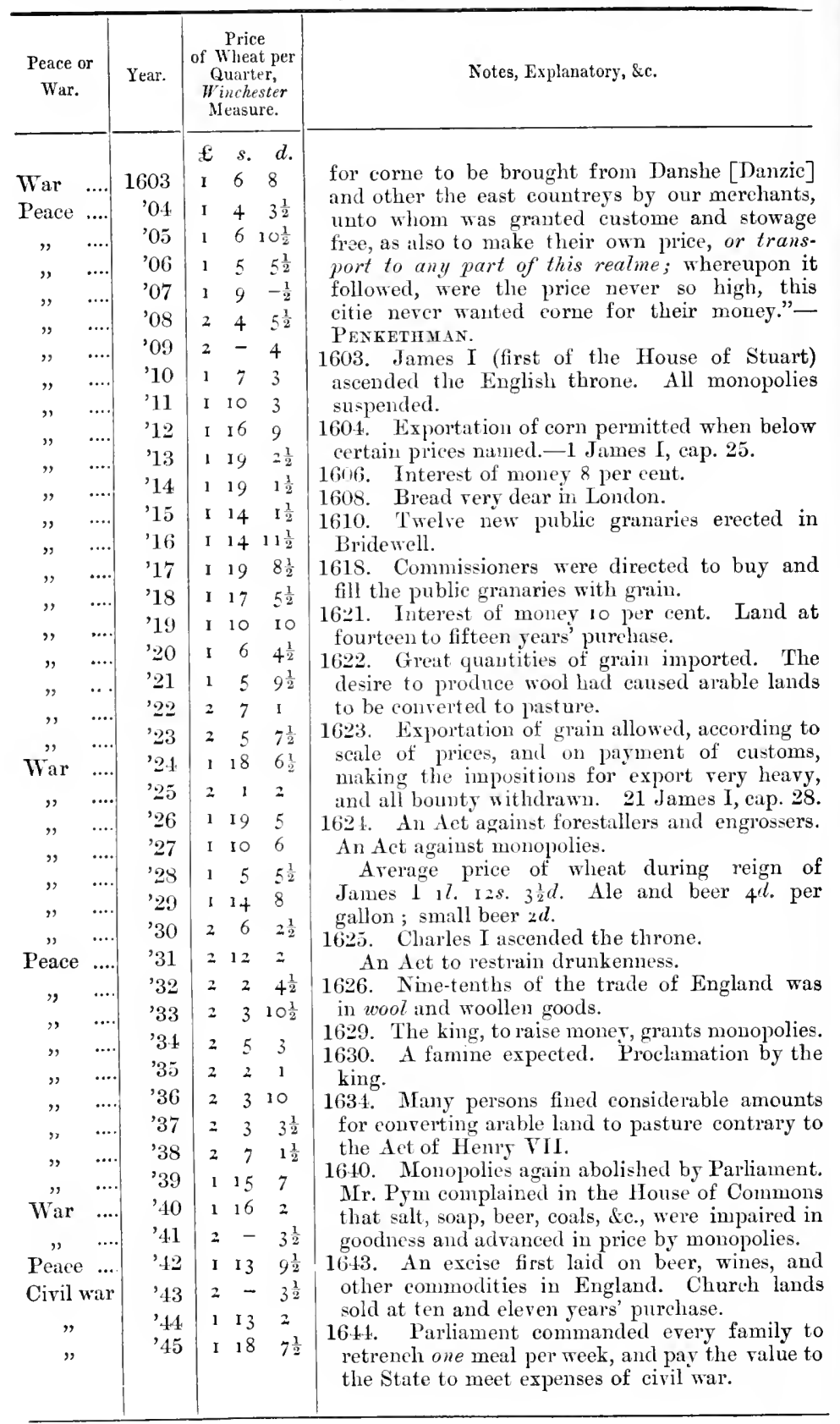


TABLE XIV.-The Price of Wheat in Linglund and Wales-Contd.

\begin{tabular}{|c|c|c|c|c|c|}
\hline \multicolumn{2}{|c|}{$\begin{array}{l}\text { Peace or } \\
\text { War. }\end{array}$} & \multirow[t]{2}{*}{ Year. } & \multicolumn{2}{|c|}{$\begin{array}{c}\text { Price } \\
\text { of Wheat per } \\
\text { Quarter, } \\
\text { Winchesier } \\
\text { Measure. }\end{array}$} & \multirow[t]{2}{*}{ Notes, Explanatory, \&c. } \\
\hline Civil & & & $\begin{array}{ll}\mathscr{E} & s\end{array}$ & $\begin{array}{l}d . \\
8\end{array}$ & \\
\hline , & & 47 & & & by Bishop Fleetwood begins at this date, and \\
\hline 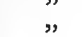 & & 48 & 315 & & differs materially from the figures here given. \\
\hline$"$ & & '49 & 311 & & We do not use Fleetwood's table. He took the \\
\hline$"$ & & '50 & & $1 \frac{3}{4}$ & mean of the price for the two halres of each year. \\
\hline " & & '5I & & $2 \frac{1}{1}$ & 1647. Nearly one-lialf of the land of the \\
\hline "’ & & 52 & & - & kingdom confiscated by Parliament. Cultivation \\
\hline . & & '53 & I II & $6 \frac{1}{4}$ & stopped in con cquence. \\
\hline & & '54 & & & 1619. The Commonwealth proclaimed. Interest \\
\hline Peace & & 55 & 19 & & of money 6 per cent. \\
\hline War & ... & '56 & I 18 & $2 \frac{3}{4}$ & 1660. Importation of grain allowed on payment \\
\hline ", & .... & 57 & 21 & & of certain duties regulated by price, but without \\
\hline & .... & 58 & 217 & & ounty. First "sliding scale" of duties. \\
\hline & & '59 & 218 & & Charles II began to reign. \\
\hline Peace & ... & '60 & 210 & $2 \frac{3}{4}$ & 1651. The Courts of Wards and Lireries wero \\
\hline " & .... & '61 & & $2 \frac{3}{4}$ & now abolished. \\
\hline$"$ & $\cdots$ & 62 & & $9^{\frac{1}{4}}$ & 1663. By 15 Charles II, cap. 7 , the ligh duties \\
\hline ", & $\cdots$ & '63 & 210 & 8 & exportation of grain were repealed. Cattle \\
\hline & 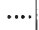 & '63 & & 4 & imported from Isle of Man. \\
\hline & & '64 & I I 6 & - & 1663. The amount of the annual rerenue was \\
\hline ar & .... & 65 & & $10 \frac{1}{4}$ & er 1,1 \\
\hline " & .... & '66 & 112 & - & 1664. The price of land was no \\
\hline " & .... & '67 & 112 & - & tion during the civil wars. \\
\hline & .... & '68 & 115 & $6 \frac{3}{4}$ & 1665. The wheaten peck-loaf now sold for \\
\hline Peace & .... & '69 & 119 & 5 & $2 s .5^{\frac{1}{2}} d$; the white peck-loaf for $3 s .7 \frac{3}{4} d$. \\
\hline " & .... & 70 & I I 7 & $-\frac{1}{2}$ & 1666. The importation of Irish eattle probibited. \\
\hline 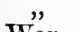 & $\cdots$ & '71 & I I 7 & 4 & 1669. The lord major and court of aldermen \\
\hline War & .... & 72 & 116 & $5^{\frac{1}{4}}$ & order an assize of bread of the best sort of \\
\hline & .... & 73 & 2 & $5^{\frac{1}{2}}$ & eaten meal usually brought to Queenhithe \\
\hline ace & $\ldots . .$. & 74 & 3 & $-\frac{1}{2}$ & \\
\hline$"$ & .... & 75 & 217 & $5 \frac{3}{4}$ & 1670. The measu \\
\hline " & .... & 76 & I I 3 & $9^{\frac{1}{4}}$ & -22 Charles II, cap. $8.13 y$ \\
\hline ", & .... & 77 & 117 & 4 & ort of eorn pernitted \\
\hline " & .... & 8 & 212 & $5^{\frac{1}{4}}$ & those permitted \\
\hline$"$ & .... & 79 & 213 & 4 & by Act of 1663 , but with higher customs duty. \\
\hline " & - & '80 & 2 & - & 1674. Interest of money 8 per cent. \\
\hline " & $\cdots$ & '81 & 2 & $5^{\frac{3}{4}}$ & 1685. James II beg: \\
\hline ” & ... & '82 & I 19 & $1 \frac{1}{4}$ & Br 1 James II, eap. 19 , regulations made for \\
\hline , & .... & '83 & I 15 & $6 \frac{3}{4}$ & it \\
\hline " & .... & '84 & I I & $1 \frac{3}{4}$ & 1688. By 1 William and Mary, eap. 12, all ex- \\
\hline ", & .... & '85 & & $5^{\frac{3}{4}}$ & portation duties were abolished, and a bounty \\
\hline " & .... & '86 & I 10 & $2 \frac{3}{4}$ & offered by way of encouragement. This was an \\
\hline , & .... & '87 & & $4 \frac{1}{2}$ & ire cha \\
\hline$"$ & .... & '88 & & $10 \frac{3}{4}$ & 1689. William III (of the united Houses of Stuart \\
\hline " & $\cdots$ & '89 & 1 & 8 & and $\mathrm{Nas}$ \\
\hline & & '90 & 110 & $9^{\frac{3}{4}}$ & 1691. The "monied interests" took the \\
\hline & $\ldots$. & '91 & I Io & $2 \frac{3}{4}$ & rom the system of national finance pursued at \\
\hline$" n$ & .... & '92 & 2 & $5^{\frac{3}{4}}$ & period, riz., "the banking system." \\
\hline 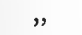 & .... & '93 & $3-$ & $1 \frac{1}{1}$ & 1692. A land-tax of $4 s$ in the pound imposed. \\
\hline , & $\ldots$ & '94. & $2 \mathrm{I} 6$ & $10 \frac{3}{4}$ & Interest of money 7 per cent. \\
\hline ? & $\ldots$ & ’95 & 27 & $1 \frac{1}{4}$ & 1695. Many of the inhabitants of Scotland were \\
\hline & $\cdots$ & '96 & & $1 \frac{1}{4}$ & $\begin{array}{l}\text { driven to migrate to Ireland from the excessive } \\
\text { priee of bread. }\end{array}$ \\
\hline
\end{tabular}


Table XIV.-The Price of Wheut in Englund and Wales-Contd.

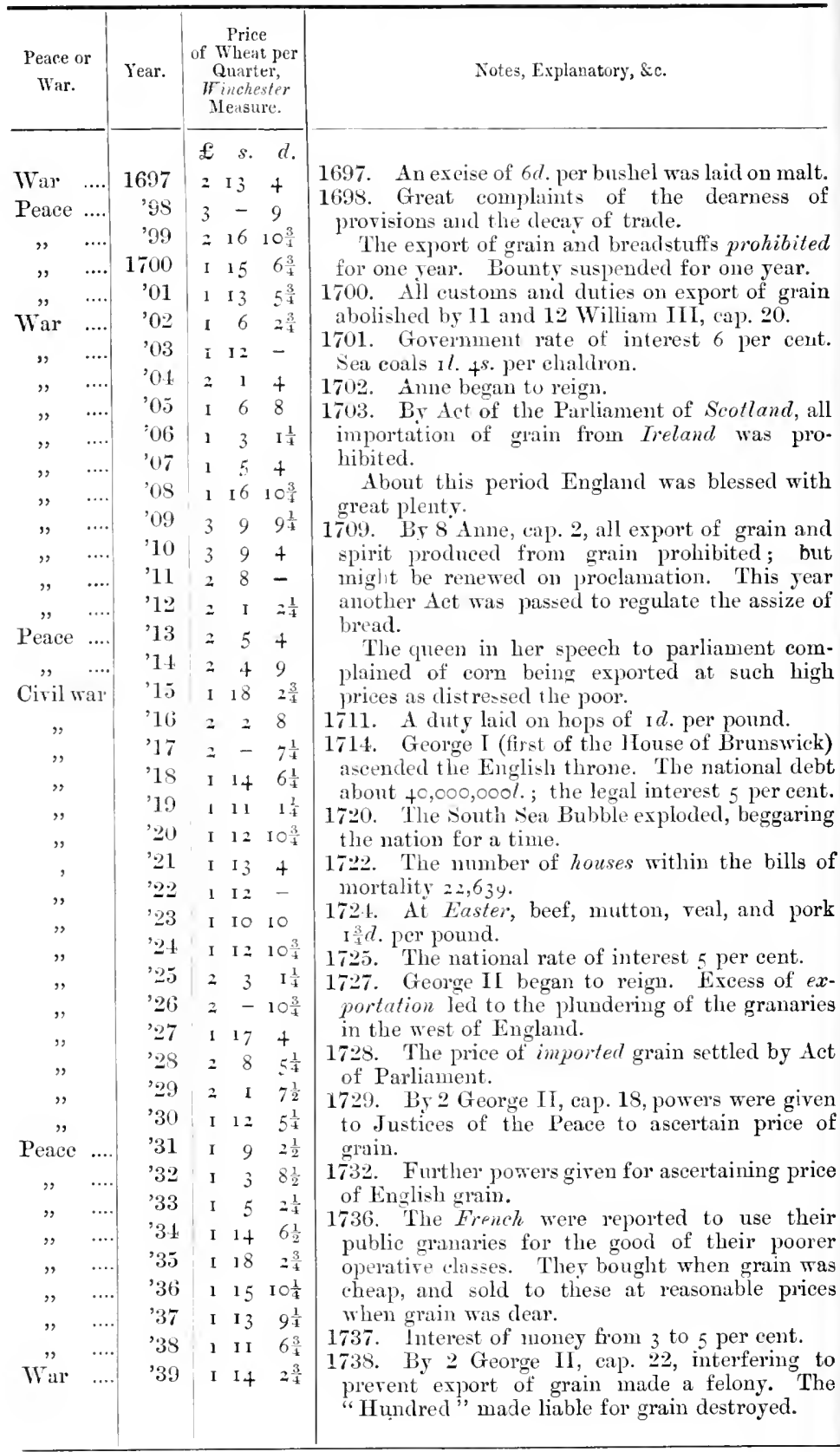


TABLE XIV.-The Price of Wheut in Englund and Wales-Contd.

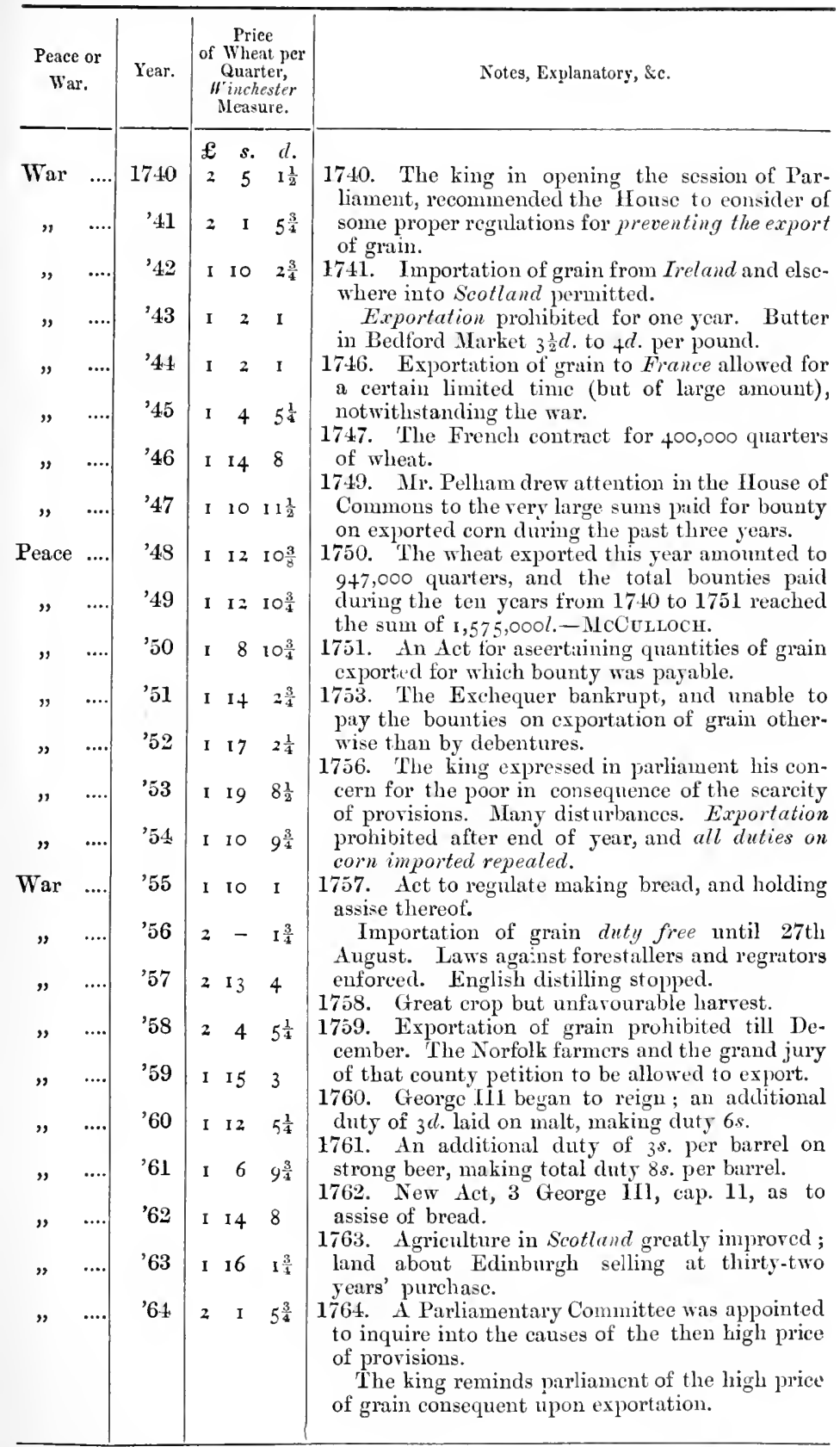


Table XIV.--The Price of Wheat in England and Irales-Contd.

\begin{tabular}{|c|c|c|c|c|c|}
\hline \multicolumn{2}{|c|}{$\begin{array}{l}\text { Peace or } \\
\text { War. }\end{array}$} & Year. & \multicolumn{2}{|c|}{$\begin{array}{c}\text { Price } \\
\text { of Wheat per } \\
\text { Quarter, } \\
\text { Winchester } \\
\text { Neasure. }\end{array}$} & Notes, Explanatory, \&c. \\
\hline War & .... & 1765 & $\begin{array}{l}\text { E } s . \\
28\end{array}$ & $\vec{a}$ & 1765. First trustworthy estimate of nati \\
\hline ", & ... & '66 & & & consumption of grain made. \\
\hline , & $\cdots$ & 67 & 217 & +4 & $\begin{array}{l}\text { 1767. Sir James steuart's famous work on Poli- } \\
\text { tical Economr published. }\end{array}$ \\
\hline 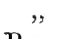 & $\cdots$ & '68 & $2 \mathrm{I}_{3}$ & & 1770. Act for registering prices of corn. \\
\hline Peace & .... & '69 & $2-$ & 7 & 1771. From this date we quote from Willich's \\
\hline$"$ & .... & 70 & & $6 \frac{3}{4}$ & annual arerage prices per imperial quarter. \\
\hline " & $\cdots$ & 271 & $=8$ & 7 & These differ materially from the Eton prices. \\
\hline , & $\cdots$ & 72 & $2 \mathrm{I} 2$ & 3 & $\begin{array}{l}\text { The exportation of lice cattle was this year } \\
\text { prohibited. See Table } \mathrm{X} \text {. }\end{array}$ \\
\hline$"$ & $\cdots$ & 73 & 212 & 7 & 1773. By 13 George III, cap. 20, all importation \\
\hline$"$ & $\cdots$ & 74 & $=14$ & 3 & was stopped when price of wheat was $44^{s}$. per \\
\hline War & .... & 75 & & 10 & quarter. Prices also fixed as to other grain. \\
\hline " & $\cdots$ & 76 & 119 & 4 & New Act as to assise and making of bread. \\
\hline ", & ... & 77 & & 11 & $\begin{array}{l}17 \mathrm{~s} \text {. Further Act, } 21 \text { George III, cap. } 50 \text {, for } \\
\text { ascertaining price of grain. }\end{array}$ \\
\hline$"$ & $\cdots$ & 78 & $=3$ & 3 & 1789 . Further Act as to ascertaining price of \\
\hline " & $\cdots$ & 79 & $1 \mathrm{I} 4$ & 8 & grain. \\
\hline " & $\cdots$ & 'so & 116 & 9 & 1791. New Act, 31 George III, cap. 30, for regu- \\
\hline " & $\ldots$ & '81 & & - & lating importation and exportation of groin; \\
\hline$"$ & .... & 's2 & 29 & 3 & very high duty lesied upon grain imported \\
\hline "” & … & 's3 & 214 & 3 & $\begin{array}{l}\text { when the home price not above } 50 s \text {. per } \\
\text { guarter. }\end{array}$ \\
\hline Peace & $\cdots$ & 'S4 & $=10$ & 4 & inchusive the account of \\
\hline " & $\cdots$ & '85 & $=3$ & I & Eton College has been kept according to the \\
\hline " & .... & 's6 & $2-$ & - & bushel of 8 ga!lons, under the provisions of \\
\hline " & .. & 87 & & $5 \frac{1}{4}$ & 31 George III, e: \\
\hline$"$ & ... & 's8 & $\approx 6$ & + & 1796. The new experiment of Bounty for import \\
\hline " & $\cdots$ & 's9 & 212 & 9 & $\begin{array}{l}\text { of grain was inangurated. Repealed same year. } \\
\text { The consumption was stated by Lord Hawkes- }\end{array}$ \\
\hline " & $\cdots$ & 90 & $=14$ & 9 & bury to be 500,000 quarters per month, or \\
\hline " & $\cdots$ & '91 & $=8$ & 7 & $6,000,000$ quarters per annum, of which i 80,000 \\
\hline War & ... & 92 & 23 & - & ported. The ralue of imported grain \\
\hline War & $\cdots$ & '93 & 219 & 3 & $\begin{array}{l}\text { this rear was } 4,360,000 l \text {. } \\
17 y 7 \text {. New Act for assise and }\end{array}$ \\
\hline " & $\cdots$ & 91 & 212 & 3 & in London. \\
\hline$"$ & $\cdots$. & 95 & 315 & 2 & 1799. A Bill was before Parlian \\
\hline$"$ & .... & '96 & 318 & 7 & instance of the Corporation of London, seeking \\
\hline " & $\ldots$. & 97 & $=13$ & 9 & w powers as to assize of bread. \\
\hline$"$ & $\cdots$ & '98 & $=11$ & 10 & 1800. The arerage growth of grain in Great \\
\hline " & $\cdots$ & '99 & 39 & - & $\begin{array}{l}\text { Eritam was estmuated oy Chalmers to be } \\
30,5+9,5 \text { I } 6 \text { quarters. }\end{array}$ \\
\hline " & *. & 1800 & 513 & 10 & 1801. The rahe of imported grain this year \\
\hline & $\cdots$ & ’01 & 519 & 6 & \\
\hline Peace & $\ldots$. & 02 & 39 & 10 & 1s04. Foreign grain to be admitted at $6 d$. per \\
\hline War & $\ldots$ & '03 & 218 & 10 & and up- \\
\hline " & .. & 04 & & 3 & 41 George III, ca \\
\hline$"$ & $\cdots$ & 05 & 49 & 9 & 1806. Free interchange of grain with Ireland per- \\
\hline "' & $\cdots$ & 06 & 319 & I & \\
\hline$"$ & .. & '07 & 315 & 4 & 1808. Exports cxceeded imports in consequence \\
\hline " & $\cdots$ & os & $4 \quad \mathrm{I}$ & 4 & dies in Spain and \\
\hline 3 & $\cdots$ & ’09 & 417 & 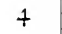 & \\
\hline
\end{tabular}


TABLE XIV.-The Price of Wheat in England and Wales-Contd.

\begin{tabular}{|c|c|c|c|c|c|}
\hline \multicolumn{2}{|c|}{$\begin{array}{c}\text { Peace or } \\
\text { War. }\end{array}$} & \multirow[t]{2}{*}{ Year. } & \multicolumn{2}{|c|}{$\begin{array}{c}\text { Price } \\
\text { of Wheat per } \\
\text { Quirter, } \\
\text { W'inchester } \\
\text { Weasure. }\end{array}$} & \multirow[t]{2}{*}{ Notes, Explanatory, Sc. } \\
\hline War & .. & & $\begin{array}{ll}\mathscr{E} & s . \\
5 & 6\end{array}$ & $\begin{array}{l}d . \\
5\end{array}$ & \\
\hline ” & .... & '11 & 415 & 3 & notwithstanding that we were at war with her. \\
\hline ” & .... & 12 & 66 & 2 & Estimated value of all grain imported $7,800,000 l$. \\
\hline ", & $\ldots$ & 13 & 59 & 9 & 1814. According to Colquhoun, the consumption \\
\hline ” & & 14 & 314 & 4 & of corn in Great Britain and Ireland this year \\
\hline$"$ & & 15 & & 7 & amounted to about $35,000,000$ quarters. Value \\
\hline eace & .... & 16 & 318 & 6 & of imported grain 2,815,3 1 $9 l$. \\
\hline ", & .... & 17 & +16 & I I & 1815. No foreign corn to be admitted until English \\
\hline ", & $\cdots \cdot$ & 18 & 46 & 3 & wheat was 80. . or more per quarter. Colonial \\
\hline$"$ & .... & 19 & $3 \mathrm{I}+$ & 6 & admitted when price reached $67 s ., 55$ George III, \\
\hline " & .... & 20 & & IO & cap. 26. \\
\hline " & $\cdots \cdot$ & 21 & 216 & 1 & 1818. The whent consumed in Great Britain was \\
\hline " & $\cdots$. & 22 & 24 & 7 & estimated by Mr. Wm. Jacob, F.R.S., at i 2,000,000 \\
\hline , & ... & 23 & 213 & 4 & quarters. Valne of grain imports $7,908,140 l$. \\
\hline , & $\cdots$ & 24 & 33 & 11 & 1820. George IV aseended the throne. \\
\hline ", & .... & 25 & 38 & 6 & 1821. New Act, 1 and 2 George IV cap. 87 , for \\
\hline " & $\cdots$ & 26 & 218 & 8 & importation and exportation of grain. \\
\hline$"$ & $\cdots$ & 27 & 218 & 6 & 1822. Corn Law Amendment Act, admitting \\
\hline " & .... & 28 & 3 & 5 & foreign wheat at $12 s$. per quarter duty when \\
\hline ", & $\cdots$ & 29 & 36 & 3 & price was $7 c s$., and $s$. duty when it was $8 \circ s$. and \\
\hline ", & $\cdots$ & 30 & 34 & 3 & upwards. New Act to regulate making and sale \\
\hline , & .... & 31 & 36 & 4 & of bread in London. \\
\hline , & $\cdots$ & 32 & 218 & $\dot{8}$ & 1825. American colonial wheat admitted at a \\
\hline , & .... & 33 & 212 & I I & permanent duty of $5 s$. per quarter. Duty of $14 s$. \\
\hline , & .... & 34 & 26 & 2 & per quarter on buckwheat. \\
\hline " & $\cdots$. & 35 & I 19 & + & 1826. Foreign grain admitted at nominal duty, \\
\hline ", & $\cdots$. & 36 & 28 & 6 & temporars. -7 and 8 George IV, eap. 3. \\
\hline " & $\cdots \cdot$ & 37 & 215 & 10 & 1827. The highest duties erer imposed upon the \\
\hline$"$ & $\cdots$ & 38 & 34 & 7 & importation of grain into Great Britain enacted \\
\hline " & .... & 39 & 310 & 8 & this year. See supplement to Table $\mathbf{X}$. \\
\hline " & $\cdots$. & 40 & 36 & 4 & 1828. Corn Law Amendment Act, with new \\
\hline ,. & .... & '41 & 34 & 4 & slicling scale adopted. \\
\hline " & $\ldots$. & '42 & 217 & 3 & 1830. William IV began to relgn. \\
\hline " & .... & 43 & 210 & I & 1835. Act to regulate the importation of grain \\
\hline " & $\cdots$ & 44 & 2 II & 3 & into Isle of Man. \\
\hline ", & $\cdots$ & 45 & 2. 10 & I0 & 1836. New det as to making and sale of bread in \\
\hline " & $\cdots$ & 96 & 214 & 8 & London ; first modern measure against adultera- \\
\hline , & .... & '47 & 319 & 9 & tion. -6 and 7 William IV, cap. 37 . \\
\hline " & .... & '48 & 210 & 6 & 1837. Victoria ascended the throne. \\
\hline , & .... & '49 & $2-$ & 3 & 1838. Act as to making and sale of bread in Ire- \\
\hline ", & .... & 50 & 20 & 3 & land. \\
\hline , & .... & 51 & I 18 & 6 & 1812. Corn Law Amendment Act. -5 and 6 Vict. \\
\hline & .... & 252 & $2-$ & 9 & cap. 14. "Reduce \\
\hline & .... & :53 & 213 & 3 & 1816. Repeal of corn laws. Duty of Is. per \\
\hline War & $\ldots$. & '54 & 3 I 2 & 5 & quarter continued until 1869 . Wheat sold at \\
\hline & & '55 & 314 & 8 & Uxbridge market on last day of year at $88 \mathrm{~s}$. per \\
\hline eace & .... & 56 & 39 & 2 & quarter: \\
\hline ” & .... & $' 57$ & 216 & 4 & $\begin{array}{l}\text { 1817. The potato failure in Ireland and parts of } \\
\text { Great Britain. The corn and narigation laws } \\
\text { suspended. } \\
\text { 1851. The Lancet Analytical Commission ap- } \\
\text { pointed. } \\
\text { 1855. Reports of Lancet Commission published. }\end{array}$ \\
\hline
\end{tabular}


Table XIV.-The Price of Wheat in England and Wales-.Contd.

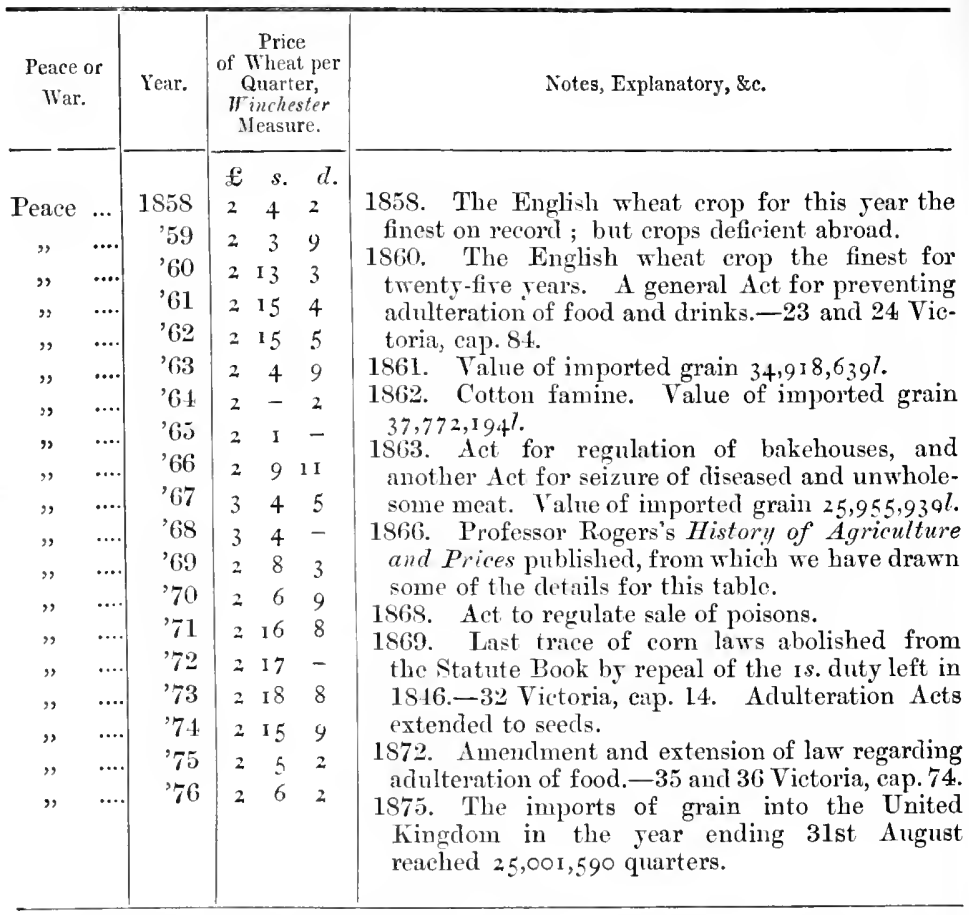

Note.-I have found it exceedingly difficult at certain periods to determine as to a state of peace, of war, or to ascertain when civil wars terminated. The figures in the first column of the table must therefore be taken as subject to correction.

\section{Famine Literature.}

The following table of Famine Literature is a necessary sequel to all that has preceded. It indicates the periods-since the invention of printing-wherein famine topics have been uppermost in public attention; and it furnishes an intimation of the works wherein the famine history of those periods will be found. I only trust it may turn out to be reasonably complete: certainly no efforts have been spared to make it so. In McCulloch's Literature of Political Economy some detailed information and criticisms upon some of the more prominent authors mentioned will be found. 
TABLE XV.-The Literature of Famines and of the Com Laws, de.

A.D.

12 Ifenry VII. The Assize of Bread; printed on rellum, with woodcuts, set forth and printed at the request of Mich. English and Jo. Rudestone, aldermun.

Assize of Bread and Ale, after the Pryse of a Quarter of Wheat, with the Weight of Butter and Cheese, and the Measure of all manner of Wood and Cole, and Lath, Bourde, and Trmbre. 4to. Printed by R. Wyer. There was, we believe, an earlier edition without date, and many later editions, the last being published in 1700 by H. Jaekson.

'84 .... John Uddall: The true Remedic against Famine and Warres; fire Sermons upon the first chapter of the Prophecie of Joel.

'86 ... Printed by Christopher' Barker: Orders denised by the Especial Commandant of the Queene's Majestie for the Reliefe and staie of the present Dearthe of Graine within the Realme.

'9:3 ... Br the same: The Renewing of certaine Orders derised by the speciall Commandements of the Queene's Majestie for the Reliefs and Stay of the present Dearth of Grain within the Realme: in the seere of our Lord 1586; now to be again executed this year 1594, upon like occasions as were scene the formere rere: with an addition of some other particular Orders for Reformation of the great abuses in alehouses, and such like.

'95 .... Jerom Benzoni (Venice): Tractatus de Fngâ, in quo explicatur quid Prineipes et Rectores Ecelesiastici ct ciriles debeant agere, tempore pestis, famis, et belli. 4to.

'96 .... Dr. William Barlow (Bishop of Rochester and Lincoln) : Translation of three Sermons on Famine and Dearth of Tictnals, by Larater L.

Same year, by - Plates: Sundrie new artificial Remedics against Famine.

'97 .... Peter Baker (probably a sermon): The Prophecy of Agabus, concerning Famine.

1611

Arthur Standish: The Commons Complaint concerning the Waste of Woods, and the Dearth of Vietuils; with four remedies for the same.

'27 .... Rev. Wrm. Gonge: God's three Arrows, Plagne, Famine, and Sword.

'30 .... Orders appointed by IFis Majestic (James I) to be straitly observed for the preventing and remedying of the Dearth of Graine and Victual. 4.to. Black letter.

'31 .... Edward Howe: A Collection of the most remarkablc Dearths and Famines.

A Decree lately made in the High Court of Starre Chamber (touching Ingrossing : Tarerners shall not sell Vietual; Bakers not sell sixteen to the dozen; no Ordinary shall exceed $2 s$. per meal; regulating the Price of Horsemeat; Suppressing Pettie Ostries, \&c.). 4to.

The Assise of Bread, together with Sundry Good and Needful Ordinances for Bakers, Brewers, Innholders', Victuallers, Vintners, and Butchers, and also other Assises in Weights and Measures, observed within the Liberties and without. 4to. Black letter. Interesting woodents.

There was published by John Penkethman: Artachthos, or a new Book deelaring the Assise of Bread by Troy and Aroirdupois Weights, containing dirers Orders and Articles made and set forth by the Right Hon. the Lords and others of His Majesty's Hon. Privy Council. Wheremto are added other necessary tables. London : R. Bishop, 1638. 4to. [This work is not mentioned by Watts or Allibone, nor in the 1st edition of Lowndes; but in the second edition it is mentioned at p. 1821 (see 1748).]

'43 ... Thomas Nutt: Nineteen Propositions for the Debiverance of City and Country from fear of Sword and Famine.

Bread for the Poor, and Adrancement of the English Nation Promised by Enclosure of the Wastes and Common Grounds of England. 


\section{Table XV.-The Literature of Fumines and of the Corn Laws-Contd.}

A.D.

1653

51

'14.

'11 ... The Rev. John Ilitriop: A Treatise of the three Evils of the last

By Adam Moore, Gent. London, 4to. "One of the earliest tracts in farour of the dirision and enclosure of commons and wastes. It is written with considerable talent."-МССбцLосн.

Rice Evans, "a Welsh eonjurer:" Mr. Erans's and Mr. Pennington's Prophesie concerning seren years of Plenty and seveu years of Famine and Pestilence.

Dr. Christopher Bennett edited a work originally written by Thomas ILoffitt: Health's Improrement; or Rules comprising or discorering the Nature, Method, and Manner of Preparing all Sorts of Food used in this Nation.

England's Improvernent by Sea and Land: to outdo the Dutch without fighting, to pay Debts without Moneys, to set to work all the Poor of England with the Growth of our own Lands, to prevent unnecessary Suits in Law, with the benefit of a Voluntary Register; directions where rast quantities of Timber are to be had for the Builcting of Ships; with the adrantage of making the Great Rirers of Fngland Navigable; Rules to prerent Fires in London, and other great Cities ; with directions how the several Companies of Handieraftmen in London may always have eheap Bread and Drink. By Andrew Sarrinton, gentleman. (Tract, 4to., pp. 198.) The last of his several schemes concerns us most here. His method was by means of Bank Granaries (p. 150), where the grain was to be stored for $1 d$. per bushel per annum, and against the produce so stored adrances were to be made to the owners as required up to within a certain marqin. The grilin would always be kept within reach. The scheme was very ingenious, like all the projeets of this author.

Dr. Fleetwood, Bishop of Ely, published Chronicum Preciosum : an Account of Mones, Price of Corn, Wages, \&c., in England, for six hundred Years last past. Second edition, 1745. M.Culloch said this work contained the best aecount of prices published in England preriously to that given by Sir F. MI. Eden-Literature of Political Economy. There was for many yeas published a broadside, An Account of the True Market Price of Wheat and Malt at Windsor for One Hundred Fears, by Willimm Fleetwood, Bishop of Ely.

Times, the Sword, the Pestilence, and the Famine.
There was published Assise of Bread and other Assises: Weights and Measures to be observed by Bakers, Vintners, Brewers, \&c. 4to. Troodeuts.

Husbandry and Trade Improved; being a Collection of many valuable Waterials relating to Corn, Cattle, Coal, IIops, Wool, \&e. By John Honghton, F.R.S. Second Edition. 4 rols., 8ro. A valuable collection of facts and opinions.

The Book of John Penkethman, first published 1638, was reprinted this rear, with a double title page, the first of which is as follows :A Collection of several Authentic Accounts of the History and Price of Wheat, Bread, Malt, \&e., from the coming in of William the Conqueror to Michaelmas, 1715 , with some oecasional remarks. The seeond title page: $\cdots A$ True Relation or Collection of the most remarkable Dearths and Famines which have happened within this Realme since the coming in of William the Conqueror to Michaelmas, 17.5. As also the Rising and Falling of the Priee of Wheat and other Graine from time to time, with the sereral oceasions thereof briefly set down. London: Printed for W. Warden, and sold by C. Davis, orer against Gray's Inn Gate, Holbourn, 1748. New edition, 1765 .

After reciting many of the incidents already quoted in the preceding tables, he sums up, "By all these monumental verities, or particular narrations of chronicled oceurrences, it appears that the cause of a dearth or famine is manifold." 
TABLE XV. - The Literature of Famines and of the Corn Laws-Contd.

A.D.

1748

49

"1. Warre, whereby both corne and lind was wasted, as also people destroyed.

"2. Unserisonable weather, extremitie of eold and frost, or raine, of windes, thunder and lightming, tempests, and sueh like.

" 3 . The abising of the coine.

"4. Excessive eonsumption and abuse of wheat and other victuals in voluptious feasts.

"5. The mneharitable greediness, or unconseionable hording of corne-masters and farmers.

" 6 . The merchants over-mueh transporting of graine into forreine parts.

"For a seventh eanse, I might here inferre, with aecusation, the evil disposition of many in racking of rents, whereby the tenants are mored, if not eonstrined, to set on their eommodities an unreasonable price."

He adds, "Againe, on the other side, there are dirers apparent causes of cheapness and plentic.

"1. Peace, whereby men lave libertie to till the ground and reap the fruit thereof.

"2. Seasonable and kindly weather, with a fruitful harrest.

"3. Great store of fine gold and silver.

" 4. The moderate use of the ereature and sparing dyet, which is very bittle practised.

“5. 'The corne-masters and farmers eharitable bountie, or conscionable exposing of their graine to sale, which is rara avis in terris, $f c$.

" 6 . The importation of graine from foreine parts, which have beene divers times knowne, through the eareful means of the prorilent magistrates within the citie of Loudon.

"Hor a seventh eause, I might adde the forbearance of racking rents, whereby the tenants (fitrming their grounds at easie rates), and other provision at reasonable priees. But so eorrupt or prone to ararice is the heart of man in these later times, that raeking of rents will never be abandoned, and consequently eheapness of graine, or other things created for the sustenance or service of man, is not likely to be knowne by any sueh canse," p. 74 .

9 .... Dr. Thomas Short, M.D., General Chronological History of the Air, Weather, Seisons, Meteors, \&c., in sundry places at different times, wherein he reviews the famines and dearths which hare afllieted the world. He remarks [rol. ii, p. 376] that among the signs of an approaehing dearth are several years of luxuriant erops in suecession.

A letter from a gentleman in town to his friend in the country, reeommending the neeessity of frugality. Third edition, Sro., pp. 24. A letter to the Right Honourable William Pitt, Esq, one of His Majesty's Prineipal Seeretaries of State, relating to the abuses practised by Bakers, Corndealers, Farmers and Millers : in consequenee of a pamphlet, intitled, Poison Detected, which that fraternity is supposed to have endearoured to suppress. 8ro., pp. 23.

'58 .... There was compiled [by Sir Charles Whitworth, M.P., ] an inquiry into the prices of Wheat, Malt, and oecasionally of other prorisions; of Land, Cattle, Se.; as sold in England from the year 1000 to the year 1765 ; computed aceording to the Winchester measure, and to the present standard of English corn. Divided into periods of ten years each, and also into periods of eireumstances. Printed for and sold by $\mathrm{T}$. Longman (at No. 39), in Paternoster-row, M.Dcc.Lxviri.

Copy of the report of an Assize of Bread made in the year 1669, by order of the then eourt of Aldermen, with remarks on the Act 31 George II, and an appendix to explain the statute 51 Henry III.

'63 .... Charles Churehill, "an English poet of unquestionable genius:" The Propheey of Famine, a Scots Pastoral. 
TABLE XV. - The Literature of Famines and of $\|$ c con It re:-C'ntd.

A.D.

1765 ... Daris : authentic aeeounts of the price of Wheat, Bread and Malt, \&e.; and also a true relition of Dearths and Famines.

'65 .... Scascity of Bread: a plin for reducing its high price. By William Frend.

'66 .... Poor Man's Praver: an elegy addressed to the Earl of Chatham (complaining of the exportation of corn). By simon Hodge, a Kentish labourer. 4to.

'66 .... Three letters to a member of the honourable House of Commons, from a country farmer, concerning the price of provisions; and pointing out a sure method of preventing future scarcity. Sro. pp. 49.

'67 .... Sir James Steurart's famous work : An Inquiry into the Principles of Politieal Economy [produced, it will be remembered, before Adam Smith's Wealth of Nations], wherein he lays down this fundamental proposition (afterwards exiggerated and misapplied by Mislthus): 1. The production of all countries are, generally speaking, in proportion to the number of their inhabitants; and 2 . The inhabitants are most commonly in proportion to the food. He then shows that the food of the earth may be dirided into two portions: (A) the natural produce of the earth; and (B) the portion which is created by human industry. A corresponds to the food of animals, and is the limit of the number of sarages. $B$ is the product of industry, and inereases (all other things being equal) in proportion to the numbers of cirilised men.

'67 .... Thoughts on the eauses and consequenees of the present high price of Prorisions. [By Soane Jennings], Second edition. Sro., pp. 26.

'67 ... An Appeal to the Publie : or Considerations on the Dearness of Corn, wherein the rulgar ideas are exposed; the mistakes of some writers discovered; the Pretended and True Causes examined; the best Preventives Elucidated; with some observations offered, tending to promote the Public Tranquillity; and the case of other provisions is oecasionall considered. Sro., pp. 59.

'67 .... The Oecasion of the Dearness of Provisions, and the distress of the Poor: with proposals for remedying the ealamity, offered to the consideration of the public: wherein the poliey of the bounty given upon the exportation of Corn, the enclosing of Commons, and Enlarging of Farms, are impartially considered. With some remarks on a lite pamphlet, intituled, A Letter to a member of Parliament on the Present Distress of the Poor. By a manufacturer [W. John Hustler, of Bradfori, Yorks]. 8ro., pp. 49.

'o7 ... Political Speeulations; or an attempt to discover the eauses of the Dearness of Provisions and High Priee of Labour in England: with some Hints for remed ring those evils. Part II. Sro., pp. 62.

67. In Dr. Thomas Short's Comparative Histor's of the Inerease and Deerease of Mankind, \&c., published this year, there was included "a Srllabus of the general States of Health, Air, Seasons, and Food for the last three hundred years ; and also a Meteorologieal Diseourse."

'67 .... Thoughts on the Causes and Consequenees of the present High Price of Provisions. This work is attributed to Edmund Burke.

Important considerations upon the Aet of the 21 George II, relative to the Assise of Bread. Sro., pp. 46 London : printed for G. Woodfall. the corner of Craig's Court, Charing Cross. Priee Is. Second edition, with additions, same year.

'68 .... Assise of Bread. Important eonsiderations upon the Act relative to the assise of bread.

Inquiry into the Prices of Wheat, Malt, and oceasionally of other Provisions, of Land and Cattle, \&e., as sold in England from the year 1000 to the vear 1765 . By Sir Charles Whitworth, M.P.

' 72 .... A' letter to the Right Hon. Lord North; attempting to show the Causes and the Remedies of the High Price of Prorisions, upon a new plan. Bу Amiens Patriæ. Sro., pp. 32. 
TABLE XV.-The Literature of Famines and of the Corn Laws-Contd.

A.D.

1772

A sketeh of a plan for reducing the present High Price of Corn and other Provisions, and for securing plenty of both for the time to come. In a letter to a member of parliament. By Pamphilus. Sro., pp. 27.

T. Elbridge Rooke, "late Lientenant in rour Majesty's reduced 108th Regiment of Foot," alldressed to the king, "Some Considerations on the present Searcity and Dearness of Provisions." Small 4to., pp. 24 ; wherein oeem the following passages:-

"The eause of the dearness of provisions, undonbtedly proeeds from too great a number of horses, still-houses, a prohibition of the distillery of wheat, too gencral a use of tea, the monopoly of farms, the goodness of the roads, and the numerons dealers in provisions.

"In this treatise we shall endeavour to prove evidently that these are the eauses, and the only causes, of the present dearness of meat; likewise a suitable and effectual remedy is proposed to reduee the price thereof to a moderate proportion, and also that of hides, tallow, soap, eandles, and leather.

"It is not intended to stop the raisers and dealers in these artieles, they shatl get as mueh as they do now, with a less sum of money in trade; neither will it prove detrimental to the landed interest, but it will essentially add to the strength and glory of the nation."

The ehief peculiarity of this writer is that his proposed remedies are nearly the reverse of those of all other writers. His panacea was the importation of grain from British Ameriea, paring a duty of one penn! per bushel!

The Expediency of a Free Exportation of Corn, with some Obserrations on the Bounty. [By Arthur Young.] London, 8ro.

Considerations on the exorbitant price of Prorisions: setting forth the pernieious effeets whieh a real searcity of the neecssaries of life must erentually hare npon the commerce, population, and power of Great Britain. To whieh is added a plan to remore the cause of our present national distress. Humbly submitted to the eandid and impartial public. By Francis Moore. Svo., pp. 98. One of his ideas was to substitute ox labour for that of horses. Horses eat, but are not eaten [in England].

The great adrantage of eating pure and genuine Bread, comprehending the heart of the wheat, with all its flour. Showing how this may be a means of promoting health and plenty, preserving infants from the grave by destroying the temptation to the use of alnm and other ingredients in our present wheaten bread. Reeommending to magistrates, partieularty in London, such an impartial distribution of justice in the exeenting the Act regulating the assise of standard wheaten bread, as may prove equally beneficient to the miller, the baker, and the eonsumer of bread. By an Adroeate for Trade. 8ro., pp. 59.

A letter on oecasion of the publie inquiry eoneerning the most fit and proper bread to be assised for general use. Showing the difficulty of executing the Aet of the 31 George II, in a beneficient manner to the poor; the constant usage and eustom with regard to Bread for many centuries; the folly of eating bread known to be made white by art and adulteration, and the great advantage of eating pure bread made of all the flour, including the heart of the wheat, as the most salutary, agrecable and nutritive aliment. Reeommended as an object of a rery serious and important nature. By an Adrocate for Publie Welfare. 12mo., pp. 74.

An inquiry into the eonnexion between the present price of provisions and the size of farms: with remarks on population as affected thereby. To which is added two proposals for preventing future seareity. By a Farmer. 8ro., pp. 146. 
Table XV.- The Literature of Famines and of the Corn Laws-Contd.

A.D. 1776

Three Letters to a Nember of the Honourable House of Commons, from a Country Farmer, eoneerning the Prices of Provisions, and pointing ont a sure method of preventing future scareity.

Humbly inscribed to Parliament. Two Letters on the Flour Trade and Dearness of Corn; wherein the former is vindicated and the Cause of the latter explained, and the mistakes and misrepresentations of ignorant and merely theoretical writers are confuted. By a Person in Business (in Hants, 1st November, 1766). Sro.

'77 ... An Inquiry into the Nature of the Corn Laws, with a View to the New Corn Bill proposed for Scotland. [By Sir James Anderson, LL.D.] Edinburgh, Sro.

'85 .... A Politica1 Inquiry into the consequences of Enelosing Waste Lands, and the Causes of the High Price of Butchers' Meat; being the sentiments of the Society of Farmers.

'90 .... By Robert Applegarth. A Plea for the Poor; or Remarks on the Price of Prorisions, \&e.; the Peasant's Labour; the Bounties allowed on the Exportation of Corn, especially Wheat; with Proposals for their Emendation.

'90 .... Representation of the lords of the committee of eomnil appointed for the consideration of all matters relating to trade and foreign plantations, upon the present state of the laws for regulating the importation and exportation of corn. London, 4to. "In consequence of the statements and suggestions made in this representation, a change, though of no great moment, was effected in the eorn laws in the course of the ensuing year." - MCCтLLOch.

'91 .... Lord shefincld. Observations on the Corn Bill now depending in Parliment.

'92 .... Considerations on the Causes of the High Price of Grain and other articles of Provision, for a number of Jears back; and propositions for redneing them; with additional remarks. By Catherine Phillips. 8ro., pp. 90.

'95 .... Considerations on the Searcity and High Price of Bread-Corn and Bread at the Market; suggesting the remedies, in a series of letters; first printed in the Cambridge Chronicle, and supposed to be written by Governor Pownal. Sro.

Accomt of the Experiments tried by the Board of Agriculture in composition of rarious sorts of Bread. Anno 1795. London : Printed for G. Nichol, Pall Mall, Bookseller to His Majesty and to the Board of Agriculture; and sold by Messrs. Robinson, Paternoster Row ; J. Sewell, Cornbill ; Cadel and Daries, Strand; William Creeeh, Edinburgh, and John Archer, I)ublin. 4to., pp. 34.

'95 .... Thoughts on the most effectual Mode of Relieving the Poor during the Present Saraity.

'95 .... Hints for the Relief of the Poor, by suggesting how they may procure a cheap and comfortable subsistence in times of searcity.

'95 .... Useful Suggestions faronrable to the Comfort of the Labouring People and of Decent Housekeepers : explaining how a small income may be made to go far in a family, so as to oceasion a considerable saring in the article of bread ; a cireumstance of great importance to be known at the present junction. 8ro., pP. 17.

'96 .... The Rev. J. Acland: An Answer to a Pamphlet published by Edward King, Esq., in which he attempts to prove the Public Utility of the National Debt; a confutation of that pernicions Doctrine, and a true Statement of the real Canse of the present Iligh Price of Provisions.

'96 .... By "W. A.:" Injuries of the Public the Cause of Famine.

${ }^{9} 96$.... An Enumeration of the Principal Vegetables and Vegetable Productions that may be substituted, either in part or wholly, in place of Wheat and other Bread-Corn in Times of Scarcity, with short notices respecting the Modes of preparing them for Use; by the author of "Some Information on the Use of Indian Corn." 
TABLE XV.-The Literature of Famines and of the Corn Laus-Contd.

A.D.

1796

97 .... In sir Frederie Morton Edeu's great work, The State of the Poor: or

An Inqunr into the Corn Trade and Corn Laws of Great Britain, and their influenee ou the prosperity of the Kingdom. By Alexander Dirom, Esq. London, 1 rol., 4 to. an History of the Labouring Classes in England, de., is given an appendix," Containing a Comparative and Chronologieal Table of the Priees of Labour, of Provisions, and of Commodities," \&c. From this work we have quoted in the present paper. He speaks of the importance of registering the priee of the chief item of the food of the people, as the most aceurate measure of the value of labour.

97 .... Dispersion of Gloomy Apprehensions with respect to the Decline of the Corn Trade. By the Rer. John Howlett [ricar of Great Dunmow, Essex]. London, 8ro.

'98 ....

The great work of Malthus-Essay on the Principles of Populationwas first published this year, wherein oecurs the following passage :-

"I certainly think that, in preference to the interest of a particular State, a restriction upon the importation of foreign eorn may sometimes be advantageous; but I feel still more certain that, in referenee to the interests of Europe in general, the most perfect freedom of trade in corn, as well as in every other commodity, would be the most adrantagcous. Such a perfeet freedom, however, could hardly fail to be followed by a more free and equal distribution of eapital, which, though it would greatly advanee the riches and happiness of Europe, would unquestionably lender some parts of it poorer and less populous than they are at present; and there is little reason to expeet that indiridual States will erer consent to saerifice the wealth within their own eonfines to the wealth of the world."

Mr. Malthus sars (Population, serenth edition, p. 257), "We know that the gencrial effect of years of cheapness and abundanee is to dispose of a great number of persons to marry, and under sueh eireumstances the return to a year merely of an average crop might produce a seareity."

It has not unfrequently been eontended that the countries most subjeet to famine are those in whieh the population usually makes the most rapid progress. To this it has been answered-that the progress of the population being more rapid than that of the means of subsistenee, famines are a necessary eonsequenee; henee the Malthusian theory-limit the population to the resourees of the country. This is in opposition to modem free-trade principles. What Malthus says (serenth edition, 1872 , p. 256 ) is :-

"Of the other great seourge of mankind, famines, it may be observed that it is not in the nature of things that the inerease of population should absolutely produee one. This inerease, though rapid, is neeessarily gradual; and as the human frame eannot be supported even for a short time without food, it is evident that no more human beings ean grow up than there is provision to maintain. But though the prineiple of population eannot absolutely produce a famine, it prepares the way for one; and by frequently obliging the lower elasses of people to subsist nearly on the smallest quantity of food that will support life, turns even a slight deficience, from the failure of the seasons, into a severe dearth; and may be fairly said, therefore, to be one of the principal eauses of famine."

He remarks also upon another well-known faet, and that is, the rapidity with whieh even old States reeover from the desolations of war, pestilenee, famine, and the eonrulsions of nature :-

"The traees of the most destruetive famines in China, Indostan, Egypt, and other eountries, are by all accounts, very soon obliterated; and the most tremendous convulsions of nature, sueh as voleanic eruptions and earthquakes, if they do not happen so frequently as to drive away the inhabitants or destroy their spirit of industry, lave 
TABLE XV.-The Literature of Famines and of the Corn Laws-Contd.

A.D.

1798 ..

'98 .. A Proposal for Supplying London with Bread at a Uniform Price from one year to another according to an Annual Assise : by a Plan that may be applied to every Corporation in the Kingdom; would give Encouragement to Agrienlture, and would prerent Rise of Prices in case of future Scanty Harrests. 8ro., pp. 39. The plan proposed was by means of granaries provided in the interest of the inhabitants.

'99 .... Observations on the Statute of the 31 George II, eap. 29 [1757-58], concerning the Assise of Bread; with oceasional Reference to the 3 George III, eap. 11, and the 13 George III, cap. 62; and to the late Statute for regulating the Assise of Bread in the City of London. By the Rev. Luke Heslop, Archdeaeon of Bucks. 4to., pp. 32.

99

Suggestions offered to the consideration of the Publie, and in partieular to the more Opulent Classes of the Community, for the purpose of redueing the Consumption of Bread-Corn; and relieving at the same time the Labouring People, by the substitution of other Cheap, Wholesome and Nourishing Food; and especially by means of Sonp Establishments, \&e. 8ro., pp. 19.

1800 .... A Maximum, or the Rise and Progress of Famine; addressed to the British People. Wright. 8ro.

1800 .... George Edwards, M.D.: Effectual means of proriding against the Distresses apprehended from the searcity and high price of different articles of Food.

1800 .... Thonghts and Details on Scareity, originally presented to the Right Honourable William Pitt, in the month of Norember, 1795. By the late Right Honourable Edmund Burke. 8ro., pp. 48.

1800 .... The True Canses of our present Distress for Provisions ; with a Natural, Easy, and Effectual Plan for the future Prevention of so great a Calamity; with some hints respeeting the absolute neeessity of an increased Population. Br William Brooke, F.S.A. Sro., pp. 85.

$1800 \ldots$ A Temperate Discussion of the Canses whieh have led to the present High Price of Bread. Addressed to the Plain Sense of the People. [By Charles Long, Secretary to Treasury.] 8ro., pp. 43.

The effect of war in sending up the priee of wheat is here very elearly shown.

1800 .... Lord sheffield, A pamphlet: Remarks on the Defieiency of Grain occasioned by the Bad Harrest of 1799 , and on the means of present relief and friture plenty. Sro.

1800 .... Striking facts addressed to those who still disbelieve in a Real Scareity, and a solemn appeal to all who think otherwise. By the author of "An Appeal to the Good Sense of the Higher and Wealthy Orders of the People," \&e. 8ro. pp. 13. "N.B.-The quartern loaf is now selling at $1 s .9^{\frac{1}{4}} d . "$

1800 .... An Address to the Plain Sense of the People on the present High Price of Bread. Sro., pp. 16.

$1800 \ldots$. Short Thonghts on the present Priee of Provisions. By an Offieer of the Volunteer Corps. Sro., pp. 15.

1800 .... A Determination of the Arerage Depression of the Price of Wheat in War below that of the preceding Peace, and of its readrance in the following, aecording to its yearly rates from the Revolution to the end of the last Peace; with Remarks on other greater variations of that entire period. Bч J. Brand, C.L., M.A., \&e., \&e. 8ro., pp. 102.

1800 .... Effectual means of proriding, according to the Exigencies of the Eril, against the Distress apprehended from the Searcity and High Prices of Articles of Food. By George Edwards, Esq. 8ro., pp. 43. Dedieated to Arthm. Young.

1800 .... Remarks on the Defieieney of Grain, occasioned by the Bad Harvest of 1799 ; on the means of Present Relief, and of Future Plenty, with an Appendix containing aeeounts of all Corn Imported and Exported, 
Table XV.-The Literuture of Fumines and of the Corn Laws-Contd.

A.D.

1800

1800 .... Thoughts on the Present Prices of Prorisions, their Causes and Remedies; addressed to all runks of the people. By an Independent Gentleman [Mr. Simmons]. 8ro., pp. 87.

1800 .... Adrice to the Poor, and llints to the Rieh, on the present Iligh Prieo of the Neeessaries of Life. A new impression, eorrected. By a Layman of Middling Rink. Sro., pp. 29, and postseript.

$1800 \ldots$. Inquiry into the Causes and Remedies of the late and present Senreity and High Priee of Prorisions, in a Letter to the Right Honourable Earl Spencer, K.G., First Lord of the Admiralty, \&e., \&e. Sro., pp. 71.

1800 .... Moderation is Silvation, addressed to the People of England at the Present Searcity. By a Plain Man. 8ro., pp. 31. "Stand to your Arms, Britons! Strike home! and spare the quartern loaf !"

1800 .... An Examination of the Statisties now in foree relating to the Assise of Bread; with Remarks on the Bill intended to be brought into Parliament by the Country Bakers. By James Nasnith, D.D., one of His Majesty's Justices of the Peaee for the County of Cambrictge and Isle of Ely. Wisbeach : Printed and sold by John White, \&e. Price $2 s .6 d$. Sro., pp. 85.

1800 .... D1. Edward Gardner, M.D., Reflections upon the Eril Effects of an Inereasing Population on the present Ifigh Prices of Provisions, partieularly Corn; upon the Bounty Aet; and upon the propriety of General Enclosures, in which a mode is suggested of relieving the present necessities of the Poor upon the prineiples of Equity. To which is added an Appendix containing some remarks upon the subject of Tythes; further Observations upon Population; and animadrersions upon some late publieations on the present scarcity.

1800 .... An Appeal to a Humme Publie for the poorer Millers and Bakers, respecting the High Price of Bread; and the injury sustained by them from the Establishment of the London Flour, Meal, and Bread Company, with an Acconnt of the Effeet the Institution of this new Chartered Compans has im immediately Raising instead of Lowering the Priee of Corn. By an Attentice Obserrer. 8ro., pp. 21.

1800 .... The Use of Indian Corn as an Article of Food. By authority, A. 'Thorn, 87, Abbey Street, Dublin. 8vo., pp. 4.

1800 .... Industry, and a Pious Submission, Charity, and a Strict Economy, recommended and enforeed, as the best means of alleriating the Present Distress. A Sermon preaehed in the Parish Church of St. Anne, Westminster, on Sunday, the 14th day of Deeember, 1800, being the day on which his Majesty's Proelamation on the Seareity of Grain was direeted to be read. By Jos. Jefferson, A.M. and F.A.S. Small 4to., pp. 28, and Appendix. In this publication is contained the remarkable resolution dlesignated "The Engagement," which I hare giren at the end of Table IX.

1800 .... On the Causes of the High Priee of Provisions. By same author. 8ro.

1800

Anouymously: The Cause of the present threatened Famine traced to its real souree, viz., an actual depreciation of our eireulating mectium, occasioned by the Paper Curreney, with which the War, the shock given to public eredit in 1794, the stoppage of the Bank in 1797, and the Bankruptcies in Hamburgh in 1796, inundated the Country to accommodate Government, and enable the merehants to keep up the price of their merehaudise, shewing by an Arithmetical Caleulation founded on faets, the extent, nay, the very mode of the progress whieh the Paper System has made in redueing the People to Paupers. With its only apparent practicable remedy. Jordan. 8ro.

1800 .... An Inrestigation into the Cause of the present High Price of Provisions. By the author of the Essay on the Principle of Population [Mr. Malthus]. London, 8ro. 
TABLE XV.- The Literature of Famines and of the Corn Laws-Contd.

A.D.

1801

'01

urgent reasons for Credit and Famine.

'OI ... Bread, or the Poor, a pocm, with notes and illustrations. By Mr. Pratt, author of Sympatly, Gleanings, \&c. 4to., pp. 88, and 21 pages of notes, probably a correct pieture of the times.

'01 .... Observations on the Act which passed into a law in 1800 , to incorporate certain persons by the name of the London Company, for the manufacture of Flour, Meal and Bread. By John Henry Prince, Bookseller. London, 8ro.

'OI ... A Bricf Reriew of the causes which have progressively operated to enhance the Price of Provisions, but particularly of Bread-Corn, with suggestions as to the best means of alleriating the present distress, and preventing the recurrence of a similar calamity. 8vo., pp. 91.

'OI .... A calm Inrestigation of the circumstances that have led to the present Searcity of Grain in Britain, suggesting the means of alleviating that evil, and of preventing the recurence of such a calimity in future. By James Anderson, L.L.D., \&c. London, Sro.

'OI .... Review of the Statutes and Ordinances of Assize which have been established in England from the fourth year of King John, 1202, to the thirty-serenth of his present majority (George III). By G. Attwood, F.R.S., London, 4 tu.

'04 ... An Essay on the Impolicy of a Bonnty on the Exportation of Grain, and on the prineiples which ought to regulate the commeree of Grain. [By James Mill, anthor of the History of British India.] London, 8 ro.

'04.... Arclibald Duncan, "of the Royal Nars :" The Mariner's Chronicle, being a collection of the most interesting narratives of Shipwrecks, Fires, Famines, and other calamities ineident to a life of maritime enterprise. "No. 1, to be completed in twenty numbers, 6d. each."

05

A Treatise on the Art of Bread making, wherein the Mealing Trade, Assize Laws, and every circumstance connected with the Art, is particularly examined.

'08 .... Mr. W. T. Comber : An Inquiry into the state of National Subsistence, as commeted with the progress of Wealth and Population, \&e., wherein muel valuable information will be found upon the operation of the effect on the people of the legislative enactments herein reviewed.

'08 .... Dr. James Anderson (Madras): Joumal of the establishment of Napal and Tuma for the prevention or cure of Scurvy, Dysentery, and Ulcers on Shipboard and Navigation: of Famine on shore.

'12 .... Thoughts upou the immediate means of meeting the Pressure of Want. By a Londou Merchant. Sro., pp. 16.

'14 .... Mr. N. Lowis: Defence of the claim for an increase of the Import Duty of Grain. Sro.

'I4 .... A letter to the Right Honomable Sir William Domville, Bart., the Iord Mayor of London [on the Assise of Bread]. By John Dumbell. 8ro., pp. 147. A scheme to compete with the Bakers.

'14.... First and Second Reports from the Committees of the House of Lords appointed to inquire into the state of the Growth, Commerce, and Consumption of Grain, and all laws relating thereto: to whom were referred the sereral petitions prescnted to the House in the session of 1813-14, respecting the Com Laws. 2nd edition.

'14 .... Considerations on the Protection required by British Agriculture, and on the Influence of the Price of Corn on Exportable Productions. By William Jacob, Esq. London, 8ro. 
TABLE XV.-The Literature of Famines and of the Corn Laws-Contd.

A.D.

Malthus. London, Sro.

'15 .... The Rer. T. R. Malthus, a pamphlet: Grounds of an Opinion on the Policy of Restrieting the Importation of Foreign Corn. 8 ro.

'15 .... The Rer. T. R. Malthus, a pamphlet: On the Effects of the Com Laws on Agrieulture, \&e. Sro.

'15 ... Mr. Darid Rieardo: An Essay on the Influenee of a Low Price of Corn on the Profits of Stock.

'I5 .... Mr. Robert Wilson (Edinburgh): Enquiry into the Causes of the High Price of Corn and Labour. Sro.

'15 .... Essay on the Appleation of Capital to Land, with Observations on the Impolicy of any great Restrictions of the Importation of Corn. By a Fellow of University College, Oxford. 8ro.

'15 .... Brickwood's Facts on the Corn Laws. 8ro.

15 .... In Mr. Joshua Milne's Treatise on Annuities, \&e., published this jear, his first table is one "exhibiting the progress of the population of Englind and Wales and the price of Whent from the Fear 1710 to 1810." We do not propose to quote that table here; but the remarks which accompany it deserve to be noticed :-

"It will be observed, that any material reduetion in the price of wheat is almost always accompanied by an increase both of the marriages and conceptions, and by a decrease in the number of burials; consequently by an inerease in the excess of births abore the deaths. Also, that any material rise in the price is generally attended by a corresponding decrease in the marritges and conceptions, and by an increase in the burials; therefore by a deerease in the excess of the births abore the deaths. Thus it appears, that an merease in the quantity of food, or in the facility wherewith the labouring elasses ean obtain it, accelerates the progress of the population, both by augmenting the aetual feeundity, and diminishing the rate of mortality; and that a seareity of food retards the inerease of the people, by prodneing in both ways opposite effects."

The theory of the increase of fecundity by reason of the food supply has been controverted.

'15 .... Mr. C. Culverhouse: Arrangement of the Bread Laws, with an Historical Introduction, and some Curious Specimens of the Ancient Bread Laws, and Tables exhibiting the Price and Assise of Bread from the Price of Wheat and Flour.

'15 .... An Essay on the Influence of a Low Price of Corn on the Profits of Stock, with Remarks on Mr. Malthus's Last Two Publications. By Darid Ricardo, Esq., London. Sro.

'15 .... Report and Evidence from the Seleet Committee of the House of Commons on the Laws Relating to the Manufacture, Sale, and Assize of Bread. London, Folio.

'16 .... Mr. Dugald Bannatyne delivered before the Literary and Commercial Society of Glasgow an essay: Observations on the Principles which enter into the Commerce in Grain, and into the Neasures for supplying Food to the People. The substance of which was afterwards published, and attraeted considerable attention.

'18 .... [Rules of] Bread Association for the District of Pinner, IIarrow Weald, Great Stanmore, Little Stanmore, and Edigware, to Eneourage Industry and Eeonomy, by indueing the Poor to Deposit small portion of their Earnings during the Summer, to be returned to them with the addition of at least half as much again from the Funds of the Charity, in the Artieles of Bread and Flour, supplied by their own Bakers, at balf-price, in the course of the Winter. Established September 1, 1817. 8vo, pp. 30, and appendix.

'19 .... Dearness not Seareity: its Cause and Remedy. By Josiah Collier. Humbly offered to the consideration of 11 is Mijesty's Ministers. 8vo., pp. 17. 
Table XV. - The Literature of Fumines and of the Corn Laws-Contd.

A.D.

1820 .... Mr. John Wright (Nottingham) : Hints on the Importation of Corn, and on Circulating Medium. 8ro.

'20 .... Letter to Sir Robert Peel on the Comparative Operation of the Corn Laws and Taration. By a Briton.

'21 ... Report from, and Minutes of Eridence taken before the Select Committee of the House of Commons on the Depressed State of Agriculture. London, folio. This report (which was drawn up by Mr. Huskissun) contains a forcible exposition of the mischierous intluence of the law of 1815. Mr. Ricardo was a member of this Committee, and not choosing to hase his opinions identified with those of the Report, he published his famous tract of 182.

'22 .... On Protection to Agriculture. By Darid Rieardo, Esq., M.P. This pamphlet diseusses the important questions of remunerating price; the influence of a law and of a high value of corn or wages and profits ; the elfect of taxition on agriculture and manufactures; the grounds on which restrictions on importation may be justified, with others of equal interest and difienlty. "Had Mr. Kicardo never written anything else, this pamphlet would have placed him in the rery first rink of political economists." - McCecLoch.

'22 .... I Leitter to the Agriculturists of the County of Salop on the present state and Future Prospects of Agrieulture. By W. W. Whitmore, Erq., M.P. London, sro.

222 .... "An Essay on the Demressed State of Agriculture." By James Cleghom [Editor of Edinluigh Farmers' Magazine]. Published by order of the Highland society. Edinburgh, 8ro.

'23 ... Observations on the Present State of Linded Property, and on the Prospects of the Landlords and Farmers. By Darid Low. Edinburgh. 8ro.

'23 .... Wright's Remarks on the Erroneous Opinions which led to the New Com Law, and also on those of the Bullionists. 8ro.

'26 .... A Disquisition on the Corn Laws, with a few Observations on Panperism, as it appears among the Higher Orters as well as among the Lower Order of Society. Bis Robert Wilson, author of the History of Hawick.

'26 .... A Compendium of the Laws passed from time to time for Regulating and Restricting the Importation, Exportation, and Consumption of Foreign Corn from the vear 1660, and a series of Accounts from the date of the Earliest Records, showing the Operation of the several Statutes, and the arerage Price of Com, presenting a complete view of the Corn Trade of Great Britain. Compiled from Public Documents. 8 ro.

'26 .... Report on the Trade in Foreign Com, and on the Agriculture of the North of Europe. B. Irilliam Jacob, F.R.S.

'26 .... Prices of Corn and Wages of Labour, with Observations, \&e. By Sir Eilward Trest [author of "Tract on Rent"]. Loudon, 8ro.

'26 .... Cheap Corn best for Farmers, proved in a Letter to G. H. Sumner, Esq., M.P. for Surrey. By one of his Constituents. [Henry Drummond, Esq., fomder of the Chair of Political Economy in the [niversity of Oxford.]

27 .... Mr. M. Fletcher, a pamphlet, On the Causes which Influences the Price of C'orn. Sro.

27 .... An Essay on the External Corn Trade. By Colonel Torrens, London, 1 rol.," 8ro. "Among the most able of the publications on the impolicy of restricting the importation of corn, may be classed Major (now Colonel) Torrens's Essay . . . . . His argunients appear to me unanswered, and to be unanswerable."-Ricardo. Political Economy.

'27 ... A Catechism of the Corn Laws, with a list of Fallacies and the Answers. [By Colonel Perronet Thomson.] London, 8ro.

'27 .... Report on the Trade in Corn and the Agriculture of the North of Europe. By M. Jacob, Esq. Printed by order of the House of 


\section{TABLE XV.-The Literature of Fumines and of the Corn Laves-Contd.}

A.D. 1827

27 Foreign Ports. Folio.

Hr. Thomas Ifopkins, a pamphlet, On Rent of Land, and its Influence on Subsistence and Population.

'28 .... Tracts relating to the Corn Trade and Corn Taws, inelnding the Second Report ordered to be printed by the two Houses of Parliament. By William Jacob, F.R.S.

28 .... Free Trade in Corn : the Real Interest of the Tandlord and the True Poliey of the State. By a Cumberland Landowner. London, Sro.

'29 .... Mr. Thomas Tooke, a pamphlet, On the Currener in connection with the Corn Trade, and on the Corn Laws.

'30 .... W. W. F. Llogd (Oxford), Prices of ('orn in Oxford in the beginning of the Fourteenth C'entury; with Miscellaneous Notices of Prices in other Places, eollected from Miss. Sro.

30

In Mr. M. T. Sadler's great work, "The Law of Population," it is contended, and the contention is to all appearance supported by the eridenee of statisties, that eheap food (he takes his example from the price of wheat) does not increase the fecundity of the people inter se. There nar be more marriages, and hence more births; but the power of feeundity is not itself increased by means of cheap food.

'30 .... Evers Man his own Purreror. Proposal for the formation of a Club for eheapening the neessaries of life; being the substance of a series of papers originally published in the Spectator newspaper, with additional remarks. 8ro., pp. 23.

'33 .... An Inquiry into the Expediency of the Existing Restrietions on the Importation of Foreign Corn; with Observations on the present Social and Politieal l'rospects of Great Britain. Br John Burton. London, Sro.

'34 .... A Clue to the cause of Dear Bread and Fillen Rents, submitted to the consideration of Members of Parliament. By a Landed Proprietor. August, 1834. Sro., pp. 8.

'34 .... Letters on the Corn Laws and on the Rights of the Working Classes, originally inserted in the Morning Chronicte, showing the injustice and also the impolier, \&e., [of the Corn Laws]. By H. B. T., London. 8ro. The real anthor of these letters is understood to hase been Mr. Deaeon Hume, one of the secretaries of the Board of Trade, who had a principal share in the consolidation of the Customs and Narigation Laws, effected in 1825 .

'39 .... Influence of the Corn Laws as affecting all elasses of the community, and partienlarly the Landed Interests. By James Wilson, Esq. London, 1839.

'39 .... The effect of Restrietions on the Importation of Corn considered with reference to the Landowners, Farmers, and Labourers. By G. R. Porter, Esq. [of the Board of Trade, anthor of the "Progress of the Nation" ]. London. 8ro.

'39 .... Corn Laws: An authentic report of the late important discussions in the Manchester Chamber of Commerce, on the Destruetive Lffects of the Corn Laws upon the Trade and Manufaetures of the Comntry. London, 8ro.

'39 ... Mr. R. Torrens. Three Letters on the Effects of the Corn Laws. 8ro.

'40 .... Mr. W. Atkinson, a pamphlet, On Mr. Huskisson, Free Trade and the Corn Laws. 8ro.

'40 .... Influences of the Corn Law as affeeting all Classes of the Conmunity, and partieularly the Landed Interests. Second edition. By James Wilson. 
TABLE XV.-The Literature of Famines and of the Corn Laws-Contd.

A.D.

1841. ... Mr. J. R. M'Culloch, a pamphlet, Statements illustrative of the Policy and probable consequences of this proposed Repeal of the Existing Corn Laws. Sro.

'41 .... Colonel William Napier. Observations on the Corn Laws. 8ro.

'41 ... An Address to the Clergy of the Established Church of England on the effects of a Scarcity of Food: showing the tendency of Starvation to engender Epidemic Disease. By a Physician. 8ro., pp. 16. An important consideration is here involved.

'41 .... Statements Illustrative of the Policy and Probable Consequences of the Proposed Repeal of the existing Corn Laws, and the Imposition in their Stead of a Moderate Fixed Duty on Foreign Corn when entered for Consumption. By J. R. McCulloch. London, 8ro. This pamplilet had a very extensive circulation.

'41 .... A Few Words on the Com Laws, wherein are brought under consideration certain of the Statements which are to be found in the Third Edition of Mr. MeCulloch's Pamphlet on the same subject. By General Sir James Clarles Dalbiac, K.C.H. London. 8vo.

'42 .... An Inquiry into the Principles which onght to regulate the Imposition of Duties on Foreign Corn; in answer [to Mr. MeCulloch's pamphlet]. By George Taylor, Esq., W.s., Edinburgh, 8vo.

'42 ... Mr. G. Beanclerc, Operition of Monopolies on the Production of Food, as illustrated by the Corn Laws, for which the only adequate Remedies are Moral Goremment and Free Trade. 8ro.

'42 ... Suggestions offered, and clata given, in proof that a sufficient supply of Bread Com for the Inbabitants of Great Britain, the growth of their own soil, and produce of their own industry, mas be obtained in the year 1813, and for an indefinite period to come. By a Tourist from the North. Sro., pp. 18.

'42 ... Vindication of a fixed Duty on Corn, \&c. By J. G. Hubbard, Esq. Lonclon, Sro.

'42 ... Information Concerning the Cost and Supply of rarious Artieles of Agricultural Produce, \&c., in rarious parts of Northern Europe. Obtained by James Meek, Esq., under instructions from government. Printed by order of the Honse of Commons. Folio. "A carefully compiled paper, comprising much useful information."-McCuLLoch.

$' 43$.... Iow will Free Trakle in Corn affect the Farmer? Being an Fxamination of the Effects of Corn Laws upon British Agriculture. By C. G. Welford, Esq., London, 8ro.

'43 .... Corn Laws. The Consequences of the Sliding Scale Examined and Exposed. Being the substance of a speech delivered in the House of Lords on the 1.th of March, 1843. By Lord Monteagle. London, Sro.

'43 .... The Rer. Robert Ererest, Chaplain to the East India Company, contributed to the Journal of this Society a short paper: On the Famines that have devastated India, and on the probability of their being periodical. The author says :

"In comparing the derastating effects of drought, which I have more than once witnessed in India, with the accounts of similar calamities in the history of that comitry, it occurred to me that no one had ever ascertained whether, in that part of the world, such unfarommble seasons had anything like a periodical occurrence. For the purposes of such an inquiry, it was impossible to refer to meteorological registers for a long series of years, as no such documents existed. The only alternative, therefore, was to examine the prices of corn for as far back as they conld be obtained; assuming that they would roughly indicate the character of the seasons. In support of this course it may be remarked that the harrests are but tritlingly affected by other atmospherical circumstances than moisture and dryness. Of heat and sunshine there is always sufficient to bring the crops to perfection." 
'Table XV.-The Literature of Fumines and of the Corn Lats-Contd.

A.D.

$1843 \ldots$

He then indicates the soures from which he had drawn information, and gives the prineipal results as follows:-

"Great irregularity was observable in amy one list; but the more numerous the lists weie from which the averiges were tilken, the greater was the approximation to a regnlar ascending and descending series, with recurrenees at about eight or ten vears' distanee, leating to the belief that if we could obtain in correct meisure of the average atmospherie ebanges orer a consideruble surface of the carth, instead of those only of particnlar localities, we should be able to observe something like regular interrals in the seasons. . . . . Assuming that the rariations in priee follow the rariations of the seasons as to druness and moisture, it was to be expected that analogous rariations might be observed in the depths of large inland seas, suel as the Caspian and the lakes of North America.

He found on eonsulting such anthorities as were arailable to him, that in the great lakes of Amerien there is a rise for three years, and then a eorresponding deeline; but this was not altogether uniform, for sometimes the suceession of similar seasons extended to five and eren ten yenrs.

'44 .... How much would the Four-pound Loaf be Lowered by the Repeal of the Corn Laws? Sro., pp. 8.

'44 .... On Cases of Starfation and Extreme Distress among the Humbler Classes, eonsidered as one of the main symptoms of the present disorganisation of Soeiety; witl a preparatory plan for remedying these evils in the metropolis, and other large cities. Br J. L., late of the Colonial Service, with an introluction by Viscomt Ranelagh. Sro., pp. 47. Only 250 eopies printed-quite enough!

'44 ... Free Trade and Protection. Being a tract on the Neeessity of Agrieultural Protection. By Arehibald Alison, Esq., F.R.S. [Author of History of Europe during the French Revolution]. Edinburgh and London, 8ro. The writer ascribed the decay of agrieulture in ancient Italy, under the Emperors, prineipally to the importation of corn from Egypt, Mamritania, \&e.

'46 .... A Preliminary Inquirs into the Physieal Laws Gorerning the Periods of Famines and Panies. Br Hrde Clarke, eontributed to the Railway Register. In this paper it was songht to show that abundant harrests led to speculation; bad harrests to panies. The author says therein : "If there be great good from giving special attention to the statistics of human life, there seems to be no less good to be sought in the study of those laws whieh regulate the supply of human food, and which influence animal and regetable life." Theh historieal and chronologieal information is bronglat to bear upon the question.

This rear (1816) J)r. Farr read before this Soeiety a paper on, The Influence of Seareities and of the High Prices of Wheat on the Mortality of the People of England. This paper is replete with statistieal and other information of rahe. The author says, "I some time ago examined nearly all the English ehroniclers and listorians, from bede and the Saxon ehronicle down to Stow and Holingshed, and extracted all the passages in which scarcities, fimines, or epidemics are mentioned." The following passages are appropriate to our present paper. Ther refer to Englind only :-

"In the eleventh and twelfth eenturies a famine is reeorded every fourteen years on an average; and the people suffered twenty yours of famine in 200 years. In the thirteentl century my list cxhibits the same proportion of famine, and nearly the same number of years of famine; the addition of five sears of high prices makes the proportion greater. Upon the whole, the scareities deerease during the three following eenturies; but the arerage from 1201 to 1600 is the samenamely, seren famine, and ten years of famines in a century. This is the law regulating scarcities in England. 
TABLE XV. -The Literature of Fomines and of the Corn Laus-Contd.

A.D.

1846

mature of these laws.'

'47 ... The Black Prophet: a tale of the Irish Famine; with illustrations on wood by William Harrey, early impressions. Sro., ornamental boards. By IV. Carleton.

49 .... Mr. J. T. Danson, F.S.S., now of Lirelpool, read before this Society a paper: A Contribution towards an Investigation of the Changes which have taken place in the Condition of the people of the United Kingdom during the eight rears extending from the II:Irrest of 1839 to the Harsest of 18.7 ; and an Attempt to develope the Connexion (if any) between the Changes observed and the Variations oceurring during the same Period, in the Prices of the most necessary Artides of Food. This, like all the writings of the same author, is marked by many points of careful obserration and philosophic reflection; while the statistics it contains are valuable.

49 .... Dr. Licon Playfair published an important treatise, On the Food of IIan in reliation to his Useful Work. This book shonld be consulted by all who desire to comprehend the full bearings of the effect of food on the human system.

The Registral-General in his Sth report (published 1819), said:-

"As statistical science and edncation adrance, the sererit y of seasons of distress-whose general conrse can be calculated-will be diminished by mutual aid; and provision will be made in prosperity against their recurrence: as the losses of shipwreck, fire, and life to society are mitigated by the rarious classes of insurances. Knowledge will banish panic and initigate pain."

'52 ... Dr. W. A. Gur, M.B., contributed to this Socicty a paper, On the relation of the Price of theat to the Perenue; and the same is printed in its Journal, vol. xri, p. 53. The main conclusions the athor arriced at were the following:-

2. A comparison of groups of years of high and low prices of wheat, issues in a result highly farourable to the theory that the price of wheat exercises a marked influence on the revenue, and this is especially the case when the rears immediately following those of high or of low prices are substituted for the ycars coinciding with them.

3. The result of these comparisons is rendered still more striking when that portion of the revenue which is derised from wheat and wheat flom is subtracted from the total net ordinars rerenue; and this correction las, at the same time, the effect of dininishing the amount of the irregularities just referred to.

The paper contains many raluable statistics.

The Bread Question, or where the shoe Pinches. By E. G. Strann. 8тo.

"Those frightful fimines br which Lurope used to be raraged ecveral times in every century have censed; and so successfully hare we grappled with them, that there is not the slightest fear of their erer retuming with anything like their former severity. Indeed, our resources are now so great that we could at worst only suffer from a slight and temporary scarcits ; since in the present state of knowledge, 
Table XV.-The Literature of Fomines and of the Com Lars-Contd.

A.D.

1857

'60

the eril would be met at the
science could easily suggest."

ene renedies which ehemieal

In the first volume of the Journal de la Société de Statistique de Paris, published this year, is an article on the Famines of France, by II. A. Legort.

'61 .... Report on the [Indian] Famine of 1860-61. By Colonel Baird Smith, 2 pirts. [Olficial.]

'61

The Rer. James E. T. Rogers, M.A. (Oxford), read before the biritish Association at Manchester a paper, Faets and Observations on Wages and Prices in England during the sixteenth and serenteenth centuries, and more particularly during the thirty-nine years $1582-1620$; the clata prineipally employed being the Fabric Rolls of York Minster, and the shuttleworth householel books. In this paper is nuth valuable information regarding prices of food; but ats this paper formed in part the basis of the work published by the same author in 1865, we need not dwell upon it here. (See 1866.)

'63

The Rer. J. E. T. Rogers, M.A., read before the Statistical Society of London this year a paper, On a Continuous Price of Whent for oneliundred and fire rears from 1350 to 1.154 . The fircts eontained herein we shall endearour to make available in the table to be giren at the end of this article.

'66 .... Free Trucle-Good's (IV. W.) Political, Agrieultural and Commereial Fallacies; or the prospect of the Nation after twenty years' Free Trade. 8ro.

'66 ... At the Social Science Congress (Manchester'), Major-General Sir' Arthur Cotton read a paper on Famines in India, theip Causes and Remedies, wherein he gires some important statistical information. Regarding the loss of property eonsequent upon these Indian famines, Colonel Smith had estimated it in 1 (r 60 at $3 \frac{1}{4}$ millions sterling. Of the loss of publie revenue, the commissioners estimated that in the eigliteen rears following 1833, in Guntoor alone, there was a loss of 900,000l. The writer said one reason assigned for these famines was the want of water; but there was no such want in India. When Guntoor lost 200,000 by famine, a river was flowing through it which nerer failed, and which in a single day carried to the sea,+ 000 million cubie yards of water; and as 6,000 cubic yards will secure a crop of rice on an acre, water enough was running to waste in that one river in a das, in that very district, to secure 700,000 acres of rice, the food of $2 \frac{1}{2}$ millions of people for a year. A single day's water would thus provicic food for five times the whole population of that district. The sole eause of the famine was that the water was not distributed orer the land. There was indeed food in abundance in of her parts of India; but there arose the difficulty of transit. The irrigating canals might be made arailable to orereome this dificulty - so that the storage of water would meet and orercome a donble difficulty. He showed that in many distriets the works required might easily be carried out at a profit.

'66 .... Professor J. E. T. Rogers, F.R.S., History of Agrieulture and Prices in England, wherein is contained tables of the prices of commodities in all parts of England between the years 1259 and 1100 , and much other information on the subject of food and prires of a nost raluable character. The author says in his preface-referring to the period orer which his inquiry extends-

"As there were no regular means for supplying deficieneies in the produce of the home narket by forcign importations, the prices of necessaries, suels as corn, give no snall insight into the eourse of the scasons; and suppiy the best means for discovering a eyele of seasons, if, as I do not dale to assert, such a eycle can yet be found."

[If Professor Rogers had had before lrim the Tables IX, X, and XII, of this present paper, he mould hare scen that there were 


\section{TAble XV.- The Literature of Fumines and of the Corn Laws-Contd.}

\begin{tabular}{c|c|c} 
A.D. & legislative influences at work eren at that remote period, whieh were
\end{tabular} designed to interfere with the ordinary course of prices.]

'67 .... The Madras Famine of 1866 . By R. A. Dalzell, M.C.S. [official.]

'67 .... Minute by Sir Cecil Beadon on the Famine of Bengal and Orissa during 1865-66. Dated 5th January, 1867. [Official.]

'67 .... Report on the Famine in the Behar' Districts and Southall Pergunnahs in 1S68. By F. R. Cockerell. Dated 15th Mareh, 1867. [Official.]

'67 .... Report of the Commissioners appointed to inquire into the Famine in Bengal and Orissa during 1866. 2 vols., 1867. [Offieial.]

'67 .... Further Report of the Commissioners appointed to inquire into the Famine in Bengal and Orissa during 1866. With appendices, 1867. [Official.]

'68 .... Report on past Famines of the Bombay Presideney. By T. A. Etheridge, Lient-Colonel, 1868. [Officiat.]

'68 .... Report on the Past Famines in the North-Western Provinees. By C. E. R. Girdlestone. 1868. [Official.]

'69 .... Mr. Wm. Newmarch, F.R.S., in his inangural address on opening the session of this Societr, selected for consideration the state of knowledge in regard to some of the topics falling within the scope of this Society, and said:

"First, as regards the accurate statistical determination of the arerage consumption of the ehief articles of food among different classes of the population-corn, butchers' meat, and colonial produce. At present we eannot speak with any approach to accuracy of the cxtent and cost of the most vital of all requirements, riz., the food of the people. We are perpetually guessing at the probable consumption of wheat and other grains per head-the same of potatoes and butchers' meat, and colonial produce; and until, by a series of cxtensive and well-derised observations of rigid statistical facts, we arrice at results entitled to eredence, we shall continue to speeulate and reason in the dark."

In the absence of such knowledge, we probably suffer considerably in the eost of produets-ment for instance.

'69 .... Rcport on the operations of the Central Committee, Famine Relief Find, North-Western Provinces, 1870. [Official.]

'71 .... Report on the Famine in the Punjab during 1869-70. 1871. [Official.]

'71 .... A Narrative of the Drought and Famine which prevailed in the NorthWestern Provinces during the rears 1868, 1869, and beginning of 1870. Compiled by Frederick Henvey, 1871.

'73 .... Bengal, the Crops of, 1865-66, for comparison with those of 1873-74. By J. C. Geddes, C.S., 1873. [Offieial.]

'73 .... Mr. W. Brittlebank, Persia during the Famine: a Narrative of a Tour in the East, and of the Journey Out and Home. Post 8ro. London. 3 s. $6 d$.

'73 .... Mr. W. Tayler' read before the East India Association in London a paper, Famines in India: their Remedy and Prevention. This paper is published in the Transactions of the Society, and is remarkable for the great practical knowledge it displays.

'74 ... Administrative Experiences recorded in former Famines. By J. C. Geddes, C.S., 1874. [Official.]

'74 .... Correspondence relating to the Famine in Bengal and Behar in 1873-74. 1874. [Official.]

'7.t ... Special Narratives of the Drought in Bengal and Behar in 1873-74, together with liinutes. By the Hon. Sir Richard Temple, K.C.S.I. 1874. [Official.]

7.4 .... Minute by the Hon. Sir Richard Temple, K.C.S.I., Lieutenant-Governor of Bengal, on the Famine in Bengal and Behar during 1874. Dated 31st Oetober, 1874. [Official.]

75 .... At the meeting of the British Association held at Bristol this rear, Professor W. Stanley Jerons, F.R.S., read a novel paper, viz.: The 
Table XV.-The Literature of Fumines and of the Corn Laus-Contd.

A.D.

Influence of the Sun-Spot Period upon the Price of Corn. After alluding to the attempts made br Mr. Carrington to trace a connection between the price of corn and the variations in the sun spots during portions of the last and present centuries, the professor said that Mr. Schuster had pointed out that the rears of good vintage in Western Europe hare oceured at intervals approximating to eleven rears, the aremge length of the principal sun-spot period. The elaborate collection of the prices of commodities in all parts of England between the rears 1259 and 1400 , published by Professor Rogers, appeared to afford the best data for deciding whether the sum-spot period influences the price of corn. For this purpose, tables of the arerage prices per quarter of wheat and other grain, expressed in grains of pure silver, were used. Each series of prices was divided into intervals of eleven yeurs, which were ranged under each other and areraged, so as to give the arerage of the first, of the seeond, of the third, \&c., years, the commencement of the period being arbitrarily assumed. It was found that the price of each kind of produce examined rises in the first four years, but afterwards falls. It is further shown that the maxima prices are found to fall into the tenth, eleventh, first, second, and third rears of the assumed elerenyear period. These results are to be looked upon as only preliminary, and need further inrestigation. It was also pointed out that commereial panies have tended to reeur during the last fifty-four years in a distinetly periodic manner. The arerage length of interval between the principal panies is about 10.8 years, nealy coinciding with ir 11 , the length of the solar-spot period. If Professor Balfour Stewart be right in holding that the sun-spot variation depends on the configuration of the planets, it would tippear that these configurations are the remote cause of the greatest commereial disasters. This is but a meagre ontline of the remarkable paper.

Food Grain Supply and Famine Relief in Behar and Bengal. By A. P. MaeDonneil, B.C.S. 1876. [Official.]

East India (Famine Correspondence) Printed Parliamentary Papers. [C. 1879.] Parts 1 to 4. 1877. [Official.]

7 .... A Century of Famines. Being partieulars of all the Famines that hare visited India since the year 1770 ; and an inquiry into the best means of providing against them. By F. C. Danvers, of the Foreign Office. [Official.]

7 .... The Landed Interest and the Supply of Food. By James Caird, C.B., F.R.S.

Mr. Stephen Bourne, F.S.S., read before the Manchester Statistical Society a paper "On the inereasing dependence of this country upon foreign supplies for food," which paper is published in the transactions of that Society.

8 .... Irrigation regarded as a preventative of Indian Famines. By W. T. Thornton, Esq., C.B. Read before the Society of Arts, 22nd Februar, 1878, and published in the journal of that Society, vol. xxri, p. 272 .

8 .... The Famine Campaign in India, 1876-78. By William Digby. "Mr Digby's own services were inraluable, and deserved a better fate than to be consigned to oblirion in these two dry and chaotic volumes."-Athenaum, 28th September, 1878. 


\section{Discussiox on Mr. Walford's Paper.}

Mr. R. H. Patterson expressed his disappointment with the paper, because Mr. Walford had departed from the first part of his paper, and had gone into general remarks on the question of famines. At the same time every section of the paper was, he thought, very interesting. He could not attach the same importance as Mr. Walford did to the depreciation of currency as one of the causes of famine. A famine was caused by the failure of the ordinary productiveness of the soil, and what the depreciation of currency had to do with it he was at a loss to understand. Mr. Walford had attributed the high price of wheat in some instances to the scarcity of money; but it was well known that if money was scarce, the price instead of being high would be very low. Mrr. Walford had given a most carefully prepared list of famines which would be of great service. He (Mr. Patterson) wonld point ont, that famines were cansed either by too nuch or too little water. In northern countries all famines were produced by cold and wet weather, and in southern countries they were cansed by hot weather and scarcity of water. He would also call attention to the fact that recent scientific observations pointed to the existence of cycles of good and bad seasons connected with the spots on the sun. If the changes in the sun, and also the altered position of the planetary bodies were considered, it would be found that a priori, there was every reason to suppose that the cosmical condition of the earth would be correspondingly altered. So long as the distribution of land and water remain unchanged, it was impossible for the physical condition of the earth to change, except from extra-terrestrial influences. And he held it certain that ere long it would be found that cycles of this kind existed corresponding with the morements, the nearness or distance, of the larger surrounding orbs. He hoped that he would be excused for expressing his disappointment at the turn the present paper had taken.

Professor Leone Levi said they must all be indebted to Mr. Walford for such a collection of luminous facts, which would be of great use to the student of statistics. He should like to ask the author of the paper'whether his attention had been directed to the cultivation of opium in India as a cause of the prevalence of famines in that country.

Mr. Thomas Hudsor wished to know if the author had taken into account the misappropriation of grain in the manufacture of intoxicating drinks. As far as his memory served him, in 1846, dming the terrible famine in Ireland, the number of quarters of foreign grain imported in that year was about equal to the quantity which was consumed in the manufacture of alcoholic liquors. This was a point worthy of Mr. Walford's consideration, because if a 
raid had been made on the distillers and brewers in the year mentioned, the necessity for the importation of so much grain would have been superseded. He also called attention to the cultivation of hops, and eited the opinion of the late Sir Robert Peel, expressed on the proposal for the repeal of the hop duty, that if the hop lands were applied to the growth of wheat, it would be much more beneficial to the country, because to that extent it would increase the food of the people.

Mr. F. Rerrotns called attention to the waste of fisheries in this country, the people not seeming to realise the value of fish as food. There was a great deal of fishing at improper times, and a misuse of the fish as an article of manure, when it might be more advantageously brought into the market for human food.

Mr. R. Denny Uruin thought it desirable to point out that a previons speaker ( $\mathrm{Mr}$. Hudson) had fallen into an error in attributing the Irish famine in 1846 to a failure of the grain crops. Barley and oats were to some extent enltivated in Ireland, but the corn erop had always been very limited, and the climate of Ireland was so uncertain that it never had been, or would be, a corngrowing country. The great Iris'. famine was owing to the failure of the staple crop of potatoes, on which the majority of the smaller tenants had, as it were, staked their existence. When that erop failed there was universal distress, for the tenants were thrown into a state of starvation, and were of eonrse nuable to pay any rent; so that the land-owning class also suffered fearfully. It was happily the ease that the average size of farms had since increased, and that the tenantry were not now so completely, as formerly, dependent on a single erop. If he understood the Indian Famines rightly, they were also terrible instances of the danger of depending on one product of the earth. All this seemed to point to the scareity, in India as in Ireland, of agricultural knowledge, and of the means of making known to the people the dangers to which they were liable to be exposed. We had no "Minister of Agriculture," whose department would be charged with the duty of warning the poorer tillers of the earth of possible reverses, and especially of the danger of staking everything on one article of food. Such a department of State might, he thought, ameliorate, if it could not wholly prevent the disastrons state of famine which had overwhelmed some portions of the empire in years past. With regard to the meteorological aspects of the questions, he feared that meteorology, although highly interesting, eould not yet claim to be looked on as a science. The cyele of bad harvests spoken of by a previous speaker would doubtless be of great importance if anyone eould sueceed in exactly measuring it-in telling us if it were a eycle of ten, or twelve, or fourteen years. But eycles and sun spots so far defied exact description, and any knowledge we had of them was, so far, of little or no use to us. He would only, in conclusion, express his great regret that he had not been able to hear the whole of Mr. Walford's paper. 
The Rev. I. Doxsey combated the riew that the climate of Ireland was unsuitable for the growth of corrl. Some of the heaviest corn and the strongest in the straw he had seen in the three kingdoms, was grown or the estate of Earl Fitzwilliam on land that had previously been bog land. He believed that drainage wonld do for Ireland what it had done for the great level in the fen counties of England, which were the best graingrowing counties in the kingdom. The cost of reclaiming the land in Ireland was the chief difficulty. The Irish famine in 1846 was relieved, as far as it could be, by the importation of corn from America. The people found that they could no longer exclusively rely upon the potato crop, and he believed they liad profited by the lesson ever since. He could not remember accurately the facts to which Mr. Hudson had referred, but his conclusion at the time of the Irish famine was that as much grain as was necessary to sustain those who perisbed by famine was turned into whisky. He felt personally indebted to the author for his paper. The facts had been collected by surmounting almost insuperable difficulties, and exhibited an indefatigable industry which was worthy of imitation by the younger members of the Society. He (Mr. Doxsey) took exception to the remarks made by Mr. Patterson in reference to the debased currency. The foreigner did not accept our currency, but regarded only the actual and not the nominal value of the silver, and sold accordingly. Therefore he thought that the debasing of currency had more to do with the question than Mr. Patterson seemed to imagine. With regard to the meteorological aspects of the question, he thought that one part of Mr. Patterson's speech answered the other. That gentleman had said that there were certain circumstances which in northern climes produced scarcity, and that there were other classes of circumstances producing famines in southern climes; but these two circumstances did not always go together. As a rule it would be found that when there was a scarcity in the northern climes there was a good supply in the sonthern climes, and vice vers $\hat{\theta}$, showing that $M_{r}$. Walford was right in saying that one of the causes of famines was want of the means of transport. Putting these two facts together, he thought that $\mathrm{Mr}$. Patterson's remarks rather strengthened Mr. Walford's argument than weakened it.

Mr. H. Moncreiff Paul said that Mr. Walford had alluded to India as an important factor in shipping wheat to this country; but if he would carry out his in restigation to last year (1878), he would find that considerably less had been sent from that country than was the case in 1877 , or even in 1876 , one reason simply being the effects produced by the famine, and another the low price offered in this country not being sufficient to warrant the shipment of grain hither. Mr. Walford had shown what he considered to be the means of preventing famines in the future, and had summed it up by saying, "I have already indicated that the only mode of permanent prevention lies, in my belief, in improved means of cultivation, if practicable, and of transport as a necessity." $\mathrm{He}$ (Mr. Paul) thought, however, that there were four elements 
involved. The first great factor was free trade. If there was free trade in any country there wonld never be famine, because supplies could be attracted to that country from other countries. A second factor was increased facilities of transit; a third, telegraphic communication; and a fourth, improved cultivation. It was quite true, as some of the speakers had remarked, that Ircland as well as Scotland were not great wheat growing countries; but that was not of much consequence, because wheat could be imported much more cheaply from other parts of the world. If the principles he had enumerated were applied to other countries, there would be no danger of famine in them. With regard to India, there was another element to be considered; there was the question of caste. An Indian would rather die than eat food to which he had not been accustomed. In the case of coolies sent from the East to the West Indies, they must have rice imported from India or Burmah for their consumption; consequently this element of caste, where it existed, was sufficient to connteract the other elements he had named; but, speaking generally, a maintenance of the four points to which he had alluded as applicable to this country, was necessary to prevent other countries from being visited by famine.

Mr. E. Hepple Hali said the paper just read was a most admirable one. He was present when the former paper was read, and he had studied its contents ever since. Notwithstanding the wonderful ingenuity Mr. Walford had displayed in handling the figures, he (Mr. Hall) confessed to some feeling of disappointment with the general results arrived at. There was onc element which had not apparently entered into the consideration of the paper, namely, that of thrift, or rather its opposite, waste. There was no time when the subject of thrift or waste was more worthy of consideration than at present. Next to the Americans, the people of this country were the largest meat consumers in the world, and next to them, perhaps, they were the most extravagant and wasteful; and he had no hesitation in saying from the experience he had in travel, that this element of waste entered very materially into the consideration of the question of famines. In regard to the question of free trade, he could not conceive, although he largely believerl in free trade, how it could affect the question of famines. If there was universal free trade, no doubt the supply to the north when the south was not so clistressed, and vice vers $\hat{u}$, on the general principle of the working of free trade, would be the means of relieving a famine. So in relation to the whole world, it was a local question, apart altogether, he thought, from frce trade. $\mathrm{He}$ had spent some time in the United States, and had learned that many portions of the country were subject to periods of famine and great scarcity; but since the introduction of railways and canals these famines had been in a great measure prevented. $\mathrm{He}$ was of opinion that the paper, on the whole, was one of the most elaborate, valuable, and carefully prepared that had ever been read before the Society since he had become a member.

Mr. F. C. Danvers said he had taken great interest in the 
famines in India. He wished in the first place to correct the statement that rice was the all-important food for India. In many parts that was so; but in sonthern India rice was really the food of the rich, the poorer elasses depending on the dry crops. If they all depended on rice, the effects of the drought would be much more serions, because rice required a great amonnt of water to bring it to perfection. In regard to opium growing in India, opium covered a comparatively small area, so that the cultivation of grain in its stead wonld not have any material effect on the conntry in times of famine. In China the case was different. The late famine had directed attention to an amonnt of snrreptitionsly grown opium in that conntry. Between rows of growing crops the Chinese planted the poppy; but when this was discovered by the anthorities they were pnnished and the plants destroyed. It was believed that the large amount of opium grown in China monopolised the gronnd which would lave otherwise been covered with grain, and which wonld have been very beneficial in the time of the late scarcity. Poppr cultivation in India, however, was not carried on to an extent snfficient to affect the food supply in any particular district. Owing to a new condition of affairs that was gradnally taking place in India, famines would probably in the future assume quite a different aspect to what they did formerly. Famines in India have hitherto been more generally famines of work than of food, becanse when there had been good crops the people nsed to store a very large proportion of the year's supply in undergronnd storehonses, and very often they had sufficient to last at least one rear of bad crops, and if the crops were not entirely destroyed, there wonld be sufficient in store to eke ont for two seasons. Upon these oceasions the famine was not a famine of food, but of work; because a large proportion of the people were agriculturists, and when a dronght took place, and it became impossible to cnltivate the land, a large proportion were thrown ont of work, and had no means of livelihood to enable them to purchase food; but since communications had increased, a great change had taken place in that respect. In many places where a railway passed throngh, and a high price conld le obtained for the gran, the grain merchants were not proof against the temptation to realise money when they had the opportunity. The consequence would be that by and by famines of food wonld be almost impossible, but famines of work, and therefore of the means to procure food, would not therefore cease to exist. The product of districts having a large produce, would be brought into the famine districts at a mnch more reasonable rate than hitherto. He was sorry that more had not been said in reference to the government dealing with famines. A famine in this country was almost impossible, but onr depeudencies in the East might be largely increased in future, and it was desirable that we should consider the best way of meeting a famine. In former years the government in India used sometimes to purchase grain, and when they employed people on famine works they would pay them in grain, and otherwise interfere with the grain trade. Early in the present century that was found out to be a great mistake, and although there had been departures from the 
general rule, orders were issued that there shonld not be any interference on the part of local govermments or their officials in the grain trade. As communications improved, the free trade in grain would have greater seeurity than in times when it was impossible to get into districts in varions parts of the conntry. There was also another question with reference to eommnnications. One effeet of railways was not only to facilitate the transport of grain from one place to another, but they also had the effect of raising the value of grain, and in a calenlation which he reeently made, he found that if a eertain railway which had been projected was construeted at a cost of abont three-quarters of a million sterling, in all probability, judging from the prices of crops in another district, the value of the erops wonk be inereased by 800,000 l. a-year; that was to say, the increased value of one year's crop would more than pay for the railway. The people wonld thus be enriehed and able to put aside from their surplus receipts money to provide themselves with food in the event of seareity in their immediate districts.

Professor Seligmanx (of Berlin) said that a few days ago he read in the "Illnstrated London News" an account of a case in which a somewhat speculative eommercial gentleman predicted a famine in the year 1641, the time of the Irish rebellion, and he attributed the cause to emigration, which was an important element in the question.

The Hon. Mr. Washburn (of the United States) said he had read with a great deal of interest the first paper prepared by $\mathrm{Mr}$. Walford, and he was astonished at the number of famines that had oceurred from the beginning of creation to the present time. These famines, undoubtedly, were in most eases beyond the power of human eontrol and foresight; but there was no question whatever that the distress caused by some of them might, in many respects, have been mitigated, and made more bearable by human skill and ingenuity. He had listened with a great deal of attention to the diseussion which had followed the reading of the essay, and had asked himself the question whether it would be possible for these famines to be repeated in future times. It did not seem to him that they eould, when he eonsidered the present means of communication between one eountry and another, and the improvements that had taken place within the last thirty or forty years in all that related to the cultivation of grain, espeeially in America, which eountry was a great factor in supplying the world with bread. During the past year America had raised the greatest erop of wheat ever known, exceeding, if he remembered rightly, four hundred millions of bushels! He also called attention to the rery extensive growth of Indian eorn in Ameriea, which, he said, was comparatively but little known in Great Britain. He had been gratified to know from reeent travels through Germany, that it was being largely introduced into that eountry. America raised such enormous quantities of that artiele so eheaply, that it had actually been often used in the Western States for finel. It was 
excellent fodder for cattle, and was eaten extensively in the form of Indian meal by the masses of the people. If it were introduced into Europe, it would be used to a great extent as an article of food, not only for cattle, but for human beings. Now-a-days we were blessed with extensive means of inter-communication. Seventy ships were now on the stocks in the shipyards of England and Scotland, which were being fitted up expressly for the purpose of carrying cattle from the United States and Canada to Great Britain. If nations were neighbourly one with another, he felt confident that there would be an end of famines; at least, that their deplorable consequences, should they occur, would be greatly mitigated.

Mr. WALFord, in reply, said that the discussion showed that althongh he had tried to exhaust as well as he could the main topies, there were many others that had been left untouched by him. In regard to the remarks made by Mr. Patterson, as to the currency question as a cause of famine, he confessed that when he first saw it stated in numerous instances scarcity of coin had produced or aggravated famines, he was very sceptical. He had, however, dealt with the question historically. He had shown the legislation that had taken place in this conntry in regard to the debasement of coin; and this debasement being admitted, its influence upon the price of food purchased from the foreigner became apparent. He had also quoted the authorities bearing upon the question of currency and food supply. He regretted that he had been compelled to wander into the question of currency, because it was not a very agreeable one, by reason of the contrariety of opinions it always engendered; but he was obliged to do so in order to complete a very important section treating of the causes of famine. Professor Levi's question about opium cultivation had been answered by other speakers. Mr. Hudson had made some remarks as to the misapplication of grain; but he lad overlooked the fact that he (Mr. Walford) had given a table in his paper relating to that very subject. In the same table there was a curions fact that had not to do with the liquor traffic at all. The rooks, choughs and crows were at one period so numerous in this country, that they not only destroyed the corn of the country, but also the roofs of houses and barus, and a reward was offered for the number of rooks that were destroyed. $\mathrm{He}$ quite agreed with Mr. Reynolds that the fisheries of this country had been neglected, but in looking at Tables IX and $\mathrm{X}$ it would be found that it was not a new question, even in a famine point of view. Many Acts of parliament had been passed encouraging the fisheries of this country, and ultimately (1801) the Government granted 30,000 . a-year by way of bounty to bring in the fish for the poor people of the country. Some of the Acts of parliament relating to this subject were so curious, that unless one actually saw them they would be believed to be part of a romance. The question of fisheries had not been neglected by him (Mr. Walford) in considering the question of famines; but it was a question that had been neglected in the consideration of food supplies generally, especially as regarded Scotland and Treland. If fish and Indian corn and 
other products that were to be found plentifully in many parts of the world were used in this country, there wonld be no danger of lack of cheap food for the poor people. One question in regard to famines was what were the food supplies that ought to be introduced in the time of famine. In reply to Mr. Denny Urlin's observations on the famines in Ireland, he might say that until 1806 , there was no reciprocal law for the import of grain into, or the export of grain from, the two divisions of the kingtom.

There were many laws passed for the prohibition of food snpplies between the two countries; but in the year mentioned these were all swept away, and at the present moment a very large amount of grain was ammally imported into this conntry from Ireland. Mr. Doxsey had also referred to Ireland and the capacity of the bog lands, when cultivated, for prodncing grain; and to him (Mr. Walforl) it did not seem elear at first sight why America should be relied on to such a large extent for our supply of grain, when it could be obtained from places much nearer home, except that America produced, owing to the climate, a drier and finer grain. In regard to the remarks made by Mrr. Paul, who made a point of telegraphic inter-communication as an important element in regulating the supply of food at famine periods, he (Mr. Walford) admitted the advantage of this agency, and in his paper had taken it for granted as an agency now existing. Mr. Hall had given some interesting statisties, and had called attention to the waste of food. If this waste was prevented, there would be no such thing as absolnte porerty in Eugland. Mr. Danvers had spoken with the anthority that belonged to the position he held in the India Office, and had convinced him (MIr. Walford) of the folls of himself or any other ontsider attempting to prononnce anthoritatively on the remedies for Indian famines. A knowledge of the circumstances of the conntry was an essential condition in all Indian problems. Professor Seligmann had spoken of migration, and it had been remarked by Mr. Danvers and others that some of the famines in India, if not attributable to, were very much aggravated by the inhabitants migrating from one district to another. The Hon. Mr. Washburn had given some information in regard to the Indian corn of the United States. In this paper he had felt some difficulty in regard to the word "com." In England this term was applied to all grain, in America to one variety only, namely, "Indian cor's;" but this latter term became confusing in a paper treating of Indian famines; for Indian corn was peenliarly the produce of the continent of America. It was sold for a rery low price, and properly cooked was a most nutritious article of food. It would be well if this could be designated "maise." He commended this snggestion to his able statistical friend (Mr. Bourne), who did him the honour to oceupy the chair this evening. Some disappointment had been expressed that the present paper treated the famine question on a different standpoint from the previous paper. In the former paper he had treated of the natural causes of famine, and in the present one he had treated of the artificial canses. In the nature of things the treatment must be quite different. What were termed the natural 
causes of famines were frequently in some degree amenable to wise and preventive treatment; but the artificial causes all arose either from want of human foresight, or from the passions and prejudices of mankind. Legislation was supposed to embody the aggregate wisdom of a nation; but in the matter of famines, as in many other social problems, it was frequently very much the other way. He was much obliged to the gentlemen who had taken part in the discussion; he saw others present who conld have thrown light upon some of the questions involved; but diffidence or want of time had prevented their doing so. As the population continued to increase, the famine question would continue to force itself upon the consideration of all thoughtful men.

Mr. S. B. GosLin, author of a pamphlet, "How to avert Famines and Droughts," was called upon to speak after the reading of the paper. He has since sent in the following notes:-

\section{Walford, Esq.,}

"After having heard and read your valuable and exhanstive paper upon Famines of the World, I would remark that (1) I consider that you have supplied fully all that could be desired for the consideration of how to avert or mitigate them. I tried to get such a table for reference, but failed some long time since. (2.) It is from this conclusive that famines not only arise from various causes, but from the fact of locality, the causes of one locality being entirely different to those of another. (3.) That they will ocenr again and again, whether from the spots on the sun, eycles, or other meteorological disturbances. (4.) To avert or mitigate them must be a study of particular circumstances and particular remedies, as much the occnpation of the civil engineer as the agriculturist or meteorologist, the remedies needed often being within the scope of the civil engineer, as has been illustrated in the facts of the reclamation and utilisation of the fen lands.

"There can be no donbt but that much may be done by scientific inquiry and investigation as well as by the compilation of further statistics.

"It is said we wish that some plans might be suggested to government for India and the colonies, to save the population in one case and the sheep in others.

"If Ireland were taken into consideration, it has been shown by James Price, C.E., at the British Association, that they have an enormous natural power wasted which might easily be ntilised for draining and bringing the land into a better state of eultivation.

"In India and the colonies it is nearly always the want of water which causes the calamity, which might be obtained from under the surface, and raised by the wind. To settle this point it needs a careful compilation of (1) the statistics of the wind all over India and in the colonies; (2) of the average depths of the wells or water-bearing strata in same parts, together with suitable sites for wind power; (3) of the waterfalls which might be utilised so as to save the employment of the vast number of cattle in raising water in times of scarcity - eating the food from the land. 
"Such statistics would be of immense service to Government and colonists, and would further the possibilities of prevention."

The Chairmax in moving a vote of thanks to the anthor of the paper for the amount of information that had been arranged in such an interesting manner, referred to the observations of Mr. Washburn, cordially endorsing his opinion that extended intercourse and kindly feeling between different nations in the interchange of their commodities, would tend to preclude any one of them suffering from severely continuous famine. He must, however, remind his friend, that the fault lay with the Americans, inasmuch as whilst England was ready to purchase the food they had to supply, America was unwilling to take payment in the articles she had to give in exchange. He warned Mr. Washburn that unless his conntrymen manifested a better spirit in this matter, it would be incumbent on the Government and capitalist on this side of the Atlantic, to stimulate industry and develope production in conntries such, for instance, as Africa, who might be willing, not only to supply us with food, but to take our clothing and goods in exchange. 
- 11 




\section{please do nOt Remove CARDS OR SLIPS FROM THIS POCKET}

\section{UNIVERSITY OF TORONTO LIBRARY}


$+\cdots$

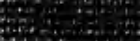

